\title{
Arquitectura y Buddhismo: La Ciudad del Nirvana
}





\title{
Arquitectura y Buddhismo: \\ La Ciudad del Nirvana
}

\author{
Alumno: Pilje Lee \\ Tutor: Javier Poyatos \\ Fecha: Julio. 2017.
}

Palabras Claves: Utopía, Nirvana, Ciudad, Estrategias.

La tesis empieza desde una pequeña idea consistente en que la Utopía occidental y el Nirvana asiático pueden ser conceptos gemelos. Si el utopismo se refiere al sistema y la ideología, el Nirvana es sobre la fenomenología y la psicología, que son géneros inevitables cuando tratan de las ciudades contemporáneas, también es una contraparte de la tradición utopista ortodoxa para generar otro punto de singularidad, entrando en la dimensión herética.

El primer objetivo de este estudio es dilucidar una síntesis dialéctica confrontando dos conceptos heterogéneos que son la Utopía y el Nirvana. Y el segundo objetivo de este estudio es comprobar la contundencia de este estudio en un nivel práctico. Por eso, las investigaciones y los argumentos se suceden en los siguientes órdenes metodológicos.

La metodología de este estudio es sencilla y clara. En el primer capítulo, se van a presentar los mantras buddhistas, cuáles son las esenciales enseñanzas de Siddhartha para llegar al Nirvana. En los capítulos 2 al 5 , se investiga los proyectos utopistas del urbanismo en el siglo XX para analizar con el criterio buddhista que se adquirirá en el capítulo 1. En los capítulos 6 y 7, se entienden las arquitecturas y jardines japoneses en los que están introducidas las filosofías zen-buddhistas que puede ser la contraparte del utopismo.

En los capítulos 8, 9 y 10, se establecen los principios sobre la epistemología, la ética y la estética con los argumentos generales, basando los datos analizados por los criterios nirvánicos. $Y$ en los capítulos 11, 12 y 13, los principios nirvánicos se aplican en la ciudad real para comprobar su contundencia, como una nueva herramienta para poder percibir la ciudad en una perspectiva alternativa, incorporando en el urbanismo los campos de la psicología y la fenomenología, 
positivamente y estratégicamente.

En el capítulo 14, basándose en los datos y principios que se han adquirido en los capítulos precedentes, se establece un nuevo principio avanzado llamado Forma Nirvánica, un índice práctico para poder describir y valorar los espacios en la perspectiva arquitectónica y urbanística.

Al final, en el capítulo 15 y 16, se argumenta sobre el sentido ontológico de este estudio para la presente era y la posibilidad para el tiempo venidero, añadiendo algunas explicaciones adicionales. El estudio llega a la conclusión.

Como ningún dharma puede ser perpetuo, la contundencia de la tesis tampoco podría ser eterna. Solamente, sería suficiente si esta tesis gana su razón de existir comprobando su utilidad y su espíritu en esta era. No obstante la contundencia y la factibilidad de la tesis ya está demostrada aplicando la idea del Nirvana al espacio urbanístico y arquitectónico.

La ciudad del nirvana sería una ciudad-dharma, lógicamente. Esta tesis no es nada más que un dharma. Depende de la situación, este estudio reproduce la extinción del dolor, y también, al contrario, puede reproducir la acumulación del dolor cuando la circunstancia cambiase en el tiempo venidero. 


\title{
Arquitectura i Buddhisme:
}

\section{La Ciutat del Nirvana}

\author{
Alumne: Pilje Lee \\ Tutor: Javier Poyatos \\ Data: Julio. 2017.
}

\section{Paraules Clau: Utopia, Nirvana, Ciutat, Estratègies}

La tesi comença des d'una petita idea consistent en què la utopia occidental i el nirvana asiàtic poden ser conceptes bessons. Si l'utopisme es refereix al sistema i a la ideologia, el Nirvana és sobre la fenomenología i la psicología, que són gèneres inevitables quan es tracta de les ciutats contemporànies, també és una contrapart de la tradició utopista ortodoxa per a generar altre punt de singularitat, entrat en la dimensió herètica.

El primer objectiu d'aquest estudi és dilucidar una síntesi dialèctica confrontant dos conceptes heterogenis que són l'Utopia i el Nirvana. I el segon objectiu d'aquest estudi és comprovar la contundència d'aquest estudi en un nivell pràctic. Per això, les investigacions i els arguments es succeeixen en els següents ordres metodològics.

La metodología d'aquest estudi es senzilla i clara. En el primer capítol, es van a presentar els mantras buddhistas, les quals són les essencials ensenyaments de Siddharta per arribar al Nirvana. En els capitols 2 al 5 , s'investiga els projectes utopistas de l'urbanisme en el segle XX per analitzar amb el criteri buddhista que es va adquirir en el capítol 1. En els capitols 6 i 7, s'entenen les arquitectures i els jardins japonesos en els quals estan introduïdes les filosofies zen-Buddhistes que poden ser la contrapart de l'utopisme.

En els capitols 8,9 i 10, s'estableixen els principis sobre l'epistemologia, l'ètica i l'estètica amb els arguments generals, basant les dades analitzats pels criteris nirvànics. I en els capitos 11,12 i 13, els principis nirvànics s'apliquen en la ciutat real per comprovar la seva contundència, com una nova eina per poder percebre la ciutat en una perspectiva alternativa, incorporant en l'urbanisme els camps de la psicología i la fenomenología, positiva i estratégicament.

En el capítol 14, basant-se en les dades i principis que s'han adquirit en els capitols precedents, 
s'estableix un nou principi avançat anomenat Forma Nirvànica, un índex pràctic per poder descriure i valorar els espais en la perspectiva arquitectònica i urbanística.

Al final, en el capítol 15 i 16, s'argumenta sobre el sentit ontològic d'aquest estudi per la present era i la possibilitat per al temps esdevenidor, afegint algunes explicacions addicionals. L'estudi arriba a la conclusió.

Com cap dharma pot ser perpetu, la contundència de la tesi tampoc podria ser eterna. Només, seria suficient si aquesta tesi guanya la seva raó d'existir comprovant la seva utilitat i el seu esperit en aquesta era. No obstant això, la contundència i la factibilitat de la tesi ja està demostrada aplicant la idea del Nirvana a l'espai urbanístic i arquitectònic.

La ciutat del Nirvana seria una ciutat-dharma, lògicament. Aquesta tesi no és res més que un dharma. Depèn de la situació, aquest estudi reprodueix l'extinció del dolor, i també, al contrari, pot reproduir l'acumulació del dolor quan la circumstància canviés en el temps esdevenidor. 


\title{
Arquitectura y Buddhismo: The City of NIrvana
}

\author{
Student: Pilje Lee \\ Tutor: Javier Poyatos \\ Date: July. 2017.
}

Key words: Utopía, Nirvana, City, Strategy.

This thesis starts from a small idea that Utopia and Nirvana can be twin concepts. If utopianism refers to system and ideology, Nirvana is about phenomenology and psychology, which are inevitable genres when dealing with contemporary cities. It is also a counterpart of the orthodox utopian tradition to generate another point of singularity, entering into the Heretical dimension.

The first objective of this study is to clarify a dialectical synthesis confronting two heterogeneous concepts which are Utopia and Nirvana. And the second objective of this study is to check the strength of this study at a practical level. For this reason, the investigations and the arguments procede in the following methodological orders.

Ths first chapter presents the Buddhist mantras which are the essential teachings of Siddhartha to reach Nirvana. Chapters 2 through 5 investigate utopian urban planning projects in the $20^{\text {th }}$ century for analysis, by using the Buddhist approach which was discussed in Chapter 1. Chapters 6 and 7 focus on Japanese architectures and gardens which introduced in Zen-Buddhist philosophies that can be the counterpart of utopianism.

In Chapters 8, 9 and 10, the principles on epistemology, ethics and aesthetics are established with general arguments based on data analyzed by nirvanic criteria. And in Chapters 11, 12 and 13, the nirvanic principles are applied in the real-life city to verify its forcefulness, as a new tool to understand the city in an alternative perspective by incorporating urbanism, fields of psychology and phenomenology, positively and strategically.

In Chapter 14, based on the data and principles that have been acquired in the previous chapters, a new advanced principle called Nirvanic Form is established, a practical index to describe and to value 
spaces in the architectural and urban perspective.

In the end, Chapter 15 and 16, this study argues for the ontological meaning of this study for this modern era and the possibility for the future.

Since no dharma can be perpetual, the strength of the thesis could not be eternal. It is sufficient if this thesis gains its reason for existence by checking its utility and its spirit in this age. Nevertheless the strength and feasibility of the thesis is already demonstrated by applying the idea of Nirvana to urban and architectural space.

Logically, The City of Nirvana would be a city-dharma. Depending on the situation, this study reproduces the extinction of pain, and on the contrary, it can reproduce the accumulation of pain when the circumstance changes in the future. 


\section{Index}

0. Introducción y Objetos. p. 1

1. Mantras del Budismo: El camino para llegar al Nirvana. p. 19

2. The Garden City, Ebenezer Howard. p. 25

3. The Broadacre City, Frank Lloyd Wright. p. 57

4. The Contemporary City, Le Corbusier. p. 81

5. New Baylon, Constant. p. 113

6. Katsura Villa Imperial, La Familia Imperial de Hachijo. p. 163

7. La Iglesia de la Luz, Tadao Ando. p. 213

8. Epistemología Nirvánica. p. 235

9. Ética Nirvánica. p. 243

10. Estética Nirvánica. p. 259

11. CSD Mórbido. p. 265

12. CSD Nirvánico. p. 323

13. NY Intervención. p. 349

14. Secularización. p. 379

15. Discusión General de los Resultados. p. 427

16. Conclusión. p. 433

17. Bibliografía. p. 437

18. Créditos Fotográficos. p. 445

19. Tablas. p. 455 
"Yo soy yo y mi circunstancia, y si no la salvo a ella no me salvo yo. " José Ortega y Gasset. 


\section{Introducción y Objetivos}

Una vez vi como un judío recibía un abrigo excelente de una mujer mayor y le daba dos bolas de billar a cambio y la echó fuera sin darle tiempo para quejarse. Si pudiera hacerlo, le querría romper la nariz. ${ }^{1}$

George Orwell. 1933. Sin Blanca en París y Londres.

El trabajador no hace falta compartir los beneficios con el patrón, sin embargo y sin escapatoria, sí comparten los perjuicios. ${ }^{2}$

Karl Marx.1844. Manuscritos Económicos y Filosóficos de 1844.

\section{La época de la crisis}

Hoy en día, se vive la era en la que todo el mundo se preocupa de la crisis de las ciudades. Incluso la prensa escrita, por ejemplo: periódicos, tesis, artículos y también en los medios digitales: Internet y los canales de televisión y en medios personales hasta las muchas conferencias, se refieren sobre la circunstancia urbana en todos los aspectos culturales, sociales, económicos, etcétera. Ninguna citación es necesaria para aceptar dicha tesis, sin embargo, se mencionarán unos artículos. Según unos informes de OCDE, los ingresos del mercado se redujeron considerablemente durante la crisis en la mayoría de los países de la OCDE y la desigualdad de los ingresos del mercado aumentó gradualmente ${ }^{3}$ Además desde el año 1999 hasta 2011, incesantemente los datos de las deudas de los hogares, cada año establecen un nuevo récord. ${ }^{4}$ Asimismo, las cuestiones de solidaridad de la sociedad destacan cada vez más con asuntos relativos como el problema de los inmigrantes, las minorías sexuales, el asunto de los desempleados, la desconfianza extendida en política y etcétera.

\footnotetext{
1 Orwell, G. Sin Blanca en París y Londres. Gihyuk Kim(tr). Munhakdongne, Inc.. Versión coreana. 2010. p. 148.

2 Marx, K. Manuscritos Económicos y Filosóficos de 1844. Youwon Kang(tr). Seoul. Iron ga Silcheon. Versión coreana. 2007. p. 15.

${ }^{3}$ AAVV. Crisis Squeezes Income and Puts Pressure on Inequality and Poverty. OECD. 15. Mayo. 2013. Fuente online:

< http://www.oecd.org/social/inequality.htm>

${ }^{4}$ AAVV. Household Income and Wealth. OECD. 2013. Fuente online:

< http://www.oecd.org/std/03_Household_income_and_wealth.pdf>
} 
No es difícil razonar el futuro de los ciudadanos cuando se enfrentan a una extenuación persistente de sus economías; Pronto los valores solamente metafísicos y sublimes como la democracia y la sana conciencia cívica, fácilmente caerán al suelo antes que otros valores menos abstractos.

El enorme crecimiento de la población en el área urbana es la causa del problema de la vivienda5; eso está profundamente involucrado en el fenómeno del desempleo ${ }^{6}$, que ofrece las oportunidades de las cuestiones educativas adecuadas y los problemas de higiene pública ${ }^{7}$; por su causalidad, el problema de la vivienda tiene que enfrentarse con la construcción de los temas de la periferia urbana y ofrecer medios de transporte público asequibles ${ }^{8}$, dilema también a nivel de los bajos ingresos; el problema del desempleo es que ahora está causando aislamientos, participaciones sociales, los problemas democráticos y los problemas sociales, sólidos en un nivel particular de ciudadanos $\mathrm{y}^{9}$, por último, se está rompiendo toda la dimensión física, económica, social y cultural de la sostenibilidad de la ciudad en su totalidad.

\section{Psicología del Utopismo}

...Antes de su muerte, todas las experiencias de todo ese tiempo se acumulan en su cabeza en una pregunta que hasta entonces no ha hecho al guardián. Le hace una señal, porque no puede enderezar ya su cuerpo rígido. El guardián tiene que inclinarse profundamente, hacia él, porque la diferencia de talla ha aumentado en perjuicio del hombre. <<¿Qué quieres saber aún?>>, le pregunta el guardián. <<Eres insaciable. Todos ansían llegar a la Ley >>, dice el hombre, << ¿cómo puede ser que, en todos estos años, nadie más que yo haya solicitado entrar?>> El guardián se da cuenta de que el hombre se está muriendo y, para hacer llegar las palabras a su oído que se va perdiendo, le grita: <<Por aquí no podía entrar nadie más, porque esta te estaba a ti solo destinada. Ahora me iré y cerraré.>> 10

Franz Kafka. 1925. El Proceso.

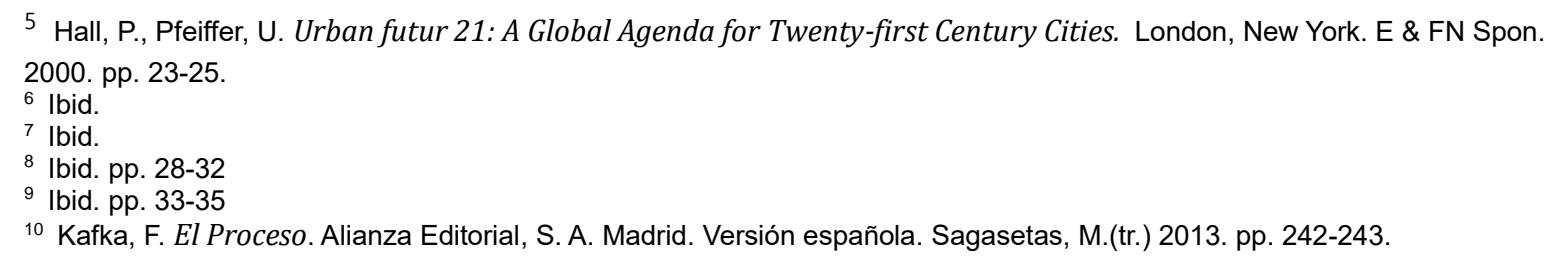


La denominación de la Utopía y su género como literatura se inició con Tomás Moro en 1516(v.-fig. 05). Sin embargo, el origen de la noción sobre el utopismo es más antiguo de lo que aparenta. Aparte de la credibilidad en la existencia del Jardín del Edén, el concepto de <<la perfección>> de los hebreos al que se refiere la biblia también puede ser una clave con la que se puede perseguir el origen del utopismo (v.-figs. 0-2) y las cunas de la civilización, como por ejemplo el Antiguo Egipto también, ellos creían en una vida después de la muerte. Así el utopismo tiene extremadamente una antigua historia, tanto que abarca todo el transcurso de la historia humana, hasta hoy en día y además se ha encontrado en todas partes como un fenómeno mundial. $Y$ siempre la idea fue transcendental o alternativa a aquellos tiempos, haciendo posible a los humanos que pudieran concebir las ideas subversivas para vencer los presentes obstáculos sustanciales contra las ideologías tiránicas imaginando otras vidas alternativas como un arma ideológica. Por lo cual, los precedentes utopismos pudieron tener un significado sobre los estados alternativos en sus particulares períodos de tiempo. En este sentido, es una inevitable verdad que los utopismos contemporáneos también habrían de reflexionar la circunstancia de la vigente era (v.-figs. 0-4, 7, 8, 9, 10).

Entonces, ¿qué significaría reflexionar la época? La respuesta de esta pregunta, sería una historia de una carencia del hombre. Dicha carencia, tal vez puede ser para un grupo o un individuo profético, y de todas formas con cierta intención personal (v.-fig. 0-3). El mito de la utopía puede ser para una clase de los acaudalados y también puede ser para la clase baja (v.-figs. 0-6, 11). Las utopías a las que aspiraron Platón, Moro y Le Corbusier, persiguen modelos sociales semejantes, eso no sería una coincidencia cabalística. Aquí existe una cierta razón de dicha semejanza, porque ellos comúnmente describen una imagen de la sociedad alternativa cuando cada uno de sus utopismos está aplicado en la ciudad como una herramienta para gobernar (v.figs. 0-1, 6). Sin embargo, en el caso de La Nueva Babilonia de Constant, es difícil de encontrar algunos puntos de tangencia, porque el desafío de Constant fue para exiliarse desde el sistema que capta a la humanidad por la ideología utilitarista, al contrario que aquellos tres casos. Si el control absoluto fuese la virtud carente de aquella época de Platón, en la época del movimiento de 1968 en Francia, a los filósofos, por ejemplo: Deleuze, Foucault y Lefebvre el concepto del control absoluto se habría percibido como la maldad que cuaja y adiestra al 
hombre. El Cuerpo sin Órganos de Deleuze era un dios para salvar la humanidad, sin embargo, para Leibniz sería un anticristo que lleva todo el mundo al caos porque según La monadología de él, depende de la perfección de las monadas, la pasividad y la actividad se definirían desde una liviana piedra hasta un dios excelente. Respecto a Deleuze \& Guattari, cuando todas las mónadas llegan al máximo nivel de libertad significa un estado en el que todo el mundo se convierte en dios, dicho estado significaría para Platón o Moro una maldad caótica. Así como se observa anteriormente, no cabe duda de que la psicología del utopismo no es nada más que una acción de reflexionar las ideologías de las eras, más específicamente, ha sido para reflexionar algunas voluntades contra algunas carencias o mutilaciones, aceptadas por los particulares grupos cuales podían haber sido la clase dominante o clase subyugada.

Además, aparte del asunto de que el utopismo reflexiona la era o alguna ideología, de algunos particulares grupos o de algún profeta, lo importante aquí es que el utopismo sigue siendo un idealismo alternativo, y eso fue sobre una historia personal y artificial porque es una producción que refleja y concibe alguna cierta filosofía humana. Por eso, debido a que dicha producción siempre tiene que surgir atravesando diversas dimensiones de la época, cultura, economía, política, sociedad, arte, filosofía, razas y más factores compuestos -cuyos caracteres fatídicamente son de alguna proporción de objetividad e impersonalidad- para poder confrontarse a una ideología personal de una manera en la que solo un dios podría saber, el discurso curiosamente se puede ubicar en un campo mitológico.

En esta era, si existe una utopía o un utopismo, y si eso se traduce en el lenguaje contemporáneo, a lo mejor, la palabra podría sustituirse aproximadamente por la de urbanismo avanzado. Obviamente, los urbanismos de cada época, tenían que contener unos elementos de cada situación. Después de la industrialización, después del régimen de Hitler, después de experimentar dos veces eventos traumáticos mundiales, y después los años de 70 s en los países con doctrina neo-liberal, en cada época los urbanismos enfrentaron ciertas situaciones limitadas (la carencia) para vencer. Pero las ciudades del nuevo milenio son cada día más complicadas y diversificadas que antes. La razón de que el paradigma moderno (que solía intentar percibir lógicamente al hombre y que pudiera ser éste sustituido por la ciencia) ya no funcionaba bien en la nueva era, por ejemplo, a veces el hombre es 
capaz de actuar ignorando la lógica, no solo para un propósito universal, sino para una victoria psicológica. Después de los años 2000, el fenómeno de que la teoría de juegos es uno de los temas más hablados en el Premio Nobel de Ciencias Económicas, puede considerarse como el fallo del paradigma moderno. Los urbanismos contemporáneos carecían de una nueva herramienta analítica para percibir la ciudad adecuadamente. Tanto como si le gusta o no, el urbanismo contemporáneo está obligado a captar todas las dimensiones sociales complejas. Si no se sigue dicha tendencia, los urbanistas que profesan el adoctrinamiento moderno no tendrían buenas opciones para poder tratar las energías y deseos complejos del hombre que se mueven debajo de la superficie de la fenomenología urbana. El urbanismo por lo tanto ya tiene que poder trabajar incorporando varias dimensiones físicas y no-físicas al mismo tiempo. En la Carta de Leipzig sobre Ciudades Europeas Sostenibles ${ }^{11}$ se proclama que la ciudad ya debe tratar directamente con los problemas demográficos, la desigualdad y exclusión social de las particulares poblaciones. La Carta reconoce que estos tipos de problemas no pueden solucionarse mediante la vigente perspectiva urbanística, lo cual significa un cierto menester de una nueva perspectiva política integrada de desarrollo urbano que puede fomentar la participación de los actores de diversos cuerpos gubernamentales, ONGs, empresas, patrones y ciudadanos. Ya es una época en la que los arquitectos tienen que, por ejemplo, entender la relación directa entre los asuntos del carril bici y la exclusión social de grupos específicos de la población. La Carta de Leipzig fue una teoría novedosa y en la perspectiva urbanística de aquel entonces, fue una heterodoxia. Cuando el mundo se introduce en la nueva era, siempre surgen nuevas teorías contundentes para poder percibir el mundo apropiadamente que se quedarán de manera ortodoxa hasta que pierdan su contundencia debido a una nueva circunstancia. En una perspectiva de ecología utópica, todos los urbanistas son utopistas y heréticos latentes. En resumen, la psicología de los seguidores del utopismo trata sobre la lucha con la ortodoxia para atraer constantemente la utopía a este mundo.

\footnotetext{
${ }^{11}$ Carta de Leipzig sobre Ciudades Europeas Sostenibles. Los ministros de Urbanismo de la Unión Europea. Leipzig. 02 mayo 2007.
} 


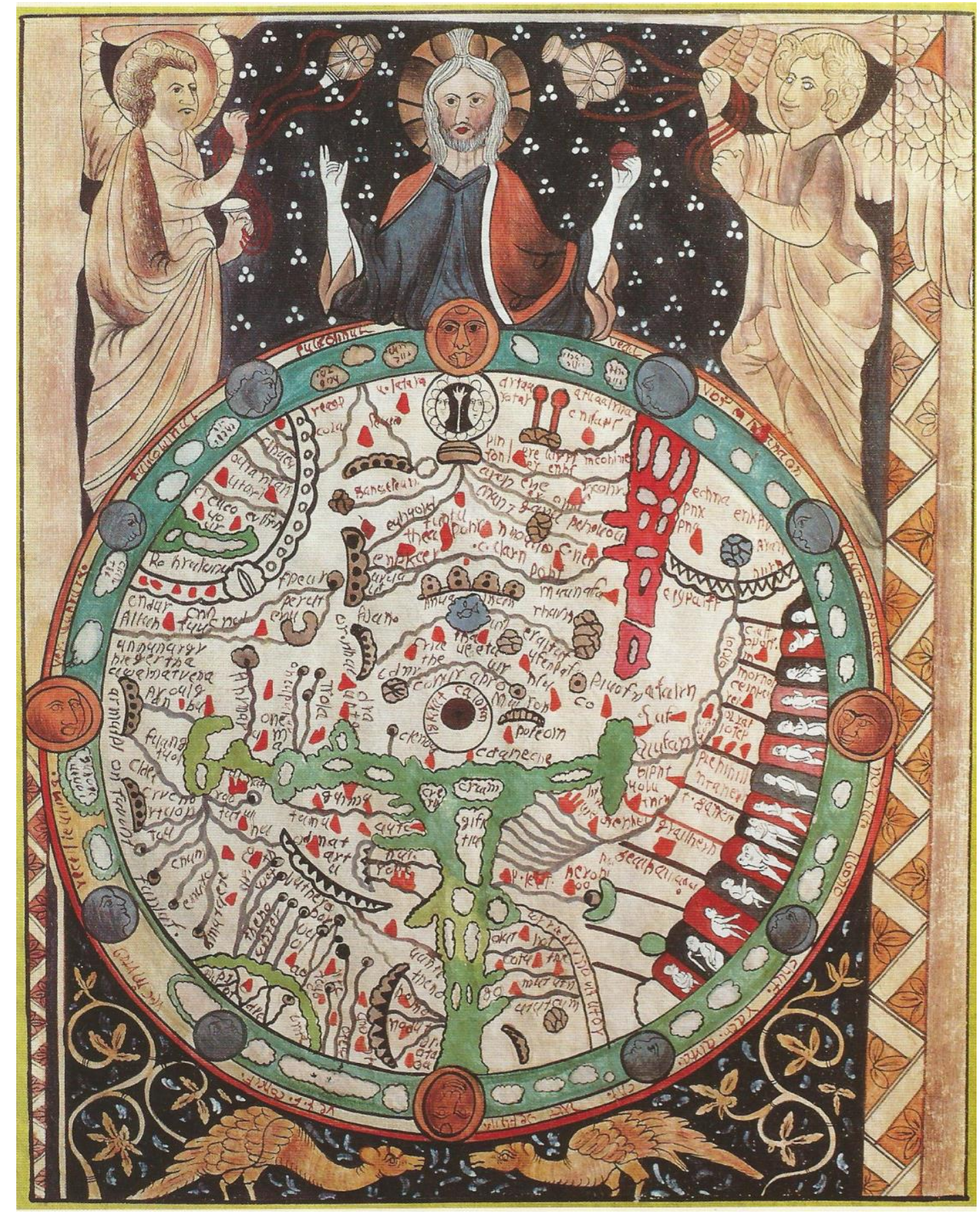

Fig. 0-1. La primera página del hebreo Sefer Yetzirah, o Libro de la Creación, s. XV. 


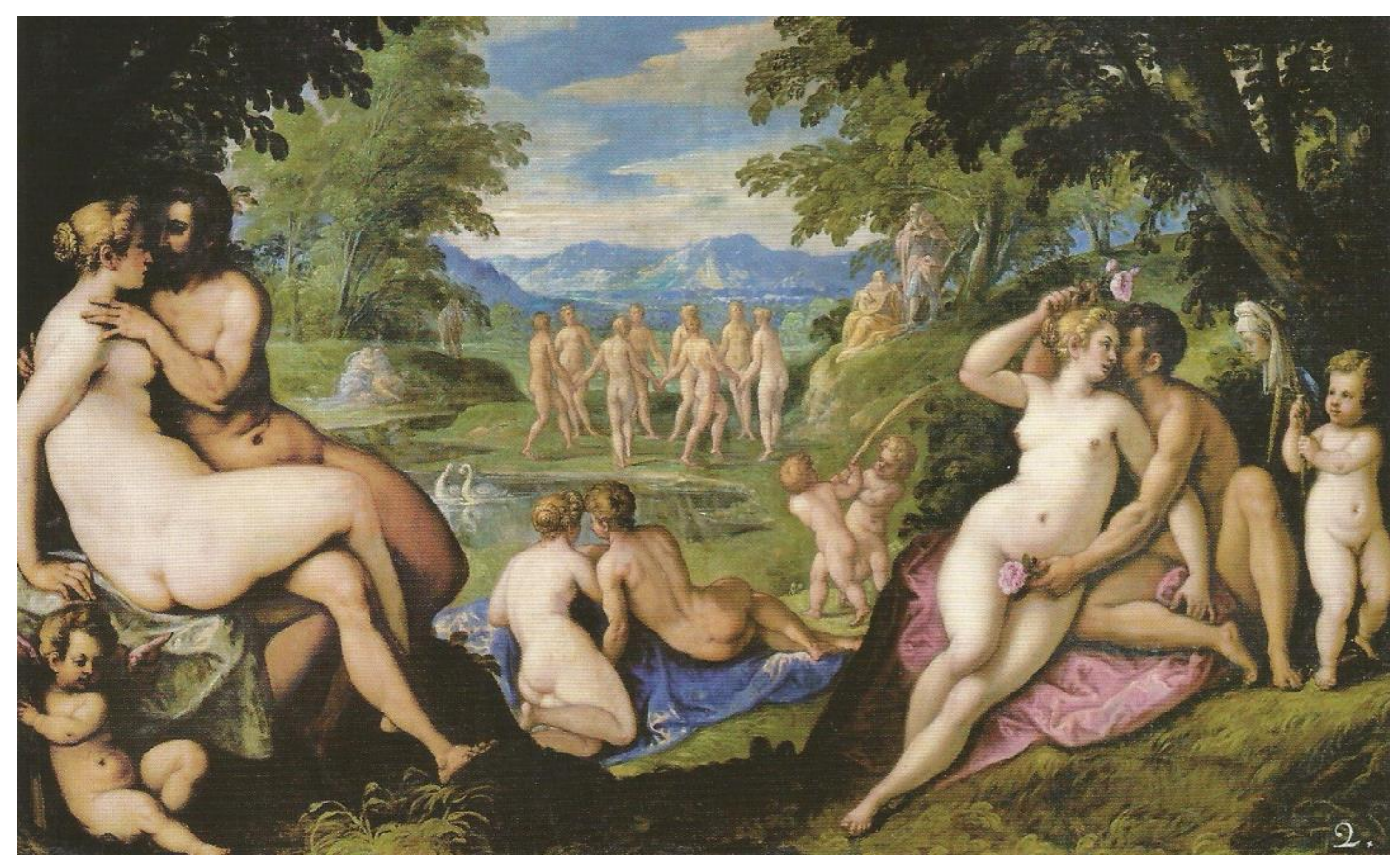

Fig. 0-2. El amor en la Edad de Oro, Pauwels Franck, c.1585-1589.

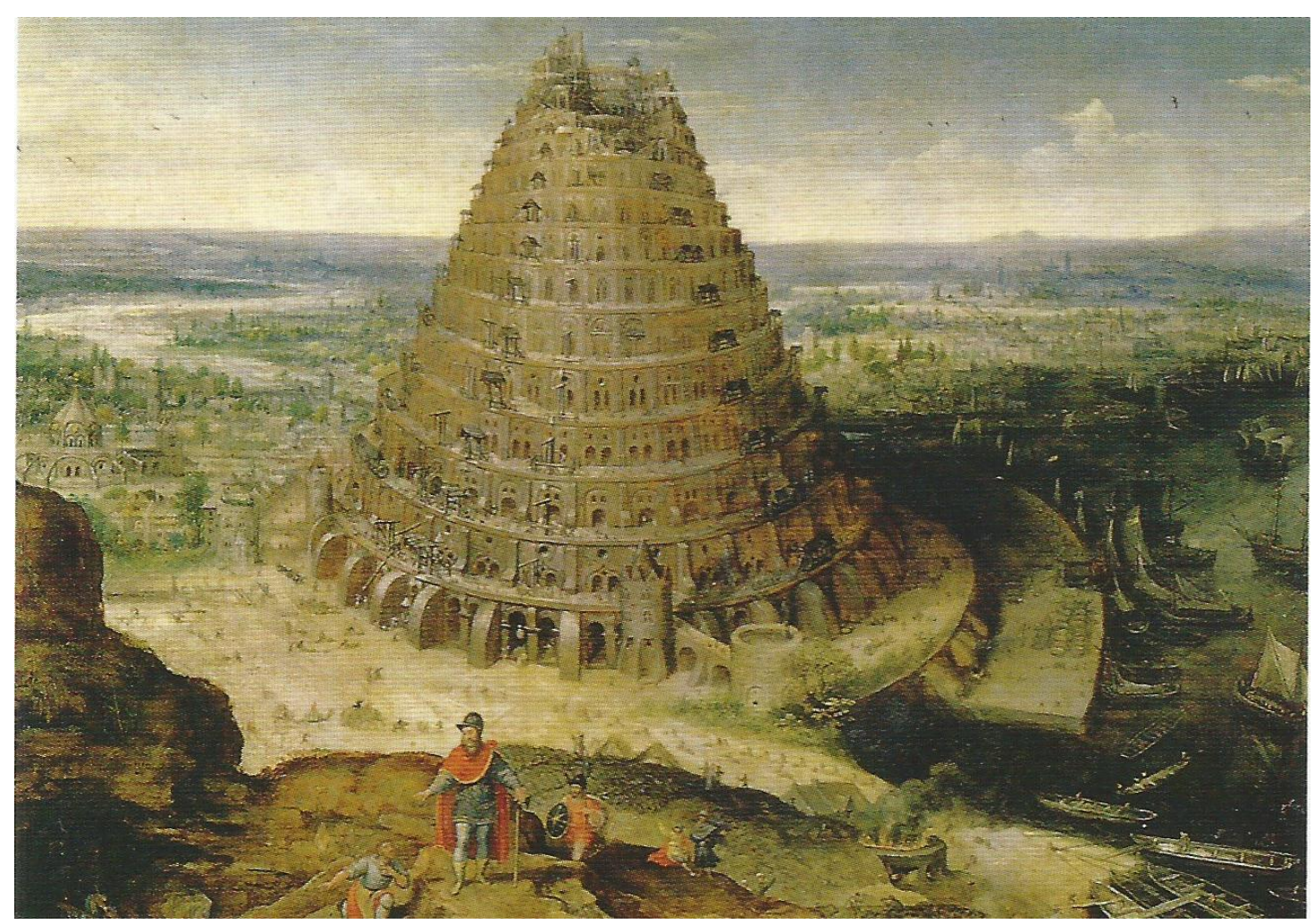

Fig. 0-3La Torre de Babel, Lucas van Valckenborgh, 1594. 


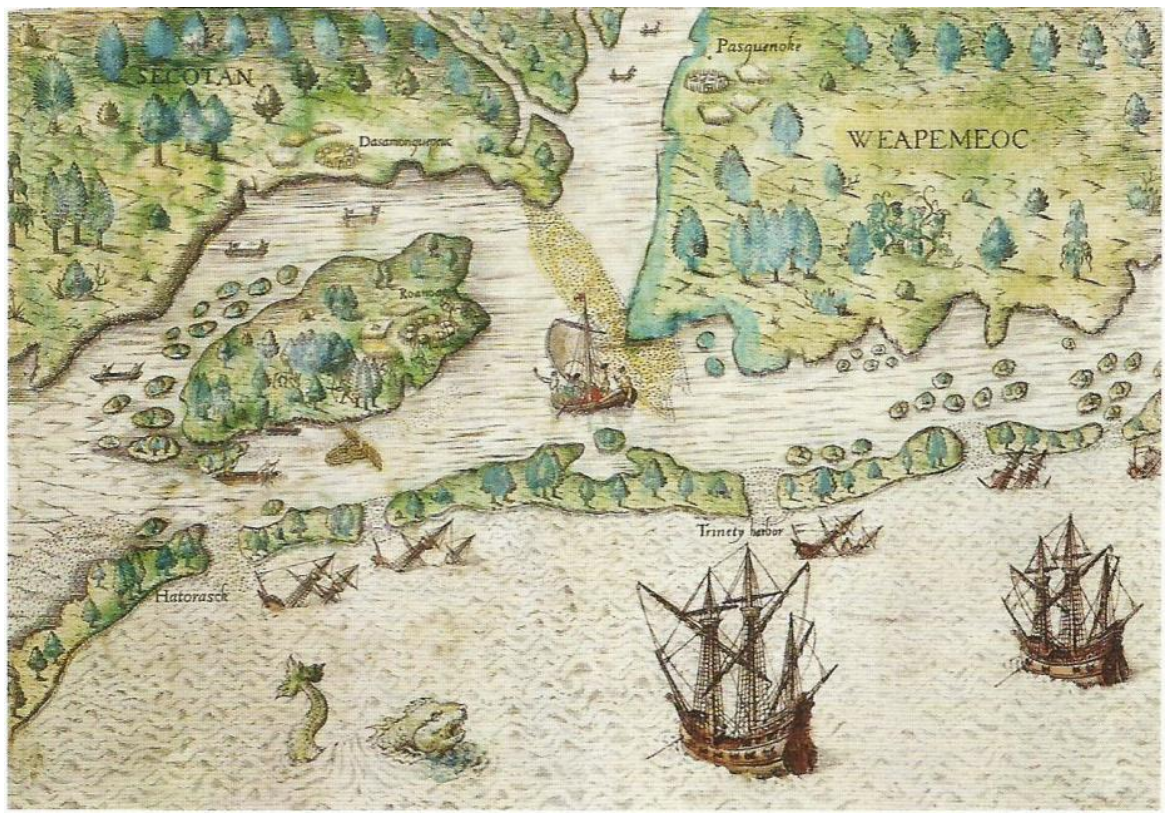

Fig. 0-4. La llegada de los ingleses a Virginia por Thodor de Bry.

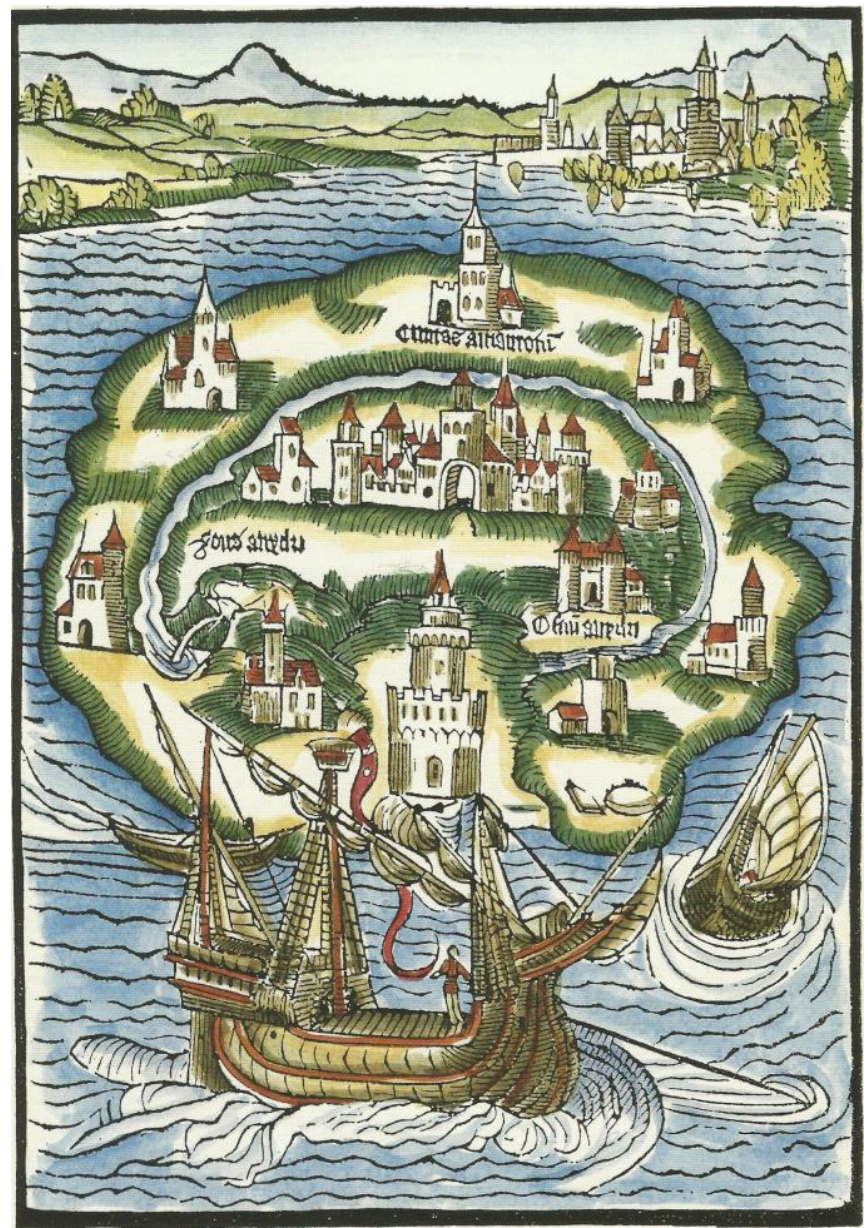

Fig. 0-5. Utopía de Tomás Moro, 1516. 


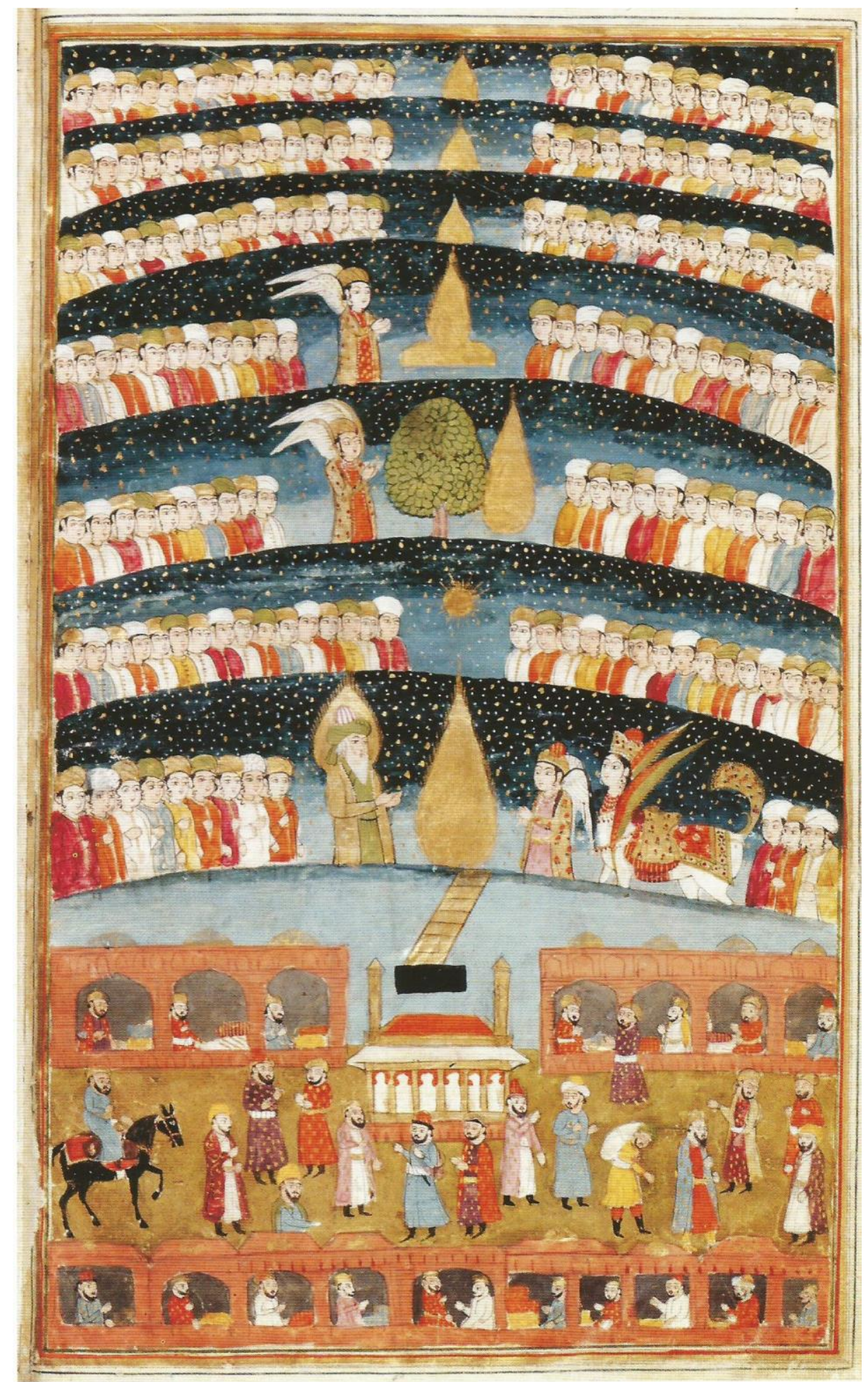

Fig. 0-6. El Paraíso de Mahoma, c. 1030. 


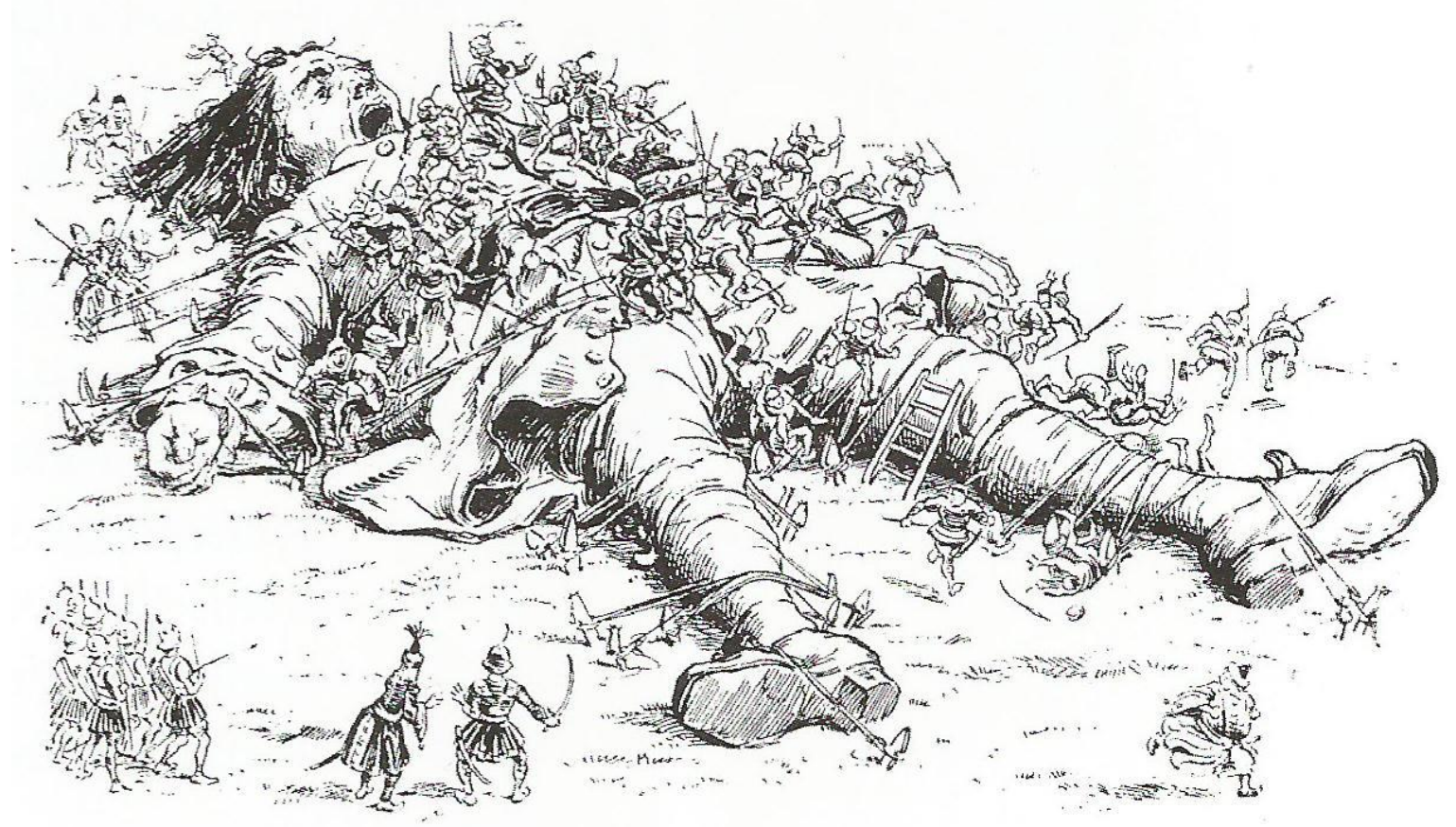

Fig. 0-7. Los viajes de Gulliver, Dibujo de E. C. Broch, de la edición de 1894.

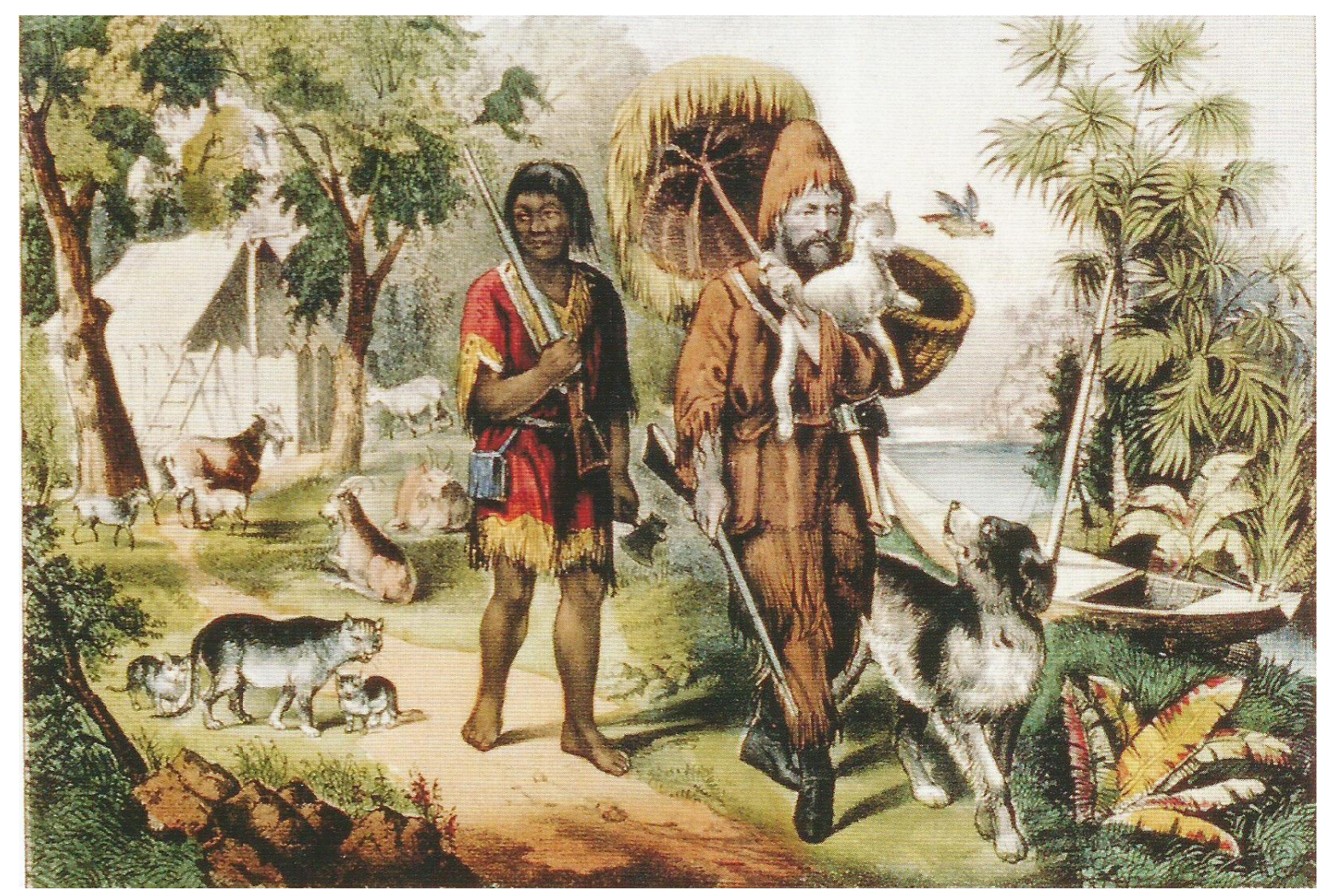

Fig. 0-8. Robinsón Crusoe y su criado Vie por Daniel Defoe, Litografía coloreada, 1874. 


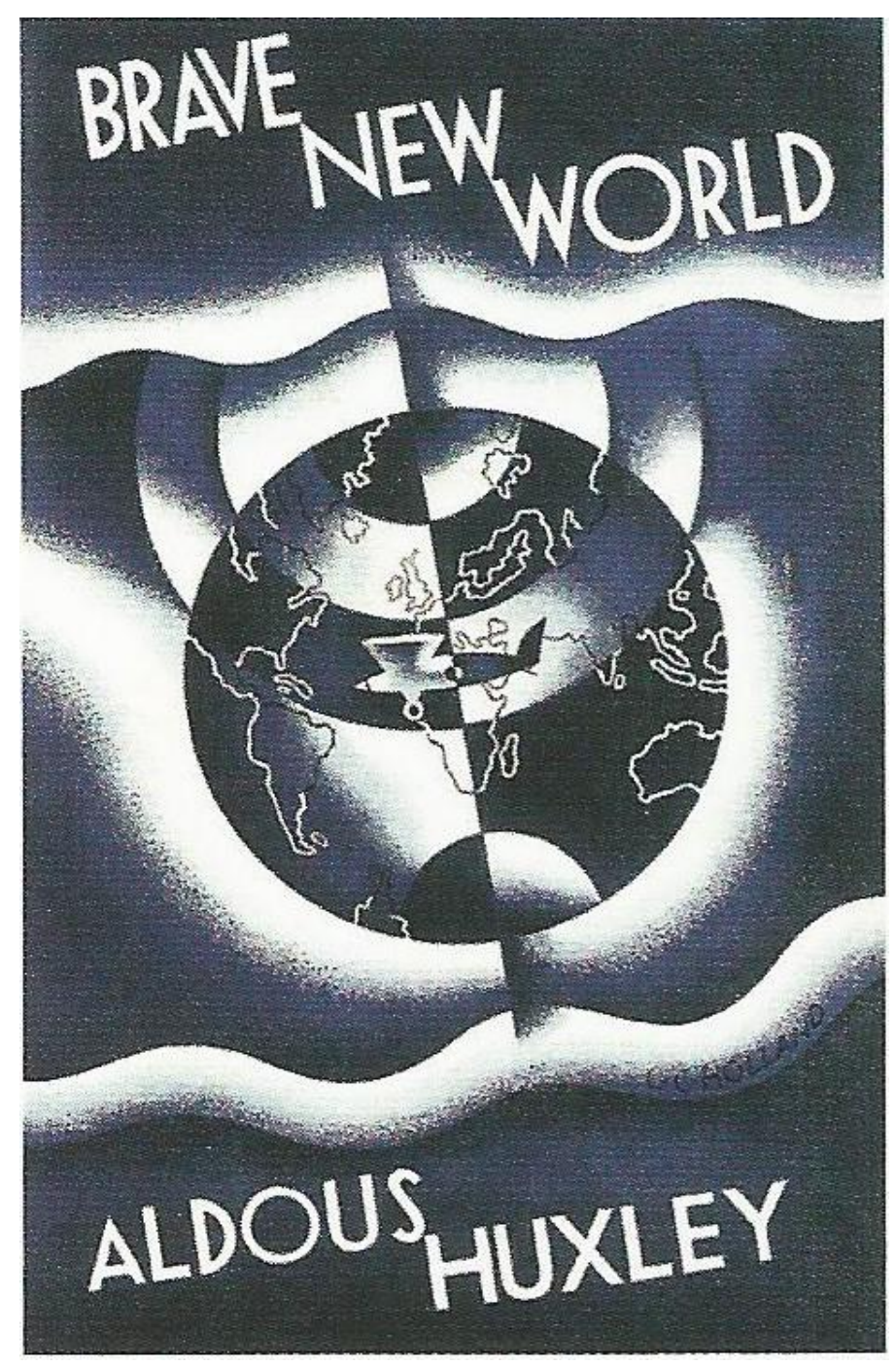

Fig. 0-9. Portada de Un mundo feliz, Aldous Huxley, 1932.

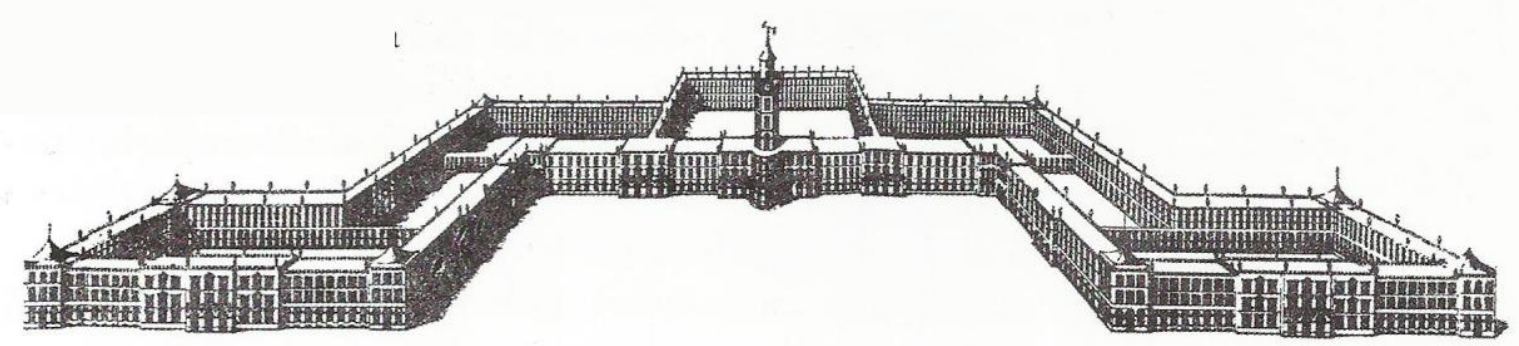

Fig. 0-10. Vista en perspectiva del Falansterio de Charles Fourier. s. XIX. 


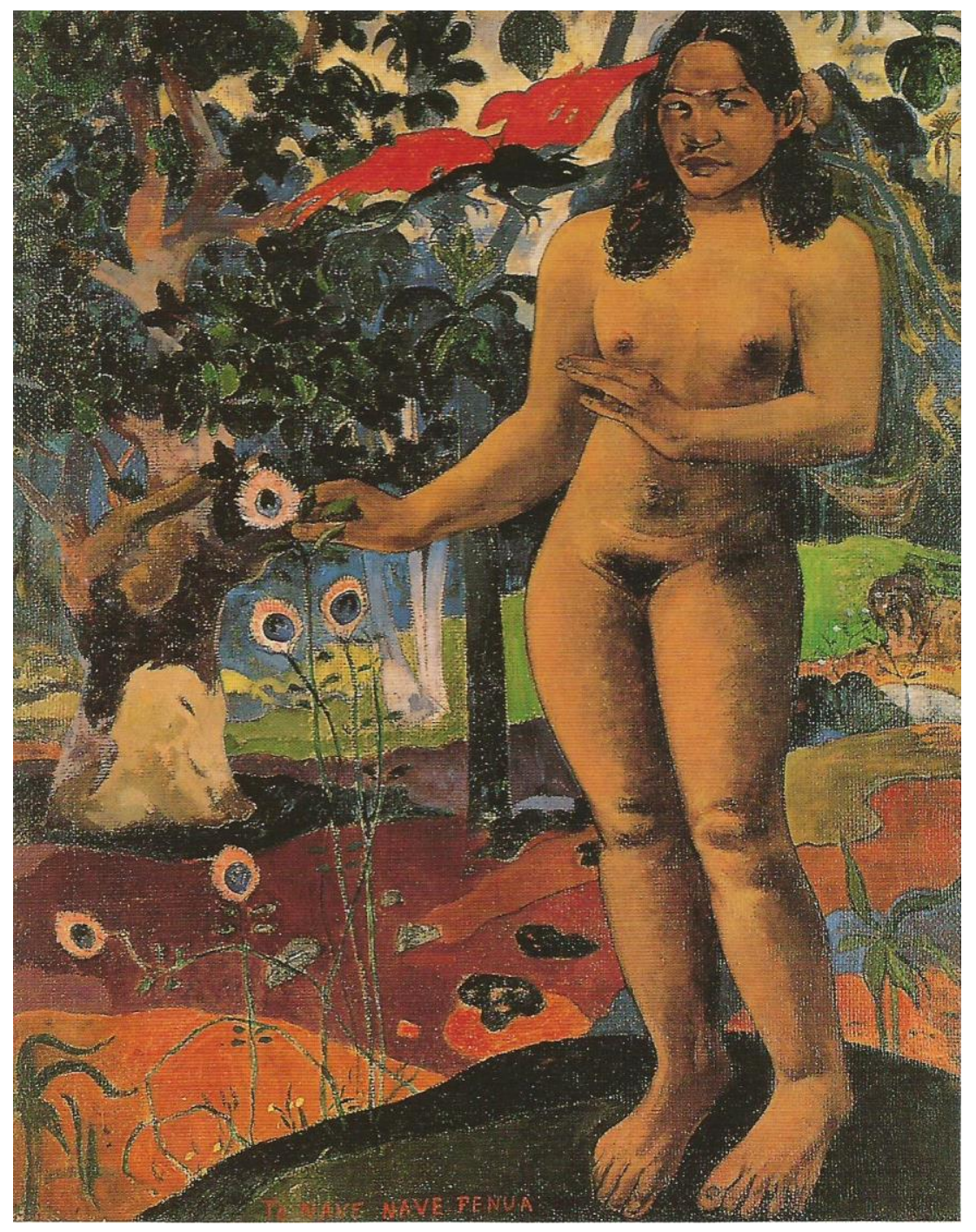

Fig. 0-11. Tierra deliciosa (Te nave nave fenua), Paul Gauguin, 1892. 


\section{El Nirvana como contraparte para la Utopía}

Ahora bien, $<<¿ Q u e ́$ es lo que hace especial a esta tesis? >>. Esta tesis, también puede recorrer la tradición utopista francesa del siglo XVIII - XIX, por ejemplo: Proudhon, Fourier, Saint-Simon y otros celebres eruditos, al final se podría llegar a una conclusión dialéctica fabulosa. Sin embargo, esta tesis no procede de esta manera, sino que va más allá, para no atraparse en un mero pensamiento anacrónico y decimonónico. Aquí sería necesaria una contraparte para completar y evolucionar el utopismo. Este estudio también responde en su origen y objetivos a aquel mensaje capital de José Ortega y Gasset con que concluye su relevante ensayo Meditación de la Técnica.

Pero la vida humana no es sólo lucha con la materia, sino también lucha del hombre con su alma. ¿Qué cuadro puede Euramérica oponer a ése como repertorio de técnicas del alma? ¿No ha sido, en este orden, muy superior el Asia profunda? Desde hace años sueño con un posible curso en que se muestren frente a frente las técnicas de Occidente y las técnicas del Asia. ${ }^{12}$

José Ortega y Gasset. 1957. Meditación de la Técnica.

Si los occidentales tienen la Utopía, los asiáticos tienen el Nirvana. Y curiosamente, a pesar de que los dos conceptos no son tan idénticos, en el término de que ambos persiguen un estado mejorado en su peculiar perspectiva, son gemelos. Anteriormente, esta tesis ya se ha referido sobre la relación entre la carencia y el utopismo. Si el utopismo se refiere al sistema y la ideología, el Nirvana es sobre la fenomenología y psicología, que son géneros inevitables cuando tratan de las ciudades contemporáneas, también es una contraparte de la tradición utopista ortodoxa para generar otro punto de singularidad, entrando en la dimensión herética de nuevo ya que es la virtud del utopismo. Este feliz matrimonio es el primer sentido ontológico de este estudio, al mismo tiempo es la respuesta de la pregunta anterior.

Como se ha comprobado, la teoría de esta tesis es sobre todo urbanística. Pero, más específicamente,

12 Ortega y Gasset, J. Meditación de la técnica y otros ensayos sobre ciencia y filosofía. Madrid. Alianza Editorial. 2004. 
dentro de las diversas ramas de la teoría de la ciudad, se trataría de una sección llamada antropología filosófica y social. Sin embargo, eso no implica una falta de consideración sobre los aspectos técnicos o el hecho de proceder demasiado conceptualmente. Porque dicha antropología también ha de tratarse, de todas formas, en algún espacio arquitectónico y urbanístico. Contemplando más profundamente dicha rama, finalmente, también podría referirse al Forma Nirvánica.

\section{El Nirvana per se}

El comienzo del utopismo fue indudablemente religioso. Según el evangelio, en occidente, para salvar la humanidad Dios descendió a su primogénito Jesucristo en semejanza de la carne y le hizo encargarse de todo el pecado de los humanos. Y cuando alguien le creyese, le permitiría la absolución y le justificaría por un ciudadano del Reino de los Cielos. La salvación de occidente fue celestial, y funcionaba como una herramienta moral que convence al comportamiento virtuoso para acoger el mito póstumamente. Pero contrariamente, la salvación del buddhismo es terrenal. No hay ninguna escena de Dios en la que pudiese ostentar su presencia. Buddha, el sabio tibetano sustituyó el lugar de los dioses por una epistemología universal con una base muy sólida. Él no presumió de la existencia de un dios externo. Si existe algún dios, para él eso tendría que ser interno de cada ser. Él reconoció que la vida es angustia. Según su adoctrinamiento, hay senderos nobles para acumular la angustia y otros para extinguirla. Claro que el estado en el cual la agonía está extinguida y no se acumula, es el Nirvana, que sería el término correspondiente a la Utopía occidental. El gran descubrimiento de Siddhartha, fueron estos caminos que llevan al Nirvana. Sin embargo, incluso actualmente en Asia y Occidente el buddhismo se entiende como una religión y aún se queda en un campo mítico. Parece que el buddhismo puede proveer una directriz de las acciones éticas para los humanos. Sin embargo, todavía existe alguna cierta dificultad de imaginar su capacidad más allá de sugerir los códigos éticos. Por eso, es una lástima que esta gran filosofía aún no haya podido comprobar su potencia como una herramienta espacial en los campos arquitectónicos y urbanísticos. La aplicación de esta filosofía ha estado limitada hasta hoy en día. Esta tesis intenta averiguar un código de acción pormenorizado y sistemático mediante la filosofía buddhista, no solo para una plataforma ética, sino también para proyectarla en aspectos urbanísticos y arquitectónicos. Esta tesis intenta tratar el concepto del Nirvana del buddhismo en la perspectiva arquitectónica y urbanística desde el nivel profundo de la esencia 
buddhista hasta el nivel práctico urbano. La tesis no pretende mostrar la superioridad de algunas arquitecturas de monasterios buddhistas de los montes de Asia, ni intenta construir las ciudades en el estilo de los templos buddhistas. Sí que ha existido en otros este tipo de nivel elemental en la interpretación del buddhismo en el campo arquitectónico, pero no era el propósito de este estudio. Esta tesis tampoco intenta proponer un estilo minimalista mezclado en un ambiente zen-buddhista de jardín, que es una aplicación superficial y mal interpretada. Excluyendo estos ejemplos de aplicaciones limitadas, en la adopción del concepto del Nirvana en el campo de la arquitectura y el urbanismo no ha existido ningún precedente de estudio por lo que sabemos, y resulta por tanto muy novedoso e incluso oportuno en las circunstancias contemporáneas.

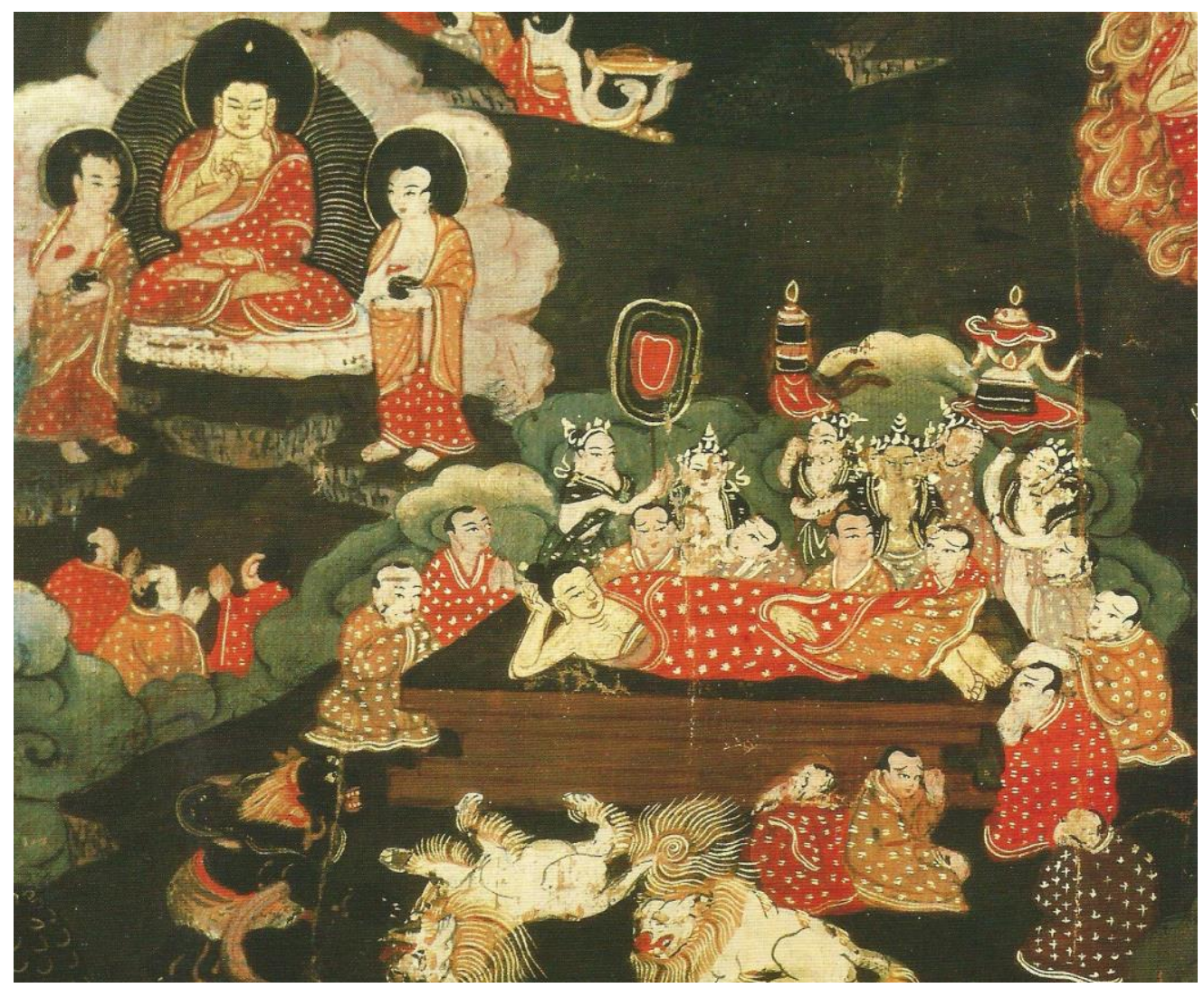

Fig. 0-12. Buddha en el nirvana, Tiet, s. XVIII. 


\section{El objetivo y la metodología del estudio}

El primer objetivo de este estudio es dilucidar una síntesis dialéctica confrontando dos conceptos heterogéneos que son la Utopía y el Nirvana. Y el segundo objetivo de este estudio es comprobar la contundencia de este estudio en un nivel práctico. Por eso, las investigaciones y los argumentos se suceden en los siguientes órdenes metodológicos.

La metodología de este estudio es sencilla y clara. En el primer capítulo, se van a presentar los mantras buddhistas cuáles son las esenciales enseñanzas de Siddhartha para llegar al Nirvana. En los capítulos desde 2 hasta 5, se investiga los proyectos utopistas del urbanismo en el siglo XX para analizar con el criterio buddhista que se adquirirá en el capítulo 1. En los capítulos 6 y 7 , se entienden las arquitecturas y jardines japoneses en los que están introducidas las filosofías zen-buddhistas que puede ser la contraparte del utopismo.

En los capítulos 8,9 y 10, se establecen los principios sobre la epistemología, la ética y la estética con los argumentos generales basando los datos analizados por los criterios nirvánicos. Y en los capítulos 11, 12 y 13, los principios nirvánicos se aplican en la ciudad real para comprobar su contundencia, como una nueva herramienta para poder percibir la ciudad en una perspectiva alternativa incorporando en el urbanismo los campos de la psicología y la fenomenología, positivamente y estratégicamente.

En el capítulo 14, basándose en los datos y principios que se han adquirido en los capítulos precedentes, se establece un nuevo principio avanzado llamado Forma Nirvánica, un índice práctico para poder describir y valorar los espacios en la perspectiva arquitectónica y urbanística.

En final, en el capítulo 15 y 16, se argumenta sobre el sentido ontológico de este estudio para esta era y la posibilidad para el tiempo venidero, añadiendo algunas explicaciones adicionales. El estudio llega a la conclusión. 


\title{
Apéndice
}

\author{
Nirvana \\ (Voz sánscr.). \\ m. En algunas religiones de la India, estado resultante de la liberación de los deseos, de la
} conciencia individual y de la reencarnación, que se alcanza mediante la meditación y la iluminación. ${ }^{13}$

Hay un equívoco que se puede cometer frecuentemente sobre la interpretación del Nirvana. Como está debidamente declarado, la definición de diccionario no insinúa que el Nirvana fuese el antimonio de la agonía o el dolor. En el marco del pensamiento occidental, el antónimo del dolor podría existir como varios vocabularios, pero principalmente serían: alegría, bienestar, calma, deleite, felicidad, gozo, hilaridad, paz, placer, satisfacción, tranquilidad y etcétera. Hasta aquí el sentido común occidental es bastante compatible con el oriental, salvo que en oriente la palabra $<<p a z>>$ es más adecuada al antónimo de <<dolor >> que la palabra <<alegría>>. En el mismo contexto, cuando piensa el antónimo de $<<$ placer $>>$, la diferencia entre las dos zonas culturales es más evidente. En la antigua India, el antónimo de <<placer>> era <<paz>>. ${ }^{14}$ En esta época, ya no hay tanta diferencia cultural a causa de a la globalización de todos los géneros culturales, mediáticos, académicos e incluso económicos. Por eso, en los países de Asia, por ejemplo, en India, China, Corea, Japón, el antónimo de <<placer >> sería: agonía, tristeza, depresión y etcétera los cuales son más exactos que $<<$ paz>> 0 <<tranquilidad >> como antónimo. Es decir, en algún sentido, placer, tristeza, agonía, alegría y tales palabras no son nada más que un grado de las emociones, así se categoriza en una rama. ${ }^{15}$ Pero al contrario, la palabra paz que Siddhartha percibió, es acerca de un estado que supera el impacto de las emociones. Un placer de un nivel extremadamente alto, también puede ser una agonía. Por eso, el Nirvana es un estado de sobre-emoción. Frecuentemente, el estado del Nirvana se suele metaforizar a un lago muy grande. Porque, en una fuente con baja profundidad, si se tira una piedra, la superficie

\footnotetext{
13 AAVV. Diccionario de la lengua española. Real Academia Española. 22. a edición. 2001.

$14 \mathrm{Kim}$, Yong-Ok. Do-ol encuentra la India. Lectura de serie en el aire en EBS (Educational Broadcasting System), Corea. EI programa fue emitido desde el 29 de agosto y hasta el 29 de noviembre del año 2002 durante 3 meses contando veintiocho lecturas.

${ }_{15}$ Ibid.
} 
de la fuente empezaría a sacudirse, pero en un lago enorme y profundo, si se tira una piedra, la superficie del lago aún mantiene su paz. La enseñanza de Siddhartha es increíblemente sencilla, es que el hombre sea como un gran lago. Si la ciudad puede llegar al estado del Nirvana, la ciudad tendría que ser un lago también. Siddhartha reconoció las causalidades de los dharmas (su significado literalmente es <<ley>> 0 <<principio>>, pero aquí se traduce como fenomenología.) para poder acoger las esencias las cuales son causas que generan las ondas en el lago llamado el hombre, quien es de mente y carne. Después de quitar la superficie de la fenomenología, se revela la verdadera cara de las cadenas de los dharmas, que también son la mente y la carne. No es sorprendente que la metodología para llegar al estado del Nirvana, tradicionalmente, implique las prácticas mentales (zen-buddhismo) y corporales (yoga). El zen no es algo solamente para adquirir una pequeña paz interior calmándose en una habitación de tatami enfrente de una pequeña escenografía japonesa. El zen-buddhismo debe distinguirse de dicha elemental filosofía, porque el concepto es más profundo de lo que parece. De este tema, se tratará en otro capítulo, profundamente e incluso sobre el ascetismo que es un método pervertido para llegar al Nirvana. El discurso y argumento del concepto del Nirvana para poder aplicarlo en el campo de la arquitectura y el urbanismo, se desarrollará dinámicamente en el proceso de este estudio. 


\section{Mantras del Buddhismo:}

\section{El camino para llegar al Nirvana}

mantra:

(Del sánscr. mantra, literalmente 'pensamiento').

m. En el hinduismo y en el buddhismo, sílabas, palabras o frases sagradas, generalmente en sánscrito, que se recitan durante el culto para invocar a la divinidad o como apoyo de la meditación. ${ }^{1}$

Como una historia común, el relato del buddhismo empieza con la aparición de un príncipe. Dicho príncipe era un sabio, y el pueblo le honró apodándolo con otro nombre, Buddha, que significa en sánscrito un santo o un personaje despertado. El nombre real de este Santo fue Siddhartha Gautama, nacido en el año 563 a. C. en Lumbini, situado aproximadamente a veinte kilómetros de la ciudad de Kapilavastu, república de Shakya, Reino de Kosala (ahora en Nepal) ${ }^{2}, 3$.Puede ser que exista controversia sobre la dirección del lugar y la fecha de su nacimiento, porque Lumbini está ubicado al sur de Nepal, cerca de la frontera Indiana, y existen varias teorías sobre su cronología biológica. Aun así, lo que importa ahora no es este tipo de informaciones, sino lo que él pensó y cómo.

\section{Dharma:}

(Skt., dhar, 'hold', 'uphold').

En el buddhismo (Pālli, dhamma) se conserva el sentido hindú de la ley y el orden cósmico, especialmente porque funciona en karma y reaparición según la ley del karma. Pero también se aplicó rápidamente a la enseñanza del Buddha (pariyatti) quien es él mismo una manifestación de la verdad que es dharma. Dharma entonces se entiende como la práctica (pariyatti) de esa verdad, y su realización en etapas (pațivedha) hasta el nirvana, de esta manera el dharma se convierte en un sinónimo. ${ }^{4}$

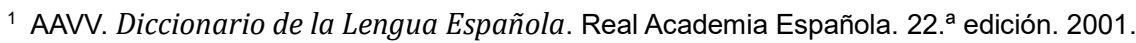

2 Vidal, C. Buddha El Príncipe. Madrid. Rotapapel, S.L.. 2011. p. 61.

${ }^{3}$ AAVV. Buddha. Encyclopædia Britannica Editorial. 2014. Fuente online: <http://global.britannica.com/EBchecked/topic/83105/Buddha>

${ }^{4}$ Bowker, J. The Concise Oxford Dictionary of World Religions. Oxford University Press. 1977. Fuente online: $<$ http://www.encyclopedia.com/topic/dharma.aspx\#1>
} 
Él es el resplandor de la gloria de Dios. Es la imagen misma de lo que Dios es. Él es quien sustenta todas las cosas con la palabra de su poder. Después de llevar a cabo la purificación de nuestros pecados por medio de sí mismo, se sentó a la derecha de la Majestad, en las alturas, y ha llegado a su superior a los ángeles, pues ha recibido un nombre más sublime que el de ellos.

Hebreos. 1:3. RVC.

El dharma, especialmente en el buddhismo, es un concepto que puede utilizarse con un amplio significado por el principio del universo kármico. ${ }^{5}$ Mediante la definición en sánscrito, se puede traducir por los principios que sostienen los fenómenos cósmicos. Según los contextos, se entiende como un particular sujeto o una entidad cognoscitiva del universo. $\underline{\text { Paralelamente, significa la doctrina de Buddha }}$ para alcanzar el Nirvana. ${ }^{6}$ Si se entiende el dharma solamente como una metodología nirvánica, en varios aspectos, esa noción tiene considerables semejanzas con la salvación de la cristiandad.

\section{Duḥkha: Angustia}

Antes de la célebre iluminación, la vida de Siddhartha fue una serie de experiencias desdichadas e insatisfechas. Su madre murió dándole a luz, la situación política y social se encontraba en crisis con un cambio de fronteras y el hambre, el reino estaba en un gran desafío de su existencia. ${ }^{7}$ El entorno al que perteneció, estaba siempre en una situación drástica. Así llegó a una tesis con firmeza, que la vida es la angustia. El vivir era la angustia. El envejecer era la angustia. Enfermar era la angustia. Hasta la cuestión de la muerte era la angustia. La vida humana fue un concepto negativo y oscuro para el príncipe. Incluso los momentos dichosos fueron angustias por su duración efímera. $<<$ La vida es la angustia. >> El Duḥkha no solamente significa que la vida es dolorosa. Es la tesis cósmica que captura

\footnotetext{
${ }^{5}$ Vidal, C. Buddha El Príncipe. Madrid. Rotapapel, S.L.. 2011. p. 138.

${ }^{6}$ Ibid. p. 139.

7 lbid. p. 134.
} 
todo tipo de Grenzsituation ${ }^{8}$ humana. ${ }^{9}$ Desde aquí, el sabio tibetano procede en su argumento.

\section{Pratītyasamutpāda: Co-surgimiento dependiente.}

Todas las condiciones son transitorias; todas las condiciones son dukkha, todas las condiciones están carentes de ser. ${ }^{10}$

Buddha

Entonces, ¿cómo surgen las angustias? El Co-surgimiento Dependiente (CSD) es la respuesta de esa pregunta. El término sánscrito de Pratîtyasamutpāda, se puede entender por tres palabras compuestas: pratītya (dependientemente)+sam (juntos)+ utpāda (levantar o surgir). Por eso, suele traducirse como coproducción condicionada u origen dependiente, de cualquier manera contiene los tres dichos significados. ${ }^{11}$ Imaginar un dharma llamado <<la clase de álgebra >>. El dharma de dicha clase consiste en otros varios dharmas como por ejemplo, un profesor de matemáticas, los estudiantes, muebles, el horario, el estilo de vestido, instituciones, libros, los comportamientos adecuados según los papeles etcétera. Y ahora suponer que un dharma llamado $<<$ el horario >> está quitado desde el dharma de $<<$ la clase de álgebra $>>$. El profesor llega a clase a las once de la noche y ayer llegó a las ocho de la mañana, y así arbitrariamente. Los estudiantes cada uno van como les conviene. ¿Se podría denominar esa situación como una clase de álgebra? El dharma llamado $<<$ la clase de álgebra $>>$ no puede existir. O por ejemplo está vez se elimina el dharma de $<<\mid$ os estudiantes $>>$. Todo es perfecto salvo que han venido los futbolistas que están jugando al fútbol en la clase, ante el profesor de matemáticas. ¿Aún podría llamarse a la clase, de álgebra? Así que todos los dharmas en este mundo surgen condicionalmente y dependientes a otros. Entonces, esta perspectiva de los dharmas dependientes se expande aplicándolos a las cuestiones de la angustia. Supuestamente, sería lógico

\footnotetext{
${ }^{8}$ En ingles, limit-situation, y en español podría traducirse como las condiciones extremas. Se indica las situaciones que la gente no puede elegir ni evitar como: el nacimiento, la coincidencia, el conflicto, el dolor, la muerte y etcétera. El concepto se desarrolló por un célebre filósofo alemán, Karl Jaspers.-(NdA)

${ }^{9} \mathrm{Kim}$, Yong-Ok. Do-ol encuentra la India. Lectura de serie en el aire en EBS (Educational Broadcasting System), Corea. EI programa fue emitido Desde el 29 de Agosto y hasta el 29 de Noviembre del año 2002 durante 3 meses contando veintiocho lecturas. Do-ol es un seudónimo de Yong-Ok Kim.-(NdA)

10 Batchelor, S. Buddhismo sin Creencias. Moraza, Ignacio José (tr.). Madrid. Gaia ediciones. Versión española. 2008. p. 148.

11 Este término, en inglés se traduce por: dependent origination, dependent arising, interdependent co-arising, conditioned arising, etc-(NdA)
} 
que Siddhartha pensara que el dharma de la angustia también podría entenderse de esa manera. Fue en ese momento en el que un mero tibetano se convirtió en Buddha. Ésta no es una metáfora obsoleta como una relación simbiótica de un cocodrilo y un pájaro, más bien, es de las cuestiones ontológicas de los orígenes.

\section{Śūnyatā: Vacío}

El Vacío es un concepto derivado desde CSD. Se debe entender que ya no hay ninguna entidad independiente que puede existir en el mundo de Siddhartha. Hasta la muerte y la vida surgen por los dharmas Inter-dependientes. No hay ningún dharma permanente. Sólo existe en una circunstancia condicionada. Eso es el significado del Vacío. No se refiere a que no existe, sino que existe solamente $\underline{\text { con las condiciones provisionales. Los dharmas siempre están vacíos. } \leq<E \text { El concepto llamado el Vacío }}$ no es la cuestión de existir y no existir, sino que es una modalidad de existir.>>12 Ahora habría que tener la precaución de no incidir en un mero nihilismo, porque primero, el nihilismo está fuera de moda y es anacrónico. Y segundo, porque el buddhismo es para llegar una ética integral impecable, ya que no se puede alegar un ego perpetuo, y se percibe a los ajenos por los dharmas que forman una parte del mundo. Así el concepto del Vacío ofrece una posibilidad de crear la ética de Causa sui13. El Buddhismo es ateísmo. Pero si existiese un dios, esa perspectiva epistemológica es el dios. Como el Dios del cristianismo también, la causa de sí es su esencia ontológica. ${ }^{14}$

\section{Anātman: No-yo}

...Ni empiezan ni acaban. Ni nacen ni mueren. Surgen de una matriz de condiciones y a su vez se vuelven parte de otra matriz de condiciones de la que surge alguna otra cosa. ${ }^{15}$

\footnotetext{
${ }^{12}$ Kim, Yong-Ok. Do-ol encuentra la India. Lectura de serie en el aire en EBS (Educational Broadcasting System), Corea. EI programa fue emitido en 10 de Octubre. 2002.

${ }^{13}$ Es un término en latín que se puede traducir por la causa de sí.-(NdA)

14 Spinoza, B. Ética demostrada según el orden geométrico. Peña, Vidal(tr). Madrid. Alianza Editorial. 9ed. 2007. p. 45.

${ }^{15}$ Batchelor, S.1997. Buddhismo sin Creencias. Moraza, Ignacio José (tr.). Madrid. Gaia ediciones. Versión española. 2008. p. 100.
} 
Ningún dharma posee un ātman ${ }^{16}$ eterno e independiente. Resulta obvio que esa tesis es una conclusión derivada fácilmente. Anātman es una palabra a la que se le ha añadido $<<A n>>$ a <<ātman>>, es decir, el negativo de yo, No-yo (NY). Es un término útil para entender la ética buddhista porque, si la práctica de la bondad requiere una motivación, la mejor intensidad de motivación viene desde uno mismo. El genuino buddhismo no refiere el amor para los ajenos, ya que no hay yo. Eso significa que no hay división entre el yo y los ajenos.

\section{Catvāri Āryasatyāni: Las cuatro nobles verdades}

Las cuatro nobles verdades (4NV) consisten en cuatro nociones perspicaces de Siddhartha. La primera noble verdad se refiere a la angustia fatídica de la actualidad humana. La segunda noble verdad se refiere al origen de la angustia. Eso significa que todas las angustias tienen sus orígenes que son los dharmas encadenados. La tercera noble verdad se refiere a la extinción de la angustia, significa que se puede eliminar la angustia por una particular metodología. Por último, el camino (método) para eliminar la angustia, suelta a los dharmas problemáticos (que producen los dolores) es la cuarta noble verdad. En el buddhismo, la primera y segunda noble verdad hacen una pareja y forman una fórmula que podría traducirse más o menos así: Acumulación del Dolor (AD). Del mismo modo, la tercera y la cuarta hacen otra pareja y forman otra fórmula que podría traducirse como: Extinción del Dolor(ED). Así que éstas dos fórmulas representan una manera de percibir el mundo en el que están encadenados los dharmas, y depende de cómo se organicen los dharmas, se puede acumular y/o extinguir el dolor.

Se propone a continuación una explicación como ejemplo: Hay un hombre. Eso es el dolor por su existencia de forma ontológica en el término del buddhismo. Aquí no cabe duda de que eso es la primera noble verdad, por otra parte este hombre quiere casarse con la Madre Teresa. Pero eso es imposible porque, primero, ella ya no existe en la tierra, y segundo, ella es una persona consagrada a

\footnotetext{
${ }^{16}$ En sánscrito significa sí mismo o ego.-(NdA)
} 
Dios, por lo que se encuentra con mucha dificultad para cumplir su deseo. Además de miles de razones, así él está sufriendo. Eso es la segunda noble de verdad.

Ahora se percibe la causa de su sufrimiento, el deseo imposible de este hombre es la causa del dolor, y al mismo tiempo es un dharma que puede conectarse a las dos nobles verdades. Si se conecta a la primera verdad, se cae en el sufrimiento, por contra, si se conecta a la cuarta noble verdad, es la extinción de los apetitos vanos, teniendo una visión correcta, lo que equivale al Nirvana. ${ }^{17}$ En el buddhismo hay ocho prácticas para llegar al Nirvana.

El Sendero Medio ${ }^{18}$

1. Visión u opinión justa (o correcta).

2. Pensamiento correcto.

3. Palabra correcta.

4. Actividad correcta.

5. Medios de vida correctos.

6. Esfuerzo correcto.

7. Atención correcta.

8. Concentración correcta.

Ahora bien, aún si ha sido brevemente, ya se han adquirido las nociones primordiales del Buddhismo que se tratarán en los proyectos utópicos siguientes.

17 Vidal, C. Buddha El Príncipe. Madrid. Rotapapel, S.L.. 2011. p. 136.

18 Ibid. 


\section{Ciudades-jardín del mañana de Ebenezer Howard:}

\section{Hacia la verdadera reforma social}

Este capítulo, y también los siguientes, no tendrán como objetivo presentar y revisar la historia de las diversas teorías urbanas, sino que se revisarán aquellas significativas que permitan entender lo que se percibe como utopía urbana. Por tanto no será necesario recorrer toda la historia exhaustivamente en un orden cronológico.

Aunque los casos de estudios que ahora se van a exponer, están tratados y publicados en numerosos libros, tesis y artículos, en el presente capítulo se van a analizar desde la perspectiva nirvánica (presentada en el capítulo anterior). En esta investigación es necesario revisar yuxtapuestamente el presente y el pasado de cada teoría del utopismo como si de un banco de pruebas se tratase y examinar las filosofías básicas y metodologías de las teorías antiguas sobre el concepto de utopía. Además, la situación de crisis actual (tratada en el capítulo cero) no es un caso aislado, de igual forma la gente y los partidarios de dicha utopía también vivieron su propia era urbana de crisis. Al igual que para saber si el coche que ha comprado es bueno o no, se conduce por la calle, se tratarán las obras de otros autores que desarrollan los teorías del utopismo occidental, y se analizarán desde el criterio nirvánico. Las contradicciones internas de cada teoría se hallarán a medida que avance el estudio y se configurarán en cada fase las virtudes de la ciudad nirvánica a través del acercamiento de la metodología dialéctica provisional. Así en cada fase se concreta, materializa y completa el concepto de la ciudad nirvana. Para conseguir esto, se han de evitar los prejuicios, el fanatismo religioso buddhista y la fe ciega. Así que los siguientes capítulos tendrán como finalidad aclarar y consolidar los cimientos de la ciudad nirvánica. 


\section{La sombra subversiva del siglo XIX}

La ambigüedad del siglo XIX consiste totalmente en la exhibición libre de una conciencia falsa, que intenta una última redención ética demostrando su falta de autenticidad. ${ }^{1}$

Manfredo Tafuri. 1973. Arquitectura y Utopía.

La lectura del libro Ciudades del mañana de Sir Peter Hall, es la forma más fácil para comprender la época apocalíptica en los años de 1880-1900 de Londres, lugar que perdió toda su gloria después de pasar por un buen periodo. Si se tiene la oportunidad de leer las historias de las vidas miserables de los pobres que vinieron desde el campo y apenas encontraron su lugar en Londres seguramente se conmoverá incluso el corazón más duro.

Cada habitación de estas putrefactas y pestilentes viviendas alberga una familia, a veces dos. Un inspector de sanidad anotó que en una de ellas encontró al padre, la madre, tres niños y cuatro cerdos! En otra un misionero había visto un hombre enfermo de viruela, su esposa que se estaba recuperando del octavo parto, y los niños corriendo por allí medio desnudos y llenos de porquería. Aquí hay siete personas viviendo en una cocina subterránea, con un niño pequeño muerto en la misma habitación. Más allá una viuda pobre, sus tres hijos, y un niño que había muerto hacia tres días. Su marido que era conductor de coches, se había suicidado hacía poco.

Pregunta a los hombres y mujeres que viven en estas pocilgas si están casados y lo único que obtendrá es una sonrisa. Nadie lo sabe. A nadie le importa. Nadie espera que deban estarlo. Sólo, en muy pocos casos, su pregunta recibirá una respuesta afirmativa. El incesto es común: no hay vicio ni sensualidad que despierte sorpresa ni llama la atención... Lo único que no les hace caer en el comunismo es la desconfianza, no la virtud, las prácticas más viles son vistas con la mayor indiferencia(...) En una de

\footnotetext{
1 Tafuri, M. Architecture and Utopia: Design and Capitalist Development. Penta, B. L. (tr). Massachusetts. The MIT Press. Versión inglesa. 1976.
} 
las calles hay 35 casas, de ellas 32 son burdeles. En otro distrito hay 43 casas con 428 prostitutas entre mujeres y niñas, muchas de las cuales no tienen más de doce años. ${ }^{2}$

La forma de los barrios de Slum en Londres se estaba extendiendo como un cáncer despiadado, a lo largo de St Martin, St Giles, Drury Lane, Holborn, Saffron Hill, Clerkenwell y hasta St Lukes, desde allí hacia el este de Whitechapel, y cruzando el río hasta Southwark. ${ }^{3}$ Estas personas humildes también habían de nacer con un derecho humano, como tener un hábitat decente como otros miembros de la sociedad. En esa situación, a pesar de los movimientos filantrópicos y del gobierno, no se obtenían resultados positivos, los terratenientes utilizaban su monopolio heredado.

En la relación diabólica entre los terratenientes y los inquilinos impotentes, no se veía ninguna posibilidad de mejora, a no ser que se ejercitara una reforma social. En consecuencia, no fue sorprendente que varias visiones anárquicas y el utopismo fueran aceptadas por los grupos de pensadores de aquel tiempo en Londres. Si se puede aceptar esta situación tan cruel, en relación con la explicación de los darwinistas, eso podría considerarse un fenómeno natural como sus teorías, llamada <<supervivencia del más apto>>. Entonces, si se capta con esta teoría a los humanos, ¿Dónde podría encontrarse la humanidad para que se distinguiese de los animales y dónde está el legado de la industrialización tras del desarrollo brillante de la tecnología; aún se está en el mismo ambiente de los salvajes en un bosque de hormigón armado? Howard no fue darwinista. Él habría pensado que la competencia de supervivencia no es el factor de evolución. ${ }^{4}$ De cualquier modo, la intervención fue inevitable. Howard, tras conocer a Piotr Kropotkin (1842-1921), veía en las nuevas tecnologías la llave, a escala regional, para la desconcentración del hacinamiento en Londres y en otras grandes ciudades, hacia comunidades en el campo, cada uno en relación orgánica con las regiones agrarias de sus alrededores. ${ }^{5}$

\footnotetext{
2 Mearns, A. v.o. 1883, The Bitter Cry for Outcast London: An Inquiry into the Condition of the Abject Poor. London. James Clarke. La citación está referenciada por la fuente secundaria: <Hall, P. v.o. 1988, Cities of Tomorrow: An Intellectual History of Urban Planning and Design in the Twentieth Century. Freixa, Consol(tr). Barcelona. Ediciones Serbal. Versión española. 1996. p. 27>

${ }^{3}$ Yelling. Slums and Redevelopment: Policy and Practice in England. London. University College London Press. 1918-1945. La citación está referenciada por la fuente secundaria: < Hall, P. v.o.1988, Cities of Tomorrow: An Intellectual History of Urban Planning and Design in the Twentieth Century. Freixa, Consol(tr). Barcelona. Ediciones Serbal. Versión española 1996. p. 27> ${ }^{4}$ Kropotkin no niega el concepto de la competencia en el estado natural, sin embargo él consideró que el factor más crucial de la evolución y la prosperidad de los seres, era el apoyo mutuo.-(NdA)

${ }^{5}$ AAVV. Urban Planning in a Changing World: The Twentieth Century Experience. London. E \& FN Spon. 2000. p. 23.
} 
Los males presentes de la vida de la ciudad son temporales y remediables. La abolición de los barrios pobres, y la destrucción del virus, son tan factibles como el drenaje de un pantano, y la disipación total de sus miasmas. Las condiciones y circunstancias que rodean la vida de las masas populares en las ciudades modernas pueden ser ajustadas en sus necesidades respecto al alto desarrollo de la raza, en el cuerpo, en la mente y en el carácter moral. Los Ilamados problemas de la ciudad moderna no son más que las diversas fases de una cuestión principal: ¿Cómo puede ser el entorno más perfectamente adaptado para el bienestar de las poblaciones urbanas? La ciencia puede analizar y resolver cada uno de estos problemas. La ciencia de la ciudad moderna -del orden de las preocupaciones comunes en el grupo denso de la población- se basa en muchas ramas del conocimiento teórico y práctico. Incluye la ciencia administrativa, la estadística, la ingeniería y la ciencia tecnológica, la ciencia sanitaria y las ciencias de la educación, social y moral. ${ }^{6}$

Albert Shaw. 1895. Municipal Government in Great Britain.

\section{Influencia desde Kropotkin y Bellamy}

La estructura principal de esta idea (la descentralización de la ciudad de Londres) pudo adquirir mayor certeza cuando Howard la compartió con Kropotkin ${ }^{7}$, referente de los anarquistas, y desde él habría podido conseguir el concepto de la propiedad colectiva y cooperativismo, ${ }^{8}$ y en vez de un gobierno, una cooperación voluntaria en el sistema de producción. ${ }^{9}$ Howard pudo concretar la imagen de la ciudad-jardín en el año 1888. Esto fue después de leer la novela Looking backward de Edward Bellamy en la que el autor quería que todos fuesen rigurosamente disciplinados durante 24 años en

\footnotetext{
${ }^{6}$ Shaw, A. 1895. Municial Goverment in Great Britain. La citación está referenciada por la fuente secundaria: <Howard, E. Garden Cities of To-Morrow. London. S. Sonnenschein \& Co., Ltd. segunda edición. 1902. p. 42>

7 Hall, P. v.0.1988, Cities of Tomorrow: An Intellectual History of Urban Planning and Design in the Twentieth Century. Freixa, Consol(tr). Barcelona. Ediciones Serbal. Versión española 1996. pp. 101-102

8 Kropotkin fue básicamente anarquista, así que no quiso una organización centralizada, más bien, quería la máxima descentralización como Howard.-(NdA)

9 Claeys, G. Searching for Utopia: The history of an idea. Condor, M(tr). Madrid. Ediciones Siruela. Versión española:2011. p. 148.
} 
un sistema comunal de educación, para que cada uno pudiese ser un trabajador necesario en la sociedad hasta que tengan cuarenta y cinco años sin excepción.

Las industrias están nacionalizadas y se realiza el cien por cien del pleno empleo por el estado. El estado es un ejército de soldados industriales. Todas las industrias: agricultura, granja, maquinaria, minería, bancaria, ferrocarril y etcétera, están organizadas burocráticamente perteneciéndose a una organización central. Aquí no hay democracia sino gerontocracia o plutocracia de una minoría de sabios y un general, que dirigen toda la dirección de sus industrias. ${ }^{10}$ La vida decentemente alimentada y protegida sería un posterior regalo si se siguiera dicho ejército industrial. ${ }^{11}$ Howard pudo soñar la imagen de una comunidad de trabajadores capacitados y reunidos. Pero fue escéptico sobre el gobierno central burocrático. En la utopía de Bellamy no existían ni la crisis de la economía ni la discriminación de salarios, pero aun así no era tan agradable. Howard también fue consiente de la necesidad de una comunidad para proteger las vidas de los obreros. Y Bellamy fue muy radical, viendo como única solución la nacionalización de toda la tierra. ${ }^{12}$

Por otro lado, la solución de Howard es más viable y práctica; crear una comunidad que aproveche los beneficios que se derivan, mientras el valor de la tierra aumenta gradualmente, logrando de ese modo que dicha comunidad sea independiente de los terratenientes. De todas formas, la doctrina de Bellamy influyó mucho en la idea de la reforma agraria de Howard, transformándolo desde un mero taquígrafo ${ }^{13}$ a un líder carismático.

Howard soñó que la verdadera reforma social fuera transcendiendo el plan regional, mediante un plan alternativo a la pervertida urbanización de Londres, que había creado un lugar terrible en la era victoriana. Parecía obvio que los elementos de la ciudad-jardín como baja densidad poblacional, vivienda decente, caminos espaciosos, transporte público y vastos espacios abiertos, no van a propiciar gente vulgar, borracha, inmoral, es más, va a divulgar el mensaje que dice que esa ciudad funciona bien por lo que no hace falta ninguna acción revolucionaria ni conflicto para adquirir una vida

\footnotetext{
10 Mumford, L. The Story of Utopias. Boni and Liveright, Inc.. $4^{\mathrm{a}}$ edición. 1928. p. 161.

11 Idem. p. 168.

12 Bellamy no explica cómo se puede lograr este tipo de utopía. Porque Julius West, el protagonista de la novela, de repente se despierta en un futuro superando 113 años desde el presente.-(NdA)

13 Howard, su profesión fue de taquígrafo.-(NdA)
} 
decente. Mientras tanto, el grupo del parlamento y los nobles estaban asustados del riesgo latente de que surgiera una revolución subversiva desde la clase baja. ${ }^{14}$

En este sentido, un movimiento filantrópico como el de Howard habría sido una solución bienvenida para cualquier clase social. Como está bien explicado por Kropotkin en Apoyo mutuo ${ }^{15}$, las sociedades de responsabilidad limitada de Howard estaban siguiendo la doctrina de Kropotkin persiguiendo el beneficio mutuo entre cooperantes y tenía fe de que si se podía reducir los conflictos de los individuos al mínimo y realizar el apoyo mutuo, entonces se crearía el compromiso que garantizase un futuro brillante y de prosperidad. ${ }^{16} \mathrm{El}$ adoctrinamiento también fue eficaz en aquel tiempo de Londres. Así, Howard fue completamente consciente de la necesidad de la reforma social y tuvo carisma suficiente para convencer a los jóvenes ricos partidarios y los intelectuales que estaban interesados en ese tipo de proyectos.

Es cierto que Howard también fue radical como Bellamy, sin embargo, él no consideró que el socialismo fuese la panacea en aquella situación lúgubre. Más bien, Howard consideró que la democracia y la cooperación serían los remedios para extinguir los conflictos de las clases; Parece ser que él creyó que el individualismo y el socialismo pueden tener una conciliación adecuada. Los terratenientes que generan conflictos sin fin entre los capitalistas y los obreros, eran la raíz del mal, y ellos fueron capaces de amenazar al Parlamento de Inglaterra. Para realizar la verdadera reforma, Howard debió pensar que ese poder tenía que romperse, o, por lo menos, era necesaria la existencia de otro poder para compensarlo en el mismo grado. La realización de esta idea fue imposible sin cooperación voluntaria. En ese sentido se puede considerar que la idea ayudó a hacer sentir algún tipo de responsabilidad ética y moral en los partidarios. Howard creyó que, una vez se hubo hecho la descentralización, las rentas del suelo en Londres caerían y la población de los condados, entonces 4,5 millones, se reduciría en una cuarta o quinta parte alcanzando menos de un millón. ${ }^{17}$

\footnotetext{
14 Hall, P. v.0.1988, Cities of Tomorrow: An Intellectual History of Urban Planning and Design in the Twentieth Century. Freixa, Consol(tr). Barcelona. Ediciones Serbal. Versión española 1996. pp. 28-33

${ }_{15}$ Kropotkin, P. v.0.1902. Mutual Aid: A Factor of Evolution. Fuente de online:

< http://www.marxists.org/reference/archive/kropotkin-peter/1902/mutual-aid/index.htm>

${ }^{16}$ Tengo que aclarar que el concepto <ciudad-jardín> de Howard es anterior al nacimiento del concepto <el apoyo mutuo> de Kropotkin, pero ellos ya se conocieron en varias reuniones.-(NdA)

17 AAVV. Urban Planning in a Changing World: The Twentieth Century Experience. London. E \& FN Spon. 2000. p. 23
} 
Como se observa en el capítulo cero, la disminución de la población tiene sentido por una resolución esencial que pueda mejorar la salud pública, incluso provee una pista para tratar los conflictos de clase y la alienación entre los miembros de la sociedad.

La idea de Howard es sencilla y al mismo tiempo arriesgada. Existiría una compañía sin fines de lucro que recaude fondos mediante la emisión de bonos que produzcan un tipo de interés fijo del $4-5 \%$. Se realizaría la compra de 6.000 hectáreas de tierras agrícolas, y el diseño de una ciudad con carreteras, energía, plantas de agua y todas las demás necesidades (v.-figs.2-2, 3, 4). ${ }^{18}$ La compañía sería la propietaria de toda la tierra, ya que la población habría aumentado, los alquileres también se levantarían de la baja tasa por acre de tierra rural a la tasa más sustancial de una ciudad de 3.000 habitantes. El alquiler de todos iría a dicha compañía y se utilizarían para pagar a los inversores originales. Mientras, los ingresos de rentas podrían estar creciendo constantemente al mismo ritmo que la ciudad; el superávit se utilizaría para los servicios comunitarios como: escuelas, hospitales, organizaciones benéficas e instituciones culturales. ${ }^{19}$

Howard descubrió este mecanismo para repartir ese valor incrementado que se derivó de las acciones previas en la tierra rural entre los residentes. Todas esas acciones iban a ser ejecutadas sin la intervención del Gobierno. En el año 1873 una encuesta oficial mostró que el ochenta por ciento de la tierra en el Reino Unido era propiedad de menos de 7.000 personas. $^{20}$ Si se considerara ese tipo de situación tan extrema, se podría imaginar qué radical fue la idea de Howard. La aristocracia de los terratenientes se acabaría en la historia. Además la idea de Howard parecía bastante factible, de manera simplemente democrática, sin la intervención del gobierno en el sistema vigente. Su libro Garden Cities of To-morrow fue, sin duda, una aportación extraordinaria intelectual para el urbanismo y también para la sociedad (v.-fig. 2-5). Él comprendió y también creyó en la dirección que una ciudad tendría que seguir. También tuvo talento de urbanista, en el sentido de extinguir varias de las angustias que sufre la ciudad (AD). ${ }^{21}$ Como se recuerda, Howard consideró la descentralización como la llave

\footnotetext{
${ }^{18}$ se buscaría atraer a la industria y a los residentes.-(NdA)

${ }^{19}$ Fishman, R. Urban Utopias in the Twentieth Century. Cambridge, Mass. The MIT Press. 1982. p. 46.

20 Ibid. p. 47.

${ }^{21}$ Acumulación del Dolor-(NdA)
} 
principal para resolver los nuevos problemas urbanos; y así de nuevo de una manera sorprendente él tenía razón, comparando con el flujo principal de los urbanismos contemporáneos.

\section{La ciudad-jardín: Letchworth}

Howard fue no solo un pensador, fue también un ejecutor. En el año 1898 escribió To-morrow: the peaceful path to real reform que hasta hoy en día se admira en el campo académico y social por su gran visión. Finalmente, en el año 1903, Garden City Association ${ }^{22}$ estableció Garden City Ltd. para construir la primera ciudad-jardín en Letchworth situada a 34 millas de Londres, en una zona de estancamiento de la agricultura y así con el precio reducido, cumplía todos los requisitos: $<<4.000 \mathrm{a}$ 6.000 acres de superficie, bien comunicada con el ferrocarril, con un buen suministro de agua y buen drenaje>>.23 (v.-fig. 2-8). Se compró un área de 3.818 acres por 155.587 libras. La Compañía de la Primera Ciudad-Jardín se registró el 1 de septiembre de 1903, con un capital de 300.000 libras, de las cuales 80.000 debían ser obtenidas inmediatamente, y con un dividendo del cinco por ciento. ${ }^{24}$ Es cierto que Garden City Ltd. fue una organización no lucrativa, lo que no significa que hubiesen pérdidas, todo lo contrario, se obtuvieron beneficios (Howard fue una persona muy brillante calculando los costes y las ganancias).

Aunque fuera tarde, (10 años después), más de lo que los patrocinadores esperaban, Garden City Ltd. empezó a poder pagar los dividendos.

Sin embargo, en Letchworth, como está declarado en la imagen de los tres imanes, para diferenciarse la ciudad-jardín con la ciudad y el campo, primero, se requiere instalar la industria en la zona agraria, pero los fabricantes siempre están preparados para moverse al campo siempre con la condición de no tener que pagar el mismo salario que en la ciudad (v.-fig. 2-1). Lo que es un disparate económico por

\footnotetext{
22 Fue establecida en 1899, justo ocho meses después de publicar el libro(To-morrow: the peaceful path to real reform).-( $\mathrm{NaD}$ )

23 Hall, P. v.o.1988, Cities of Tomorrow: An Intellectual History of Urban Planning and Design in the Twentieth Century. Freixa, Consol(tr). Barcelona. Ediciones Serbal. Versión española 1996. p. 105.

24 Ibid.
} 
sí mismo. De todas formas, al final, su arte oratorio logró convencer a los inversores diciendo que podrán generar suficientes beneficios a través de las rentas de las viviendas y de las tiendas, indirectamente. ${ }^{25}$ Si no puede incorporar la industria y el campo, esa ciudad-jardín no tiene ventaja al ser comparada con los otros suburbios. Además, si no hay industria, no será dicha ciudad adecuada para la gente de salario bajo, sino que como mínimo para la gente de la clase media (v.-figs. 2-9, 10).

En el año 1904, Raymond Unwin y Barry Parker fueron asignados como los arquitectos y planificadores que realizaron la visión de Howard con gran acierto. La pareja formada por Unwin y Parker, ambos con estudios y experiencia en el campo del planeamiento urbano, desarrollaron la idea de Howard, quien no tenía nada destacable en su carrera académica. Sin menospreciar el trabajo realizado por Letchworth que ha dado el color particular al town-country con el diagrama de los tres imanes (v.-fig. 2-1).

Ellos también, al igual que Howard, querían perseguir el objetivo social, ${ }^{26}$ concretamente Unwin comentó que <<tanto en la planificación de la ciudad como en la disposición de las casas es importante evitar una completa separación de clases que es lo normal en las modernas ciudades británicas>>. Y ellos creyeron que la creatividad puede adquirirse en el proceso de entender nuestro pasado con vasta imaginación. En su caso, el pasado significa la época medieval de la sociedad aldeana y los sistemas de gremios que proporcionaba un modelo histórico, el hecho de que el pueblo era una realización orgánica de la gente que se relaciona una con otra(v.-figs. 2-6, 7). ${ }^{27}$

En el año 1917, Inglaterra carecía de muchas viviendas para apoyar a los héroes vueltos de la guerra. El Parlamento emitió el programa llamado nuevas ciudades después de la guerra que proporcionaba fondos para más de 100 ciudades-jardín. ${ }^{28}$ La metodología era liderada por el gobierno centralizado, irónicamente porque Howard nunca confió en él. Como resultado, es significativo que la idea de Howard haya sido certificada oficialmente.

\footnotetext{
25 Ibid. p. 136

${ }^{26}$ Hall, P. v.o.1988, Cities of Tomorrow: An Intellectual History of Urban Planning and Design in the Twentieth Century. Freixa, Consol(tr). Barcelona. Ediciones Serbal. Versión española 1996. p. 106

27 Ídem. p. 108.

${ }^{28}$ Fishman, R. Urban Utopias in the Twentieth Century. Cambridge, Mass. The MIT Press. 1982. pp. 77-78
} 
Frederic Osborn fue uno de los seguidores de Howard indirectamente, de manera decisiva descartó la táctica de Howard de apelar a los particulares, confiando en las acciones voluntarias. Osborn eligió en su lugar ganarse a los políticos, funcionarios, planificadores y profesionales. ${ }^{29}$ La diferencia principal entre Howard y Osborn, se ubica en la actitud frente al gobierno, Howard no creía en el gobierno centralizado, por el contrario Osborn prefería un gobierno cuanto más centralizado mejor, para no tener límites. A Osborn le había gustado la idea de la ciudad-jardín, y la interpretó por su cuenta, incluso la metodología para realizarlo. El derecho del ciudadano a la vivienda fue igual -en el mismo contexto se entiende- al de la alimentación y la ropa para Osborn. Esa posición en la comprensión del estado de bienestar, parece persuasiva para la izquierda y los conservadores en el parlamento. Nuevas ciudades-jardín iban a proporcionar sitios amplios para viviendas familiares con la industria cercana, como Howard planeó, gracias al gobierno. Fishman en su libro valora que eso era el equilibrio entre el individualismo y el colectivismo que también podría ser favorable para Howard. ${ }^{30}$ 


\section{Sobre lo que supo Howard: Una charla epistemológica y nirvánica}

Si durante la lectura de la historia de Howard hubiera que destacar lo que más impresiona, eso seguramente sería su deseo innovador -tal vez visión o pasión- hacia la reforma social, y no, el hecho de que Howard no tuviera educación oficial a partir de los 14 años. Como los humanos no pueden desear lo que no pueden percibir, en el caso de Howard, podría decirse que su concepción del deseo comienza en Estados Unidos de América. Él estuvo viajando por allí por varios años, durante su período de rápido crecimiento urbano. En aquel tiempo, varias industrias pioneras con aprendizajes filantrópicos ya habían comenzado a crear nuevas comunidades en asociación con las grandes fábricas recién instaladas en el campo, por ser más barata la construcción en suelo rústico. The Garden City Ltd. recibiría las rentas a modo de pequeña compensación, también para su inversión (aun si esta no fuera motivo de filantropía). ${ }^{31}$ Estos pueblos creados por la empresa, contienen la esencia de la idea que Howard iba a propagar; una nueva ciudad construida alrededor de una planta descentralizada, combinando así trabajar y vivir en un ambiente sano. ${ }^{32}$

Para poder entender en más profundidad las obras que Howard produjo, se tiene que analizar su metodología de comportamiento, y su interpretación de aquella era del mundo. Después de la industrialización, aquel Londres tuvo que sufrir los problemas de falta de hábitat decente y de higiene pública, que son derivados de la superpoblación de la ciudad y de la impotencia del gobierno. Howard se consideró escéptico sobre la eficacia de los gobiernos con poderes centralizados, incluso en los que se habían establecido creyendo en la buena voluntad de los responsables.

Howard habría sentido que la voz del Parlamento de Inglaterra hablaba sólo para representar los beneficios de los terratenientes. Sin embargo, no perdió la esperanza en la buena voluntad de los humanos; los numerosos discursos y el movimiento de la ciudad-jardín incluso su filosofía filantrópica, se basan en la fe en la buena voluntad de los humanos. A Howard, parece que no le importa cuanta gente le apoya o están de acuerdo con su visión, debido a que el comienzo del movimiento de la ciudad-jardín fue provocado por gente con visión e inversores; una vez iniciado, el plan tendría la

\footnotetext{
${ }^{31}$ AAVV. v.o.1975. Urban and Regional Planning. Abingdon. Routledge. $5^{\text {a }}$ edición. 2011. p. 28.

32 Ibid. p. 31.
} 
estructura empresarial que se podría mantener, y sostener con expansibilidad desde el principio, y Howard lo enfocó de esta manera. Él había tenido la visión de que todas las ciudades de Inglaterra serían estimuladas por el viento del movimiento de la ciudad-jardín. Entonces, como se ha comentado anteriormente, sin que diera mucha importancia a cuanta gente le apoya o no, aunque no sea una reforma (o tal vez revolución) agraria completa, Howard fue realista buscando el equilibrio <<perfecto>> en cuanto a los recursos para las minorías en desventaja, aun así, él no perseguía el equilibrio perfecto.

Mucha gente se confunde con el concepto de utopía como si fuera un mundo perfecto o la vida perfecta, pero no lo es. Además, originalmente, la perfección es un concepto teológico aunque con el transcurso del tiempo el concepto está ligado al utopismo. Y en cada época se produce un particular utopismo, puesto que cada etapa del utopismo contenía su peculiar fragilidad, límite o defecto por ausencia de la perfección. ${ }^{33}$ En este sentido, el utopismo es soñar con una sociedad perfecta en un mundo imperfecto. Howard estaba aceptando la diferencia de los miembros de la sociedad e igualmente el concepto de la responsabilidad de las altas posiciones de la pirámide social. La gente de clase baja también tenía derecho de disfrutar de una casa decente y asequible en su situación, con un espacio público y amplio, y poder tener una vida feliz. El inicio del proyecto es la manera: $<<$ desde arriba hacia abajo>>, pero, al final, toda la clase de la sociedad se levanta $<<$ desde abajo hacia arriba>>, para ayudar a la clase baja, y les ayudan a ascender por lo menos hasta la clase media. Es decir, el movimiento llamado ciudad-jardín fue la herramienta que invoca la re-territorialización en la geografía de las capas de la sociedad jerárquica, sin sangre, pero sólo con un pequeño cambio en el pensamiento. Y no existe una duda particular sobre la sostenibilidad del plan de Howard, sin contar lo que es requerido en todos los comienzos de cada proyecto. Este problema se soluciona por la gente iluminada de buena voluntad y los inversores (que siguen los beneficios). Las tablas del cálculo y las teorías económicas también certifican la viabilidad del proyecto.

Si se puede citar su único defecto, sería que la sostenibilidad del proyecto está garantizada condicionalmente en función de los tres siguientes factores: circunstancias sociales, económicas e industriales. Imaginar que no está preparada la atmósfera social filantrópica; de hecho, era que sí lo estaba, sin embargo, si se indaga más profundamente, inmediatamente se llega a la idea, pasando

\footnotetext{
${ }^{33}$ Claeys, G. Serching for Utopia: The history of an idea. Condor, M(tr). Madrid. Siruela. 2011. pp. 11-12.
} 
unas pocas fases de análisis mental, del posible peligro de la construcción de una nueva ciudad-jardín. Si cada vez que la ciudad esté nuevamente degenerada como aquel tiempo de barrios pobres de Londres, perdiendo su vitalidad, lo que llevaría a una situación catastrófica, ¿la ciudad Letchwoarth tendría que pensar en construir otra ciudad-jardín? Es cierto que es un remedio dramático, y también efectivo (en ese tipo de metodología se tienen que observar bien cómo Howard está mostrando su postura contraria al mundo de aquel tiempo).

Howard percibió la $\mathbf{A D}^{34}$ justamente, pero no ha podido tratarlo bien. En el resultado, solo se centró en la ED ${ }^{35}$ moviéndolo geográficamente. Entonces dicho ED no puede ser el verdadero remedio. Cuando se recuerda la metodología de Howard en la perspectiva nirvánica, entonces para él, el sistema demoníaco de terratenientes y la situación de las viviendas de slum (bajas) en Londres fue un semillero de los diferentes tipos de tragedia urbana, en otras palabras del buddhismo sería $<<$ Acumulación del Dolor>>, de una de las dos fórmulas derivadas desde las cuatro nobles verdades (4NV). Howard sabía lo que era $\mathbf{A D}$ en aquel tiempo, pero él carecía de la segunda fórmula para extinguir el dolor urbano, o sea ED. Puede sonar un poco abstracto, pero esa pequeña diferencia influiría mucho en el resultado final.

En realidad, mientras él pisa su camino de ED, podría extinguir más dolores, por lo menos mientras la situación se lo permite, pero el origen del dolor sigue siendo igual. Se puede esperar sólo el efecto de un analgésico simple. Aquí no se indaga una solución permanente, sería estupendo, pero no se pretende generar una controversia sobre eso. La resolución tiene que ser sostenible. Mientras si Howard no toca el dharma de AD, la propuesta de él, o sea ED siempre se queda con este límite.

\footnotetext{
${ }^{34}$ Acumulación del Dolor-(NdA)

${ }^{35}$ Extinción del Dolor-(NdA)
} 


\section{Sobre lo que Howard hubo de hacer: Una charla ética y nirvánica}

Antes de empezar los proyectos, el cálculo económico ya fue preparado. En su único libro (honesto y muy breve) que publicó en su vida, llamado Garden Cities of To-morrow, demuestra todos los artículos financieros. Exhaustivamente estima hasta cinco libras por unidad, dando razones específicas con frases lógicas estudiadas. Y el diagrama llamado los tres imanes que se incluyó en el libro puede ser un buen recurso para evaluar incluso la virtud ética de Howard. Los conceptos prácticos para la gente de los tres imanes son: renta baja, tasa baja y bajo costo de la vida pero con salarios altos. Esos cuatros conceptos son esenciales en la ciudad-jardín, y dado que los espacios salubres relacionados con los espacios naturales son elementos básicos, y han sido resueltos técnicamente bien, no hay bastantes materias que criticar sobre las soluciones ambientales tomadas.

Sin embargo, como se ha mencionado con anterioridad, el proyecto fue lanzado (recalco lo que se mencionó sobre que se lanzó con buena fortuna) apoyado por capitales de enormes deudas (hipotecas) y partidarios; fijándose la tasa de interés sin que excediese un $4 \%$. La finca pertenece -legalmente- a cuatro nobles responsables por honor y fe. La gente de la ciudad-jardín tenía que afrontar la grave dificultad financiera desde el principio. Las hipotecas originales que se vendieron poco a poco fueron subiendo de valor; los directores (incluso Howard y sus amigos) las compraron por 4.000 libras y en el principio eso era todo, pero las hipotecas que se vendieron al público en el primer año ascendieron a 60.000 libras llegando incluso a las 150.000 libras finalmente. En estos tres años, la empresa se vio obligada a gastar más de 600.000 libras para construir carreteras, fábricas de gas, generadores eléctricos y otros servicios públicos necesarios para la ciudad. ${ }^{36}$ La empresa, Garden City Ltd. necesitaba aumentar sus préstamos para obtener más capital, sin embargo, nadie quería hundirse en el abismo más profundo de deudas. La calidad de las viviendas que Unwin y Parker diseñaron requerían de recursos aún más lujosos, así que, lamentablemente, los diseños de Unwin y Parker tuvieron que descartarse y los promotores especulativos tomaron el control en Letchworth consiguiendo el efecto contrario a lo que buscaban Unwin y Parker originalmente.

\footnotetext{
${ }^{36}$ Fishman, R. Urban Utopias in the Twentieth Century. Cambridge, Mass. The MIT Press. 1982. p. 71.
} 
Teniendo en cuenta las virtudes de los tres imanes, cuando se piensa en los valores que Howard persiguió: alquiler bajo, tasa baja, bajo costo de la vida, se comprueba que éstos no fueron posibles por que los inversores y los capitalistas son codiciosos. Los empresarios (inversores), podrían querer contratar una mano de obra a un salario inferior al de la ciudad, sin embargo, podrían mantener el mismo salario puesto que podrían alcanzar unos beneficios indirectos suficientes que complementen a través de los ingresos percibidos por las rentas y las tiendas. ${ }^{37}$

Con lo comentado anteriormente, que el plan funcione, sin tener en cuenta la ética o moral de los actores intervinientes, es totalmente viable. En la perspectiva macroscópica, este plan requiere la intervención del gobierno centralizado, capitalistas e inversores. Sin embargo, esto estaba revelando los puntos débiles de la ciudad-jardín; aunque no fue un error técnico de Howard.

Incesantemente la fragilidad humana (que estaba oculta tras su optimismo) siguió existiendo en las cabezas de los contratistas(especuladores). Y cuando la avaricia de los inversores haya crecido excesivamente más de lo que se había calculado y no se pudiese controlar careciendo de alguna estrategia de Garden City Ltd., al final la ciudad-jardín experimentaría otra vez la pesadilla de Londres. Básicamente, el esquema de la ciudad-jardín fue diseñado para que sea viable sin ningún motivo filantrópico. Es un resultado obvio de no haber diseñado ED.

Luego, Howard se encontró en otro momento en el que tuvo que decidir; el monopolio parcial. Como se describe anteriormente, Howard no creyó en Bellamy, cuya utopía se basa en el concepto del gobierno centralizado, la administración en socialismo e incluso la virtud de obediencia a las instituciones. ${ }^{38}$

Por su parte, Howard despliega una lógica muy extraña respecto a lo anterior y que no se diferencia mucho de Bellamy; Howard puso un aparato (normas) como si fueran obra de Bellamy (con una autoridad superior). Tal vez, la idea pudo parecer un poco peligrosa puesto que trabajarían todos en la misma fábrica, comprarían pan en la misma tienda, y si no les gusta el dueño, se propone una nueva votación y lo sustituyen. No es necesario criticar hasta niveles detallistas tan profundos, pero, en este mundo hay temas que se pueden decidir mediante la opinión de la mayoría y existen otros en los que

\footnotetext{
${ }^{37}$ Hall, P. v.o.1988, Cities of Tomorrow: An Intellectual History of Urban Planning and Design in the Twentieth Century. Im, C.H \& Ahn, G.H(tr). Seúl. Hanul books. Versión coreana: 2009. p. 136

${ }^{38}$ Mumford, L. The Story of Utopias. Boni and Liveright, Inc.. $4^{\text {a }}$ edición. 1928. p. 168.
} 
no se pueden. Howard supo en qué parte se necesita la asistencia de la autoridad. Él contrapesó los beneficios (sólo para minorías indudablemente) en que la infraestructura de conciencia social y económica se produce, destruyendo el bienestar colectivo, con los beneficios añadidos por medio de comprar un área que es en ese momento rural, cuyo valor puede subir igualándose al de la ciudad. En ese tipo de compensación, fácilmente se puede generar la re-territorización entre las clases sociales, y, en consecuencia, la primera vez fue en la dirección positiva, su próxima re-territorización va a venir de la misma manera que la de la ciudad de Londres.

El guión fluye así. Howard solo ha movido el problema geográficamente ${ }^{39}$, no extinguido. El esquema reveló su contradicción interna. Si los hebreos hubiesen escapado de la cruel vida de esclavitud del faraón de Egipto para disfrutar de una vida esclava pero menos cruel en Canaán, su marcha nunca se habría llamado éxodo. Fue éxodo porque habían encontrado su libertad, pero no menos crueldad de esclavitud. Del mismo modo ocurriría para quienes abandonasen Londres para moverse a la ciudadjardín. Si el proyecto de la ciudad-jardín fuera solamente para ganar tiempo para preparar otro exilio, este tipo de discurso sería en vano.

Las acciones filantrópicas pronto iban a cruzar el límite, todavía no es convincente el hecho de que los salarios fuesen a subir según las rentas suben, los beneficios adicionales de la ciudad podrían usarse para el público por el consejo central de la ciudad-jardín. No se puede encontrar ninguna manera particular de que los residentes (inquilinos, mano de obra,...) también acumulen su capital. Los residentes también han de tener su manera para alcanzar los beneficios adicionales. Sin referirse a que sea mediante el ahorro. Es más, cuando se hicieron los contratos legales, no se estableció ninguna condición para que la empresa entregase la posesión de la tierra gradualmente a la comunidad en base al pago de las rentas; esto contradice uno de los principios del plan de Howard. Todavía quedan ciertas dudas respecto el punto de compensar la inversión original. Para provocar una acción de CSD ${ }^{40}$ hacia la dirección positiva, el flujo del capital tiene que ser en doble sentido, sino sólo habrá malos efectos secundarios.

\footnotetext{
${ }^{39}$ Es la expresión de David Harvey. “Capitalism never solves its problem. It moves around geographically."-(NdA)

${ }^{40}$ Co-surgimiento dependiente-(NdA)
} 
Finalmente, la ciudad-jardín se construyó completamente (aunque sea en un tamaño más pequeño de lo que se esperaba). Irónicamente, al final la ciudad se convirtió en una víctima de los capitales especulativos del suelo. Pero posteriormente, en el año 1962 una ley del parlamento puso la ciudad en manos de un organismo nacional. ${ }^{41}$ Es un momento dramático debido a que la recuperación del proyecto Ciudad-jardín fue realizado por el gobierno que Howard nunca imaginó que pudiese ocurrir.

Después llegaron a Jericó. Más tarde, salió Jesús de la ciudad acompañado de sus discípulos y de una gran multitud. Un mendigo ciego llamado Bartimeo (el hijo de Timeo) estaba sentado junto al camino. Al oír que el que venía era Jesús de Nazaret, se puso a gritar; <<jJesús, Hijo de David, ten compasión de míl>> Muchos lo reprendían para que se callara, pero él se puso a gritar aún más, <<iHijo de David, ten compasión ${ }^{42}$ de míl>> Jesús se detuvo y dijo; <<Llámenlo.>> Así que llamaron

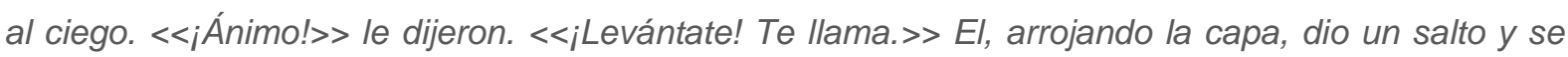
acercó a Jesús. $<<¿ Q u e ́$ quieres que haga por ti?>> le preguntó. $<<R a b i ́$, quiero ver $>>$ respondió el ciego. $<<$ Puedes irte >> le dijo Jesús; <<tu fe te ha sanado. >> Al momento recobró la vista y empezó a seguir a Jesús por el camino.

Marco 11:46-52. NVI.

Si se observa con el término de CSD $^{43}$ a este proyecto, los dharmas que tienen papeles importantes serían: intelectuales iluminados, los capitalistas, filántropos, empresarios y los pueblos del campo. Ya que los otros dharmas importantes, por ejemplo: los terratenientes que todavía mantienen su manera de pensar y dominan el parlamento son el verdadero criadero de las agonías de la ciudad.

La existencia de un remedio para resolver el daño es indudablemente necesario, pero, la existencia de un remedio para eliminar el origen de la angustia lo es también. Por lo cual, Howard pudo generar el ED tan vulnerable y no sostenible. No habiendo interpretado con la perspectiva más universal, considerando todos los dharmas que están relacionados, su proyecto necesariamente siempre sería

\footnotetext{
41 Hall, P. v.o.1988, Cities of Tomorrow: An Intellectual History of Urban Planning and Design in the Twentieth Century. Im, C.H \& Ahn, G.H(tr). Seúl. Hanul books. Versión coreana: 2009. p. 135.

${ }^{42}$ Compasión: en la versión de Reina Valera 2000 lo traduce como misericordia.-(NdA)

${ }^{43}$ Co-surgimiento dependiente-(NdA)
} 
incompleto e ineficaz. En este sentido, como todo está relacionado con los dharmas pero hay unos dharmas particulares excluidos, que son los terratenientes y el parlamento. En The Garden City Ltd, aún no se encuentra la razón (se refiere a la auto-razón interna en el proyecto: causa de sí) de existencia. Por lo cual ese proyecto, aunque se ha podido realizar casi por un milagro, también siempre encuentra el riesgo de no realizarse porque requiere un filantropismo que es difícil de conseguir sin estímulos para los promotores. El concepto llamado filantropismo de occidente y la compasión del buddhismo son ligeramente diferentes. Ambos conllevan las acciones de ayudar pero de manera distinta, primero ayudas a esa persona que está en peor situación, sólo la persona ajena recibe la ayuda; segundo, al ayudar se ayuda a uno mismo, por lo que en sentido estricto, en la perspectiva nirvánica, no tiene que existir el filantropismo. El filantropismo y el narcisismo se engloban en la misma categoría. Por los nombres de filantropismo y narcisismo, incesantemente se crea división entre los egos (yo)s y los ajenos.

El filantropismo es un concepto bueno pero que no es tan sencillo. Este concepto, desde el principio y hasta el final, se divide en una u otra clase constantemente. También este concepto surge siempre en las relaciones jerárquicas. Por ejemplo, suponga que hay 5 personas en un grupo. La persona $\mathrm{A}$ tiene el poder de 5 (es un nivel de poder que sea económico etc.), B tiene 4 , del mismo modo $\mathrm{C}$ tiene 3, D 2 y E tiene 1. La dirección en la que la gente siente misericordia sería así: A->B->C->D->E. La persona $\mathrm{E}$ no tiene un objetivo particular con el que sentir misericordia (a no ser que sea de sí mismo). Además, el resto de la gente de las clases superiores pueden sentir compasión sobre la agonía de la gente de las clases bajas, o no, dado que no es obligatorio sino una opción que puede escogerse.

La misericordia de Siddhartha nunca insistió en este tipo de responsabilidad social, porque si actuamos de esa manera, nos espera un resultado espantoso que exclama $<<e l$ poder es todo>>. Él negó cualquier clase de misericordia que surgiera de este modo. $Y$ no exigió la presencia de la existencia de un $<<B i g$ Brother $>^{44}$ como lo es The Garden City Ltd. (pero que en la práctica ha sido necesario su nacimiento o algo que actúe como tal) La empresa tenía que entregar la posesión de la tierra a la comunidad cuando las rentas excediesen las inversiones originales, y las rentas tendrían

\footnotetext{
44 Los cuatro miembros honrados elegidos. -(NdA)
} 
que transformarse en impuestos, por lo menos.

La ética nirvánica (NY) ${ }^{45}$ empieza cuando desaparecen las fronteras del amor narciso y del amor ágape por medio de reconocerse a sí mismo con la intención; que todos somos miembros del universo; porque una dharma, -humano(s)- se relaciona con el universo sin perder ni un pequeño dharma. ${ }^{46}$ No es porque una unidad particular sea superior a otra; porque cada unidad son los dharmas que cosurgen interdependientemente, igual que la práctica de la bondad entre ellos, al mismo tiempo que con el universo, y uno mismo. Esto proporciona el motivo sincero. El amor de Siddhartha no es narcisista, porque ya no se puede distinguir el universo y uno mismo.

Cada día la gente de la clase media va desapareciendo de la ciudad, los números de varias investigaciones lo corroboran. Según un estudio de la OCDE, el efecto redistributivo del gasto de los gobiernos impidió efectivamente el aumento de la pobreza en los años 80 y 90, pero, a partir del año 2000, la clase baja se ha visto apartada de recibir estos beneficios, porque los países desarrollados entraron en la etapa del rápido envejecimiento de la población. Por lo cual, los gobiernos tuvieron que aumentar los gastos en servicio médico y en pensiones. Y los numerosos estudios muestran que no es suficiente sólo con tener trabajo para poder evitar la pobreza. ${ }^{47}$ No es la intención la de proponer modelos socialistas ni anarquistas, simplemente es curioso este silencio que nos rodea: $<<i A s i ́$ estamos bien o no?>>. La solución alternativa que corresponde a cada época ha de encontrarse y comprobar el escenario de esa llamada tendenciosa, todo esto también sería el objetivo de este estudio. Aún mucha gente consideraría que en el presente hemos logrado la mejor sociedad y el sistema político y de mercado. Sí lo es pero para los privilegiados y acaudalados.

La metodología de Howard, especialmente durante el proceso del proyecto, se basa en involucrar a los expertos de diferentes campos. En otra palabra contemporánea, lo llamamos el <<Partnership>>.

\footnotetext{
45 No-yo-(NdA)

46 Kim, Yong-Ok. Do-ol encuentra la India. Lectura de la serie en el aire en EBS (Educational Broadcasting System), Corea.

El programa fue emitido en 17 de Octubre. 2002.

47 AAVV. Growing Unequal? : Income Distribution and Poverty in OECD Countries. OECD Publishing. October 2008.
} 
La forma de trabajo con este concepto es casi igual que las acciones que salen cuando la gente entiende el co-surgimiento interdependiente (CSD) y la compasión del buddhismo.

La cooperación indudablemente es concepto esencial en el campo de la regeneración de la ciudad. La cooperación requiere una proposición que haga mover los cuerpos de la sociedad orgánicamente. No tan burocráticamente, los cuerpos emiten y reciben las opiniones de uno a otro sin jerarquía alguna. Porque se tiene una mentalidad de objeto colectivo. Del mismo modo que, sin ciudadanos, la sociedad pierde su significado de existencia (CSD). Además, la intensidad de voluntad es indudablemente sostenible como la auto-defensa. (NY) 


\section{Sobre lo que Howard deseó: Una charla estética y nirvánica}

...la creatividad procedía de una comprensión imaginativa del pasado; que la Edad Media proporcionaba un modelo histórico; que los viejos edificios habían crecido a partir de la tierra donde se hallaban; que el pueblo era la personificación de la pequeña comunidad; que el arquitecto y el planificador, al conservar y mejorar los valores tradicionales de la comunidad para futuras generaciones, eran los guardianes de la vida artística y social. ${ }^{48}$

No sería fácil criticar desde la estética nirvánica lo que Howard deseaba. Él sólo dibujó cinco diagramas en su libro de pocas páginas; en todos los diagramas, meticulosamente, está escrito que no hay que dibujar el plan antes de decidir donde construir.

Se puede razonar los valores que Howard perseguía; pero su estética está poco concretada. Unwin y Parker que fueron asignados como arquitectos y planeadores de la ciudad-jardín, tenían una visión semejante a Howard. Ellos aprovecharon el espacio público de uso cotidiano para que los residentes recuperaran sus vidas.

Si, en lugar de desperdiciar rincones en patios abarrotados de trastos y en sucias calles traseras, se reuniera todo el espacio de una serie de casas en una gran extensión, se podría conseguir una buena plaza o un jardín; las casas orientadas de manera que la habitación principal estuviera bien soleada, podrían disponerse alrededor de cuadrados que se irían abriendo para dar paso a otros a la manera de las escuelas de Oxford y Cambridge. ${ }^{49}$

\footnotetext{
48 Hall, P. v.o.1988, Cities of Tomorrow: An Intellectual History of Urban Planning and Design in the Twentieth Century. Freixa, Consol(tr). Barcelona. Ediciones Serbal. Versión española 1996. pp. 107-108.

49 Ibid. p. 108.
} 


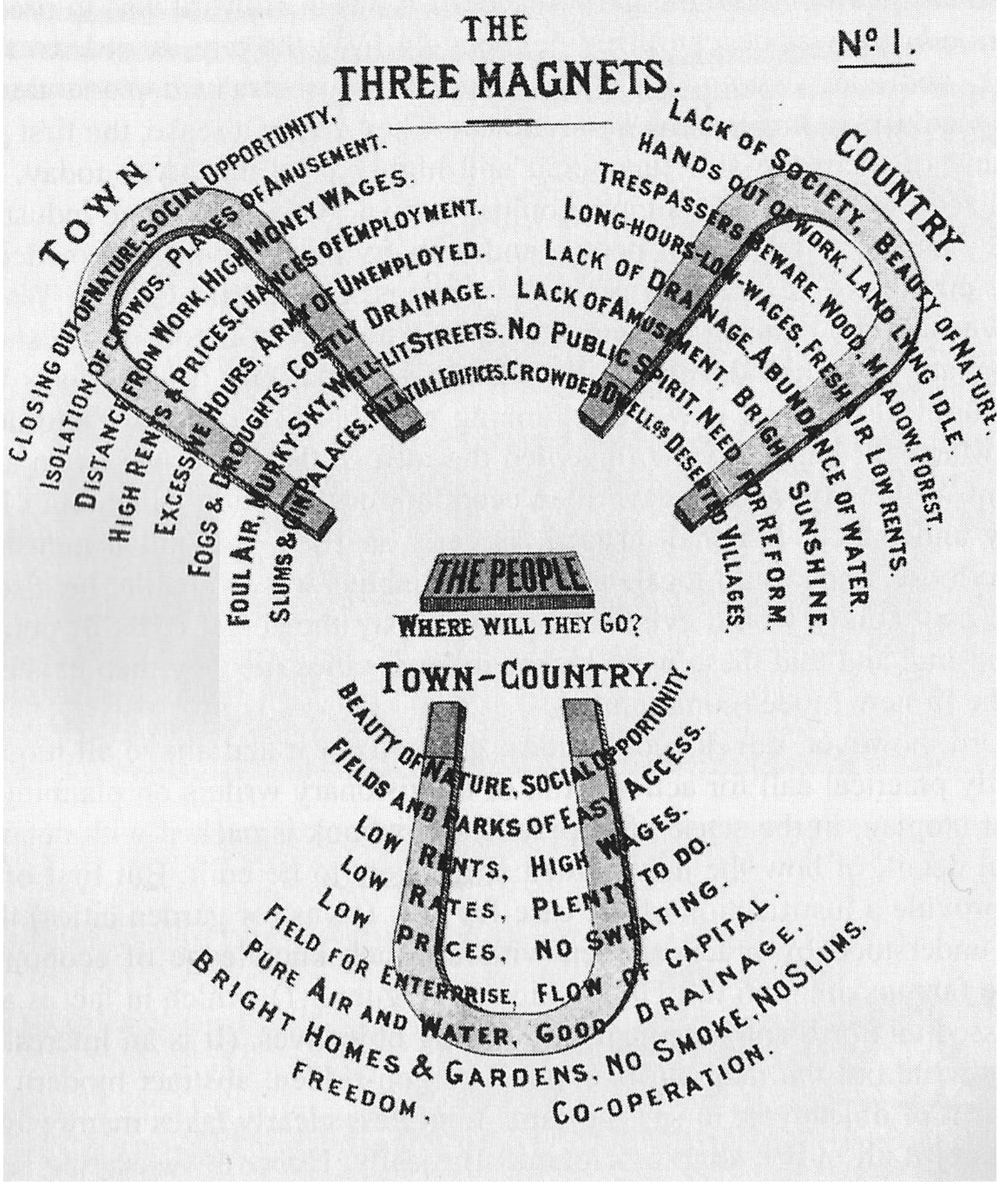

Fig. 2-1. Diagrama №1 para Ciudad Jardín de Ebenezer Howard. 


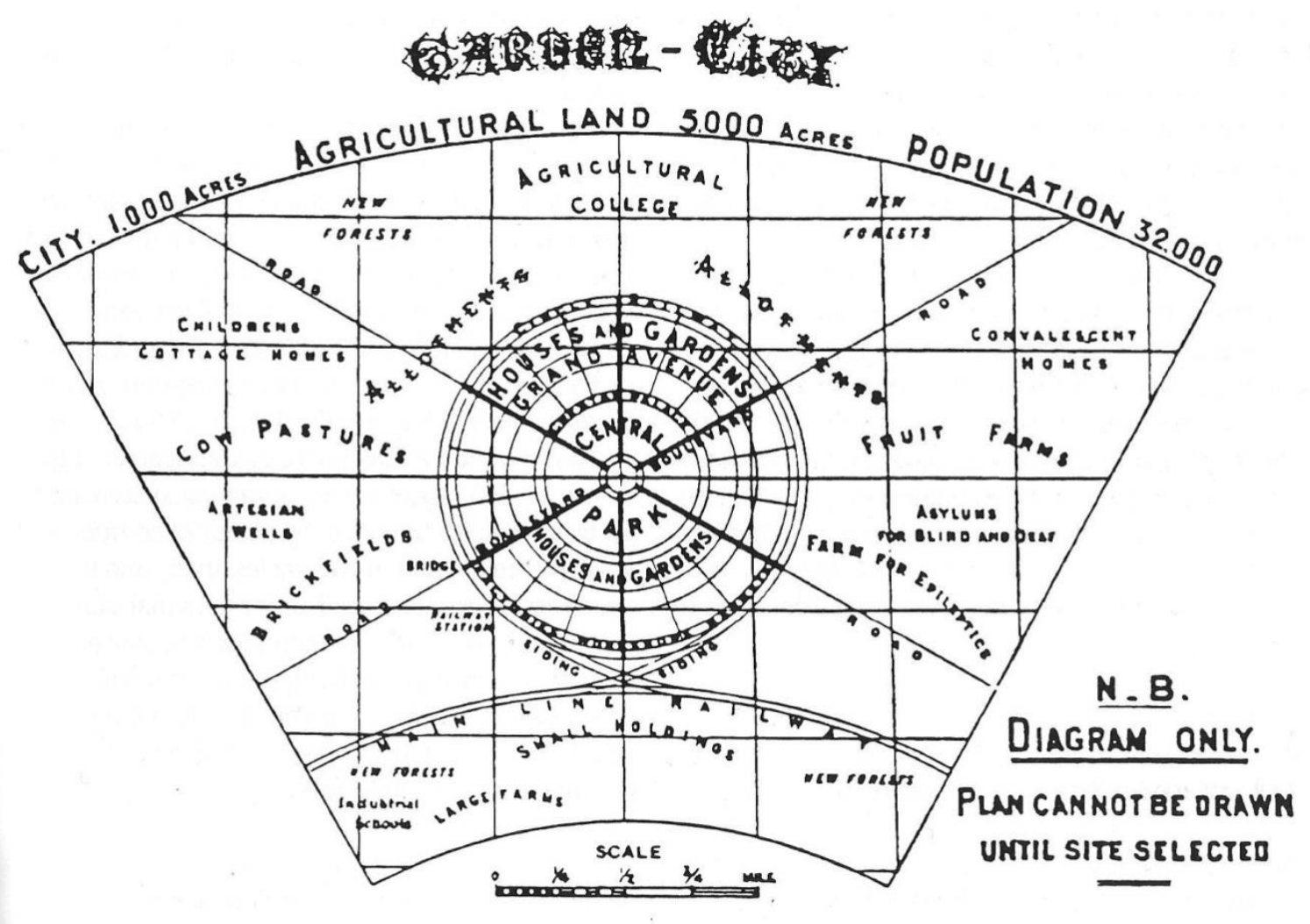

Fig. 2-2. Diagrama №2 para Ciudad Jardín de Ebenezer Howard. 


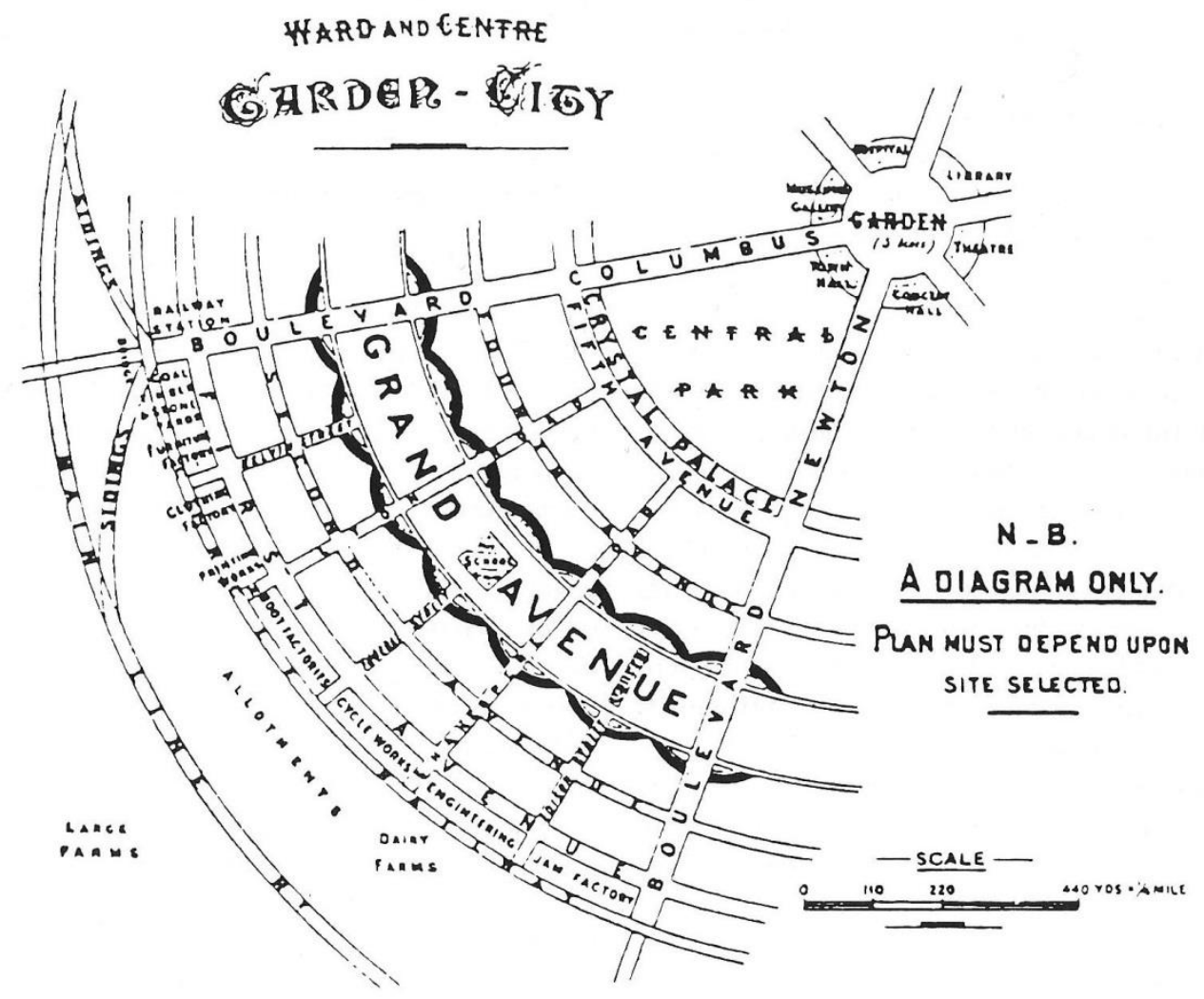

Fig. 2-3. Diagrama №3 para Ciudad Jardín de Ebenezer Howard. 


\section{DHAGRAM}

ILLUSTRATING CORRECT PRINCIPLE OF A CITY'S GROWTH-OPEN COUNTRY EVER NEAR AT HAND. AND RAPID COMMUNICATION BETWEEN OFF-SHOOTS.

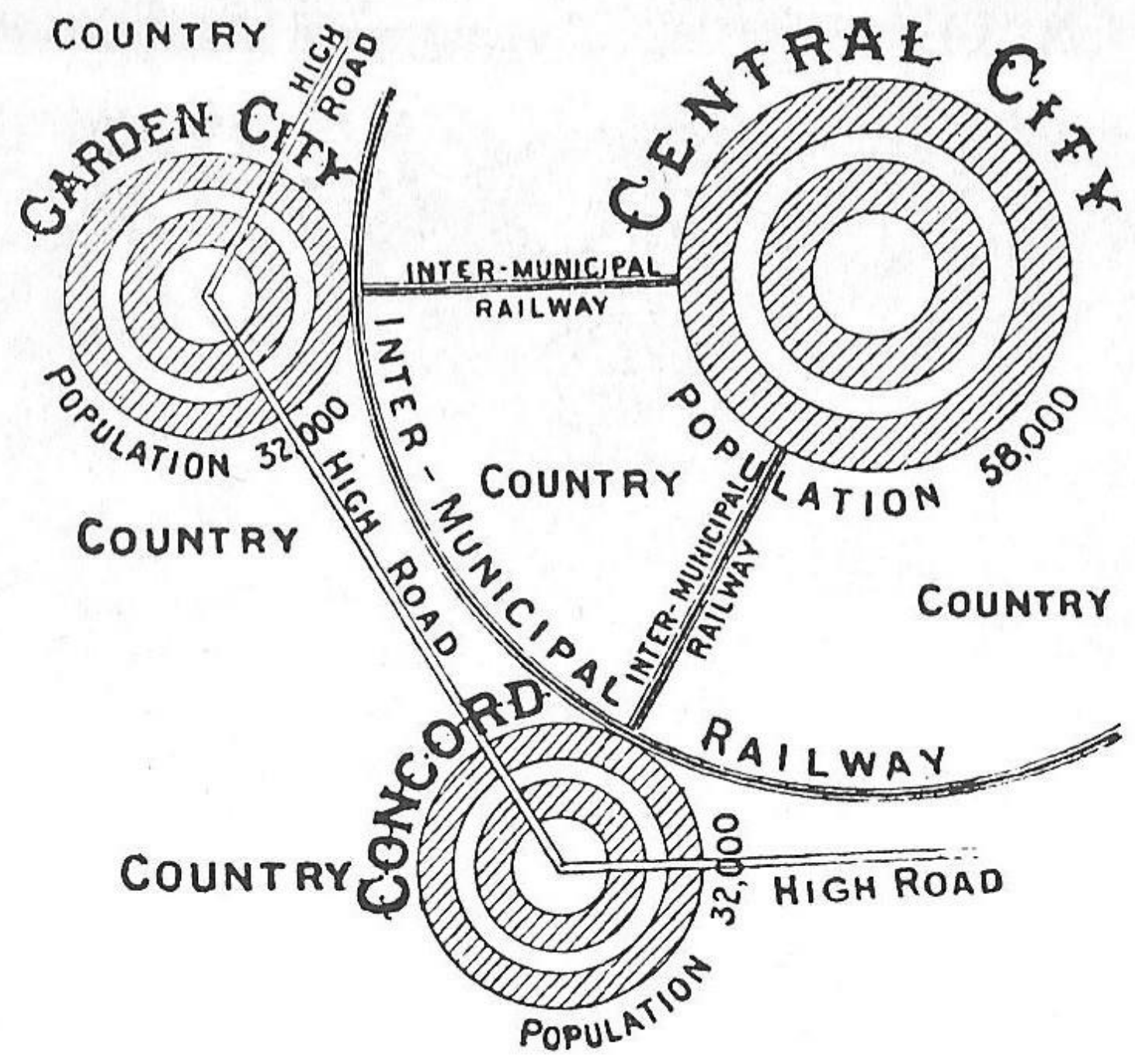

COUNTRY

Fig. 2-4. Diagrama №5 para Ciudad Jardín de Ebenezer Howard. 


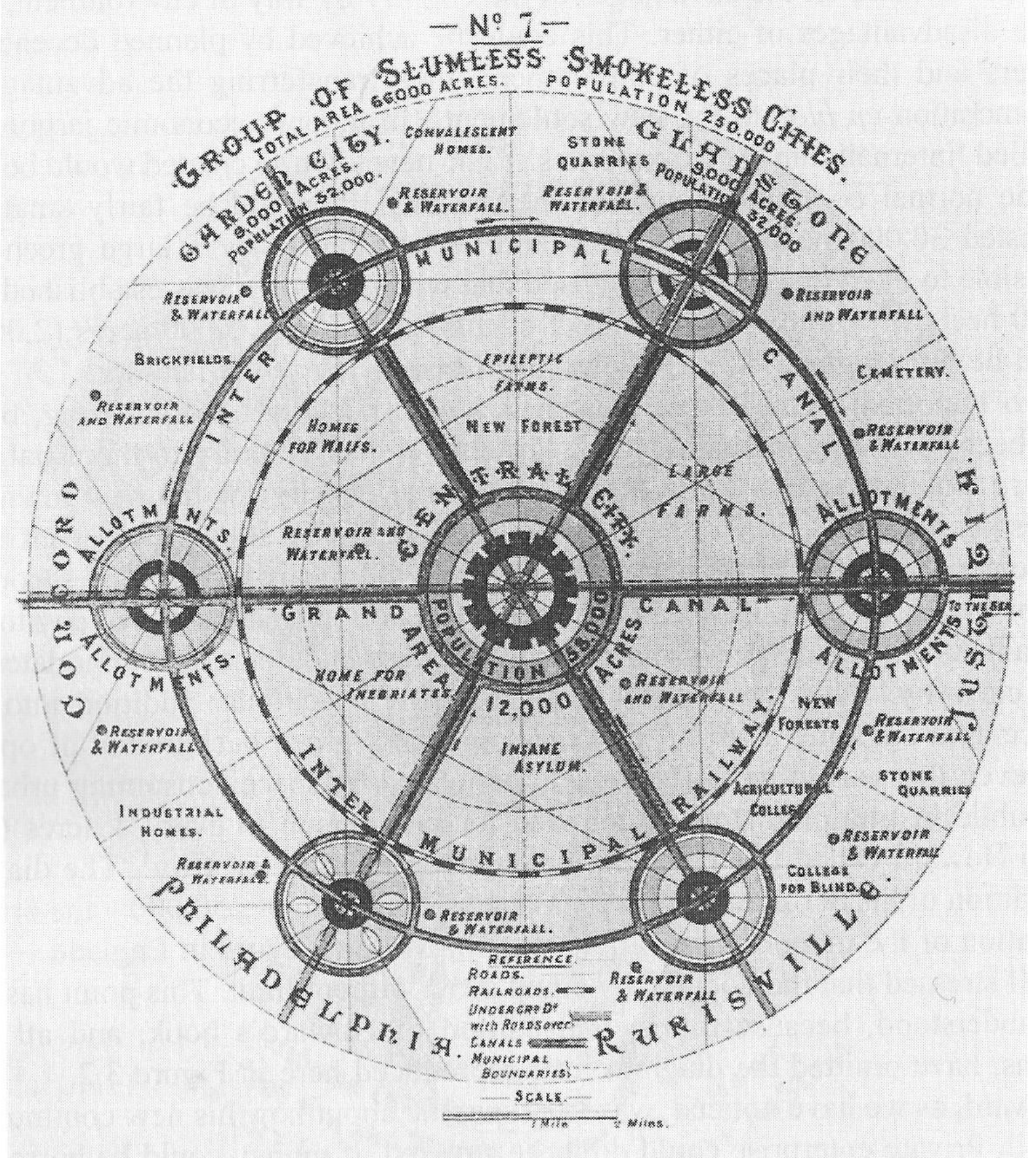

Fig. 2-5. La Ciudad Social de Ebenezer Howard. 


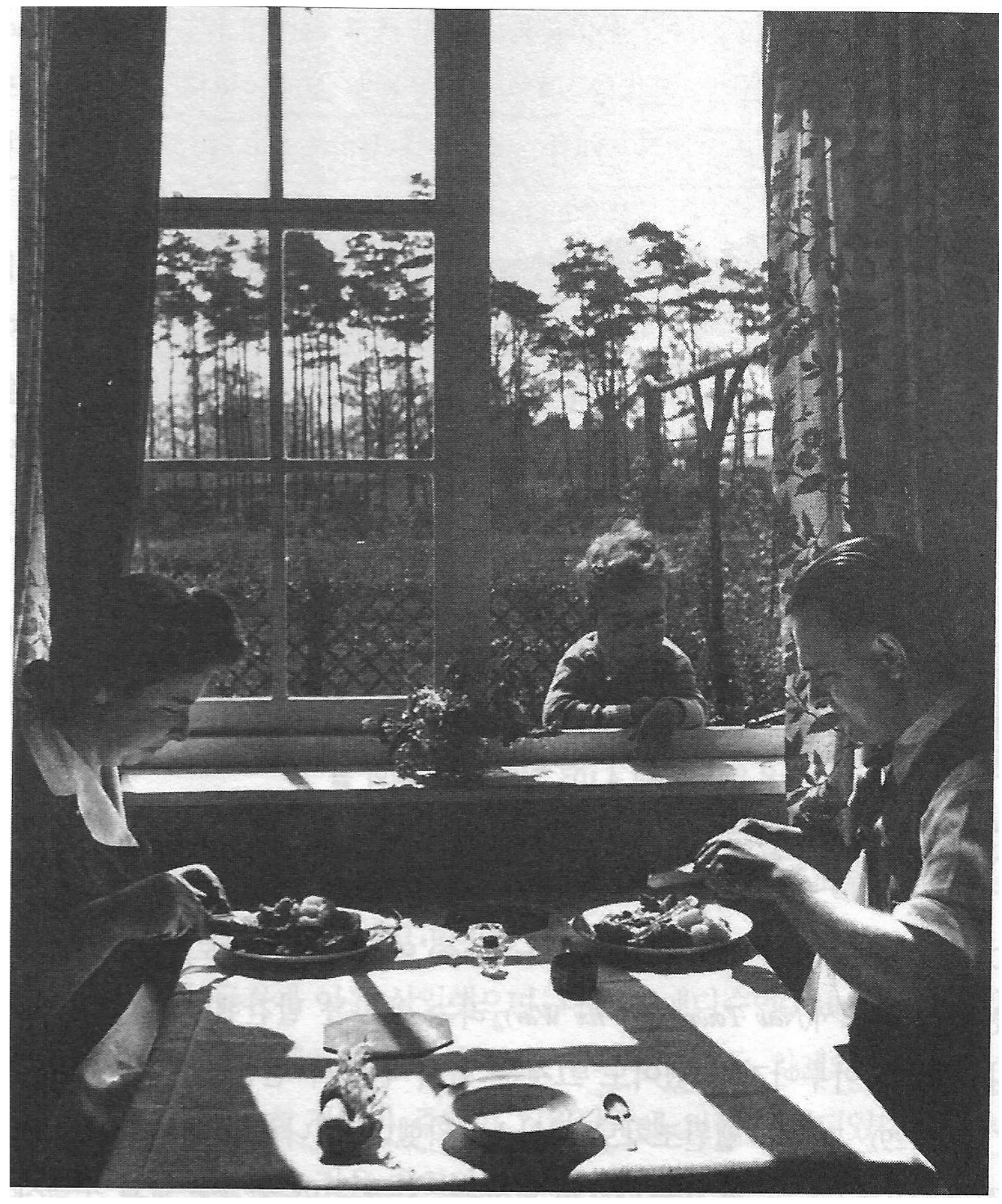

Fig. 2-6. Comida del domingo de la clase obrera en la Ciudad-Jardín de Unwin. 


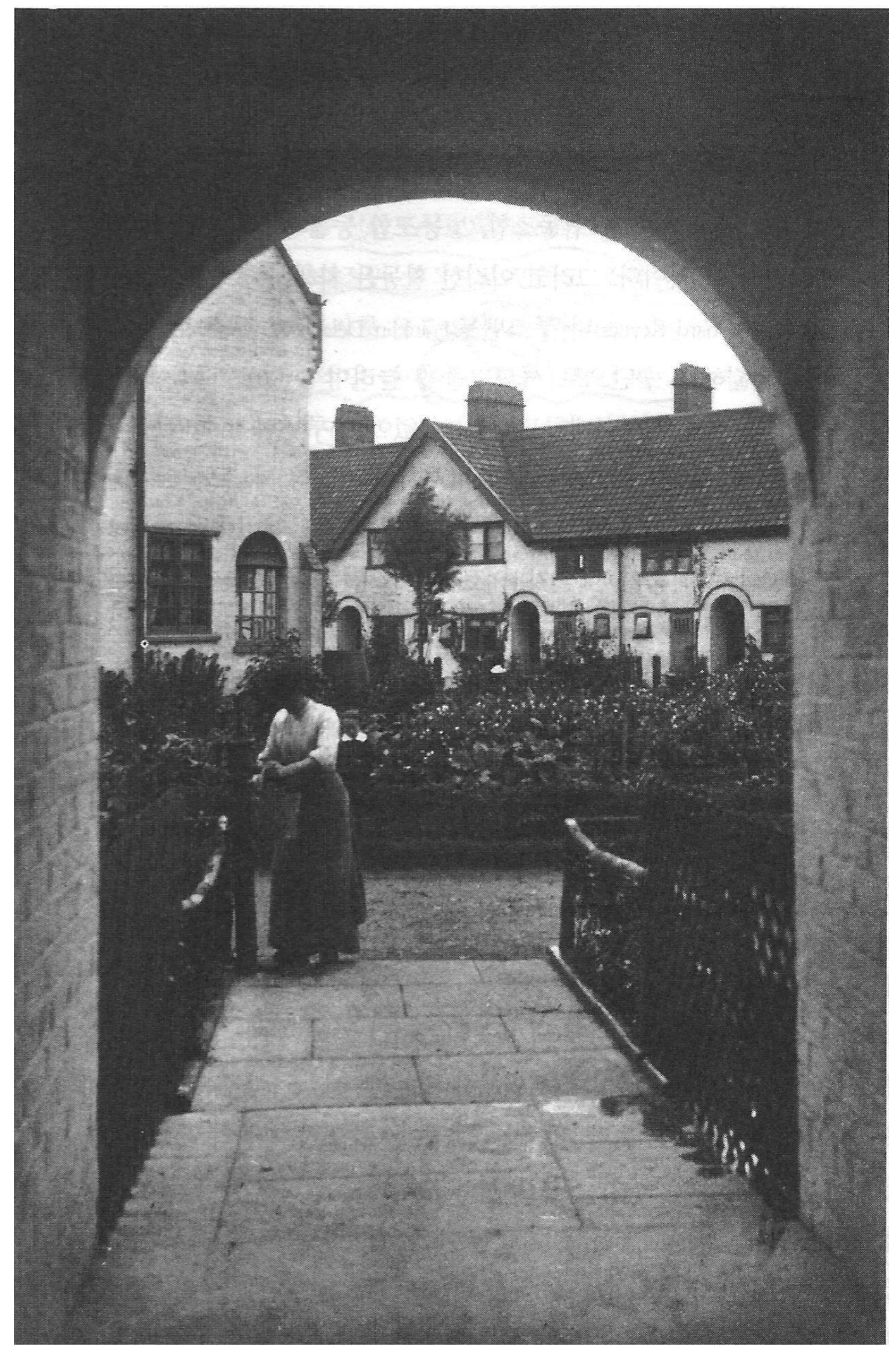

Fig. 2-7. Jardín interno de la residencia de Unwin-Parker. 


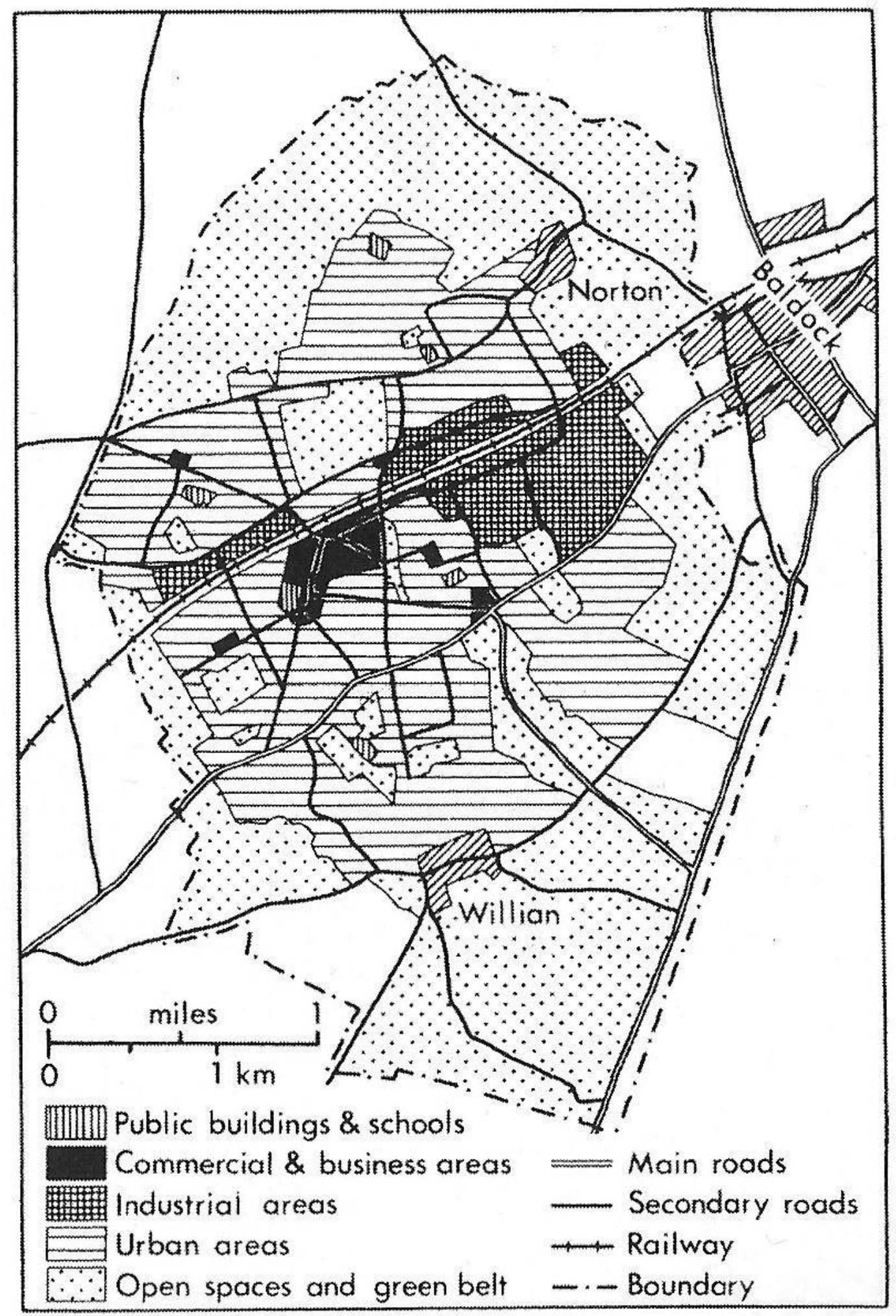

Fig. 2-8. Plan de Letchworth Ciudad-Jardín. 


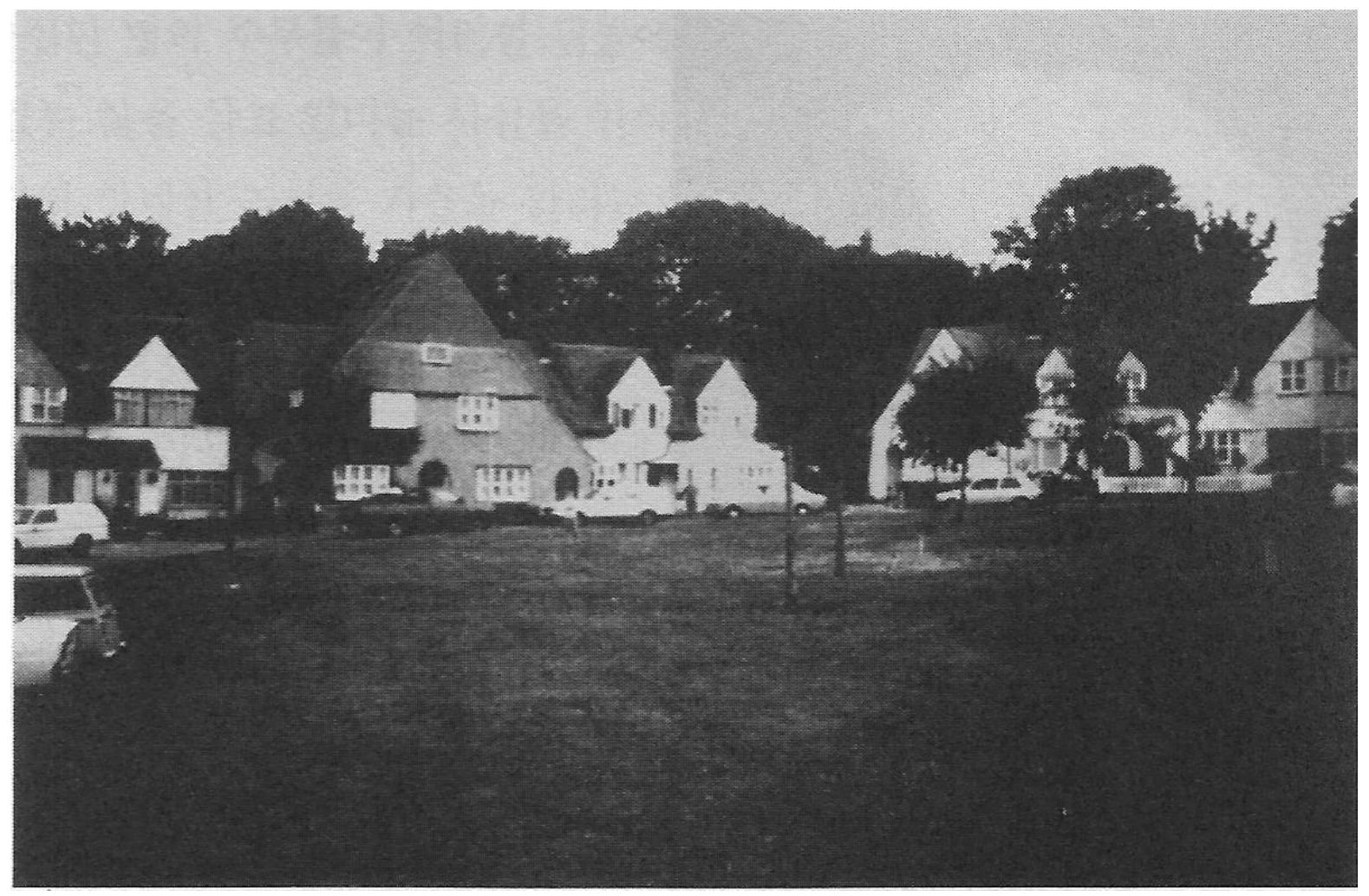

Fig. 2-9. Letchworth la primera ciudad-jardín. 


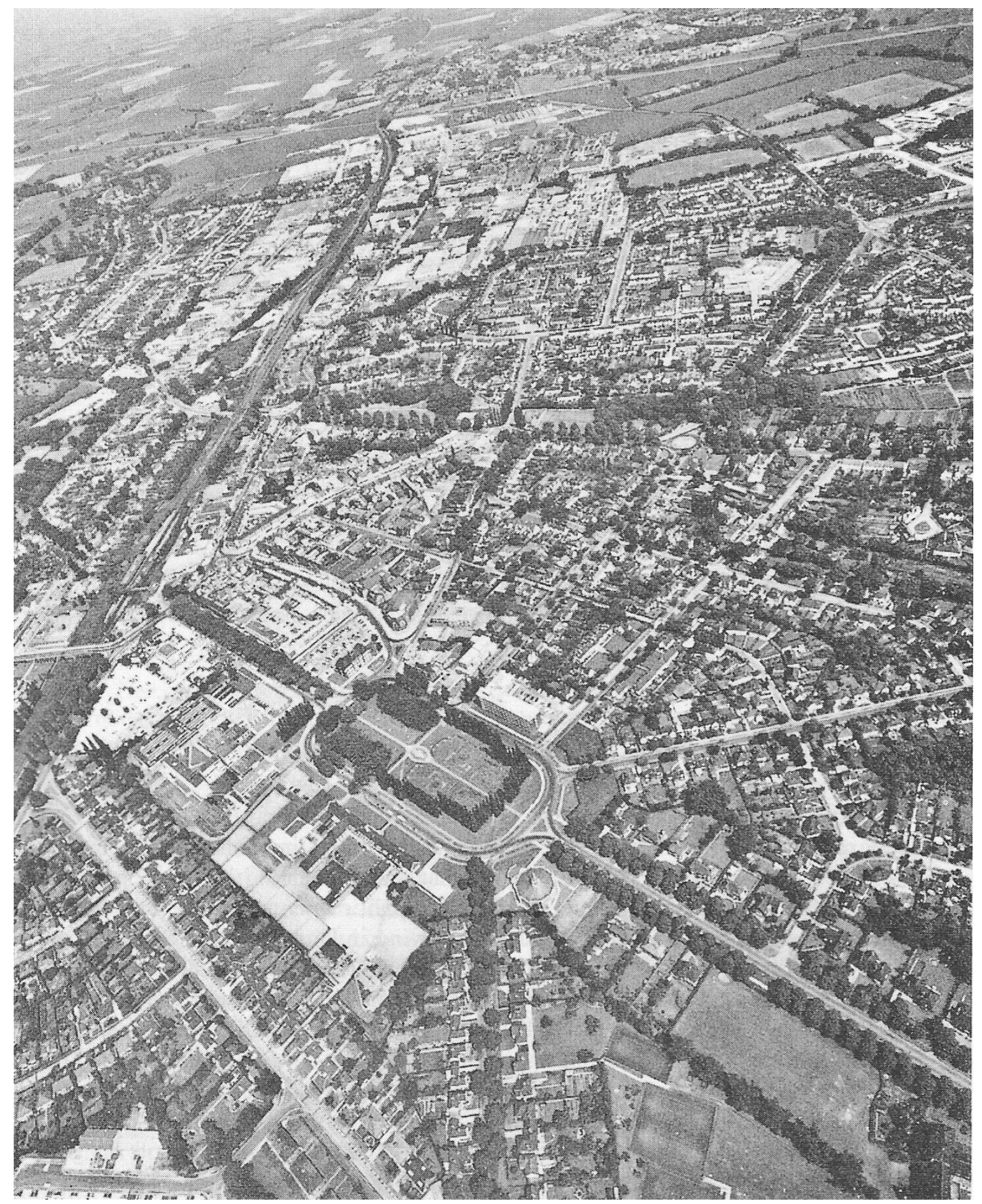

Fig. 2-10. Letchworth desde el aire. 


\section{Broadacre City de Frank Lloyd Wright}

\section{: Arquitectura de la Democracia Americana}

Una curiosa y variada región, mucho menos monótona que nuestro mundo inglés de hoy en día, reposada en sus zonas menos pobladas, pero en todo caso llena de bosques, quizás mucho más que ahora, que en según qué lugares se transformarán en parques y jardines llenos de casas (...) Las nuevas carreteras atravesarán los campos, cortando una colina aquí y cruzando un valle por medio de enormes viaductos allí, y estarán siempre llenas de un tráfico multitudinario de rápidos (y no necesariamente feos) mecanismos; y por todos sitios, en medio de los campos y de los árboles, los cables avanzarán de poste en poste. ${ }^{1}$

H. G. Wells. 1901. Anticipations.

El célebre libro llamado Anticipations de Herbert George Wells, describió algunas cosas proféticas en el año 1902. Él imaginó un mundo paralelo: Mismos océanos, continentes, ríos y tierras que el nuestro, pero en el mundo paralelo, las fronteras nacionales son insignificantes, porque en cualquier parte los ciudadanos pertenecen a una misma civilización donde las leyes y normas dominan equitativamente. ${ }^{2}$ Todo está ordenado y no hay trabajos triviales. La tierra y los recursos naturales pertenecen toda a la comunidad. Sin embargo, de todas formas, el paisaje social y político que Wells imaginó, no fue nada más que otra variación de República de Platón, una oligarquía por los elegidos rigurosamente educados y disciplinados. ${ }^{3}$ La sociedad se divide por varias clases según sus profesiones. ${ }^{4}$

La inmensa penetración de Wells sobre el futuro imaginado era un tanto radical (lo que se debe prestar atención en el mundo paralelo, es el nivel del desarrollo científico) porque todavía en aquel tiempo no

\footnotetext{
1 Wells, H. G. v.o.1901. Anticipations of the Reaction of Mechanical and Scientific Progress upon Human Life and Thought. London. Chapman and Hall. La citación está referenciada por la fuente secundaria: <Hall, P. v.o.1988, Cities of Tomorrow: An Intellectual History of Urban Planning and Design in the Twentieth Century. Freixa, Consol(tr). Barcelona. Ediciones Serbal. Versión española 1996. p. 287>

2 Mumford, L. The Story of Utopias. Boni and Liveright, Inc.. $4^{a}$ edición. 1928. p. 185.

${ }^{3}$ Platón. Politeia (República). Lee, H(tr). Seoul. Doduls. Versión coreana. 2006.

${ }^{4}$ Mumford, L. The Story of Utopias. Boni and Liveright, Inc.. $4^{\mathrm{a}}$ edición. 1928. p. 187.
} 
había podido transcender la edad del ferrocarril y los lentos carros que iban con la fuerza de los caballos (Se recuerda que hasta al año 1900, en EE.UU. ningún niño murió en la calle por culpa de un accidente de coche). Sin embargo, Wells ya estaba proclamando una nueva era de las infraestructuras gigantes que habría construido creando un nuevo tipo de carreteras, las que sirven sólo para los vehículos que viajarían a la máxima velocidad. En realidad, Henry Ford consiguió el sistema para los productos de masas en Highland Park en el año $1913 .{ }^{5}$ Así se puede considerar que ya estuvo equipado y preparado el ámbito para entrar en la nueva era con los vehículos de producción en masa, como Wells describió.

\section{Presagios de la edad del automóvil}

Gracias a la gran aportación de la revolución de Ford, la profecía de Wells se cumplió. Y, en el año 1920, la generalización de la posesión del automóvil (también hasta la clase obrera) hizo que se considerara que fuese normal tener empleo y poder vivir a largas distancias del lugar de trabajo. También el número de personas que diariamente hacían el recorrido desde su trabajo a casa en su propio coche empezó superar al número de personas que conformaban el tráfico interno de las ciudades como: Washinton, Kansas City, St Louis. ${ }^{6}$ Eso fue -aunque no sorprendente- la evidencia obvia de que las periferias estaban creciendo con mayor velocidad que los centro-urbanos. La tendencia de la suburbanización se hacía cada día más evidente; las periferias de Nueva York crecieron un $67 \%$ y en el centro un $23 \%$, y en Cleveland la relación fue de $126 \%$ y $12 \%$, y en St Louis $107 \%$ y 5\%. ${ }^{7}$ Se recuerda que antes del año 1914 en Inglaterra, los promotores no querían construir los edificios con distancias superiores a 4 calles desde los ferrocarriles. Pero, entonces, llegando a los años 20 , el índice de posesión de automóvil de los ciudadanos aumentó. Fue un resultado lógico que los patrones del desarrollo también cambiaran; construyéndose en aquellos suelos que no habían

\footnotetext{
${ }^{5}$ Nevins, A. Ford: The Times, The Man, The Company. New York. Charles Scribner's Sons. 1954. La citación está referenciada por la fuente secundaria. <Hall, P. 1988, Cities of Tomorrow: An Intellectual History of Urban Planning and Design in the Twentieth Century. Freixa, Consol(tr). Barcelona. Ediciones Serbal. Versión española 1996. p. 286.>

${ }^{6}$ Hall, P. v.o.1988, Cities of Tomorrow: An Intellectual History of Urban Planning and Design in the Twentieth Century. Freixa, Consol(tr). Barcelona. Ediciones Serbal. Versión española 1996. p. 288.

7 Tobin, G. A. v.o.1976. Suburbanization and the Development of Motor Transportation: Transportation Technology and the Suburbanization Process. In: Schwartz, B.(ed). La citación está referenciada por la fuente secundario. <Hall, P. 1988, Cities of Tomorrow: An Intellectual History of Urban Planning and Design in the Twentieth Century. Freixa, Consol(tr). Barcelona. Ediciones Serbal. Versión española 1996. p. 288>
} 
podido ser alcanzados por los ferrocarriles. ${ }^{8}$

Las anticipaciones de Wells, <<Autopista>> surgieron entre los años 1913-1921, en Alemania. Fue una vía rápida de 6 millas en Berlín cruzando Grünewald a fin de que permitiese el desplazamiento diario de los trabajadores desde la distancia hasta la ciudad.

En el régimen de Hitler, a los nazis les encantaban las Autobahnen y construyeron 2.400 millas hasta al año 1938 con una velocidad monstruosa. Hall criticó que las formas de las autopistas eran muy primitivas y no entendía muy bien lo que constituyen en sí mismas, pero aún es cierto que construyeron un nuevo paisaje monumental. Los numerosos países liberales democráticos fueron influidos fácilmente por este concepto novedoso. ${ }^{9}$ En consecuencia de todas esas cosas, entre las cuales está la producción en masa de los automóviles de Ford, la Autobahnen de la República de Weimar y la de los nazis e incluso las opiniones públicas, ya estaban preparando un buen ámbito para el nacimiento de las ideas de Wright, que pudiera llegar hasta las raíces de EE.UU.(v.-fig. 3-1).

\section{La era de las máquinas de Chicago y Sullivan}

Frank Lloyd Wright, el protagonista de este capítulo, después de salir de la escuela secundaria, recibió la educación civil de ingeniería en la Universidad de Wisconsin durante menos de un año. En aquella época no existía la escuela de arquitectura, y en el año 1887 fue a Chicago, donde pudo recibir la más alta educación arquitectónica. ${ }^{10}$ Por aquel entonces, Chicago estaba pasando una etapa muy dinámica por su repentina aparición como uno de los mayores centros industriales del mundo. Sin embargo, al mismo tiempo, la ciudad, detrás de la imagen fabulosa, cada vez más fue cayendo enferma por las incesantes expansiones de los suburbios pobres de la ciudad y el asunto del desempleo. Estas imágenes contrapuestas de los pobres y rascacielos habrían hecho sentir a la ciudad una gran disociación. Tal vez, fue natural para Wright dado que creció en un ámbito agrícola, el darse cuenta que en Chicago no existían las virtudes que él valorara tanto, puesto que creció con su abuelo

\footnotetext{
8 Hall, P. v.o.1988, Cities of Tomorrow: An Intellectual History of Urban Planning and Design in the Twentieth Century. Im, C.H \& Ahn, G.H(tr). Seoul. Hanul books. Versión coreana: 2009. p. 380.

9 Hall, P. v.o.1988, Cities of Tomorrow: An Intellectual History of Urban Planning and Design in the Twentieth Century.

Freixa, Consol(tr). Barcelona. Ediciones Serbal. Versión española 1996. p. 292.

${ }^{10}$ Fishman, R. Urban Utopias in the Twentieth Century. Cambridge, Mass. The MIT Press. 1982. pp. 101-102
} 
ayudando en los trabajos familiares, y con tareas intelectuales como por ejemplo, leer libros con su madre. Todo estaba en armonía para un ser humano y, además le permitió observar el mal funcionamiento de la ciudad. ${ }^{11}$ Como Howard reconoció, la concentración de la riqueza fue la raíz del mal, Wright también insistió en cuestionarlo, reconociendo esa contradicción para implantar su democracia ideal que sobreviviera en Chicago, y más allá en Estados Unidos(v.-figs. 3-9).

En Chicago, hay otro aspecto más al que prestar atención: Louis Sullivan. Wright se quedó impresionado de su concepción de la democracia, y pronto fue reconocido como primer discípulo y heredero de la filosofía de Sullivan. Se convirtió en fiel creyente de la Democracia de la arquitectura, como si hubiera recibido un bautismo del espíritu democrático. Sullivan pensó sobre el papel de la arquitectura en la sociedad, y creyó que el bienestar de la república dependía totalmente del arquitecto. Para Sullivan todas las arquitecturas tradicionales constituyeron una tendencia no democrática, un mal legado que dominó a los humanos, y que ha de sustituirse por una nueva forma que pueda expresar el estilo de una vida democrática.

Para Sullivan, la democracia significó la libertad para que el hombre pueda estar centrado en sí mismo, autónomo, soberano, individual, un dios individual. Pero los clientes del $<<$ feudalismo industrial $>>$, según expresión de Robert Fishman, querían el estilo tradicional que representara visiblemente la grandeza de la clase de los dominantes (en la edad de moderna, construir una arquitectura de feudalismo industrial es totalmente anacrónico). Para Wright, como para su maestro, la Democracia de la arquitectura era necesaria para completar la edad moderna acabando la edad antigua. La idea de democracia tenía que salir de forma visible y funcional. ${ }^{12}$

\section{La lectura de Hull House}

Mientras tanto, el papel de la arquitectura y del arquitecto Sullivan, aún necesitaba pulirse más; Wright intentó definir por sí mismo dicho papel del artista en la sociedad, y esta definición se estrenó en un discurso titulado <<el arte y la artesanía de la Máquina>>, en Hull House en el año 1901. El título del

\footnotetext{
11 Ibid. p. 102-103.

12 Fishman, R. Urban Utopias in the Twentieth Century. Cambridge, Mass. The MIT Press. 1982. p. 104-105.
} 
discurso suena bastante extravagante, porque, como se ve, en el objetivo de realizar la democracia de la arquitectura, hay ciertas necesidades de enfrentar y negar tradiciones, según la teoría de Sullivan. Sin embargo, irónicamente, el remedio importante para la ciudad de la era de las máquinas que Wright encontró, fue revivir la artesanía medieval. Consideraba que la industrialización fue el enemigo necesario del arte y de la democracia (v.-figs. 3-2, 3).

La estrategia que derivó en Hull House, fue la reactivación del movimiento del arte y de la artesanía. Wright pensó que las máquinas bien orientad era la base del movimiento de la artesanía ideal, definitivamente gracias a la influencia de William Morris (1834-1896) que fue un artesano, y sabía cómo eran los pueblos ingleses anteriores, y cómo se habían arruinado por el industrialismo. La idea principal de Morris, era restringir el papel de las máquinas para que los humanos disfruten su labor y su capacidad con dignidad, encargando las tareas menos importantes a las máquinas. Así que el arte creativo de los humanos se puede integrar en el proceso del trabajo y los gremios cooperativos restaurarían las técnicas de antigua artesanía. ${ }^{13}$

Para Wright, la máquina era para los humanos, para liberarles de los trabajos penosos y nos permitiese dedicarnos a las cosas más artísticas, de forma que fuera la base esencial de la dignidad de los individuos y familias en el tiempo de la devastación. Wright concluyó que el papel del artista creador debe ser dominar la grandeza de la máquina, la ciudad, y darle $<<U N$ ALMA $\gg .^{14}$

Mi Dios es la maquinaria, el arte del futuro será la expresión del artista individual a través de los mil poderes de la máquina, la máquina haciendo todas las cosas que el trabajador individual no puede hacer, y el artista creativo es el hombre que controla todo esto y lo entiende. ${ }^{15}$

Charles Ashbee.

\footnotetext{
${ }^{13}$ Fishman, R. Urban Utopias in the Twentieth Century. Cambridge, Mass. The MIT Press. 1982. p. 107.

14 Ibid. p. 109.

${ }^{15}$ Crawford, Alan. Ten letters from Frank Lloyd Wright to Charles Robert Ashbee. Architectural History 13. 1970. p. 64. La citación está referenciada por la fuente secundaria: <Fishman, R. Urban Utopias in the Twentieth Century. Cambridge, Mass. The MIT Press. 1982. p. 108>
} 


\section{Broadacre City}

En pocos días aprendí a ver la vida despojada de su esplendor. Ya no contemplé a esas ajadas mujeres con la despreocupada mirada de la juventud. Ya no vi carácter en las formas encorvadas y en los cabellos grises de los hombres. Empecé a darme cuenta de que mi propia madre había seguido la misma rueda infernal sin tener ni un día de ocio, ni una hora libre que le permitiera escaparse de las manos exigentes de los niños, o de la obligación de remendar y lavar.

Garland, H. 1917. A Son of the Middle Border. ${ }^{16}$

Wright, como si fuera un profeta, estaba lleno de convicción sobre lo que sabía y con ello, a dónde tenía que llevar la ciudad. La ciudad ideal (que sería Broadacre City para Wright) era como una herramienta intelectual en su cabeza, y una vez la concibió, pudo extenderla para cualquier campo según en qué se aplica: el cuerpo gubernamental, los institutos educativos, la religión e incluso la economía, por ejemplo el sistema bancario. Además, como la Gran Depresión devastó y condenó el mercado de la bolsa (1929), sintió la necesidad de completar su trabajo con más urgencia. ${ }^{17}$

Las falsas teorías se propagaron por cualquier lugar, en las grandes ciudades, debido a sus concentraciones expansivas, que hace mucho que perdieron su valor peculiar o tal vez, fue porque ellas reconocieron el verdadero aspecto de la modernidad, la disociación. La ciudad ya no fue moderna sino obsoleta. ${ }^{18}$

En abril de 1935, Wright estrenó <<Broadacre City >> en el Rockefeller Center. Broadacre City contenía el principio de descentralización gracias a los automóviles y autopistas, como Ebenezer Howard hizo con La Ciudad-Jardín gracias a los ferrocarriles de no precio tan caro. Sería apropiado que ese tipo de movimientos de descentralización (uno de Howard y el otro de Wright), se

\footnotetext{
${ }^{16}$ Garland, H. A Son of the Middle Border. London: John Lane, The Bodley Hand. 1917. La citación está referenciada por la fuente secundaria: < Hall, P. v.o.1988, Cities of Tomorrow: An Intellectual History of Urban Planning and Design in the Twentieth Century. Freixa, Consol(tr). Barcelona. Ediciones Serbal. Versión española 1996. p. 299>

${ }^{17}$ Fishman, R. Urban Utopias in the Twentieth Century. Cambridge, Mass. The MIT Press. 1982. p. 122.

18 Ibid. p. 123.
} 
comprendiese en dos perspectivas distintas (v.-figs. 3-4, 8). Howard sigue la virtud de la cooperación de la comunidad -como en la época medieval- considerándola que es la base de la vida, así la ciudad tiene una forma perfectamente simétrica y compacta para generar el espacio público y los equipamientos. Sin embargo, la virtud primordial de Wright fue el individualismo. Allí no existe un centro $<<$ reconocible $>>$, y ningún punto en el cual el mundo natural da paso a un entorno dominado por el hombre (v.-figs. 3-5, 6). Cada familia ocupa una granja con suficiente espacio, como cada ciudadano tiene derecho a ocupar un acre en que la gente pueda establecerse. La descentralización llegará hasta el punto en que se hace vago y ambiguo la distinción entre el área urbana y rural (El medio ambiente se convierte por el hombre en una parte de la naturaleza $)^{19}$ Es una expansión urbana, pero no es dispersión (sprawl), desde el principio no existía ningún núcleo reconocible de la ciudad, por lo que no hay particular dirección de su expansión. Por eso, aquí en Broadacre City, la expansión y la descentralización son conceptos compatibles (v.-fig. 3-7). Además, como no hay distinción entre lo rural y lo urbano, el síntoma de sprawl ya no tiene sentido patológico. ${ }^{20}$

Esta fue la idea que Wright sacó de su infancia en la granja de su abuelo y de su tío, experimentando el proceso de una familia que se va a colapsar. ${ }^{21}$ Pudo aprender el equilibrio de la labor física e intelectual en la granja de su abuelo con las compensaciones que fueron siempre apropiadas. ${ }^{22}$ Naturalmente, pudo concebir los conceptos esenciales para estar independiente una familia (La tierra era la última frontera que tendría que protegerse. v.-fig. 3-2).

En la ciudad moderna que Wright percibió, no existía una labor verdaderamente productiva. La mayor parte de los ciudadanos vivía con la ansiedad de poder perder su hogar no pudiendo pagar el alquiler. Supo que la psicología de la vida urbana era un peligro para la salud mental nacional. ${ }^{23}$

Distinguió tres formas: renta por tierra, renta por dinero (interés), renta por ideas (control de invenciones). Los tres son el apoyo de la vida <<vicaria >> del rentista, cuya existencia es vicaria en el

\footnotetext{
19 Fishman, R. Urban Utopias in the Twentieth Century. Cambridge, Mass. The MIT Press. 1982. pp. 92-93.

20 Básicamente, en este contexto un sprawl, sería de un área urbana. Pero si fuera en una área rural, ya pierde su sentido.$(\mathrm{NdA})$

21 Sus padres se divorciaron. Y Wright se quedó sin recursos con su madre. Gracias a su abuelo y su tío, pudo vivir en una granja con ellos.-(NdA)

${ }^{22}$ Fishman, R. Urban Utopias in the Twentieth Century. Cambridge, Mass. The MIT Press. 1982. p. 98

${ }^{23}$ Ibid. p. 124
} 
sentido económico porque se basa en el trabajo de otros, y vicarial psicológicamente porque el rentista no puede tener sentido de sí mismo como un individuo productivo. La ciudad es el gran lugar de Renta y por lo tanto el centro natural para la vida vicaria y el <<instinto de rebaño>>.24

\section{La realización de Broadacre City}

Para muchos, la arquitectura de Wright $y<<l a$ arquitectura de la democracia americana $>>$ eran sinónimos. Como un egoísta descarado y un pionero en el campo de los medios más conocidos, Wright alentó la identificación popular de sí mismo con el espíritu americano. Cultivó una imperiosa imagen de hablar con simplicidad, democracia de anti-colectivista y trató personalmente de encarnar la noción de individualismo radical. ${ }^{25}$

Para realizar la verdadera vida urbana, con labor sincera, pero sin beneficios dependientes ajenos, Wright sugiere una legislación que expropia todas las tierras. En el sentido de que valora mucho la tradición de la familia es muy conservador, pero ahora exige un método socialista para realizar una genuina democracia con la arquitectura. Los conceptos que parecían que serían incompatibles, ahora encajan bien en el concepto dialéctico, o herético. Además, aún si se distribuyese las tierras a todas familias americanas según el plan de Wright, no habría ningún problema práctico, pues en el año 1930 en EE.UU toda la población americana entraba perfectamente con el programa de Broadacre City para el estado de Texas. ${ }^{26}$ Después de la expropiación (y distribución) de todas las tierras, en cada propiedad, los ciudadanos eran trabajadores empleados por sí mismos, a parte de su profesión. En su tierra, nadie va a ser desempleado ni esclavo de nadie que arrebatara los frutos dependientes. Los ciudadanos de Broadacre City, sin excepción, tendrían las habilidades para ser agricultores a tiempo parcial, mecánicos a tiempo parcial e intelectuales a tiempo parcial. Si las máquinas estaban al servicio del hombre, el trabajo fabril podría convertirse en un ejercicio de artesanía mecanizada. La diferencia de las tareas de todos los días, entre el trabajo y el ocio, se ve atenuada. ${ }^{27}$ Para Wright como Howard,

\footnotetext{
24 Ibid. pp. 124-125.

25 AAVV. 1966. The City Reader. Oxon. Routledge. LeGates, R. T. \& Stout, F. (eds). 2011.

26 Fishman, R. Urban Utopias in the Twentieth Century. Cambridge, Mass. The MIT Press. 1982. p. 127

27 Ibid. p. 128.
} 
la propiedad sirvió para definir y proteger el mayor bien de la sociedad.

Sin embargo, aparte de todo eso, en la realización de Broadacre City, sería importante presentar el sistema monetario que Wright propuso. Básicamente el sistema monetario de Broadacre City es un dispositivo de seguridad para que los financieros no puedan acumular el capital en algún tipo de clase particular o distinguida; consecuentemente la fuerza excesiva de los financieros no supera la de la clase obrera. Originalmente es una versión más suave que la de Pierre Joseph Proudhon(1809-1865) que dice que los productos sólo pueden intercambiarse por los productos. ${ }^{28}$ Pero, Wright adopta la versión de Silvio Gesell que propone diseñar y publicar la moneda perecedera. ${ }^{29}$ La moneda es un producto que nunca caduca, sin embargo, en el caso del producto de la patata, empieza a perder su valor, justo después de su cosecha por su carácter perecedero. Entonces, artificialmente delimita la caducidad en las monedas (cada año pierden cierta porción de su valor). Si el capital no se puede acumular, normalmente habrá otro sitio para los especuladores, pero la tierra está completamente protegida por la ley de Homestead ${ }^{30}$. Además, el mercado de empleo también es estable, porque la ciudad se mantiene por la economía de pequeña escala y el $100 \%$ de Homesteaderos son autoempleados en su Broadacre. La familia tiene la seguridad de no depender totalmente de la industria local.

${ }^{28}$ Proudhon, P. J. ¿Qué es la Propiedad? Lee, Y. J(tr.). Seoul. Acanet. Versión coreana. 2013. p. 325.

${ }^{29}$ Fishman, R. Urban Utopias in the Twentieth Century. Cambridge, Mass. The MIT Press. 1982. p. 132.

${ }^{30}$ La Ley de Asentamientos Rurales.-(NdA) 


\section{Sobre lo que supo Wright: Una charla epistemológica y nirvánica}

Wright percibió que la renta que amenaza las familias americanas era la raíz de maldad de la ciudad. Los beneficios sin su propio esfuerzo, cada vez más, hicieron enfermar la ciudad. Wright creyó que la psicología de la vida urbana era peligrosa para la salud mental del estado. $Y$ de igual modo, la economía urbana ponía en peligro el bienestar físico del estado. ${ }^{31}$ Los síntomas patológicos urbanos sobre la salud mental y física, en realidad, se originaron en la misma raíz. El método de abolición del sistema de renta, en otro término $A D^{32}$. Wright propuso una exhaustiva expropiación que ha sido buena fórmula de $\mathrm{ED}^{33}$, y aunque todavía quedan algunos temas polémicos sobre su metodología, por lo menos fue un método permanente. Ahora el valor del individualismo y la familia están protegidos. Pero, como la sociedad no puede existir sin individuales, un individual no se puede definir fuera de la sociedad.

La sociedad nirvánica se sostiene por concebir la trascendencia de los individuales diferenciales de la sociedad, por contra, los individuales se perciben únicamente entre las integraciones (relaciones circunstanciales); en el resultado, el individuo se puede incorporar al concepto llamado Anātman (NY) ${ }^{34}$. Sin embargo en el caso de Wright, existe la diferenciación de los individuos pero, apenas se puede predecir la integración, y se lleva siempre el riesgo de fuga de los individuos. Todo es cuestión de equilibrio.

Wright fue un hombre religioso, pero su religión fue un sin-dogma del corazón. El Reino de Dios está dentro de ti, era su texto favorito de las escrituras. Teología era una pelea sin punto, una obstrucción a la búsqueda de la verdad, a la que podrían contribuir todas las religiones del mundo. La religión une a la persona con la gran armonía de la naturaleza; que era la salvación. ${ }^{35}$

Robert Fishman.

Como Wright no confiaba en la religión, si estaba ya institucionalizada, pensó que también tiene que

\footnotetext{
${ }^{31}$ Fishman, R. Urban Utopias in the Twentieth Century. Cambridge, Mass. The MIT Press. 1982. p. 124.

${ }^{32}$ Acumulación del Dolor-(NdA)

${ }^{33}$ Extinción del Dolor-(NdA)

${ }^{34}$ No-yo-(NdA)

${ }^{35}$ Fishman, R. Urban Utopias in the Twentieth Century. Cambridge, Mass. The MIT Press. 1982. p. 140
} 
ser diseñada. Creyó que la religión tiene que ser más universal; ha de fundamentarse en el Espíritu libre del ser humano individual. Literalmente, creó una religión de los Hippies y su estilo de humanismo (nunca se llamó humanismo, sin embargo, fue claramente humanista en su postura). Él estaba obsesionado por un mundo de ficción que se originó cuando nació en un ambiento rico, y pasó de manera inestable el periodo de crecimiento, experimentando principalmente la escisión de los miembros de la familia. Por lo cual, como el mundo está diseñado por todas partes exhaustivamente por el arquitecto omnipotente, quiere decirse que Su reino ya ha venido. Eso significa que es el advenimiento de los Cielos, al mismo tiempo el apocalipsis de la sociedad secular. Ya no hay ningún sitio para ocupar la flaqueza (fragilidad moral) humana y su inestabilidad. Desaparece el discurso pero aparece la profecía. Eso suena familiar; que es autocracia, sin embargo esta vez fue Arquitectocracia. ¿Fue eso verdaderamente una utopía? Seguramente, él también fue consciente del límite de su esquema. Pero su metodología de construir un mundo perfecto que pudiera superar la debilidad humana y los elementos indefinidos ha acabado por contradecirse a sí misma, en el sentido de que el viaje para ir a la verdadera democracia no era democrático. 


\section{Sobre lo que Wright hubo de hacer: Una charla ética y nirvánica}

Por lo tanto, el retorno de la familia como la unidad económica básica resolvería el problema de la labor. (El riesgo de perder el trabajo.) El razonamiento de Wright aquí muestra el tremendo peso de la responsabilidad social que su teoría pone en la familia. ${ }^{36}$

Tal vez, el dilema ético que más molestó a Wright, podría resumirse en una frase: <<¿Broadacre City podría encontrar el espíritu y la virtud de la democracia en esta relación extraña tanto como contradictoria entre el individualismo extremo de Wright y el liderazgo profético de una minoría que controla todo el proceso de implantación y mantenimiento del proyecto? >> Su metodología y proceso se quedan todavía ambiguos, pero, como la tierra (inmuebles) fue donde Wright encontró la base elemental de la democracia, la consideró el método fundamental para preservarla, también surge desde la economía de la tierra.

Si una vez completada la expropiación y la distribución según la ley de la ciudad, el sistema empezará a funcionar -y desde aquí <<one-man-architect-government>> revela su ironía. Básicamente, todos los ciudadanos de Broadacre City, hacen trabajo físico e intelectual. Las fábricas y las instituciones económicas tienen que existir por la razón de que son unidades que apoyan a las familias. Cualquier tipo de industria centralizada tiene la posibilidad de abrumar el sistema, por eso él se opuso y enfatizó ese tipo de emergencia venidera. En las pequeñas fábricas, las familias no pierden su posición para sostener la base de la economía de la ciudad. Por eso Wright llegó a una conclusión que era excluir incluso el gobierno.

\footnotetext{
${ }^{36}$ Ibid. p. 130.
} 


\section{Sobre lo que Wright deseó: Una charla estética y nirvánica}

Como se ha repasado en el capítulo previo, Howard fue un pensador que tenía mucha preocupación por los problemas del hábitat humano. Si se recuerda el plan de ciudades-jardín, desde su inicio, Howard no negó el menester de la existencia del gobierno central. Estos dos utopistas, ambos, empezaron por la noción de la descentralización. En el caso de Howard quiso distribuir el poder del gobierno central a los pequeños gobiernos locales (aún son centrales en cada territorio de influencia, a su nivel). Sin embargo, en el caso de Wright, como puro radical de sus maestros precursores, negó cualquier tipo de poder institucional mediante la construcción del Broadacre City sin ninguna parte dominante. Las ciudades del estilo de Howard se expresan con los espacios públicos, concentrando cada pequeño espacio de los miembros de Ciudad-jardín, para establecer y restaurar la virtud comunitaria de la etapa medieval, cuyos frutos fueron cooperaciones y brillantes espacios públicos de forma geométrica; que ahora están delimitados por el cinturón verde, así que se define su tamaño apropiado que se suele expresar en el tamaño de quince minutos andando.

La expansión que fue maldad para Howard, fue para Wright la virtud que debía perseguir. Como los árboles y bosques crecen, la ciudad se extiende sólo con la condición de no haber quedado ningún organismo sistémico central, así que Wright elimina el fracaso institucional, sin crear ningún cuerpo dominante. Y la fragilidad humana se sustituye por los arquitectos elegidos en cada comunidad. Si se hubiese planeado adecuadamente, se podría extender incesantemente según el plan del arquitecto, pensó. El módulo viene desde los ciudadanos motorizados que se pueden mover a 60 millas por hora.

Wright intentó diseñar las organizaciones e instituciones que no abarcaban todo tipo de poder central. Incluso el tamaño de las escuelas no son excepciones de su módulo, para que ninguna tradición académica sea dominante en el campo de la educación y la interpretación. En realidad, aquí no se puede ignorar la posibilidad de considerarlo solamente como un teórico de todo su plan. En realidad, Howard insistió en realizar su plan por medio de conocer a la gente con poder y utilizar todas las infraestructuras sociales. Por otra parte, Wright como Juan el Bautista, solo proclamó lo que tenía que predicar, diciendo; $<<$ Voz del que clama en el desierto: Preparad el camino de la Democracia $>>$ y antidemocráticamente, él sugirió que el gobierno expropie todas las propiedades del suelo. No cabe duda 
de que aquí hubo una gran ignorancia en el razonamiento del proyecto, y su fundamento legal, e incluso en los conocimientos científicos sociales. Wright, en su desarrollo intelectual y físico de su etapa de crecimiento, ha sido más convincente -aunque alguna vez dogmático- sobre su fe, que la bendición de Broadacre Ciity es algo que toda la gente tiene que saber y disfrutar. Por lo tanto su plan fue independiente y también heterodoxo en el sentido de que sabía sintetizar en una noción, la doctrina de la democracia (de Sullivan) y la máquina (de Morris) con el método dialéctico, y se consolidó a sí mismo desde la línea de la ortodoxia. El resultado natural de matiz individualista fue más denso que el de Sullivan.

El modelo de Broadacre City es muy autoritario, -no tanto como el de Le Corbusier- porque el esquema que aplicó, un único principio, a varios componentes del pensar y decidir, desde el principio hasta final, es de apariencia remarcablemente bonita y aseada. El patrón cuadrícula, tan bien planeado, nos insinúa cual es el plan democrático. Mientras tanto, poco a poco, habrá gente que empiece a tener una sensación como si hubiese entrado en un parque de atracciones; que es un juego intelectual de alguien, es decir, de Wright. Una vez se ha establecido una ciudad, se repite su proceso de expansión sin fin. El extremo de la idea individual de la persona, de la familia, en sus casas y calles se extiende hasta el horizonte; Ese proceso no se llamaría urbanización sino individualización.

En una colina de la ciudad, hay un arquitecto que acaba de terminar su obligación celestial, ve abajo no la ciudad, sino las unidades individuales. El helicóptero personal y los vehículos diseñados en el futuro, son los únicos elementos que rompen la escena súper estática de Broadacre City(v.-fig. 3-8). 


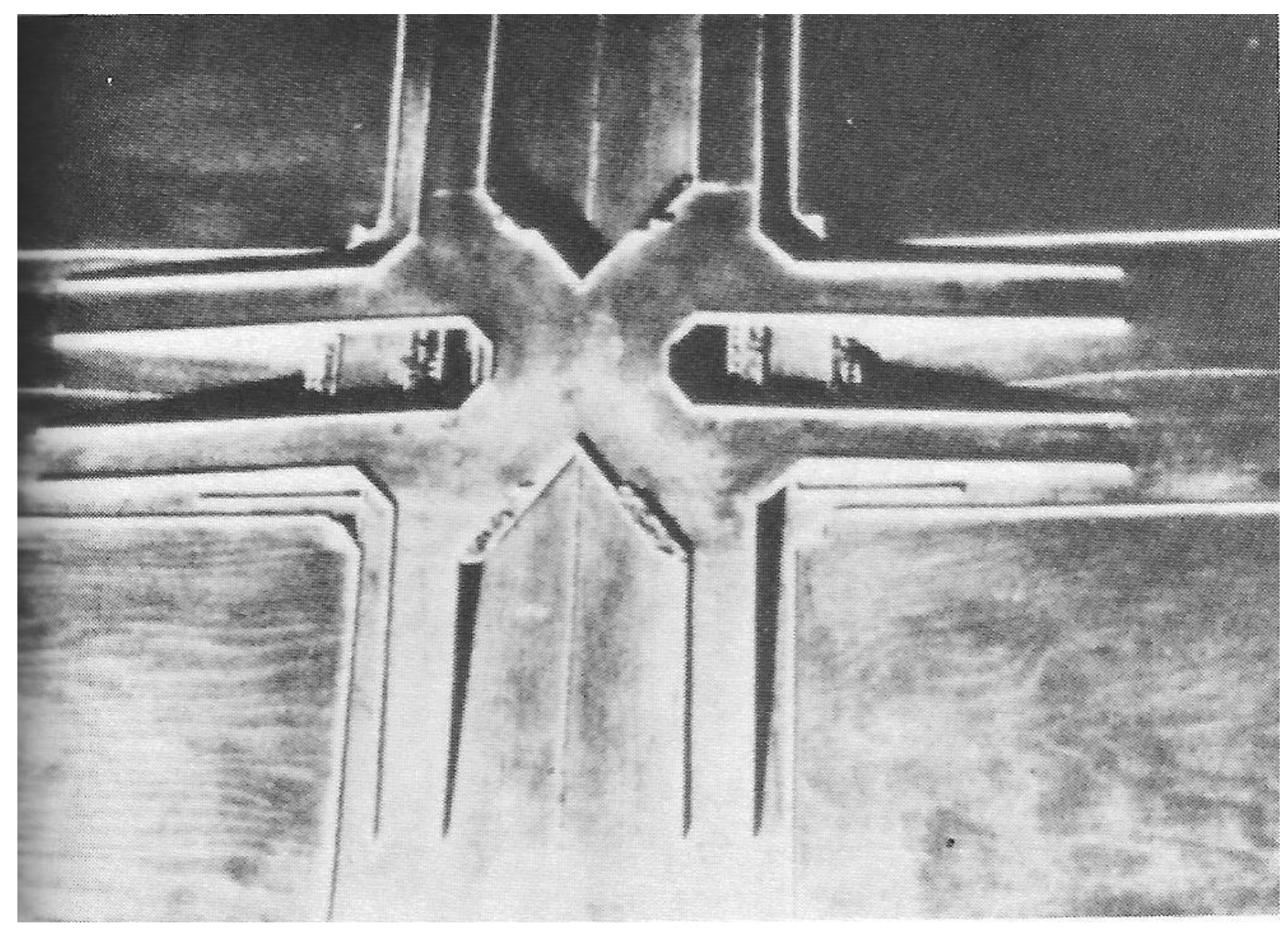

Fig. 3-1. Autopista de intercambio de Broadacre City. 


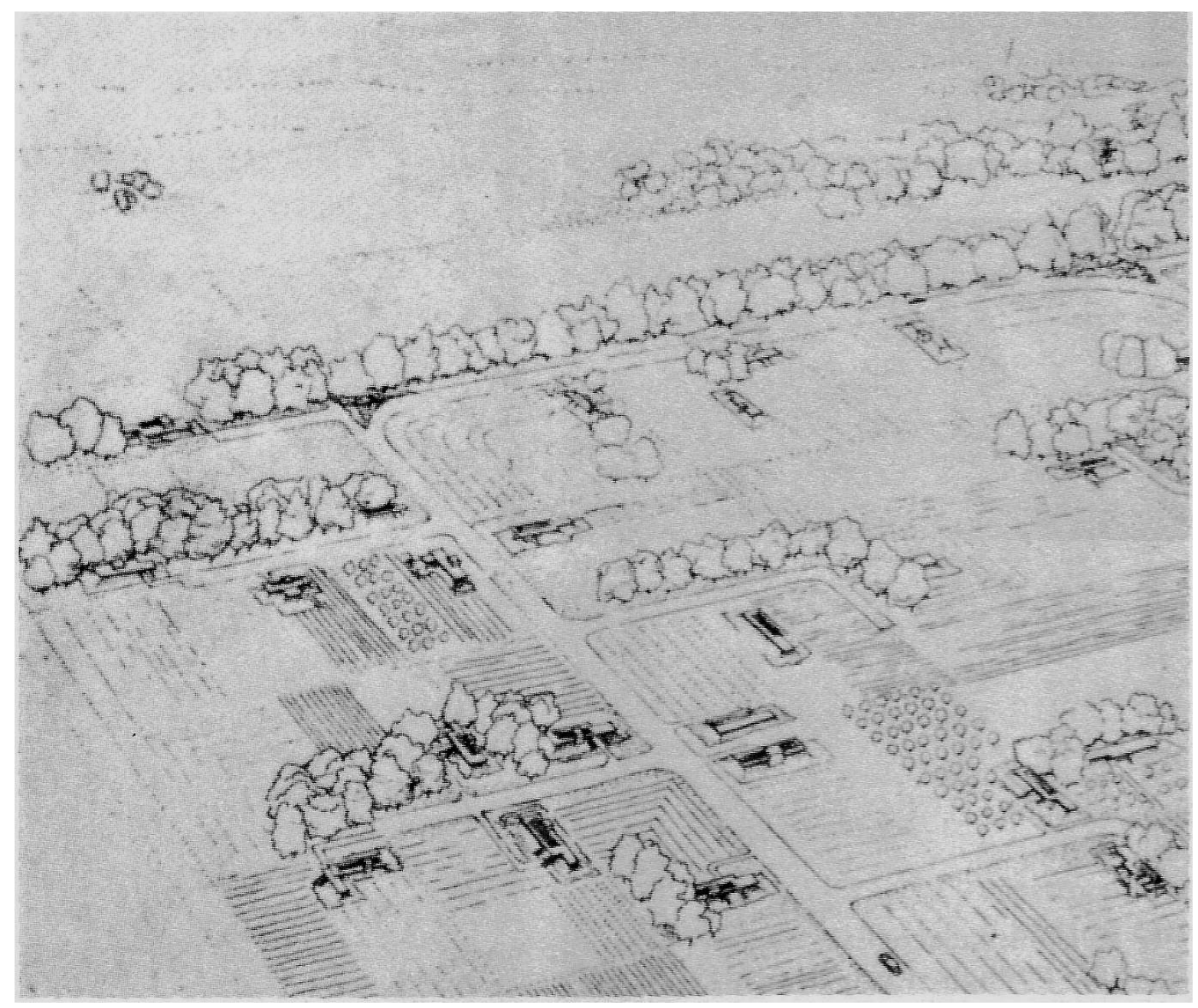

Fig. 3-2. Casa de Berma para trabajadores cooperativos. 


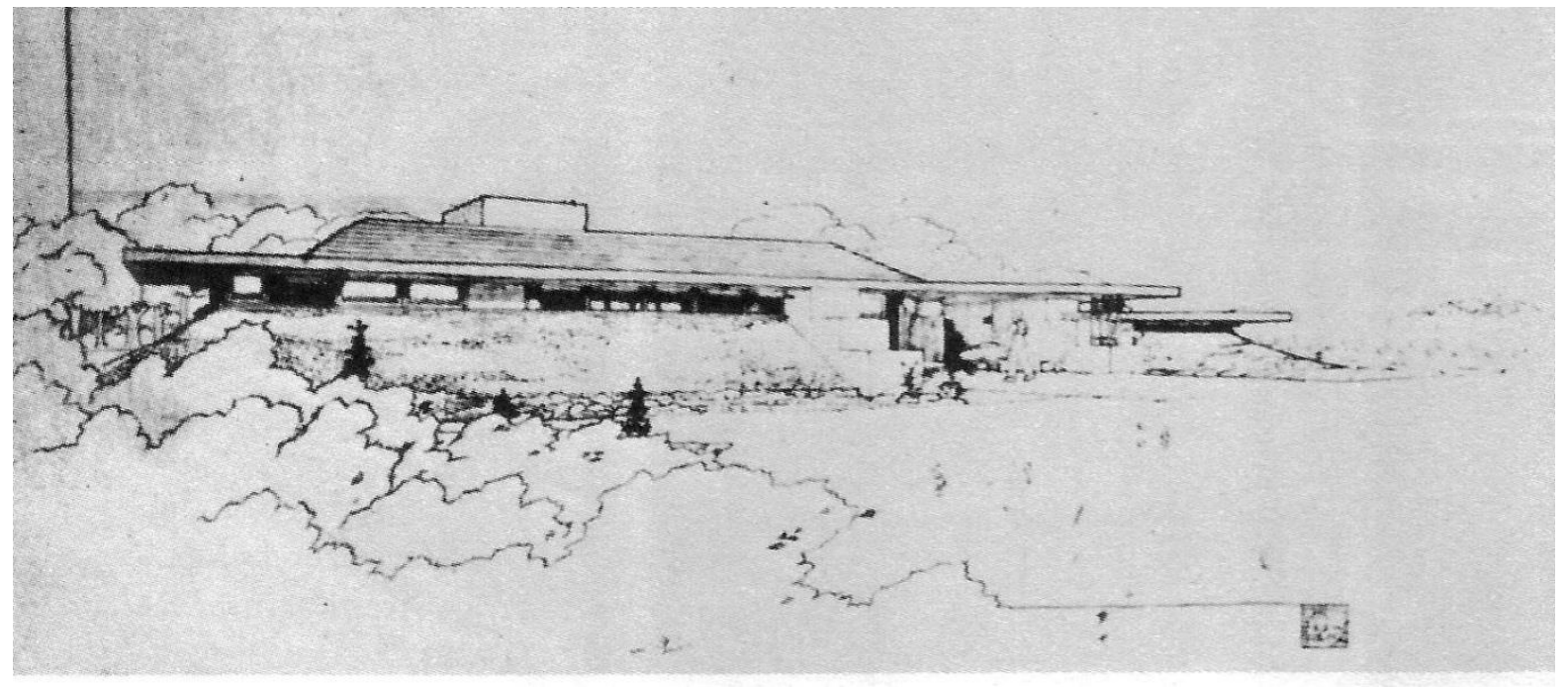

Fig. 3-3. Casa de Berma. 


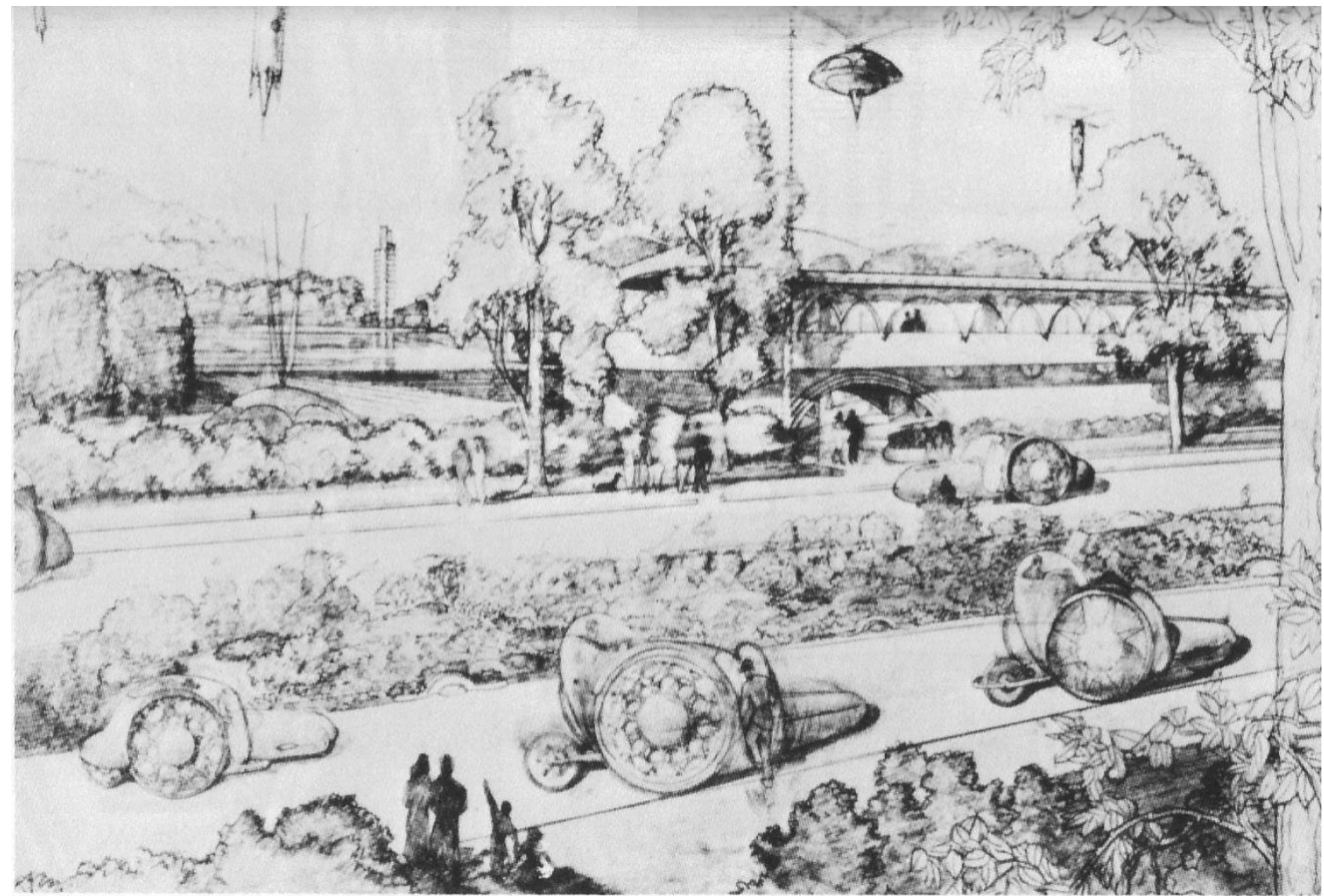

Fig. 3-4. Dibujo de pincel de Frank Lloyd Wright. 


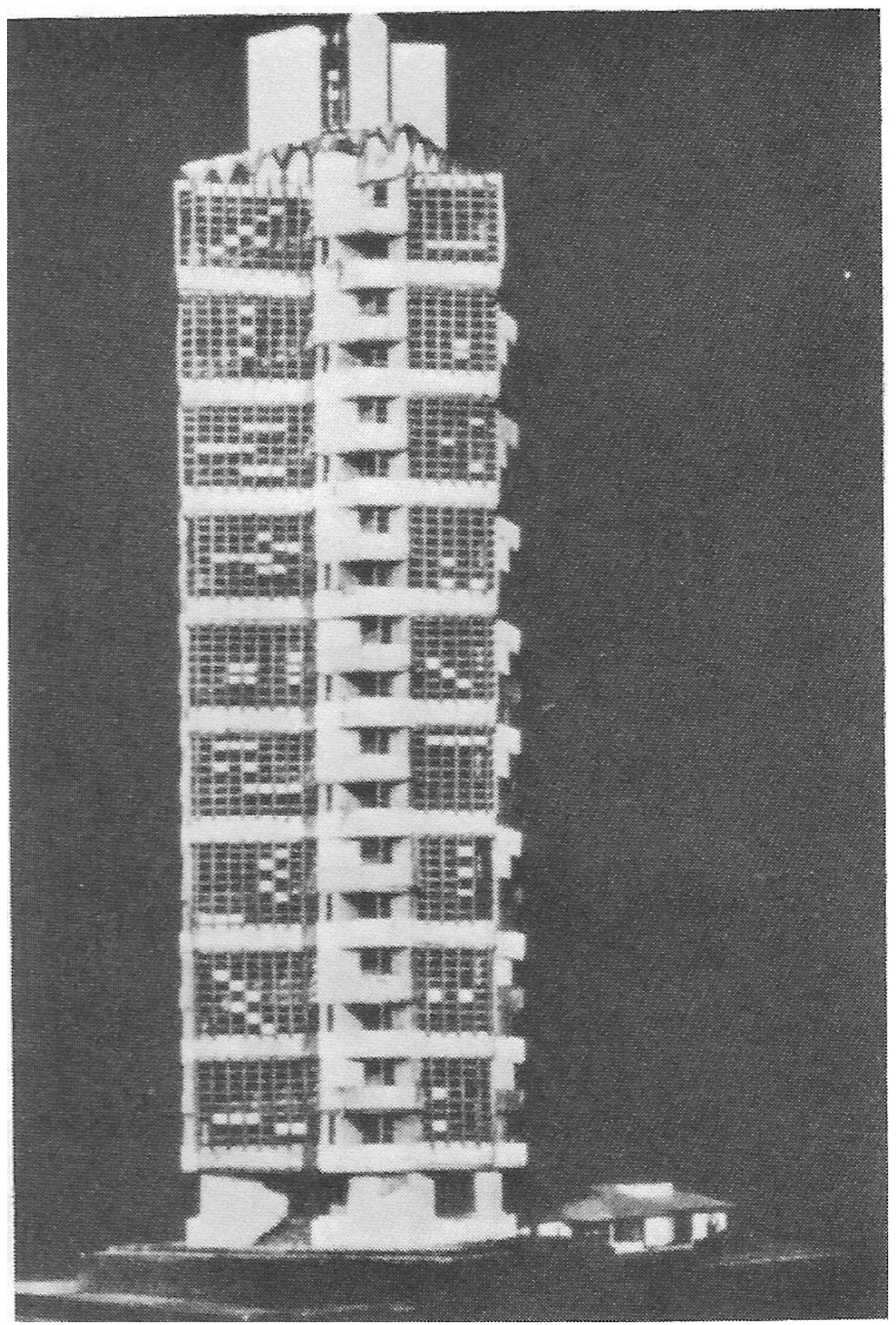

Fig. 3-5. La maqueta del bloque de viviendas para Broadacre City de Frank Lloyd Wright. 


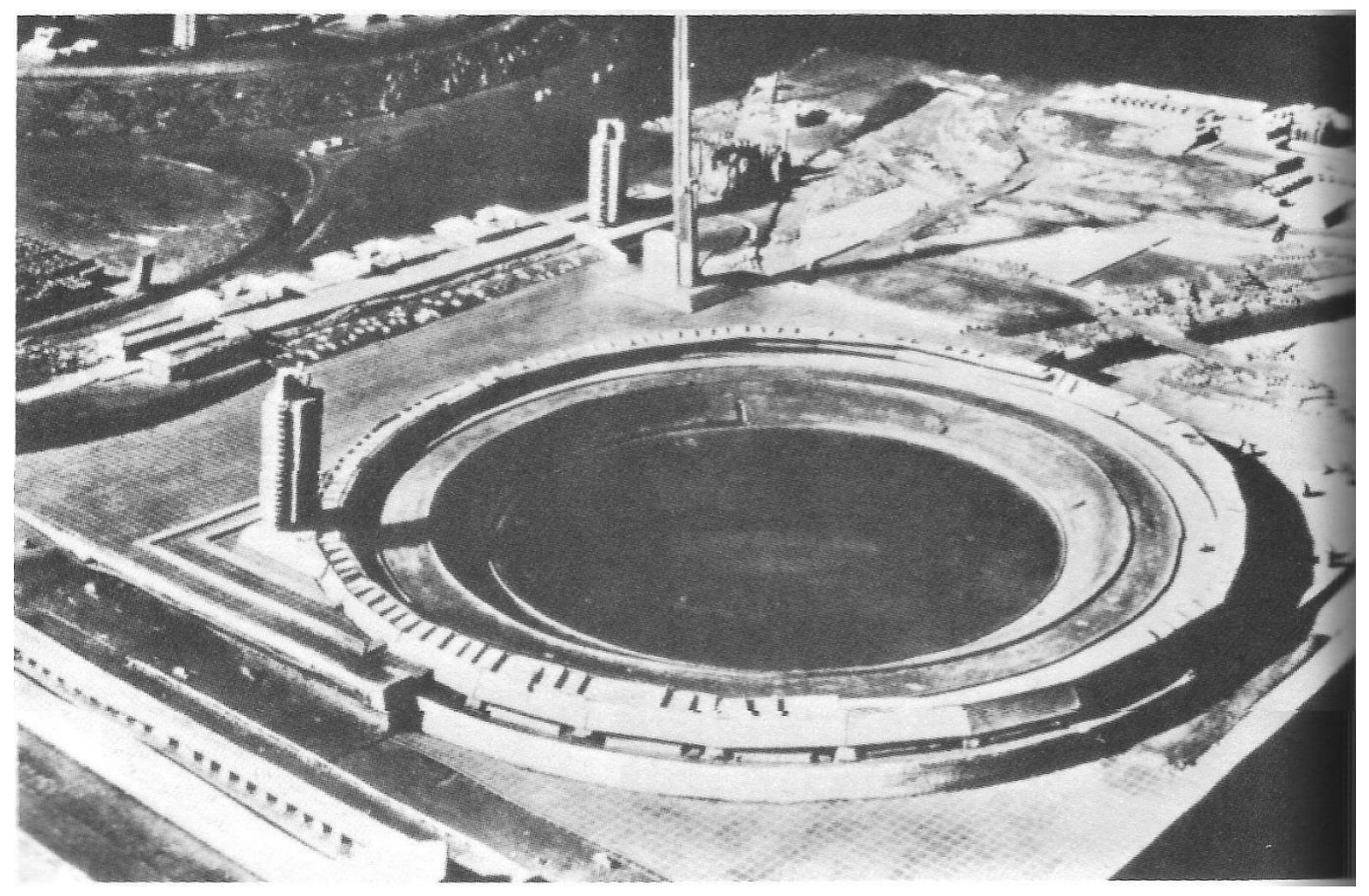

Fig. 3-6. La maqueta del circo de Broadacre City de Frank Lloyd Wright. 


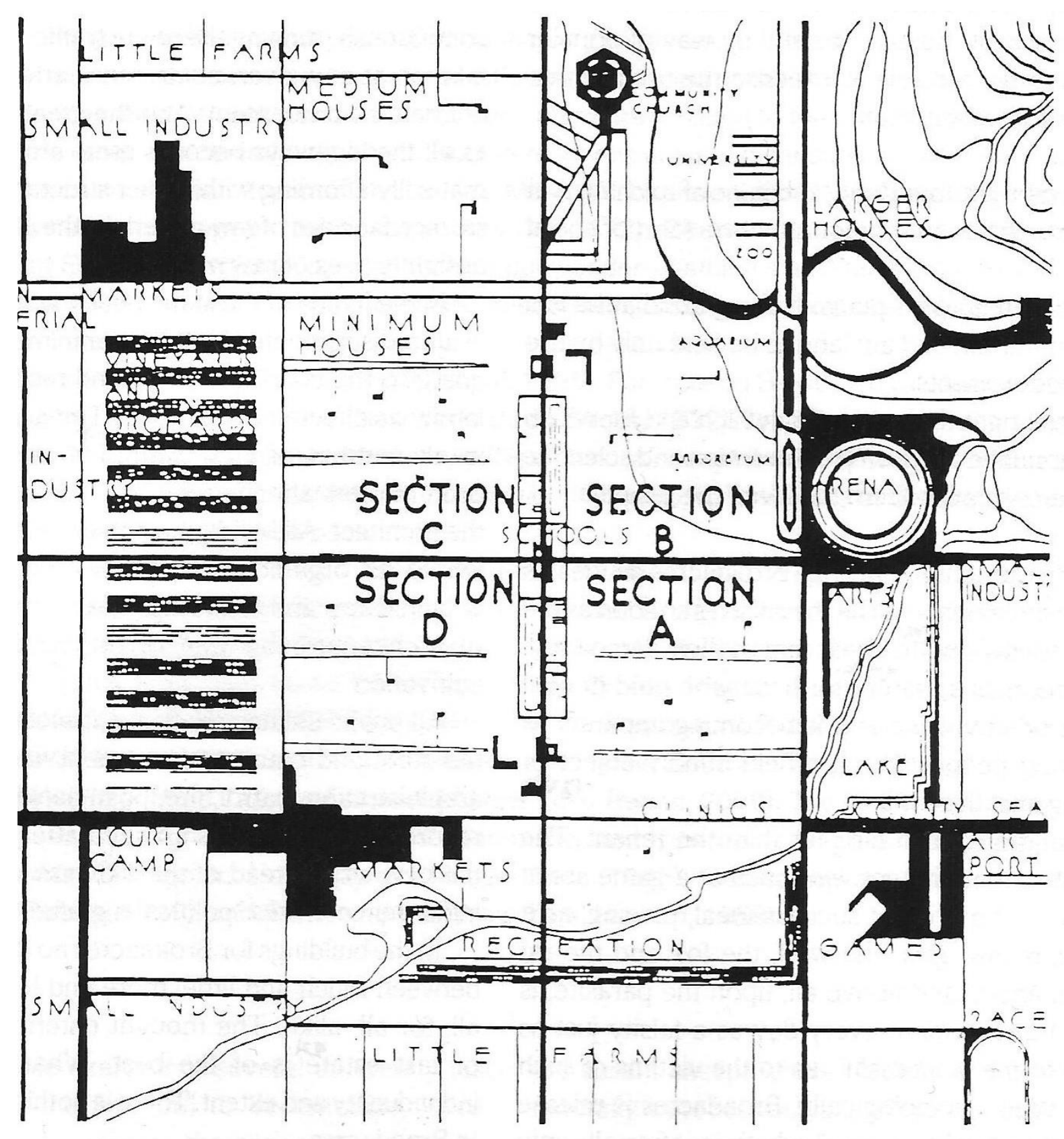

Fig. 3-7. Plano del centro de Broadacre City. 


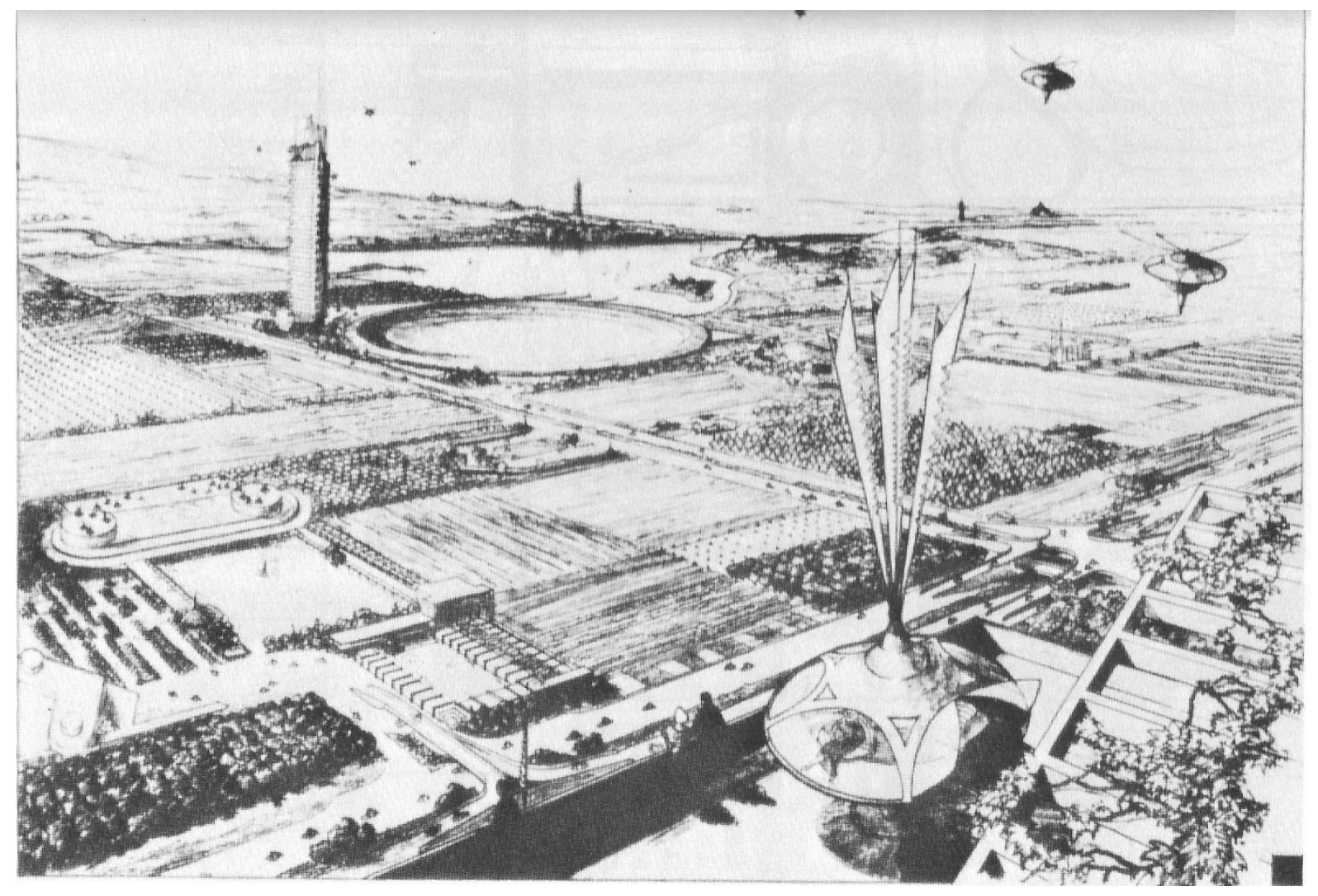

Fig. 3-8. The Broadacre City de Frank Lloyd Wright. 


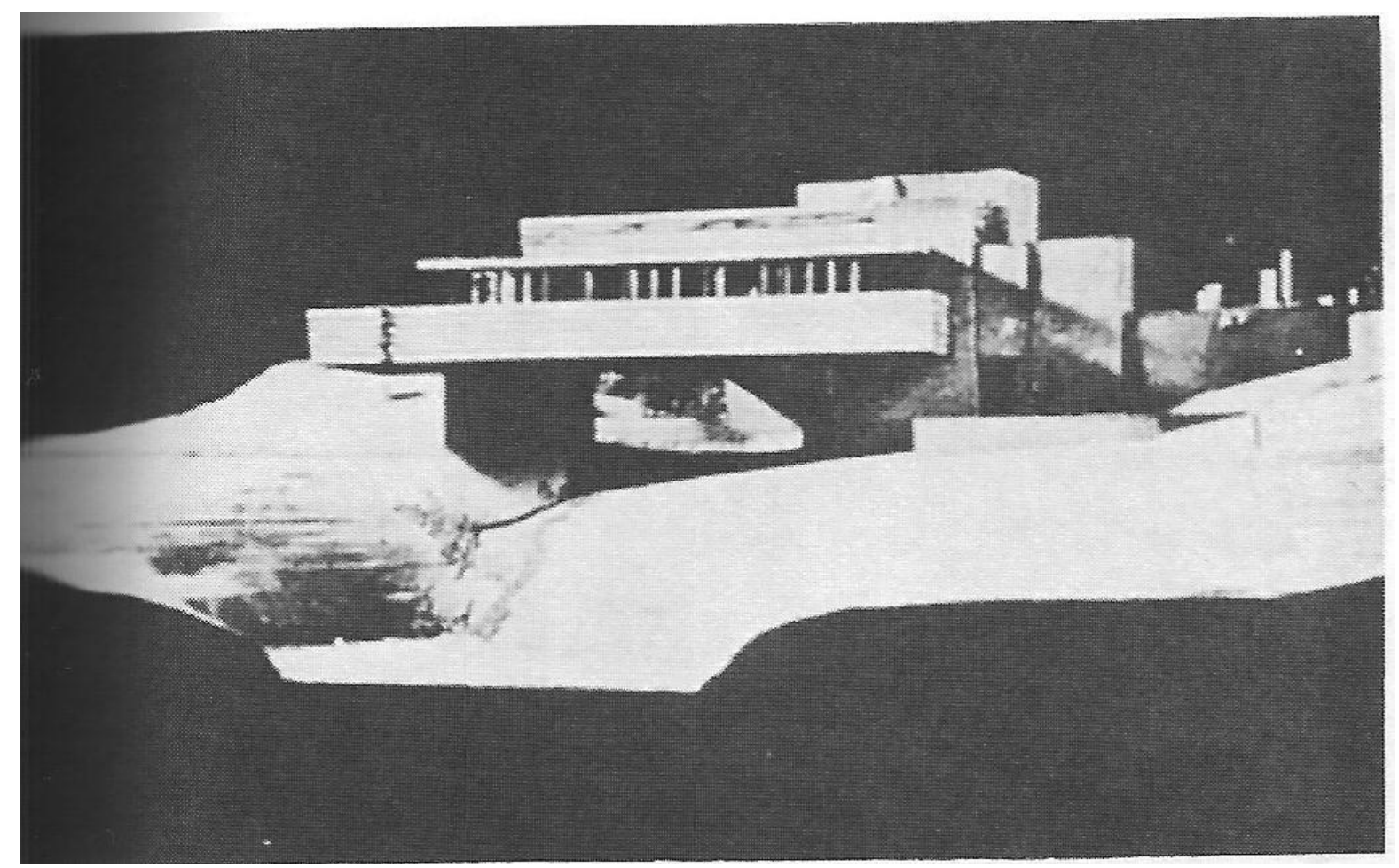

Fig. 3-9. Típica casa en pendiente de Broadacre City. 


\section{La Ciudad Contemporánea de Le Corbusier:}

\section{¡Debemos construir en un espacio limpio!}

Howard y Wright fueron grandes urbanistas que soñaban independientemente con sus utopías sagradas. Sin embargo, hay otro maestro de la edad moderna, llamado Le Corbusier, arquitecto y urbanista que recibe distintas evaluaciones de los críticos, al que unos adoran y otros desdeñan. Su talento artístico fue sobresaliente, desde pequeño trabajó como grabador de estuches para relojes. Eso sugiere que su posición social perteneció a la élite artística de la comunidad artesanal, organización de los atelier, que funcionaba gracias a los maestros de artesanía y sus aprendices. A pesar de todo, después de la revolución industrial, la comunidad se agitó y tuvo que experimentar por sí misma ese cambio de aires en la ciudad.

\section{Frank Lloyd Wright versus Le Corbusier}

Antes de tratar a Le Corbusier, sería conveniente tener una pequeña charla sobre Wright, para así poder entenderle completamente comparando, de manera yuxtapuesta, sus posturas respecto cada utopía.

Como se ha observado, Wright quiso descentralizar las ciudades (debido a la baja densidad de población) por eso, la Broadacre City se encuentra incesantemente en expansión urbana, y de este modo mantiene su densidad apropiada; en consecuencia, los individuos y las familias tienen garantizados su verdadero individualismo e independencia. Sin embargo, para poder realizar el éxodo, los arquitectos requieren una absoluta autoridad (referido en el capítulo tres) como: Arquitectocracia. Presuntamente dicha autoridad sería una solución muy agradable también para Le Corbusier, pero justamente aquí es donde se revela la mayor diferencia entre ellos.

Wright quería esa autoridad para que la densidad se pudiera resolver satisfactoriamente, pero, por otra parte, Le Corbusier quería que las ciudades subieran su densidad de población debido a la eficiencia urbana, especialmente mediante el asunto del transporte, quería que la ciudad tuviera su forma geométricamente perfecta. En el plan realizado por Le Corbusier, Ilamado <<La Ciudad 
Contemporánea>>, se celebra la eficiencia y la belleza que vienen desde la gran burocracia, cuya administración total de la sociedad, en su opinión, era bastante deseable, logrando así el orden y la armonía absolutos.

La ciudad de hoy en día es una cosa agonizante porque la forma de ella no es geométrica. Para construir en la intemperie habría que sustituir nuestros actuales planes de azar que todos nosotros tenemos hoy, por un plan unificado. A no ser que hagamos esto, no hay salvación. ${ }^{1}$

Le Corbusier. 1929. Urbanismo.

Ambos creyeron que la industrialización condicionó la nueva época de tecnología en relación a la arquitectura y la ciudad. Además, ambos quisieron construir la ciudad en un espacio vacío. En el caso de Wright, en un campo abierto, y en el caso de Le Corbusier, en París, destruyendo todos los edificios pre-existentes (la municipalidad de París discriminó a Le Corbusier, expresándolo suavemente, por carecer de la comprensión del contexto urbano).

Tal vez pudieron coincidir en que debían imaginar el futuro separado del pasado, para invocar una nueva era. Eso fue para ellos la premisa compartida imprescindible, para llegar a la noción llamada <<libertad individual >>. Se pueden interpretar sus filosofías como reacciones sucesivas para preservar el valor del movimiento de artes y oficios en la época de las máquinas.

Entonces, La Ciudad Contemporánea de Le Corbusier y The Broadacre City de Wright, pueden considerarse como respuestas alternativas hacia aquella era, para reconciliar a los humanos y a la naturaleza. ${ }^{2}$ Ahora bien, se podrían categorizar a los tres maestros (incluyendo a Howard) según los datos y los valores que ellos perseguían. Lo primero para Howard fue la cooperación y para Wright fue el individualismo. Entonces, sería interesante que Le Corbusier fuera la síntesis de ellos: Howard y Wright. En realidad, lo es.

\footnotetext{
${ }^{1}$ Le Corbusier. v.o.1929. Urbanisme. Etchells, F.(tr.) New York. Dover Publications, Inc. Versión inglesa. 1987. p. 175.

${ }^{2}$ Fishman, R. Urban Utopias in the Twentieth Century. Cambridge, Mass. The MIT Press. 1982. pp. 163-164.
} 


\section{La Chaux de Fonds y L'Eplattenier}

Le Corbusier nació en la ciudad llamada La Chaux de Fonds en Suiza, 6 de octubre de 1887. En esa ciudad, el padre de Charles-Édouard Jeanneret ${ }^{3}$ fue un maestro gravador de un atelier. En aquel tiempo, el sistema de fabricación de la ciudad seguía funcionando sin gran escala de organización, cada atelier producía partes particulares del reloj (dentro de un atelier hay tres o cuatro artesanos y el aprendiz, que hacía cosas básicas de la producción). Por eso, como se puede imaginar, cada atelier tuvo que mantener su especialidad y una precisión estándar a fin de que las diferentes partes pudieran acoplarse bien. De esta manera el ámbito, es decir, la comunidad de los atelieres y su forma de trabajo, le hizo concebir naturalmente el concepto de estándar y exactitud, el que sería imprescindible para hablar de fabricación (la producción en masa).

Fue un proceso natural, (el talento de Le Corbusier en el dibujo fue destacable desde su infancia, recordemos) su padre le encargó la fase de grabar la caja del reloj a la edad de los 13 años, incluso le dio permiso para realizar un curso académico de bellas artes, también. Fue en La Chaux de Fonds donde pudo formarse el marco básico de comprensión entre él y la ciudad. Le Corbusier creía en dos tipos de valores cruciales: uno era la necesidad de la producción en masa, las grandes organizaciones, y el control desde arriba, y el otro es su propia capacidad para la artesanía, la cooperación y la autodisciplina, mientras que La Chaux de Fonds su ciudad natal estaba en el medio de una gran transición drástica entre dos eras que parecen incompatibles y contradictorias. ${ }^{4}$

Como los padres de Le Corbusier, L'Eplattenier (su primer maestro en La Escuela de Artes Aplicadas) pudo fácilmente reconocer el talento del joven Jeanneret. Junto con el profesor y el tipo de educación de la École des Beaux Arts en París, recibió una gran influencia del movimiento de artes y artes y oficios de la rama francesa. Así, L'Eplattenier fue una de las personas que creía que la única solución era revivir las antiguas artes: talla de madera, esmalte, y pintura mural. ${ }^{5}$ Él era un tipo de profesor de los que siempre alientan a sus estudiantes para buscar su particular inspiración desde el patrón de algunas formas sugeridas por la naturaleza, y no desde la moda. Su enseñanza más importante era que todo el arte verdadero tiene que tener como objeto final la regeneración de la sociedad.

\footnotetext{
${ }^{3}$ Le Corbusier es un heterónimo que recibió desde su abuelo.-(NdA)

${ }^{4}$ Fishman, R. Urban Utopias in the Twentieth Century. Cambridge, Mass. The MIT Press. 1982. pp. 165-166.

${ }^{5}$ Ibid. p. 167.
} 
Una parte de nosotros a menudo nos reunimos en la cima de la montaña más alta...en medio de picos y grandes pendientes agradables, grupos de animales, horizontes infinitos, cuervos volando, nos preparamos para el futuro. Allí, el Maestro dijo, construiremos un templo dedicado a la naturaleza. Nosotros vamos a dedicar nuestras vidas a él. Dejaremos la ciudad y viviremos en el bosque al pie de la estructura que vamos a llenar tranquilamente con nuestras obras. El espíritu de todo el lugar se encarnaría allí. Todos los animales, todas las plantas. Una vez al año habrá una gran celebración. En las cuatro esquinas del templo se encenderán los fuegos ceremoniales. ${ }^{6}$

Le Corbusier. 1925. On Sundays.

\section{Ema}

Antes de que empezara la carrera profesional de Jeanneret, tuvo que viajar a Italia con herramientas básicas de dibujo. Esa peregrinación fue algo simbólico para el joven Le Corbusier en el sentido de que Italia, modélica en sus grandes monumentos del arte y a la vez justa sucesora de la gramática de la arquitectura griega. Para él fue la meca definitiva que pisar. Después de viajar a Italia y pasando por Budapest y desde allí a Vienna, finalmente llegó a Paris en el año 1908.

El Monasterio Cartujo fue un lugar dramático de su vida donde encontró una idea, la más esencial de La Ciudad Contemporánea: la organización colectiva y la libertad individual. Estos dos conceptos se encuentran bipolizados en la sociedad. En el monasterio de Ema se demuestra un ejemplo real en el que los dos distintos conceptos pueden coexistir sin contradicción en un esquema, así recuerda Le Corbusier que el monasterio de Ema corona la colina en el armonioso paisaje de la Toscana, estructura medieval que producía placer intelectual contemplando la combinación tectónica según los dos caracteres del estilo de vida de los monjes cartujos.

Un apartamento de monjes tiene dos habitaciones, y según estos dos caracteres, sería una vida muy

\footnotetext{
${ }^{6}$ Le Corbusier, L'art décoratif d'aujourd'hui. Paris. 1925. pp. 198-199. La citación está referenciada por la fuente secundaria: < Fishman, R. Urban Utopias in the Twentieth Century. Cambridge, Mass. The MIT Press. 1982. p. 168.
} 
privada e individual de meditación. La habitación está mirando hacia el valle de abajo; en este espacio no puede existir nada salvo Dios y un monje en sí mismo. Y en el resto de caracteres de los espacios del monasterio, se nota que las células están conectadas estructuralmente al espacio comunal: oraciones, visitas, comida, cementerios. ${ }^{7}$

Este esquema altamente estandarizado y reproducible, el producto de una estricta regla fue identificado por Le Corbusier como un diagrama para una estructura comunitaria ideal, que balancea la libertad individual y la organización colectiva. Esto fue, por supuesto, una concepción bastante romántica de un posible orden social. ${ }^{8}$

La organización no es algo simbólico, es un cuerpo burocrático que va a traer una armonía genuina a la sociedad. La forma geométrica y simétrica de La Ciudad Contemporánea, es la expresión de la sociedad liberada de la ignorancia y el conflicto. Al final, a través de la administración, se liberan los humanos que viven ya sus vidas individuales con creatividad. Eso sería la conclusión que Le Corbusier insinuó cuando acabó de exponer el plan a la exposición atraída del Salon d’Automne.

\section{Paris y Auguste Perret}

Hay una pequeña historia de cómo el joven Jeanneret encontró a Auguste Perret en el año 1907. Después de llegar a París, Jeanneret conoció a los innovadores del momento: Henri Sauvage, Frantz Jourdain, y Eugène Grasset. Allí preguntó $<<¿$ Dónde puedo encontrar la arquitectura moderna? $>>$ Grasset le recomendó que fuera al atelier de Charles y Auguste Perret. ${ }^{9}$ En el taller de Perret Jeanneret podía practicar su nueva técnica de diseño y un distinto método de acercamiento al trabajo respecto al enseñado por L'Eplattenier en La Chaux de Fonds. Irónicamente, los asuntos que interesaban a Jeanneret habían sido descuidados por su primer maestro L'Eplattenier. Perret animó a Jeanneret para que estudiara matemáticas avanzadas, mecánica y ciencias de los materiales. Básicamente Perret fue

\footnotetext{
7 Fishman, R. Urban Utopias in the Twentieth Century. Cambridge, Mass. The MIT Press. 1982. pp. 203-204.

${ }^{8}$ Gans, D. The Le Corbusier Guide. New York. Princeton Architectural Press. 2000. p. 19.

${ }^{9}$ Fishman, R. Urban Utopias in the Twentieth Century. Cambridge, Mass. The MIT Press. 1982. p. 170.
} 
un tipo de persona que pensaba que la arquitectura moderna en la nueva era tenía que formarse con nuevos vocabularios, como Sullivan y Wright. Para él estos temas tenían bastante posibilidad de generar una gramática moderna. Pronto Perret también notó la capacidad de Jeanneret, y le designó para labores cada vez más importantes. Jeanneret empezó a absorber la doctrina de Perret rápidamente.

Pero, mientras tanto, surgió una contradicción entre los dos adoctrinamientos, eso fue un gran dilema para Jeanneret. En aquel período, todavía no tenía una peculiar solución sobre esa colisión de las dos enseñanzas desde sus dos maestros, para conciliar o eliminar. Sin embargo, por lo menos, podía sentir que sus estudios eran elementos atractivos que no podría abandonar.

Ahora bien, no sería difícil de reconocer que la filosofía de Perret fue contraria a la visión de Le Corbusier (ya que el deseo final de antiguo profesor L'Eplattenier era regenerar la sociedad enferma por medio de resucitar los valores espirituales antiguos de los artesanos). De todas formas, todavía inmadura la perspectiva del joven Jeanneret, que tenía 21 años en aquel tiempo, no pudo tener otra opción que abrazarlo todo a pesar de ser valores contradictorios.

En consecuencia, afrontó una pelea interna para construir su identidad arquitectónica (que mantuvo después por muchos años) hasta poder esbozar una pequeña silueta de ella. No fue simplemente una cuestión de adoptar o negar. La situación seguía siendo así, pero en cierto modo su instinto estaba guiándole a un resultado. De todas formas, el futuro de Le Corbusier se estaba dibujando en su cabeza, tuvo que ser algo de la Edad de la Máquina; solamente no había encontrado una justa posición para conciliar dos nociones bipolares. Entonces, Jeanneret tendría que tomar una decisión que sería, primero, negar cualquier tipo de ideal cooperativo, porque la forma de sobrevivir y prosperar de la comunidad artesanal estaba corriendo hacia su final por la acumulación del capital.

La producción en masa de los productos, y el fruto natural nacido en la edad de la máquina, tuvieron que tratarse directamente.

Los años desde 1909 hasta 1916 serían los de indagación personal, significativos en Jeanneret para transformarse en Le Corbusier mediante una larga indagación aislado en sí mismo, desvelándose por 
las noches lejos del mundo secular. No por un equilibrio mimético ilusorio, sino por una síntesis genuina dilucidada que el joven Le Corbusier estaba buscando. Y su alternativa tendría que ser, originalmente, heterogénea, sin embargo. Tendría que estar basada en una verdadera fidelidad hacia la experiencia bajo las dos doctrinas. Al final, Le Corbusier empezó a reconocer un potencial inherente en la belleza y el orden de las máquinas.

Así pues, el Dom-Ino representa el <<arte de pensamiento>> que Le Corbusier había estado buscando desde 1908, un arte en el que los cálculos del ingeniero y los sentimientos del arquitecto están perfectamente sincronizados, un arte en armonía con la razón y el poder de la máquina. Esta arquitectura de la Edad-Máquina también es necesariamente una arquitectura colectiva. Existe para satisfacer las necesidades de masas y puede encontrar su expresión más fina sólo en las grandes empresas. Donde los artesanos habían trabajado como individuos para cliente individuales, el diseñador de la Edad-Máquina debe ser parte de una organización capaz de coordinar sus planes desde el tablero de dibujo hasta la línea de producción para el montaje en el mismo sitio. La estructura del Dom-Ino, por lo tanto, tiene importantes implicaciones en la estructura del sistema industrial que Le Corbusier esperaba construir. ${ }^{10}$

El edificio llamado Dom-Ino fue la génesis de una semilla y un módulo universal que se deseaba fervientemente. Con el hormigón armado y las fábricas inútilizadas después de la primera guerra mundial, la estandarización de las partes del edificio, y la nueva manera de producción sistémica, encontraron una oportuna penetración contemporánea. Le Corbusier pensó que había descubierto una sólida gramática de la arquitectura moderna (v.-fig. 4-1).

\section{Una ciudad contemporánea para tres millones de habitantes}

Como se ha observado, Le Corbusier seguía su experimento mental con empeño. Fue en el año 1922,

10 Ibid. p. 180. 
cuando la oportunidad vino a él para probar el resultado de su experimento. En ese año, se había encargado de una exhibición sobre urbanismo del organizador del Salon d'Automne. De algún modo, su desafío buscó una reconciliación del mundo de la naturaleza (incluso los humanos) y la máquina. Y pronto, las ideas introducidas en Dom-Ino se expandieron desde La Chaux de Fonds, finalmente, hasta Paris (v.-fig. 4-2). En el plan de La Ciudad Contemporánea ya estaba concebido los principios generales y la dirección de dónde su diseño tenía que llegar. ${ }^{11}$ Decía que la ciudad es demasiado importante para dejar a los ciudadanos que la diseñen. Eso es porque, debido al resultado de numerosas decisiones individuales, la ciudad antigua fue llevada a una situación apocalíptica. (v.-fig. 4-9)

¿Puede usted imaginar a la gente que se involucra en una batalla sin saber sus objetivos? Sin embargo, eso es exactamente lo que está sucediendo. Las autoridades están obligadas a hacer algo, por lo que les dan privilegios a los policías o los montan a caballo, inventan señales de sonido y señales luminosas, ellos proponen poner puentes sobre calles o mover los pavimentos debajo de las calles, más ciudadesjardín son sugeridas, o se decide suprimir los tranvías, y así sucesivamente. Y estas decisiones han llegado a un estado de prisa frenética en el orden, es decir, para mantener un Monstruo en la bahía. Ese MONSTRUO es la ciudad magnífica. ${ }^{12}$

Le Corbusier. 1929. Urbanismo.

Ahora, la ciudad requiere una nueva manera en la toma de decisiones que sería de <<arriba hacia abajo >> por alguien que sepa en qué dirección ésta sociedad tendría que ir, para acoger la nueva edad de las máquinas. En este caso, Le Corbusier se consideró a sí mismo con una autoridad absoluta. La nueva era tuvo que ser desconectada del pasado para establecer un nuevo orden industrial. Los problemas actuales se consideraban como un resultado natural de que la ciudad no estuviera construida perfecta, geométricamente. Le Corbusier dijo que $<<$ idebemos construir en un espacio limpio! >> Así fue tan ardiente su deseo que quiso empezar del nivel cero (v.figs. 4-3, 4).

El paisaje urbano de París era tan desordenado (según su criterio) que era desfavorable para Le

\footnotetext{
${ }^{11}$ Fishman, R. Urban Utopias in the Twentieth Century. Cambridge, Mass. The MIT Press. 1982. p. 189.

${ }^{12}$ Le Corbusier. v.o.1929. Urbanisme. Etchells, F.(tr.) New York. Dover Publications, Inc. Versión inglésa. 1987. pp.164-165.
} 
Corbusier. El plan de Haussmann fue también para la transformación y la reordenación de París, pero la idea sobre el grado de dicha transformación provocaba una disociación enorme entre Haussmann y el suizo.

Para Le Corbusier, el orden se expresa mediante formas puras. La Ciudad Contemporánea es una cuadrícula de calles perfectamente simétricas. Reina el ángulo recto. Dos grandes súper-autopistas (una en dirección este-oeste, la otra norte-sur) forman los ejes centrales; que se cruzan en el centro exacto de la ciudad......la simetría poderosa de la Ciudad Contemporánea simboliza la victoria de la razón sobre la oportunidad, de la planificación sobre el individualismo anárquico, del orden social sobre la discordia. ${ }^{13}$

La Ciudad Contemporánea está clasificada según cada función particular, primero las oficinas, industrias y viviendas, después se colocan las infraestructuras de transporte, como autopistas, trenes subterráneos, caminos de acceso, incluso ciclovías y paseos peatonales (v.figs. 4-6, 7, 8). En consecuencia, la ciudad requirió varios niveles de intercambio sistémico. Así el centro de la ciudad funciona como un núcleo del sistema de todos los movimientos. Por debajo, las dos grandes autopistas se cruzan; y debajo de ellas estaría la estación del metro donde todas las líneas se corresponden; encima de las autopistas se ubica la principal estación de ferrocarril, en cuyo techo los aviones pueden aterrizar.

Por detrás de esa idea, existe una virtud Ilamada eficiencia, que fue esencial para Le Corbusier cuando concibió el plan para una ciudad moderna. Finalmente consigue la velocidad de la ciudad. La velocidad es la libertad, la libertad de intercambio, de encuentro, de comercio y de coordinación. <<La ciudad que alcanza velocidad, logra un éxito >>. ${ }^{14}$ Alrededor de la terminal principal, en medio de un gran parque, se colocan 24 rascacielos que constituyen el centro de negocios de la ciudad. Este centro de negocio es mucho más concentrado que los sectores más concurridos de aquel tiempo en París. Aquí, una alta densidad significa que, el conjunto de todos los rascacielos permite que $500.000-800.000$ trabajadores -grupo de élite categorizado por tres profesiones: industriales, científicos, artistas- ocupen

\footnotetext{
${ }^{13}$ Fishman, R. Urban Utopias in the Twentieth Century. Cambridge, Mass. The MIT Press. 1982. p. 190.

14 Ibid. p. 191.
} 
la zona a la vez. Con esa colosal densidad (permitida por las 24 torres) se cubren solamente menos del $15 \%$ de la zona del centro de negocios. ${ }^{15}$

Los rascacielos de La Ciudad Contemporánea tienen un especial significado simbólico; su genuina solución para la edad de la máquina, también eran una verdadera alternativa de los dos adoctrinamientos personales. El joven Le Corbusier todavía no podía negar ninguna de las dos distintas enseñanzas de sus maestros, debido a que sería una acción que negaría la identidad de su filosofía. Por eso, estos rascacielos representan una re-conciliación entre la naturaleza y la máquina. Geométricamente, la ciudad tiene perfecta forma simétrica, y en el centro de la ciudad los rascacielos están envueltos por los parques. Las estructuras artificiales muestran su potencia -gracias a las avanzadas técnicas de ingeniería- en la naturaleza concediendo más del $85 \%$ del plan para zona verde. Las gigantescas alturas de las torres, con brillantes materiales (acero y cristal), y las formas de las estructuras de sucintos pilares fueron victoriosas también en el terreno funcional.

\section{La sociedad élite.}

Como ya se ha referido anteriormente, los trabajadores del centro de negocios son la élite de la sociedad. Una soberanía de la clase distinguida. Ese tipo de tradición de la sociedad viene desde Henri de Sant-Simon (1760-1825) que definió una clase llamada industriels que son la élite de industriales, científicos y artistas. Y dicha clase iba a ser líder de las grandes organizaciones de la producción y sustituir la función del gobierno. ${ }^{16}$ Sant-Simon también deseó la existencia de una autoridad absoluta, así que propuso un estado militarista de la sociedad y un sistema pacífico y bien orientado. Hace ya más que dos milenios pero, Sant-Simon, Wells e incluso Le Corbusier están diciendo lo mismo que Platón. ${ }^{17}$ Le Corbusier quiso que la sociedad de élite sustituyera a los cuerpos gubernamentales, encargándose de todos los papeles administrativos, de esta manera la sociedad estaría liberada de las agonías sucedidas en el pasado.

\footnotetext{
15 Ibid. p. 192.

16 Ibid. p. 194.

17 Claeys, G. Searching for Utopia: The history of an idea. Condor, M(tr). Madrid. Ediciones Siruela. Versión española: 2011. p. 143.
} 
En la ciudad de la élite, el paisaje de la ciudad fue espectacular. Las 60 plantas de las torres extendidas desde la tierra, estaban intentando alcanzar el cielo. La imagen de los industriels, apropiadamente, se nota en el centro de negocios (v.-figs. 4-6, 7). En el medio de esa fabulosa zona verde, el centro de la ciudad revela su majestuosidad. Las alturas y las fachadas brillantes y modernas, quizá insinúan el triunfo de los ingenieros y el sistema de fabricación en serie para un estándar.

La ciudad encarna una nueva visión, y aquí no hay ningún anhelo nostálgico sobre el pasado de numerosas y equivocadas comprensiones. Indudablemente, la ciudad fue una reflexión de un arquitecto, pero en algún sentido, también de los ciudadanos, ya que algún día reconocerán que la sociedad ha logrado finalmente su virtud (ese tipo de postura de persuasión es terriblemente similar a la de Wright)

En las terrazas panorámicas de las últimas tres plantas de los rascacielos, Le Corbusier puso tiendas, cafeterías, restaurantes, galerías de arte, y hasta teatros. Los techos de las torres se transforman por la noche en un jardín colgante utilizado como discoteca. La élite se reúne, charla y disfruta de sus hazañas. Estas torres administrativas de la ciudad, se consideraron como un privilegio de una clase particular (v.-figs. 4-5, 10, 11). Entonces, surge una cuestión: ¿Dónde se quedan los proletariados y los trabajadores de oficinas subordinadas? De todas formas, también son elementos necesarios para el funcionamiento de la ciudad. La respuesta es: para ellos hay lugares preparados en el margen de la ciudad central, de un modo más modesto. Aun estando marginados del centro de la ciudad la calidad no disminuye (según la palabra de Le Corbusier); solamente, son humildes y con edificios menos fastuosos. En consecuencia, destacar la división de clases es inevitable.

Una casa y su posición representan una posición social en la jerarquía del dueño. Es una idea muy discutible y parece una invención arriesgada.

\section{La Ciudad Radiante: una versión posterior de La Ciudad Contemporánea}

La Ciudad Radiante puede entenderse en un mismo contexto que La Ciudad Contemporánea en el sentido de que la manera de buscar la síntesis aborda dos conceptos contrarios: la autoridad absoluta y la libertad individual. Sin embargo, el enfoque de Corbusier cambió; si fue el papel de los industriales 
con el que enfocó La Ciudad Contemporánea, esta vez, fue el syndicat, es decir, enfocó más hacia la forma del sistema en las organizaciones sociales.

Le Corbusier creyó que el sindicalismo podría proveer una pirámide de jerarquías naturales, que consiste en numerosas y rígidas capas de clase, donde la división se basa en el orden y el plan. La parte inferior de la pirámide es el Sindicato, la clase de trabajadores, empleados de oficinas subordinadas que ocupan la parte baja. Los trabajadores pueden elegir una persona (como un representante y director) entre sus compañeros para que represente la opinión de sus compañeros de trabajo en el consejo del comercio regional, y los directores de cada fábrica forman el consejo regional que es el bloque más básico del esquema de burocracia. Entonces, en cada fábrica hay un director representativo de los trabajadores, y en el nivel más superior, cada ciudad (regional) tendría un líder que pudiese administrar las fábricas en su región. Finalmente, en el nivel supremo se encuentra, el Consejo Nacional que se sitúa en lo más alto de esa jerarquía, y sustituye al Estado. El Consejo Nacional tiene la responsabilidad de coordinar la producción entera del país.

La orden se transmite desde el Consejo Nacional a los Consejos Regionales (Comunidades), y aquél asigna las tareas a las fábricas y también a los pequeños negocios individuales. El representante de los sindicatos vuelve del consejo regional con las instrucciones que determinan el papel de su fábrica. ${ }^{18}$ Todos los trabajadores se incorporan en un concepto llamado sindicalismo cuyo objetivo es necesariamente colectivo. Los representantes de cada nivel son originalmente compañeros de trabajo, así que Corbusier pensó que deberían tener carácter de trabajador y tendrían que perseguir los beneficios colectivos y no solamente los de los inversores y capitalistas. En conclusión, el dilema entre estas dos distintas ideas bipolares han sido reconciliado e implementado, por medio de la derivación de las dos distintas doctrinas hacia sus virtudes extremas, que son la autoridad y la participación. Así que la utopía de Corbusier ha sido una vez más fortalecida en el sentido de la autoridad y la libertad.

Sin embargo, ¿cuál es la pieza que falta aquí? La autoridad de la clase que culmina la pirámide. Y la actividad de la sociedad funciona como una única vía de arriba hacia abajo. La vida brillante de los rascacielos acristalados se permite a los líderes, incluso la vida lujosa de la noche. Según la explicación de Le Corbusier, es un privilegio justo para los que se lo merecen. Y, por otra parte, los trabajadores menos dedicados a tomar decisiones de la sociedad, son destinados también a una vida humilde que

\footnotetext{
${ }^{18}$ Fishman, R. Urban Utopias in the Twentieth Century. Cambridge, Mass. The MIT Press. 1982. p. 228.
} 
merecen. Realmente, ese tipo de división de clase, por su posición, su tamaño de casa, su profesión etc., sería dudoso que fuera deseable como verdadera virtud de la ciudad. Es una cosa remarcable que Sir. Peter Hall criticara con la máxima crueldad la idea de Corbusier; diciendo

...La causa principal de su error, tanto en el caso de Le Corbusier como en el de sus seguidores, era que los arquitectos de clase media no sabían de qué manera vivían las familias trabajadoras. En su mundo,

<<Mamá no está sola en casa con los niños, sino está comprando en Harrods. Estos, cuando son pequeños juegan en los jardines de Kensington acompañados por la niñera. A los ocho años van a la escuela y a los trece a un colegio privado, en ambos casos en régimen de internado. Y durante las vacaciones están en el campo, practicando deportes de invierno, navegando o en cualquier otra ocupación similar; bronceándose con el viento y el sol. En ninguno de los casos andan alborotando por los rellanos o jugando con las tapas de los cubos de basura.>>

Esta es la razón por la que los ricos siempre vivirán bien en altas densidades de población, porque tienen servicios; es por ello que las citas que hemos hecho de Le Corbusier son tan reveladoras. Pero para la gente normal y corriente, como Ward dice, los barrios suburbanos tienen más ventajas: mayor privacidad, menos ruido o, en todo caso, mayor libertad para hacerlo. Tener esto en espacios con grandes densidades de población, exige grandes presupuestos, cosa que no puede esperarse en el caso de las viviendas subvencionadas públicamente. El punto más delicado es el de los niños: puesto que <a menos que puedan jugar durante su infancia, al crecer se convertirán en un problema>...Evidentemente, Le Corbusier desconocía toda esta problemática porque era de clase media y, además, no tenía hijos. ${ }^{19}$

\footnotetext{
19 Hall, P. v.o.1988, Cities of Tomorrow: An Intellectual History of Urban Planning and Design in the Twentieth Century. Freixa, Consol(tr). Barcelona. Ediciones Serbal. Versión española 1996. p. 238.
} 


\section{Sobre lo que Le Corbusier supo: Una charla epistemológica}

Le Corbusier fue un intelectual destacable que creyó que la contribución de los artistas y élites tiene que estar en consciente elitismo cuando la sociedad se encuentre en una situación desesperante, y eso sería considerado como la virtud genuina. Se recuerda que hubo una pequeña divergencia de la postura con que se trató la sociedad entre Howard y Wright, y generaron gran diferencia en cada una de sus imágenes utópicas. Las metodologías de Howard y Wright son distintas a la de Le Corbusier en el sentido de que Howard y Wright persiguieron la dispersión de la ciudad y por contra Le Corbusier persiguió la concentración más radical de la ciudad. Otro factor relevante que distingue a Howard y Wright es, que aunque en la categoría llamada dispersión sean iguales, sin embargo en otro sentido, Howard consideró las virtudes de la comunidad medieval y Wright consideró su virtud en una radical libertad individual. Indudablemente, también los planes de escala enseñan sus diferencias; Howard decidió basarse en la infraestructura ferrocarril, y Wright en la vía de coches personales. La manera de la realización de los proyectos también enseña particulares estilos de los maestros, Howard fue un utopista preparado con una técnica de elocuencia y política, y gracias a su firme fundamento de los cálculos, pudo construir las ciudades-jardín. Pero en el caso de Wright, tuvo un plan ideal (llamado Broadacre City) donde existía una profecía sedentaria por su arquitectocracia. Así que el camino para ir a la ciudad del mañana está desconectado con el presente de modo diferente a como lo proponía Howard. Eso es lo que les diferencia, pudiendo denominarse a uno hacedor (Howard) y al otro pensador (Wright).

La razón de por qué se generan ese tipo de diferencias es que Howard insistió en soñar una utopía aceptando la fragilidad y defectibilidad humana en el mundo imperfecto. Cuando se mira su utopía, su obra está construida ladrillo a ladrillo meticulosamente, y parece que supo hasta dónde su idealidad podía realizarse. Son evidencias los muchos aparatos sistémicos que utilizó para proteger la sostenibilidad de la utopía.

Por el contrario, en Wright y Le Corbusier, en sus palabras y escritos, no hay ningún tipo de conciliación respecto a la circunstancia del mundo real. Fueron profetas que creyeron que este mundo puede transformarse en una imagen perfecta por medio de un plan perfecto, y no lo dudaban. Para 
ellos, la fragilidad humana era algo que no tiene que existir o debe extinguirse en el mundo de la perfección. Es necesario recordar la imagen de The Broadacre City, que era tan estática que fue eliminada de la humanidad, ya que, si no se podía controlar, para Wright era mejor que no existiera o simplemente que fuese ignorada. Este marco de pensamiento se puede aplicar en Le Corbusier perfectamente.

A lo mejor para Le Corbusier, el concepto <<la humanidad >> era inconcebible, por ejemplo, quiso destruir París con una excavadora para empezar de nuevo. Pensó que París era disfuncional porque no estaba construida perfecta, geométricamente. Claro, su plan se negó por la municipalidad de París sin dudarlo ni un segundo.

Le Corbusier sueña incesantemente con una desconexión con el pasado y el presente para un futuro purismo sin pecado. Fatídicamente, su plan está flotando siempre en las nubes; su reino ha de venir, pero la frase nunca se expresa en la forma <<pretérito perfecto>>.

En otro sentido, puede existir una distinta interpretación sobre la metodología de Le Corbusier. Puede ser que, por causa del proceso de llegar a la idealidad, tan costoso e ineficaz, consideró así la situación; que él hubiera preferido que un profeta iluminado liderara el pueblo. Porque una vez el pueblo haya entrado la tierra prometida, la mayoría de las partes des-iluminadas también podrían comprender que el proceso era justo. Una imagen categórica e imperativa no puede ser durable; está demostrado históricamente. También recordando la filosofía de Siddhartha, La Ciudad Contemporánea es un resultado herético en la perspectiva nirvánica. Una utopía no puede percibirse de repente, la utopía tiene que poder concebirse desde el momento actual, desde sí misma, comprendiendo el proceso desde el estado presente hasta el momento utópico. El camino es lento, costoso, e ineficaz, pero llegará al destino si la trayectoria no es equivocada. Porque está conectado este camino hasta allí. De todas formas, es obvio que Le Corbusier estaba tan harto y escéptico sobre la lentísima toma de decisiones particulares en el sistema democrático y la traición del régimen de Vichy, ${ }^{20}$ que su reacción era lógica en algún sentido.

Como se ve en anterior párrafo, no es difícil reconocer que la visión de Howard era la más cercana

${ }^{20}$ Fishman, R. Urban Utopias in the Twentieth Century. Cambridge, Mass. The MIT Press. 1982. p. 251. 
respecto a las demás a la perspectiva nirvánica. Howard supo cómo puede transformar ciudades desesperadas en ciudades del mañana. La primera edición del título de su libro es: un camino pacífico para una verdadera reforma. $\mathrm{Y}$ supo desde dónde, y hacia dónde tiene que proceder el proyecto. Proclamó específicamente su metodología y estableció unos dharmas que pueden complementar o asistir en un campo práctico; por ejemplo, para los dharmas problemáticos: el parlamento-dharma, los terratenientes-dharmas e incluso la codicia-dharma. Sin embargo, Le Corbusier tuvo una imagen perfecta pero no supo cómo encarnar la imagen en un mundo defectuoso. Una cosa interesante es que todavía el mundo no comprendía su idea y tuvo la voluntad de ejecutar su plan por la fuerza (su viaje para encontrar esa autoridad deseada está descrito y bien criticado por Fishman. ${ }^{21}$ ) También Fishman criticó severamente un defecto crucial de su plan ¿La autoridad, que es la virtud más esencial del esquema, cómo puede generar el concepto participación en la sociedad?22 Desde los años de 1930 hasta 1940, hay numerosos episodios con el régimen de Vichy, pero es simplemente una narración de los retos vacíos y las negaciones; no haría falta tratarlo aquí más profundamente. El esfuerzo político de Le Corbusier fue agresivo y activo, pero la reacción de los políticos no fue nada favorable.

${ }^{21}$ Fishman explicó el deseo distorsionado sobre la autoridad absoluta de Le Corbusier dedicando ocho páginas de extremo criticismo.-(NdA)

${ }^{22}$ Fishman, R. Urban Utopias in the Twentieth Century. Cambridge, Mass. The MIT Press. 1982. p. 242. 


\section{Sobre lo que Le Corbusier deseó: Una charla estética}

Con la enorme cantidad de 215 páginas de ilustraciones en el libro llamado Urbanisme de Le Corbusier, todavía no se ha obtenido una ciudad realmente construida -salvando el proyecto de la India porque era una colonia y su objetivo de existencia es diferente al de una ciudad normal, por lo que no sería adecuado en este caso. Aun así, se puede disfrutar la belleza de la ciudad contemporánea mediante las imágenes. Fue un autor prolífico en sus libros y artículos de revistas, así que no es difícil comprender su visión estética del mundo. Una vista panorámica de La Ciudad Contemporánea ofrece bastante información. Para empezar, en esa pintoresca imagen, no se puede borrar la vasta sensación estática. Y para la gente que vivió la etapa de la modernidad e incluso la mayoría de las personas que viven en la edad contemporánea la imagen que tienen de la ciudad de Corbusier es bastante moderna. En una plano vacío, geométricamente ordenadas las líneas, los rascacielos de una altura monstruosa que enseñan una jerarquía perpetua, con los apartamentos pequeños en el margen, y el sistema de transporte que penetra el centro de la ciudad y distribuye las ramas alrededor del centro, todos estos aparatos son símbolos que dicen a los ciudadanos que $<<$ la ciudad es totalmente funcional, y eficaz con velocidad. >> La Ciudad Contemporánea divide las clases, y eso fue considerado como una virtud, las máquinas están preparadas para capturar a los ciudadanos según su clase. ¿Desde el principio, el hormigón armado no era aplicado para comunicarse y entenderse el uno a otro? Ese avance de la tecnología tectónica hizo posible que los edificios estructurales abrieran sus espacios en cualquier dirección, y los muro cortina de los edificios fueron mucho más liberados que nunca. Sin embargo, al final nada de eso fue nirvánico ni utópico. Una belleza nirvánica se puede capturar cuando un Atman desaparece, y encuentra NY. Le Corbusier insiste con empeño en la existencia del Atman dominante. Y la filosofía y la virtud que él persigue, se ve muy bien en las imágenes. Una vez está definida la clase, irrevocablemente, la distingue entre los dharmas, y busca un cierto ego que genera obsesiones, y la obsesión genera la angustia. Alli empezará una opresión invisible entre los humanos. En aquel tiempo, si se hubiera publicado este libro con un título parecido a antiutopía seguramente habría ganado bastante aceptación entre el público. 


\section{Sobre lo que Le Corbusier tuvo que hacer: Una charla ética}

La virtud, es decir, la forma jerárquica de la sociedad de Le Corbusier, se sucede desde Platón y SantSimon. ${ }^{23}$ El modo de servicio colectivo y cómodo es desde luego un regalo fascinante de la edad moderna.

Por ejemplo, Charles Fourier (1772-1837), de otra tradición utópica francesa, no sería la primera persona que propuso una forma vida en comunidad, sabiendo que fue Tomás Moro (1477-1535) quien fue el iniciador del género de la Utopía junto con otros pensadores. A propósito, Fourier creyó que podría solucionar toda la tragedia de la pobreza de París con el servicio del placer colectivo, controlado por el sistema llamado el phalanstère. Por medio del falansterio, es decir, sistema de vida comunal, teóricamente, se pueden resolver los fallos principales del desarrollo moderno y se aumentaría la eficacia de cooperación siendo un innegable motivo de realización para Howard e incluso para Le Corbusier. ${ }^{24}$ El falansterio literalmente persigue los servicios colectivos que han de ser satisfactorios. La vida falansteriana gestionada apropiadamente, tiene que ser necesariamente sistémica y colectiva. Los servicios colectivos incluyen números tipos de espacios públicos lujosos, por ejemplo: teatros, bibliotecas, salones de baile e incluso los comedores. La diferencia entre Fourier y Le Corbusier es que, en el primer caso fue diseñada una imagen del palacio barroco, y en el segundo caso fueron los rascacielos en medio del gran parque. ${ }^{25}$ Así, en consecuencia, la ciudad brillante ha representado una extraña fusión de dos visiones bipolares: la autoridad que viene desde la bien organizada jerarquía de Saint-Simon, y la libertad de los individuales que vienen desde los servicios públicos, exhaustivos y lujosos. Tal vez para Le Corbusier, el falansterio fue la última pieza para perfeccionar la sociedad extremadamente dividida entre las clases. Le Corbusier nunca va a considerar que la división de clases fuera la primordial maldad para generar la lucha de clases. Es un tipo de utopía que se opone exactamente al nirvana en el término de que en las imágenes de Le Corbusier no se puede encontrar una ética de NY (no-yo: anātman), sino la ética de Sí (yo: ātman). Le Corbusier no tuvo que distorsionar la doctrina del sindicalismo y el falansterio, poniendo la divergencia de la calidad y la forma de libertad

\footnotetext{
${ }^{23}$ Fishman, en su libro <Urban Utopias in the Twentieth Century> dijo que Le Corbusier probablemente no habría leído SantSimon. Pero es obvio que ellos están en la misma categoría.-(NdA)

${ }^{24}$ Furier, C. v.0.1808. Teoria de los Cuatro Movimientos. Byun, G.C.(tr.,ed.) Seoul. Book World. Versión coreana. 2007. pp. 3031.

${ }^{25}$ Fishman, R. Urban Utopias in the Twentieth Century. Cambridge, Mass. The MIT Press. 1982. p. 234.
} 
que depende de la clase. La libertad significa una vida privilegiada para los líderes que vivirían en el centro de negocios, pero en el barrio suburbano la libertad es una regla que se debe seguir en la clase obrera. La división de clase no puede ser una virtud sino un mal encadenamiento de esclavitud que corta y modifica la humanidad como quiere. La libertad que Le Corbusier concibió, es una libertad patológicamente distorsionada. Además, seguramente, él no habría considerado su error.

En el año 1934, Le Corbusier fue invitado a Italia, ya que Mussolini tenía interés en la arquitectura moderna, pero, al final negó el plan de La Ciudad Radiante. Así que él tuvo que volver a Francia con las manos vacías desde la tierra del fascismo, irónicamente. ${ }^{26}$

\footnotetext{
${ }^{26}$ Ibid. p. 240.
} 


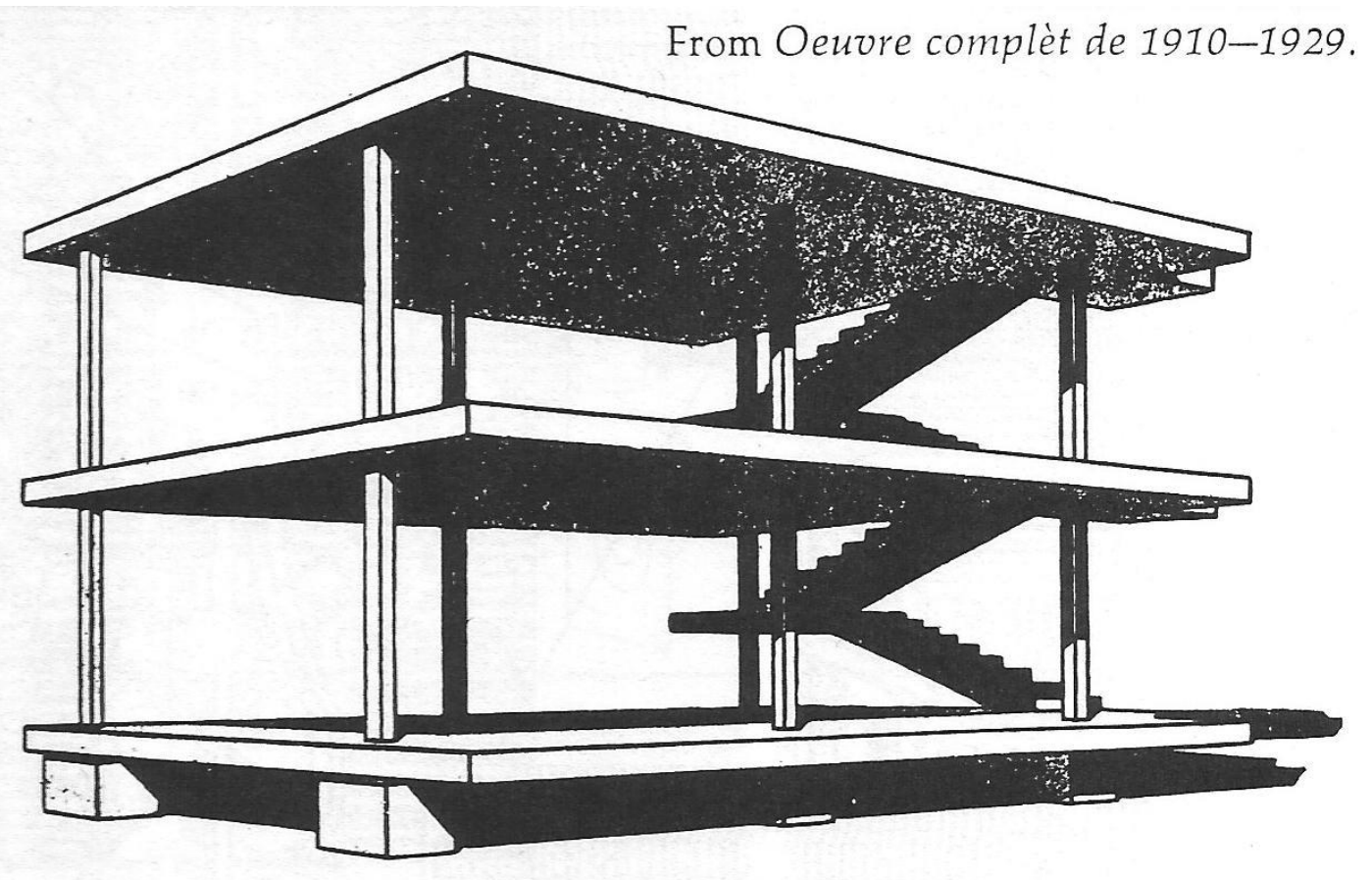

Fig. 4-1. La estructura básica de la Casa Dom-Ino. 


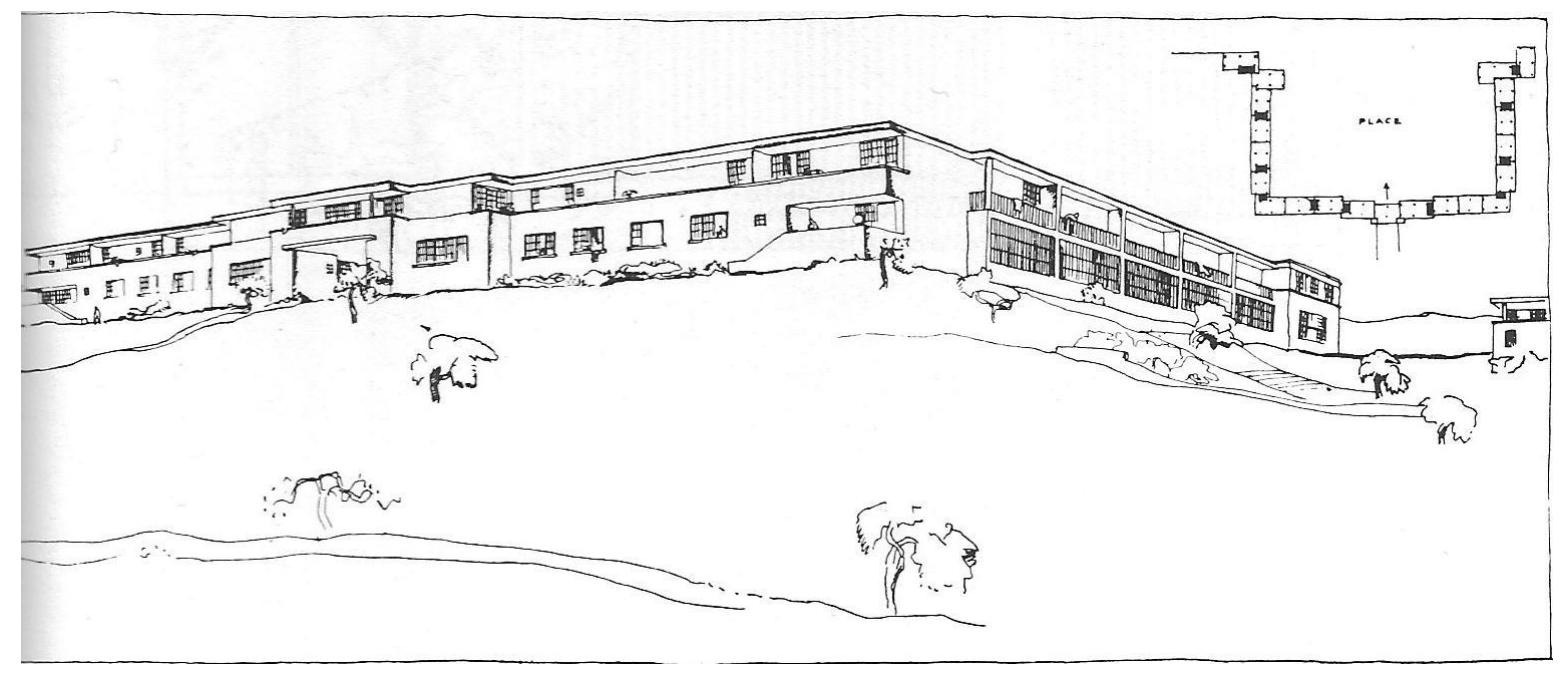

Fig. 4-2. Un grupo de casas Dom-Ino de Le Corbusier. 


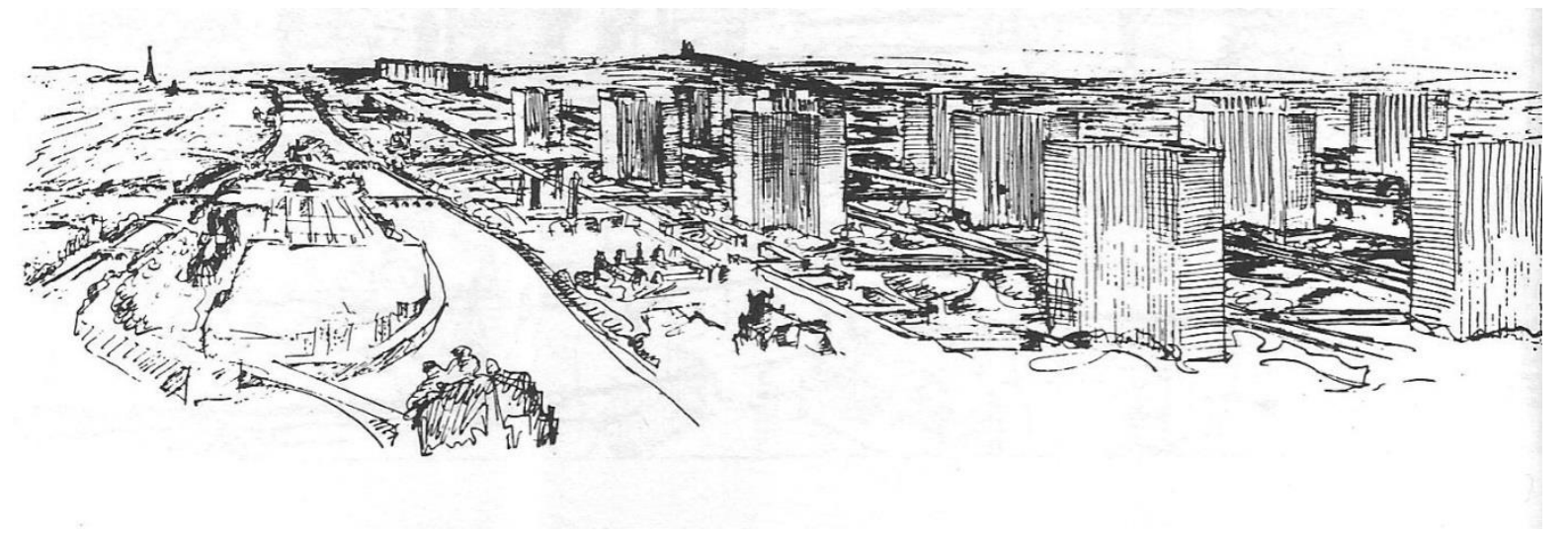

Fig. 4-3. El Plan Voisin de Le Corbusier para Paris. 


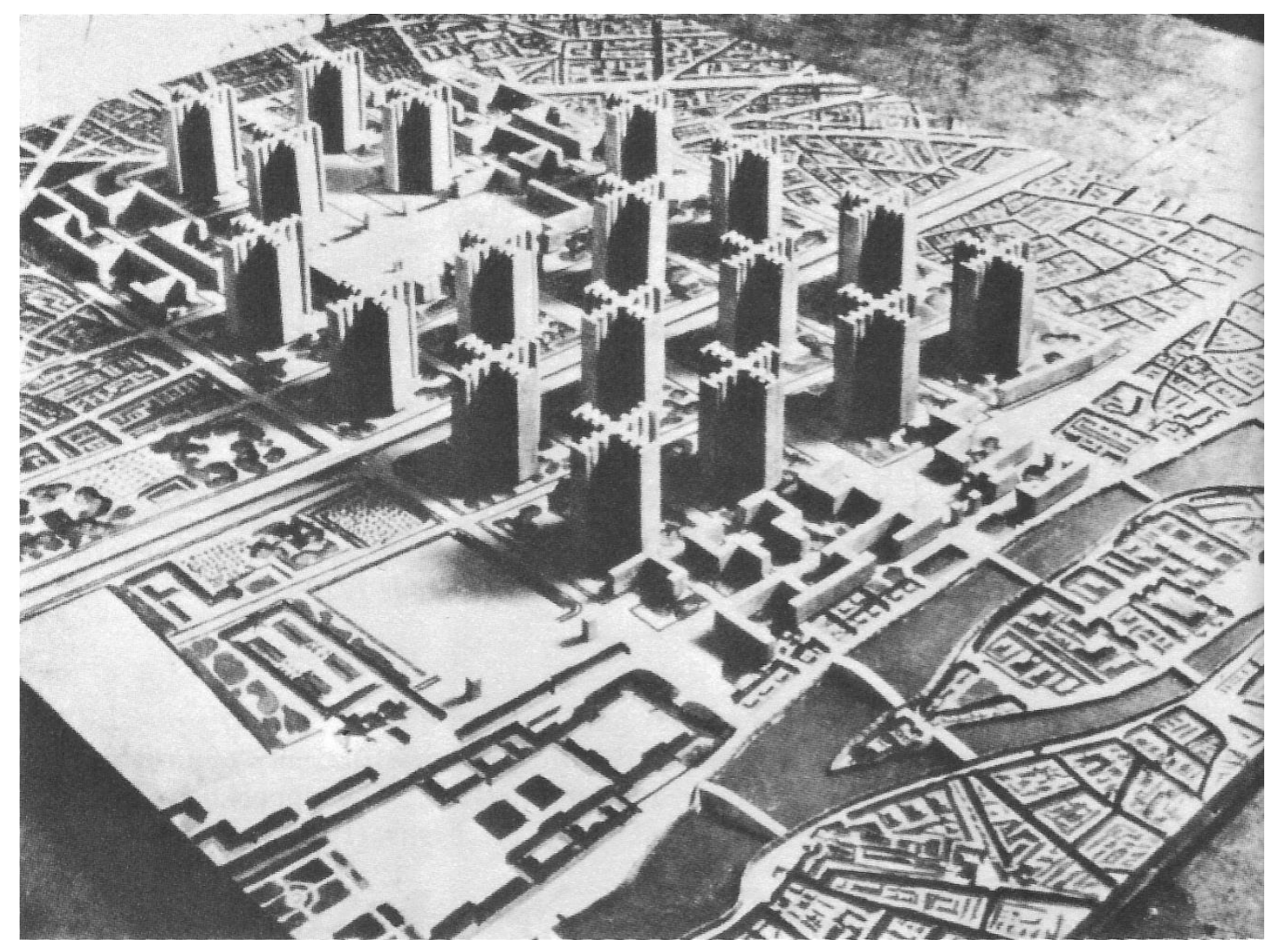

Fig. 4-4. La maqueta del Plan Voisin de Le Corbusier. 


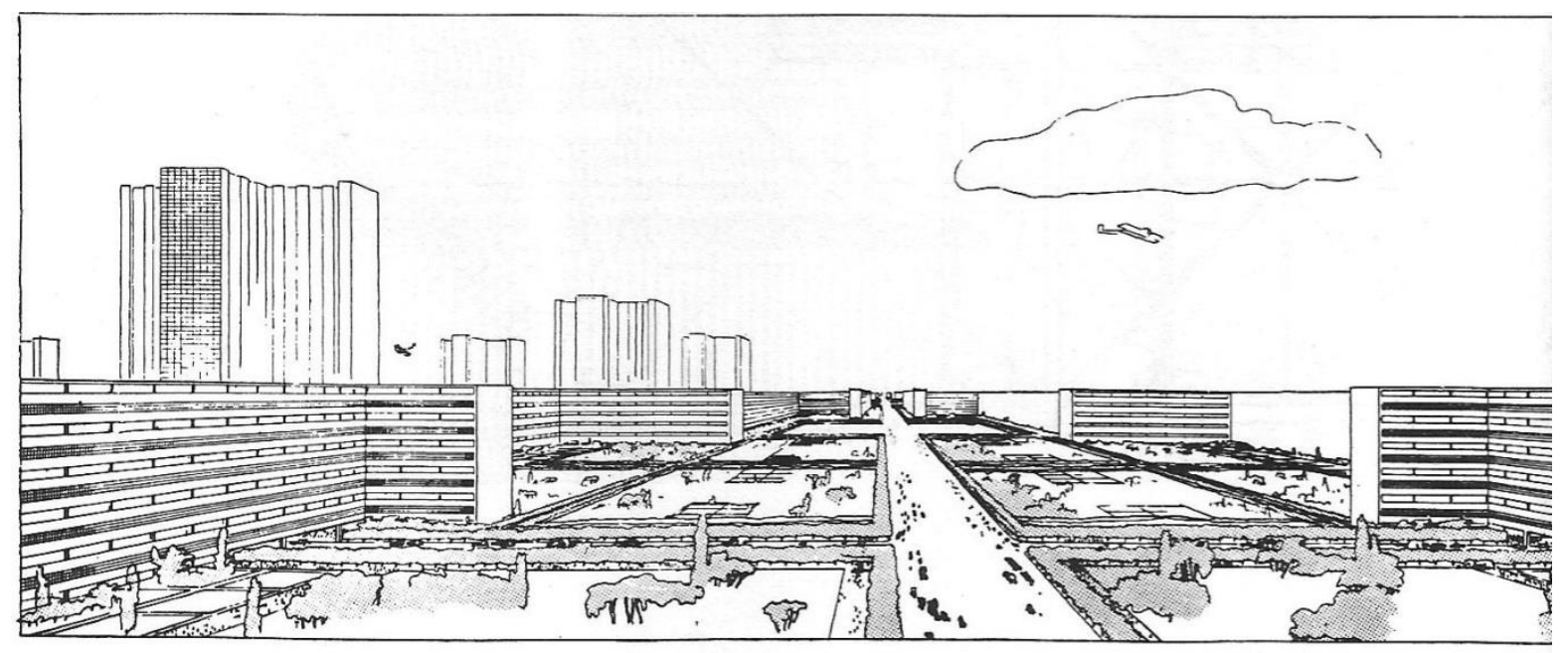

Fig. 4-5. Apartamentos para las élites de la Ciudad Contemporánea de Le Corbusier. 


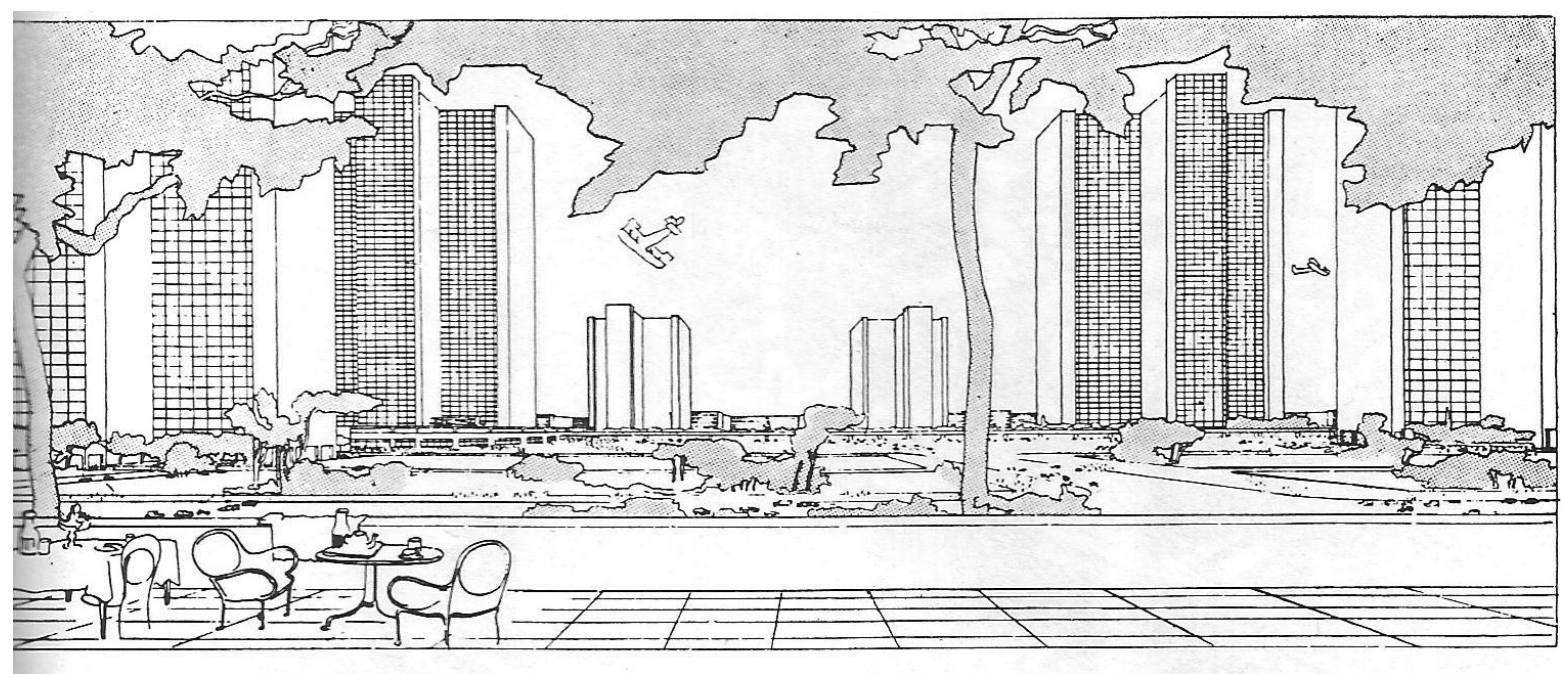

Fig. 4-6. Distrito de negocios de la Ciudad Contemporánea. 


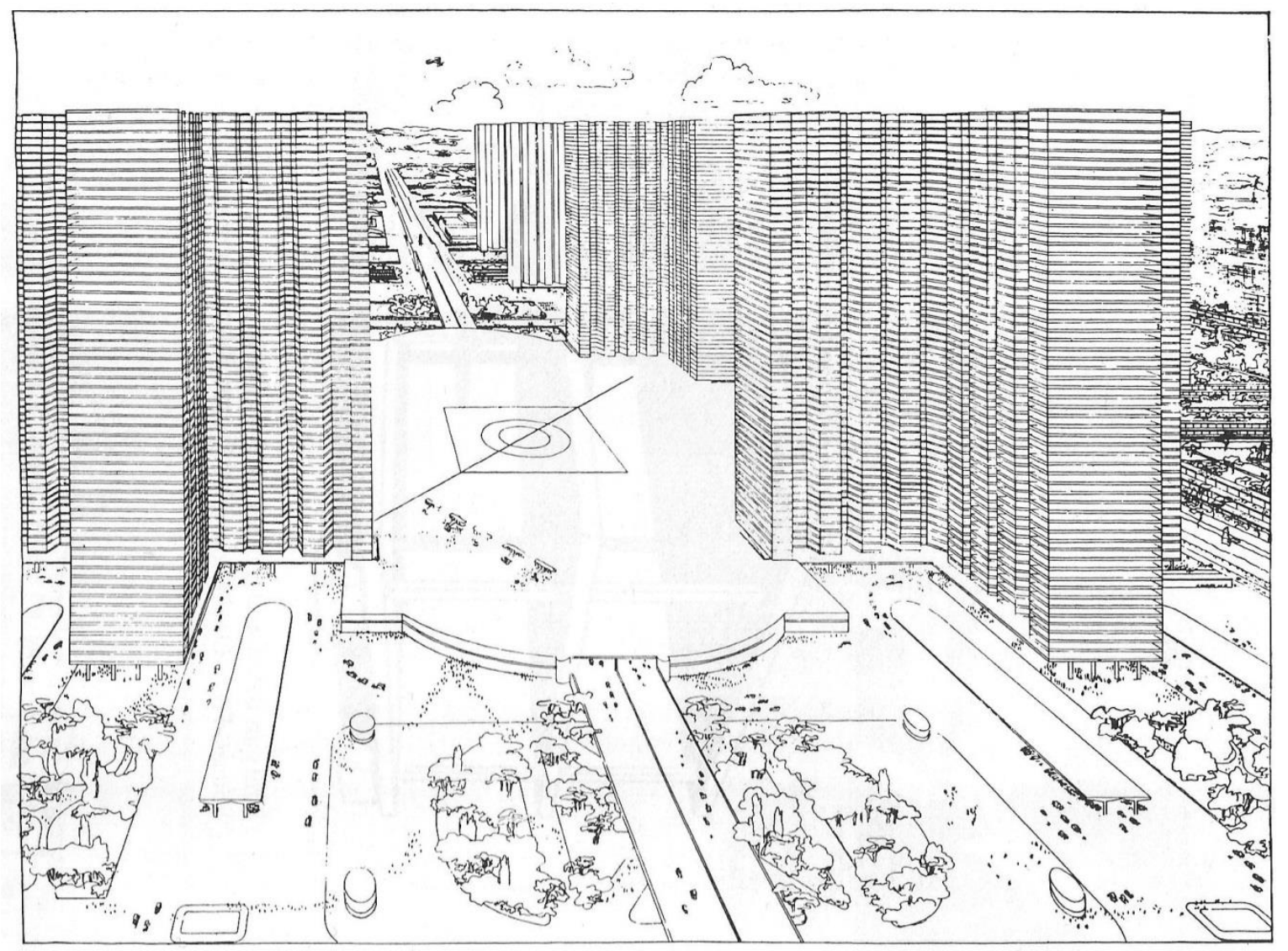

Fig. 4-7. El centro de la Ciudad Contemporánea de Le Corbusier. 


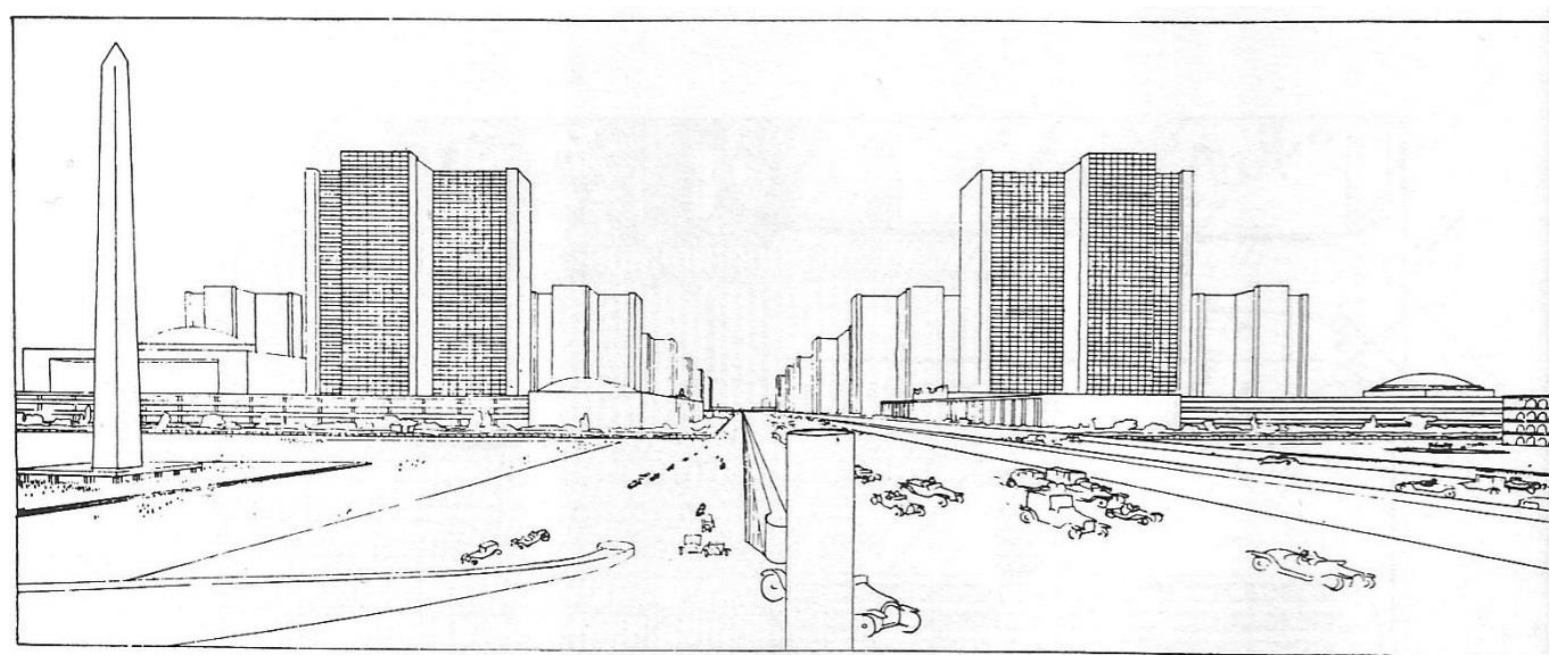

Fig. 4-8. Una super-autopista de la Ciudad Contemporánea de Le Corbusier. 


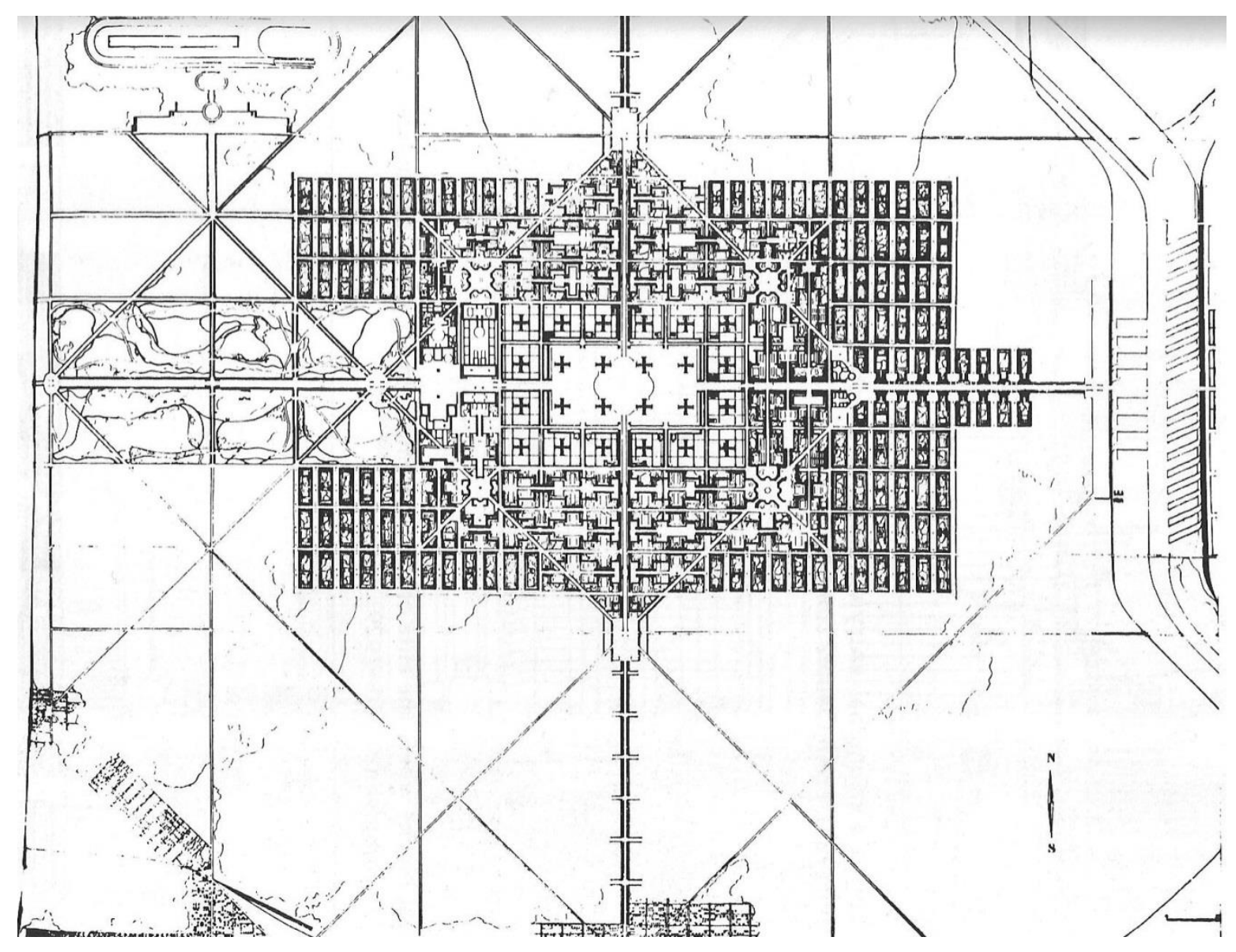

Fig. 4-9. El plan de la Ciudad Contemporánea de Le Corbusier. 


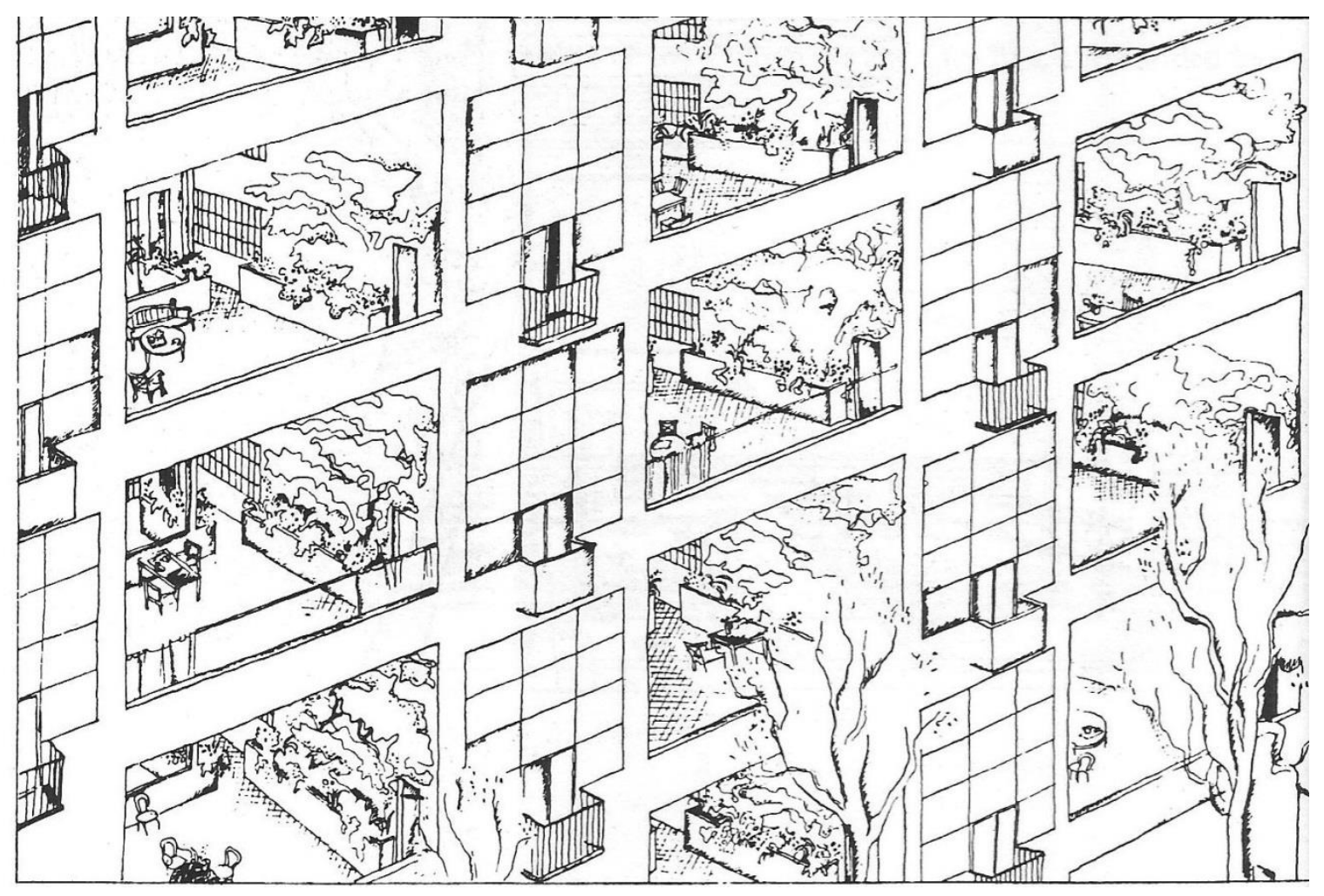

Fig. 4-10. Jardines colgados del bloque de apartamentos. La Ciudad Contemporánea. 


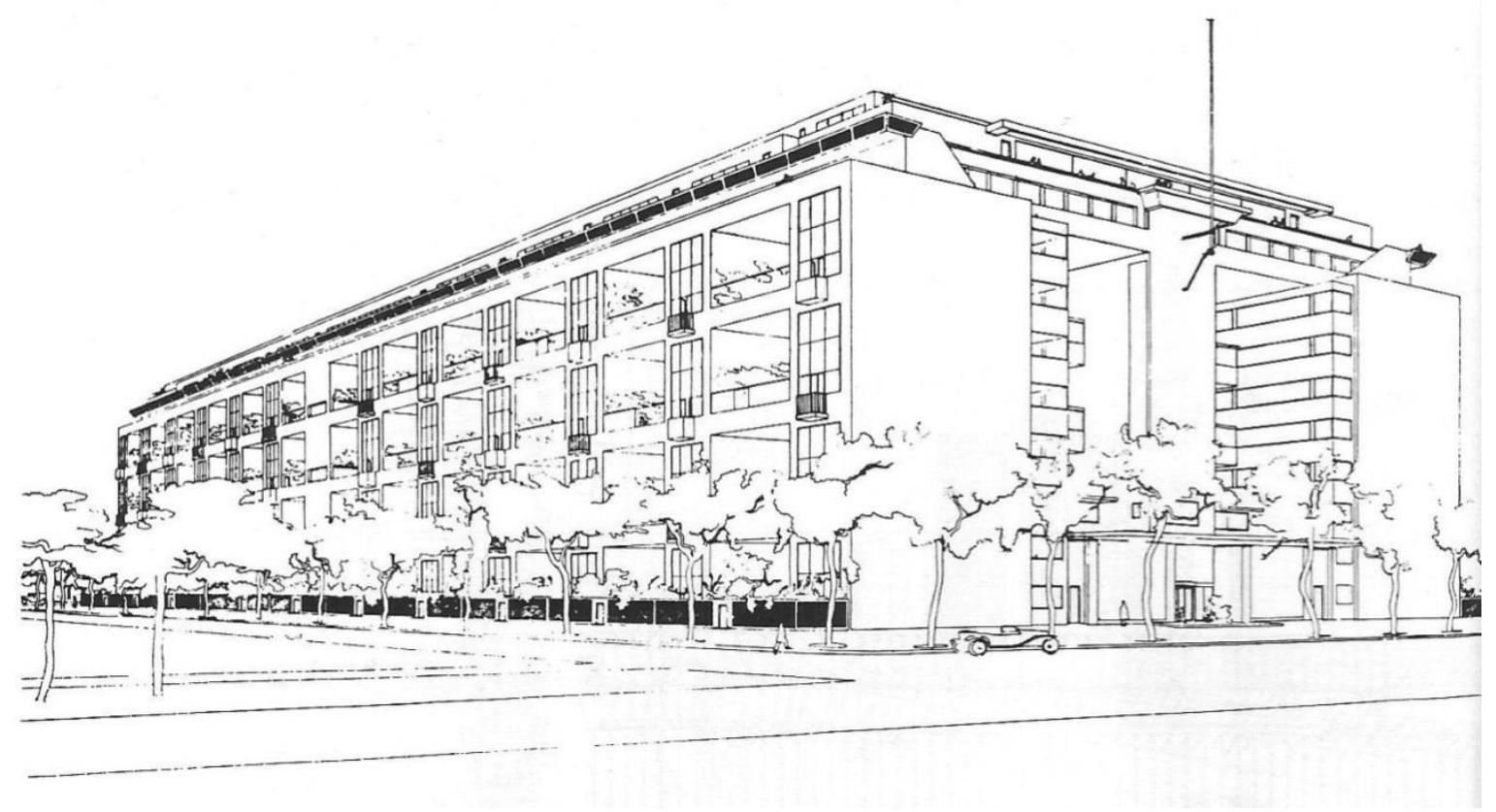

Fig. 4-11. Villa-Apartamento para la élite. La Ciudad Contemporánea. 


\section{La Nueva Babilonia de Constant}

\section{: Una vida nómada sin fronteras basada en un instinto creativo y lúdico}

Esta expresión (La sociedad utilitarista) designa todas las formas conocidas de sociedad, incluidos los estados capitalistas y socialistas modernos. Pone en evidencia una realidad fundamental, que es la misma para todas las formas de vida colectiva, pasadas y presentes: la explotación de la fuerza de trabajo del ser humano. La <<utilidad>> es el principal criterio que se aplica en la apreciación del hombre y de su actividad. El creador, el homo ludens, sólo puede hacer valer sus derechos de forma excepcional.

Lo contrario de una sociedad utilitarista es una sociedad lúdica, en la que el ser humano, liberado por la automatización del trabajo productivo, se encuentra por fin en condiciones de desarrollar su creatividad. Las expresiones <<sociedad de clases $>>y<<$ sociedad sin clases >> no reflejan este conflicto, o bien lo hacen de un modo imperfecto. Ahora bien, es evidente que la sociedad lúdica sólo puede ser una sociedad sin clases. La justicia social no garantiza de ningún modo la libertad, ni la creatividad, que es la libertad hecha realidad. La libertad no sólo depende de la estructura social sino también de la productividad. Y el crecimiento de la productividad depende de la tecnología. En este sentido, <<la sociedad lúdica >> es un concepto nuevo. ${ }^{1}$

Constant. 1974. La Nueva Babilonia.

Constant Nieuwenhuys fue un pintor holandés entrenado en la academia de Beaux-Arts en Ámsterdam. Nació en el año 1920, y no tardó mucho tiempo en destacar su talento de dibujo en el campo de las bellas artes. Constant es el protagonista de este capítulo, y es conocido como co-fundador de COBRA, y de Situacionista Internacional. En aquel tiempo, su retórica terapéutica: dérive, urbanismo unitario y la construcción de situaciones, fueron herramientas para abarcar las supersticiones utilitaristas obsoletas, gracias a abrir totalmente una nueva visión utópica en la que la sociedad anti-utilitarista se dividía en estos

\footnotetext{
${ }^{1}$ Constant. v.o. 1974. La Nueva Babilonia. Lambert, J.C.(ed.) Barcelona. Editorial Gustavo Gili. Versión española. 2009. pp. 7-8.
} 
miembros: Personas que expresan su creatividad, personas fieles al instinto lúdico y personas que escapan de la esclavitud (consistente en el trabajo y el hogar fijo).

Fue un artista que insistió en una vida nómada. Su herencia son los dibujos y maquetas de La Nueva Babilonia, que aún tienen bastantes detalles factibles. Además, Constant contempla el concepto de <<play >> gracias a un libro llamado Homo Ludens (1938) de Johan Huizinga. Las obras que Constant produjo provienen básicamente de él, representándolas con fidelidad, por lo que se podría considerar como un homenaje al mismo.

\section{COBRA}

Para conocer a Constant, sería conveniente volver a 1948 el año en que fundó Grupo Experimental Holandés con los jóvenes artistas. Después de unos meses, se unió a unos grupos de artistas influyentes de Copenhague y Bruselas; y se denominaron COBRA, significado del cual es la abreviatura de las tres ciudades de origen de cada grupo: Copenhague, Bruselas y Amsterdam.

Especialmente, se concentraban en los juegos de niños, cuyas creatividades guardan una forma preinstitucionalizada, no-filtrada por ningún aparato ideológico. Es decir, el asunto de COBRA se situaba en el instinto de la creatividad inconsciente. Como se puede imaginar, intentaron captar inspiraciones desde los dibujos -en otra palabra, grafitis. En aquella época, la mayor parte de los artistas produjeron sus resultados colaborando con el mecanismo dominante de la sociedad; el caso de los vanguardistas fue el mismo que la perspectiva de COBRA. ${ }^{2}$ Tenían fe en las pequeñas pintadas de las calles expresadas en crudo y pre-domesticadas. Los miembros de COBRA adoraban las líneas rápidas e infantiles. Ese tipo de línea no persigue una forma recta ni contiene proporciones clásicas; figuras expresadas sin usar las técnicas tradicionales del dibujo. Sus líneas estaban temblorosas y borrosas (v.figs. 5-1, 2, 3). Tal vez, COBRA habría pensado que, si no se volvía al estado de los niños, no se podía prometer nada respecto un futuro positivo, debido a que los humanos están afectados por el utilitarismo.

\footnotetext{
${ }^{2}$ AAVV. The Activist Drawing: Retracing Situationist Architectures from Constant's New Babylon to Beyond. Zegher, C \& Wigley, M. (ed.) New York, Cambridge, Massachusetts. The Drawing Center \&The MIT Press. 2001. p. 34.
} 
Persistentemente, experimentaron inspirándose desde la manera en que los niños se enfrentan al mundo. Constant, en el primer número de la revista Reflex de COBRA en 1948, manifestó que: <<Los niños no conocen otra ley que la sensación espontánea de la vida y no sienten necesidad de expresar algo más: vital, franco, inmediato, energético, espontáneo, y experimental >>3 COBRA, literalmente, se deseducó a sí mismo.

Nuestro arte es el arte de un período revolucionario, simultáneamente la reacción de un mundo que se hunde y el heraldo de una nueva era. Por esta razón, no se ajusta a los ideales de la primera, mientras que las de la segunda todavía tienen que ser formuladas. Pero esta es la expresión de una fuerza de vida que es la más fuerte para ser resistida, y de un significado psicológico considerable en la lucha por establecer una nueva sociedad. El espíritu de la burguesía todavía impregna todas las áreas de la vida, y de vez en cuando incluso pretende traer el arte a las personas.

Pero este arte es demasiado rancio para servir como medicamento por más tiempo. El garabateo de tiza en las aceras y paredes muestra claramente que los seres humanos habían nacido para manifestarse; ahora la lucha está en plena marcha contra el poder que les forzaría a ponerse la camisa de fuerza por un secretario o plebeyo y privarlos de esta primera necesidad vital. Una pintura no es una composición de color y líneas, sino un animal, una noche, un grito, un ser humano, o todas estas cosas juntas. El objetivo, el espíritu abstracto del mundo burgués ha reducido la pintura a los medios que le dieron vida; la imaginación creativa, sin embargo, busca reconocer todas las formas e incluso en el ambiente estéril de lo abstracto ha creado una nueva relación con la realidad, encendiendo el poder sugestivo que cada forma natural y artificial posee para el espectador activo. Este poder sugestivo no tiene límites y por lo tanto se puede decir que después de un período en el que no significa NADA, el arte ha entrado ahora en una época en la que significa todo. 4

Constant. 1948. Manifesto en Reflex \#1

\footnotetext{
${ }^{3}$ Constant. Manifesto. Reflex \#1. Septiembre-Octubre. 1948. La citación está referenciada por la fuente secundaria: <AAVV. The Activist Drawing: Retracing Situationist Architectures from Constant's New Babylon to Beyond. Zegher, C \& Wigley, M. (ed.) New York, Cambridge, Massachusetts. The Drawing Center, The MIT Press. 2001. p. 34>

${ }^{4}$ Situationist International Online. <http://www.cddc.vt.edu/sionline/presitu/manifesto.html>
} 
Aquí vemos una forma de creación dionisíaca con la cual Constant entiende la evolución de la sociedad y el arte. Las reproducciones y producciones espontáneas en serie de COBRA, como las de los niños, necesariamente pierden el sentido lógico en su campo de acción. ${ }^{5}$

Por la razón de que es un trabajo que depende de los instintos lúdicos (que no estén domesticados ni institucionalizados) apela a una emoción poética. Y la emoción se excede (reproducida por las series de trabajo de COBRA), una vez está empezando a tener influencia en la conciencia de los ciudadanos, la inercia del consciente colectivo empieza a poseer fuerza subversiva, que influye en la superestructura (ideología) de la sociedad utilitarista.

En $<<$ Cultura y contra-cultura $>$, un texto de la segunda edición de Reflex, Constant entiende la historia del arte como un conflicto de encadenamiento sin fin, entre la demolición y el formalismo. ${ }^{6}$ La reproducción incesantemente ejecuta su poder por medio de los cuerpos de los artistas. Ya no se puede detener la producción. Las preguntas que sean lógicas o ilógicas, y la espectativa de los grupos de interés que no quieren la revolución, se queda todo en vano, después de pasar la demolición exorbitante de la poesía. Los miembros de COBRA experimentaron sus dibujos en sus ensayos, muebles, apartamentos y casas de amigos con figuras infantiles y garabatos. Eso aún se queda en el campo conceptual, por motivo de no haberlo captado sustancialmente. Ahora bien, el fenómeno de los dibujos, es directamente una acción política. $^{7}$

El año 1951, Constant dejó COBRA. y empezó a dibujar más abstractamente. Se recuerda cómo eran las formas y líneas en el periodo con los COBRA, sin embargo ahora, las líneas se convierten en más definitivas y las manchas se vuelven más precisas. Posteriormente Constant viajó a Londres en el año 1952. Mark Wigley explicó en su famoso libro que, Constant en el tiempo que pasó en Londres se quedó fascinado por la complejidad de la forma urbana. En el año 1953, Constant estaba ya totalmente obsesionado con los espacios. Conocer al arquitecto Aldo van Eyck fue un gran salto para Constant en

\footnotetext{
${ }^{5}$ v.-Nietzche. F. v.0.1872. El nacimiento de la tragedia en el espíritu de la música.

${ }^{6}$ AAVV. The Activist Drawing: Retracing Situationist Architectures from Constant's New Babylon to Beyond. Zegher, C \& Wigley, M. (ed.) New York, Cambridge, Massachusetts. The Drawing Center, The MIT Press. 2001. p. 35.

${ }^{7}$ Ibid. p. 36.
} 
su trabajo, ya que le recomendó los libros a estudiar. Analizando las técnicas de construcción en la biblioteca, empezó a familiarizarse con los nuevos materiales, como hormigón armado y nuevos metales: titanio, aluminio y acero inoxidable. ${ }^{8}$ Como se puede suponer, en el año 1953 , los trabajos de Constant cambiaron Tri-dimensionalmente. Tres dimensiones en los trabajos que podían directamente albergar las formas espaciales. La mayor parte de sus obras durante los siguientes tres años eran escultóricas inspiradas por el constructivismo.

En el mismo año 1953, Team 10 -también referido como Team X, fue formado con unos arquitectos y otros invitados participantes en el $9^{\circ}$ Congreso de CIAM, desafiando su enfoque doctrinario de urbanismo. Alison \& Peter Smithson fueron los colegas de Aldo van Eyck en Team 10. Ellos estaban indagando sobre el patrón de los movimientos de los niños jugando en la calle, y de esta manera presentan los resultados de su estudio. Fue un modelo significante de la forma reproducida no solamente en dibujo sino también en otro medio más espacial. Constant ha tenido más libertad para aportar su idea utópica que antes. Como se confirma de manera sencilla visualmente, el proyecto Golden Lane Housing (1952) tuvo ya el patrón básico de las redes de La Nueva Babilonia(v.-fig. 5-18).

Este estudio fue presentado en 1953 como un gráfico horizontal en la que las imágenes de los niños jugando gradualmente dan paso a las propuestas urbanísticas y culminan en el proyecto de los Smithsons “Golden Lane Housing" de 1952, el plano con el diseño de red fue una gran inspiración para el patrón de la Nueva Babilonia.

Mark Wigley.

Alison y Peter Smithson consideraron el modelo de clúster como empático con el complejo estilo de vida indígena de la ciudad. Su patrón era como un eco del situacionista "dérive" a través de la ciudad, y se

\footnotetext{
${ }^{8}$ Wigley, M. Constant's New Babylon: The Hyper-Architecture of Desire. Rotterdam. 010 Publisher. 1998. p. 20.
} 
anticipó el plan de Nueva Babilonia. ${ }^{9}$

Simon Sadler

La creatividad del trabajo de Constant fue expresado en geometría abstracta para facilitar un juego incontrolado. Suena auto-contradictorio, porque en el período en que estaba con el grupo COBRA negaban todas las formas geométricas estrictamente definidas. Ahora bien, La Nueva Babilonia necesitó encontrar su forma practicable más allá del campo de juego de los niños. El enfoque ha cambiado después del viaje de Londres. Ahora, su objetivo principal, es producir el espacio superando su campo de trabajo de dos dimensiones para pasar al campo de tres dimensiones. En su espacio, en el juego de niños, ha empezado a considerar el elemento de la escala humana. Para establecer una línea, involucraba las ideas arquitectónicas en La Nueva Babilonia. Correr, saltar, girar y escalar son elementos lúdicos que son extraídos del campo de juego y aplicadas en su maqueta son consideradas como acciones creativas. Gracias a este aparato, su diseño se transforma en un instrumento técnico de generar acciones creativas, en otra palabra, acciones políticas de los participantes, es decir, de los ciudadanos. Debord fue una buena alianza que pudo acompañar esa idea. Al final, como había muchas partes filosóficas que podían compartir Constant y Debord, les llevó a la fundación de Situacionista Internacional en el Julio del año 1957.

\section{Vocabularios de Situacionistas ${ }^{10,11,12}$}

Constant ya tenía un esbozo de La Nueva Babilonia a través de la influencia de los Smithsons, antes de concebir una concreta semilla filosófica. El proyecto de Golden Lane ya estaba insinuando bastante -con su particular forma de red- una cierta dirección en la que La Nueva Babilonia podría llevarse. No obstante, para el elemento ambiental lúdico (es decir, psicogeográfico), era grande la influencia de Debord. Sería

\footnotetext{
${ }^{9}$ Sadler, S. The Situationist City. Massachusetts. The MIT Press. 1999. p. 21

${ }^{10}$ Debord, G. Preliminary Problems in Constructing a Situation. Internationale Situationniste \#1. 1958. La citación está referenciada por la fuente secundaria: <AAVV. Situationist International Anthology. Knabb, Ken(ed. \& tr.) Berkeley. Bureau of Public Secrets. 2006. pp. 51-52.

${ }^{11}$ Debord, G. v.o.1967. La Sociedad del Espectáculo. Smith, D.N.(tr) New York. Zone Books. Versión inglesa: The Society of the Spectacle. 1994. $\mathrm{N}^{\mathrm{a}}$ de párrafos 37, 36, 42.

${ }^{12}$ Debord, G. Theory of the Dérive. Internationale Situationniste \#3. 1958. La citación está referenciada por la fuente secundaria: <AAVV. Situationist International Anthology. Knabb, Ken(ed. \& tr.) Berkeley. Bureau of Public Secrets. 2006. p. 62>
} 
necesario referirlo en este momento, a fin de que se pueda comprender las retóricas peculiares, los mantras que practicaban los Situacionistas.

Algunos vocabularios han de tratarse posteriormente con más detalle, que son: Dérive y Détournemen, que de hecho son conceptos muy íntimos uno a otro, porque en alguna perspectiva, son elementos derivados, que construyen el urbanismo unitario.

\section{Urbanismo Unitario}

La teoría de la utilización combinada de artes y técnicas como medios que contribuyen a la construcción de un entorno unificado en una relación dinámica con experimentos en el comportamiento.

\section{Situación construida}

Un momento de la vida construida concretamente y deliberadamente por la organización colectiva de un ambiente unitario y de un juego de eventos.

\section{Situacionista}

En relación con la teoría o la actividad práctica de la construcción de situaciones. Aquel que se dedica a la construcción de situaciones. Un miembro del Situacionista Internacional.

\section{Psicogeografía}

El estudio de los efectos específicos del entorno geográfico (ya sea conscientemente organizada o no) en las emociones y la conducta individuales.

\section{Dérive (Derivar)}

Un modo de comportamiento experimental relacionado con las condiciones de la sociedad urbana: una técnica de paso rápido a través de ambientes variados. El término también designa un periodo específico ininterrumpido de dérives. 
Dérives implica el comportamiento lúdico y constructivo y la conciencia de los efectos psicogeográficos, y son además bastante diferentes de las nociones clásicas del viaje de paseo.

En un dérive uno o más personas durante un cierto periodo dejan sus relaciones, sus actividades laborales y de ocio, y todos sus otros motivos habituales para el movimiento y la acción, y se dejan arrastrar por las atracciones del terreno y los encuentros que hallan allí.

\section{Détournement(Tergiversación)}

Abreviatura de <<Tergiversación de los elementos estéticos preexistentes $>>$. La integración de las producciones artísticas presentes o pasadas en una construcción superior de un entorno. ... En un sentido más elemental, la détournement entre las antiguas esferas culturales es un método de propaganda, un método que revela el desgaste y la pérdida de importancia de esas esferas.

\section{Descomposición}

El proceso en el cual las formas culturales tradicionales se han destruido a sí mismas como resultado de la aparición de los métodos superiores del control de la naturaleza que hacen posible y necesarias las construcciones culturales superiores. Podemos distinguir entre la fase activa de la descomposición y la demolición efectiva de las viejas superestructuras -que llegó a su fin alrededor de 1930- y una fase de repetición que ha prevalecido desde entonces. El retraso en la transición desde la descomposición hasta las nuevas construcciones está vinculado a la demora en la liquidación revolucionaria del capitalismo.

\section{Situacionista Internacional}

El famoso grupo SI (abreviándolo) tuvo su inauguración en el año 1957, en un bar de Italia. Los delegados fueron de dos grupos principales: uno, Movimiento Internacional para un Bauhous Imaginista (19541957), y el otro, Letrista Internacional (1952-1957). También, había un Constant que ya no era miembro de COBRA. Como se ve en el período final de cada grupo, ambos se unieron como un matrimonio para abrir una nueva y ancha perspectiva, no como el caso de COBRA, que aún estaba atrapado por sí mismo 
en una dogmática y estrecha perspectiva. Constant salió del grupo COBRA debido a una incompatibilidad política, y cada uno siguió su ruta independiente.

Guy Debord estaba liderando el grupo Letrista Internacional en aquel tiempo. El carácter de grupo estaba inclinado a los aspectos conceptuales en el campo urbano, sin embargo, Asger Jorn de Imaginista Bauhous, propugnó los aspectos prácticos. ${ }^{13},{ }^{14}$

A propósito, Debord y Jorn propusieron unas actuaciones en el mapa y en la ciudad de Paris. Para ellos, el mapa es algo que puede modificarse, por lo que lo cortaron y dispusieron en la manera de dérive, recomponiéndolo. Y habrían observado los efectos en sus emociones, -patrón de- comportamientos individuales según los cambios del ambiente, es decir, psicogeografía.

Recorrieron los lugares para al final producir nuevas cartografías. Se movieron o flotaron por la ciudad francesa según sus deseos, el resultado, la ciudad vieja se transformó en otra. Eso es la idea esencial de Détournement, lo cual es también una relevante pieza para construir La Nueva Babilonia de Constant. Un lugar se transforma en otro mediante la integración del pasado y el presente. Las producciones artísticas improvisadas estaban proponiendo una nueva manera de percibir una ciudad. Esas rojas y curvadas flechas marcan los lugares en los que ellos flotan a lo largo de los cuales ellos derivan(v.-figs. 5-4, 5). ${ }^{15}$

Como sus resultados fueron improvisados, fácilmente se puede saber que el área de actividad del concepto llamado dérive estaría profundamente relacionado con el inconsciente de los jugadores y de la ciudad (si la ciudad tiene algún tipo de voluntad, o sea no impersonal). En este sentido, ese tipo de acciones tenían unas ciertas partes comunes con las series de acciones de COBRA. Se creía que los dibujos automáticos tenían el poder subversivo para poner una abertura en aquel tiempo tan escéptico para los artistas. Constant pretendió a adaptar esa estrategia positivamente en su utopía.

\footnotetext{
${ }^{13}$ Sadler, S. The Situationist City. Massachusetts. The MIT Press. 1999. p. 4.

${ }^{14}$ Las complicadas explicaciones genealógicas de cada grupo, no son factores cruciales para entender el siguiente paso, por lo tanto si se desea una mayor información, se puede encontrar en el libro <<The Situationist City >> del autor Simon Sadler, donde se organiza la introducción sobre este tipo de información con un breve diagrama.-(NdA)

${ }^{15}$ AAVV. The Activist Drawing: Retracing Situationist Architectures from Constant's New Babylon to Beyond. Zegher, C \& Wigley, M. (ed.) New York, Cambridge, Massachusetts. The Drawing Center, The MIT Press. 2001. p. 47.
} 
La crisis en el urbanismo está empeorando. La construcción de los vecindarios, antiguos y modernos, se encuentra en un evidente desacuerdo con las formas establecidas del comportamiento, y más aún con las nuevas formas de vida que estamos buscando. El resultado es un ambiente estéril y deprimente en nuestro entorno. En los barrios más antiguos, las calles han degenerado en autopistas, las actividades de ocio se comercializan y quedan desnaturalizadas por el turismo. Las relaciones sociales se hacen imposibles...Son la expresión extrema del bienestar de los burgueses, y todas las preocupaciones lúdicas están ausentes en ellos...Nosotros ansiamos aventura. Al no encontrarlo en la tierra, algunos hombres han ido a buscarla en el estado de ánimo. Nosotros, preferimos primero apostar por un cambio en la tierra. Proponemos la creación de situaciones allí, nuevas situaciones. Contamos con infringir las leyes que impiden el desarrollo de las actividades efectivas en la vida y en la cultura...Nuestro dominio, entonces, es el nexo urbano, la expresión natural de una creatividad colectiva, capaz de incluir las energías creativas que se liberan con la decadencia de una cultura basada en el individualismo. ${ }^{16}$

Constant. 1959. Internationale Situationniste. \#3.

Parece que intentaban atraer una sociedad alternativa sobre una serie de acciones coherentes, reproductivas, practicables e inmediatas, es decir intentaban construir situaciones. Durante los años de 1957-1959, los trabajos de Debord y Jorn (La ciudad desnuda), también tendrían que entenderse desde su particular manera de construir las situaciones. Y con las situaciones acumuladas se cree que formarían y reflejarían cada etapa de los conscientes transcendentales y revolucionarios del pueblo, dinámicamente. ${ }^{17}$ Mientras tanto, los situacionistas compartieron esa interesante perspectiva, y también entre los miembros practicaban independientemente su peculiar disciplina. El adoctrinamiento de $\mathbf{S} \mathbf{I}^{18}$, no es malo si el adoctrinamiento de SI fuera importado desde Letrista International de Debord. Pero, había un movimiento poco heterogéneo que Constant pretendió crear dentro del grupo. La ciudad de La Nueva Babilonia de Constant, se parece a una mezcla de constructivismo y expresionismo abstracto. El nivel de

\footnotetext{
${ }^{16}$ Wigley, M. Constant's New Babylon: The Hyper-Architecture of Desire. Rotterdam. 010 Publisher. 1998. p. 115.

${ }^{17}$ Sadler, S. The Situationist City. Massachusetts. The MIT Press. 1999. p. 105.

${ }^{18}$ Situacionista Internacional-(NdA)
} 
abstracción de las líneas ${ }^{19}$ mantuvieron una peculiar característica: son suficientemente elásticas para acomodar y para ejercitar la voluntad del homo ludens con la nueva tecnología ingenieril. ${ }^{20} \mathrm{~A}$ Debord no le gustó el estilo de Constant, pero Constant, al menos, se mantiene fiel al concepto llamado dérive que se explicó en la segunda revista (1958) de SI. Las líneas que expresan las energías liberadas y sus orientaciones, insinúan un comportamiento lúdico entre las direcciones dispuestas libremente en el espacio. Obviamente, Debord fue escéptico con ese tipo de movimientos dentro de SI. Pronto, por la desigualdad en la percepción del urbanismo unitario, en el año 1960, Constant se despidió con SI.

Los compañeros que quieren una nueva, libre arquitectura, deben entender que esta nueva arquitectura principalmente se basa no en las líneas libres, poéticas y formas, (...) sino más bien en los efectos atmosféricos de las habitaciones, pasillos, calles, ambientes vinculados a los gestos que contienen. La arquitectura debe avanzar mediante la adopción de situaciones que se mueven emocionalmente, en lugar de las formas que se mueven emocionalmente, como el material con el que funciona. Y los experimentos realizados con este material guiará hacia formas desconocidos. ${ }^{21}$

Guy Debord.

\section{Urbanismo Unitario}

Antes de estrenar la maqueta de La Nueva Babilonia hasta el año 1959 en Museo Stedelijk (en Ámsterdam), en realidad, Constant ya había hecho una prolífica actividad para tener la idea e incluso su forma de manera más concreta, durante los años 1958-1960 a través de sus ensayos en la revista de SI también. Como está referido anteriormente, ahora se halla una necesidad de entender el concepto más profundamente, llamado <<Urbanismo Unitario >> que es una noción primordial con $<<$ El Modelo Social $>>$ para formar La Nueva Babilonia. Básicamente, el Urbanismo Unitario es un proyecto social para

\footnotetext{
${ }^{19}$ No tanto nivel como COBRA cuyas líneas estaban nubladas, no definidas ni con formas concretas.-(NdA)

${ }^{20}$ Sadler, S. The Situationist City. Massachusetts. The MIT Press. 1999. p. 107.

${ }^{21}$ Debord, G. Report on the Construction of Situations. 1957. La citación está referenciada por la fuente secundaria:

< Sadler, S. The Situationist City. Massachusetts. The MIT Press. 1999. p. 107>
} 
recomponer la ciudad con el objetivo de enriquecer la vida cotidiana. ${ }^{22}$ La Europa oeste y el norte de América experimentan un drástico cambio -con motivo del crecimiento de la población y su consecuencia, que es la aparición de las grandes ciudades, que toman papeles primordiales y funcionan como los teatros que reproducen la cultura contemporánea. Constant entiende la ciudad como un paisaje artificial donde la aventura de los humanos se despliega. Por supuesto que la declinación de la cultura también ha sido un gran motivo de ese tipo de pensamiento incluso de COBRA.

Constant captura la palabra <<cultura > como un término del juego de la vida. ${ }^{23}$ Ello significaría que la civilización humana ya tendría que haber superado los deseos materiales. Si no, el estilo de nuestra vida no podrá escapar de la sujeción a las labores. Así que naturalmente los seres humanos podrían desear un objeto sin condiciones, más creativamente. Es decir, los humanos pueden encontrar el sentido de la vida, por la vida en sí misma. Por eso el urbanismo encuentra una nueva situación que le permite transformarse de todas formas, porque el fracaso del vigente urbanismo moderno que aún se queda en un nivel de intervención estética, no es capaz de capturar nuestra vida apropiadamente e incluso el aspecto cultural. Para Constant, los urbanistas parecían separados de la cuestión cultural. El fracaso del urbanismo moderno en un hábitat humano (por ejemplo los problemas de tráfico y de las viviendas), y la desaparición de un espacio social en el cual podría surgir una nueva cultura, provocó el hundimiento de la ciudad moderna.. ${ }^{24}$ Por eso la instancia dominación de otra alternativa surge.

El Urbanismo Unitario es flexible, respeta nuestra libertad de cambiar nuestra manera de vida, se adapta a cada situación, a cada necesidad, a todas las posibilidades técnicas, geográficas o psicológicas, eso es la objetivación del impulso creativo, la colectivización de la obra de arte, la materialización del estilo dinámico de vida.

La realización de la vida en el sentido del Urbanismo Unitario, depende en gran medida del lugar del espacio social en la planificación urbana. Es aquí, después de todo, donde la mayoría de los eventos que

\footnotetext{
22 Sadler, S. The Situationist City. Massachusetts. The MIT Press. 1999. p. 117.

${ }^{23}$ Wigley, M. Constant's New Babylon: The Hyper-Architecture of Desire. Rotterdam. 010 Publisher. 1998. p. 132.

${ }^{24}$ Ibid. p. 131.
} 
influyen y determinan la vida diaria toman lugar. Es aquí donde una intervención deliberada en el medio ambiente material tiene mayor efecto, sólo aquí esta intervención puede convertirse en un juego colectivo destinado a la creación de nuestro entorno. ${ }^{25}$

Constant. 20 de diciembre, 1960. En la lectura del Museo Stedelijk.

\section{U.U. es una perspectiva que considera el urbanismo en el campo del espacio físico y del espacio}

social en equilibrio. Es un reto que devuelve el derecho nativo a los ciudadanos que nos haga poder disfrutar la vida creativa activa, no pasiva. U.U. involucra necesariamente una transformación del presente hábitat o incluso del estilo de vida humano. La estrategia del arte tradicional ya no era necesaria. La vigente forma cultural no era adecuada para tomar un papel en la presente situación urbana declinada. Y el urbanismo tuvo que producir un espacio social. EI U.U. considera que hasta la influencia psicológica es necesaria, y cómo ésta ejercita el medio ambiente, para poder generar un vínculo más sólido e interactivo entre el medio ambiente y la vida, o sea psicogeografía. ${ }^{26}$ La psicogeografía para Constant no es más que una manera de activar el medio ambiente. Una activación por las vidas creativas participativas, en este contexto significa construir un espacio social también. Así el concepto psicogeografía converge en U.U.

\section{Détournement}

Lo que equivale a decir que, por ser el collage un método que deriva su virtud de su ironía, porque parece ser una técnica para utilizar cosas sin acabar de creérselas, es también una estrategia que puede permitir tratar la utopía como imagen, trataría en fragmentos sin que tengamos que aceptarla in toto, lo que representa sugerir, además, que el collage podría constituir incluso una estrategia que, al soportar la ilusión

\footnotetext{
${ }^{25}$ Constant. Unitair Urbanisme. Manuscrito inédito de una lectura del Museo Stedelijk. Robyn de Jong-Dalziel(tr). 20 de Diciembre, 1960. La citación está referenciada por la fuente secundaria: <Wigley, M. Constant's New Babylon: The Hyper-Architecture of Desire. Rotterdam. 010 Publisher. 1998. p. 132>

${ }^{26}$ Wigley, M. Constant's New Babylon: The Hyper-Architecture of Desire. Rotterdam. 010 Publisher. 1998. p. 134.
} 
utópica de la invariabilidad y el destino alimentase una realidad de cambio, movimiento, acción e historia. ${ }^{27}$

Colin Rowe \& Fred Koetter. 1975. Ciudad Collage.

Durante el proceso de U.U., la ciudad experimenta un drástico cambio en la superficie, dicho cambio se llama détournement. La manera en que se entiende este concepto, podría tener una ventaja grande además del concepto de regeneración urbana. La ventaja es una reproducción del significado en un nuevo y distinto contexto urbano, que está en un eterno cambio constante. El concepto Détournement, básicamente, es un tipo de acción de reforma. Es importante para SI no construir una nueva ciudad desde cero como lo hizo Le Corbusier. Debord cree que cualquier elemento artístico pre-existente puede utilizarse con elementos heterogéneos mediante nuevas combinaciones. Cuando aún no estaba formado SI, en un documento que se llama Una Guía de Usuario para Détournement. 1956. Debord y su colega Wolman refirieron esa estrategia con un agradable ejemplo del descubrimiento de la poesía moderna, en cuanto a la estructura analógica de que las imágenes pueden crear una nueva relación, afrontando las palabras referenciadas que intervienen una en relación a otra. En su coincidencia, dogmas convencionales restrictivos pierden la posición de su coherente autoridad. ${ }^{28}$ Además, en aquella época, una indagación sobre los nuevos significados que surgen cuando los elementos heterogéneos se encuentran, ya era una tendencia probada hace tiempo en los artistas contemporáneos de vanguardia. ${ }^{29}$

En el año 1959, en la revista de SI \#3, Debord proclama unos comienzos de este concepto y su poder. Originalmente este concepto, Détournement realiza dos principios fundamentales en el proceso. El principio uno, es perder los significados originales después de experimentar Détournement y el segundo es una emergencia inesperada del nuevo significado, al mismo tiempo. Estas series de acciones tienen que considerarse como un proceso sin separación (en varios aspectos, Détournement se parece a un

\footnotetext{
${ }^{27}$ Rowe, C. \& Koetter, F. Ciudad Collage, Editorial Gustavo Gili. S. A. Barcelona. Versión española. 1998. pps. 144-145. En la versión original: Rowe, C. \& Koetter, F. Collage City. Cambridge, Massachusetts. The MIT Press. 1983. p. 149. ${ }^{28}$ Debord, G. \& Wolman, G. J.. A User's Guide to Détournement. 1956. La citación está referenciada por la fuente secundaria:

<AAVV. Situationist International Anthology. Knabb, Ken(ed. \& tr.) Berkeley. Bureau of Public Secrets. 2006. p. 15>

${ }^{29}$ El trabajo inicial, especialmente en los años de 1910-20 de Marcel Duchamp, se quedaría un notable ejemplo para siempre.-(NdA)
} 
collage). El Détournement tiene necesariamente un poder de poseer un significado dual. Como es un trabajo práctico, también posee una ventaja de reproducir (perpetuamente) su significado y lo enriquece la oportunidad de combinar elementos con otra perspectiva. Pero lo más interesante y lo que provee la justicia de este juego para SI es que, Détournement tiene un significado histórico y a la vez social. Si se percibe este pensamiento como un juego de devaluación, hay unas reglas que otro miembro relevante de SI, Jorn propone. Alega que todos los elementos culturales del pasado han de desaparecer. ${ }^{30} \mathrm{Y}$ Détournement empieza negando los valores pre-existentes de las expresiones institucionalizadas descomponiendo los métodos y las expresiones artísticas obsoletas. Al final, se encuentra un nuevo género de creación.

La desviación no sólo conduce al descubrimiento de nuevos aspectos de talento; además, chocando directamente con todas las convenciones sociales y legales, no puede dejar de ser un arma cultural poderosa al servicio de una lucha real de clases. La baratura de sus productos es la artillería pesada que rompe a través de todos los obstáculos del entendimiento. Es el significado real de la educación artística proletaria, el primer paso hacia un comunismo literario. ${ }^{31}$

Guy Debord \& Gil J. Wolman. 1956.

\section{El Modelo Social}

Experimentando el détournement, la Tierra empieza a formar las partes de LNB. Y como está referido anteriormente, Constant propone dos ideas condicionales las cuales son el U.U. y el El Modelo Social para definir LNB. Entonces, como ya se ha revisado el U.U. hasta ahora, se tratará el tema del El Modelo Social.

En esa sociedad, sin excepción, todas las personas se dedican a las actividades creativas. En la perspectiva material, la historia humana se puede entender como una pelea incesante del hambre debido

\footnotetext{
${ }^{30}$ Debord, G. Détournement as Negation and Prelude. Internationale Situatinniste \#3. 1959. La citación está referenciada por la fuente secundaria: < AAVV. Situationist International Anthology. Knabb, Ken(ed. \& tr.) Berkeley. Bureau of Public Secrets. 2006. p. 67>

${ }^{31}$ Debord, G. \& Wolman, G. J.. A User's Guide to Détournement. 1956. La citación está referenciada por la fuente secundaria: < AAVV. Situationist International Anthology. Knabb, Ken(ed. \& tr.) Berkeley. Bureau of Public Secrets. 2006. p. 18>
} 
a las circunstancias humanas. La carencia y la demanda son dos conceptos opuestos que siempre existirían. Así, Constant procede en su lógica, y pregunta que $<<$ la historia de la humanidad no nos ofrece ningún precedente que nos sirva de ejemplo, puesto que las masas jamás han sido libres, es decir, libremente creativas. En cuanto a la creatividad, ¿qué ha significado, sino el rendimiento de las personas? $>>32,{ }^{33}$ Entonces, surge una pregunta ¿qué tipo de proceso ha de involucrarse para llegar al punto donde verdaderamente cada hombre sea libre para crear su vida? Constant explica 4 condiciones previas. Las premisas de abajo, las habría escrito cuando se imaginó que el reino marxista estaba realizado, puesto que su pensamiento y su modelo social encaja con el marxista. En algún día, todos los trabajos nocreativos serían automatizados, la cantidad de las producciones serían suficientes para todo el mundo y la minoría cesaría de ejercitar sus poderes sobre la mayoría. Si se recuerda la situación progresiva de la tecnología en aquel tiempo, la psicología del utopísmo de Constant era bastante comprensible y su guión fue deseable en el aspecto social también.

-La automatización de todas las actividades <<útilies>> y repetitivas libera, a nivel de las masas, una energía que a partir de ahora podrá ser utilizada para otras actividades.

-La propiedad colectiva del suelo y de los medios de producción y la racionalización de la producción de bienes de consumo favorecen la transformación de dicha energía en actividad creativa.

-Al desaparecer el trabajo productivo, los horarios colectivos dejan de tener sentido. Por el contrario, las masas dispondrán de una cantidad considerable de tiempo libre.

-La independencia respecto al lugar de trabajo tiene como consecuencia la independencia respecto al hábitat, al lugar de residencia. La movilidad de cada individuo en el espacio se ve incrementada. ${ }^{34}$

\footnotetext{
${ }^{32}$ Constant. v.o. 1974. La Nueva Babilonia. Lambert, J.C.(ed) Barcelona. Editorial Gustavo Gili. Versión española: La Nueva Babilonia. 2009. p. 13.

${ }^{33}$ Constant. La Nueva Babilonia.Escrito en alemán durante 1960-1965. Publicado en 1974. Hammond, P.(tr) Versión inglesa. La citación está referenciada por la fuente secundaria: <Wigley, M. Constant's New Babylon: The Hyper-Architecture of Desire. Rotterdam. 010 Publisher. 1998. p. 160>

${ }^{34}$ Constant. v.o. 1974. La Nueva Babilonia. Lambert, J.C.(ed) Barcelona. Editorial Gustavo Gili. Versión española. 2009. pp. 14-15.
} 


\section{Los Nuevos Babilonios}

Así diseñadas dos columnas conceptuales, generan una convergencia dialéctica al concepto llamado Los Nuevos Babilonios. Y Los Nuevos Babilonios, en el término de Johan Huizinga (Homo Ludens), consiste en dos nociones cruciales, que son el Dérive y Desorientación. Ahora bien, antes de indagar sobre esas ideas, vamos a conocer un concepto periférico que se llama <<La Megaestructura y La red $>>$ de LNB, por un trabajo previo (v.-figs. 5-15, 16). Como se refirió anteriormente, Dérive significa <<Deriva>> en español y en el término de SI es flotar en la vasta red conectada por medio de numerosos sectores.

Aquí, la red se puede comprender como un aparato infraestructural para ampliar la eficacia de El Modelo Social en LNB. Recordando el carácter de EMS (El Modelo Social) como una proposición, es obvio que Los Nuevos Babilonios son liberados del uso de sus tiempos para toda la vida. Sin ninguna restricción, se puede marchar a cualquier sitio al momento, por cada interés o afición particular (v.-fig. 5-6). Constant declara el final de la vida imperativa de la pequeña área de hábitat e incluso de su lugar de trabajo que supone un yugo insistente. Los Nuevos Babilonios, en otra denominación Homo Ludens (Desde ahora se apunta HL en abreviatura), recupera una primitiva actividad de la humanidad, explorar su entorno natural. HL empezará a utilizar su tiempo y su energía según su necesidad de juego, de aventura, de movilidad y etcétera. Porque todas las condiciones de LNB van a facilitar la libre creación de HL. HL pretenderá transformar, recrear su entorno. El significado de estos método de acción para HL, es la creatividad per se lo cual significa manifestar en todos los ámbitos de actividad, incluso aplicándose a sí mismo, la exploración de su propia creación. ${ }^{35}$

...En nuestro caso, lo urbano debe dar respuesta a la movilidad social, y ello implica, en relación a la ciudad estable, una organización más rigurosa a gran escala y, al mismo tiempo, una mayor flexibilidad a pequeña escala, que es la escala de la complejidad infinita. En cualquier circunstancia la libertad de creación exige

\footnotetext{
35 Ibid. p.15.
} 
que dependamos lo menos posible de las contingencias materiales. Así pues, dicha libertad propone una vasta red de servicios colectivos, más solicitados por una población en movimiento que por las poblaciones estables de las ciudades funcionales. ${ }^{36}$

Constant. 1974. La Nueva Babilonia.

Una vez los sectores de LNB están instalados en la tierra, se van a transformar según los juegos de HL, montando y desmontando los sectores, los muros, los suelos y puentes que son diseñados movibles. Así los sectores se expanden transformándose. La Megaestructura es un resultado lógico según el escenario. Los sectores van a proceder a su colonización hasta cubrir toda la tierra ya que la tierra es redonda (v.-fig. 5-17). Y eso significa que cualquier lugar es accesible para todos y la tierra se convierte en un hogar general y ya no existe el concepto de economía nacional. HL considera la vida como un viaje incesante a través del mundo el cual es cambiante. Cada día se ofrece un mundo nuevo para viajar. Indudablemente, la autoridad para los cambios de ámbito es de los HL. ${ }^{37}$

Jugar con los elementos ambientales, es la esencia de la cultura de LNB. Constant alega que el juego es posible debido a la técnica de control integral de todos los elementos, que se convierten en una creación consciente del medio ambiente. ${ }^{38} \mathrm{La}$ atracción de los elementos ambientales se puede describir mediante los siguientes tres aspectos característicos. Primeramente, existen los elementos ambientales que definen construcciones espaciales. Su rango de determinación cubriría la forma del espacio, el material, el color y la estructura de la construcción. La estructura tiene como una forma de esqueleto horizontal, ya que Constant prefiere una estructura neutra que sea posible para poder aceptar todos los tipos de transformaciones frecuentes del interior (v.-figs. 5-7, 10). Las estructuras están divididas en sectores (v.figs. 5-9, 11, 13). El sector es la unidad básica más pequeña de la red de LNB. En segundo lugar, existen los elementos ambientales que definen la calidad del espacio, como modificar las condiciones atmosféricas,

\footnotetext{
${ }^{36} \mathrm{Ibid}$

${ }^{37}$ Constant. La Nueva Babilonia. The Hague. The Haags Gemeetenmuseum. 1974. p. 3. Fuente online:

<http://isites.harvard.edu/fs/docs/icb.topic709752.files/WEEK\%207/CNieuwenhuis_New\%20Babylon.pdf>

${ }^{38}$ Ibid. p. 10.
} 
por ejemplo: temperatura, humedad, luz, sonido, etc. En cualquier momento, todos Los Nuevos Babilonios son capaces de modificar estos elementos (v.-figs. 5-14, 18). Eso significa que los habitantes de los sectores ya no seguirán el ritmo de la naturaleza. Por último, están los elementos que no definen la calidad del espacio, pero generan efectos psicológicos durante las diversas actividades: moverse, comer, beber y el uso de la comunicación verbal o de otro tipo, etc. en La Nueva Babilonia. Además, aparte de estos aspectos objetivos, habrá otros aspectos subjetivos que se ejercen sobre nosotros. La gente podrá discernir los elementos visuales, sonoros, táctiles, olfativos y gustativos. ${ }^{39}$ Estos elementos ambientales son fertilizadores primordiales para enriquecer el concepto HL. La accesibilidad, el nomadismo, la atracción de los elementos ambientales, en el Homo Ludens, son conceptos profundamente interrelacionados.

El ambiente de un entorno, al poseer ciertas características plásticas y acústicas propias, depende de las personas que se encuentran en él. Una persona sola puede sufrir dicho ambiente de forma pasiva, o bien cambiarlo en función de su estado anímico del momento. Ahora bien, con la entrada de una segunda persona se deja notar una nueva influencia, y la interacción de ambas influencias excluye cualquier forma de pasividad. Las cualidades de un entorno y de su ambiente ya no dependen únicamente de los datos materiales, sino del modo como son percibidas, apreciadas y utilizadas, de la "nueva mirada" proyectada sobre las mismas. Y cuando una tercera persona y una cuarta persona se unen a las dos primeras, la situación se vuelve más compleja y escapa al control de cada una de las personas presentes. A medida que el número de visitantes aumenta y que la composición del grupo cambia, la complejidad se incrementa, al mismo tiempo que decrece la influencia individual sobre el espacio. ${ }^{40}$

Constant. 1974. La Nueva Babilonia.

\section{Dérive y la vida nómada}

\footnotetext{
${ }^{39}$ Constant. La Nueva Babilonia. The Hague. The Haags Gemeetenmuseum. 1974. p. 10. Fuente online: <http://isites.harvard.edu/fs/docs/icb.topic709752.files/WEEK\%207/CNieuwenhuis_New\%20Babylon.pdf>

${ }^{40}$ Constant. v.o.1974. La Nueva Babilonia. Lambert, J.C.(ed) Barcelona. Editorial Gustavo Gili. Versión española. 2009. pp.44-45
} 
Somos los símbolos vivos de un mundo sin fronteras, de un mundo de libertad, sin armas, en el que todo el mundo puede viajar sin limitaciones desde las estepas de Asia Central hasta las costas atlánticas, desde las atlas mesetas de Sudáfrica hasta los bosques finlandeses. ${ }^{41}$

Vaida Voivod III, presidente de las Comunidad Mundial de los Gitanos.

Extracto de una entrevista publicada en Algemeen Handelsblad, Ámsterdam, 18 de mayo de 1963.

Los $\mathrm{HL}^{42}$ viajan gracias al encanto de los elementos ambientales. Y como Guy Debord refirió en la revista de SI \#2(1958), Dérive es una práctica básica de los SI. Si Dérive es una técnica de paso rápido a través de ambientes variados, supuestamente, esa acción podría implicar un comportamiento lúdico y constructivo y la conciencia de los efectos psicogeográficas. Cuando los valores utilitaristas, cuestión de producción y las restricciones físicas (las fronteras, el clima, la distribución de la riqueza ${ }^{43}$, la hasta el tiempo) desaparecen, la nueva humanidad podría experimentar el máximo valor del instinto lúdico como el equipo de COBRA anhelaba. Ellos (HL), se marchan sin aviso, y encuentran un rendez-vous (puede ser alegría o no) posible en un lugar inesperado con otros viajeros. El destino de HL, está desorientado. Posiblemente, se desplaza como fluyendo a los lugares (no es importante que sea un lugar que conozca o no). HL observa su medio ambiente. Se puede encontrar con alguien, o no. El lugar desde dónde se marcha, puede ser un lugar que jamás volverá a ver. Porque, todos los sectores cambian, los elementos medio ambientales, el clima, la luz, la oscuridad (el tiempo pierde su significado ya), y todo. Las partes de los sectores se montan, y desmontan de varias maneras. Los HL, según la teoría de Détournement, modifican el mapa preexistente, cortando, plegando y desplegando, superponiendo, disponiéndolo nuevamente. Escapando desde el yugo de la producción, se convierte en un sujeto autónomo del medio ambiental creativo.

\footnotetext{
${ }^{41}$ Ibid. p. 6.

${ }^{42}$ Homo Ludens-(NdA)

${ }^{43}$ Se refiere la propiedad colectiva de la tierra y todos los productos producidos.-(NdA)
} 
En un dérive una o más personas durante un cierto periodo dejan sus relaciones, sus actividades laborales y de ocio, y todos sus otros motivos habituales para el movimiento y la acción, y se dejan arrastrar por las atracciones del terreno y los encuentros que hallan allí. El azar es un factor menos importante en esta actividad de lo que uno podría pensar: desde un punto de vista de dérive las ciudades tienen contornos psicogeográficos, con corrientes constantes, fijos en puntería y vórtices que desalientan fuertemente la entrada o salida de las zonas determinadas. ${ }^{44}$

Guy Debord.

Aquí, el espacio de LNB tiene todas las características de tener una forma laberíntica. Dicha forma, con las escaleras arbitrarias define el espacio social de LNB y a la vez es una expresión directa de la independencia social. ${ }^{45}$ Los laberintos y escaleras son aparatos principales que oscurecen el concepto de los diferentes niveles, otra vez como cuando éramos niños. Cuando éramos divertidos, cuando cogíamos el ascensor por primera vez en nuestra vida, o encontrábamos una litera en la casa de algún amigo de la infancia (v.-figs. 5-8, 12). Eso podría considerarse un desaprendizaje para recuperar nuestro instinto lúdico primitivo. Perdiendo el camino, permite conocer otra manera de vivir al HL cuyo mundo siempre estaría en el proceso perpetuo del détournement. En ese momento, se olvida la perspectiva utilitarísta que nos reemplazaba como una mera pieza en la producción total. El estado de la Nueva Babilonia siempre está en exploración sin miedo de perderse en su vida nómada. En este momento HL se escapó de la sociedad utilitarista, la aleatoriedad quita su deshonor, y su ineficacia ya no se llama maldad.

\section{El instinto creativo}

\footnotetext{
${ }^{44}$ Debord, G. Theory of the Dérive. Internationale Situationniste \#2. 1958. La citación está referenciada por la fuente secundaria: < AAVV. Situationist International Anthology. Knabb, Ken(ed., tr.) Berkeley. Bureau of Public Secrets. 2006. p. 62>

${ }^{45}$ Constant. La Nueva Babilonia. The Hague. The Haags Gemeetenmuseum. 1974. p. 11. Fuente online:

<http://isites.harvard.edu/fs/docs/icb.topic709752.files/WEEK\%207/CNieuwenhuis_New\%20Babylon.pdf >
} 
En la sociedad lúdica que Constant esperaba, los humanos expresan naturalmente sus creatividades. Sin embargo, este deseo primitivo y latente, está restringido en la sociedad actual cuyo carácter es relativamente estático y rígido respecto las anteriores. Así que dicha sociedad empieza a tener una cierta tendencia de pretender criar a los humanos útiles para ella, mutilando el instinto creativo. Si el objetivo estuviera determinado, la manera del viaje o del camino, efectivamente generaría una figura ortodoxa y sedentaria. Constant dice que con estas condiciones educativas, es difícil provocar todas las creatividades espontáneas. ${ }^{46}$

...El sofista pertenece, por naturaleza, al tipo de vagabundo. Además de vagabundo, es parásito par droit de naissance (por derecho de nacimiento). Pero al mismo tiempo los sofistas han creado el medio en que cobraron forma las ideas helénicas de educación y cultura. El saber y la ciencia griegos no han nacido en la escuela (en el sentido moderno). No se han ganado como productos accesorios de la preparación para

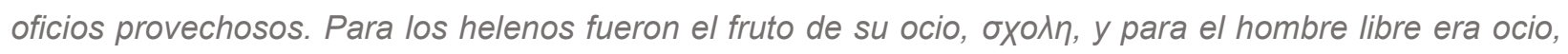
tiempo libre, todo aquel en que no estaba reclamado por el oficio público, por la guerra o por el culto. La palabra <<escuela >> conoce una prehistoria sorprendente. En este medio ocioso del hombre libre, el sofista encaja perfectamente como primer representante de una vida de meditación e investigación. ${ }^{47}$

Johan Huizinga. 1938. Homo Ludens.

${ }^{46}$ Ibid. p. 8.
${ }^{47}$ Huizinga, J. v.o.1938. Homo Ludens. Imaz, E.(tr) Madrid. Alianza Editorial, S. A. 2012. pp. 224-225 


\section{Sobre lo que Constant supo: una charla epistemológica y nirvánica}

Los humanos estaban en un estado de concentración en una lucha que nunca acaba, compitiendo el uno con el otro. ${ }^{48}$ Los propietarios versus los inquilinos, los patronatos versus los empleados, y de esa misma manera se prolonga a las tribus étnicas, los hombres, las mujeres, los niños, los discapacitados, los mayores, los homosexuales, los extranjeros, los miembros de la sociedad que siempre están categorizados por un grupo tanto de mayoría como de minoría. Si usted está en el grupo grande, es afortunado, sin embargo, en el caso reverso trágicamente no tiene tanta suerte. La genuina prosperidad no viene sacrificando el grupo de la minoría. La competencia es un concepto vacío, por lo menos en la medida en que sobreviviera tan solo el más apto, como decía Darwin. Ya somos conscientes de que Constant fue un anarquista. Por eso, su empeñosa pelea en varios aspectos para extinguir las fronteras y barreras que nos ponen en las crueles competencias, está bastante relacionado con la idea de Piotr Krofotkin, que es conocido como el príncipe de los anarquistas. Porque indudablemente, la perspectiva que entiende la evolución de las razas en el sentido del apoyo mutuo ${ }^{49}$ está más valorada que la evolución por la competencia en Constant, como ahora se ha podido comprobar. Constant no niega el resultado, o sea el gran legado de la competencia humana, pero es cierto que él fue escéptico sobre la manera de entender la virtud del desarrollo humano. El conflicto originado en la sociedad utilitarista tuvo relación directa con dicha barrera o frontera de las clases y eso fue lo que él percibió. El viaje (entendiendo el $A D^{50}$ ) de Constant para encontrar el origen de la agonía y la interrelación agresiva en la sociedad se describe así brevemente. Ahora, la competencia y el conflicto colectivo para la subsistencia se sustituyen por la creatividad lúdica llegando a una etapa que no tiene precedente, cuya capacidad de producción es suficiente para librar a las personas del yugo de la producción.

El reto que pretende basar el elemento lúdico en $\mathrm{LNB}^{51}$ está influido por Johan Huizinga. Se recuerda la

\footnotetext{
${ }^{48}$ Constant. La Nueva Babilonia. The Hague. The Haags Gemeetenmuseum. 1974. p. 9. Fuente online: <http://isites.harvard.edu/fs/docs/icb.topic709752.files/WEEK\%207/CNieuwenhuis_New\%20Babylon.pdf>

${ }^{49}$ Kropotkin, P. v.o.1902. El Apoyo Mutuo : Un Factor en la Evolución. Ha, S.W.(tr.,ed.) Seoul. Greenbee. Versión coreana. 2012.

${ }^{50}$ Acumulación del Dolor-(NdA)

${ }^{51}$ Los Nuevos Babilonios-(NdA)
} 
metodología de COBRA, intentaban encontrar una inspiración desde los juegos de los niños en la calle, sin estar institucionalizado por ninguna ideología. Cuando el hábito aún no se relaciona con ningún interés peculiar, supuestamente, la creatividad tiene que manifestarse en una forma espontánea.

...Encuentra a su hijo de cuatro años sentado en la primera silla de una fila de ellas, jugando <<al tren>>. Acaricia al nene, pero éste le dice: <<Papá, no debes besar a la locomotora, porque, si lo haces, piensan los coches que no es de verdad $>>$. En este $<<$ como si $>>$ del juego reside una conciencia de inferioridad, un sentimiento de broma opuesto a lo que va en serio, que parece ser algo primario. Ya llamamos la atención acerca del hecho de que la conciencia de estar jugando en modo alguno excluye que el mero juego se practique con la mayor seriedad y hasta con una entrega que desemboca en el entusiasmo y que, momentáneamente, cancela por completo la designación de <<pura broma〉>. Cualquier juego puede absorber por completo, en cualquier momento, al jugador. La oposición $<<e n$ broma $>>$ y $<<e n$ serio >> oscila constantemente. El valor inferior del juego encuentra su límite en el valor superior de lo serio. El juego se cambia en cosa seria, y lo serio, en juego. 52

Johan Huizinga. 1938. Homo Ludens.

Los niños y los animales no están jugando porque es obligatorio, sino porque allí está la libertad. Y se encuentran a gusto en ello. Huizinga dice en su libro Homo Ludens, que justo en esto consiste su libertad. Si se observa otro aspecto del juego, después de que esté originado su consentimiento, tal como, $<<$ como si... >>, se tiene una representación, una desviación de la realidad, donde aún se siente como si se tratara de un orden superior. Además, si una vez se ha jugado un juego, permanece en el recuerdo, también posiblemente se puede transmitir al campo espiritual o a la tradición. Y se puede repetir el juego en cualquier momento, y ya es un elemento imprescindible del culto. Pero no es siempre igual que antes. Solamente, forma una estructura sólida como una cultura. ${ }^{53}$

\footnotetext{
${ }^{52}$ Huizinga, J. v.o.1938. Homo ludens. Imaz, E.(tr) Madrid. Alianza Editorial, S. A. 2012. p. 25

53 Ibid. pp. 27-28.
} 
Tal vez Constant dio una mayor atención, como lo hizo Huizinga, al siglo XVII cuando el gran teatro secular prosperaba, los dramaturgos solían comparar al mundo con un escenario donde los humanos desempeñan sus papeles. Este elemento lúdico de la vida humana le habría parecido una buena roca dónde poder construir su utopía teatral. Constant habría creído que este tipo de producción de la cultura, o sea la participación, convocaría a todos los sujetos (que deseen expresar o expresan su deseo), desde el trabajo, el manicomio, el ágora, la escuela, el museo, el mercado, el parlamento, la calle, la cueva, debajo del puente. Ontológicamente, los sujetos llevan sus deseos; estos deseos se reproducen. Los deseos son combustibles directos que hacen funcionar los sectores, y flotan por ellos, que tienen escaleras cambiantes como laberintos. En este momento se observa que dicha producción de la cultura (en otro término participación) está involucrando hasta los temas contemporáneos, como consolidar la ciudadanía y la democracia urbana. También se trata de una reproducción de una voluntad cuyo objetivo es abordar este tipo de retos directamente. Constant ha creado un diagrama de los sectores que pueden funcionar por los deseos. Se nombra un párrafo de Anthony Vidler, que explicó el poder de este diagrama de la reproducción, citando a Michel Foucault y Gilles Deleuze.

Finalmente, cada diagrama es inter-social y está en un estado de transformación. Nunca funciona para representar un mundo preexistente; produce un nuevo tipo de realidad, un nuevo modelo de la verdad. No se sujeta por la historia, ni cuelga sobre la historia. Se crea la historia mediante el deshacer de las realidades y significaciones precedentes, creando tantos puntos de emergencia o de creatividad, de coyunturas inesperadas, de los continuos improbables. ${ }^{54}$

Constant percibió que la ciudad moderna y funcional es la causa que acumula la agonía urbana. En dicha ciudad, todo está dispuesto según las necesidades específicas de producción y reproducción: vivir, el trabajo, la recreación y la circulación del tráfico. Todo es acerca de la eficiencia. ${ }^{55}$ En esa perspectiva, deseó, de cualquier modo, sustituir la ciudad utilitarista y obsoleta por otro paradigma de una ciudad

\footnotetext{
${ }^{54}$ AAVV. The Activist Drawing: Retracing Situationist Architectures from Constant's New Babylon to Beyond. Zegher, C \& Wigley, M. (ed.) New York, Cambridge, Massachusetts. The Drawing Center \&The MIT Press. 2001. p. 86

${ }^{55}$ Ibid. p. 96.
} 
creativa y lúdica. Creyó que formar un medio ambiente que permitiese expresar la creatividad con los elementos lúdicos, sería el verdadero remedio para extinguir la acumulación de la agonía urbana, y con el resultado experimental ya se sabe que, si fuera distorsionada la manera de expresar los deseos humanos, la energía se transformaría y se proyectaría de una manera agresiva y violenta. La forma de la ciudad tenía una inmovilidad física. Ya los humanos dejaron de ser nómadas. Este trabajo no tiene el objetivo de encontrar un enlace lógico entre la forma de una ciudad eficaz y una vida sedentaria. Sin embargo, se puede decir que dicha ciudad eficaz y la vida sedentaria son elementos primordiales para quienes son privilegiados.

Ya está claro como estaba revelado el $\mathbf{A D} \mathbf{D}^{56}$ para Constant. Ahora en su esquema para negar (el $\mathbf{E D}{ }^{57}$ ) la ortodoxia urbana y utilitarista gana la justicia. El nivel de desarrollo de la tecnología industrial y de la agricultura estaría preparado para criar una nueva generación, puesto que en ese planeta hace mucho tiempo que la cantidad total de producción alimentaria sería suficiente para todos los humanos. El proyecto llamado La Nueva Babilonia es una revelación de que los humanos escapados desde una vida sedentaria, disfrutan una vida nómada. La nueva generación $(\mathrm{HL})$ apasionadamente involucrada en su propia vida creativa, espontáneamente participa en la sociedad lúdica. Definitivamente, LNB es una antítesis atractiva de la sociedad utilitarista. Por lo cual, tener hostilidad contra la sociedad utilitarista es una virtud en LNB. En el caso de La Ciudad-Jardín, Howard se concentró en la manera de tratar la agonía. Sin embargo, en el caso de Constant, intentó tocar el origen de la agonía directamente. Aún es pronto para juzgar cual era más efectivo para la bondad humana, porque ese tipo de problemas siempre estaría implicado en los temas circunstanciales y complejos de aquel tiempo. E incluso el juicio ético de cuál sería justo o no, o mejor y peor, sería un discurso de otra dimensión. Sin embargo, por lo menos, la metodología de Constant fue más justa en la perspectiva nirvánica percibiendo el AD con su peculiar apariencia. Si una vez, está percibido bien el AD, el problema del ED se queda solamente en un problema técnico.

\footnotetext{
${ }^{56}$ Acumulación del Dolor-(NdA)

${ }^{57}$ Extinción del Dolor-(NdA)
} 


\section{Sobre lo que Constant hubo de hacer: una charla ética y nirvánica}

Ahora, brevemente, se recuerdan los contenidos epistemológicos. Cuando, en la perspectiva nirvánica, se refiere al $\mathbf{A D}$ o ED, hay que darse cuenta de que ese tipo de charlas derivan del concepto llamado CSD $^{58}$ cuya esencia consiste en poder percibir el mundo como los dharmas inter-relacionados. Eso significaría que se puede esperar a poder reconocer justamente los dharmas que forman el camino de ED. También supuestamente, es posible diseñar el camino de ED, interviniendo en el dharma problemático directamente. Los caminos, en otra palabra las maneras de combinar los dharmas, reproducen los fenómenos, es decir, los fenómenos se reproducen por los dharmas combinados. Por lo cual, una perspectiva surge, que todo es el vacío, porque los fenómenos existen siempre interdependientemente. La existencia de ningún dharma (un fenómeno también es un dharma) es absoluta. En esa humildad, esa perspectiva reproduce la ética nirvánica.

Cuando el humano ya no sea cautivo del sistema productivo, como Constant pronosticó, la gente podría observar su vida desde la perspectiva del juego. Y Constant dice que la liberación del potencial lúdico del hombre está directamente relacionada con su liberación como ser social. ${ }^{59}$ En la última fase a donde Constant quiere llegar, los HL viajan libremente, disfrutan sus acciones creativas, generan y manipulan las nuevas situaciones activamente, no hay conflicto, se realiza una sociedad sin clase. La libertad depende de la estructura social, sin duda, y también del aumento de la productividad, y dicha productividad depende de la tecnología. La sociedad utilitarista ha sido un AD, y la sociedad lúdica ha sido una alternativa, o sea el ED. Sin embargo, aún quedan unas dudas de si esa sociedad sería verdaderamente ED o no.

Por ejemplo, para empezar, esa sociedad es aún sospechosa de que pueda ser otra nueva versión gastada de la tecnocracia. Sí que hay referencia en la que se conoce la actitud de Constant sobre este tema, sin embargo, su convicción, su fe, es sedentaria.

\footnotetext{
${ }^{58}$ Co-surgimiento dependiente-(NdA)

${ }^{59}$ Constant, La Nueva Babilonia. The Hague. The Haags Gemeetenmuseum. 1974. p. 2. Fuente online: <http://isites.harvard.edu/fs/docs/icb.topic709752.files/WEEK\%207/CNieuwenhuis_New\%20Babylon.pdf>
} 
Pregunta: Pero ¿cómo puede uno saber estas condiciones ahora? Sus planes y modelos dan la impresión de un mundo tecnocrático, cuya escala solo despierta el miedo. ¿Pero no necesitará el hombre un entorno menos artificial, más ligado a la naturaleza, en el futuro?

Respuesta: el miedo a la tecnología es reaccionario. La liberación de las masas sólo se hace posible por el desarrollo tecnológico. Sin la automatización de la producción, el potencial creativo de las masas sigue siendo una ilusión. La tecnología es una condición necesaria para la Nueva Babilonia. Además, creo que, en el mundo por venir, la naturaleza ya no será capaz de ofrecer un entorno satisfactorio para la realización cultural. 60

Constant. Autodialogo en Nueva Babilonia. Opus International \#27, September, 1971

Afortunadamente, somos una generación posterior a Constant, y sabemos que su previsión estaba equivocada. Más bien, el resultado es como se desarrolla la tecnología, la gente quiere buscar más su satisfacción en la naturaleza, no en el medioambiente artificial. Cuando se contempla desde la circunstancia contemporánea es más obvio. Los Nuevos Babilonios aún son pasivos, y antes de que sean activos, la sociedad tiene que gobernarse por los situacionistas. Entonces, no se ve una diferencia tan relevante con la tecnocracia que Le Corbusier soñaba.

Luego, la libertad de la que los situacionistas están hablando, al final se basa en una creación, y dicha creación requiere las virtudes y los mantras de SI, es decir, la disciplina. Es una auto-contradicción en sí misma, porque desde el movimiento de COBRA hasta el de SI, Constant seguía buscando el desaprendizaje. Sin embargo, ese desaprendizaje es, en algún sentido, entrenamiento. Además, eso fue

\footnotetext{
${ }^{60}$ Constant. Autodialogue on New Babylon. Opus International \#27. 1971. Anon.(tr.) Fuente online: <http://www.notbored.org/autodialogue.html>
} 
un movimiento autónomo para los SI pero es heterónomo a los demás. Salvando estas dudas, aún queda otra más. El movimiento de SI, estrictamente dicho, LNB, es un éxodo total desde la sociedad utilitarista, de la cual aún no se sabe del todo bien su significado. La ética de LNB es una negación del utilitarismo. Sí que hay cuestiones a tratar, a veces en el orden categórico. Entonces, las cuestiones a tratar en el orden utilitarista se ignoran. Igualmente, sabemos que hay situaciones no deseables, pero que sin embargo tenemos que manejar, como, por ejemplo, el tema de la guerra y la defensa propia, la distribución de la riqueza, etc., etc. Así, existen temas complicados que se definen solamente en dos categorías. Se requiere una categoría superior que pueda reconocer ambos campos adecuadamente. En este sentido, en LNB vemos un límite a la hora de incorporar estas ideas exigentes. Es cierto que, aunque se trata de una libertad más intensa que nunca, es una libertad mutilada aún, al no poder abarcar las dos concepciones. Antes de enfrentar esa libertad imperfecta a los sectores bajo el control de los situacionistas, así LNB necesariamente tiene que soportar su límite ético. Por eso, en La Nueva Babilonia no existe libertad autónoma, sino libertad gobernada que es un estado de auto-contradicción.

\section{Actuar libremente no es elegir el mejor medio para lograr un fin, sino que es elegir el propio fin en sí mismo.}

61

Sin embargo, si se pudiera echar un vistazo al lado positivo de LNB, se encontraría una cosa interesante en los sectores, porque resulta que sus programas están vacíos. En estos sectores los significados se obtienen en cada instante, por medio de la vida libre de los situacionistas, quienes crean diversos programas efímeros. O sea, en una interpretación nirvánica, los seres logran sus peculiares significados no por ser protagonistas, sino por su devenir condicional en el espacio al que se pertenece en cada momento. Un sector vacío no está vacío, más bien, está lleno de posibilidades de adaptarse a la nueva circunstancia venidera. De todas formas, eso está directamente relacionado con el concepto $\mathbf{N Y}^{62}$, porque una búsqueda de lo significativo en las relaciones no fijadas ni orgánicas (dejando la virtud utilitarista). Es

\footnotetext{
${ }^{61}$ Sandel, M. Justice: What's the Right Thing to Do? Nueva York. Farrar, Straus and Giroux. 2009. p.109. Fuente online:<<http://www.justiceharvard.org >>, <<https://books.google.es/books?id=SKEeHVwT5UMC\&printsec=frontcover\&hl=ko\#v=onepage\&q\&f=false>> ${ }^{62}$ No-yo-(NdA)
} 
un arte en el que todos los seres-dharmas practican ser otros seres-dharmas con compasión. ${ }^{63}$ Es una ética del devenir, y ética del CSD a la vez. La ética del CSD está vacía porque los dharmas no son perpetuos sino efímeros según las circunstancias y las relaciones con otros dharmas. Únicamente, cuando se justifica un cierto camino de los dharmas surgidos, un dharma existe, así se diagnostica. Es un enfrentamiento de la humilde ética del nirvana, en otra palabra la ética del devenir. El diseño representa el concepto de vacío formando una enorme mega-estructura. En LNB, los sujetos, los programas, nada es eterno. Sin embargo, existen condicionalmente e interdependientes un dharma junto a otro. En este sentido, podría considerarse que es una ética de las más cercanas a la ética nirvánica entre las cuatro éticas que se han revisado.

La arquitectura difiere, pues, en cada circunstancia y en cada lugar. Resulta difícil de hacer, al tiempo que también es infinitamente abierta y libre. Una actitud que tienda hacia la ampliación total de aquellas libertades tempranas del pensamiento arquitectónico moderno podrá conducir a la arquitectura - más allá de las neo y las posmodernidades- hacia un reino donde las ideas no tengan límites, donde la medida final de la arquitectura resida en sus esencias perceptivas, y que cambie la experiencia de nuestras vidas.

Steven Holl. 1992-1994. La circunstancia del lugar y la idea. ${ }^{64}$

\footnotetext{
${ }^{63}$ v.-Deleuze, G., Félix, G. v.o.1980. Mil Mesetas: Capitalismo y Esquizofrenia 2. Kim, J.I.(tr) Seoul. Saemulgyul Publishing House. Edición coreana. 2003. pp. 452-453.

${ }^{64}$ Holl, S. v.o.1992-1994. Cuestiones de Percepción: Fenomenología de la Arquitectura. Puente, M.(tr.,ed.) Barcelona. Editorial Gustavo Gili, S. L. Versión española. 2011. p. 41.
} 


\section{Sobre lo que Constant deseó: una charla estética y nirvánica}

La realización del proyecto empezará cuando la economía sea capaz de satisfacer las necesidades. Una automatización de todas las áreas no va a permitir que haga falta dedicarse a los trabajos no creativos. ¿Entonces, de qué tipo de forma tendrían que ser las construcciones y qué tipo de conversación estética ha de manifestarse? La topografía de LNB65 fue incrustada ya en el mantra de SI, llamado Détournement. Si se observa el proceso del détournement, se podría entender la razón de la topografía de LNB.

Como antes de todas las revoluciones siempre existen los presagios, el proyecto de LNB no se realizó en un día. Primero, los situacionistas van a instalar los sectores en las ciudades, pero en unas ubicaciones estratégicas sustituyendo las construcciones preexistentes. Así en el principio, los sectores existen de forma desplegada. En esta fase, los sectores todavía sólo tienen un papel como lugar de encuentro, parecido a un centro sociocultural. Y cada vez más se va disminuyendo la duración del trabajo de los ciudadanos, naturalmente, la concepción del hábitat se desintegra gradualmente. Ahora bien, los sectores y las construcciones desarrollan vínculos. Los sectores se referencian y crean diversos lugares, expandiéndose, los sectores se reagrupan, se quedan en una megaestructura. Citando la frase de Constant, dijo que se unen y forman una totalidad. ${ }^{66}$ Las aglomeraciones de los sectores formarán una red enorme física (porque el espacio en sí mismo es una red.) Cubriendo el suelo, en un segundo nivel al aire libre, se encuentra ese colosal paisaje artificial, porque es para descongestionar el tráfico en el suelo, así que los sectores se elevan gracias a los piloti. La construcción de LNB crea un paisaje de terraza en la azotea que no parece terminar en su expansión.

El sector es el elemento más pequeño en la base de la red de LNB. Las dimensiones de los sectores son mayores que las dimensiones de las construcciones que forman las aglomeraciones en la ciudad. Algunos de los sectores serían para la vivienda familiar y otros sectores serían para los servicios públicos. La base

\footnotetext{
${ }^{65}$ Los Nuevos Babilonios-(NdA)

${ }^{66}$ Constant. v.o.1974. La Nueva Babilonia. Lambert, J.C.(ed) Barcelona. Editorial Gustavo Gili. Versión española. 2009. p. 22
} 
de la escala es la morada familiar independiente. Y dependiendo de la trama de las relaciones sociales, en una ciudad general, se establecen unos vínculos en la escuela, en el trabajo, en la política, en el ocio, etc. Dicha relaciones sociales, se añaden a los vínculos familiares. ${ }^{67}$ La imagen general de LNB es como un esqueleto horizontal. La escala de su cubrimiento es más o menos 10-20 hectáreas. Las construcciones elevadas 15-20 metros de la tierra, tienen una altura total de 30-60 metros. La forma de la construcción es variable totalmente, porque los elementos del ensamblaje son móviles, y pueden montarse y desmontarse de varios modos fácilmente, incluso fue considerada la reutilización de los elementos. Un sector, con solo su apariencia, no puede saberse cuál es su función. Los espacios tienen caracteres neutrales. Eso es porque, dichos espacios tienen que estar preparados para utilizarse espontáneamente en arbitrarios programas instantáneos cuando los HL vayan a practicar el dérive. ${ }^{68}$

67 Ibid. p. 25.

68 Ibid. p. 28. 


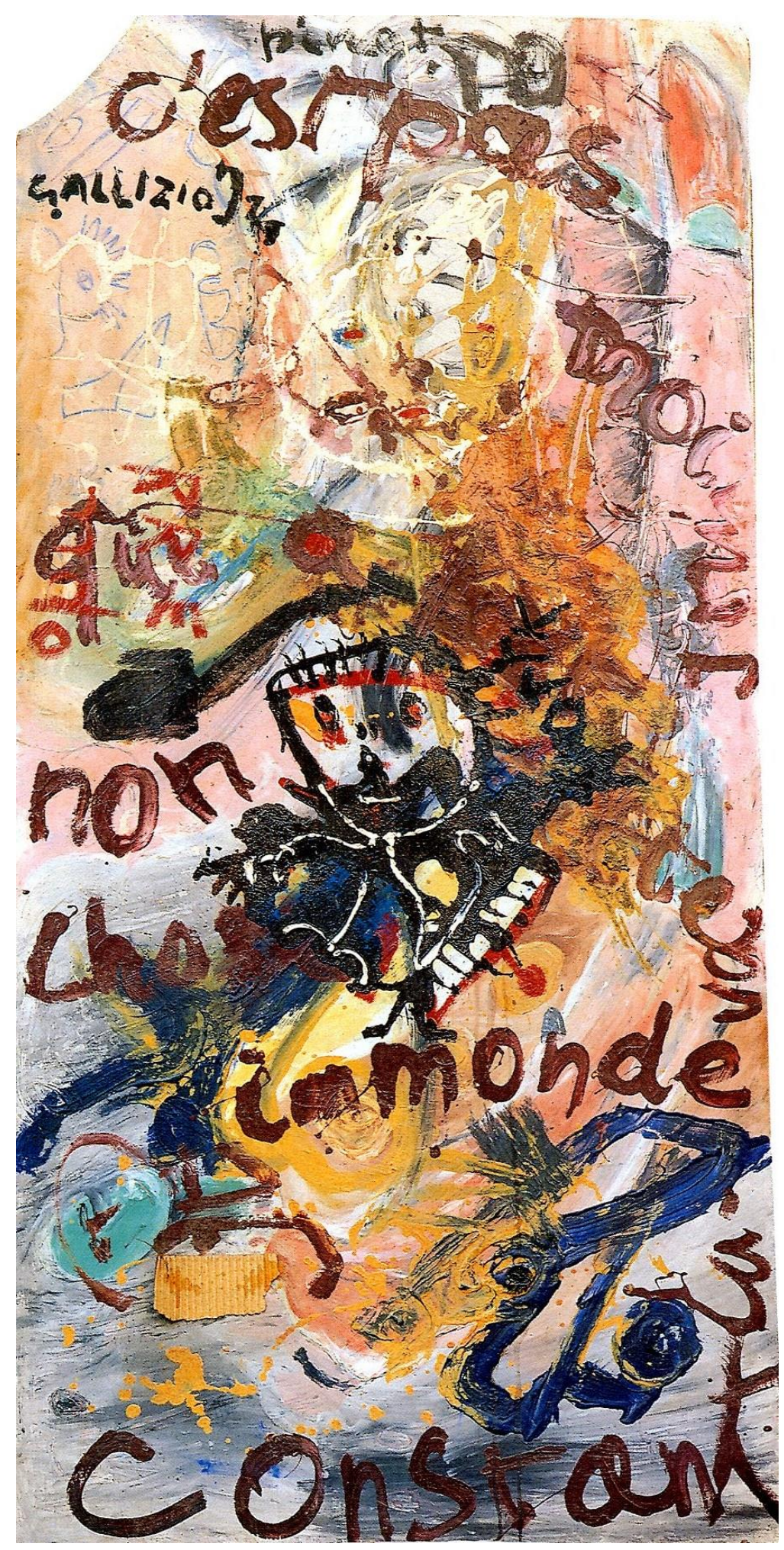

Fig. 5-1. Oppera Collecttiva, Pinot Gallizio, Asger Jorn, Constant. 


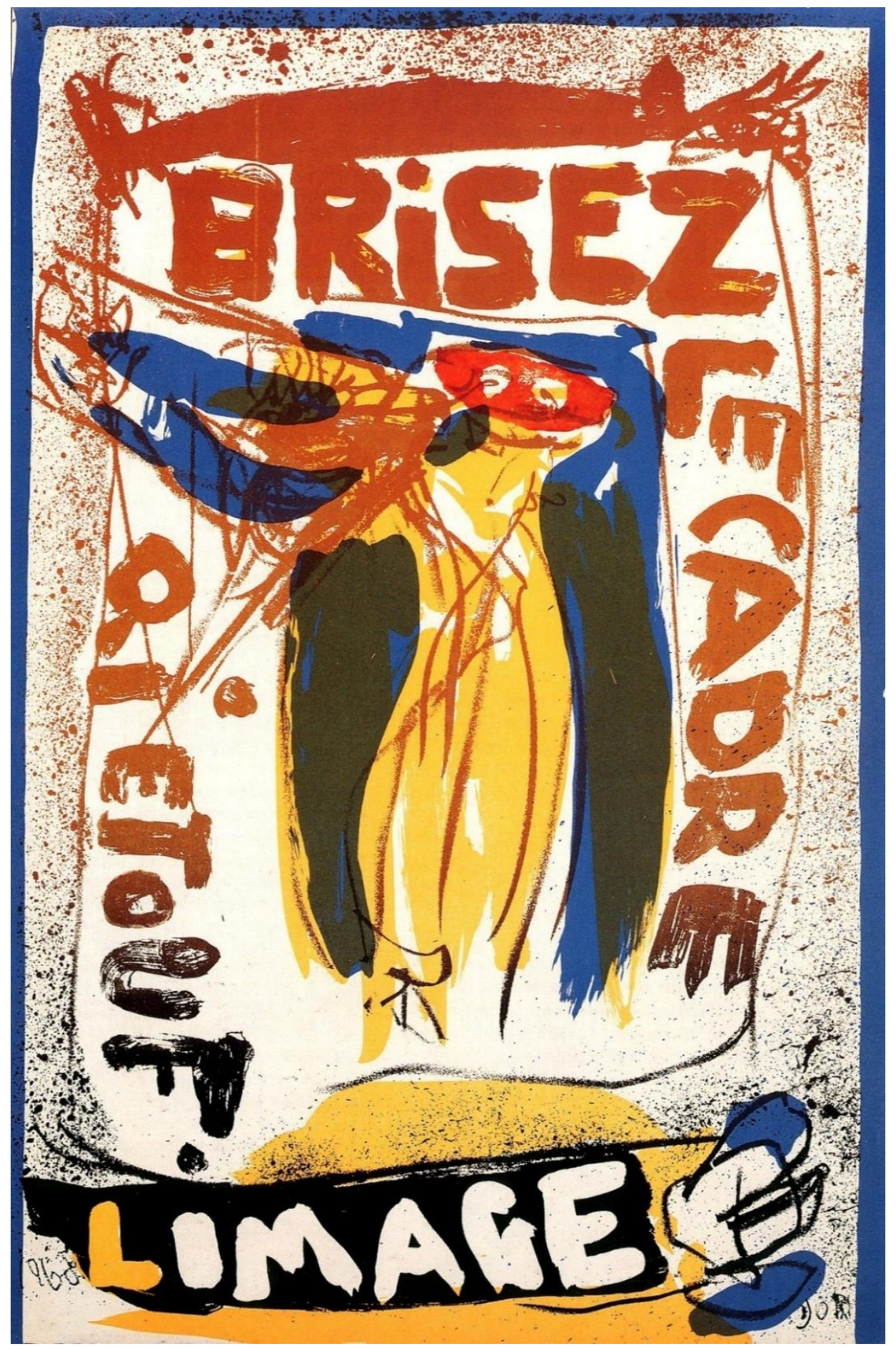

Fig. 5-2. Pas de puissance - Imagination, Asger Jorn. 


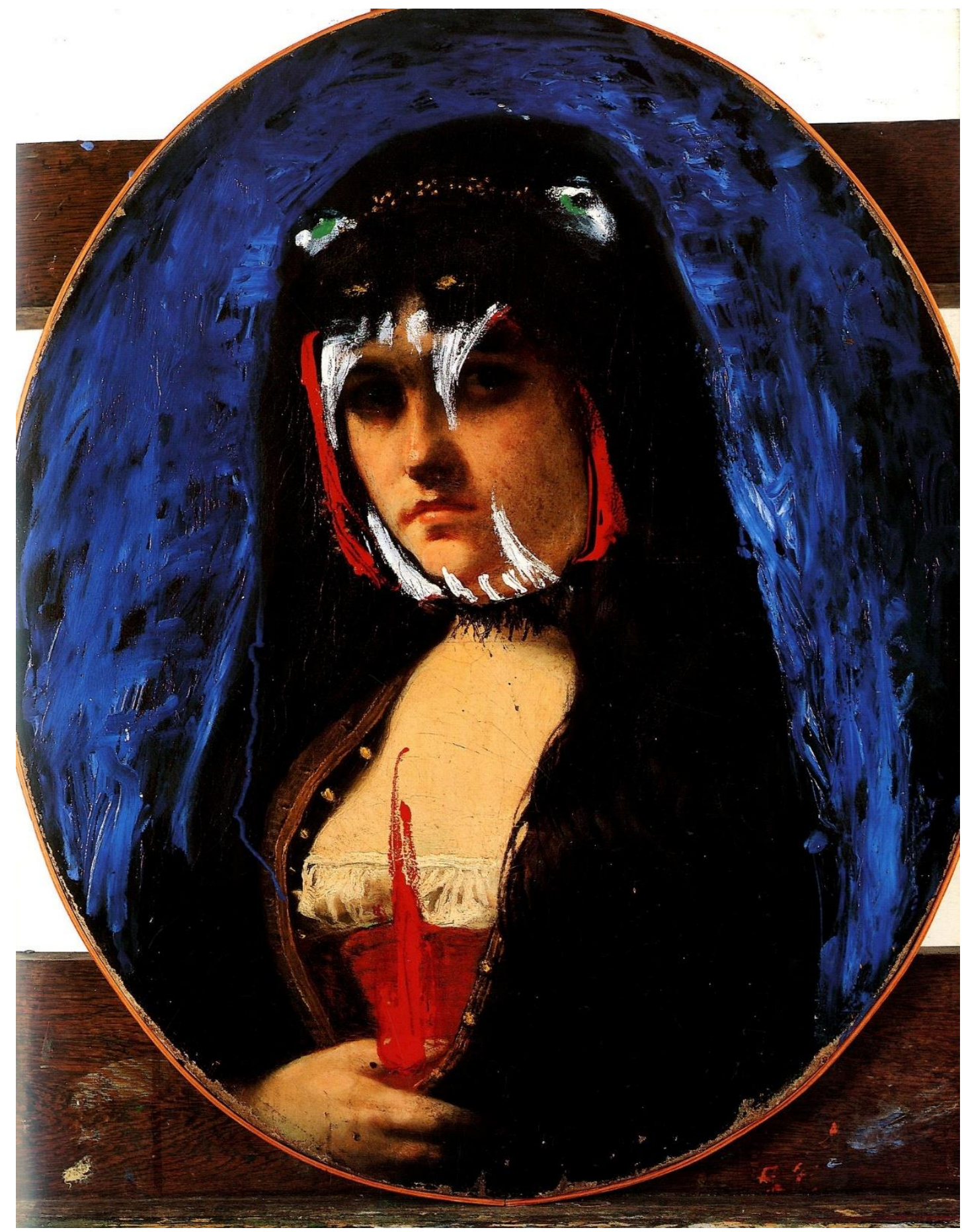

Fig. 5-3. Poussin, Asger Jorn. Grand baiser au Cardinal d'Amérique, Asger Jorn. 


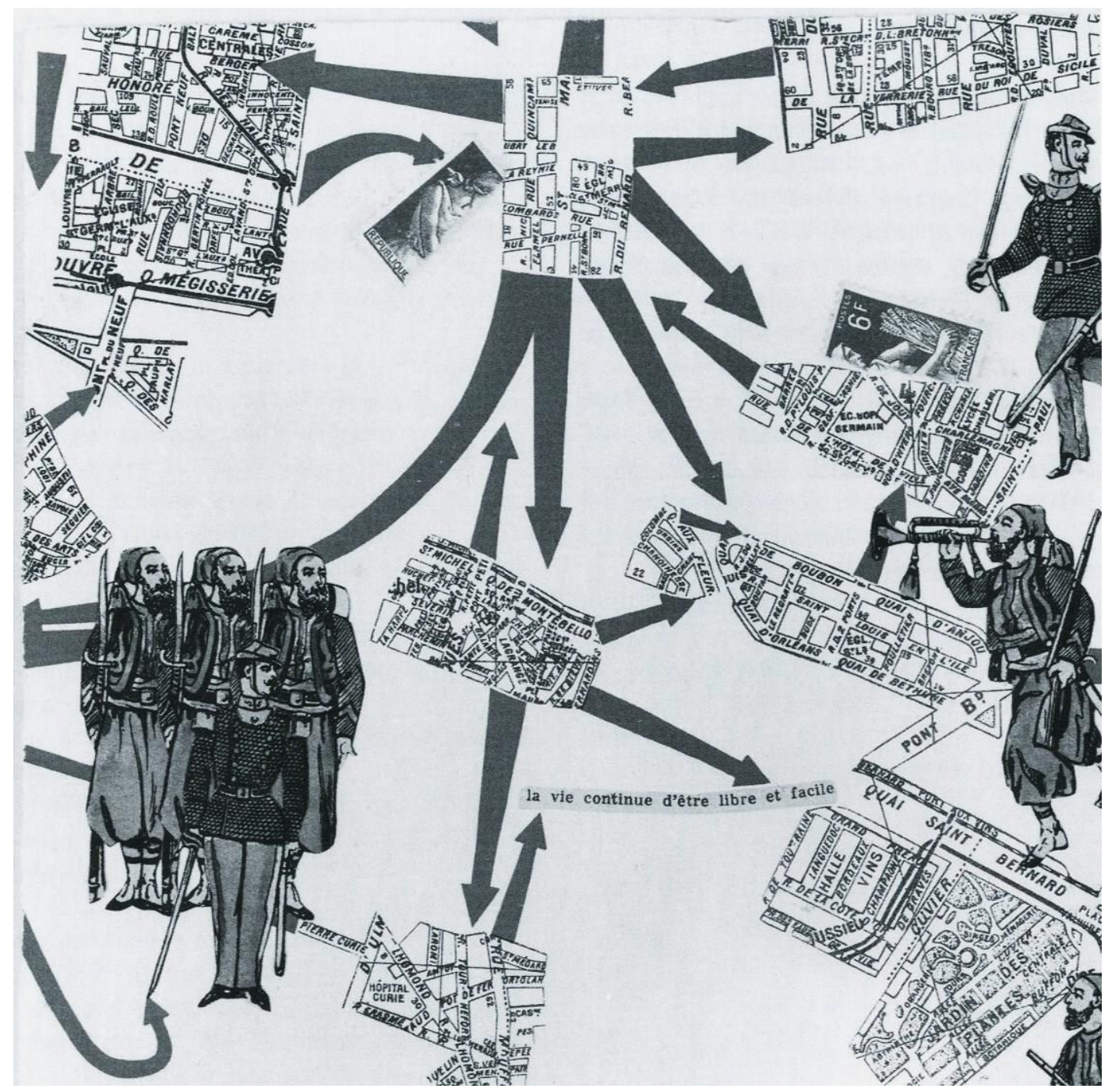

Fig. 5-4. Life continues to be free and easy, Guy Debord. 


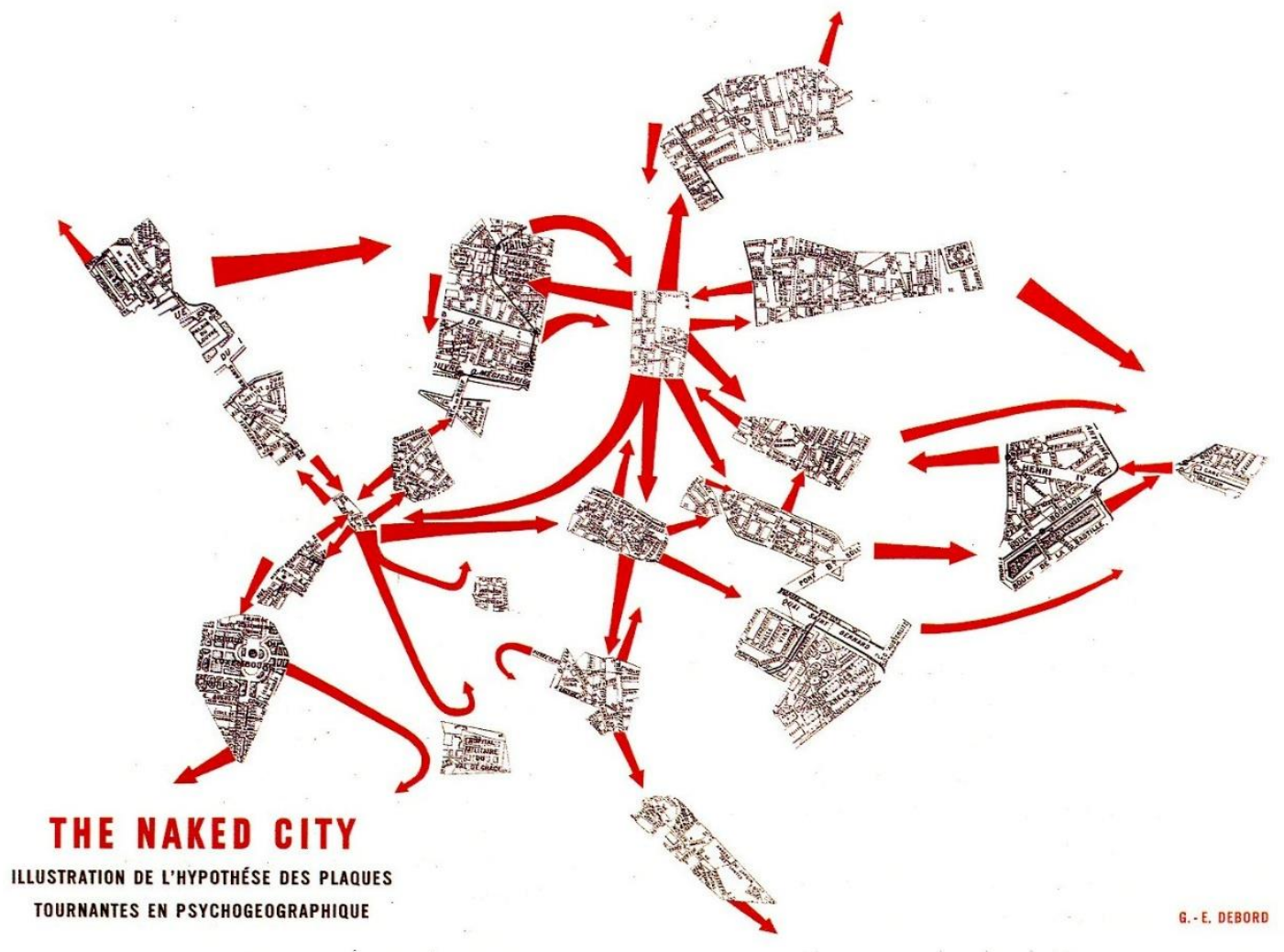

Fig. 5-5. La Ciudad Desnuda, Guy Debord. 


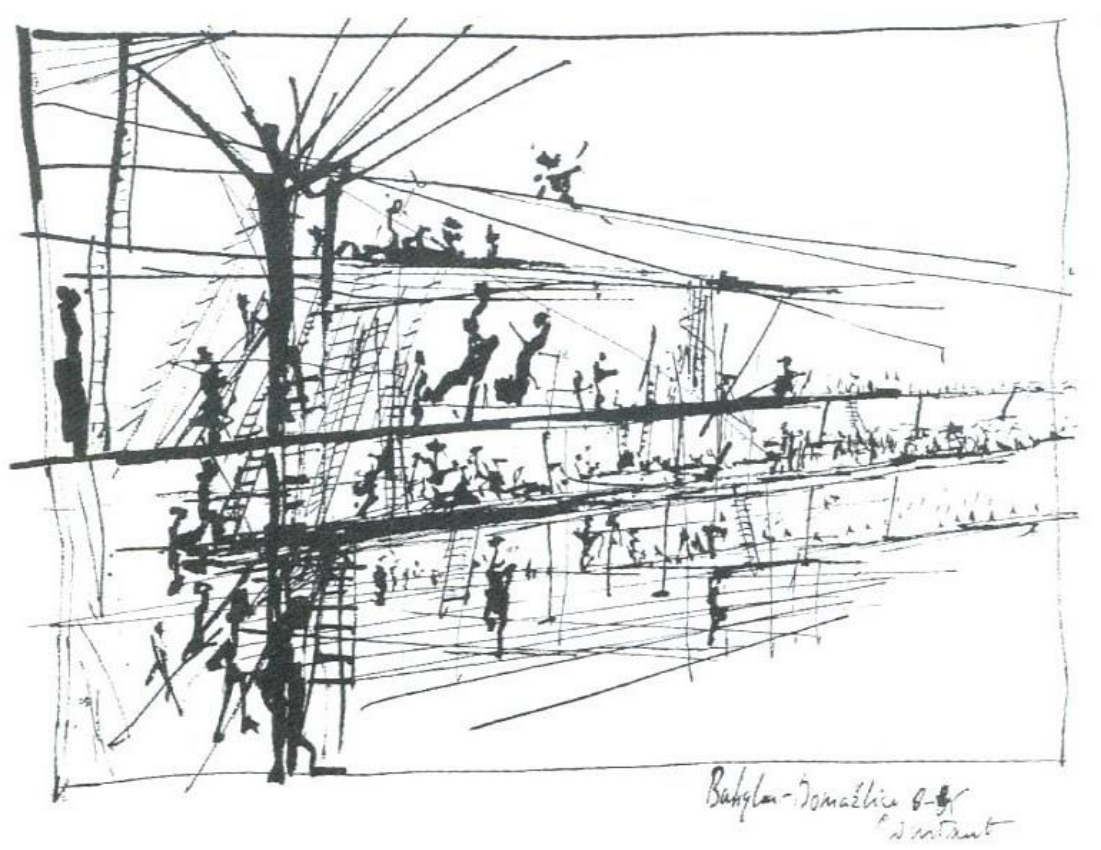

Fig. 5-6. Dibujo de la Nueva Babilonia en el viaje de Constant.

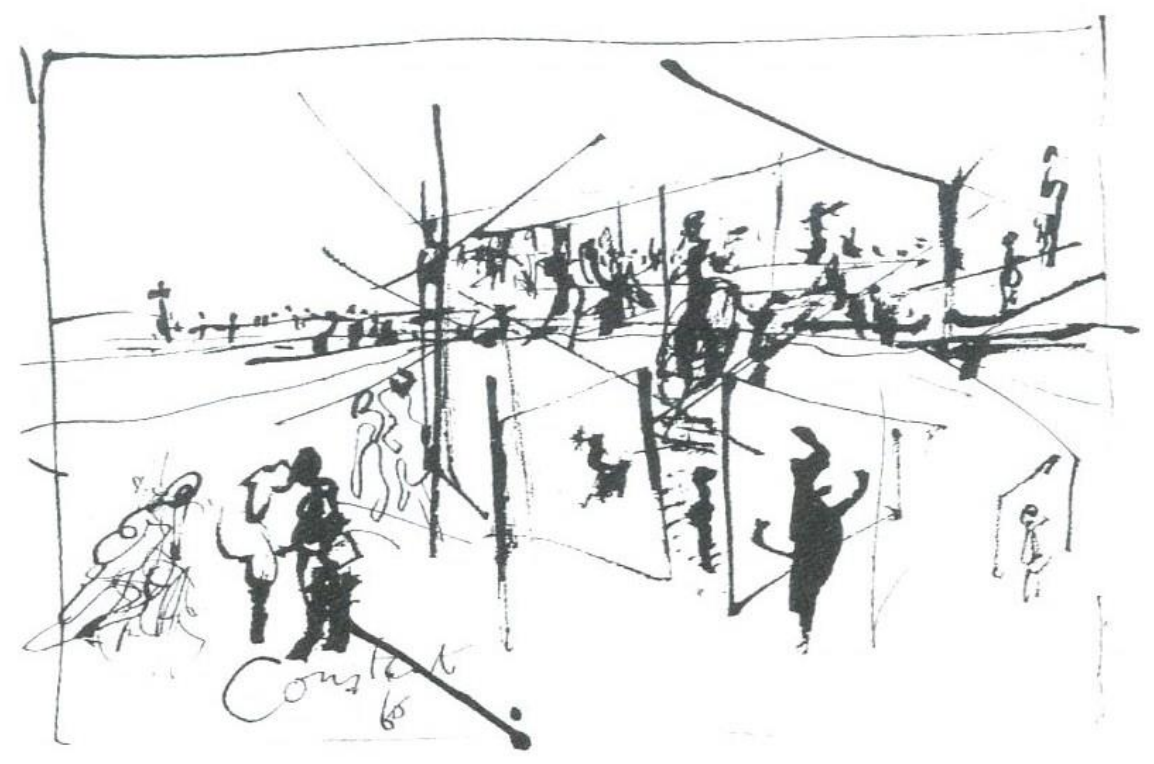

Fig. 5-7. Figuras del espacio en Nueva Babilonia de Constant. 


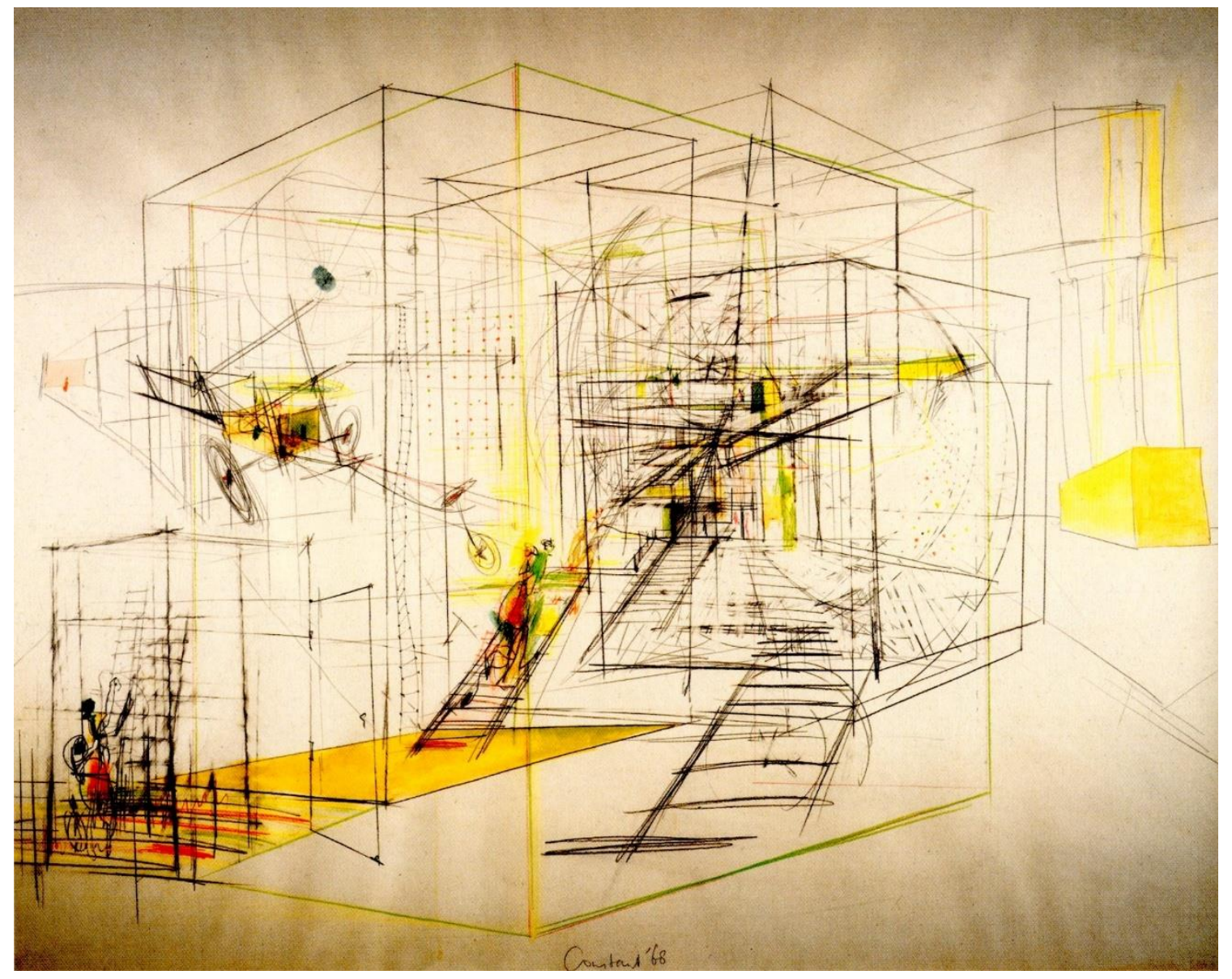

Fig. 5-8. Dibujo para un laberinto movible de Constant. 


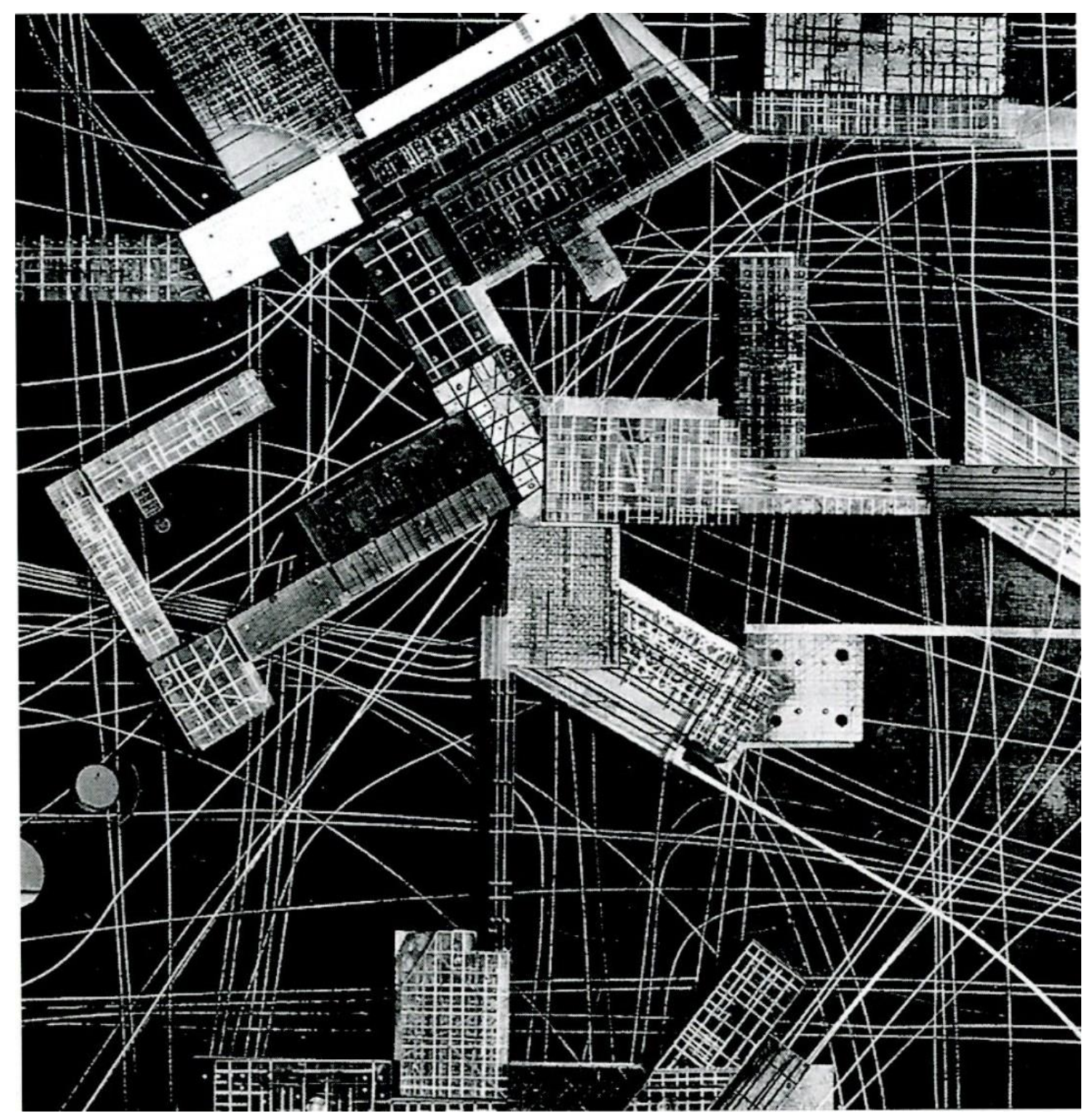

Fig. 5- 9. Grupo de Sectores de Constant. 


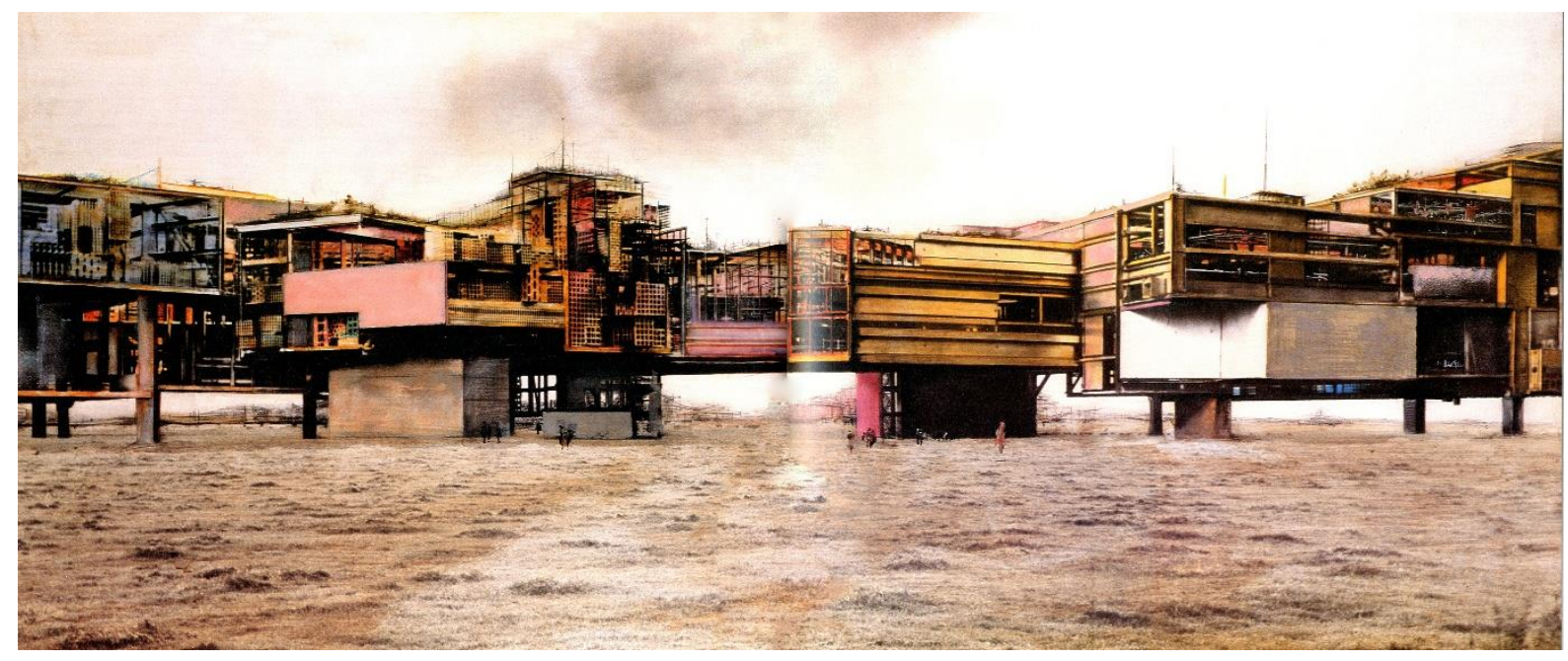

Fig. 5-10. Imagen de sectores de Nueva Babilonia de Constant. 


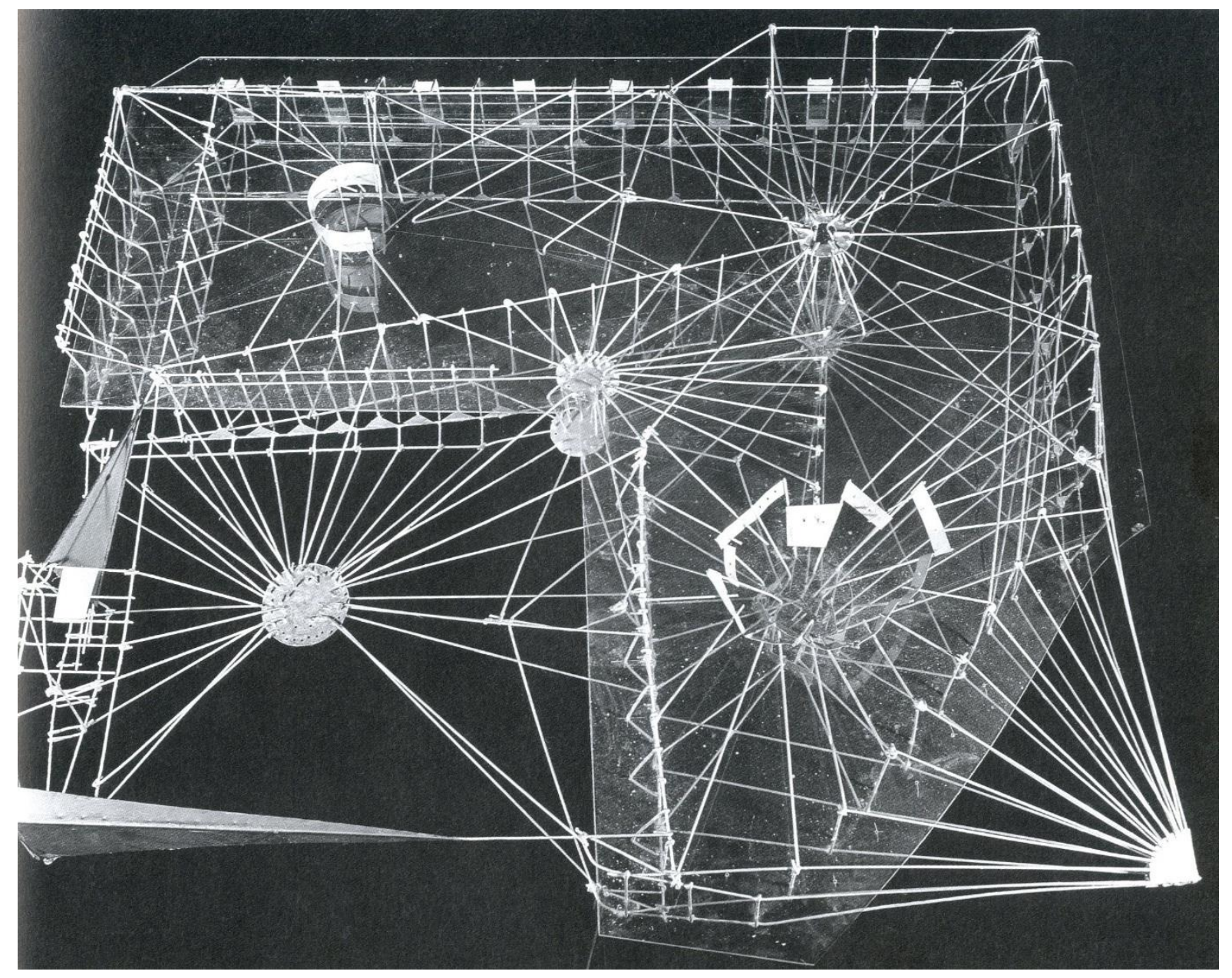

Fig. 5-11. La maqueta del sector de la Nueva Babilonia de Constant. 


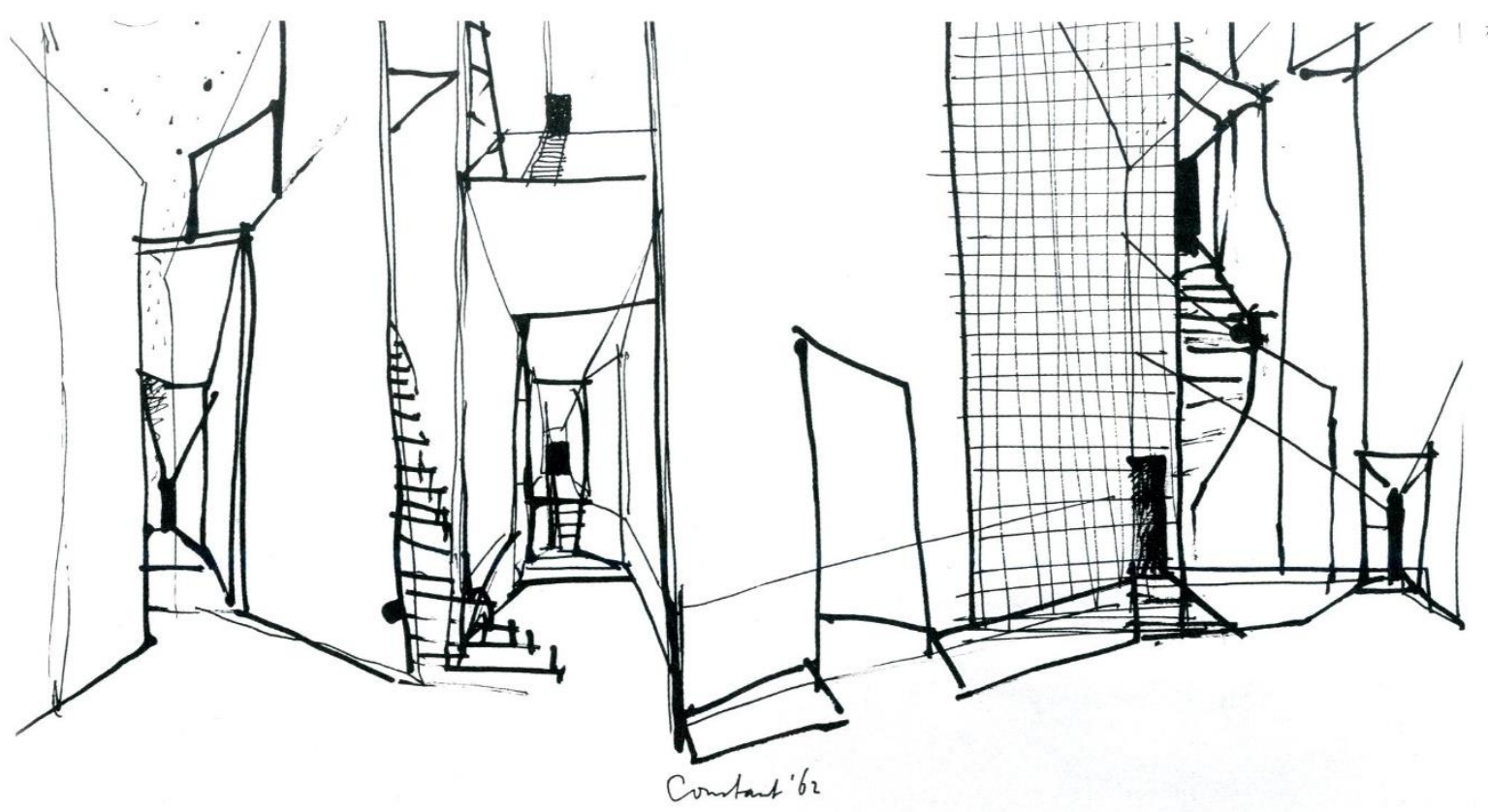

Fig. 5-12. Laberintorium de Constant. 


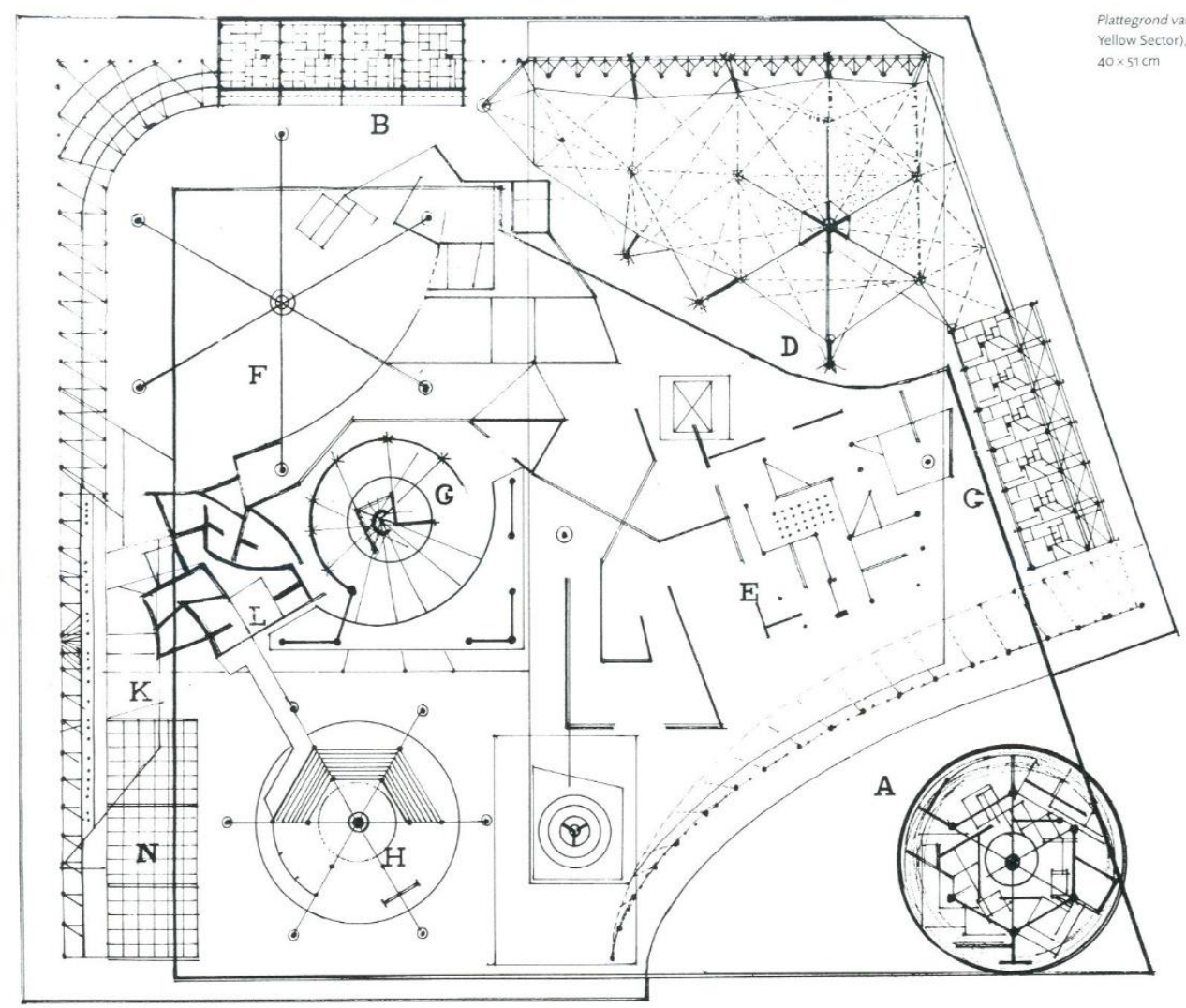

Fig. 5-13. Mapa del sector amarrillo de Constant. 

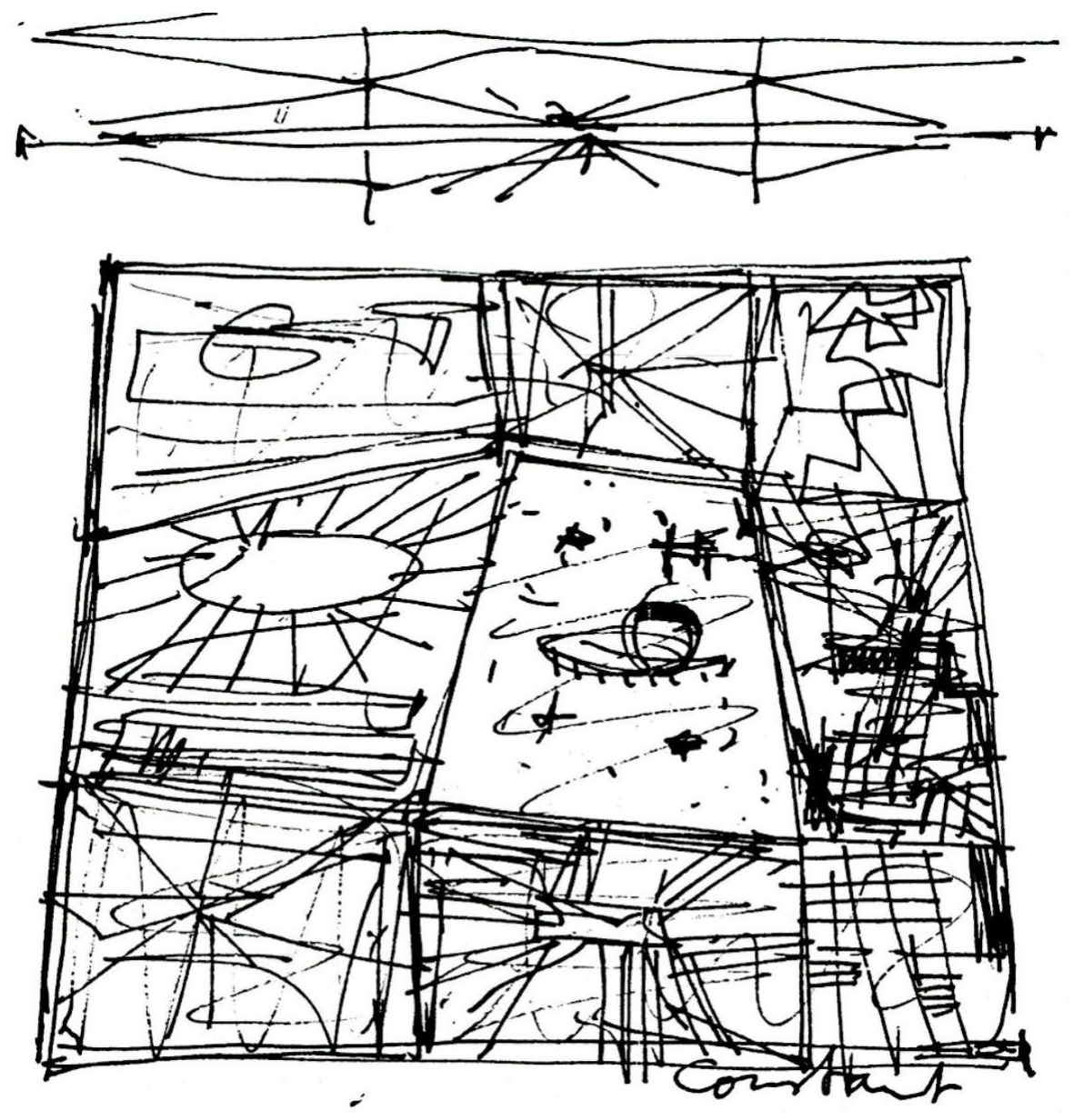

Fig. 5-14. Plan y sección de sectores agrupados de Constant. 


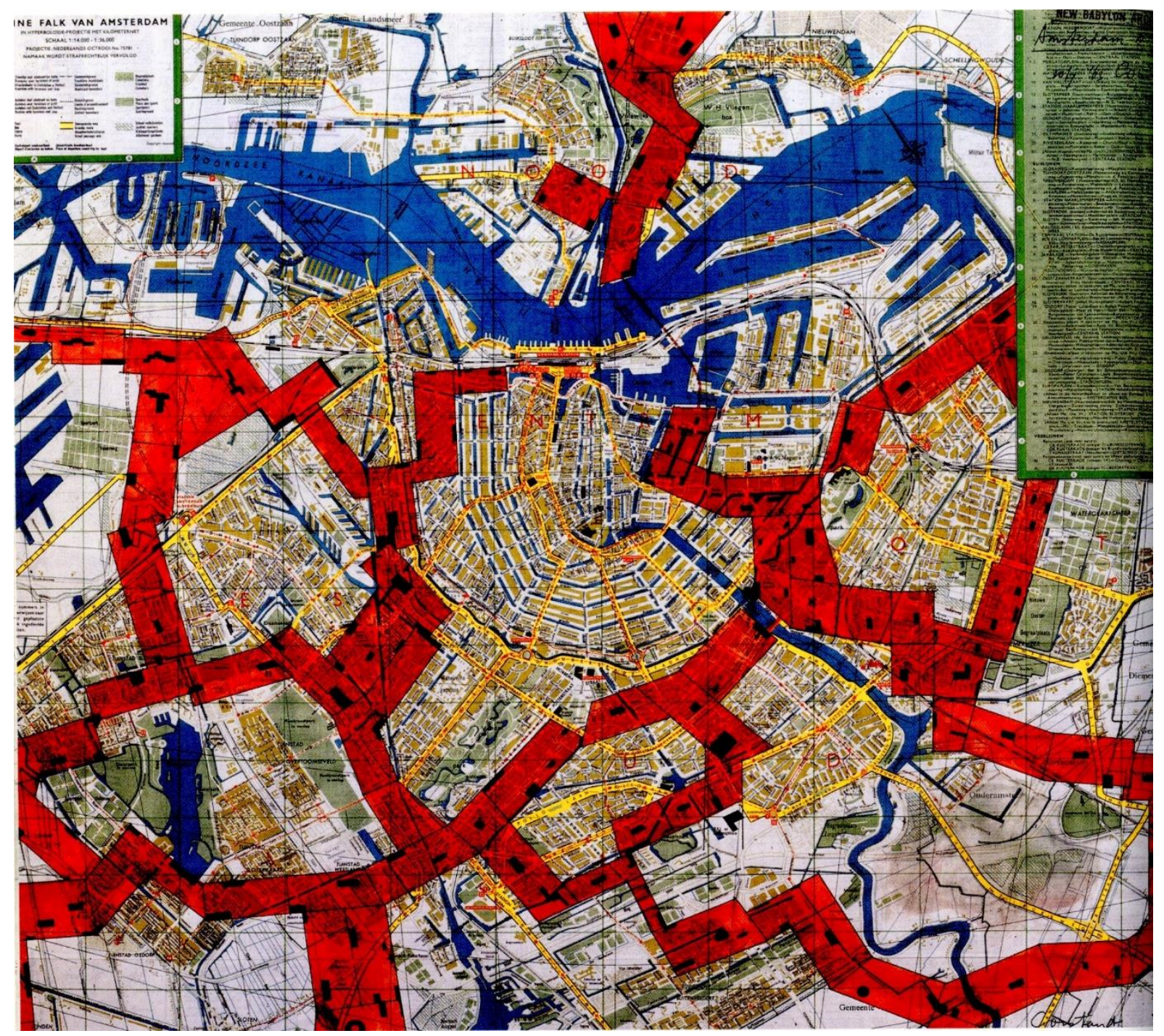

Fig. 5-15. Nueva Babilonia Amsterdam de Constant. 

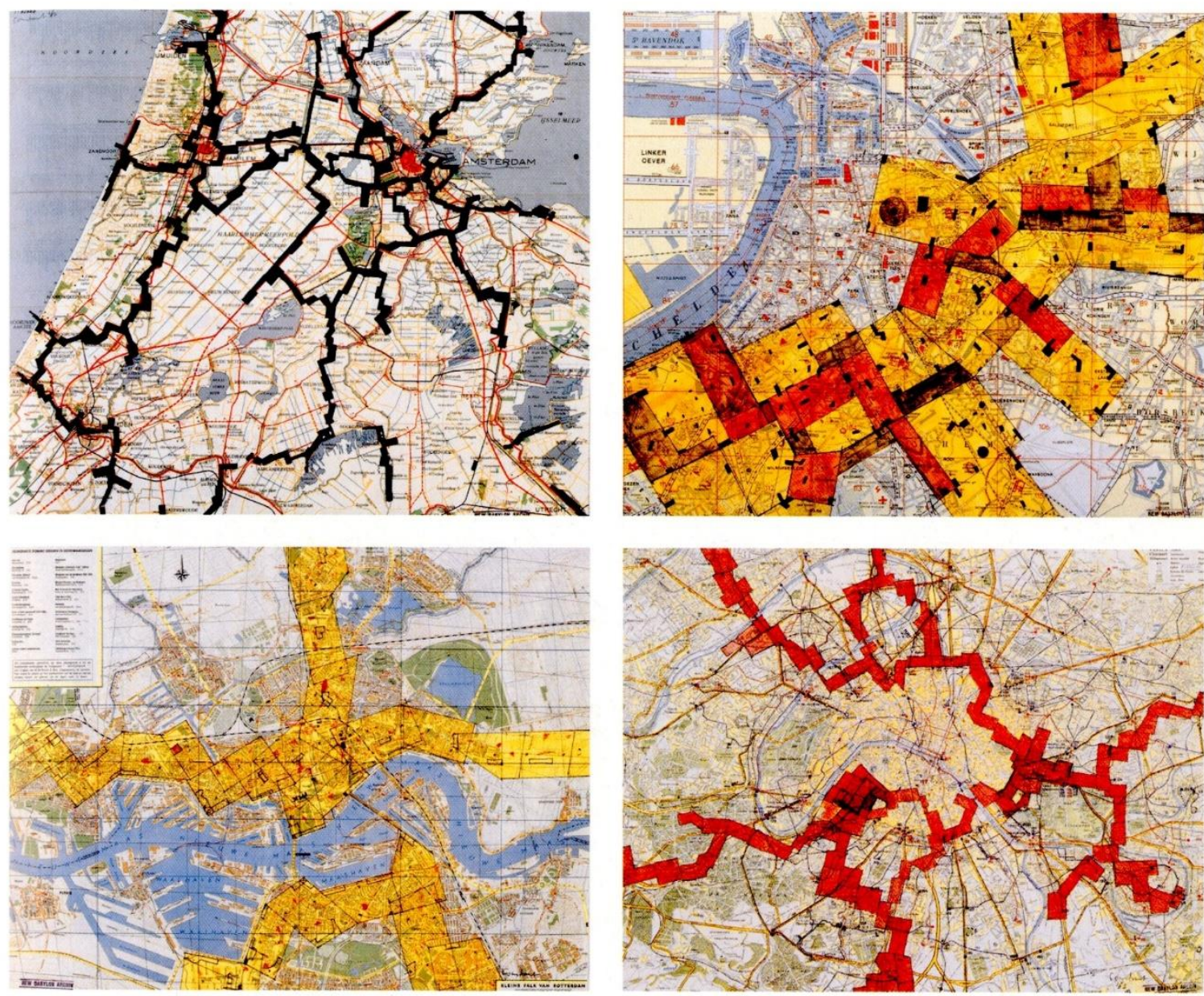

Figs. 5-16. Nueva Babilonia Holanda, Antwerpen, Roterdam, Paris, de Constant. 


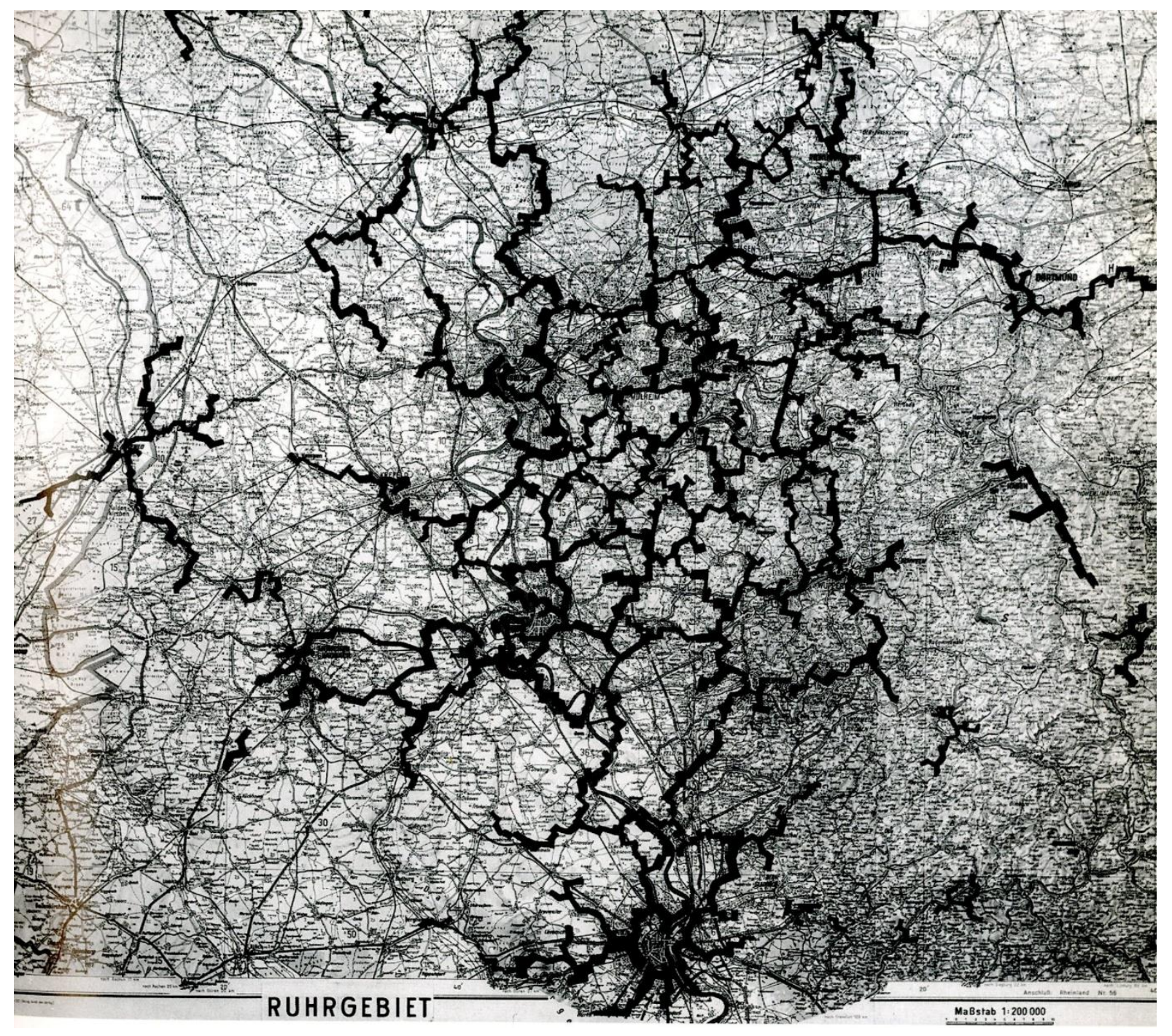

Fig. 5-17. Nueva Babilonia Ruhrgebiet de Constant. 


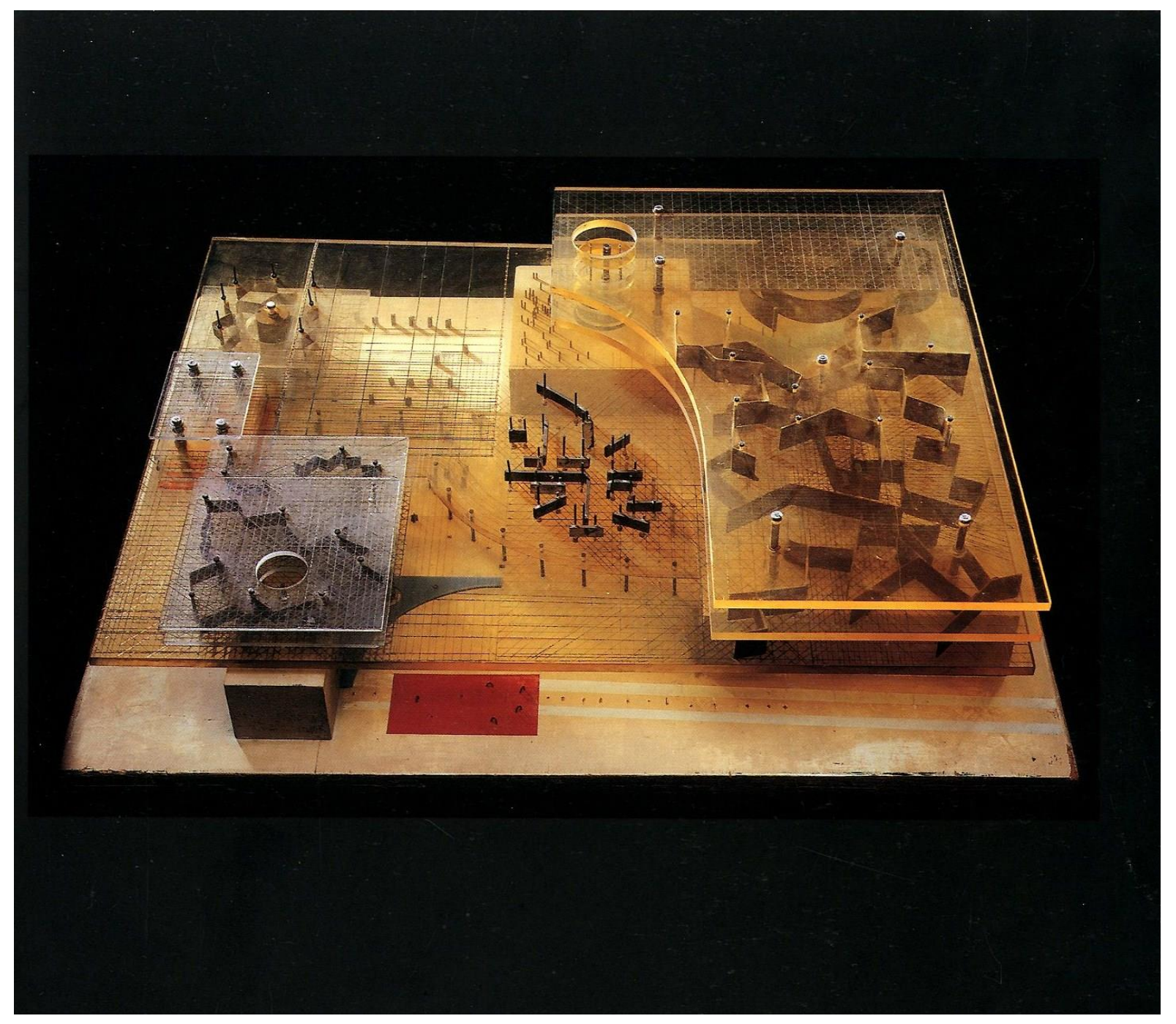

Fig. 5-18. Sector Oriental de Constant. 


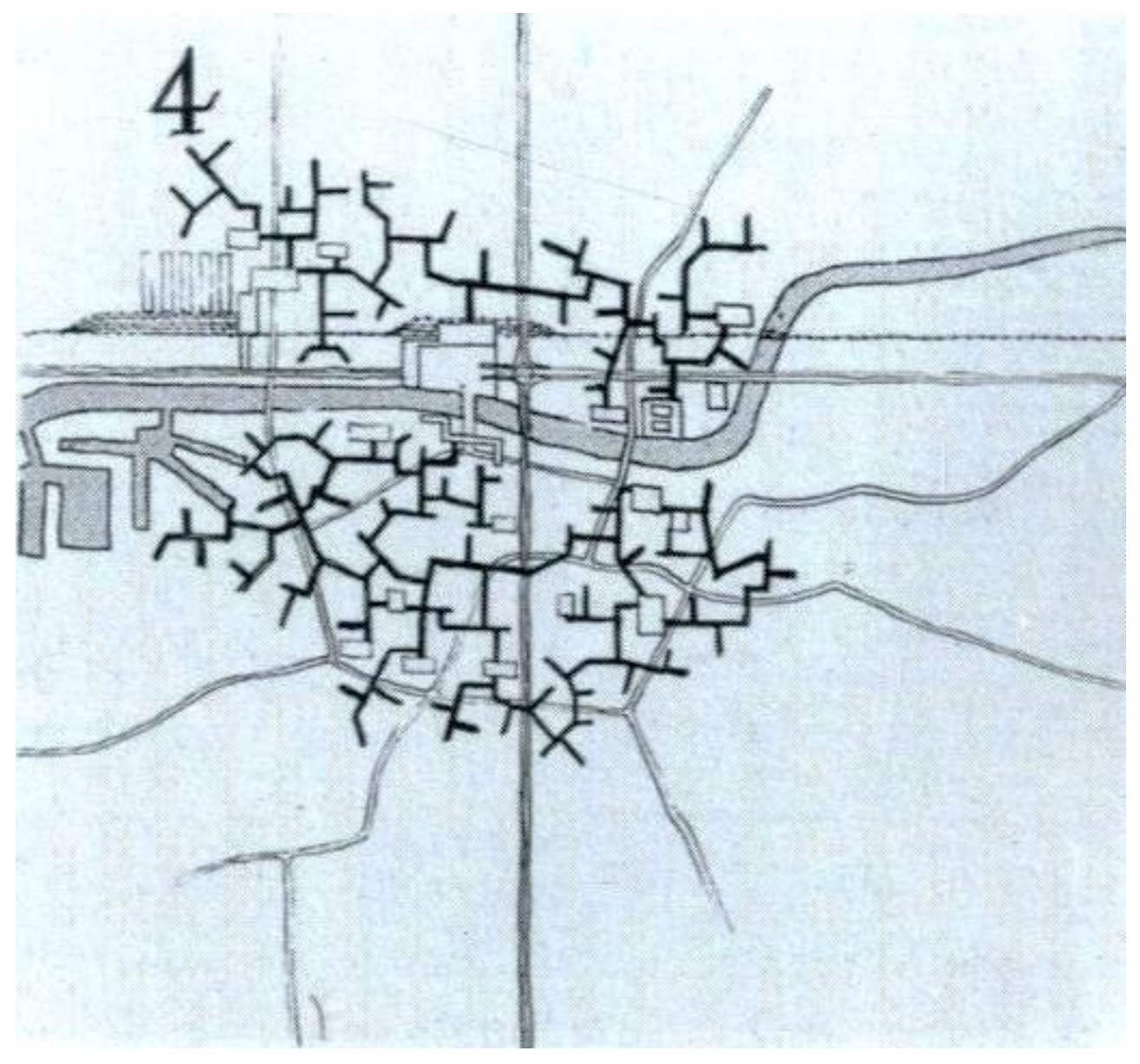

Fig. 5-19. Cluster City de Peter Smithson en 1952. 


\section{Katsura}

\section{: Un Lugar para Perderse y Encontrarse}

\section{Origen}

Katsura Imperial Villa de Japón, fue construido en tres etapas distintas. La construcción empezó en el año 1615 por la orden del príncipe Toshihito (1579-1629) de La Familia Imperial de Hachijo. Después de su muerte, la villa fue abandonada hasta al año 1641, cuando en ese mismo año la renovación y la ampliación de la villa fue planeada gracias al hijo de Toshihito, es decir, Toshitada (1619-1662) quien se prometió en el año 1641 con la princesa Fu. ${ }^{1}$ No se sabe exactamente cuándo el príncipe Toshitada pudo completar la construcción, sin embargo, por lo menos se sabe que cuando el emperador Gomizunoo (1596-1680) visitó a Katsura Imperial Villa, fue completada la obra. ${ }^{2}$

\section{Shoin Zukuri \& Sukiya Zukuri}

Cuando se habla sobre Katsura siempre existen debates e interpretaciones controvertidas. Eso es porque principalmente, en Katsura Villa están incrustadas diversas filosofías de las distintas etapas, y según dichas filosofías se hizo posible aplicar peculiares estilos revelando sus idiosincrasias sociales. Por eso, si alguien propone una interpretación muy dogmática o desviada, en este caso siempre se acaba provocando otra interpretación pretendiendo insistir en la posibilidad de la existencia de otro estilo dominante de Katsura. La arquitectura y el jardín de la villa son unos bagajes artísticos de varios contenidos de estilos arquitectónicos, filosofías, ideologías sociales y los deseos secularizados y desecularizados.

En el principio del siglo XVII japonés (el periodo de Edo), existían dos estilos prevalecientes de la arquitectura, que son: Shoin zukuri y Sukiya zukuri. El primero, Shoin zukuri, era el estilo preferido

\footnotetext{
1 AAVV. Katsura: Imperial Villa. New York. Phaidon Press Ltd. 2011. p. 9.

2 Ibid. p. 24.
} 
por la clase samurái y los sacerdotes en aquella época. Básicamente, usa un sistema de proporción llamado kiwari. Es fácil de entender si recordamos las cinco órdenes de la arquitectura clásica occidental; cada una con un peculiar estilo que implica sus proporciones en el entablamento y en la base. Los romanos que sucedieron al espíritu griego, usaron estos órdenes como un lenguaje, con la rigurosa gramática arquitectónica. De la misma manera, a los samuráis y sacerdotes les gustaba expresar sus posiciones sociales por medio de una estética autoritaria de la proporción kiwari.

El segundo estilo, Sukiya zukuri, persigue otra estética diferente. Mientras que el Shoin zukuri expresaba su particular lenguaje arquitectónico, Sukiya zukuri perseguía un estilo rústico, humilde, flexible y menos formal que Shoin zukuri. Sukiya zukuri definía el carácter de los espacios con muebles y según el nivel de los elementos decorativos, mientras que Shoin zukuri definía el carácter de los espacios por la proporción kiwari que es un módulo unitario riguroso de tatami, ventana, columna, etc. ${ }^{3}$ Como se puede imaginar, el uso de los materiales de Sukiya zukuri era también más modesto. Por ejemplo, el estilo de Shoin zukuri utilizaba las piedras bien alisadas en el techo para formar una imagen soberana y majestuosa, mientras que Sukiya zukuri usaba briznas de paja. Este estilo era originalmente para el hábitat de los plebeyos, ${ }^{4}$ y era llamado estilo Soan. Dicho estilo era de casitas de té que fueron amadas por las clases nobles y también samuráis, debido a que tenían un anhelo de la vida rústica, y ya era una tendencia de la cultura residencial el poner las casitas de té dentro de sus jardines.

Lo interesante de la villa de Katsura es que se pueden encontrar ambos estilos. Los planos de los edificios principales fueron fabricados por el estilo Shoin zukuri como normal. Por otra parte, las elevaciones y las decoraciones a veces están expresados en el estilo de Sukiya zukuri. Eso es porque en aquella época, el poder de Tokugawa shogunato (gobierno militar) era predominante en Japón. Así que la familia imperial de Hachijo naturalmente habría tenido antipatía contra la clase samurái. Eso era de alguna manera la expresión de que La Corte Imperial de Kyoto no apoya, más bien, le disgusta la estética samurái. ${ }^{5}$ Gracias a esta relación política compleja de las dos clases dirigentes, Koshoin y

\footnotetext{
3 Ibid. p. 18.

4 Ibid. pp. 17-18.

Ibid. p. 19.
} 
Chushoin de Katsura podían crear sus peculiares estéticas ambiguas, como el estilo de Sukiya zukuri dentro del plano de Shoin zukuri. Los intérpretes dicen que Katsura es un Shoin zukuri que parece Sukiya zukuri (v.-fig. 6-18).

\section{General Plan of Katsura}

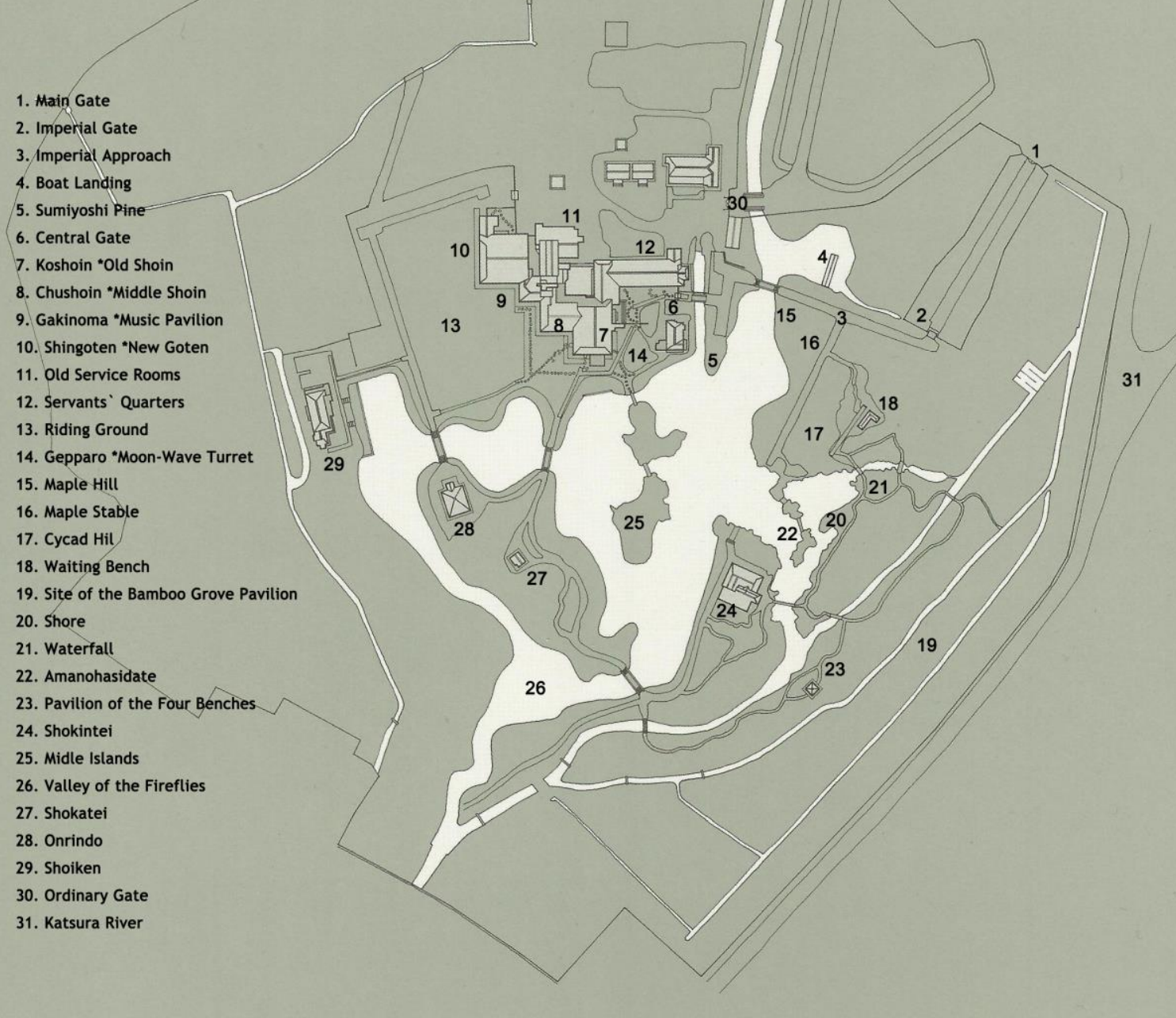

Fig. 6-1. Plano general de Katsura. 


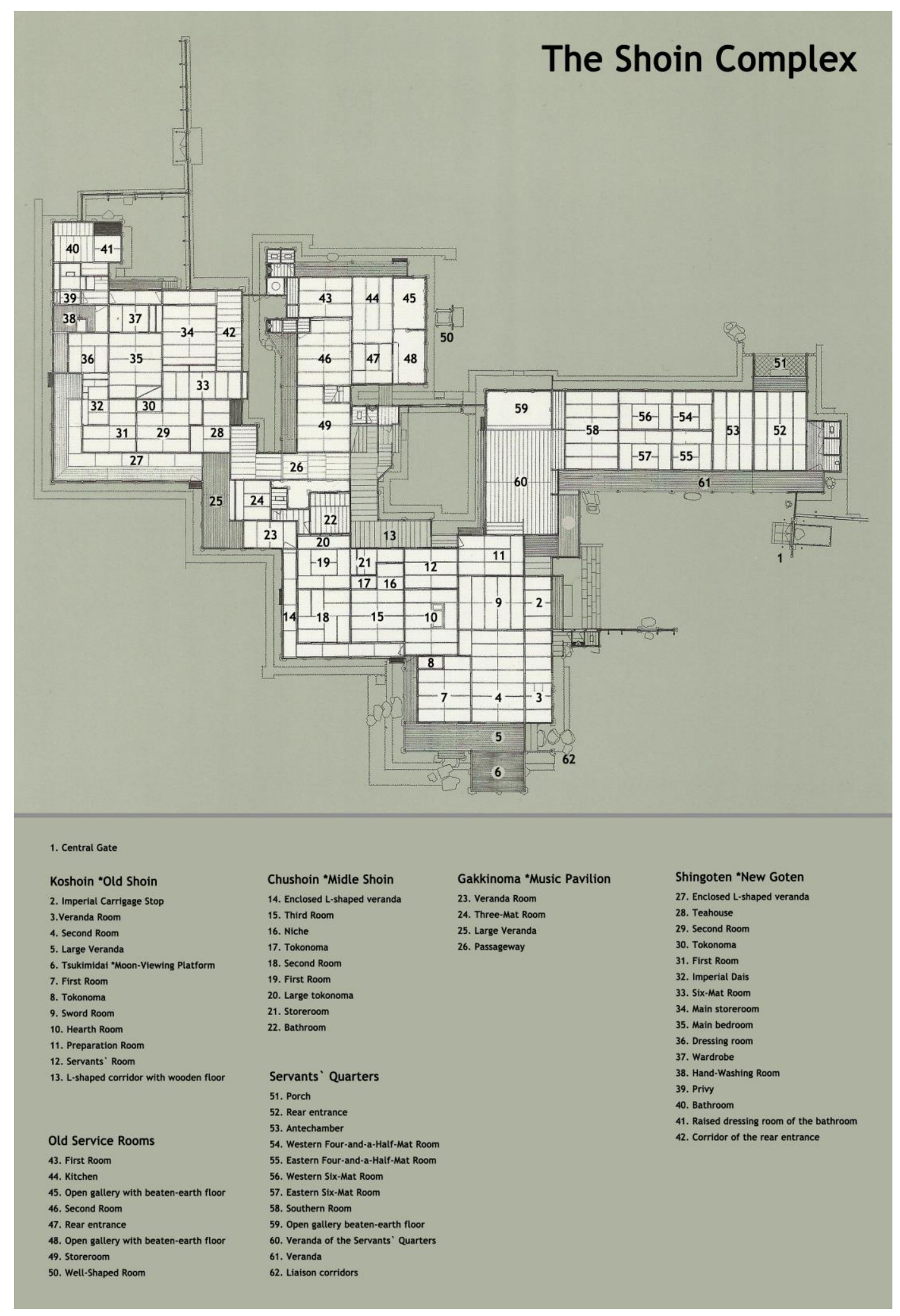

Figs. 6-2. El complejo de Shoin. 


\section{La profundidad especial en Katsura}

Katsura, como se refirió anteriormente, tiene que entenderse por la unión de tres edificios según cada etapa de construcción (v.-figs. 6-1, 2). En la primer etapa, que se inició en el año 1615, Koshoin (viejo palacio. v.-figs. 6-11) ${ }^{6}$ fue construido por Toshihito, como ya se nombró anteriormente, y su ampliación y renovación fue iniciada por su hijo, el principe Toshitada. Eso fue la segunda etapa de la construcción, y se denominó Chushoin (medio palacio. v.-figs. 6-19, 27, 30). Este año, 1641, el príncipe Toshitada fue prometido con la princesa Fu. En la última etapa se supuso que la construcción se completaría en el año 1663. En la tercera etapa, Shingoten (nuevo palacio. v.-figs. 6-29, 31, 32, 33) y Gakkinoma (pabellón de música. v.-figs. 6-24, 25, 26, 28) fueron construidos y también se construyeron más casas de té. ${ }^{7}$ Dichas tres partes principales del palacio, enfrentan al jardín, en línea. Esta formación de los complejos recuerda una formación de los gansos cuando vuelan en grupo, los japoneses lo llaman Ganko(v.-figs. 6-10, 19, 20, 24, 25). ${ }^{8}$

Koshoin se colocó enfrentando el estanque artificial de Katsura, de manera que, fácilmente, se puede observar su intención para poder observar la luna y su imagen reflejada en el estanque (v.-figs. 6-10, 13, 14). A la derecha de Koshoin, se añadió Chushoin, retirándose la fachada de la elevación más hacia atrás. Cuando el príncipe Toshihito decidió construir Koshoin, en el plano solo existían dos habitaciones, las partes de los asistentes y los cuartos de los sirvientes. Por eso, la extensión fue necesaria para Toshitada para empezar su vida matrimonial con su mujer, la princesa Fu. Por el contrario, su padre fue escéptico del estilo de la arquitectura samurái, sin embargo el príncipe Toshitada fue optimista respecto a esta sociedad ${ }^{9}$ (como la princesa Fu también era de la familia samurái). Así que se entiende porqué Toshitada hizo la extensión de Katsura en la forma de Ganko, dicha forma tenía un estilo simbólico en la arquitectura para la sociedad samurái. Arata Isozaki, en su ensayo de Katsura, refirió que la formación de Ganko es una manera peculiar de la arquitectura tradicional

\footnotetext{
${ }^{6}$ En japonés, Shoin(書院) significa literalmente un cuarto de letras o de escritura, así se insinúa un edificio para estudiar o dibujar. Sin embargo, es un edificio de residencia, aunque se llamaba así. Y Ko(古) significa viejo. Chu(中) de Chushoin significa el medio. Al final, Shin(新) de Shingoten, significa el nuevo. Así que Shingoten significa el nuevo palacio-(NdA)

7 AAVV. Katsura: Imperial Villa. New York. Phaidon Press Ltd. 2011. p. 24

8 Ibid. p. 19.

${ }^{9}$ lbid. p. 20.
} 
japonesa que expresa la profundidad del espacio (la profundidad, en el sentido de superponer los planos), de diferente manera de la arquitectura occidental que conseguía la profundidad del espacio por medio de la perspectiva(v.-figs. $6-15,16,17) .{ }^{10}$ La profundidad genera un efecto que asigna una importancia jerárquica en los espacios, como la sociedad samurái.

Aquí se encuentra un genuino placer a la hora de observar Katsura. La extensión de Shingoten fue realizada de la misma manera que Chushoin, como, Chushoin fue añadido a la derecha de Koshoin, y Shigoten fue añadido igualmente a la derecha de Chushoin, retirándose atrás poco a poco. Al final, la formación de Ganko se hizo ideal para que los observadores pudiesen enfrentar el estanque abriendo una escena espectacular en cualquier veranda de las tres. ${ }^{11}$ Añadiendo más cuerpos al edificio preexistente, la zona verde se extiende conjuntamente. En el otro lado del estanque, La Villa Katsura se ve muy dramática respecto las articulaciones de sus complejos, como la forma de Ganko hacía retirarse a Chushoin, y Shingoten, generando un efecto estético inesperado con la profundidad espacial. Las miradas se mueven según los observantes pasean. En ésta tranquila escena, durante un paseo o en un juego de barco en El Río Katsura, se crean perspectivas dinámicas. La jerarquía espacial de todos los lugares ha sido reunida en una escena superponiendo las perspectivas de un paseante. En realidad, la formación de Ganko fue un método de la expresión espacial de la sociedad samurái, sin embargo, la expresión de la jerarquía samurái fue destruida, al contrario que su virtud, contingentemente. Perdiendo su originalidad, ganó una virtud inesperada.

\section{Las escenas interiores}

Las características de los shoins parecen particularmente elegantes y ligeras; eso se debe en parte al hecho de que todas las fachadas que se enfrentan al sureste contienen discrepancias sutiles. ${ }^{12}$

Arata Isozaki.

En Koshoin y Chushoin de Katsura, los espacios se dividen por las unidades de tatami y las pantallas

\footnotetext{
10 Ibid. p. 19

11 Ibid. p. 20

12 lbid.
} 
de fusuma. El tatami, como se conoce generalmente, es una unidad de esteras y es un elemento imprescindible de la arquitectura tradicional japonesa. ${ }^{13}$ Su color suave y la modestia que sale desde su materialidad no excesiva, insinúa la peculiar nobleza de Katsura. El suelo de las habitaciones está ensabanado con los tatamis esteras, así que naturalmente su margen oscuro (de algodón tintado) ofrece un módulo interesante para aplicar a las habitaciones flexiblemente y queda bien con la proporción kiwari de las partes de madera. El material es de paja de arroz, cuyo color claro es casi igual que el de la tierra, encontrándose con otros materiales de maderas tintadas que han atravesado varios procesos de tratamiento, generando así una imagen rústica.

Cuando la luz natural atraviesa fusuma, el espacio se llena por una luz suave, y la oscuridad de las maderas de la proporción kiwari en las esquinas, las columnas y varias partes del palacio absorbe hasta la sombra, sintiéndose así amable en este espacio. ${ }^{14}$ Básicamente, fusuma es una puerta corrediza, pero que además de aplicarse para las puertas, también se utiliza para las ventanas y los muros. Gracias a que su material es de papel con enrejados de madera, la luz del exterior puede atravesar los muros, y gracias a que las divisiones son movibles, los espacios se quedan más flexibles respecto a sus usos. Cuando todos los fusumas están abiertos el cambio es muy drástico contrariamente a cuando están cerrados. En Koshoin y Chushoin, estas líneas verticales y horizontales intervienen entre ellos (kiwari, fusuma, tatami) creando los espacios infinitos a través de sistema unitario. ${ }^{15}$

Tanto en Shingoten como en Koshoin el fusuma y tatami se usan como un método primordial para definir los espacios. Pero en Shingoten en particular, se usan los armarios y los estantes que asignan los caracteres a los espacios, acumulándose y ensamblándose. Además cada habitación está decorada con un distinto estilo y distinto nivel de elaboración. En Shingoten, se pueden disfrutar los diversos espacios de diseño. ${ }^{16}$

\footnotetext{
13 v.-figs. 21, 22, 23.

14 v.-figs. 34, 35, 36.

15 AAVV. Katsura: Imperial Villa. New York. Phaidon Press Ltd. 2011. p.23

${ }^{16}$ Ibid. p. 23
} 


\section{Jardín}

El jardín de Katsura se compone de piezas hechas en diferentes tiempos y siguiendo distintos métodos de diseño. Lo que les conecta es finalmente nuestra mirada a medida que pasa a través. Al igual que la mirada que experimenta el espacio dispuesto en la formación en cuña, como los gansos que vuelan en grupo, la mirada en el jardín se dislocó una vez y se desplazó en varios momentos antes de que continuara su camino. Y es la ruta de paseo que teje la mirada y sintetiza la experiencia visual. ${ }^{17}$

Como se refirió anteriormente, en el siglo XVII de Japón, existían dos estilos arquitectónicos cuyos caracteres eran contradictorios entre sí. En Katsura, dichos estilos co-existen de igual forma y en las casas de té se puede encontrar esa tradición fácilmente. Uno era Shoin zukuri, y el otro era Sukiya zukuri. Posteriormente, cuando se aplicó el estilo Sukiya zukuri en los hábitats de los plebeyos y las casas de té, se denominó estilo Soan. En aquella época de Japón, la estética de Soan era una cultura para la gente de la clase dominante. Aparentemente, esa arquitectura en una casa de samurái suena paradójico, pero ellos lo consideraron como una virtud modesta de los aristócratas. ${ }^{18}$ (A los samuráis les gustaba crear pequeñas escenas rusticas y artificiales en sus jardines). Así, ha sido común que el estilo Soan se aplicara en las villas de los samuráis y en sus jardines. Este estilo fue el más sistematizado por Sukiya zukuri en Katsura. Indudablemente, el jardín y las casas de té no eran solamente para pasear y tomar un té (v.-figs. $6-37,38,39,40,41,42,43$ ).

Llego después de una lluvia de la mañana. Después de recibir una cálida bienvenida por los miembros de la casa, dio un paseo por el jardín, durante el cual visitó las casas de té y disfrutó de las vistas de las flores de cerezo y las extrañas rocas. Después de tomar un té y dulces en la ceremonia del té, volvió al Shoin y comió fideos de udon. Luego fue invitado al barco por el río Katsura, pero el viaje fue cancelado y pronto el grupo volvió a la orilla porque había mucha dificultad en el control de la barcaza, debido al oleaje del río después de la lluvia y el fuerte viento.

17 Ibid. p. 27.

18 Ibid. p. 25. 
Pasando por Ume, el campo de equitación, (los invitados) fueron a la casa de té Shoiken. Luego, desde el Valle Luciérnaga pasaron a la Shokintei Casa de Té, cruzaron el puente de piedra, y fueron a la Cuesta de Palma del Sagú. Y volvieron a andar sus pasos durante una corta distancia de vuelta a la Shokatei (apreciación de flor) Casa de Té. Continuando, volvieron a lo largo del Camino Real (Miyukimichi) hasta que llegaron a la orilla del Río Katsura. disfrutaron de los paseos en bote por el río durante bastante tiempo. Volviendo al jardín, tomaron una barcaza más pequeña fuera del estanque, donde recitaron poemas, siendo inspirados por los dos preciosos pinos ......Finalmente, cuando el anochecer se acercaba, subieron a la Gepparo (Torreta de Onda-Luna) para admirar el reflejo de la luna en el estanque. ${ }^{19}$

Como se ve el jardín, las casas de té e incluso Gepparo, son aparatos con diversos propósitos. El jardín fue diseñado para poder mirar a través de varias perspectivas desde la terraza llamada Tsukimidai (The Moon-Viewing Platform. v.-figs. 6-13, 14). Existen numerosos puntos en los cuales se puede observar el escenario, pretendiendo ellos (los observadores) concentrarse en él (o en el ritual). Cuando el observador de la escena se mueve de su sitio, la perspectiva se rompe. Y dependiendo de su peculiar itinerario, la manera de andar, el ritmo de respirar, el material del pavimento y su patrón, las escaleras, tierras inclinadas, el sonido de los vientos con los árboles, el cambio de superficie del agua, la distancia entre las piedras destinadas a caminar (stepping stones) y etcétera, etcétera, otra vez se forma una nueva escena (v.-figs. 6-3, 4, 5, 6, 7, 8, 9, 10, 12). Este tipo de experiencias del observador se acumulan según los cambios del tiempo durante del día y varias temporadas del año en la primavera, el verano, el otoño y el invierno.

La forma de Ganko amplia este efecto en la escena, profundizando los espacios. Al final, destruye el muro entre el mundo real y el otro mundo artificial rústico perdiendo la conciencia de cual era el mundo secular y el mundo del juego (paseo y el ritual de té).

\footnotetext{
${ }^{19}$ AAVV. Katsura: Imperial Villa. New York. Phaidon Press Ltd. 2011. p.27.
} 
Las escenas de la entrada de la villa

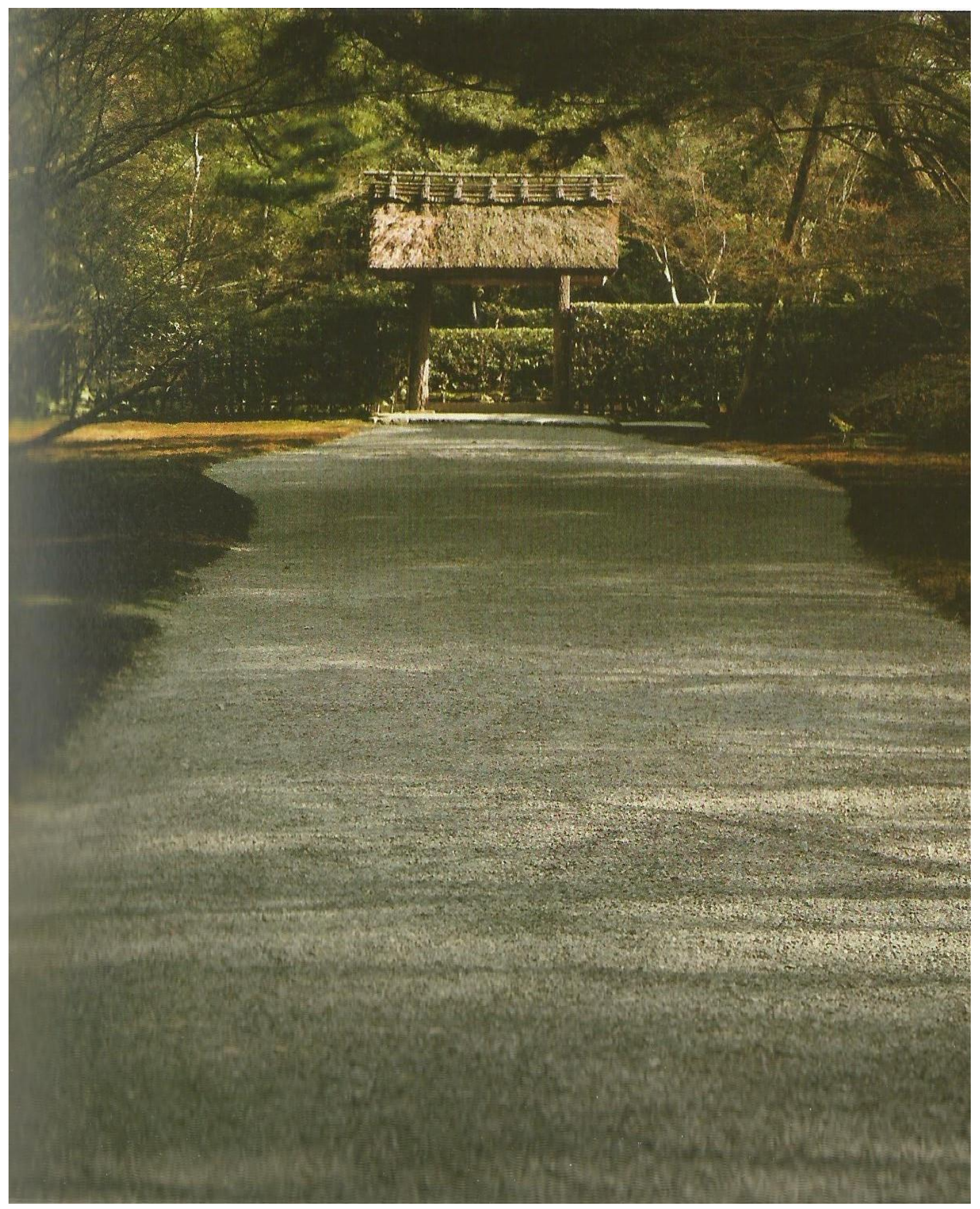

Fig. 6-3. La puerta imperial desde la puerta principal. 


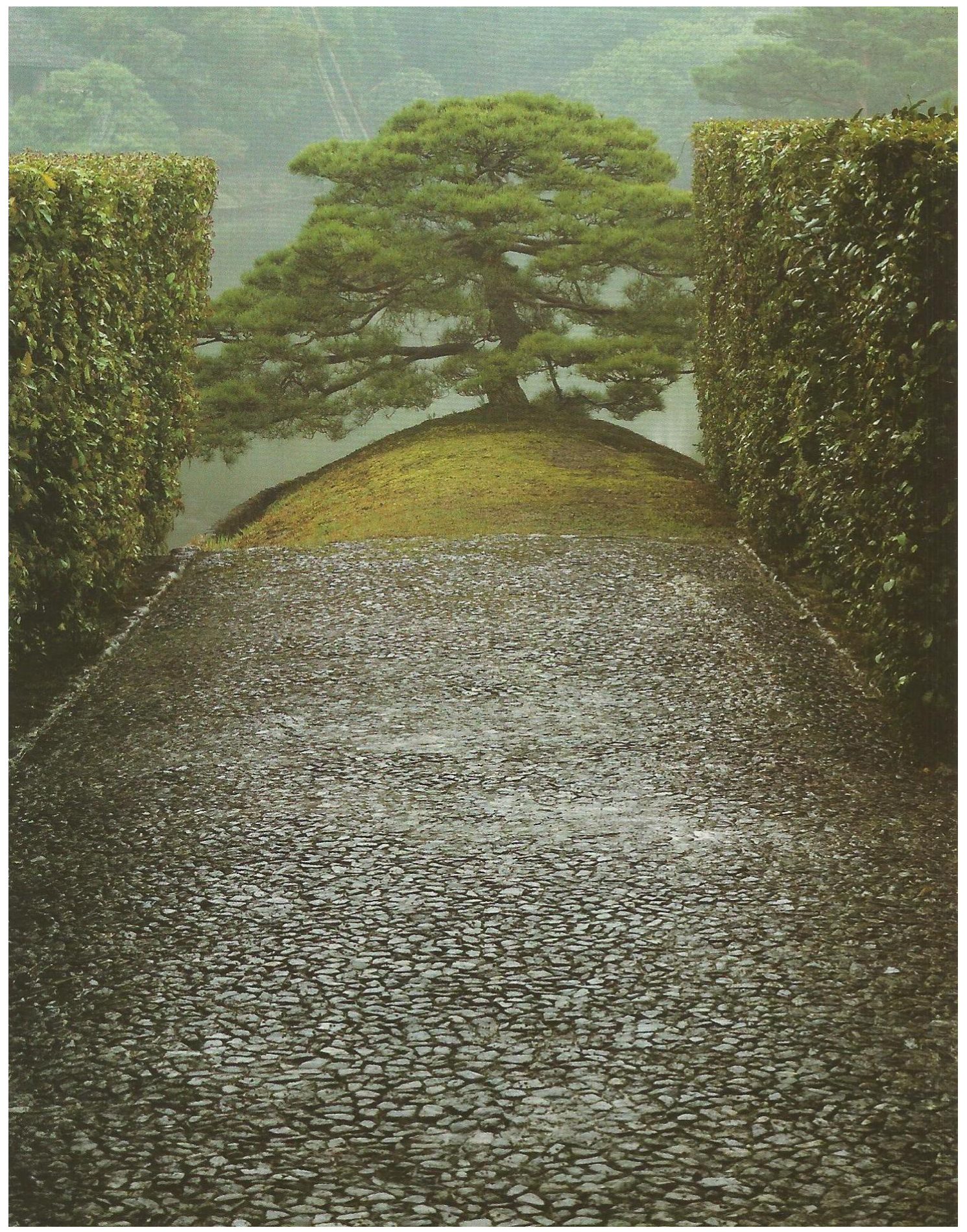

Fig. 6-4. El pino Sumiyoshi. 


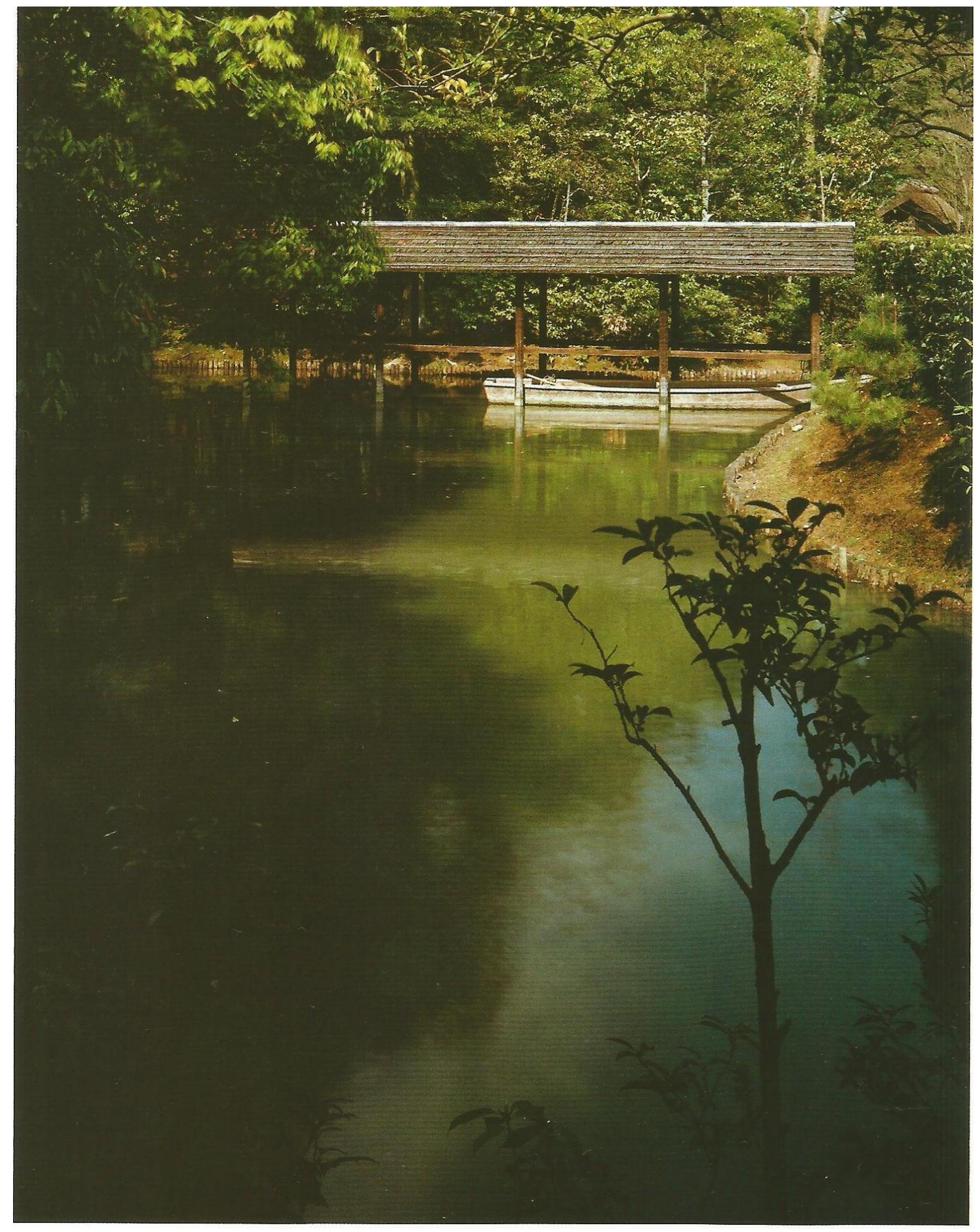

Fig. 6-5. Embarcadero en el río Katsura. 


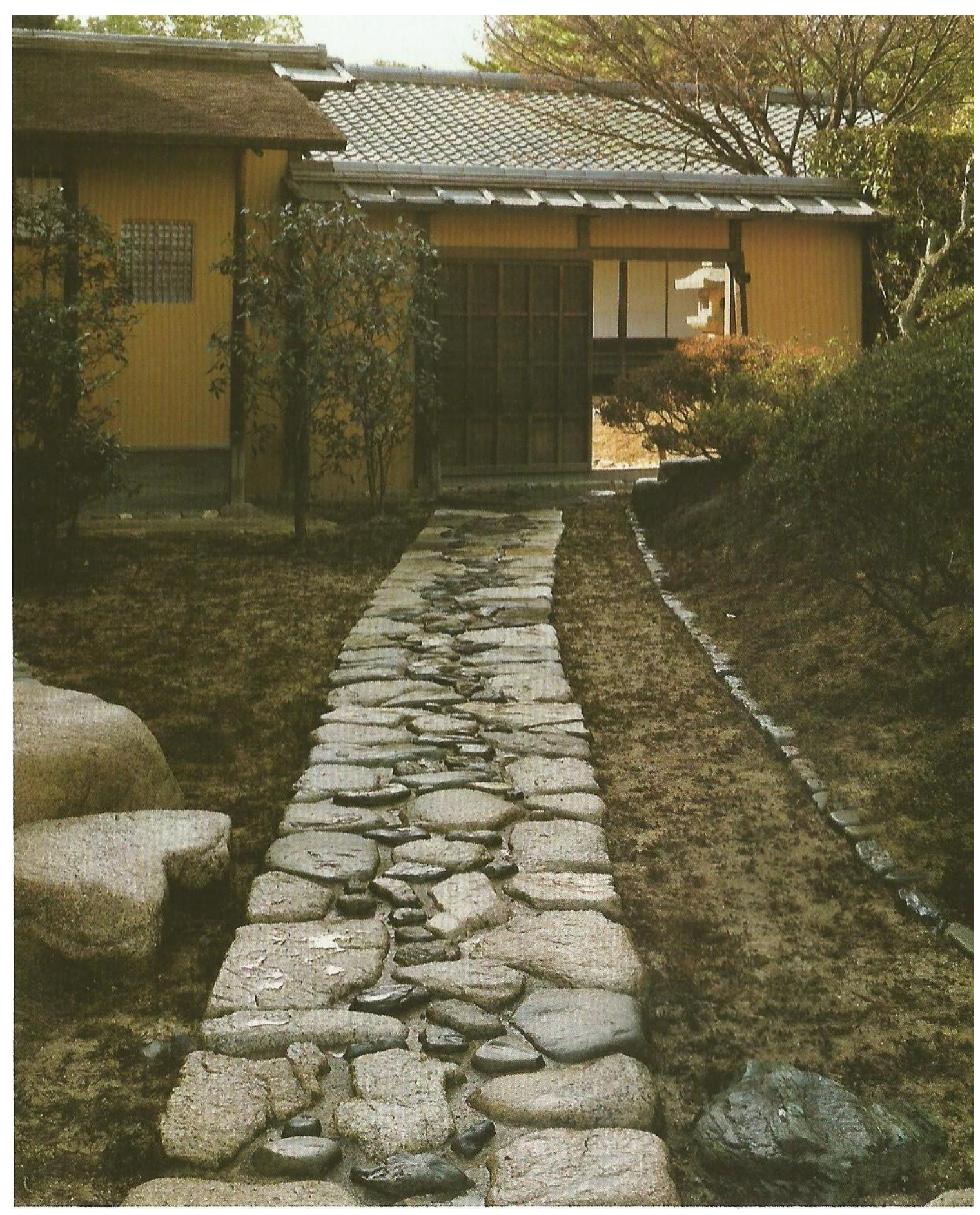

Fig. 6-6. La puerta del jardín. 


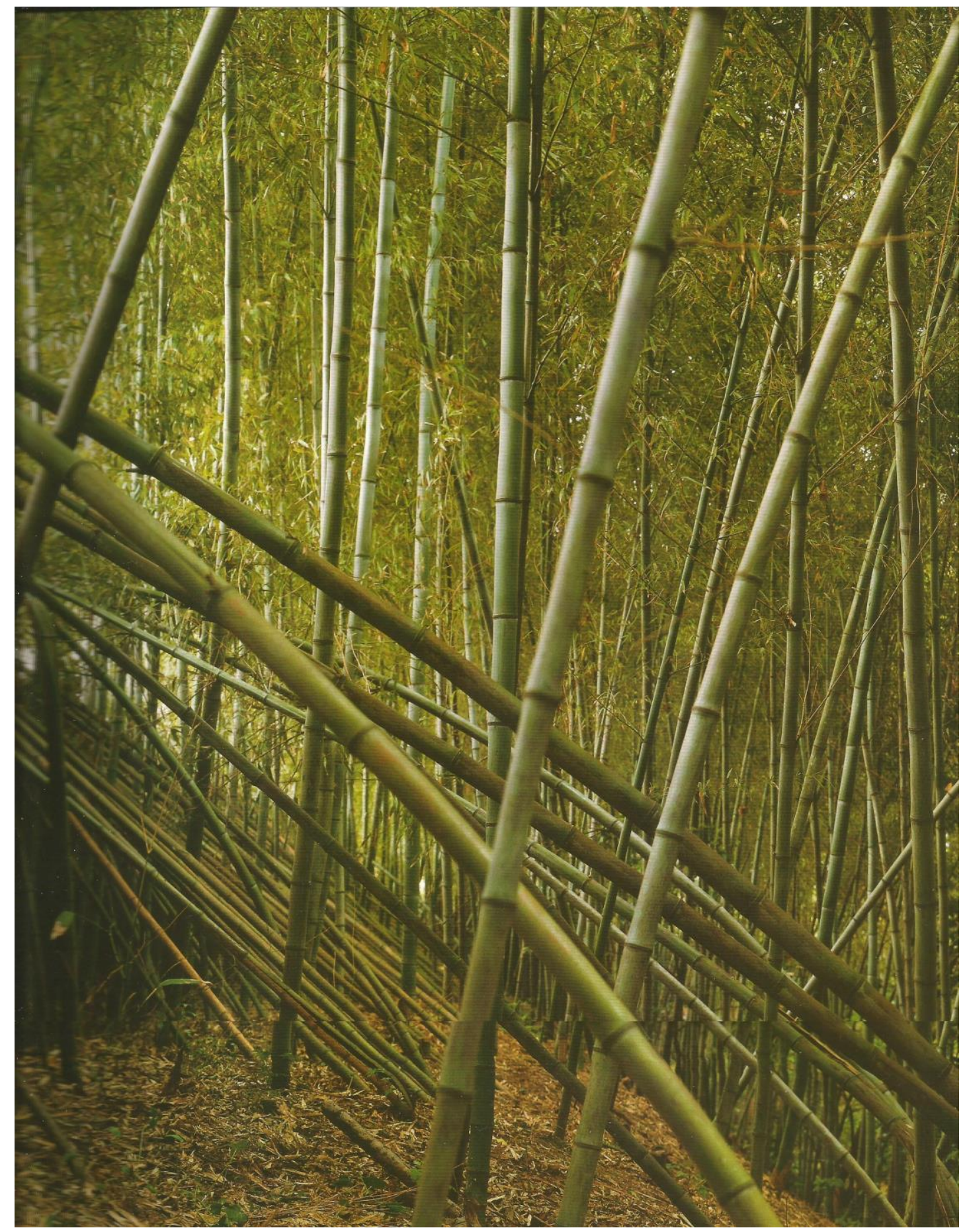

Fig. 6-7. La parte trasera de la valla de bambú. 


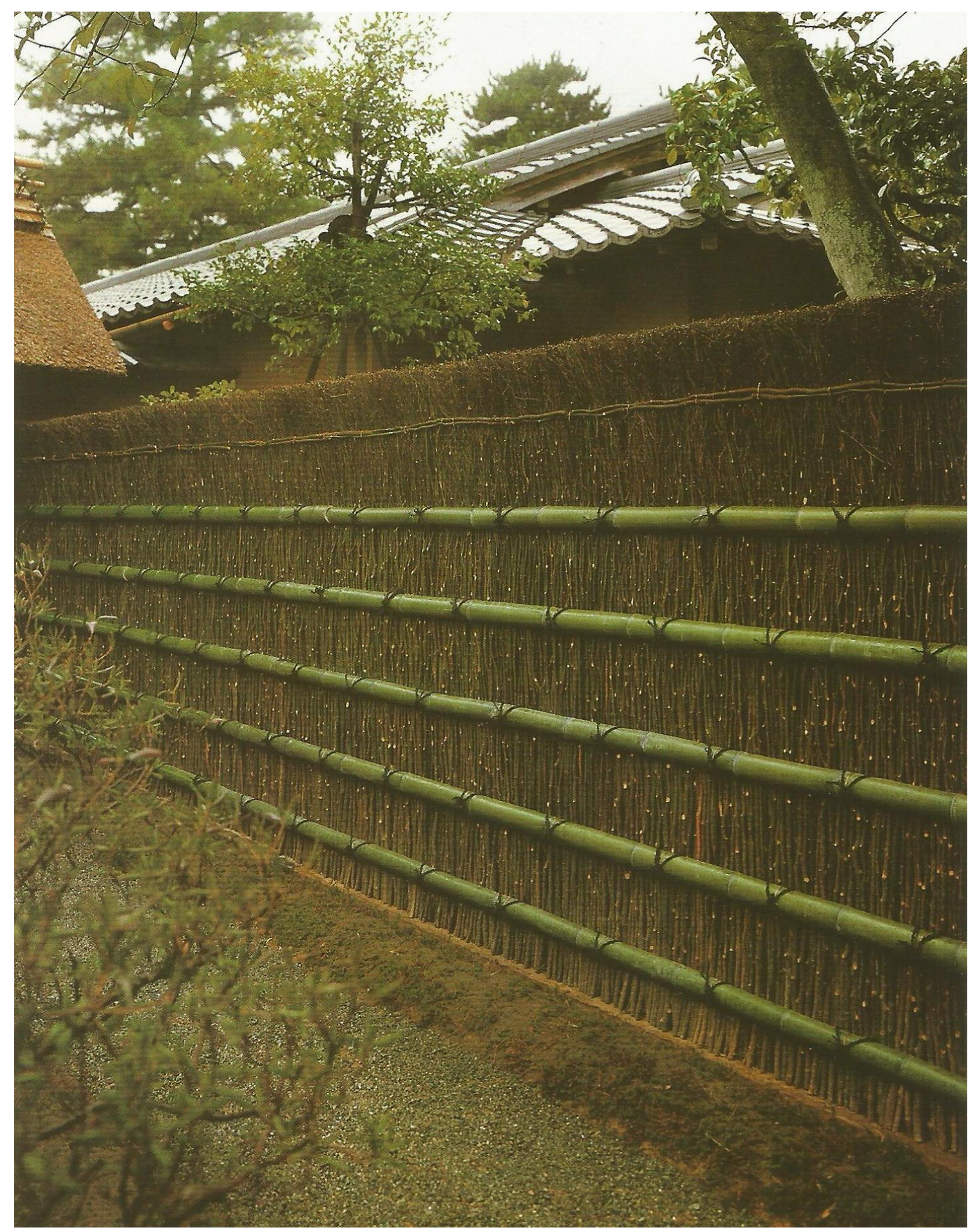

Fig. 6-8. La valla del spicebush cerca de la puerta central. 


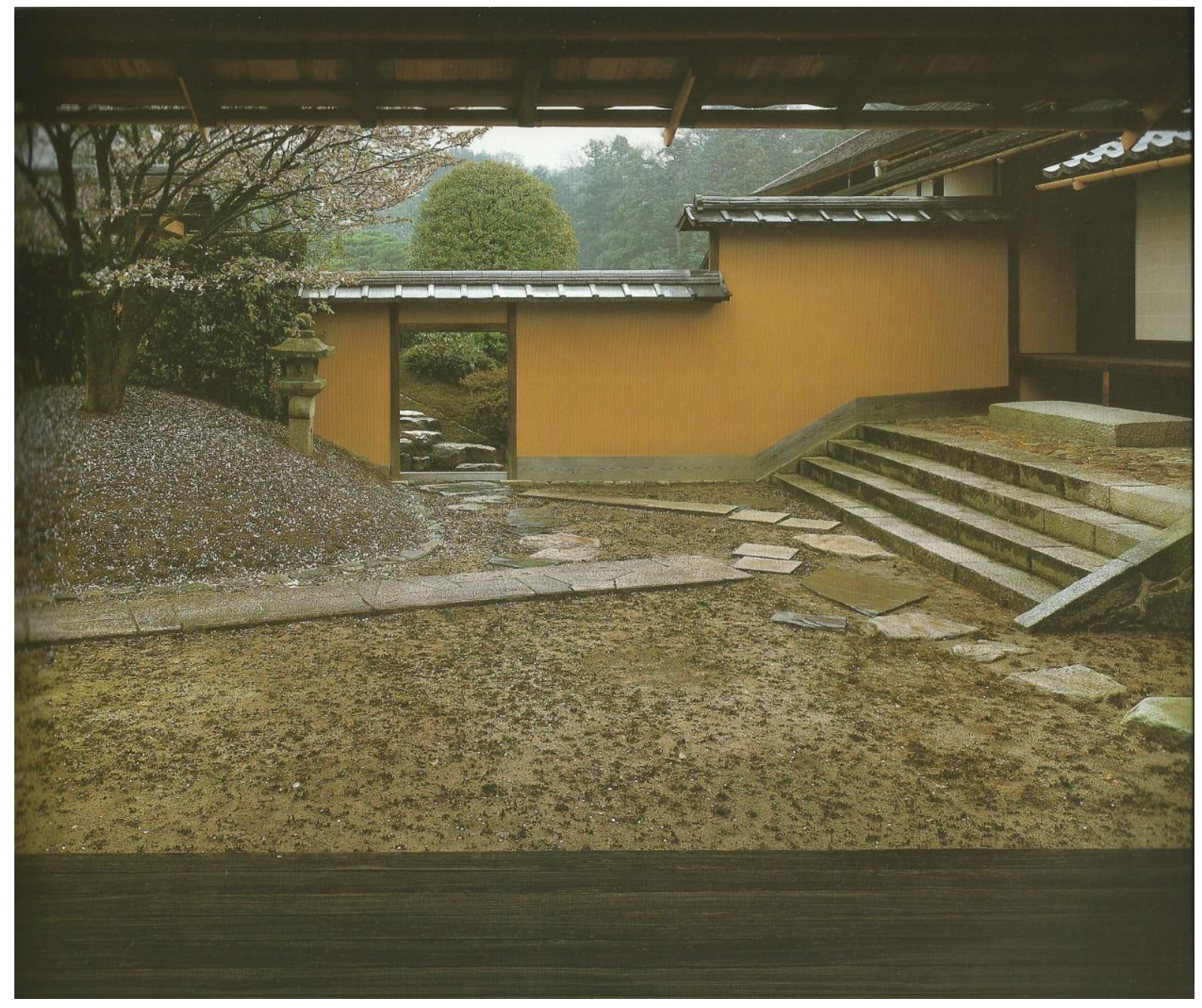

Fig. 6-9. La puerta del jardín y la entrada a la Koshoin. 


\section{Las escenas de Koshoin}

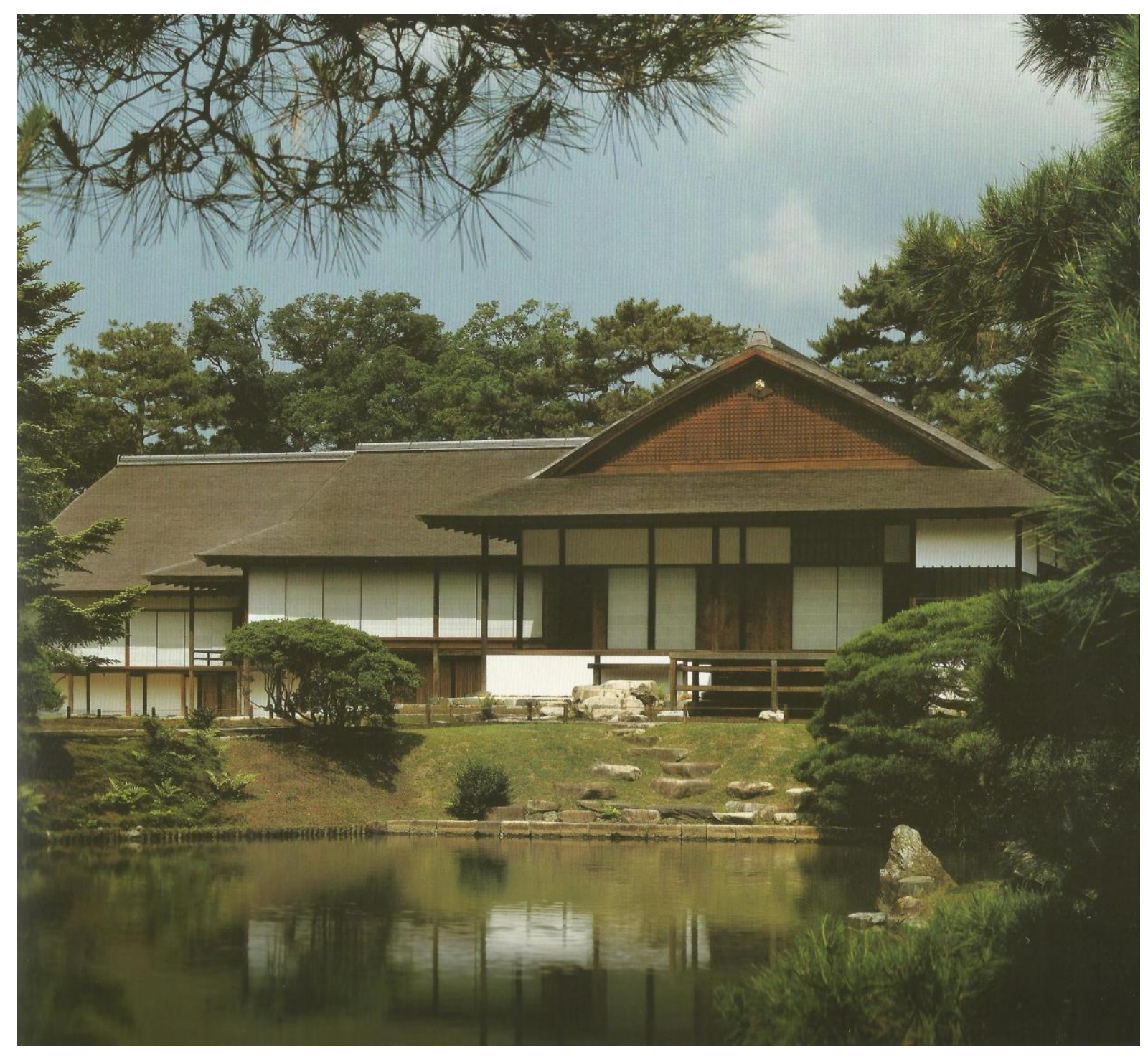

Fig. 6-10. El complejo de los Shoines desde el estanque. 


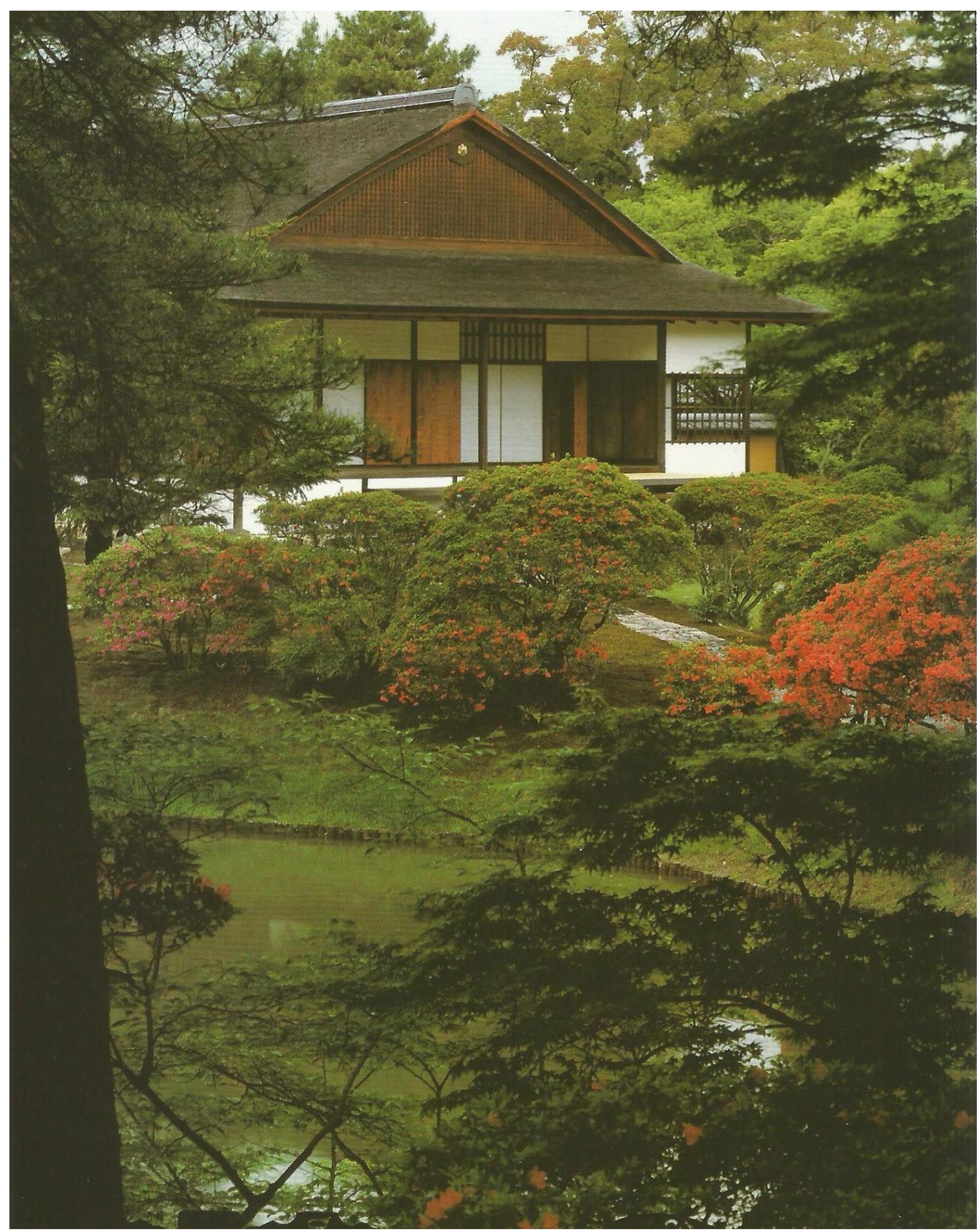

Fig. 6-11. El Koshoin desde el este. 


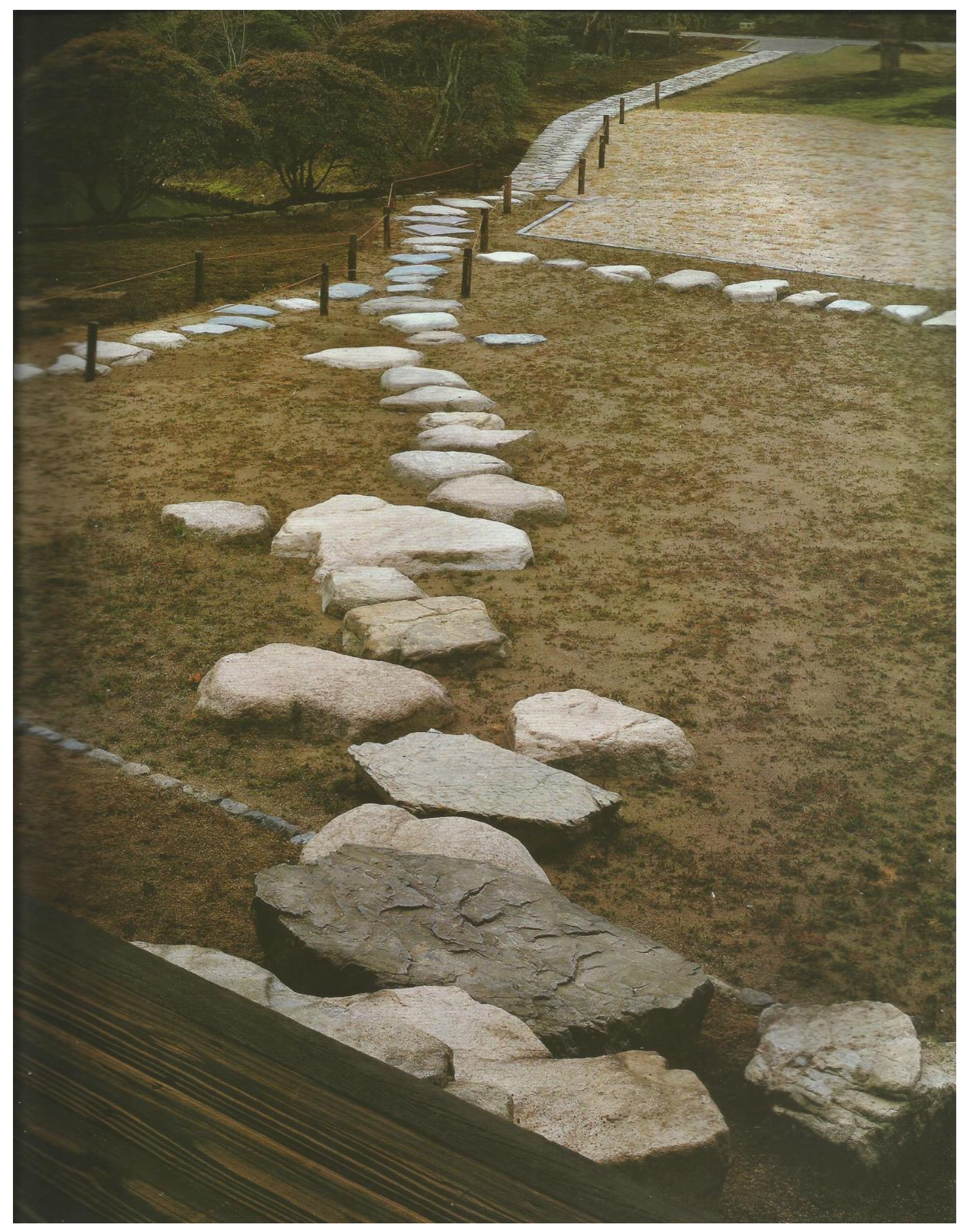

Fig. 6-12. El camino de piedras a Koshoin. 


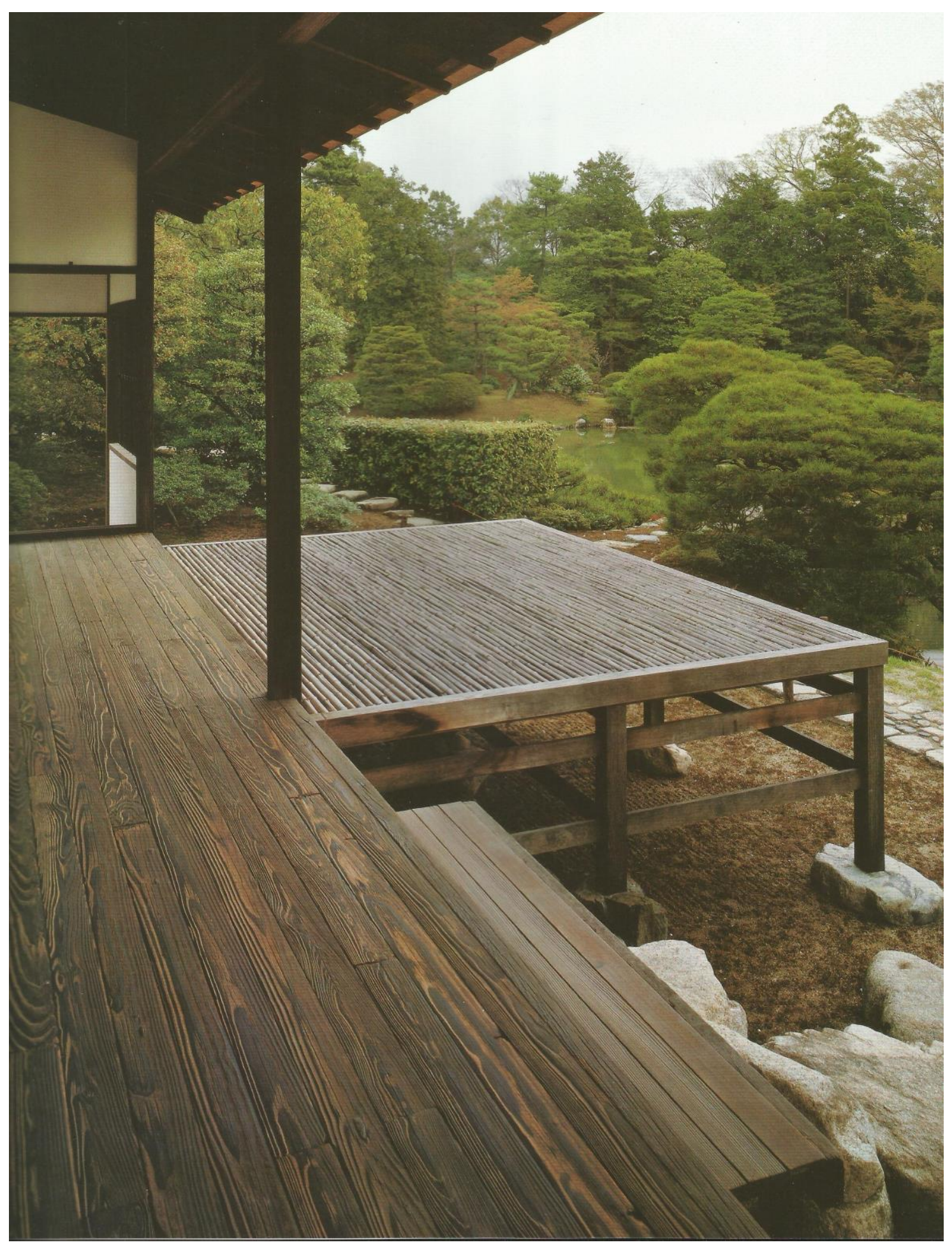

Fig. 6-13. La gran terraza y Tsukimidai. 


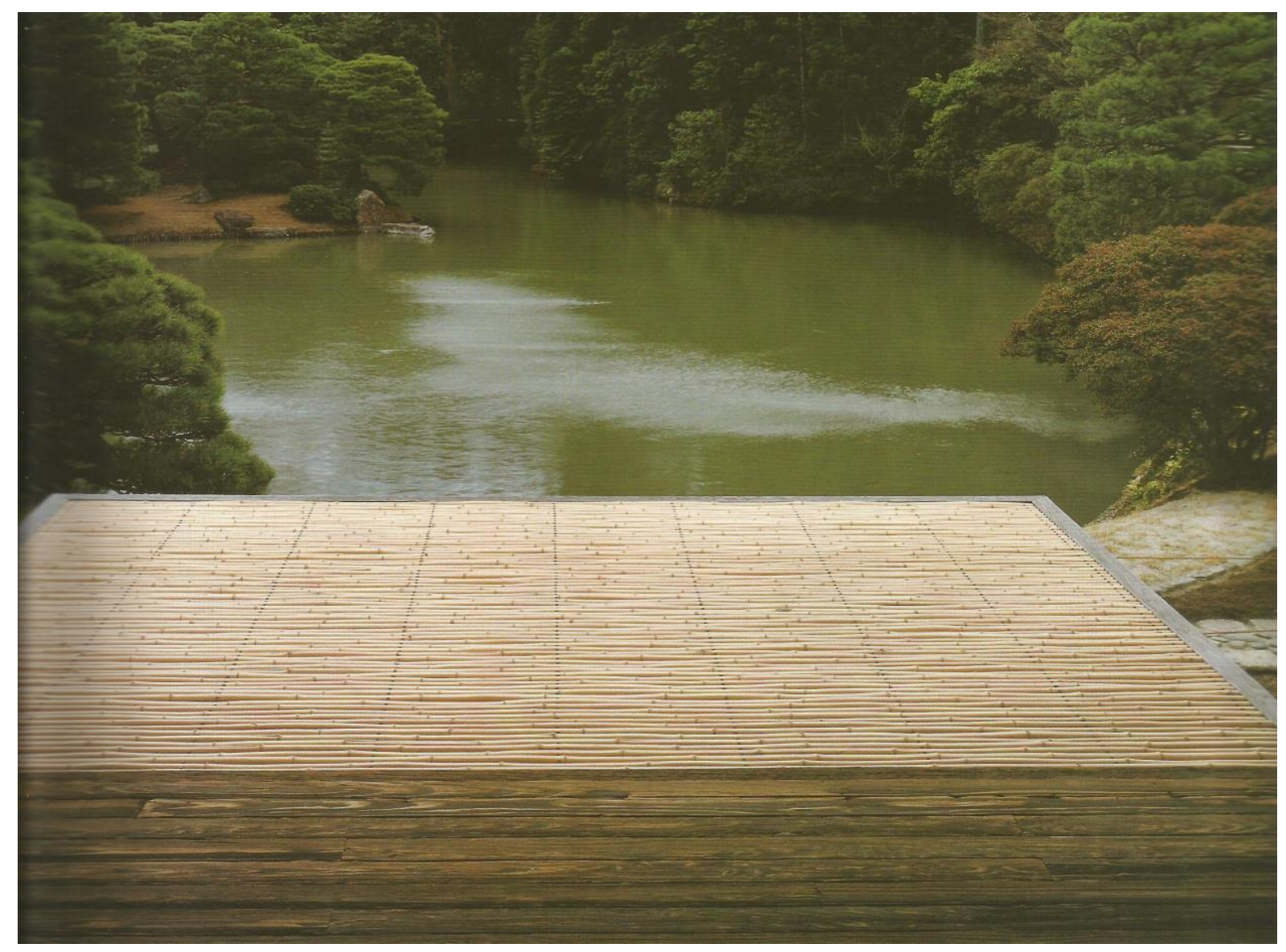

Fig. 6-14. Tsukimidai de Koshoin. 


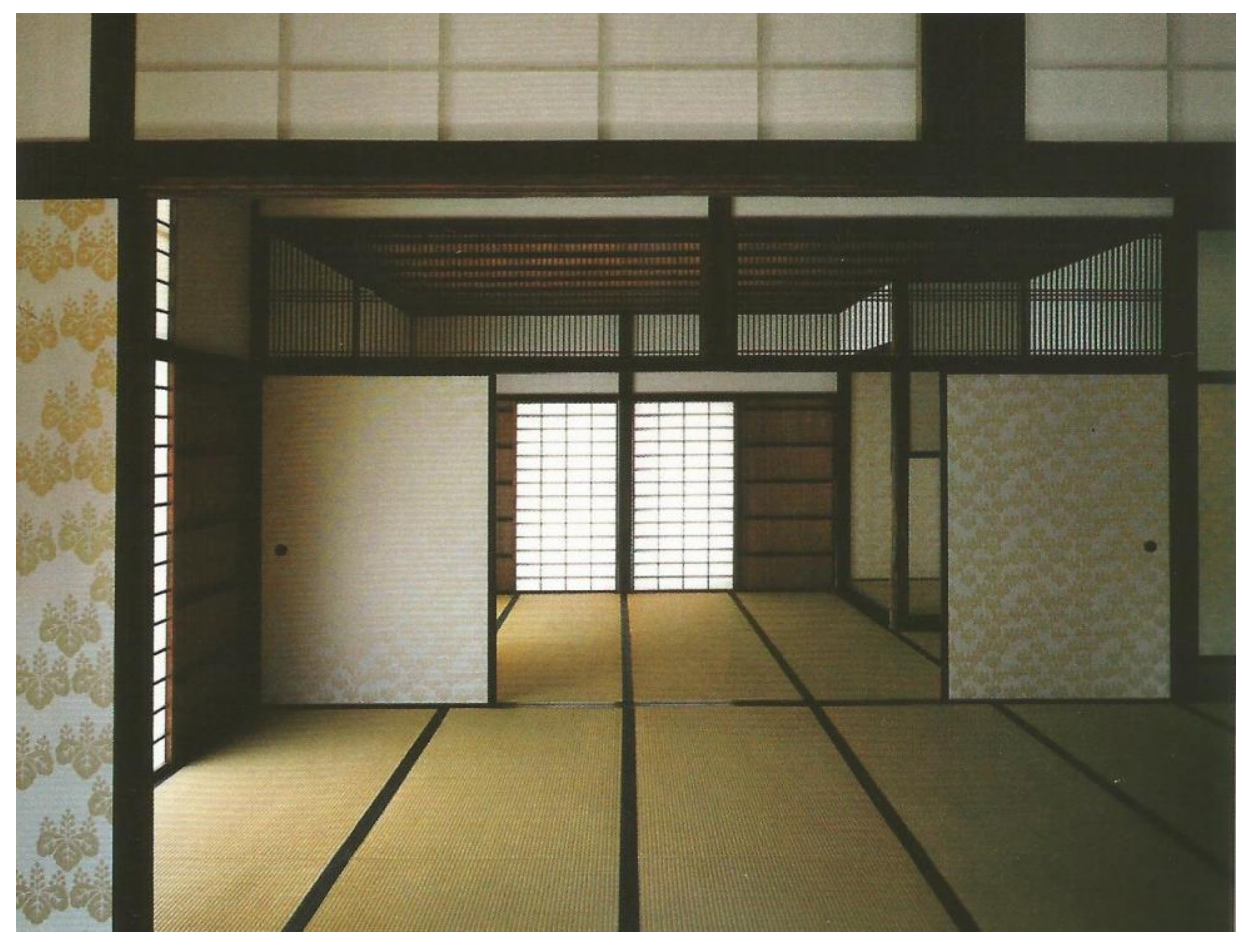

Fig. 6-15. La primera habitación desde la segunda habitación de Koshoin.

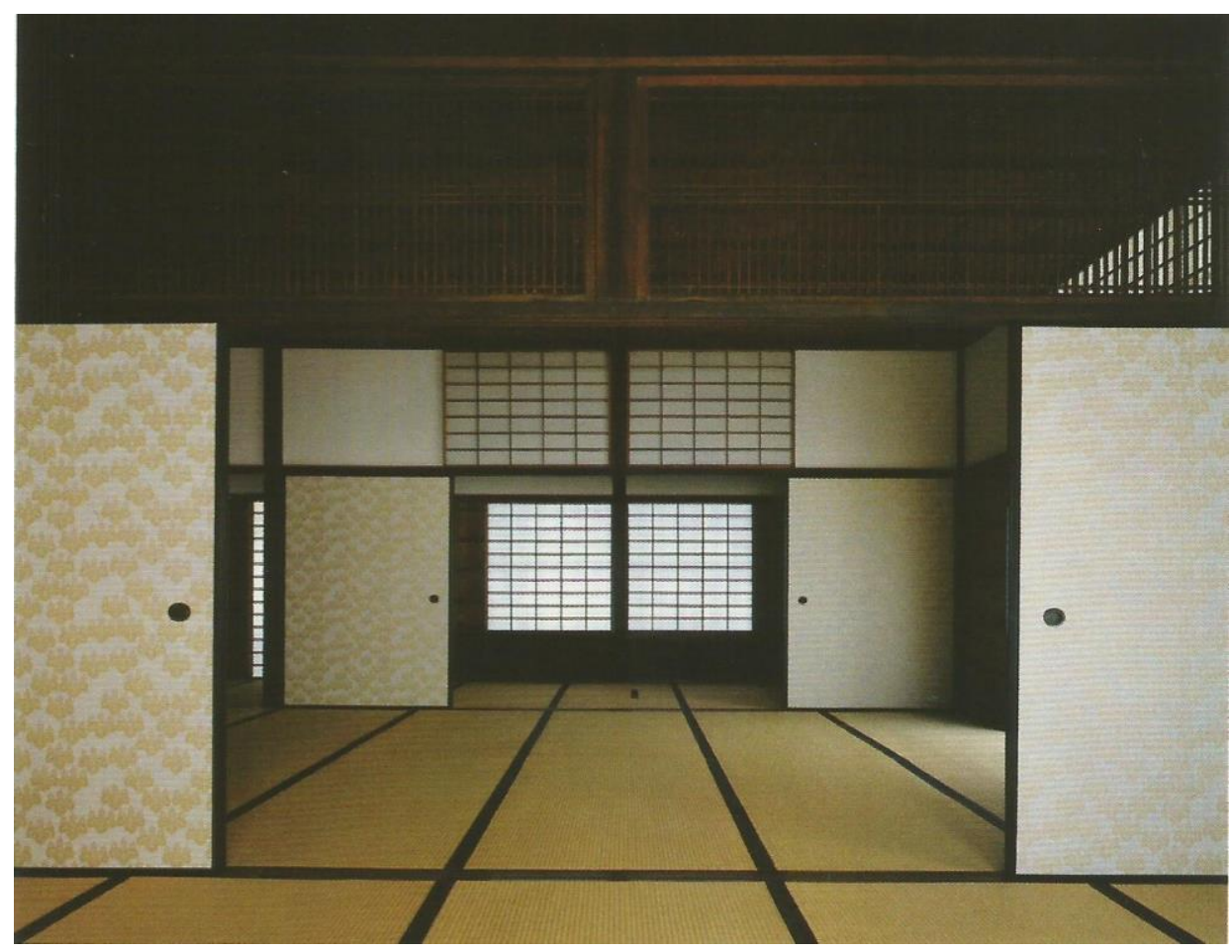

Fig. 6-16. La segunda habitación y la sala de la terraza desde la primera habitación de Koshoin. 


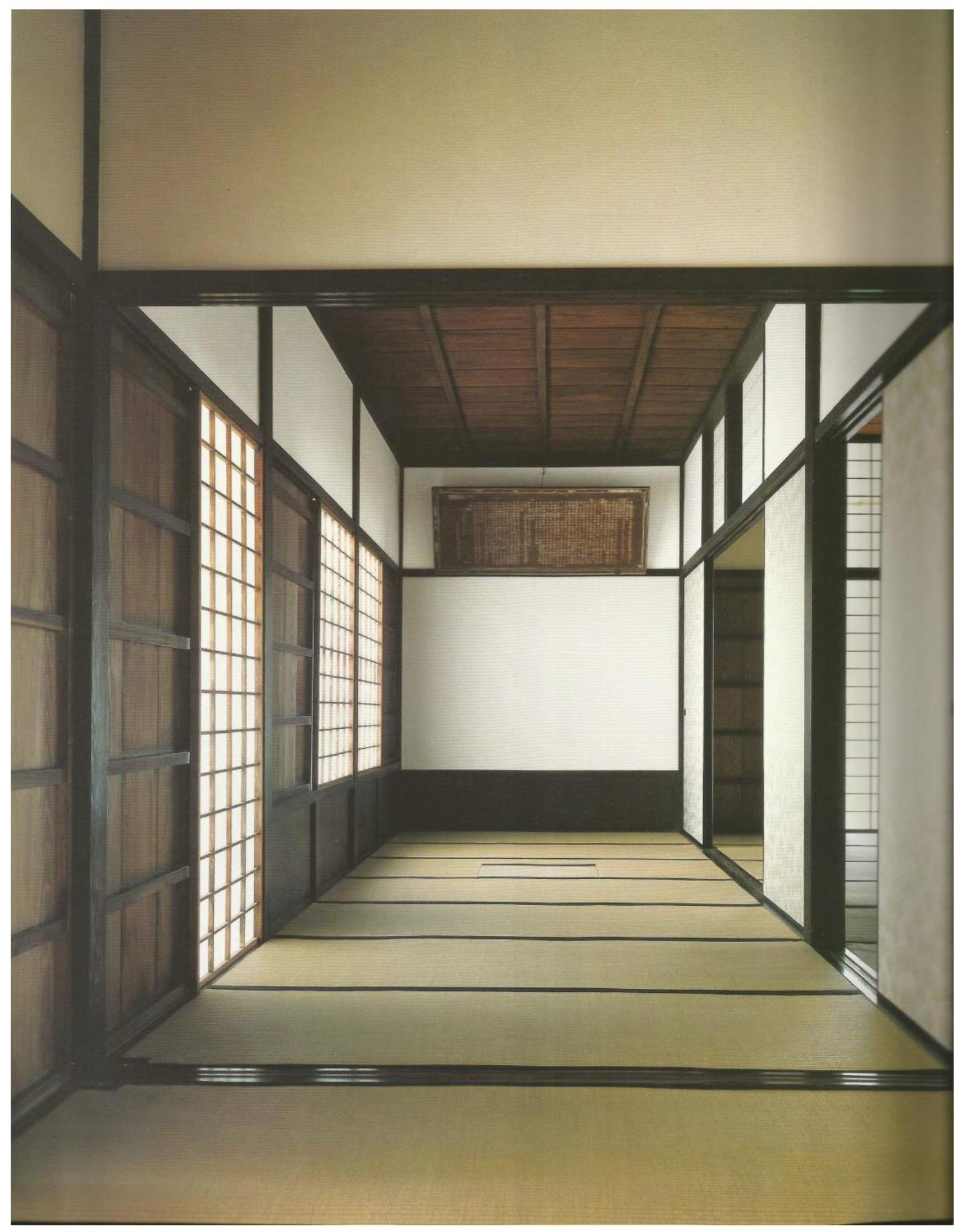

Fig. 6-17. Sala de la terraza de Koshoin. 


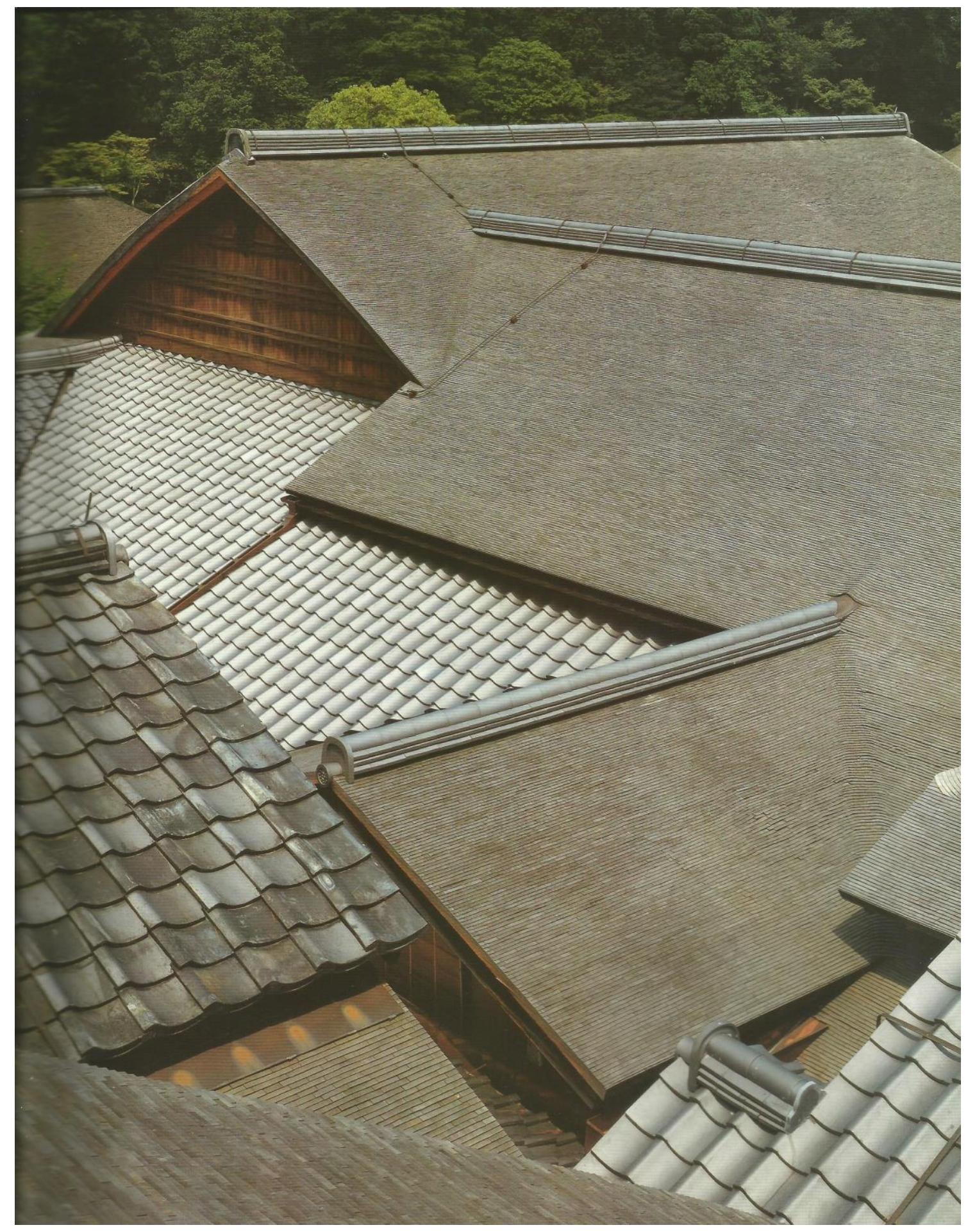

Fig. 6-18. Los techos de Koshoin y Chushoin desde Shingoten. 


\section{Las escenas de Chushoin}

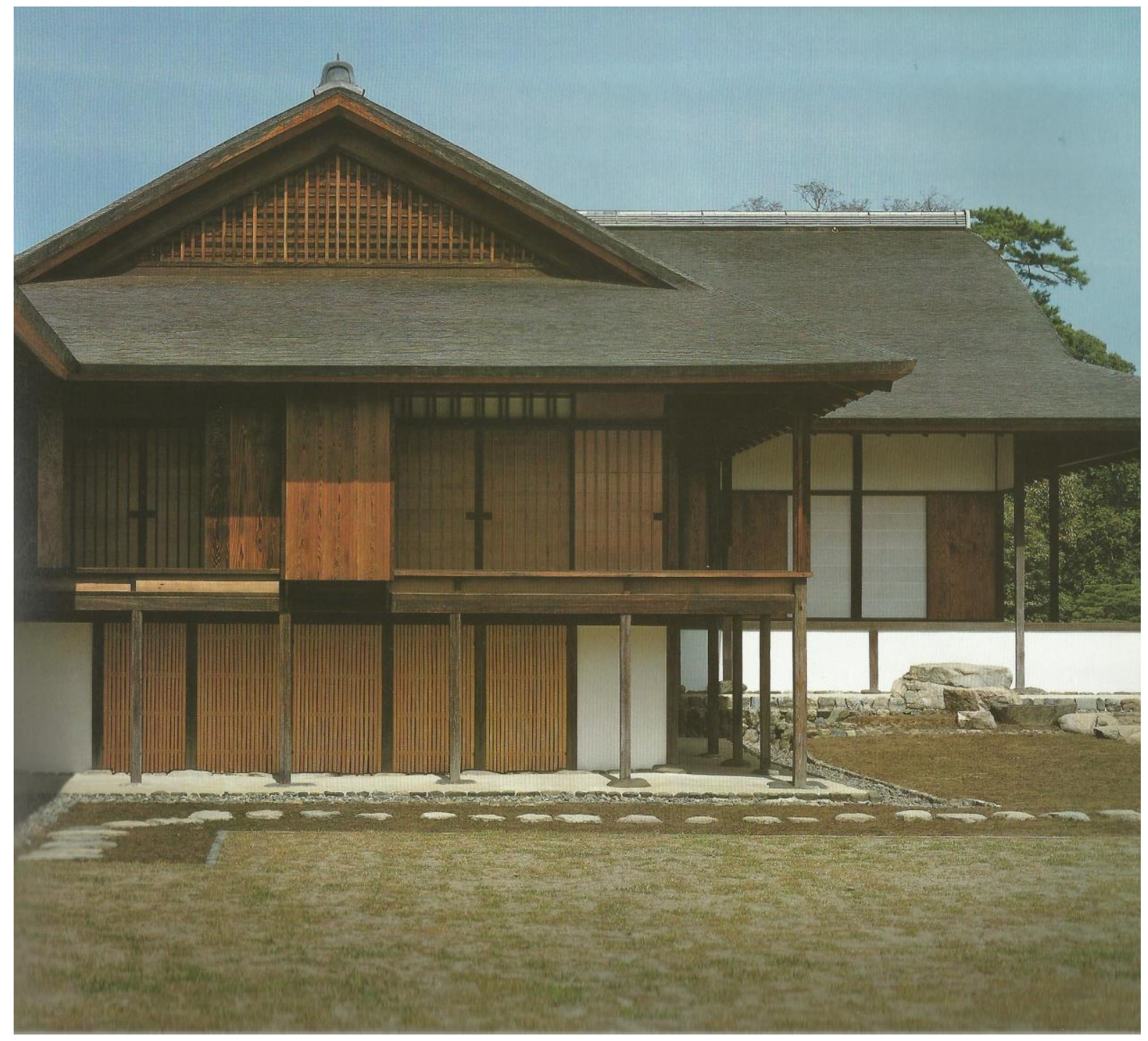

Fig. 6-19. El frente sur de Chushoin. 


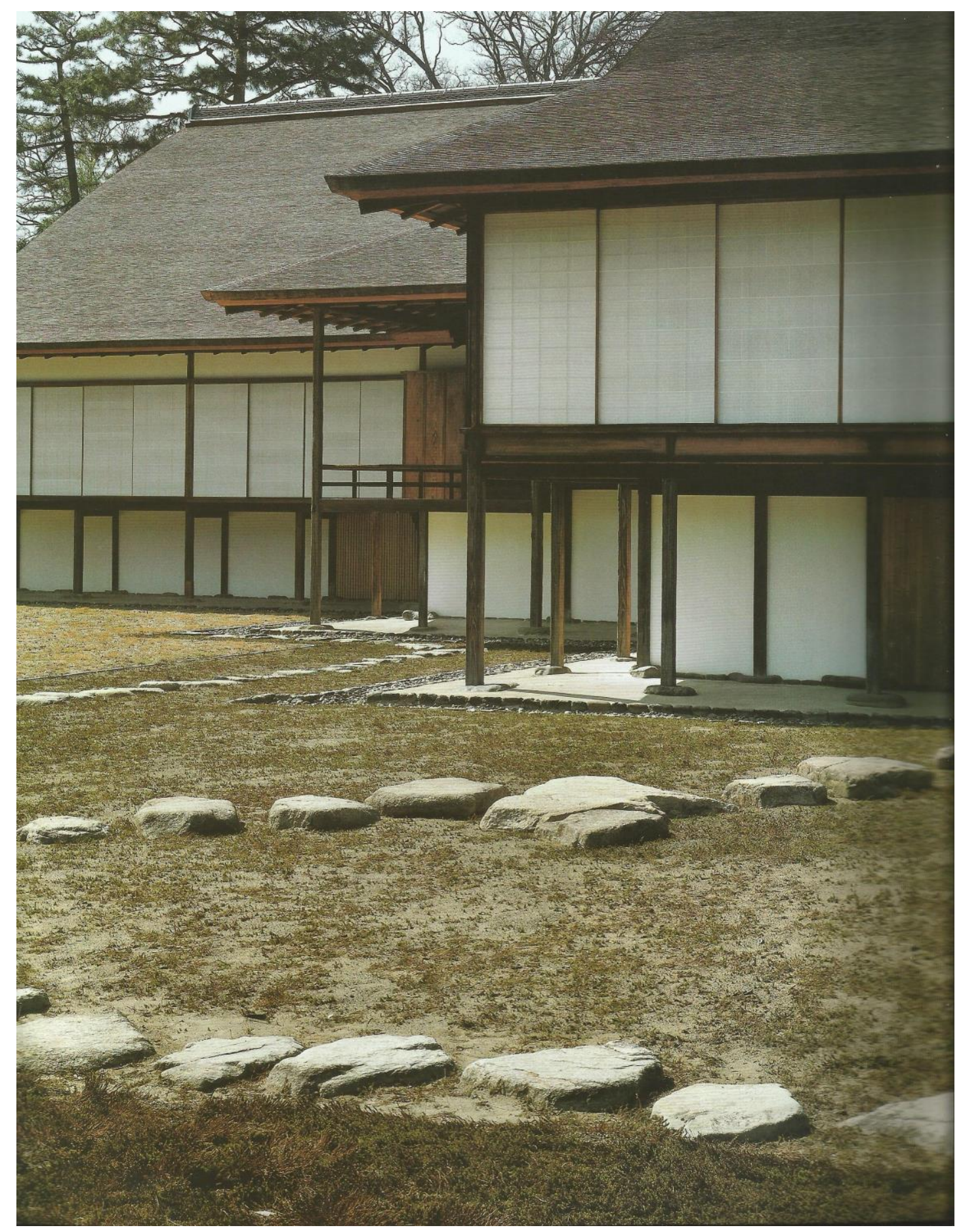

Fig. 6-20. El complejo de Shoin desde el lateral izquierdo, Shingote, Gakkinoma y Chushoin. 


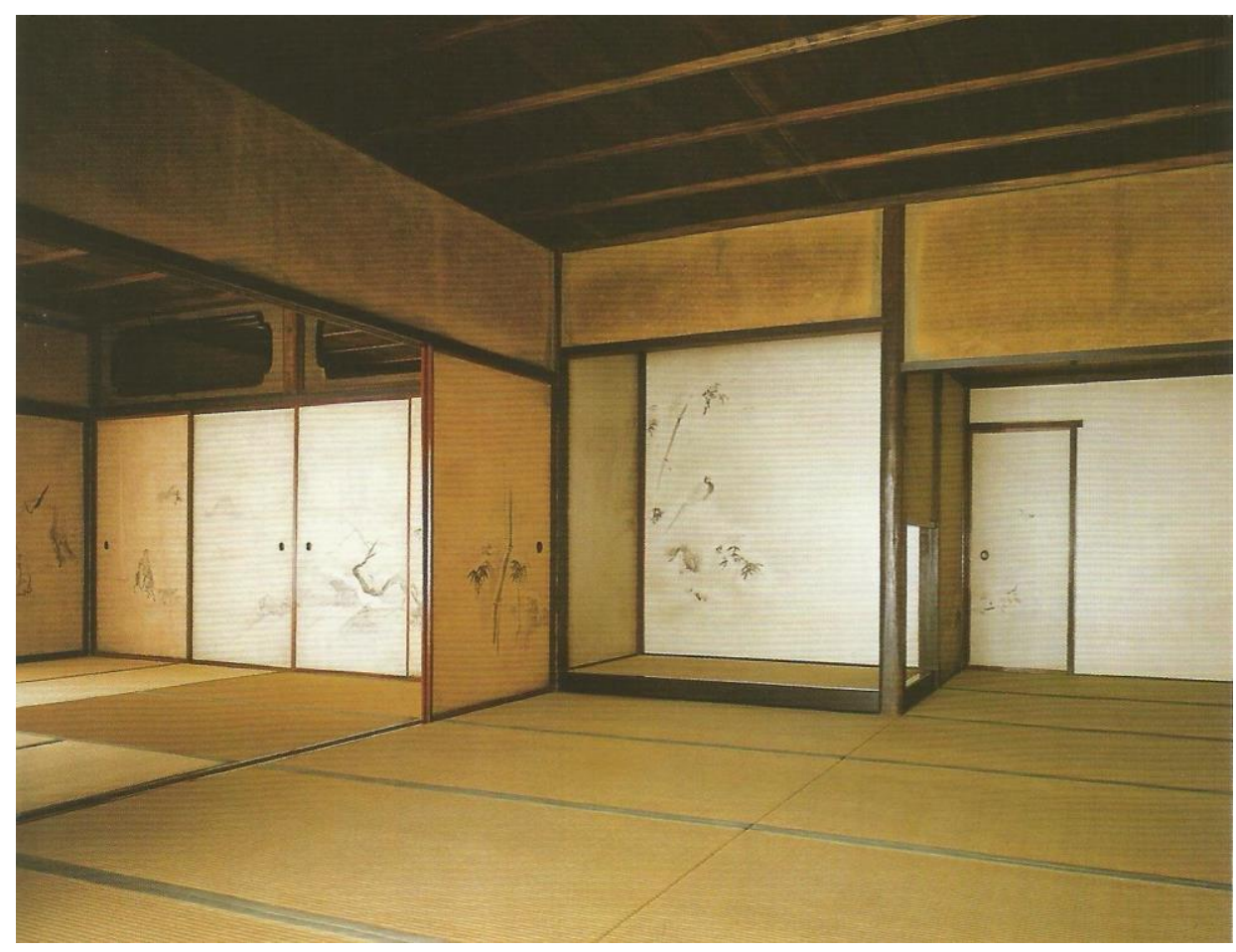

Fig. 6-21. La segunda y tercera habitación de Chushoin.

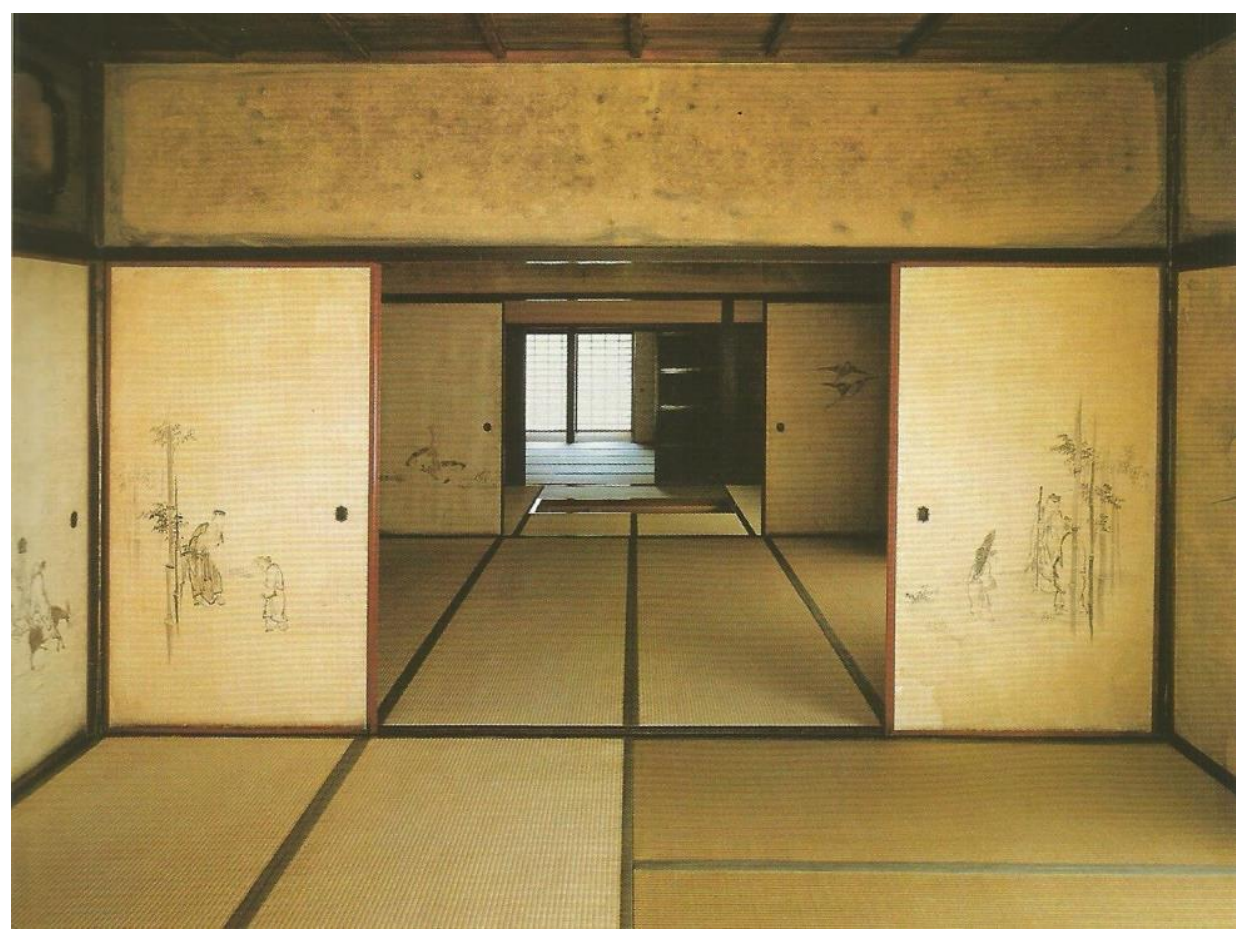

Fig. 6-22. La tercera habitación desde la segunda habitación de Chushoin. 


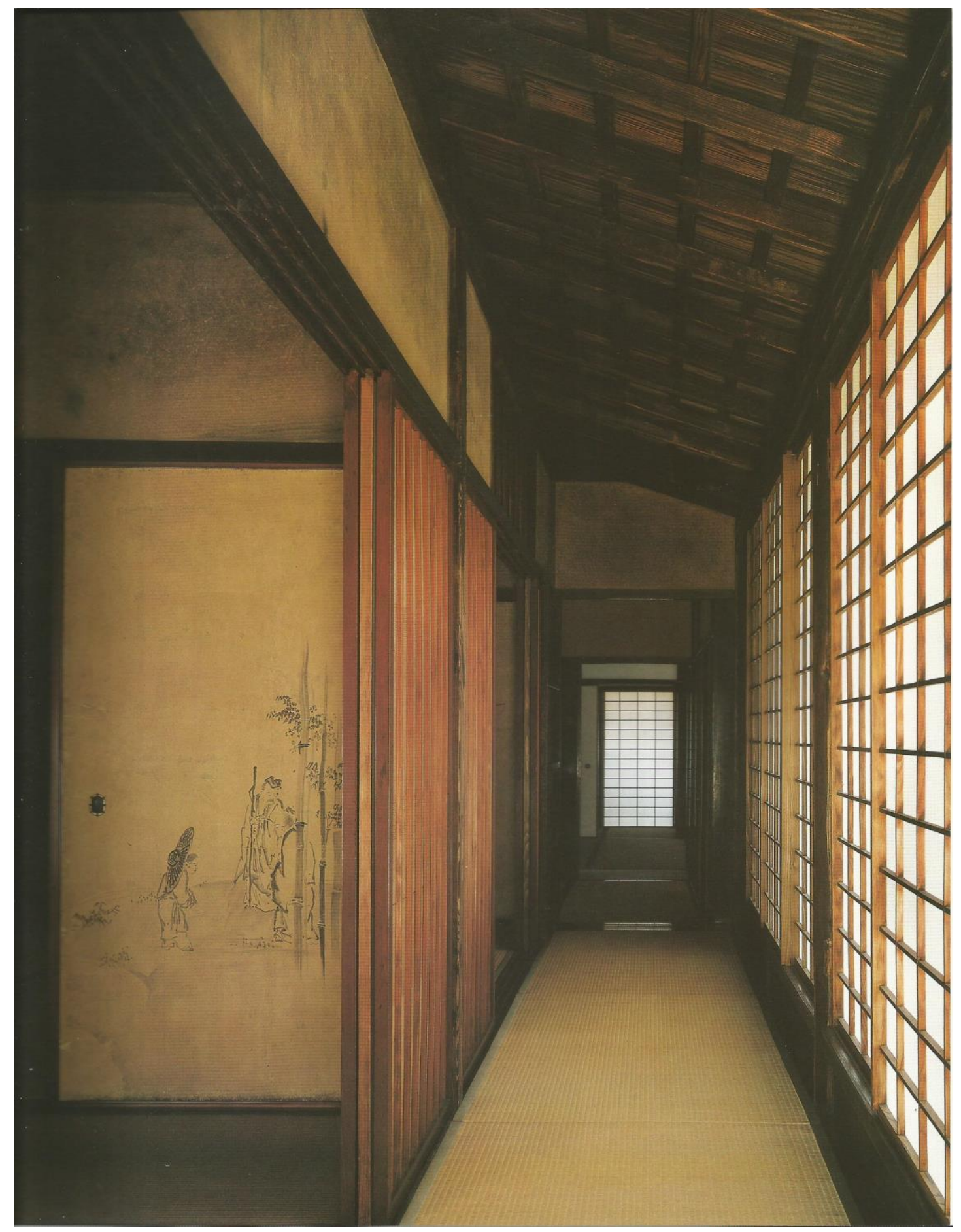

Fig. 6-23. Sala de la terraza cerrada desde el frente al sur de Chushoin. 


\section{Las escenas del Pabellón Musical}

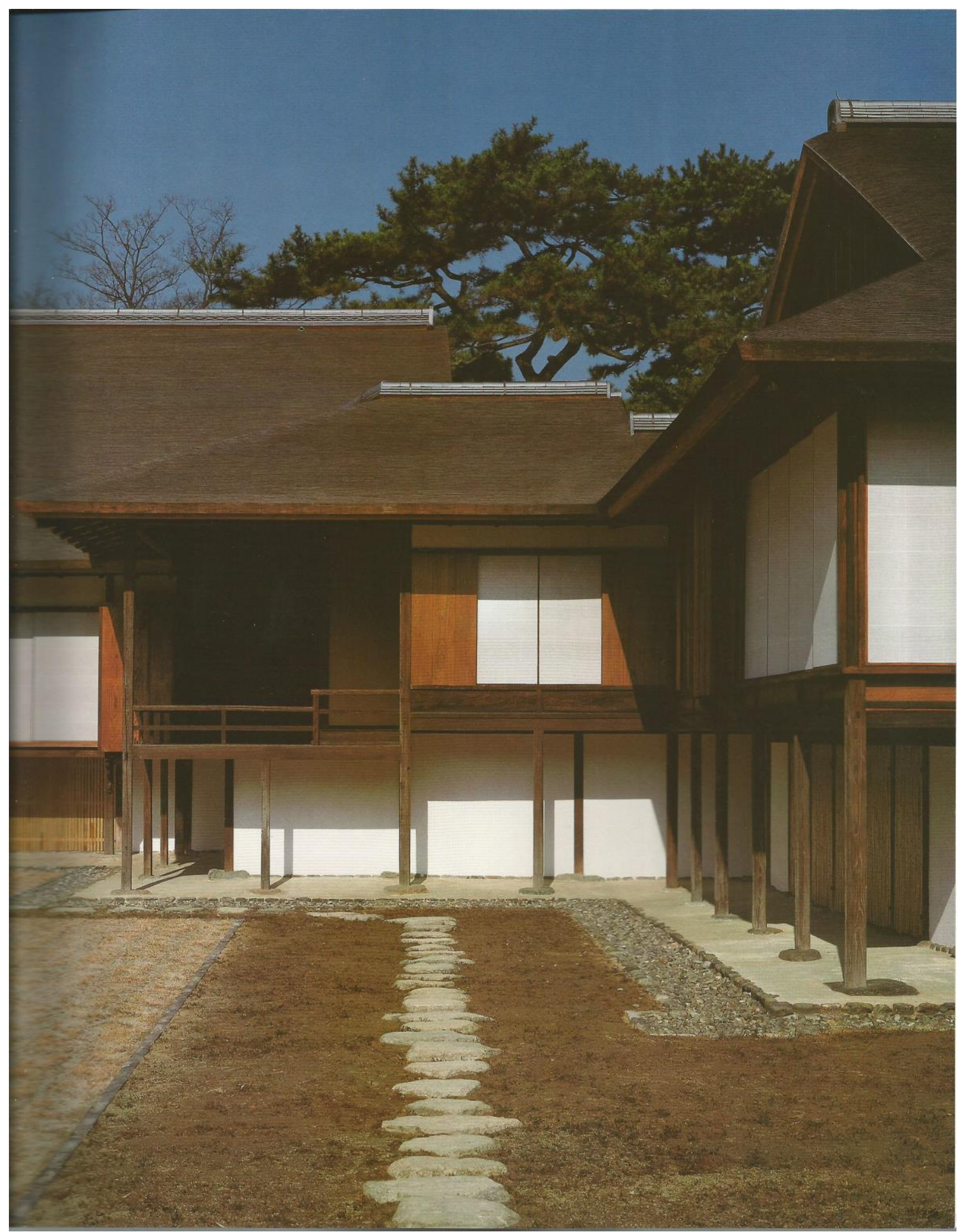

Fig. 6-24. Gakkinoma desde el este. 


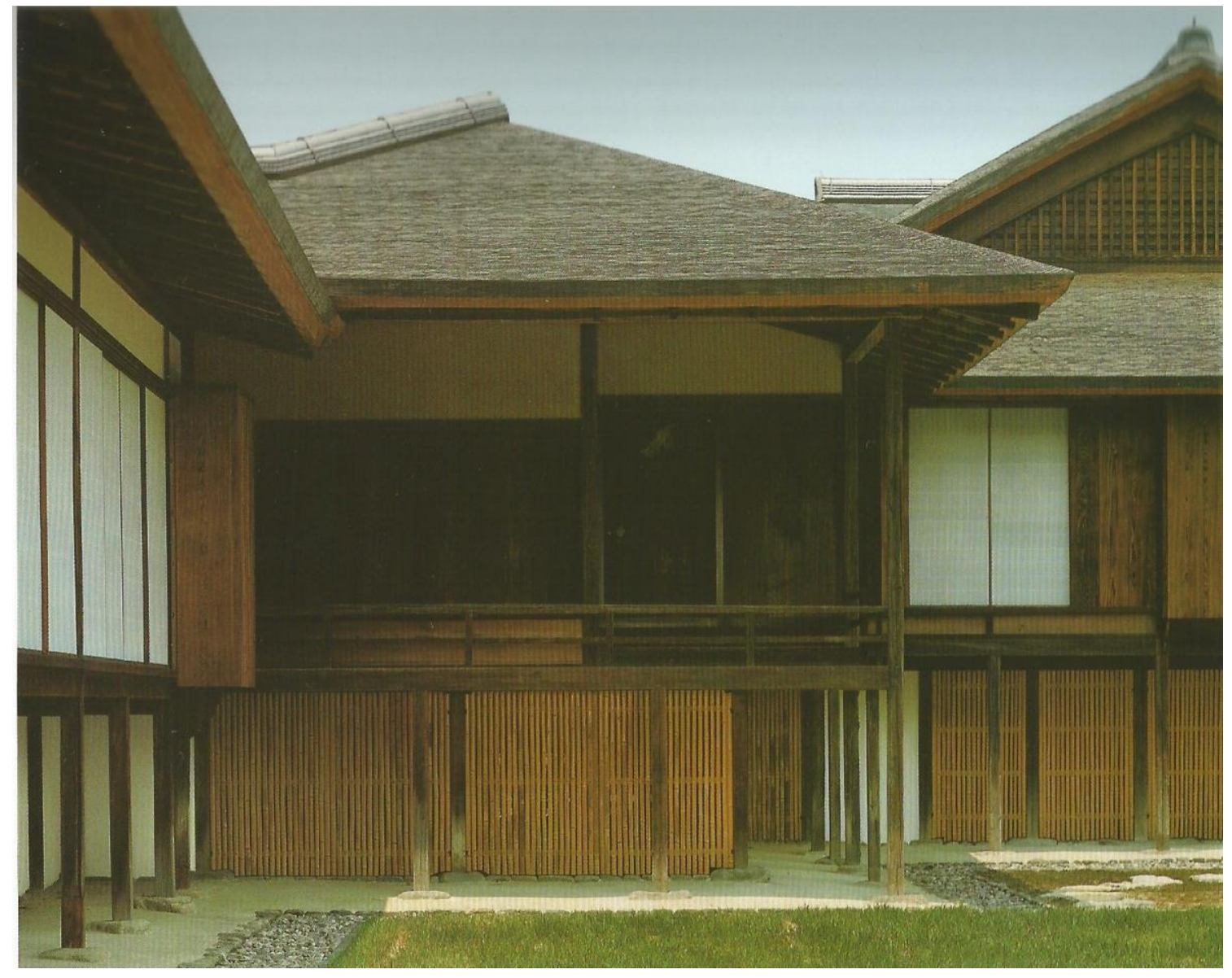

Fig. 6-25. Gakkinoma desde el sur. 


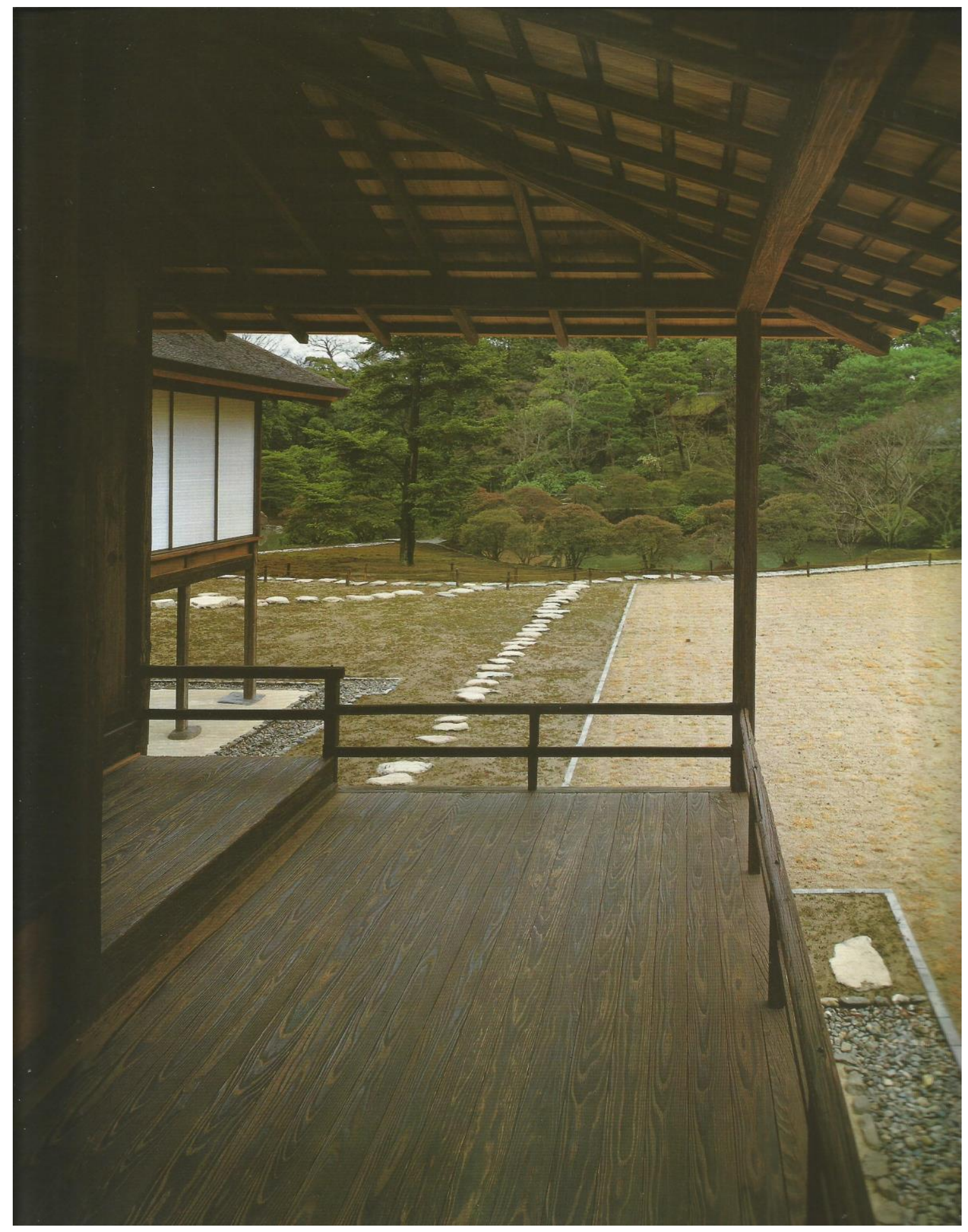

Fig. 6-26. La gran terraza de Gakkinoma. 


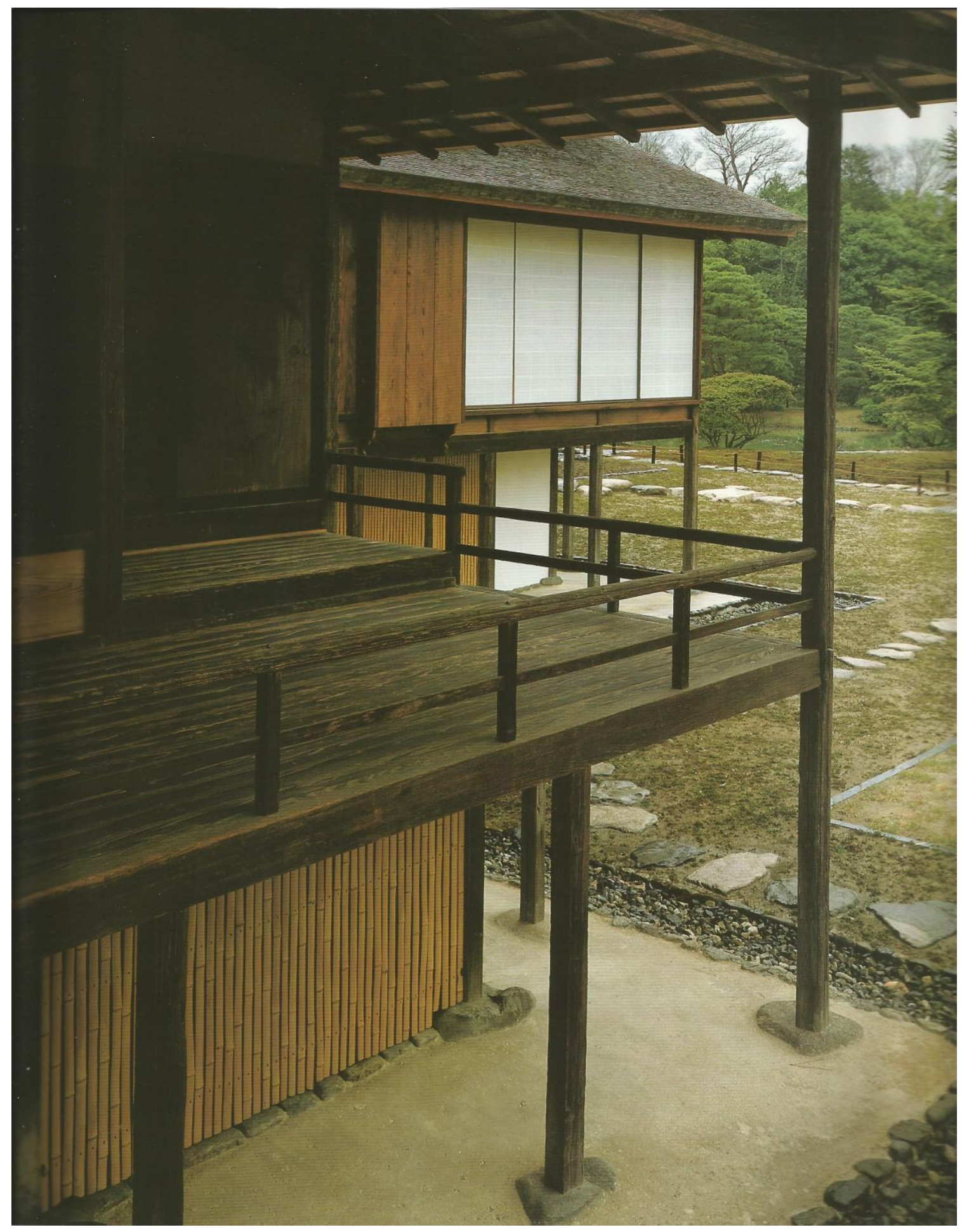

Fig. 6-27. La gran terraza y a la derecha Chushoin. 


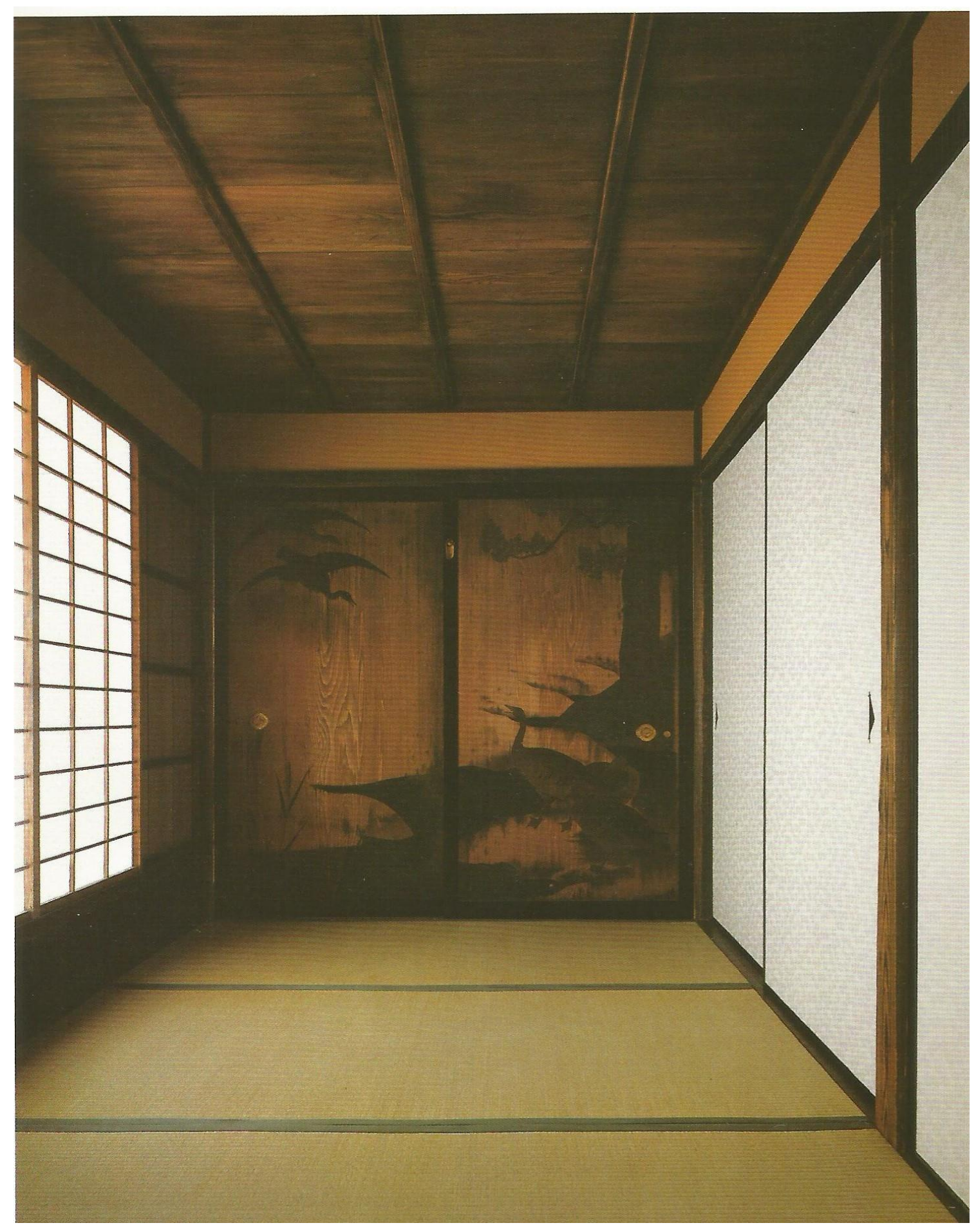

Fig. 6-28. Sala de la terraza de Gakkinoma. 


\section{Las escenas de Shingoten}

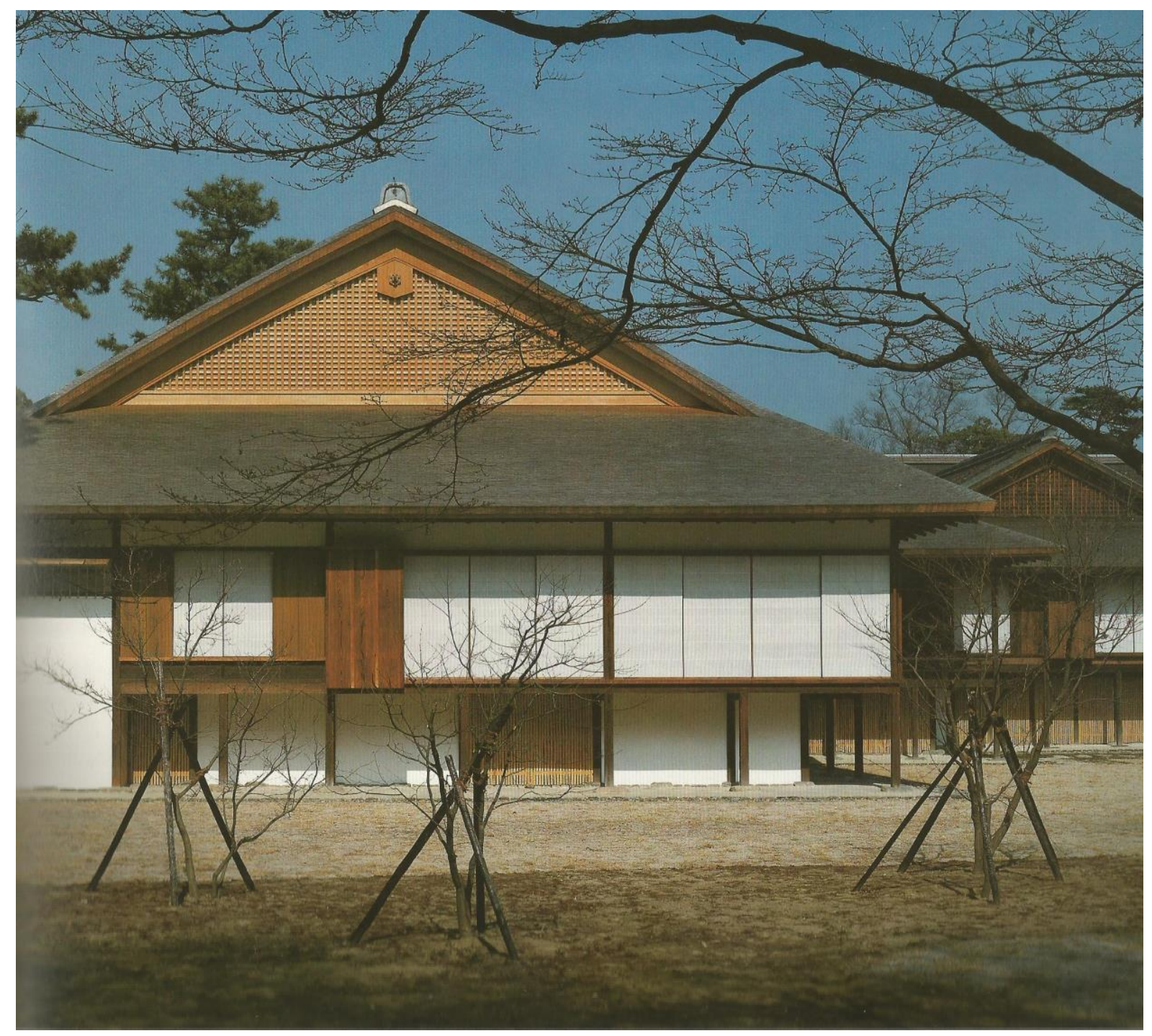

Fig. 6-29. El frente sur de Shingoten. 


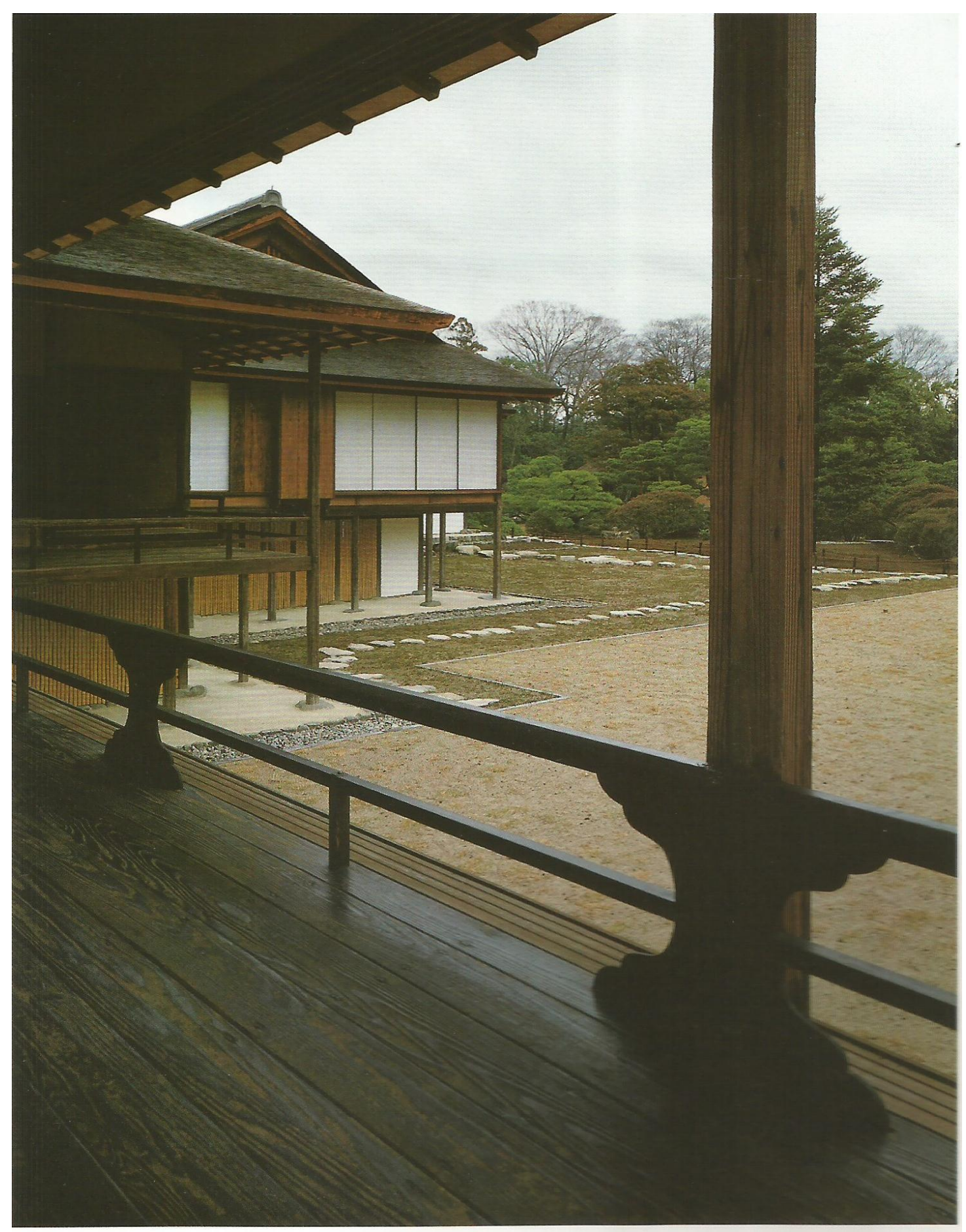

Fig. 6-30. Gakkinoma y Chushoin desde la terraza de Shigoten. 


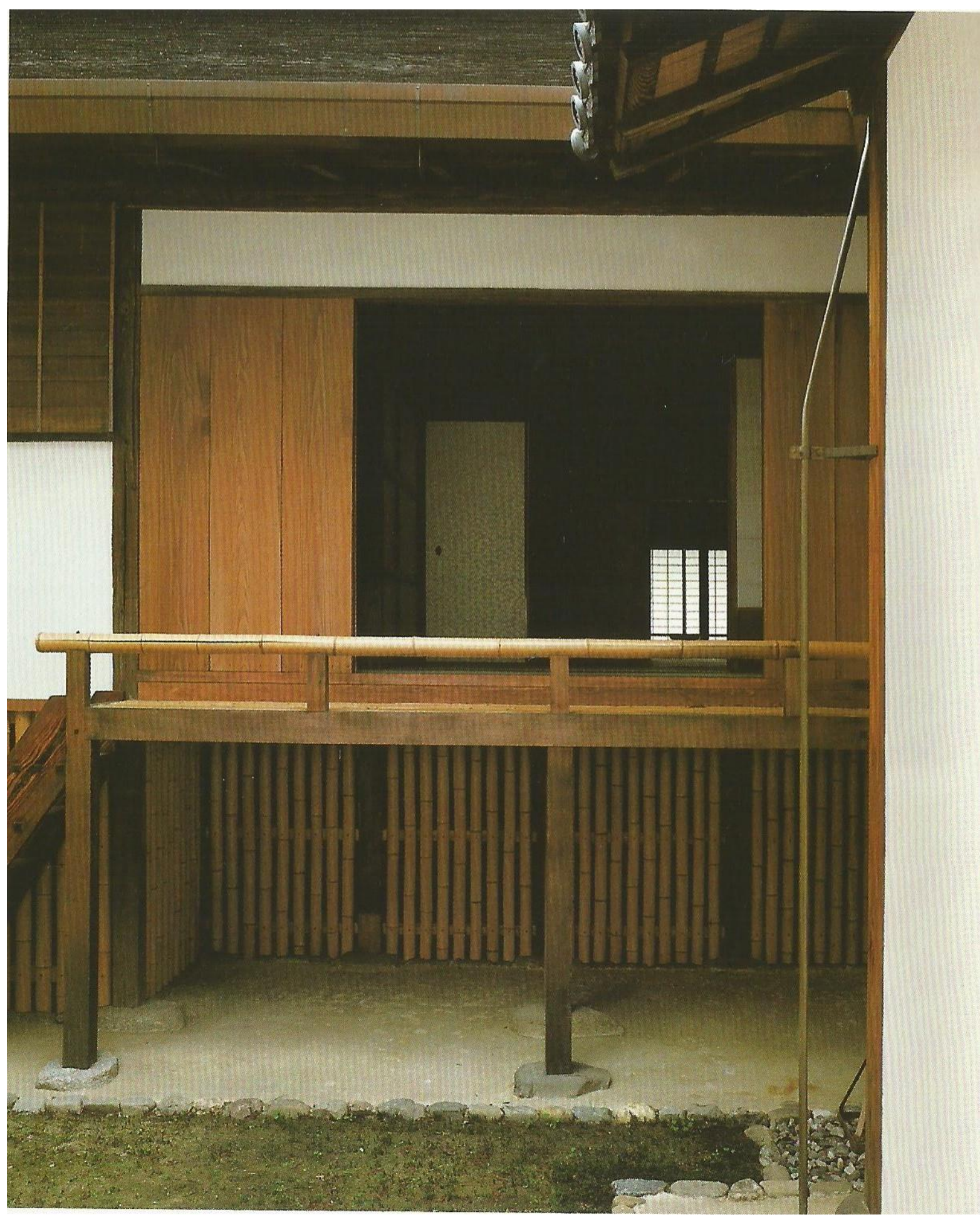

Fig. 6-31. Detrás de Shingoten. 


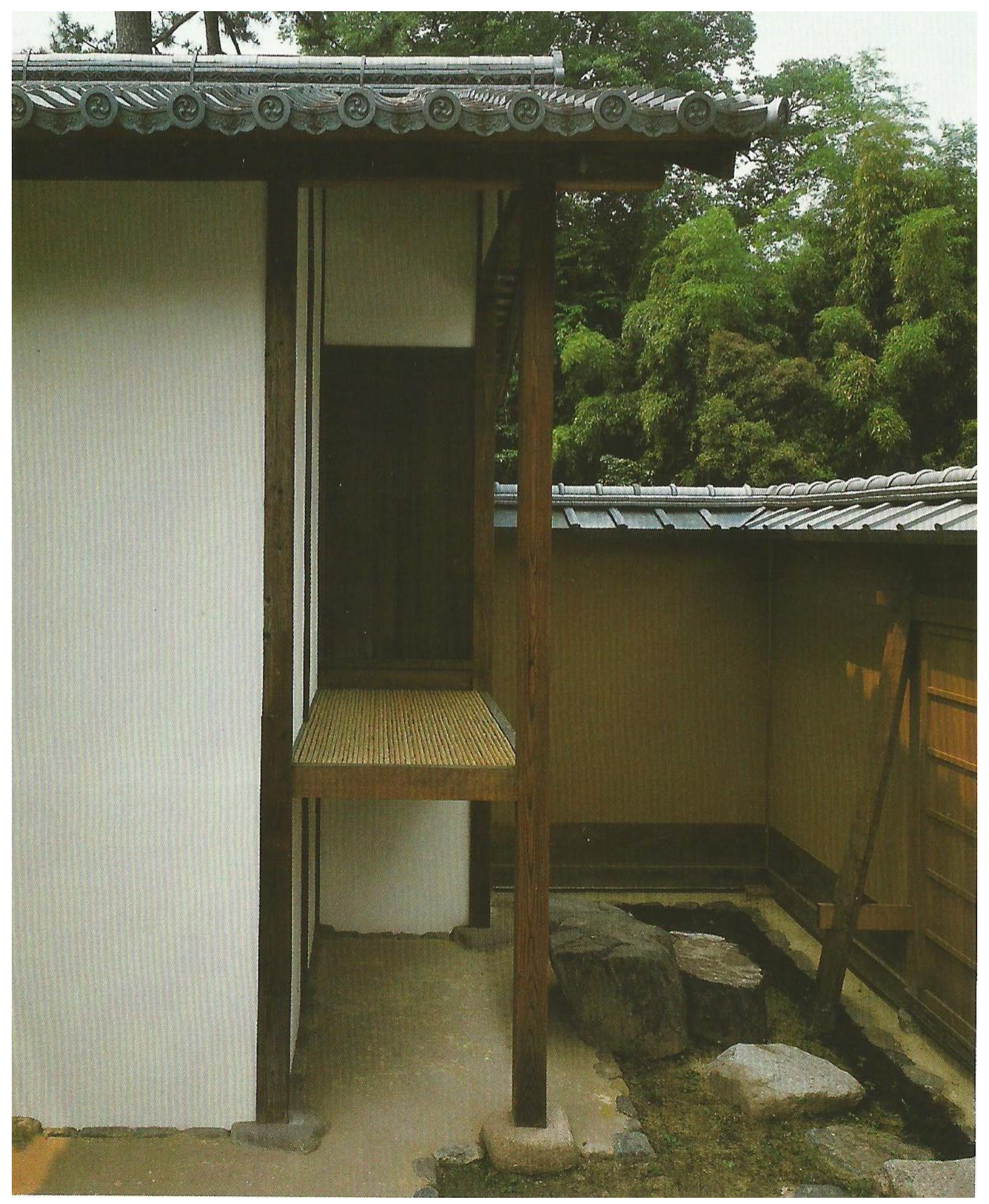

Fig. 6-32. El patio oeste de Shingoten. 


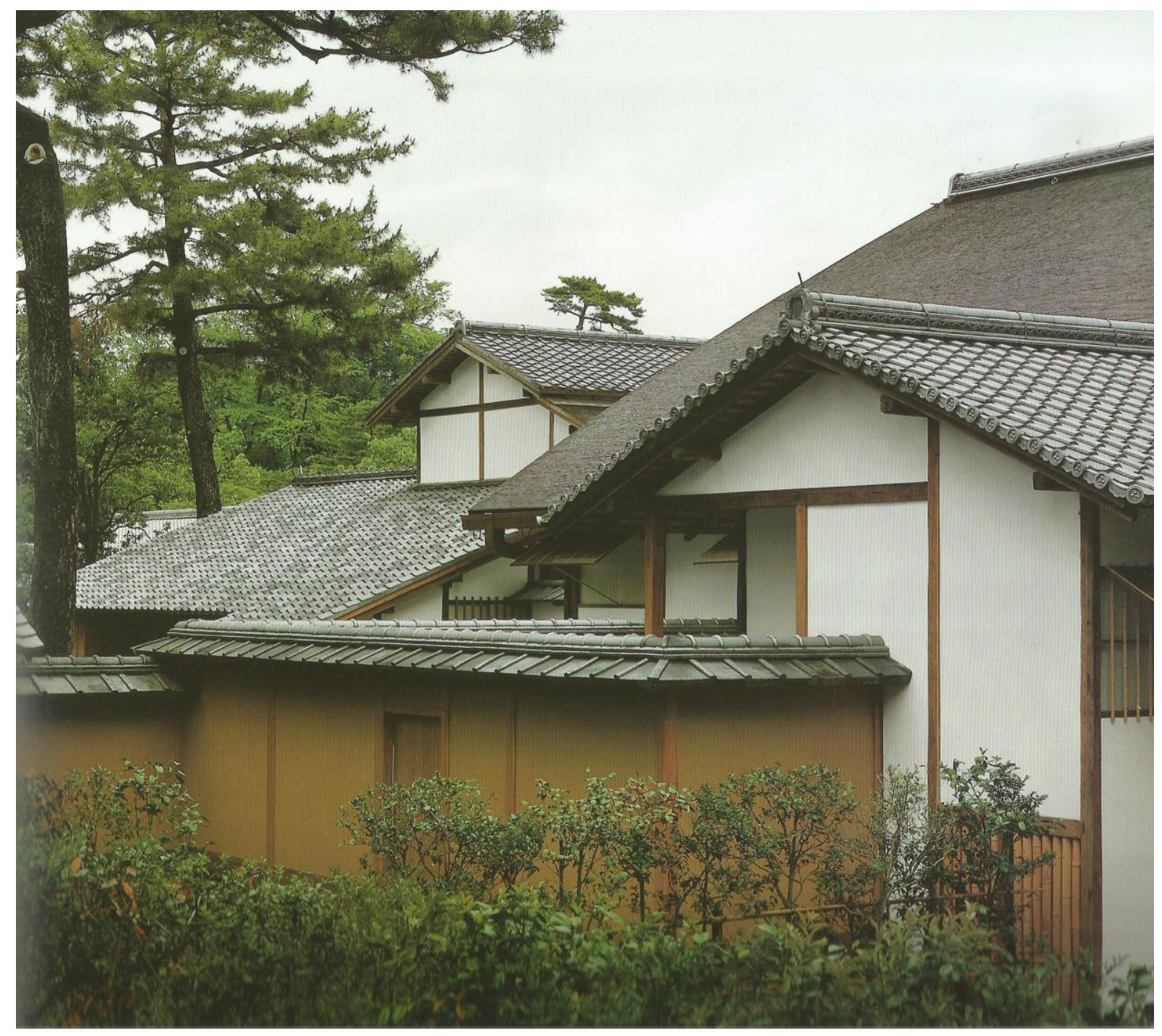

Fig. 6-33. El techo de Shingoten. 


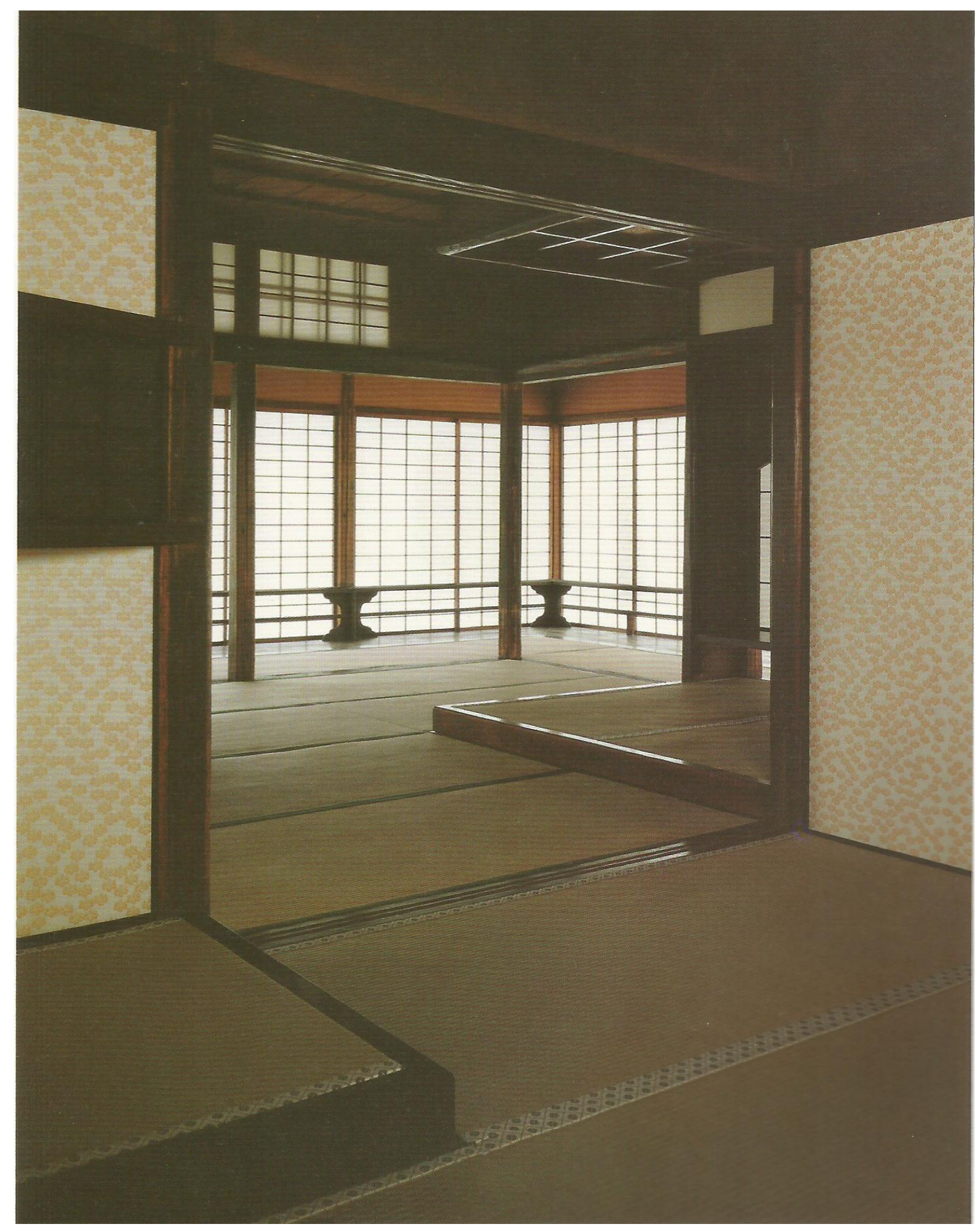

Fig. 6-34. La esquina sureste de la terraza cerrada de Shingote. 


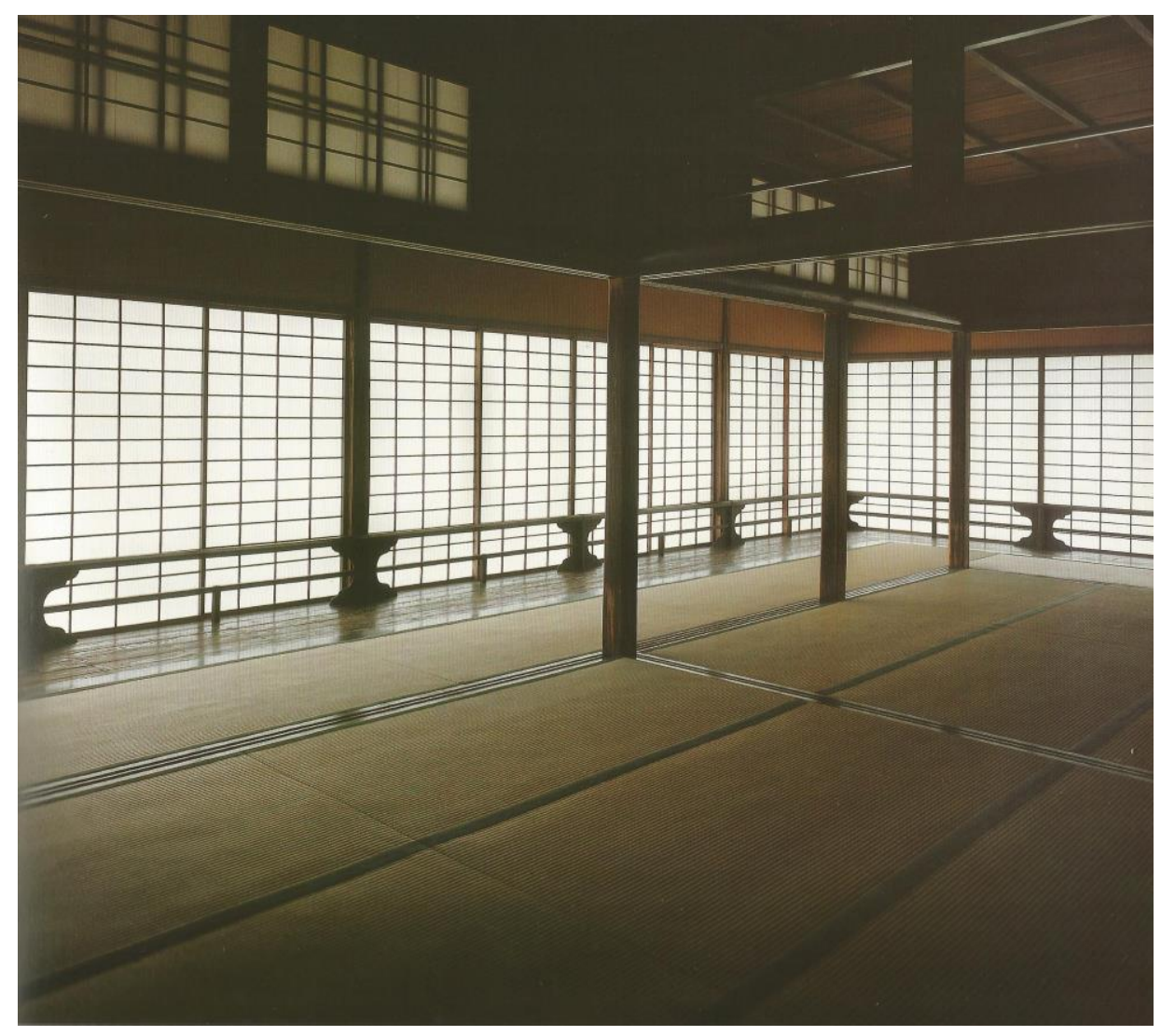

Fig. 6-35. La terraza cerrada desde la primera y segunda habitación de Shingoten.

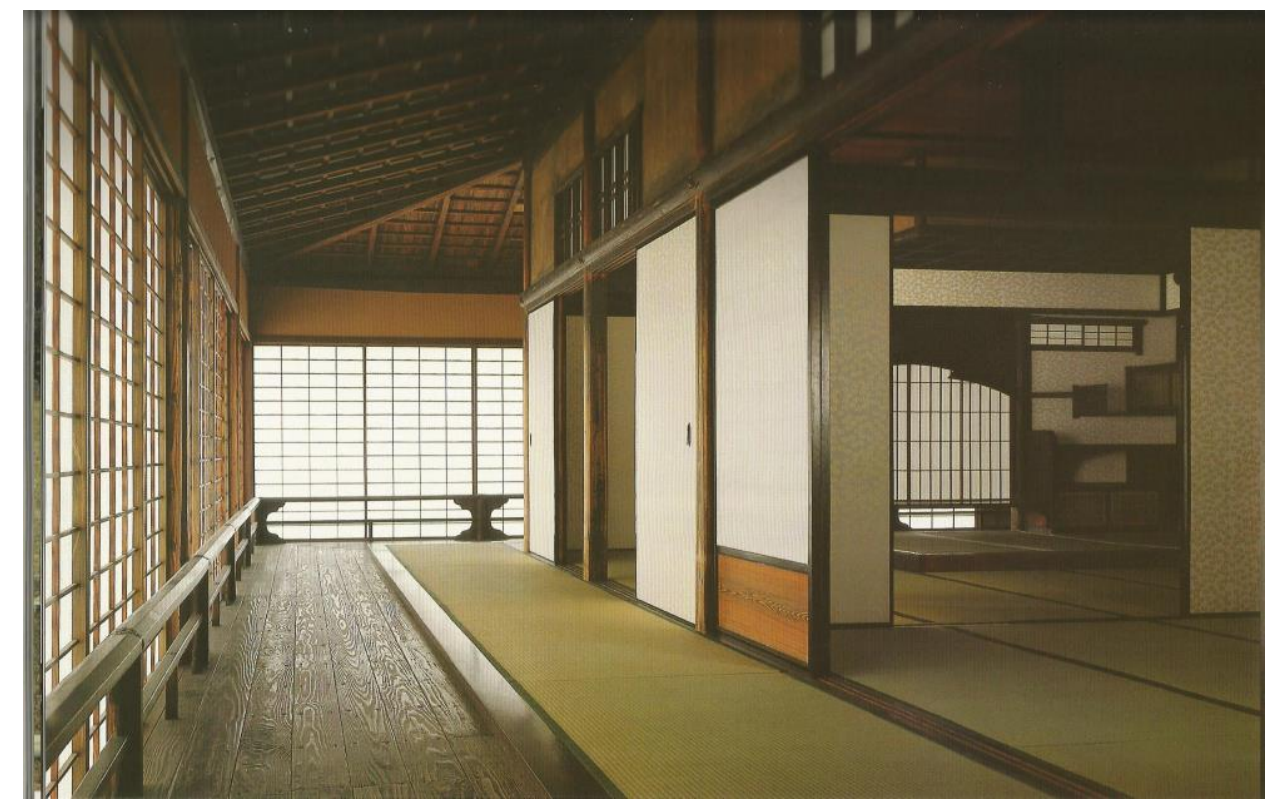

Fig. 6-36. La primera y segunda habitación de Shingoten desde la terraza cerrada. 


\section{Una interpretación nirvánica de Katsura}

Después de llegar el Rey a la villa de Katsura, primero paseó por el jardín y tomo el té en la casa de té (v.-figs. 6-37, 38, 39, 40, 43). Eso es como un juego ritual, en realidad, en Japón, cuando alguna persona noble actúa de alguna manera, se expresa con el verbo <<jugar >> juntos. Por ejemplo, si un rey hubiera llegado a un restaurante, se expresaría como $<<$ el rey ha jugado a llegar a un restaurante $>>$. Los nobles incesantemente jugaban a ese tipo de juego de ir y volver entre dos campos de realidad y juego. Así intentaron entrar a un orden superior por medio de la cultura del zen y del té. ${ }^{20}$

Si dijéramos que Siddhartha tuvo un árbol frondoso que le ofreció buena sombra durante el día, la luna llena le habría dado un ambiente dramático y solemne ${ }^{21}$; así los Hachijos tenían las casas de té como Gepparo, Tsukimidai y el juego de paseo en barco. Aparte del propósito básico del hábitat, los palacios y los jardines, nunca podrían interpretarse sin referirse a la cultura zen. Aún parecería razonable que alguien dijese que los dormitorios existen para dormir bien y el dormir bien es para hacer el zen bien. Parece que el palacio existe principalmente para la vida zen, considerando las otras funciones del palacio como periféricas. Prácticamente, lo que el rey hizo todo el día después de llegar al palacio es despreciable. Sin embargo, el grupo de paseo con el que el rey iba, dedicó su tiempo en cantidad considerable, y enseña el cuento que pretendieron cumplir todos los procesos del paseo, y cuando tuvieron que cancelar el turno para el juego del barco, no lo consideraron como si fuera una mera omisión de un proceso insignificante. ${ }^{22}$ El ambiente afecta a los paseantes independientemente a cada uno, en cada proceso de los sentenciosos rituales, en las naturalezas artificiales, en el barco en el río Katsura, en las perspectivas que se acercan y en las que se alejan, en varias escenas superpuestas (formación Ganko) de Koshoin, Chushoin y Shingoten, mezclando indistintamente sus particulares experiencias y el estado de los paseantes. Al final el ambiente total se convierte en un aparato de zen. De todas formas, como Siddhartha, antes de adquirir la gran iluminación practicaba la técnica de la meditación, una cultura buddhista que, necesariamente, contiene los elementos del zen. Lo que aprendió Siddhartha desde los maestros de la ciudad Rajagarha, la capital del Reino de

\footnotetext{
20 Huizinga, J. v.o.1938. Homo ludens. Imaz, E.(tr) Madrid. Alianza Editorial, S. A. 2012. p. 33.

21 Siddhartha ya estaba viajando durante seis años buscando el nirvana, practicando varias disciplinas bajo el control de varios maestros en las escuelas de pensamiento religioso. Según la leyenda, salió desde su casa cuando tenía 29 años y encontró la verdad última cuando tuvo 35. Para más información, v- <<Vidal, C. Buddha El Príncipe. Madrid. Rotapapel, S.L.. 2011>>

22 AAVV. Katsura: Imperial Villa. New York. Phaidon Press Ltd. 2011. p. 27.
} 
Magadha, fue la metodología que le hace poder alcanzar $a<<u n$ lugar en el que nada existe $>>$ y $<<u n$ lugar donde no hay ni pensamiento ni no-pensamiento >>.23

La meditación y el zen son conceptos parecidos y fáciles de confundir. Mediante una importación de los contenidos culturales sin bastante contemplación del contexto cultural, fácilmente se suele generar un contenido superficial y falso. O sea, con una postura de loto en un cuarto, de pantalla fusuma y suelo de tatami o un jardín pacífico con una fuente artificial, no pueden directamente capturar el concepto llamado zen. Básicamente, se entiende que la cultura zen influyó en la acción ética del buddhismo clásico, a través de un camino de cultivo espiritual gradual (v.-figs. 6-41, 42). Por eso, prácticamente, cuando se refiere al zen, la mayor parte del discurso se ubica en el campo ético. ${ }^{24}$ Por ejemplo, alegando no matar o tener misericordia o compasión de otra vida, así se enfatiza un estándar moral. Y esto sería el elemento que diferencia la meditación y el zen, en la medida en que el zen pretende despertar a las personas para superar la materialidad del mundo por medio de una perspectiva ética. La cultura zen enseña su peculiar fetichismo inherente sobre la naturaleza en Katsura cuyo jardín está meticulosamente formado por una naturaleza artificial. Al final dicho fetiche sobre las pequeñas naturalezas artificiales y la postura ética para superar las materialidades de los mortales (los dharmas) son ciertos criterios que distinguen el zen y la meditación. No se intenta discriminar la definición de la meditación, sino que merece destacar solamente que el concepto llamado zen pertenece a los campos epistemológicos muy profundos, mucho más de lo que se imagina habitualmente, y con muy ricos sentidos. Ahora bien, el superar las materialidades (el despertar del sentido de los dharmas, o sea el Nirvana) tendría que satisfacer una condición de que dicho despertar o nirvana ha de empezarse en el mundo al que se pertenece, lógicamente. $Y$ una miniatura de dicho mundo fue el jardín de Katsura.

Como Siddhartha tenía una pequeña sombra del árbol pipal, los japoneses tenían este jardín artificial como una miniatura de la naturaleza. Gepparo era para observar y admirar tranquilamente la hermosa luna llena, y encontrar otra luna en el reflejo del río. Reconociendo el cambio del clima y el transcurso

\footnotetext{
23 Vidal, C. Buddha El Príncipe. Madrid. Rotapapel, S.L.. 2011. pp. 65-65,

${ }^{24}$ Harvey, P. An Introduction to Buddhist Ethics: Foundations, Values and Issues. Cambridge. Cambridge University Press. 2000. p. 143
} 
del tiempo, contemplando las fórmulas de las Cuatros Nobles Verdades (4NV), habrían llegado a momentos de iluminación en la vida humana. Los procesos del paseo condujeron a los paseantes a sustituir los sujetos (incluso a sí mismos) a los dharmas, incesantemente (v.-figs. 6-44, 45, 46). Luego, habrían creído que podrían superar las materialidades de los dharmas perdiéndose a sí mismos $\left(\mathbf{N Y}^{25}\right)$, y encontrarían otra verdad del nirvana, en este solemne y humilde jardín del rey.

Estudiar el Buddha-camino es estudiar el yo.

Estudiar el yo es olvidar el yo.

Olvidar el yo es ser iluminado por los diez mil dharmas. ${ }^{26}$

Dogen.

${ }^{25}$ No-yo-(NdA)

${ }^{26}$ Harvey, P. An Introduction to Buddhist Ethics: Foundations, Values and Issues. Cambridge. Cambridge University Press. 2000. p. 144 


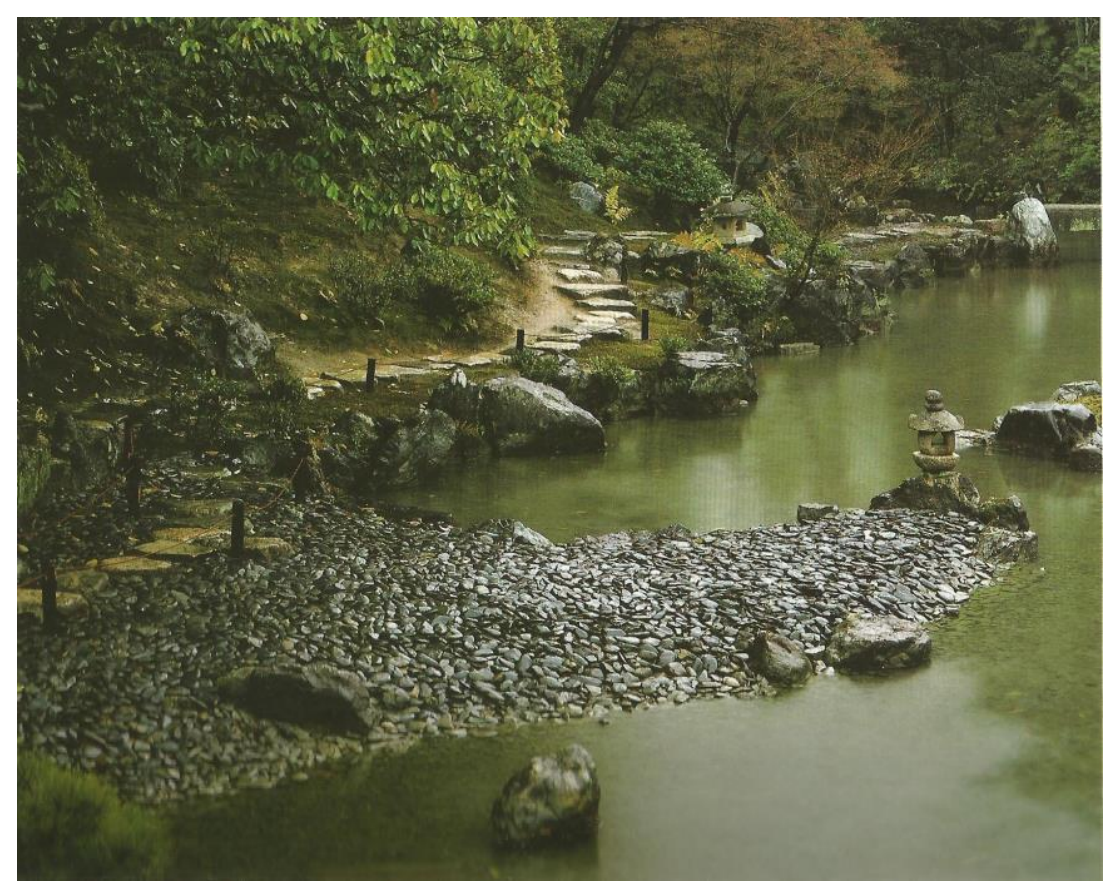

Fig. 6-37. Camino del río y camino a Shokintei que es la casa de té.

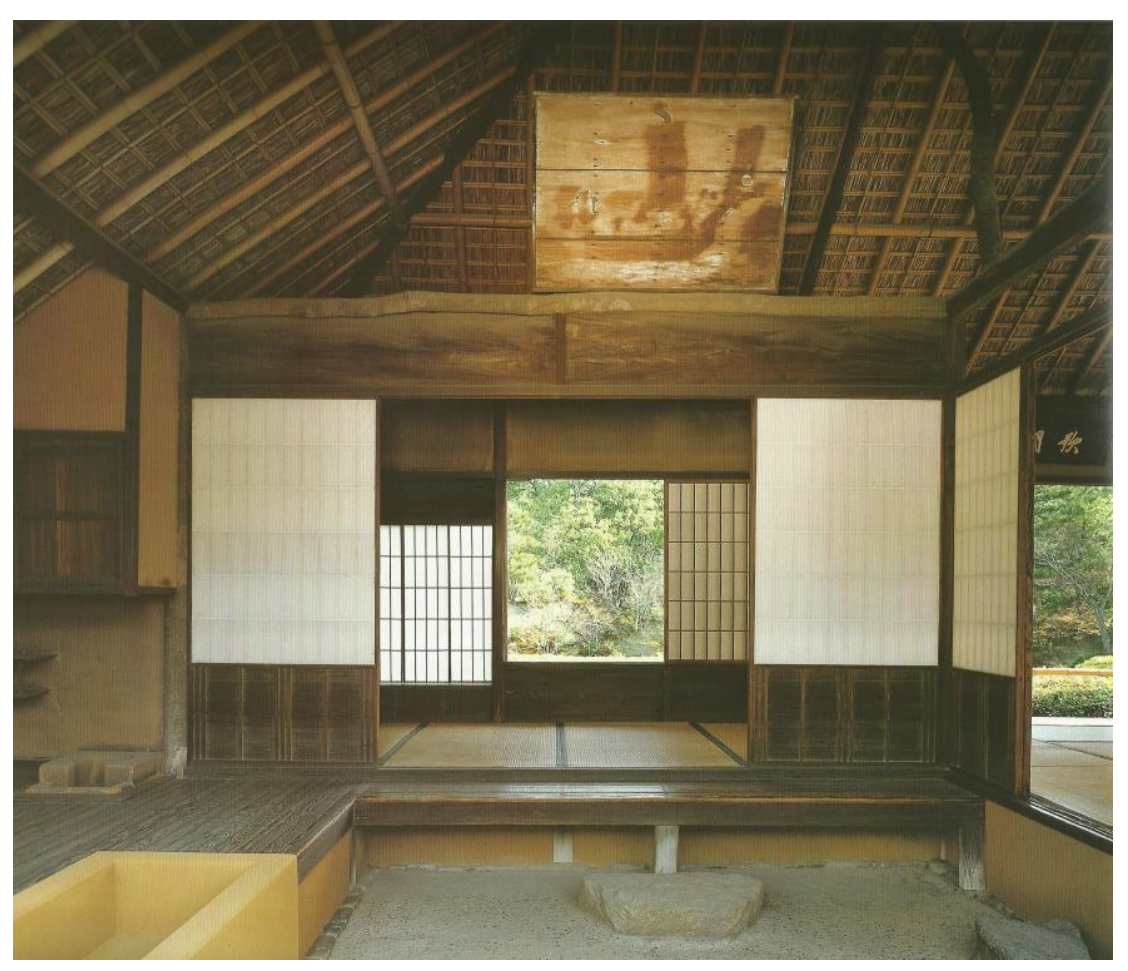

Fig. 6-38. El área de la ceremonia del té de Gepparo. 


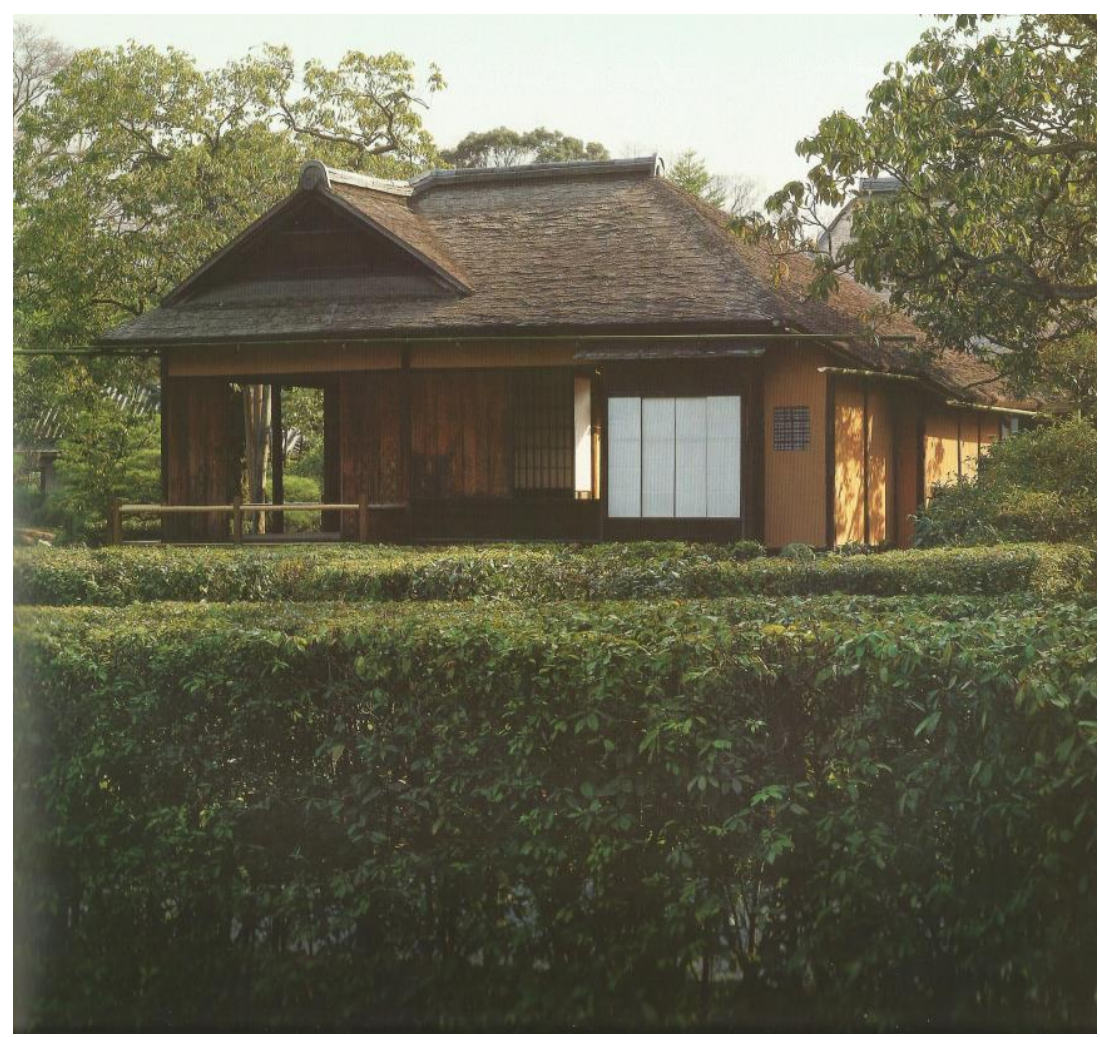

Fig. 6-39. Gepparo desde el norte.

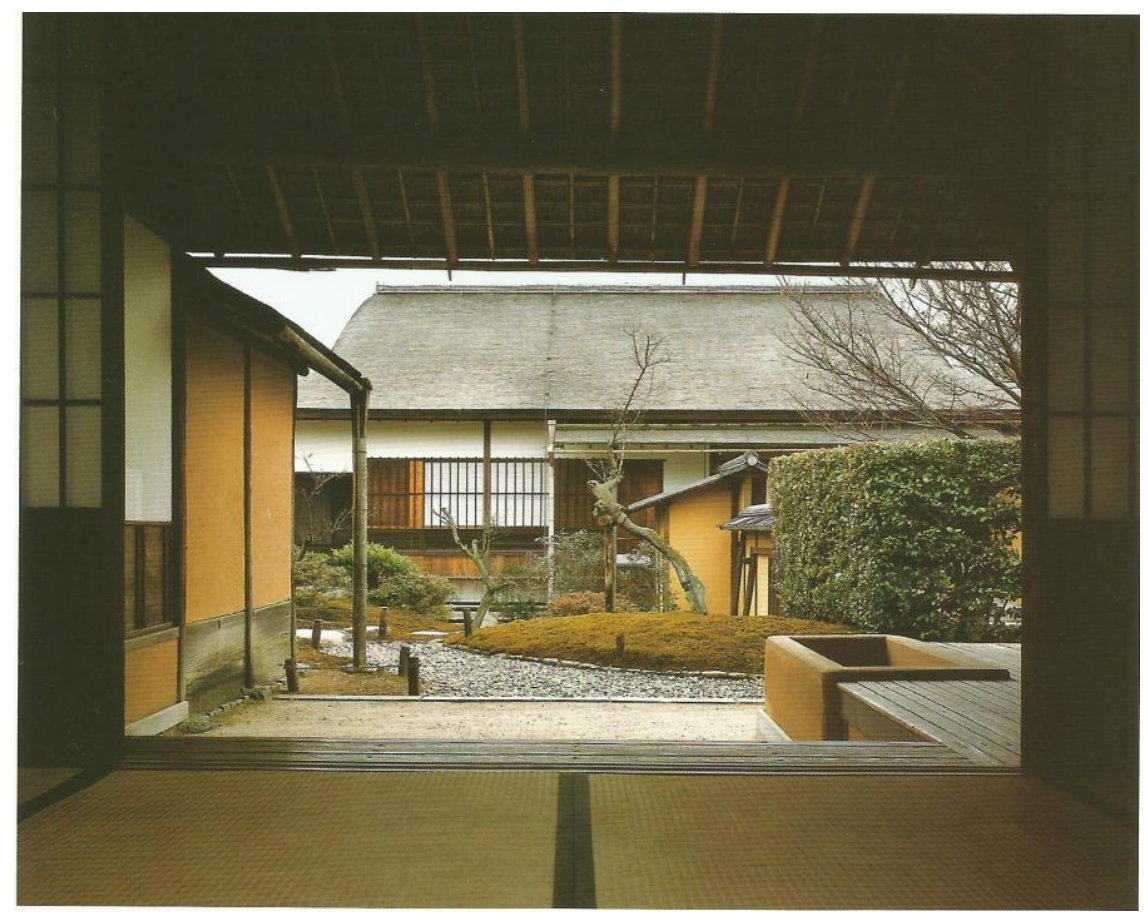

Fig. 6-40. Koshoin desde Gepparo. 


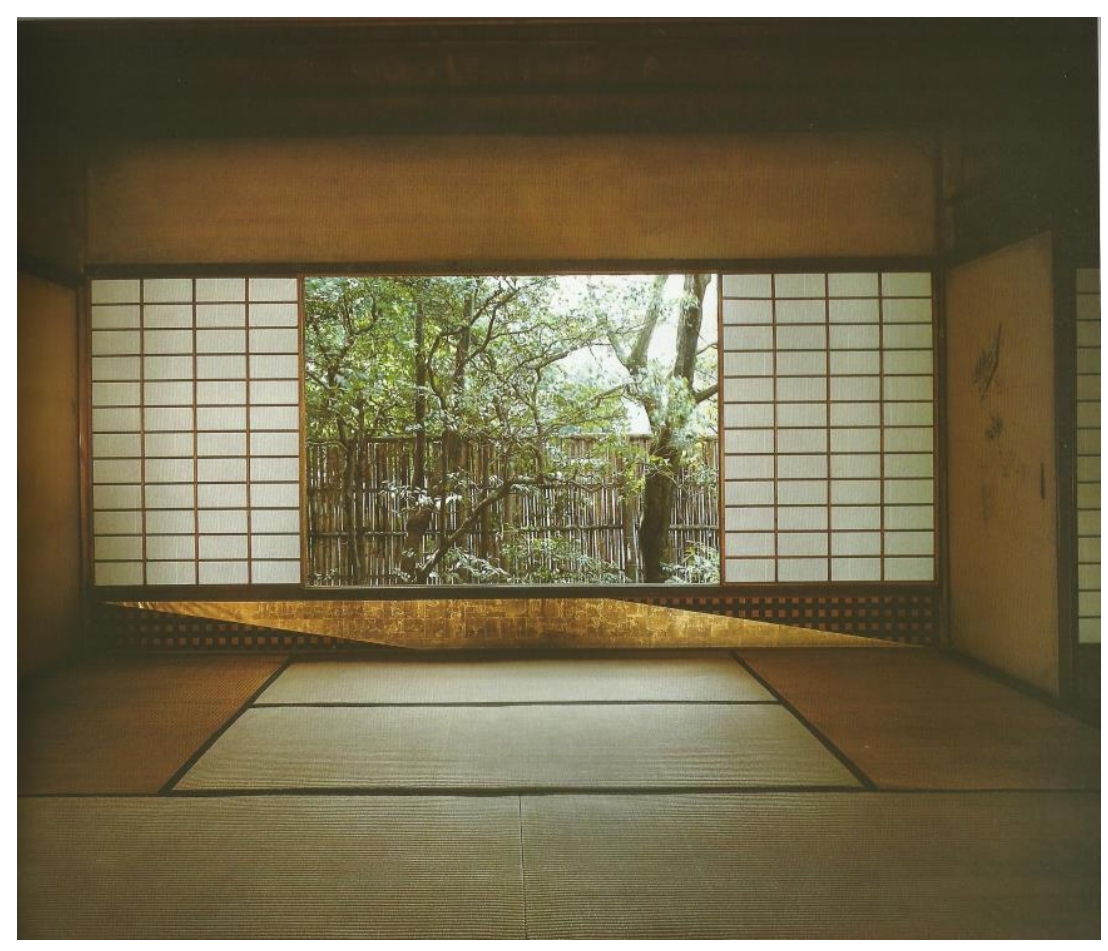

Fig. 6-41. La habitación de Shoiken la casa de té.

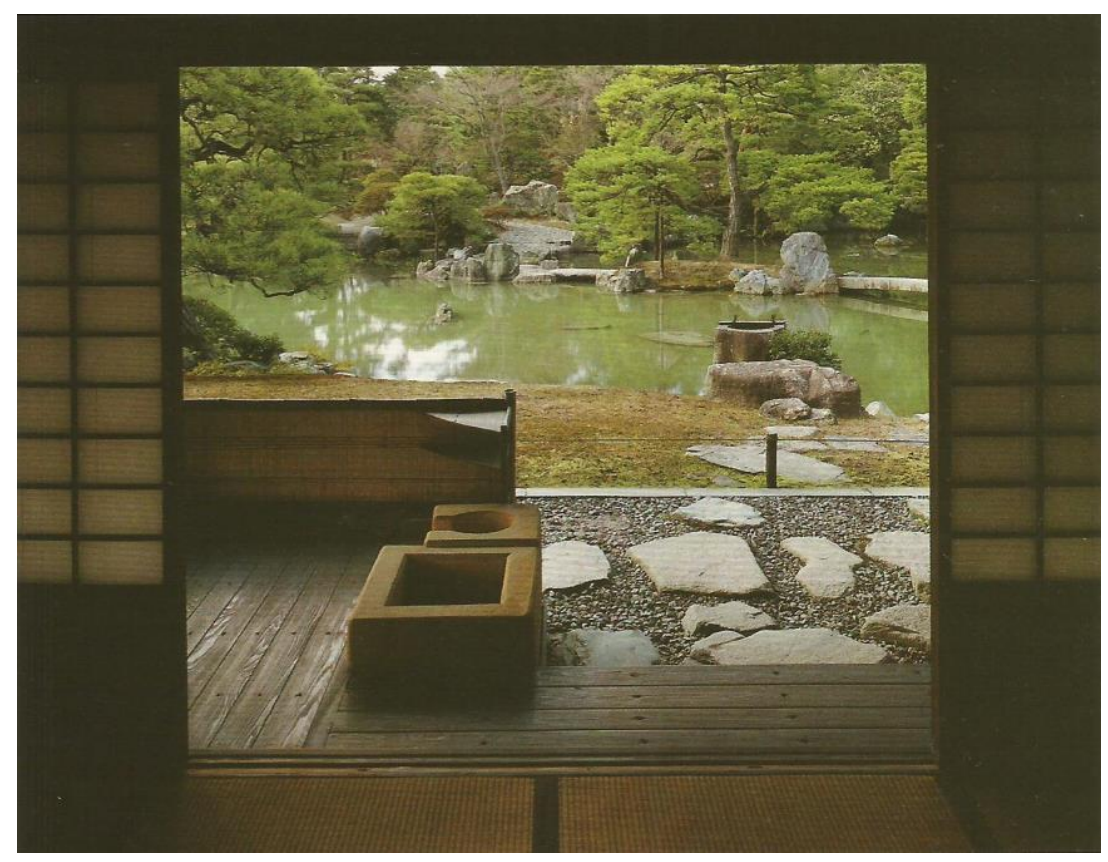

Fig. 6-42. La terraza de Shokintei la casa de té. 


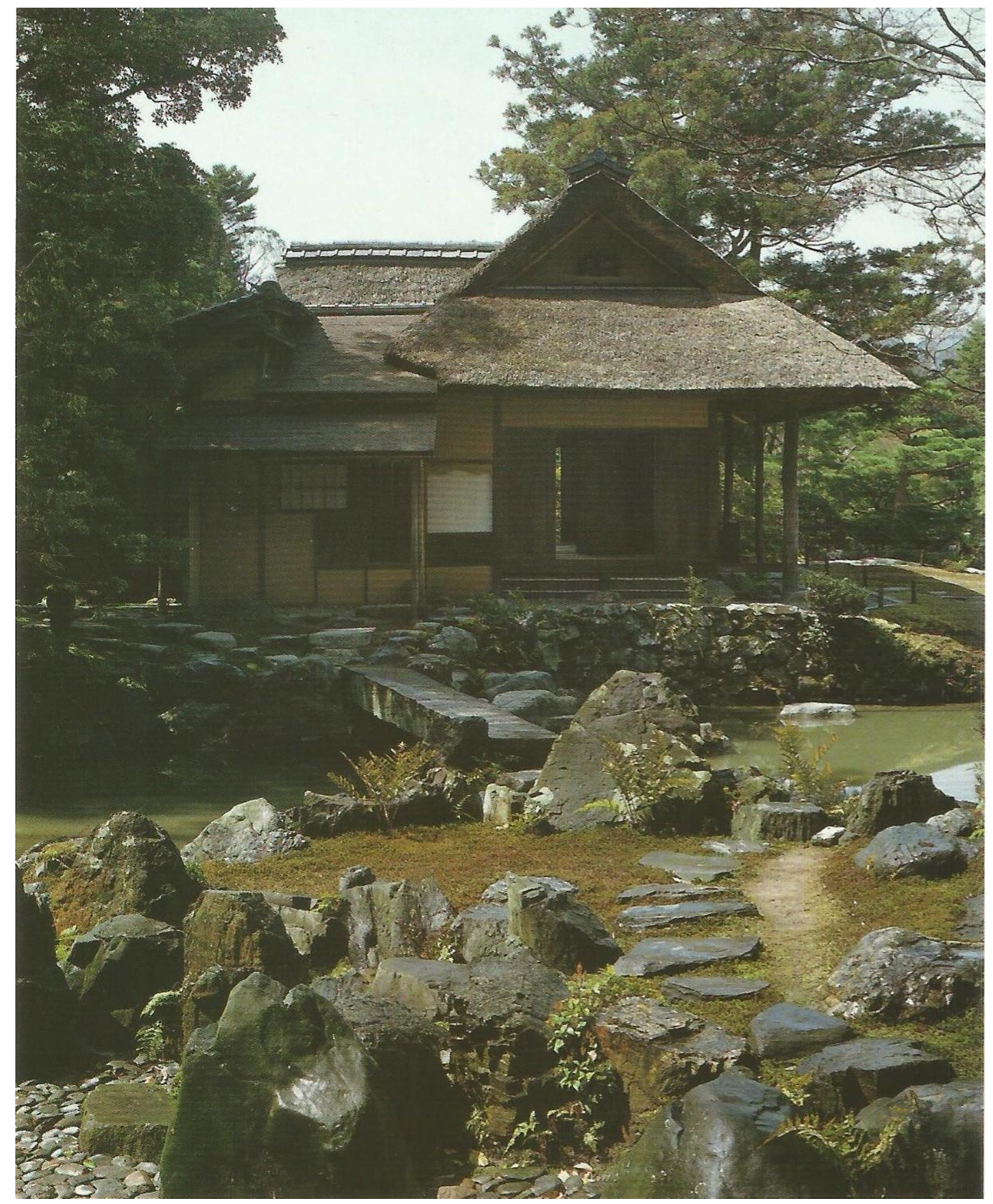

Fig. 6-43. Shokintei, casa de té desde el este. 


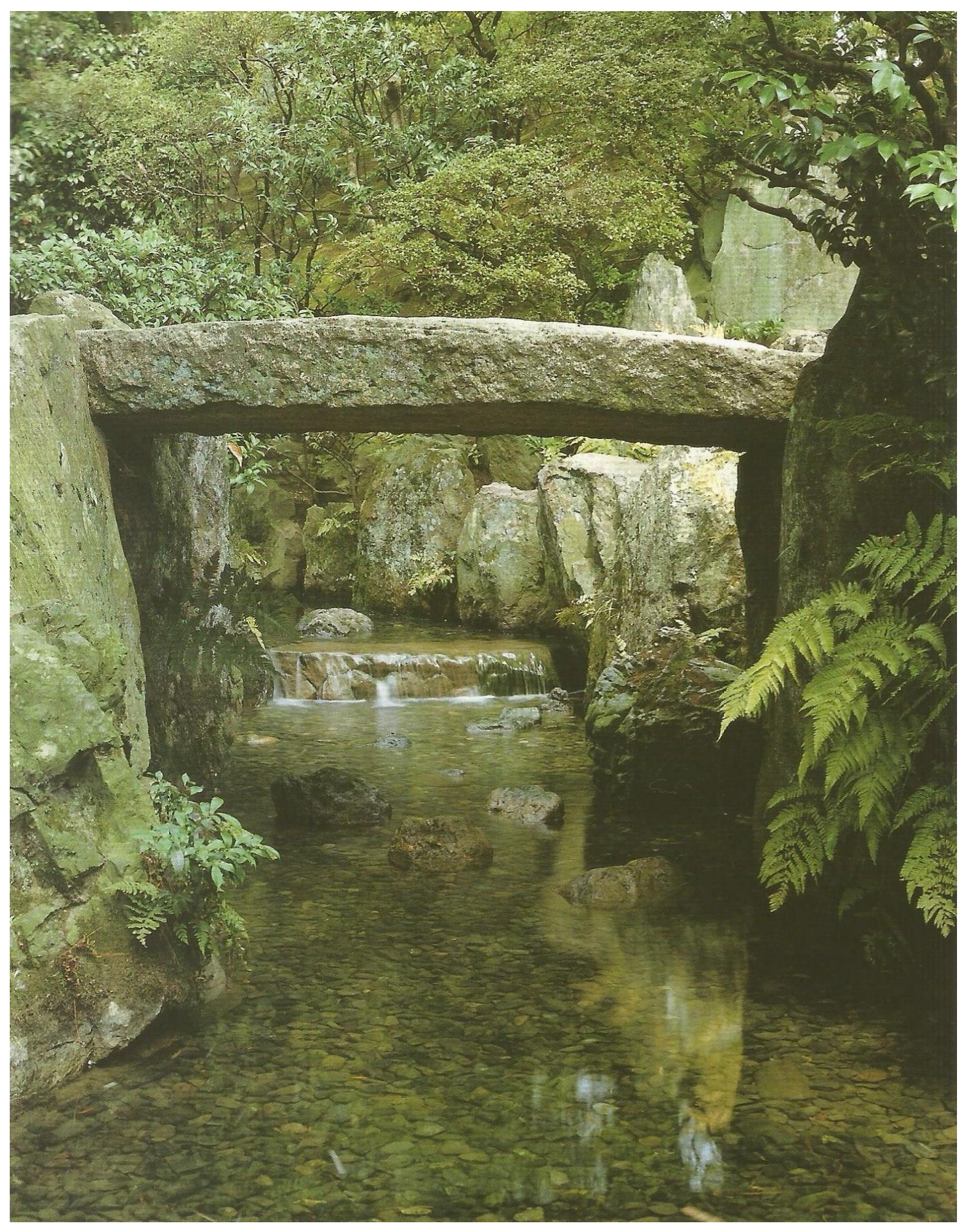

Fig. 6-44. El Puente Shirakawa. 


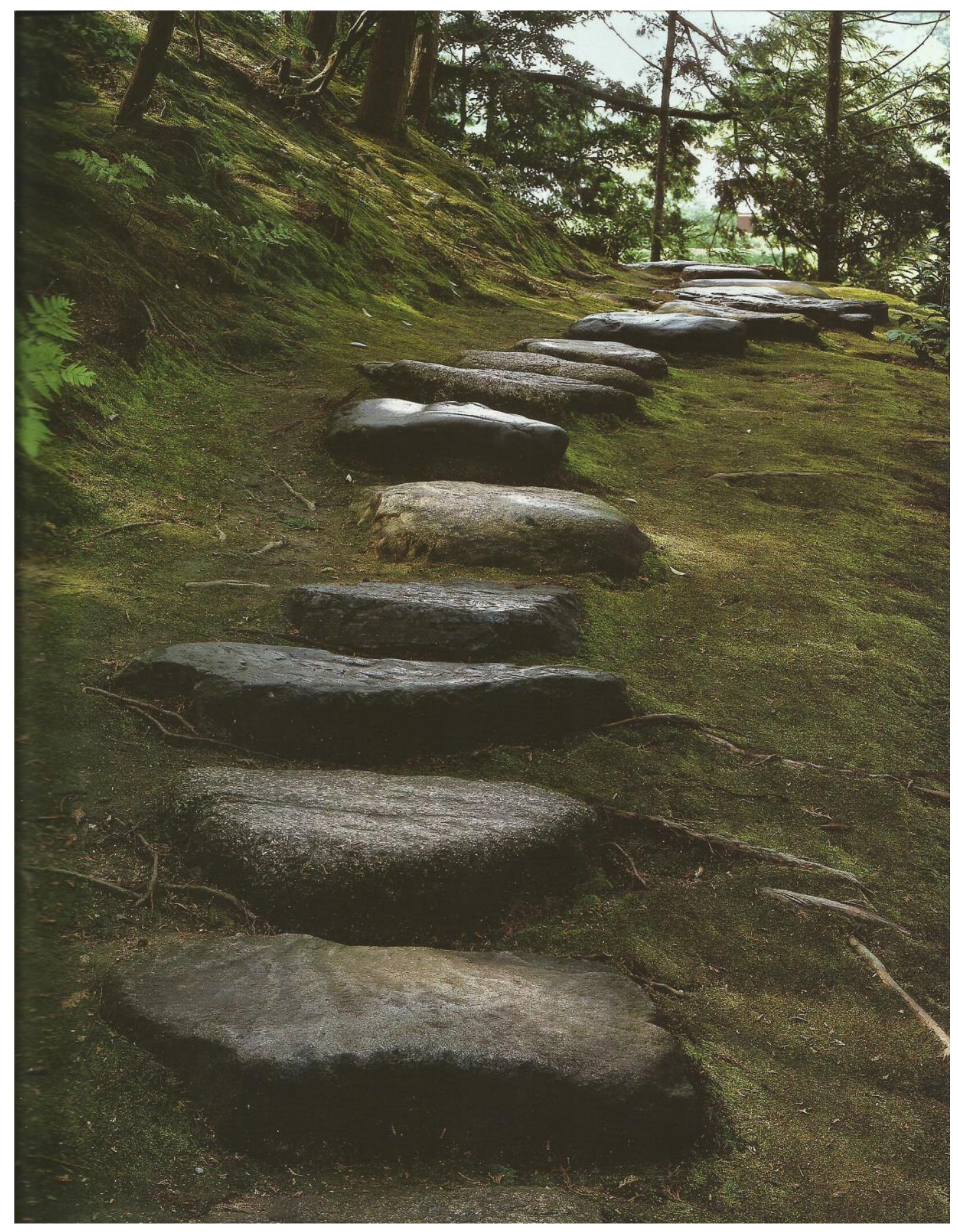

Fig. 6-45. El camino de piedra a Shokatei la casa de té. 


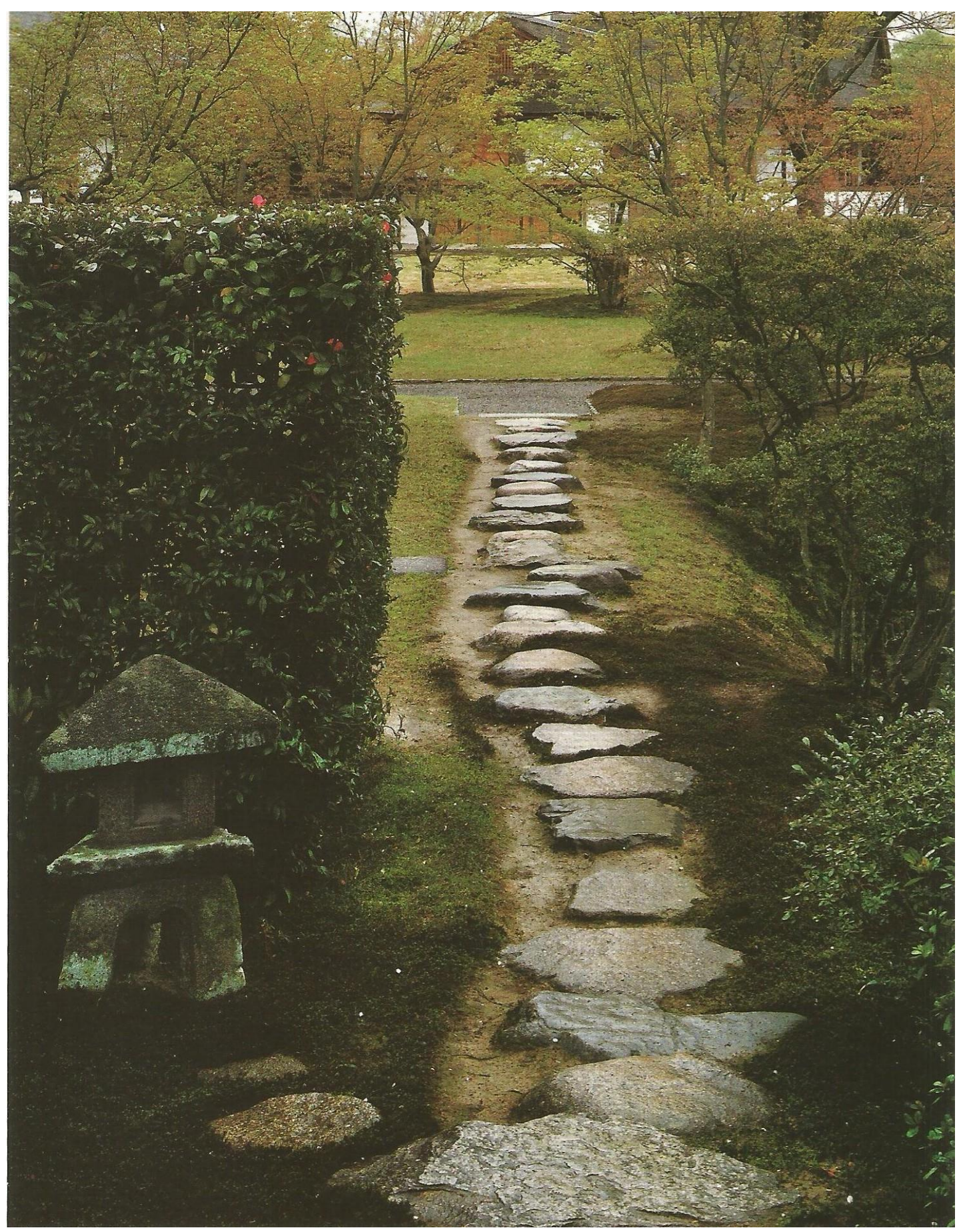

Fig. 6-46. El final del paseo. Se ven los Shoines desde el sur. 


\section{La Iglesia de la luz de Tadao Ando : El Zen-buddhismo en la iglesia cristiana contemporánea}

Creo que la Iglesia de la Luz también crea un espacio de la nada. Se trata de <<haber nada>>. Una simple caja en la que se dibujan múltiples manifestaciones de la luz se adopta como el espacio de encuentro. La gente viene a la iglesia para encontrar a Dios y a los hermanos creyentes $u$ otros participantes que podrían ser no creyentes. El rendimiento arquitectónico de la iglesia es, en este sentido, igual que la sala de té japonesa. No hay nada a excepción de los despertares profundos del yo en la mente (kokoro en japonés) de los participantes. ${ }^{1}$

Tadao Ando.

\section{Tadao Ando}

En este capítulo, se trata un caso crucial de la arquitectura del Zen-buddhismo de Tadao Ando, quien era ya célebre arquitecto japonés antes de ganar el Premio Pritzker en el año 1995. También enseñó en la Universidad de Tokyo y en América, siendo profesor visitante de las universidades de Yale (1987), Columbia (1988) y Harvard (1990). ${ }^{2}$ Hasta hoy en día, él es uno de lo más distinguidos arquitectos con una legendaria reputación, ganando numerosos célebres premios en el campo internacional de la arquitectura.

Nació en Osaka, Japón en 1941. Originalmente fue un boxeador, sin embargo, después de acabar su bachillerato trabajó en unos despachos de la arquitectura, aunque no le gustó su ambiente autoritario. Así que decidió viajar por EE.UU., Europa, y África para enseñarse a sí mismo, dibujando las arquitecturas monumentales durante los años de 1962-1969. Después del viaje, en el año 1969, estableció Tadao Ando Architect \& Associates sin poseer un título. ${ }^{3}$ La importancia de este capítulo viene desde el origen de este brillante arquitecto cuyo pensamiento está relacionado profundamente con el Zen-buddhismo de Japón. El objetivo es entender su vocabulario arquitectónico que se revela

\footnotetext{
1 Baek, J. Nothingness: Tadao Ando's Christian Sacred Space. Oxon. Routledge. 2009. p. 195.

2 “Tadao Ando 1989/1992”. El Croquis. Madrid. El Croquis Editorial. 1993. n 58. p. 4.

3 Ibid.
} 
en sus arquitecturas. El capítulo es de una inmensa importancia en el sentido de que ahora se observará una versión contemporánea de Katsura en una gran arquitectura del zen-buddhismo.

\section{La Iglesia de la Luz}

El talento arquitectónico de Ando se destaca especialmente en las arquitecturas religiosas en la medida en que él sabe interpretar el Dios de los occidentales con su peculiar filtro que se sintetiza con la religión tradicional de Japón, como si fueran de una misma fuente. Pero antes de tratar profundamente este tema metafísico, primero, se conversará con los materiales tangibles, así que sería más conveniente establecer una cabeza de puente desde el nivel físico para poder entrar en otra dimensión del discurso.

La Iglesia de la Luz está ubicada en un suburbio residencial de Osaka(v.-fig. 7-9). El plan original era el añadido a una vieja iglesia de madera. Sin embargo Ando construyó un edificio adicional al lado de la iglesia preexistente, independientemente(v.-fig. 7-13). Como la situación económica de la iglesia no era tan favorable, el proyecto tuvo que proceder con un bajo presupuesto. ${ }^{4}$ Como se puede imaginar, debido a su pobre financiación e incluso al tamaño de la parcela, el nuevo edificio empezó a tener una sencilla figura geométrica(v.-fig. 7-1). Un cubo con un plan rectangular sencillo fue construido con la medida de 18,000 metros de longitud, 6,280 metros de anchura y 7,000 metros de altura(v.-figs. 7-12, 14). Un muro independiente penetraba dicho cubo por el lateral, diagonalmente, con forma de $<<\mathbf{L}>>$ (v.-fig. 7-2). Dicho muro en forma de $L$ divide el plan rectangular en el espacio de la capilla y un pequeño espacio de entrada, ya que entra con su largo al cubo con 15 grados de ángulo desde fuera hacia dentro, cortando de esa manera la esquina de la iglesia, y generando así 1,600 metros de anchura y 5,350 metros de altura de abertura (v.-figs. $7-8,10,14$ ). Cuando se pasa dicha abertura y se gira 180 grado enfrentando al centro de la capilla, se descubre que el suelo va descendiendo hacia al altar. ${ }^{5}$

El muro situado detrás del altar está perforado por la figura de una cruz(v.-fig. 7-3). En el interior de

\footnotetext{
${ }^{4}$ Comentario de Ando en la película siguiente: <Frick, M. Tadao Ando: From Emptiness To Infinity. The 10th EBS International Documentary Festival: Docs on City \& Architecture. 22 de Oct, 2013>>

${ }^{5}$ Ando, T. v.o.1991. Tadao Ando: Details 1. Tokyo. A.D.A. EDITA Tokyo. Futagawa, Y.(ed.), Eisenman, P.(criticismo). 1999. pp. 156-163.
} 
la iglesia no hay cruces, (debido a que en el lugar donde tendría que existir la cruz, se prescinde de su presencia física) sin embargo es una manifestación del vacío en el icono de la cristiandad, siendo una retórica arquitectónica poderosa y allí él está tratando el tema de la imposibilidad de representar lo norepresentable. ${ }^{6}$ Se recuerda que en el capítulo de las mantras del buddhismo, el vacío (Śūnyatā) no trata la cuestión del existir o no, sino la forma de existir.

Dentro de la capilla, la oscuridad y la luz proveniente desde la abertura de la cruz, pueden generar un contraste de claroscuro(v.-fig. 7-4). En el lado de la capilla, del modo en que se acerca el muro de la figura de $L$, se generan otras aberturas también. $Y$ como el muro de la figura con forma de $L$ tiene una altura 18 centímetros menor que el cubo, de ésta manera también, fluye una suave luz en el muro por sus aberturas desde arriba(v.-figs. 7-4, 5, 6, 7, 8). El pavimento y los bancos fueron fabricados por un bajo coste, tablones de andamios de madera cuya textura es áspera y humilde como la iglesia, así que su superficie se destaca en la luz(v.-fig. 7-11). La superficie de los muros está suavizada para reflejar la luz, el viento y el sonido, efectivamente. ${ }^{7}$

\section{El Śūnyatā (vacío) y el ma}

La retirada aparente de Dios vinculado a la cruz genera una visibilidad incomparable. El poder y la profundidad de la iglesia surge de esta integración entre el vacío que simboliza la retirada de Dios -la condición de su presencia renovada- y la cruz que brilla en el fondo que constituye la oscuridad. El vacío renueva y revitaliza la presencia de la cruz, o la medida del amor divino. Por la misma razón, el vacío espacial de la Iglesia de la Luz no sólo se refiere a la imposibilidad de representar lo irrepresentable, sino también a la presencia del Dios del mundo que está en la forma de un ser humano destinado a morir en la cruz. ${ }^{8}$

Jin Baek.

Se va a hablar sobre el muro que está detrás del altar y porqué está vacío el lugar de la cruz (v.-fig.

\footnotetext{
${ }^{6}$ Baek, J. Nothingness: Tadao Ando's Christian Sacred Space. Oxon. Routledge. 2009. p. 159.

7 Ibid. p. 160.

8 lbid.
} 
7-3). Dios, quien es omnipotente y creador del mundo, vino en un cuerpo humano, murió en la cruz para la completa redención de la humanidad, resucitó y posteriormente ascendió al cielo. Para Ando, no es necesario expresarlo con un símbolo visible, o no tendría que serlo. Este tipo de interpretación buddhista de Ando es $100 \%$ compatible al cristianismo. Básicamente, la postura de su pensamiento viene desde la religión tradicional Japonesa. Ando dice que los japoneses consideran que el Buddhismo y la cristiandad son similares en el sentido similar de Siddhartha y Jesús, en el que ambos sugirieron una humanidad paradigmática y representativa por un salvador. ${ }^{9}$ Así que para Ando fue lógico construir una iglesia cristiana de la misma manera que construiría un espacio de zen o té. La iglesia de la luz está vacía como un interiorismo de minimalismo estático, sin embargo, allí puedes sentir una pequeña brisa, lluvia o nieve por medio de las aberturas de la capilla, cuyo espacio se encuentra vacío, evacuado hasta el símbolo de cristiandad, y desde dicha cruz que forma una abertura, entra la luz que es muy cambiante pasando con el tiempo, incluso su reflejo y sombra sobre los muros, y los visitantes experimentan la virtud de la iglesia con los elementos climáticos. La capilla, o sea un espacio santuario, es un lugar donde la gente va para encontrar o sentir la presencia de Dios, tanto en regiones Occidentales y en Asia. Ando cree que Dios existe en la naturaleza. ${ }^{10}$ Eso es una perspectiva también aceptable absolutamente en la cristiandad. La Iglesia es un lugar en el que Dios mora, y se entra en la presencia de Dios, y al final, se reconoce que Dios está en los corazones.

Mi pensamiento se centra en el problema planteado por la diversidad de elementos contradictorios a los que la arquitectura debe acomodar. Resulta impensable intentar, con razonamiento pobres, escapar a tal contradicción, porque es en este forcejeo sincero y comprometido, y en la presentación de los conflictos que implica, en lo que para mí consiste la práctica de la arquitectura en este momento. Para la arquitectura contemporánea, reducida a ser utilizada únicamente como vehículo de inversión seguro para el capital, ésta es sin duda la única forma de resistencia para poder cumplir con su deber de mejorar la sociedad. El hueco existente entre los elementos en oposición debe ser penetrado. Este hueco se corresponde con el concepto estético japonés del ma. El ma no es nunca una paz dorada, sino un lugar de violentos conflictos. Y es esta brutalidad del ma la que me permite continuar poniendo

\footnotetext{
9 Baek, J. Nothingness: Tadao Ando's Christian Sacred Space. Oxon. Routledge. 2009. p. 188

10 También es compatible con el concepto de Dios hebreo en la omnipresencia. -(NdA.)
} 
a prueba y provocando al espíritu humano. ${ }^{11}$

Tadao Ando. 1993. Pensando en el Ma, Entrando en el Ma.

Solía utilizar el término de <<ma>> en algunos de mis escritos, y eso a veces se tradujo en <<nada>>. Creo que, en inglés, <<mu>> y <<ma>> ambos se pueden traducir en $<<$ nothingness $>>$ (nada) justificadamente. Para mí, ambos tienen relación con lo invisible. Mientras $<<m u>>$ es el que uno no puede sentir, <<ma>> hace que sea palpable y tangible. Creo que tanto Nishida y Lee, el líder de la Escuela de las Cosas(Mono-ha), hicieron hincapié en lo invisible como el lugar donde reside lo espiritual. Otra vez, <<ma>> es la sensación de lo que se esconde detrás de lo visible. La cruz de la luz vuelve a despertar este sentimiento, ya que rejuvenece la sensación de estar vivo mediante la realización de una presencia característica de la luz en la oscuridad. ${ }^{12}$

Entrevista con Tadao Ando. Julio de 7, 2003.

Ando quiso demostrar esta experiencia arquitectónicamente poniendo el $<<$ nada $>>$, así la luz del exterior que ha sido expresado arquitectónicamente por las aberturas reproduce un espacio sagrado. ${ }^{13}$ En la Iglesia de la Luz, no hay nada excepto una profunda iluminación en sí misma de los visitantes. ${ }^{14}$ Los siempre cambiantes rayos de luz que penetran en las aberturas tienen el poder de destruir el volumen ortogonal de la iglesia hasta que un sujeto percibe la luz como la última manifestación del espíritu. ${ }^{15}$ Un sencillo código de minimalismo, del vacío y de lo estático, se convierte en un espacio característico por Ando atrayendo los elementos climáticos y del tiempo. Indudablemente, dichos elementos más el tiempo son factores primordiales que provocan experimentos espirituales. Ando

\footnotetext{
11 Ando, T. "Pensando en el ma, entrando en el ma”.El Croquis: Tadao Ando 1989/1992. nº 58. Madrid. El Croquis Editorial. 1993. pp. 10-11.

12 Baek, J. Nothingness: Tadao Ando's Christian Sacred Space. Oxon. Routledge. 2009. pp. 197,199.

13 Ando, T. "From the Church on the Water to the Church of the Light". AAVV. The Japan Architect. June 1989. Esta citación fue referenciada por la fuente secundaria: <Ando, T. Tadao Ando: Complete Works. Francesco Dal Co(ed.). London. Phaidon Press Limited. 1995. p. 455>

14 Baek, J. Nothingness: Tadao Ando's Christian Sacred Space. Oxon. Routledge. 2009. p. 194-195.

15 Escrito de Frampton, K. "Ando at Millennium". Desde el libro: <Ando, T. Tadao Ando: Light and Water. New York. The Monacelli Press, Inc. 2003. p. 8>
} 
llama a este tipo de espacio vacío para experimentar las sensaciones climáticas e incluso espirituales, ma.

Los fuertes matices de materiales simples y sus texturas hacen hincapié en composiciones espaciales simples, y por lo tanto provocan una conciencia de un diálogo con elementos naturales como la luz y el viento. En todas mis obras, la luz es decisiva en la formación de espacio. ${ }^{16}$

Tadao Ando. 1977. A Wedge in Circumstances.

Naturaleza en forma de agua, luz, y el cielo restauran la arquitectura de una metafísica a un plano terrenal y dan vida a la arquitectura. La preocupación por la relación entre la arquitectura y la naturaleza conduce inevitablemente a una preocupación por el contexto temporal de la arquitectura. Yo quiero enfatizar el sentido del tiempo y crear composiciones en las que una sensación de fugacidad del paso del tiempo es una parte de la experiencia espacial. ${ }^{17}$

Tadao Ando. 1991. From the Periphery of Architecture.

\section{Shintai}

En la experiencia espacial mediante la sensación del ma, como expresa Ando, requiere una premisa en la que se cree que el cuerpo humano es capaz de internalizar el mundo exterior, o sea Shintai. ${ }^{18}$ Shintai percibe el mundo articulando las direcciones desde sí mismo: hacia arriba, abajo, delante, detrás, derecha, izquierda y etcétera. Así que cada espacio del mundo se convierte en un espacio heterogéneo, como el cuerpo humano el cual tiene forma asimétrica en diversas direcciones. Lo

\footnotetext{
16 Ando, T. "A Wedge in Circumstances". AAVV. The Japan Architect. Junio. 1977. Esta referencia fue citada por la fuente secundaria: <Ando, T. Tadao Ando: Complete Works. Francesco Dal Co(ed.) London. Phaidon Press Limited. 1995. p. 444>

17 Frampton, K. "Ando at Millennium". Desde el libro: <<Ando, T. Tadao Ando: Light and Water. New York. The Monacelli Press, Inc. 2003. p. 6.> La citación está referenciada por la fuente secundaria: Tadao Ando, "From the Periphery of Architecture", in Tadao Ando: Complete Works, ed. Francesco Dal Co (London: Phaidon, 195), 465. Frist published in Japan Architect 1. January 1991.

${ }_{18}$ Shintai en japonés, se usa en un término del cuerpo humano, sin embargo, su significión literal es un componente del espíritu y la carne.-(NdA)
} 
interesante aquí es, cuando el cuerpo articula el mundo, el cuerpo simultáneamente se articula por el mundo. ${ }^{19}$

Ahora bien, el mundo exterior está preparado para interiorizarse por Shintai. Por ejemplo, una frase: <<yo veo un pájaro >>. En esta frase, $<<y o>>$ y <<un pájaro >> están interconectados, constituyendo como otra dimensión(ma) experimental y espacial por Shintai. En dicha nueva dimensión de ma, ya no hay $<<$ yo >> ni <<un pájaro >>, ya que ha surgido otro nuevo dharma de <<El-yo-quien-está-mirandoun-pájaro>>..20 Al final, <<yo>>, o sea el <<expandido-yo>>, como un dharma ordinario y efímero entre las series de las representaciones, logra aquí un nuevo sentido ontológico en la nueva cosmovisión. Como La Iglesia de la Luz que estaba vacía por dentro con simplicidad, y la cruz que estaba omitida en la capilla, en el espacio de ma Shintai se entiende como un reproductor del mundo maravilloso. Shintai ya no es una mera criatura sino un creador poderoso. ${ }^{21}$ De nuevo la explicación: la capilla vacía, el icono mutilado de la cristiandad, el cuerpo humano que interioriza el mundo dentro sí mismo, es decir, el concepto del Shintai despega lo sustancial de los egos que estaban adheridos a los sujetos, ${ }^{22}$ así que de ésta manera los humanos se convierten en un sabio-shintai (epistemológico), artista-shintai (estético) y santo-shintai (ético) que reaccionan dinámica y virtuosamente al nuevo mundo de los dharmas fragmentados; el mundo se convierte en Shintai, el Shintai se convierte en el mundo. ${ }^{23}$

\section{Proceso del argumento}

\section{無(Vacio) $\rightarrow$ 間(Ma) $\rightarrow$ 身體(Shintai) $\rightarrow$ 無我(No-Yo) $\rightarrow$ 涅槃(Nirvana)}

\footnotetext{
19 Ando, T. "Shintai and Space". Architecture and the Body. New York. 1988. Esta citación fue referenciada por la fuente secundaria: <Francesco Dal Co. Tadao Ando: Complete Works. London. Phaidon Press Limited. 1995. p. 453>

20 Baek, J. Nothingness: Tadao Ando's Christian Sacred Space. Oxon. Routledge. 2009. p. 163

${ }^{21}$ Ibid. p. 163.

22 Ibid.

23 Ando, T. "Shintai and Space. Architecture and the Body. New York. 1988. Esta citación fue referenciada por la fuente secundaria: <Francesco Dal Co. Tadao Ando: Complete Works. London. Phaidon Press Limited. 1995. p. 453>
} 


\section{Una interpretación nirvánica de La Iglesia de la Luz}

Hasta ahora, se ha visto los conceptos primordiales de la arquitectura zen-buddhista de Ando. Se observa el vacío (無) con una sencilla forma de espacio que es un aparato para destacar el elemento climático; sería la luz, en el caso de La Iglesia de la Luz, y pueden ser otros elementos climáticos en otras obras, como por ejemplo en el proyecto llamado La Iglesia en el Agua, donde el agua era el elemento climático que quiso atraer Ando. En La Iglesia de la Luz, una intensa luz penetraba la oscuridad del cubo a través de la abertura en el muro de altar con un corte cruciforme, y por el corte de la figura de $\mathrm{L}$ del muro; cuyas luces fluyen por los muros alisados y el pavimento modesto tranquilamente y rellenando el espacio. Ando dice que este patrón de sus arquitecturas es para expresar la pureza que existe en la relación entre los individuos y la naturaleza. ${ }^{24}$

El argumento de Ando nos llevaba al concepto llamado ma (間). En el espacio del vacío, surge una vista interna en el individuo que corresponde con el espacio. Ando crea los espacios indefinidos (porque usa el vacío) relacionados con la emoción humana (experimentos climáticos, del tiempo y espiritual) y las zonas intersticiales, ${ }^{25}$ al final, él quiere crear un significado social y con sentimientos mutuos. ${ }^{26}$ En este espacio los visitantes experimentan individualmente sus particulares sensaciones y se convierten en los Shintai-s (身體).

Como se ve, el concepto de Shintai estaba relacionado con el concepto de NY ${ }^{27}$ (無我) del buddhismo como en chino "la gente del espacio" (間) toma afecto por la arquitectura ética de Ando. La gente despierta como un sabio-shintai en el ma, la gente sabe disfrutar la estética del espacio como un artista-shintai, la gente busca significado social y mutuo de la arquitectura como un santo-shintai. Ya se refirió anteriormente, que el estado del despertar en el que los dharmas no son unidades independientes sino surgentes dependientes, es el Nirvana. Y ahora, la arquitectura es capaz de

\footnotetext{
24 Ando, T. Tadao Ando: Light and Water. New York. The Monacelli Press, Inc. 2003. p. 64.

25 Ma (間), en japonés o en chino, literalmente significa un particular espacio entre dos algo, o sea una zona intersticial. Sin embargo, como esta zona está vacía (porque, si no está vacía, entonces no hay espacio y está lleno por algo, así que ya no lo llamaríamos espacio), una traducción por el <<nada >> también sería justo. Además, cuando se refiere <<humano $>>$ en chino en japonés, se escribe <<人間〉>, porque los asiáticos perciben los humanos, ontológicamente, como los seres existentes siempre entre otros seres. -(NdA)

${ }^{26}$ Ando, T. "A Wedge in Circumstances". AAVV. The Japan Architect. Junio 1977. Esta referencia ha sido citada por la siguiente fuente secundaria: <Ando, T. Tadado Ando: Complete Works. Francesco Dal Co (ed.) London. Phaidon Press Limited. 1995. p. 444>

27 No-yo-(NdA)
} 
mover el espíritu humano y permite vislumbrar lo eterno dentro del momento; así que el estado del Shintai está en el Nirvana; ya que la experiencia (el experimento de la interiorización) dentro del cuerpo humano y la morada de la eternidad están dentro de quien lo percibe. ${ }^{28}$

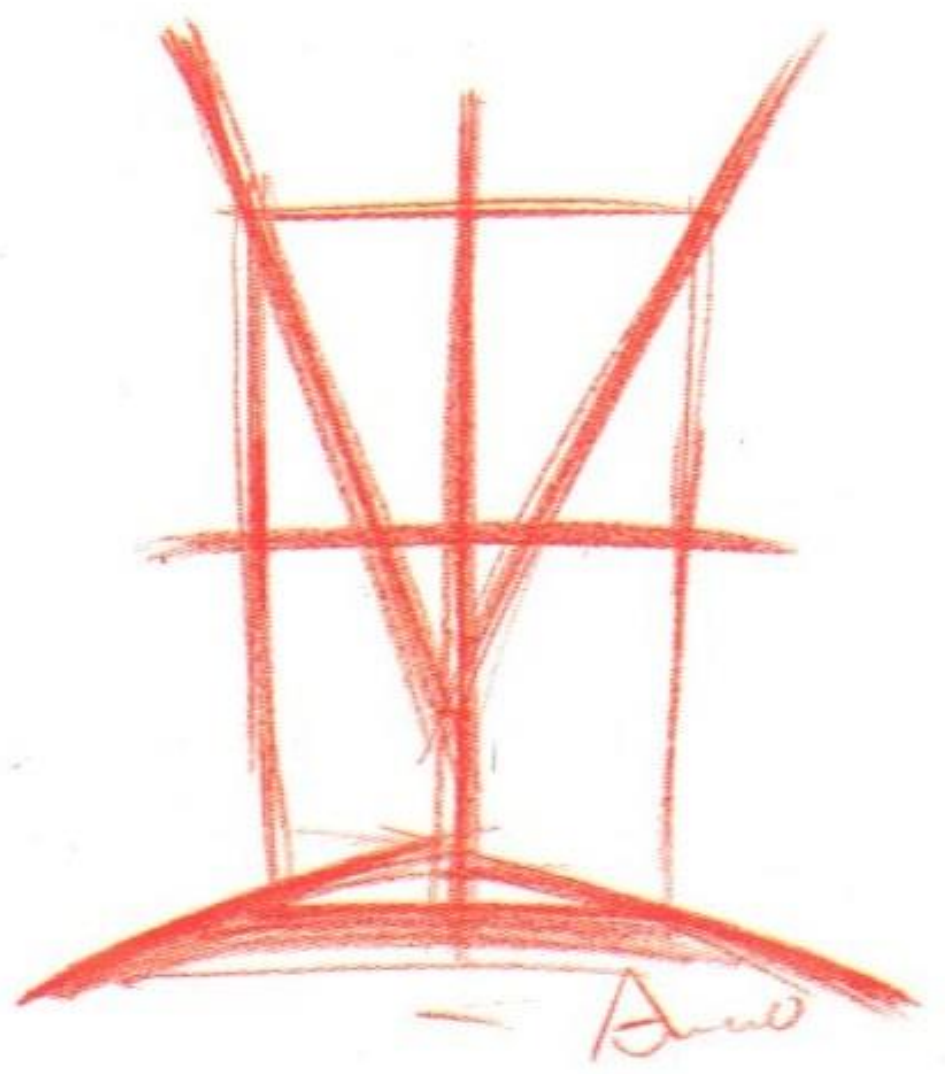

Fig. 7-1. Dibujo del concepto.

28 Ando, T. <The Eternal within the Moment>. Francesco Dal Co(ed.) Tadao Ando: Complete Works. London. Phaidon Press Limited. 1995. p. 474. 


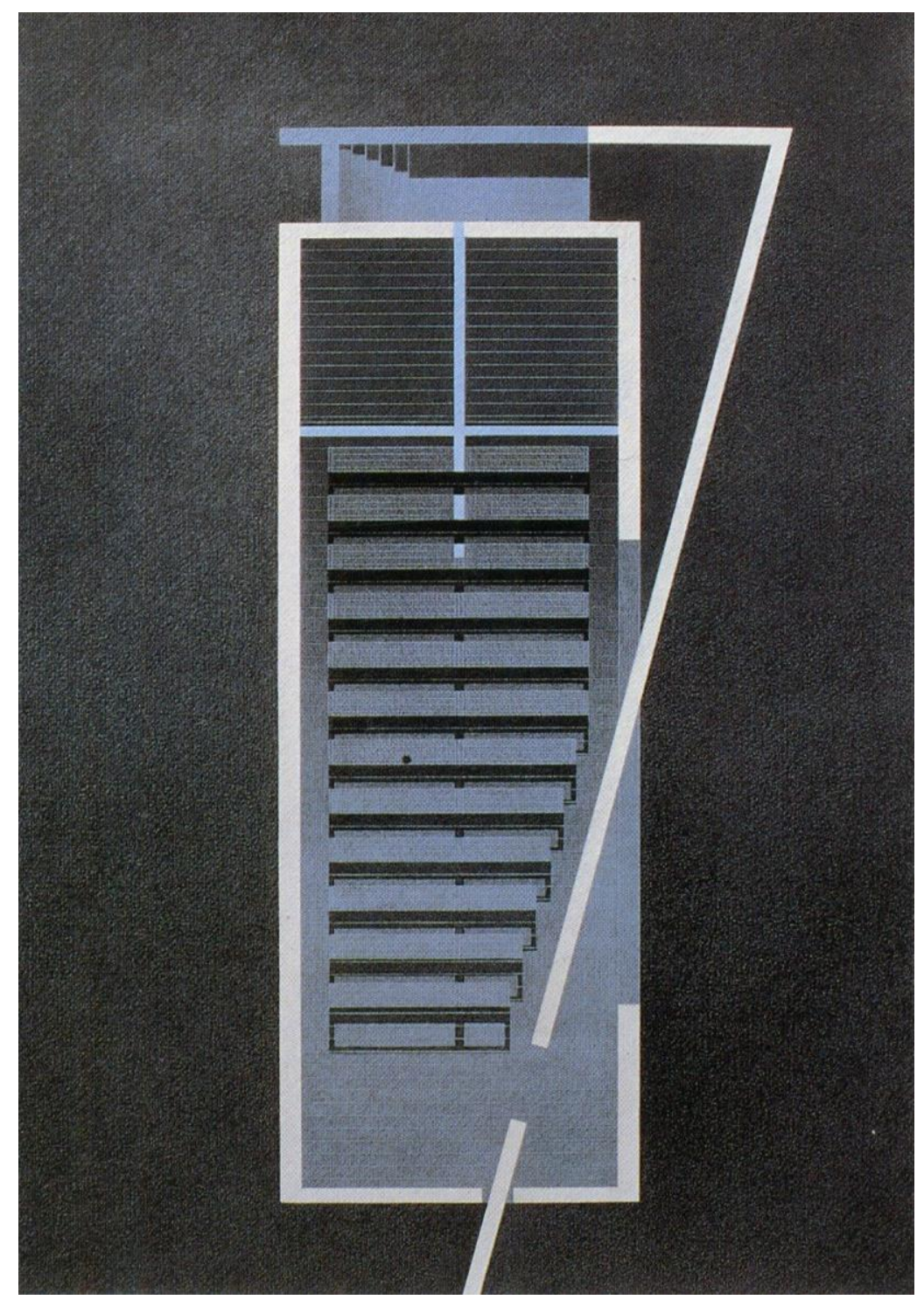

Fig. 7-2. Dibujo del plano. 


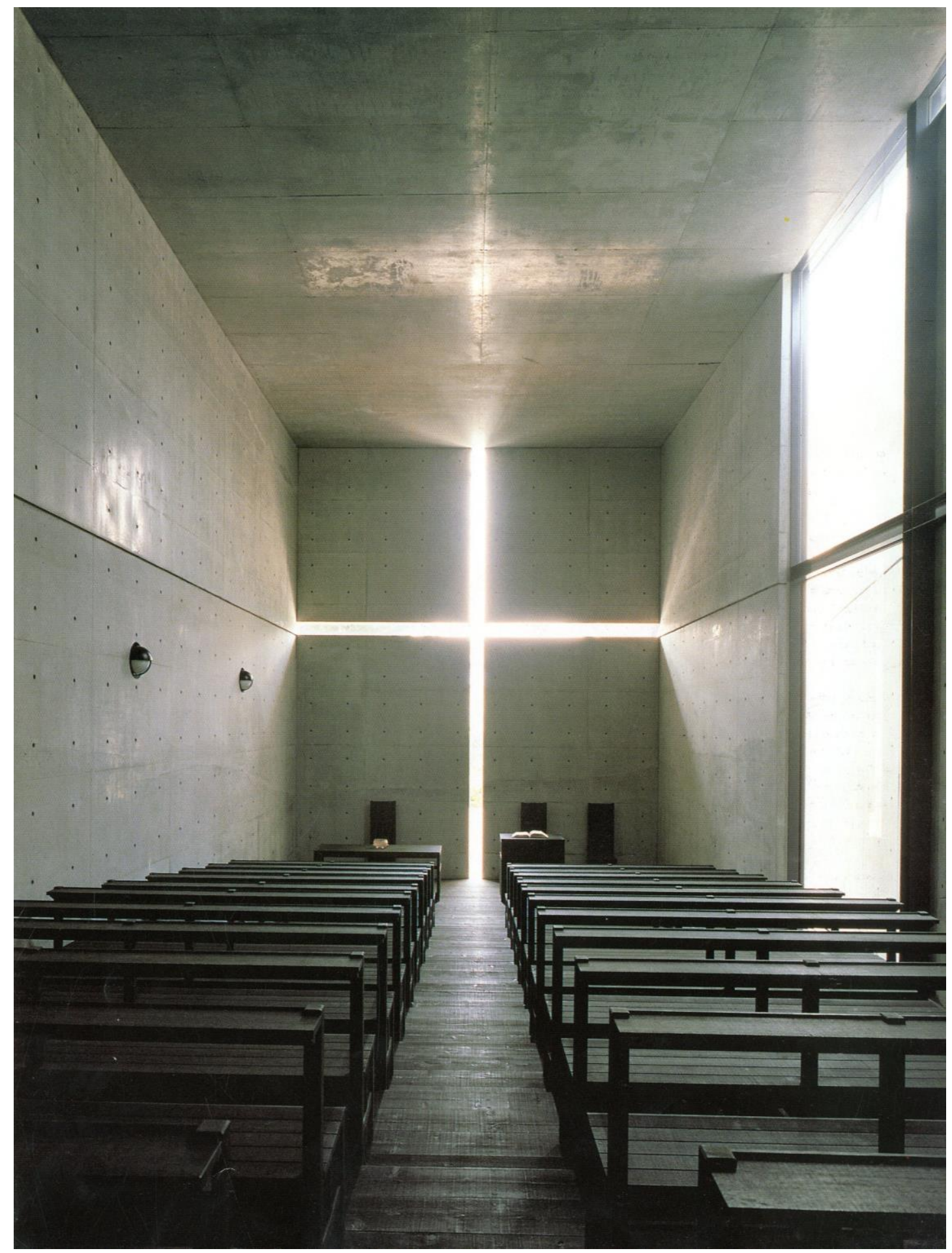

Fig. 7-3. Perspectiva hacia al altar. 


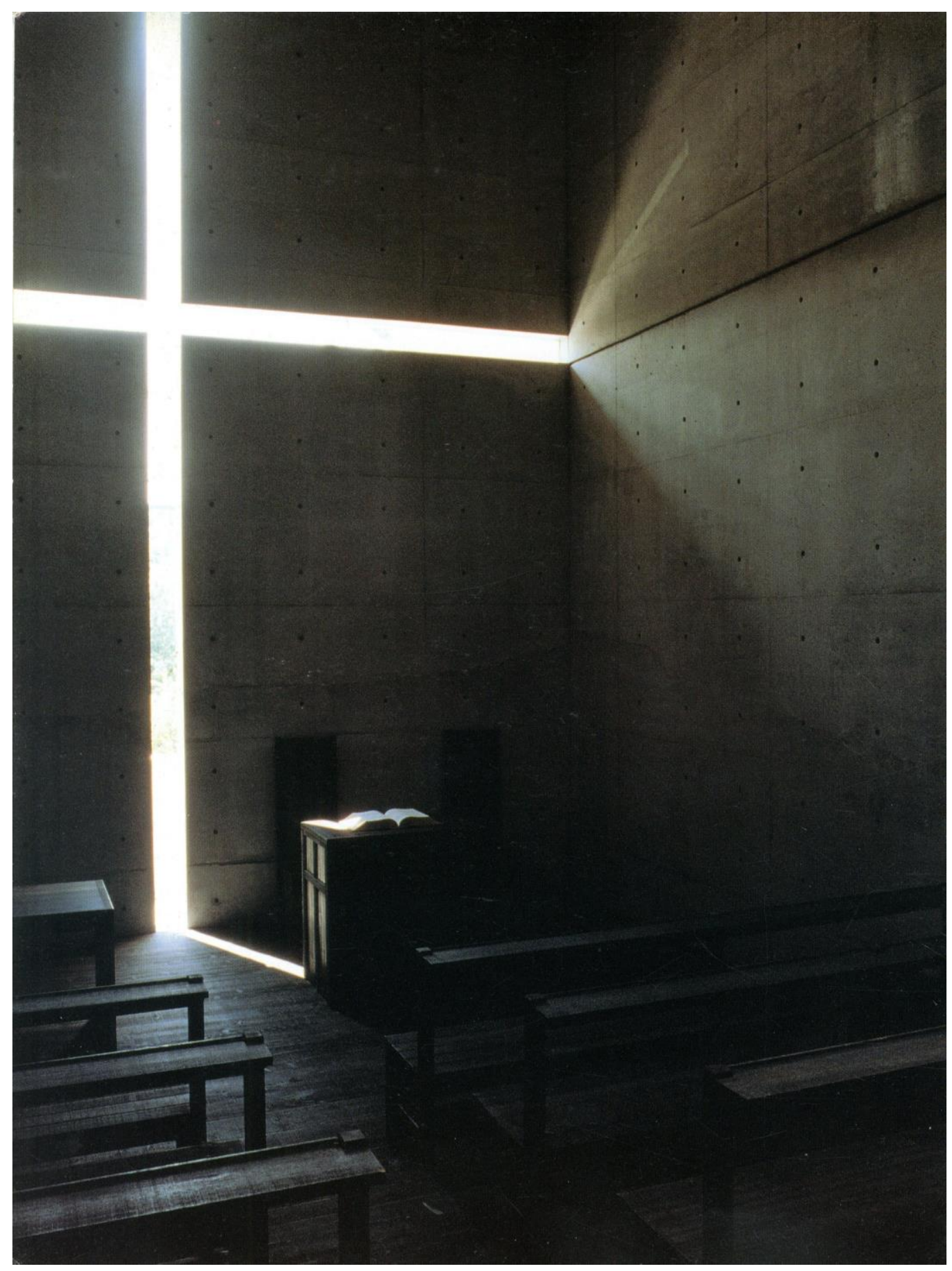

Fig. 7-4. Altar. 


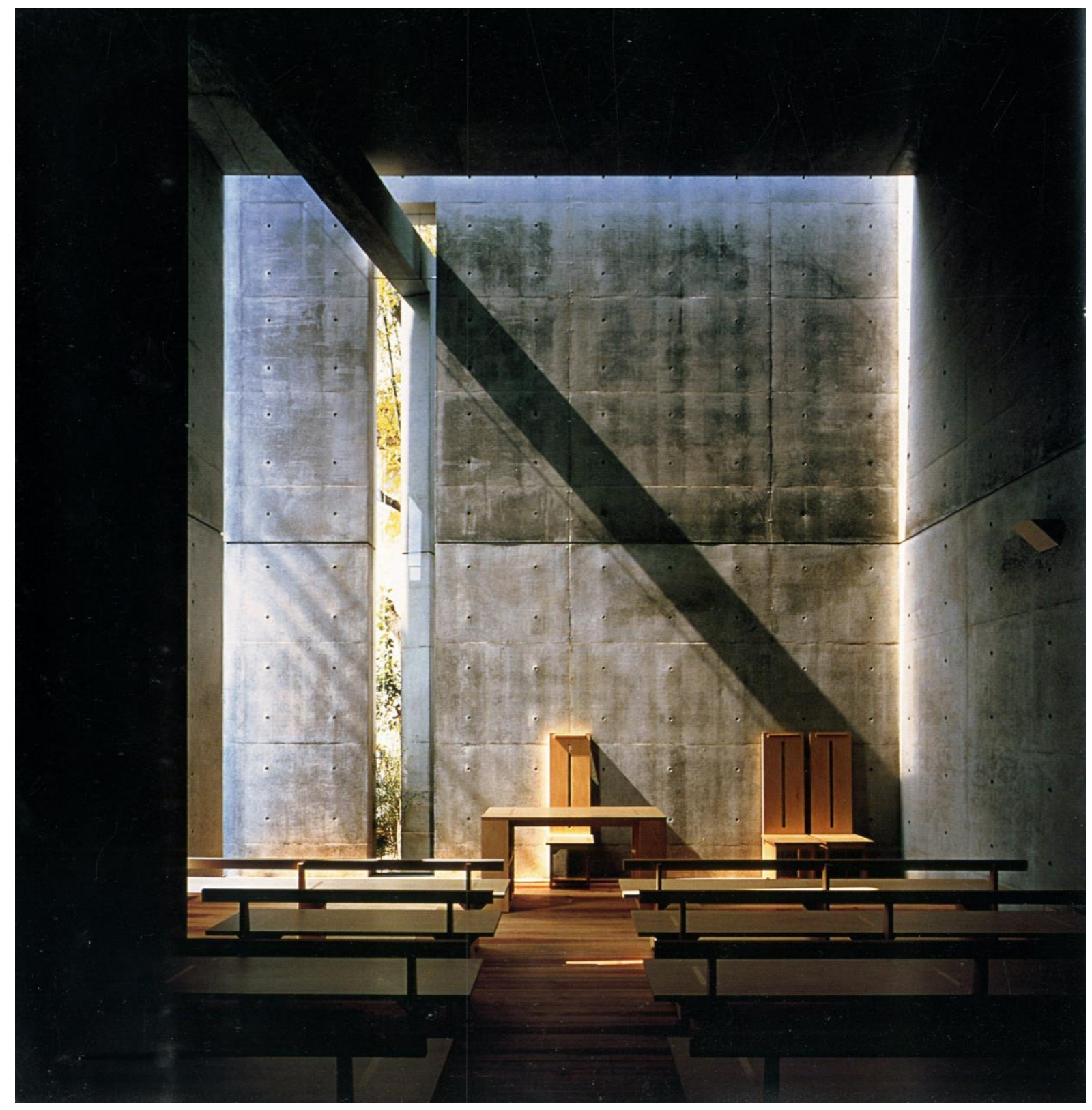

Fig. 7-5. Altar de la escuela del domingo. 


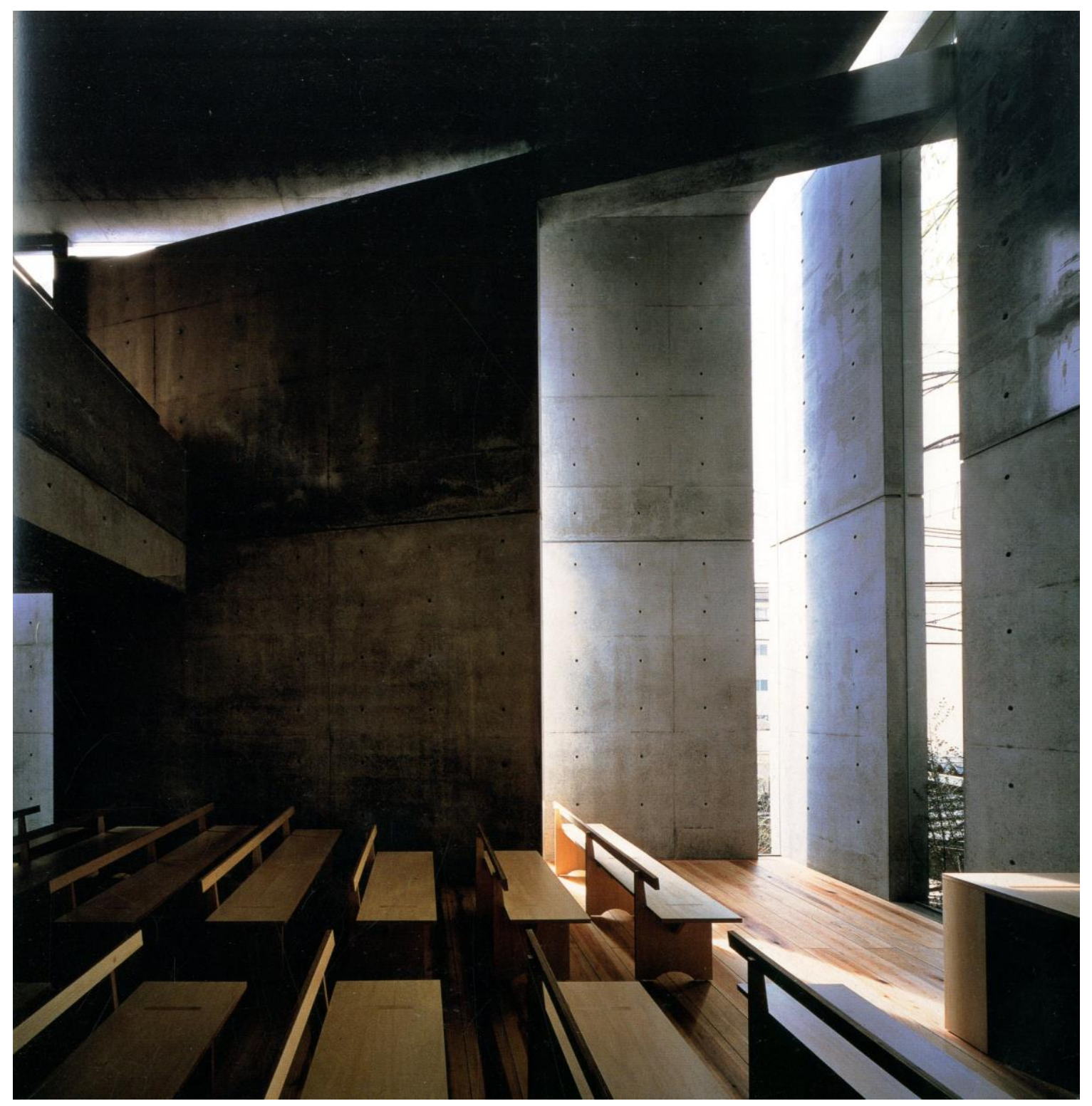

Fig. 7-6. Interior de la escuela del domingo. 


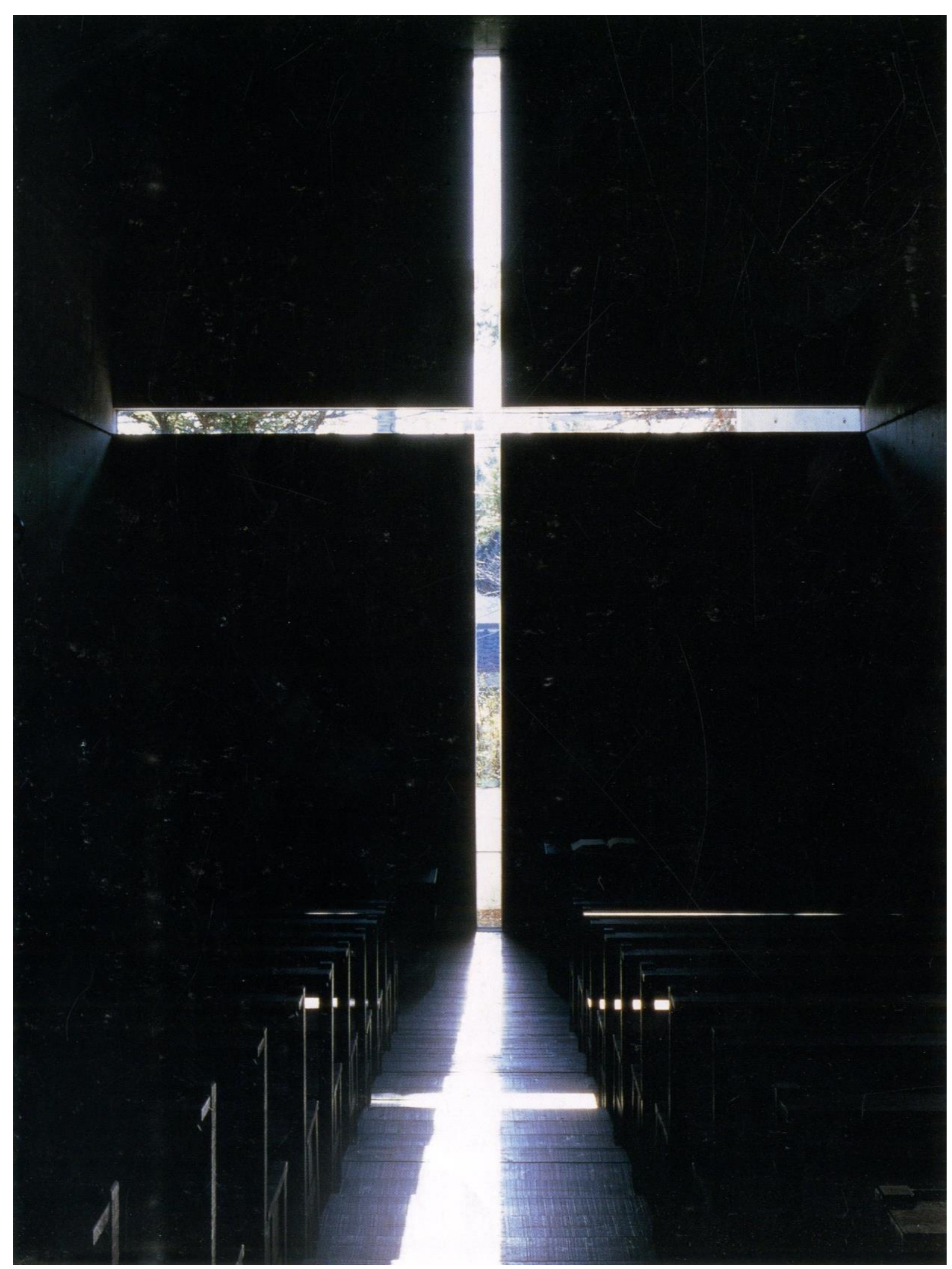

Fig. 7-7. Altar y apertura. 


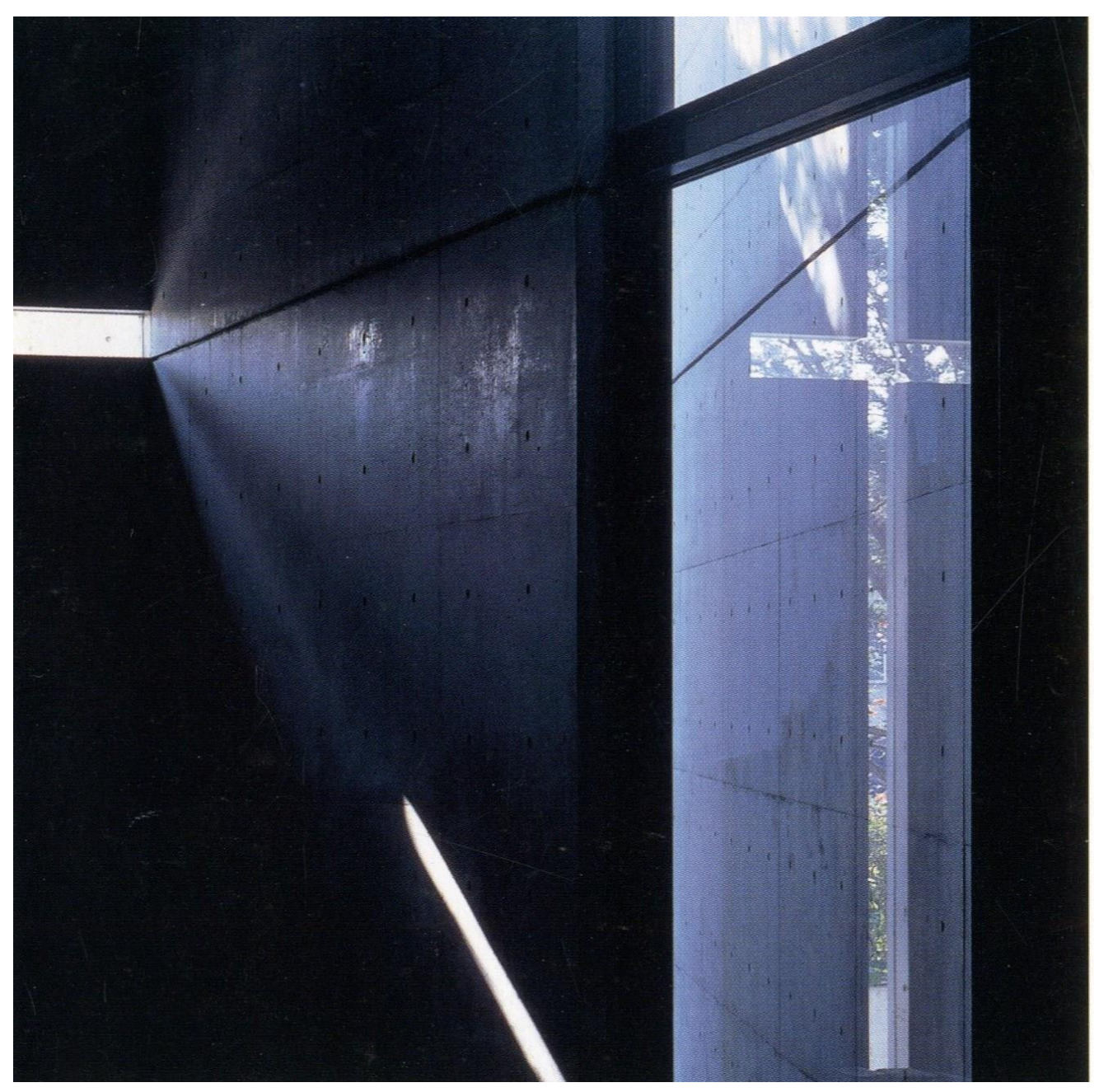

Fig. 7-8. Apertura lateral. 


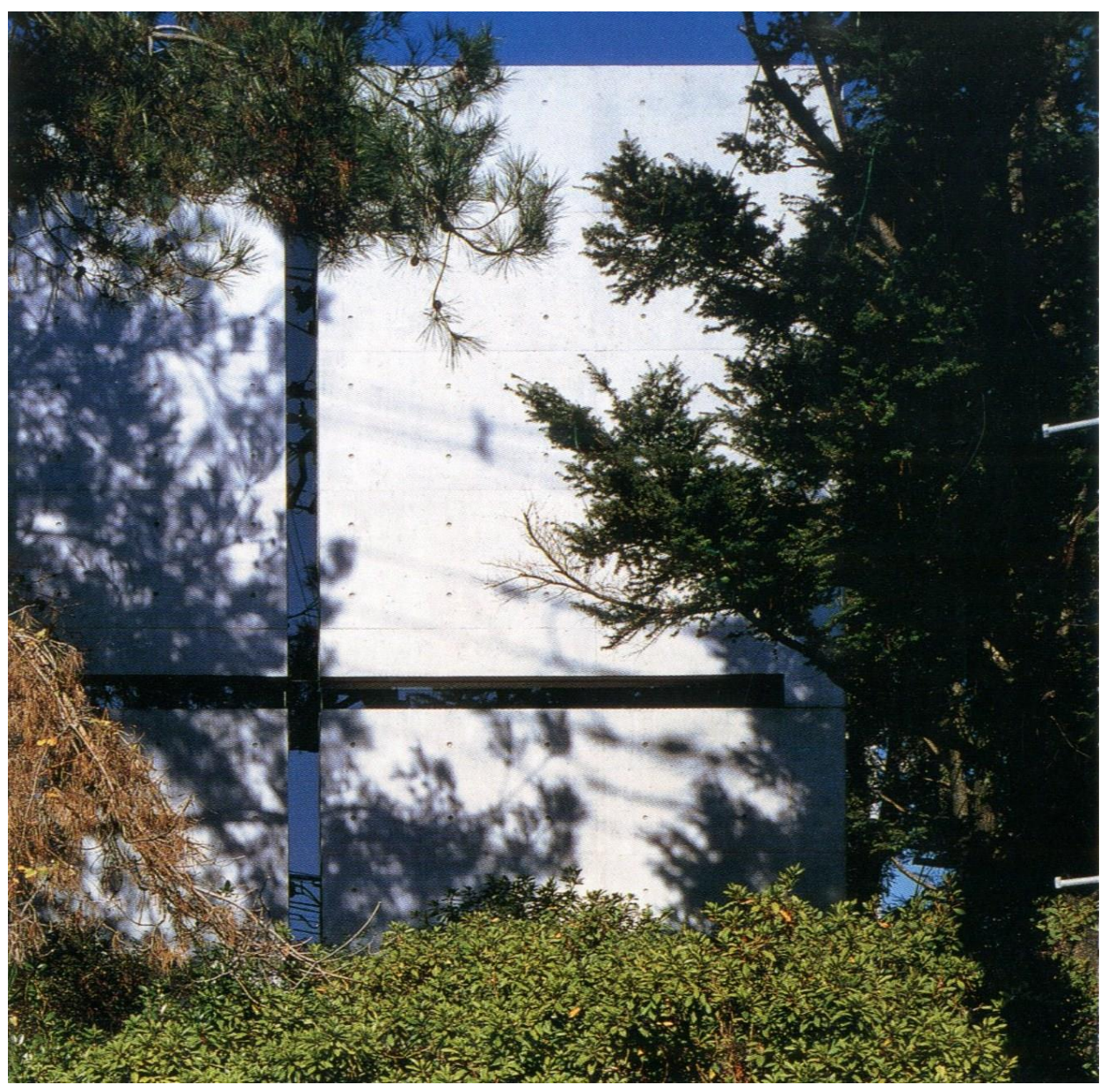

Fig. 7-9. Exterior desde la calle. 


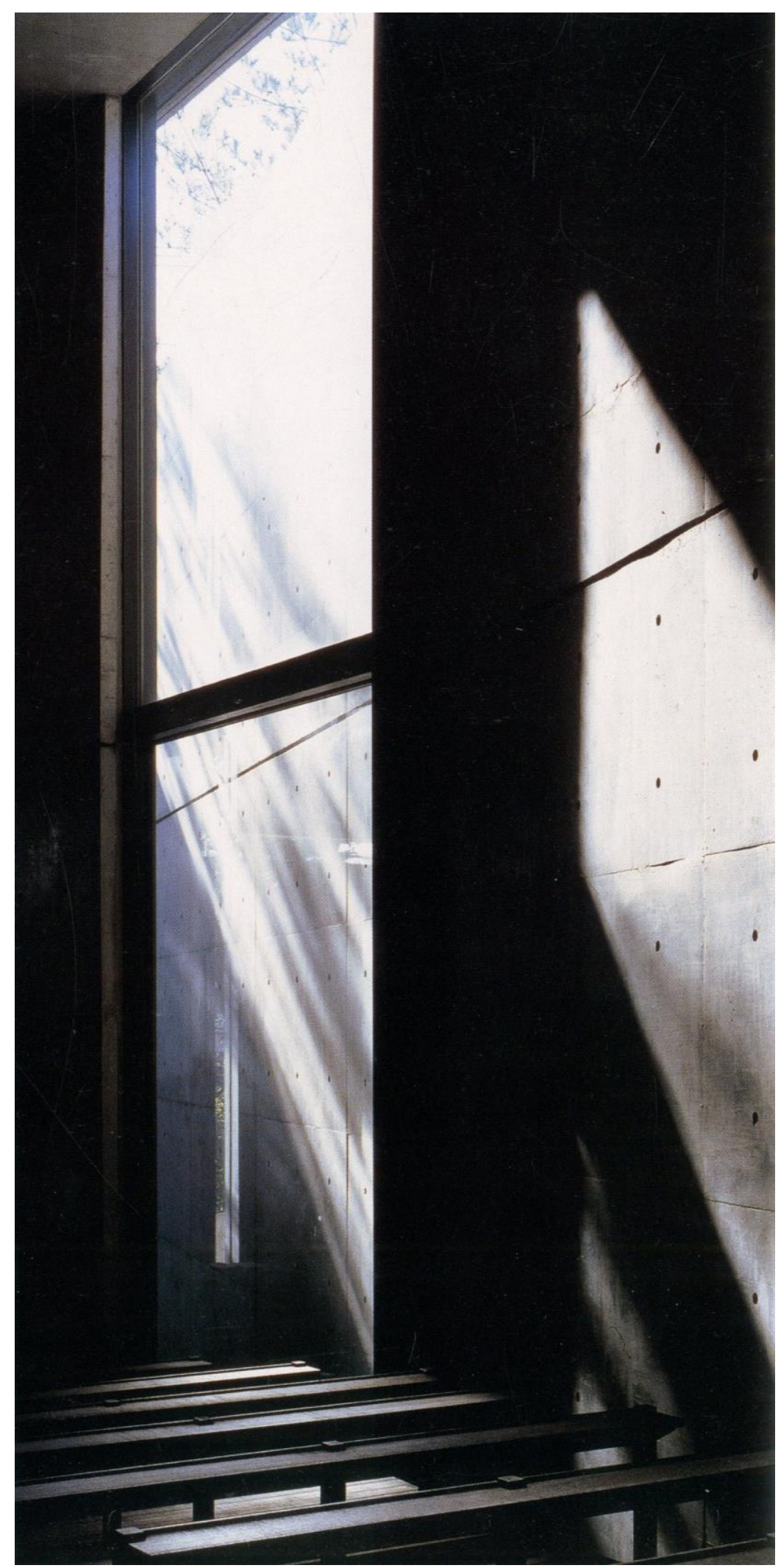

Fig. 7-10. Luz que entra por la pared de hormigón armado. 


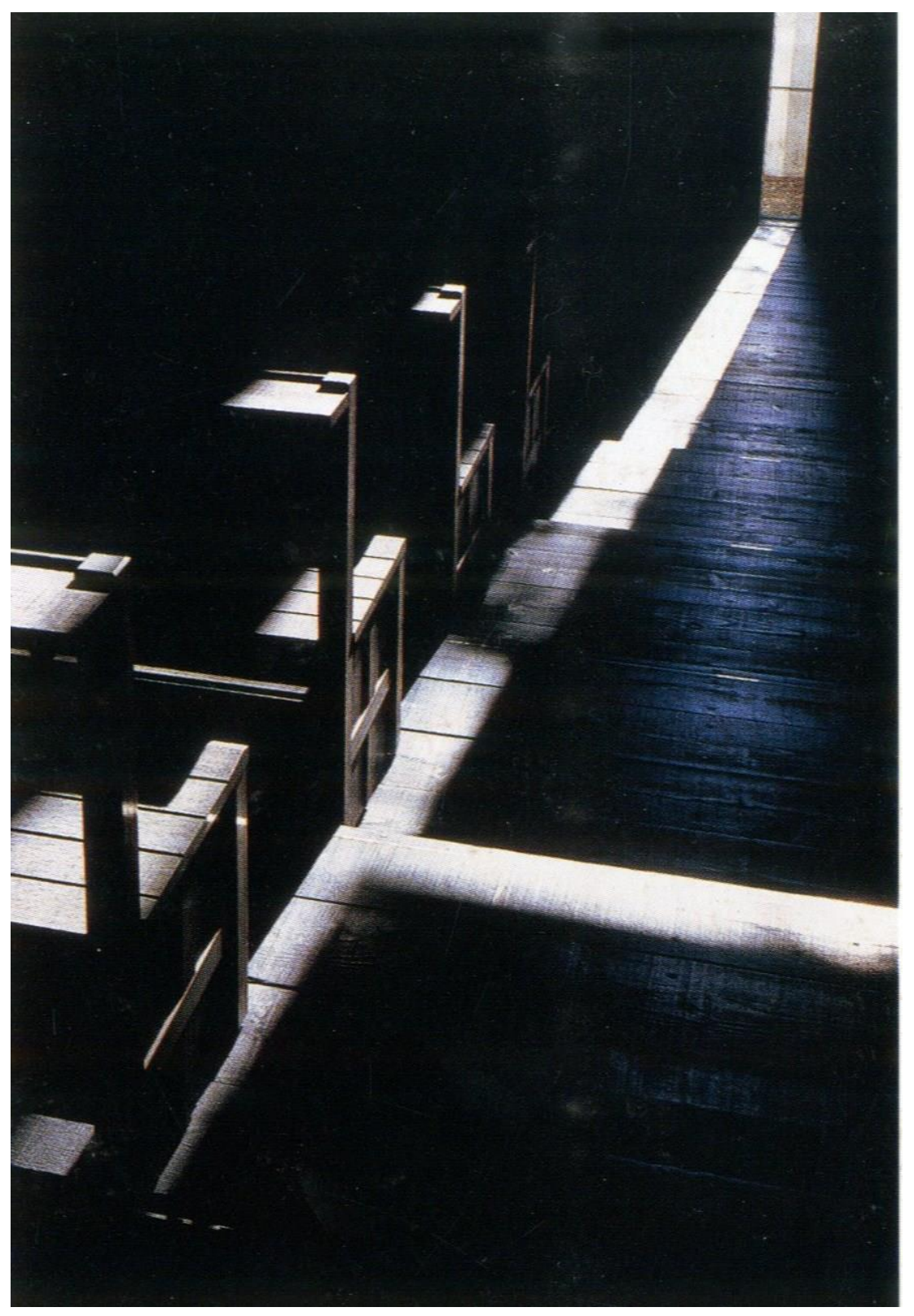

Fig. 7-11. Suelo con la luz de la apertura del crucifijo. 


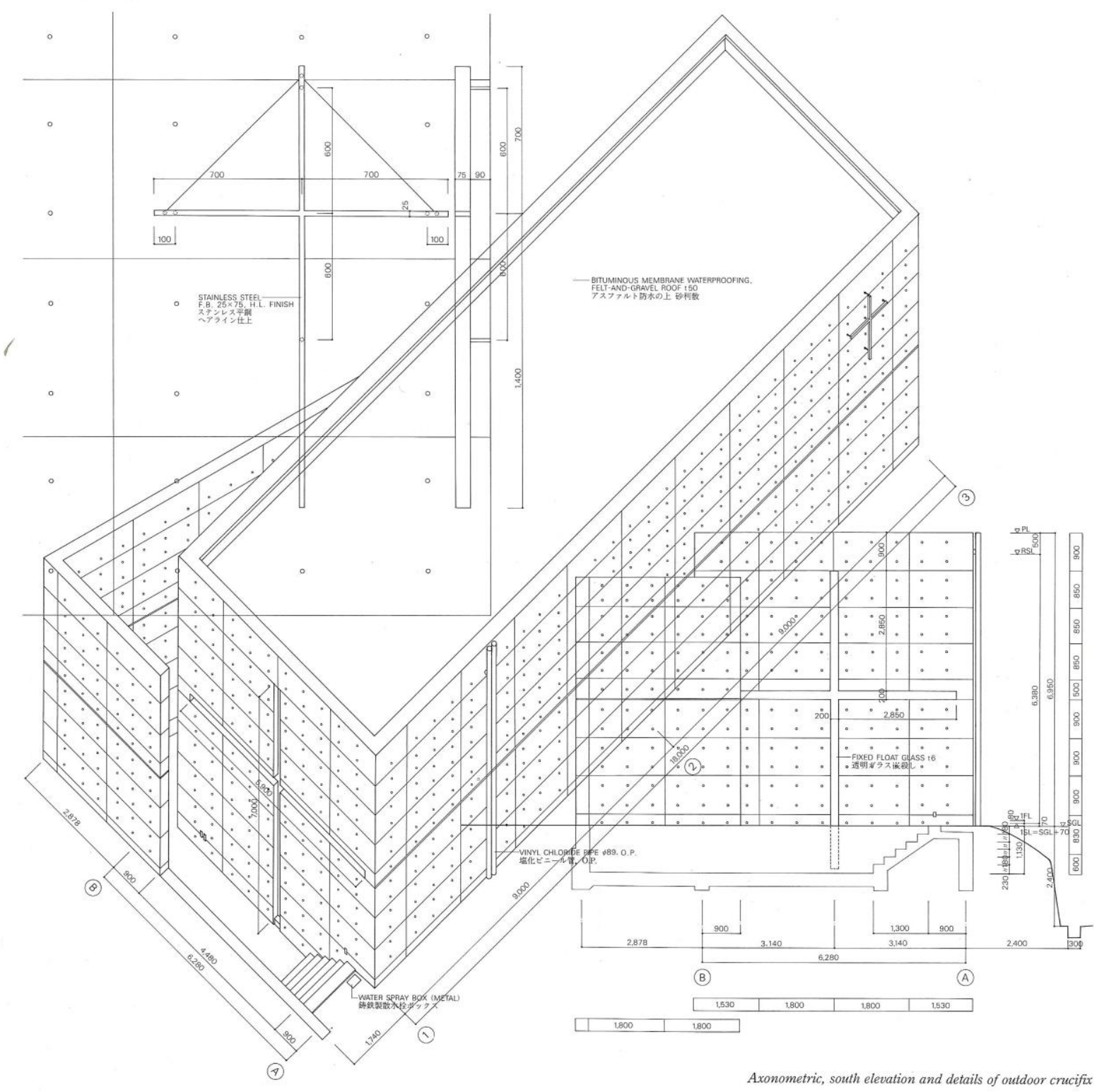

Fig. 7-12. Axonométrica, elevación sur y detalles del crucifijo exterior. 


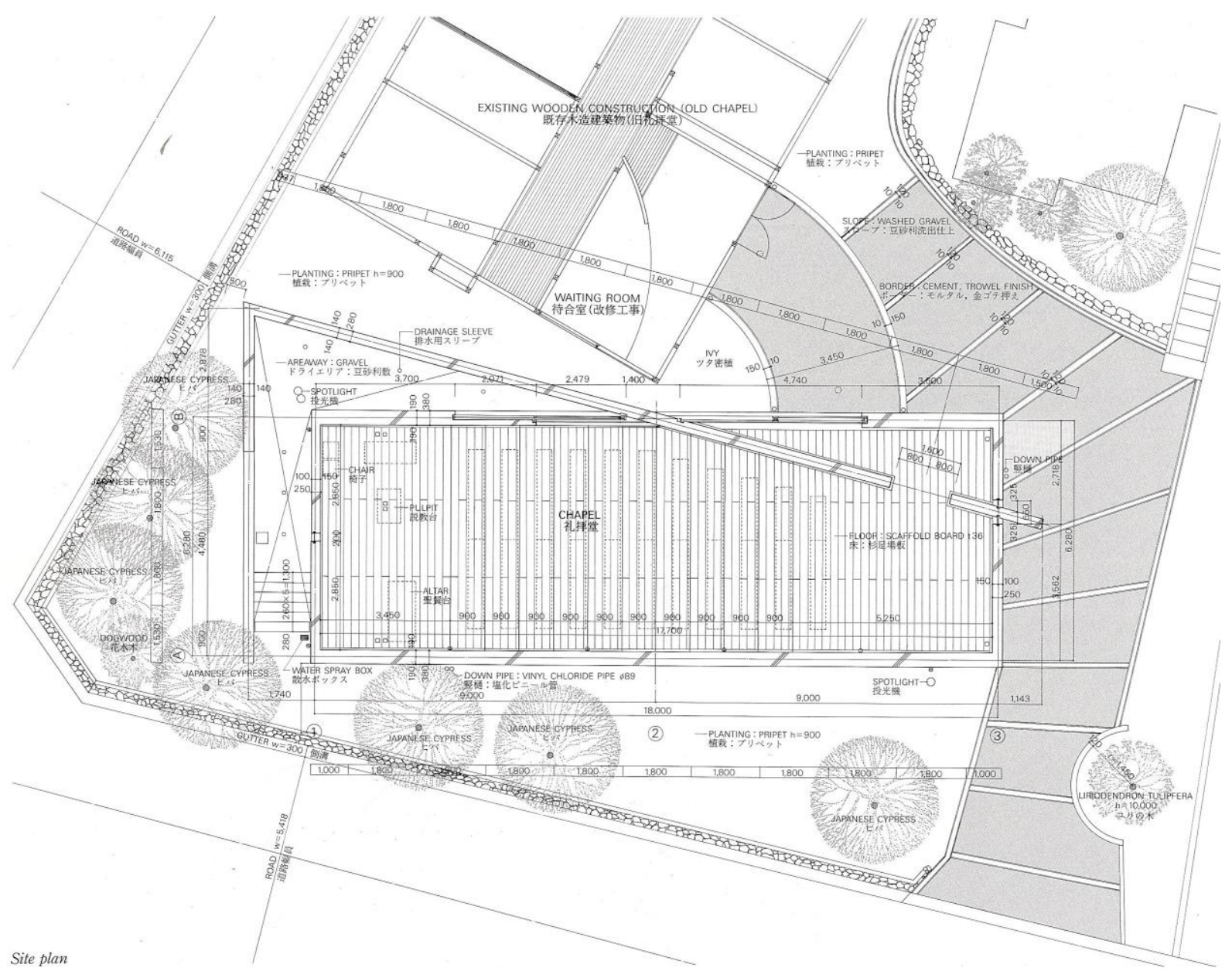

Fig. 7-13. Plano del lugar. 


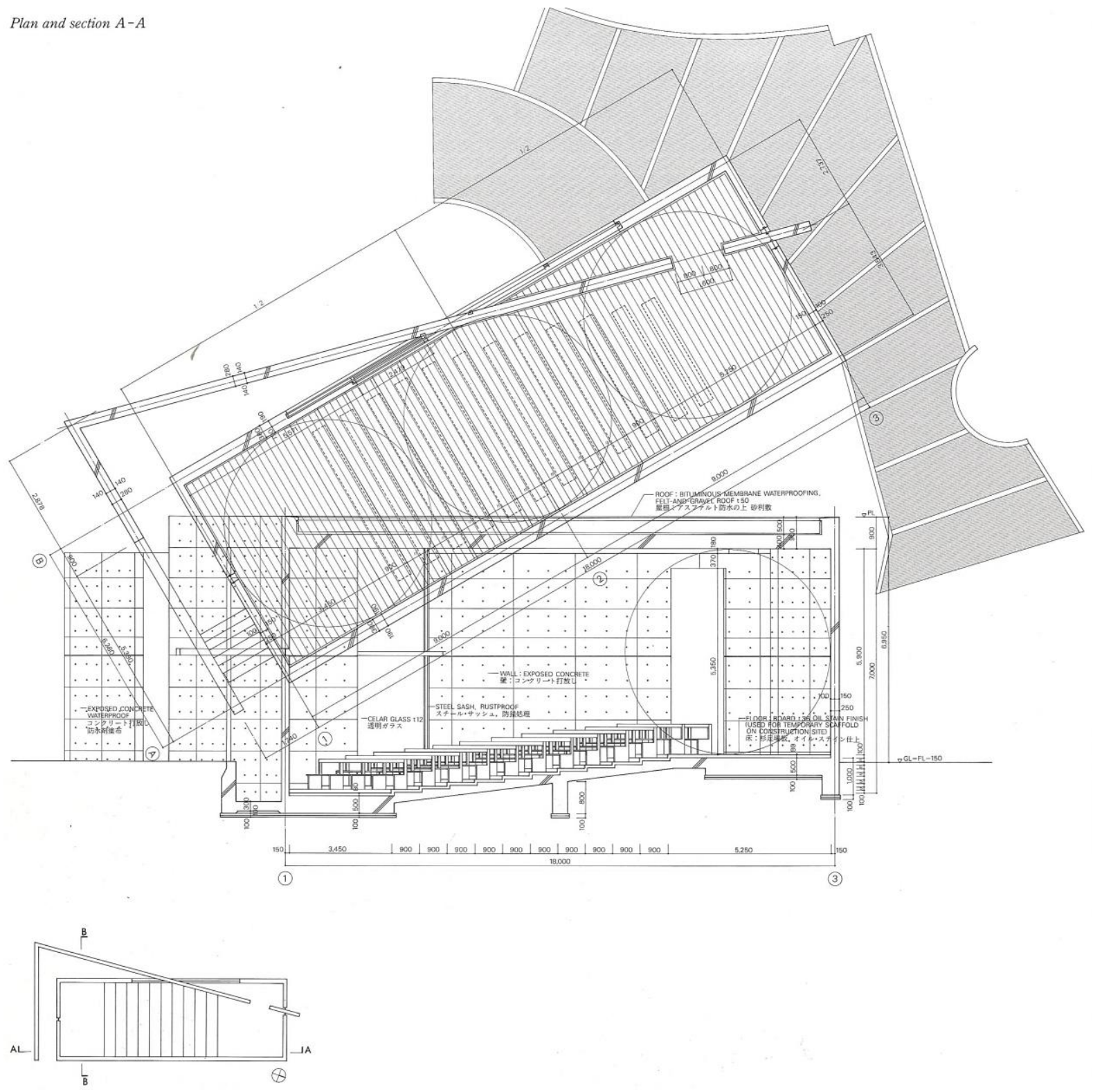

Fig. 7-14. Plano y Sección A-A. 


\section{La Epistemología Nirvánica}

Uno de los remedios que el cura y el barbero dieron, por entonces, para el mal de su amigo, fue que le murasen y tapiasen el aposento de los libros, porque cuando se levantase no los hallase -quizá quitando la causa, cesaría el efecto-, y que dijesen que un encantador se los había llevado, y el aposento y todo; $y$ así fue hecho con mucha presteza.

Miguel de Cervantes. 1605. Don Quijote.

Hasta ahora, en la primera parte de esta tesis (específicamente en el capítulo uno) se han revisado brevemente los mantras del buddhismo, que son herramientas para analizar los proyectos utópicos occidentales y las obras zen-buddhistas orientales. A continuación, en la segunda parte (en los capítulos $2,3,4$ y 5), se trataron cuatro proyectos urbanísticos relevantes occidentales del siglo XX basados en pensamientos utópicos, y al final, en la tercera parte (los capítulos 6 y 7) se analizaron dos espléndidas obras de la tradición zen-buddhista japonesa.

Por ello, la trayectoria por dónde la ciudad del nirvana tiene que ir, está aproximadamente esbozada. Ahora pues, la cuarta parte (los capítulos 8,9 y 10) va a ganar significado infiriendo dicha trayectoria con vocabularios y materias más específicos, estableciendo indudablemente unos ciertos principios.

Como se refirió en el capítulo cero, las tres ramas cruciales de este estudio consisten en responder a las tres preguntas siguientes: ¿qué es lo que sé?, ¿qué es lo que debo hacer? y ¿qué es lo que deseo? Primero, la pregunta tan abstracta, $<<$ ¿qué es lo que sé? $>>$. Actualmente podría expresarse con palabras más concretas. ¿Los humanos cómo perciben su cuerpo y los exteriores de éste -por ejemplo: la arquitectura, la ciudad, la sociedad etc.?, ¿Cómo se podrían percibir dichos asuntos justamente?, ¿éstas cosas son posibles? ¿sería imposible?, ¿o por lo menos, hasta qué nivel se podría decir que es posible? Este tipo de preguntas van a abordarse en la perspectiva nirvánica según los principios dilucidados, basándose en los buenos argumentos de los 6 tipos de investigaciones.

En segundo lugar, la pregunta, $<<$ ¿qué es lo que debo hacer? $>>$. Se establecen unos criterios preguntando: ¿con los verdaderos conocimientos y la genuina percepción, cómo se puede juzgar qué 
es justo o no en la perspectiva nirvánica, y cómo se podría reaccionar según dichos criterios?

En tercer y último lugar, la pregunta es: <<iqué es lo que deseo?>> Dicha pregunta trataría las siguientes cuestiones: ¿Con la justa epistemología y ética, la ciudad en qué se convertiría? ¿Qué tipo de diseño se puede esperar? ¿En este diseño se refleja la filosofía, y cómo influye en la vida humana? ¿Cuál es la virtud del diseño nirvánico? Las cuestiones se van a contemplar desde la perspectiva nirvánica. En este capítulo se contempla la primera pregunta: ¿qué es lo que sé?

\section{Comienzo de la Epistemología}

Como se refirió en el capítulo uno, la primera enseñanza del Sendero Medio es la Visión Justa (u opinión justa o correcta). En este presente capítulo donde se plasma el concepto de una percepción justa, sería apropiado y efectivo empezar el argumento haciendo hincapié en los mantras que se ha revisado anteriormente en el capítulo uno. Además es lógico que para ganar legitimidad en el desarrollo del argumento de este capítulo se empiece en un punto de ortodoxia de la enseñanza de Buddha. La Visión Justa es un elemento primordial en la enseñanza del Sendero Medio. Si se malinterpreta la Visión Justa del Sendero Medio, todo el esfuerzo para cumplir el resto de los siete senderos medios sería en vano.

Tener la Visión Justa se entiende en buddhismo como entender el dharma correctamente. El dharma es el elemento que forma el mundo según el principio de CSD $^{1}$, y es el mundo mismo. Los dharmas se reúnen y se descomponen. Los dharmas forman las células somáticas, establecen las civilizaciones, provocan las guerras, la herrumbre y los estropicios, ayudan a la gente y marginan a las minorías. Los dharmas hacen que las cosas puedan ser las cosas. El principio de los dharmas, es decir CSD, es el diagrama conceptual. Debido a que existen diagramas conceptuales que reproducen la agonía y la paz, hay dos tipos de CSD que son $\mathbf{A D}^{2}$, que produce la agonía, y $\mathbf{E D}{ }^{3}$, que produce la paz. En este sentido, una más concreta explicación terminológica buddhista de La Visión Justa se entendería como una percepción justa de los dharmas que se han colocado en los caminos de AD y ED.

\footnotetext{
Co-surgimiento dependiente-(NdA)

2 Acumulación del Dolor-(NdA)

${ }^{3}$ Extinción del Dolor-(NdA)
} 


\section{La Síntesis desde los cuatro proyectos utópicos}

Este estudio ya ha recorrido los cuatros proyectos utópicos en la segunda parte (capítulos 2, 3, 4 y 5) analizándose desde la perspectiva nirvánica. Se recuerda el capítulo dos en el que Howard percibió el proceso de AD correctamente, sin embargo como no pudo encontrar un tratamiento directo en el proceso de ED, al final su plan maestro quedó como no sostenible. No cabe duda que todo lo que él hizo fue relevante en el sentido de su arte elocuente y carismático a la hora de realizar el proyecto, y junto la manipulación de los actores dharmas, plasmó un dharma llamado La Ciudad-Jardín. De todas formas, parece que fue consciente de los elementos cruciales en el proyecto y los principios de CSD.

En el capítulo tres, en el caso Broadacre City, Wright al igual que Howard percibió adecuadamente los dharmas de la maldad. Los fenómenos patológicos urbanos estaban amenazando la salud de la familia americana, igual que la salud corporal y mental del pueblo. El interés de la renta fue un fruto vicario de los terratenientes y eso significaba para Wright la raíz de la maldad. Siempre el problema es $<<$ ¿cómo diseñar ED?>>. Howard tuvo el arte de la elocuencia y el carisma en la recaudación de fondos para Garden City Ltd. Y obviamente eso fue efectivo en los jóvenes financieros ilustrados e intelectuales. Afortunadamente todo fue acorde al plan de Howard; sin embargo, el plan necesariamente contiene un factor crítico del que no puede liberarse. Porque su ED nunca trató a los dharmas de AD directamente. El límite de Howard siempre se revela de esta manera. Pero contrariamente a él, en el caso de Wright, no se ve nada de duda a la hora de tratar los dharmas de AD. El sistema lo fue todo, y él lo destruyó. Ya que percibió el diagrama de agonía por su cuenta, su recetario es más claro que el agua alpina. Una exhaustiva expropiación del Estado. Para llegar a la utopía, parece que Wright no pudo esperar eternamente convenciendo al congreso de los Estados Unidos. Sería contradictorio con la metodología democrática si fuera una expropiación masiva. La arquitectura democrática fue el lema de Wright, pero irónicamente el método profético fue un tanto paradójico. Después de todo, surge una pregunta diciendo que: « ¿Así se llega a la utopía autocráticamente?>>. Su utopía no existió conectándose al mundo real y en un proceso cronológico, sino que existió irrealmente sin ninguna probabilidad. El efecto de su ED es indudable, pero el factor irreal que es la expropiación masiva para invocar la utopía no se puede encontrar en el mundo real. Y 
eso evidentemente fue todo probado.

En el capítulo 4 se habla sobre Le Corbusier, ciertamente un caso de estudio muy interesante. La posición de percibir el $\mathbf{A D}$ y su tratamiento fue literalmente extraordinaria. Se recuerda su proclamación diciendo que $<<$ ¡Debemos construir en un espacio limpio! >>. Le Corbusier se crió definitivamente en una familia burguesa. En consecuencia, en su plan Ilamado La Ciudad Contemporánea no resultaba fácil contemplar objetivamente el punto de vista de la clase obrera. Él sintió superficialmente los fenómenos patológicos urbanos, y por tanto no supo observar de dónde venía la raíz de aquellas maldades de la ciudad. Como no sabe lo que es AD, tampoco sabe dónde está el origen desde el cual finalmente tendría que eliminarlo. Así que simplemente quiere empezar desde cero. Cuando una máquina no funciona correctamente, hay dos opciones, que siempre son arreglarla o comprarla de nuevo. Lo que es importante aquí es que la ciudad no es una máquina, ni una cosa. Cuando una ciudad no va bien, no se puede comprar otra vez. Puede ser un sencillo cambio de papel en la mesa del arquitecto, pero la realidad no es así. ${ }^{4}$ Cuando se analiza el plano de La Ciudad Contemporánea, se siente como si se estuviera mirando un escenario donde Le Corbusier funciona como un arquitecto vicario de Dios que regala la utopía a la tierra. Quiso una separación total para el presente desde el pasado vergonzoso. Por eso su esquema sigue teniendo el límite impreciso, pensando en el ED que propuso se pueden ver las acciones de los dharmas sin embargo nunca se ve el proceso de la combinación y las identidades de los dharmas mediante el aspecto de CSD ${ }^{5}$.

En el capítulo cinco, el estudio recorre una utopía de Constant cuya propuesta alternativa y futurista tenía una interpretación de utopía, en el que su género era básicamente diferente comparando con los tres antecedentes en la medida de la conciencia de los problemas. Hay una parte en la que Constant vio una tendencia proliferada del materialismo pervertido y distorsionado debido a la influencia de las ciudades y que estaban produciendo los síntomas patológicos contemporáneos. Hasta aquí se podría decir que eran semejantes Howard, Wright y Constant en el sentido de la postura de percibir AD. Sin embargo Constant se lo estaba replanteando de nuevo, profundizando en la causa de los problemas no desde el sistema y los acaudalados, sino desde la capa más primitiva de la humanidad que es la

\footnotetext{
${ }^{4}$ Para una mayor crítica sobre este tema se puede referenciar desde: < Hall, P. 1988, Cities of Tomorrow: An Intellectual History of Urban Planning and Design in the Twentieth Century. Freixa, Consol(tr). Barcelona. Ediciones Serbal. Versión española 1996. p. 27>

${ }^{5}$ Co-surgimiento dependiente-(NdA)
} 
felicidad y el juego. Consideró que el juego era un elemento principal de la vida humana, es decir percibió la carencia del deleite. Claro que era de sentido común que la importancia del juego y su deleite fuera ignorada en la sociedad del materialismo y el utilitarismo de aquella época. Este tipo de acercamiento peculiar de Constant al problema desde el punto de vista antropológico fue gracias a la influencia del libro de Johan Huizinga Homo Ludens. Constant demuestra que el juego puede ser el elemento esencial de la vida nómada ${ }^{6}$. La interpretación de $\mathbf{A D ^ { 7 }}$ fue muy original, y su $\mathbf{E D}^{8}$ también muy idiosincrático. Quiso que los humanos interactuaran con el ambiente de la manera más creativa, dejando el pensamiento anacrónico y obsoleto. Los niños no juegan obligatoriamente, pero lo hacen porque hay en eso un divertimiento. Constant metió el elemento lúdico en el urbanismo. Había posibilidades de que pudiesen generar discursos polémicos sobre su plan de La Nueva Babilonia cuya escala mega-estructural cubría todo el planeta. Sin embargo, por lo menos, la legitimidad de AD y la lógica coherente de la aplicación desde AD hasta ED fue plausible.

Ahora bien, este estudio, desde el punto de vista de los cuatro proyectos (de Howard, Wright, Le Corbusier y Constant), ha podido lograr unos principios para proponer la ciudad del nirvana. Si se pudiese resumir un poco radicalmente, en el primer principio se diría que la ciudad utópica no es algo dado, sino que es algo que puede existir en el mundo real. El segundo principio es que, si no se pueden percibir los dharmas que existen detrás del muro fenomenal de $\mathbf{A D}$, en consecuencia, el ED que se habría correspondido al AD necesariamente se queda como una pieza inconclusa. El tercer principio es que la factibilidad depende de la combinación eficiente del CSD. Por último, el cuarto principio es que aparte de la legitimidad de la interpretación de $\mathbf{A D}$, si el ED no corresponde a $\mathbf{A D}$ de la manera adecuada, entonces este ED no puede ser sostenible.

\section{La síntesis desde los dos proyectos zen-buddhistas}

En los capítulos de Katsura y La Iglesia de la Luz, el estudio ha podido comprobar la posibilidad de

\footnotetext{
6 En este contexto, el término de nomadismo no tiene nada que ver conGilles Deleuze \& Félix Guattari. El concepto nomadismo de Deleuze y Guattari, tiene un sentido más abstracto. Ellos intentaron demostrar la lógica del exilio de las acciones significantes con prioridad en su célebre obra Mil Mesetas(1980).-(NdA)

7 Acumulación del Dolor-(NdA)

8 Extinción del Dolor-(NdA)
} 
la doctrina de Siddhartha para aplicarse en la arquitectura y el paisajismo zen-buddhista.

En el capítulo seis, en la villa imperial de Katsura, el propósito de la obra no fue para tratar algunos asuntos sociales o problemas, sino tan solo fue para establecer el hogar de una persona, así que podría tener distinta magnitud en el aspecto social. La familia de Hachijo era descendiente real y no tuvieron una gran ideología filantrópica ni pionera. Solamente, los Hachijos quisieron llegar al nirvana desde la vida terrenal y cotidiana. Tal vez, era lógico para ellos que los asuntos prácticos para mantener la vida no eran en su mayoría parte de la intervención del proyecto -tenían muchos sirvientes y los Hachijos nunca habrían necesitado coser su propia ropa de seda estropeada. Así que la villa Katsura era un aparato puro de zen con el objeto auto-disciplinario.

Los paseos por el jardín, el juego de barco ${ }^{9}$, la ceremonia de té y en el Gepparo, en todos estos procesos los practicantes buddhistas buscaban la verdad contemplando lo efímero de los dharmas. Los aparatos dispuestos meticulosamente en el jardín, era un mundo en miniatura artificial a fin de que el paseante perciba una nueva ética de superación. Básicamente, Katsura es una casa, pero es difícil borrar la sensación de estar ante un templo o un santuario. Eso es porque dichos lugares ejemplares, en el mundo occidental, son para experimentar la presencia de dios o sentir la consciencia de un vínculo con un ser transcendental. Así que en el mismo contexto, en Katsura el sujeto se vincularía con otros dharmas, el tiempo y el espacio, y al final experimenta una consciencia parecida. En La Iglesia de la Luz, también se puede reconocer la misma categoría del tema.

La metodología zen-buddhista hace que los sujetos perciban el mundo por unos ciertos procesos de paseo en el zen-jardín, En la obra de Ando dicha metodología zen-buddhista está más estructurada y concreta, gracias a los vocabularios sólidos de Kitaro Nishida ${ }^{10}$. La arquitectura ética a la que Ando se refiere, es un espacio que llena el cuerpo con la afección y la inspiración; así que se hace sentir a los sujetos que no están solos, ni tampoco abandonados en este mundo cruel; sino que están todos vinculados como si cada uno fueran dharmas co-surgidos dependientemente (CSD). Desde 無(vacío) hacía 間(ma), y desde間(ma) hacia 身體(Shintai), y otra vez desde 身體(Shintai) hacia 無我(No-Yo),

\footnotetext{
9 El término original (船遊び;遊船), tendría que traducirse en español por: <<hacer una excursión del barco>>. Sin embargo, para destacar el sentido de la serie de particulares acciones disfrazadas como si estuvieran en otro mundo ( o alguna situación superada de las condiciones mortales), se ha traducido por <<un juego >> salvando el sentido original japonés.-(NdA)

10 La mayor parte de los vocabularios que usa Ando, fue debida a la influencia de un filósofo legendario que llamado Kitaro Nishida. Sobre este tema, Ando así mismo lo confesó varias veces en las entrevistas.-(NdA)
} 
y por último desde 無我(No-Yo) hacia 涅槃(Nirvana), de esta manera el concepto de la arquitectura ética fue expendido y enriquecido. Así se dilucidó un proceso de ED ${ }^{11}$ desde NY ${ }^{12}$ hasta al Nirvana. El en espacio ético llamado Ma, el sujeto se convierte en artista-shintai, santo-shintai y sabio-shintai. La arquitectura ética de Ando, de igual forma que la virtud de zen-buddhismo, estaba diseñada teniendo en consideración el Nirvana como la estación terminal de este viaje. Como se puede comprobar en su ensayo The Eternal within the Moment ${ }^{13}$, se esfuerza incesantemente en introducir los elementos climáticos temporales en su expresión arquitectónica, para que los sujetos puedan sentir la eternidad y espontáneamente se internalice el experimento corporal. Entonces, el Shintai-dharma podría ya desencadenar su yugo y entraría en el nirvana. Eso fue el esquema básico de Ando en su proyecto.

El proceso de paseo que se ha dispuesto meticulosamente, la experiencia de la luna reflejada en el Gepparo, la casa de té y la luz suave atravesando la ventana de fusuma de Katsura, la luz que viene desde la cruz perforada, el contraste de brillo y la oscuridad del espacio, el tiempo, el clima de La Iglesia de la Luz... todo es la evidencia de lo efímero que son los dharmas y su profunda relación con el nirvana. Además, no hay duda que este tipo de acercamiento al nirvana es absolutamente ortodoxo, reflejándose en la doctrina de Siddhartha.

\footnotetext{
11 Extinción del Dolor-(NdA)

12 No-yo-(NdA)

${ }^{13}$ Ando, T. The Eternal within the Moment. Francesco Dal Co(ed.) Tadao Ando: Complete Works. London. Phaidon Press Limited. 1995. p. 474.
} 


\section{Proposición sintética}

Los frutos son humildes porque justo acaba de empezar este estudio, y a la vez son sinceros porque se han logrado contrastando el cuerpo de este estudio con los casos de estudio. Posteriormente se encuentran los 5 principios que, desde ahora, van a funcionar como criterios esenciales en los capítulos 11, 12 y 13 que son los últimos proyectos de este estudio, antes de introducir la conclusión.

0. Todos los dharmas son efímeros.

1. La utopía presupone la posibilidad de la realización.

2. La constelación de los dharmas que se han percibido en el proceso de $\mathbf{A D ^ { 1 4 }}$ ha de descomponerse.

3. $\mathbf{E D}^{15}$ tiene que tratar directamente los dharmas de $\mathbf{A D}$.

4. La efectividad de CSD $^{16}$ tiene que ser sostenible.

${ }^{14}$ Acumulación del Dolor-(NdA)

${ }^{15}$ Extinción del Dolor-(NdA)

${ }^{16}$ Co-surgimiento dependiente-( $\left.\mathrm{NdA}\right)$ 


\section{La Ética Nirvánica}

...Hemos distribuido hábiles seudónimos para que nadie sea reconocible. ¿Por qué hemos conservado nuestros nombres? Por rutina, únicamente por rutina. Para hacernos nosotros también irreconocibles. Para hacer imperceptible, no a nosotros, sino todo lo que nos hace actuar, experimentar, pensar. $Y$ además porque es agradable hablar como todo el mundo y decir el sol sale, cuando todos sabemos que es una manera de hablar. No llegar al punto de ya no decir yo, sino a ese punto en el que ya no tiene ninguna importancia decirlo o no decirlo. Ya no somos nosotros mismos. Cada uno reconocerá los suyos. Nos han ayudado, aspirado, multiplicado. ${ }^{1}$

Gilles Deleuze \& Félix Guattari. 1976. Rizoma.

La comprensión de la ética nirvánica ha sido discutida desde el capítulo de Howard, debido a esto y en la misma línea, en este apartado el estudio va definir los vocabularios y los criterios de la ética nirvánica de forma más detenida. Ya que la epistemología nirvánica se inicia por la Visión Justa, la ética nirvánica también se va a comprender de igual manera. La ética nirvánica necesariamente ha de tratar el tema de la ética ambiental, y no solamente en el campo metafísico, puesto que tiene que estar conectada y referenciada a los discursos en el nivel práctico, arquitectónico y urbano, estableciendo así los criterios de las acciones venideras y tratando el problema de la conciliación entre la teoría y la práctica.

\section{Discursos posibles de la ética nirvánica}

Ya es el momento de probar la equidad de los principios éticos y sus características. Además, por medio de la experimentación de ideas, también se podría proponer el límite de su aplicación. En esta sección se tratan algunas nociones que se han expuesto sin comprobación de las premisas.

\footnotetext{
${ }^{1}$ Deleuze, G. \& Guattari, F. v.o. 1976. Rizoma. Pre-Textos. Valencia. José Peréz \& Umbelina Larraceleta. (tr.) Versión española. Titulo original: Rhizome. 2013.
} 


\section{Proposición I}

i) Sería suficientemente obvio el hecho de que no hay ninguna cosa que sea mala por su propia existencia. Además, este tipo de pregunta ontológica está ya fuera del discurso de qué es ético o virtuoso o no. ¿Entonces, si la manera de existir de este mundo fuera según su cualidad $\left(\right.$ CSD $^{2}$ aquí es un concepto para definir su ontología) y seguir su cualidad ( $\mathbf{N Y}^{3}$ aquí es un concepto para definir su ética) sería virtuoso? ¿Por eso es posible establecer una ética lícita?

ii) Respondiendo a la anterior pregunta: Si no es posible, (si la virtud del mundo y la de los anexos son distintos) ¿cómo se puede negar otro tipo de criterio que habría surgido por otra fuerza ontológica, por ejemplo: el fetiche, el utilitarismo, el totalitarismo, el segregacionismo etc.? ¿Dónde está la base del argumento? ¿Los anexos del mundo, por sí mismos, persiguen su peculiar excelencia ontológica?

\section{Demostración I}

i) Los anexos contenidos de este mundo también existen en la virtuosa manera de CSD y por eso surge la razón para poder exigir de nuevo la ética de NY al mundo, porque desde el principio NY es un concepto inmanente. Si se opone y desobedece a esta virtud de NY, entonces eso significa que el concepto de CSD puede ser no virtuoso para alguien. Así que se pierde toda la base del discurso.

ii) Sería lógico juzgar que los anexos del mundo existen según la misma virtud de CSD. Y recordando el caso de Howard, no sería justo considerar que la manera de vivir de los terratenientes-dharmas que toman exorbitantes intereses de la clase baja, y el sistema-dharmas (los hombres del congreso) que aportan los acaudalados, fueran virtuosos naturales. Eso es porque cada día la clase obrera va a perder más proporción de riqueza gracias a que el valor de la moneda nunca aumenta, más bien baja, según el sistema del mercado vigente actualmente. Con el tiempo la base de la pirámide se va a hundir. Entonces, naturalmente el depredador de la pirámide tiene que encontrar una alimentación alternativa,

${ }^{2}$ Co-surgimiento dependiente-(NdA)

${ }^{3}$ No-yo-(NdA) 
haciendo un nuevo sacrificio en su propio grupo predatorio. A la larga, la caída de la sociedad era inminente, eso es porque la cadena ecológica tiene la forma característica en la que la serpiente se muerde la cola. Este tipo de convivencia no puede ser sostenible. Sacrificar su vida para salvar su vida es contradictorio y difícil de considerar, debido a su forma de existencia natural. Por lo cual, la bondad del mundo se puede aplicar de igual manera a los anexos-dharmas del mundo. Además, no es contrario a su naturaleza el exigir este principio de la ética nirvánica a los dharmas. De éstos, algunos parecen que tienen otra manera de existencia, sin embargo, eso no significaría que siguen la excelencia de su virtud natal.

\section{Proposición II}

i) ¿Si CSD es la virtud del mundo natural y su manera de supervivencia, y si eso se pudiese admitir como ético cuando se revela su excelencia, entonces, cuál es el límite de la aplicación práctica al urbanismo y la arquitectura?

ii) ¿Si la incumbencia de la aplicación del principio fuese exhaustiva, en el campo práctico algunas situaciones imposibles de aplicar, -por las condiciones económicas, sociales, geográficas etc., dicho principio se quedaría sin ninguna posibilidad de salvación? ¿Si el principio nirvánico es algo que puede conciliarse, se podría considerar como un concepto contaminado o herético?

iii) ¿Qué tipo de iluminación puede existir: la manera profética, la auto-iluminación, emisión epidémica etc.? ¿Y éste tipo de evangelización podría parecer nirvánica?

\section{Demostración II}

i) Ya fue demostrado en el capítulo de Constant. La forma de las mega-estructuras, los programas neutrales de los sectores y el desarrollo de la tecnología, todo insinuaba la filosofía del nomadismo y $\mathrm{HL}^{4}$. La manera de aplicación en el campo urbanístico o arquitectónico tendría que ser exhaustiva. Los

\footnotetext{
${ }^{4}$ Homo Ludens-(NdA)
} 
muros, masas, columnas, ventanas, techos, colores, longitud, anchura, vegetaciones etc., la ética nirvánica se puede revelar por su diseño. Por lo cual, el diseño que se ha aplicado en el principio ético, se puede reconocer visualmente también. Además, el límite de la aplicación no sólo cubre el campo físico sino también el no-físico. En el capítulo de Howard, no sólo en el campo estético, intentó tratar varios actores de dharmas enfrentando los asuntos de intereses de los grupos, la justicia de ONG, la manera de cooperación con los cuerpos gubernamentales etc. Así que el límite de aplicación se delimita incluyendo el campo metafísico.

ii) Sí que pueden existir numerosos obstáculos en el proceso de las intervenciones nirvánicas. En el caso de Howard, los ignoró, en los casos de Wright y Corbusier, trataban dichos inconvenientes demasiado radicalmente perdiendo la realidad y factibilidad del proyecto. Por último, en el caso de Constant, se ve la consistencia de la filosofía del proyecto. Eso es porque ya estaba entendiendo el factor del tiempo. Así que considerando dicho factor y aunque la Nueva Babilonia no podría perfeccionarse instantáneamente, sabía que algún día la mega-estructura iba a cubrir todo el planeta, extendiéndose ya que la tierra es redonda. Por eso, la importancia del proyecto no es sobre el problema de la perfección en el instante, sino sobre la direccionalidad correcta. Si el proyecto contiene una direccionalidad justa, entonces sólo queda el tema de la sostenibilidad. Es verdad que pueden existir algunos obstáculos no anticipados, pero esto no significa que se tiene que cambiar la idea. Constant no ha hablado sobre construir la mega-estructura al mismo tiempo, en todo el planeta, pero eso no significa que se pueda contaminar la ortodoxia. Porque el proyecto aún estaba en proceso de la perfección.

iii) En el caso de Wright, fue escéptico sobre la esperanza de la inteligencia colectiva y su moralidad colectiva. Así que era lógico que fuera escéptico también sobre la idea de que algún día la inteligencia colectiva podría llegar a la conclusión apropiada para completar su proyecto llamado The Broadacre City. Desde su punto de vista, lo que faltaba a la sociedad era una idea profética y a la vez, un extraordinario liderazgo para realizarla. Sin embargo, la manera de evangelización nirvánica no tiene que ser opresiva. El centro de la cuestión no es la eficiencia provisional sino el poner la base correcta. Teniendo en cuenta la base de la ética nirvánica, los ciudadanos-dharmas se perciben uno a otro en la comunidad cósmica, y los otros dharmas aún no iluminados aprenden esta verdad con el cuerpo 
personal, no proféticamente. Esta manera de emisión de la idea tal vez no sea eficiente por el momento, sin embargo, si una vez empieza esta epidemia agradable, nunca va a parar hasta que ilumine a todos los cuerpos-dharmas piel a piel, lenta y definitivamente.

\section{Apéndice}

Se podrían hacer muchas preguntas sobre el nirvana, y dicho nirvana sería sobre el nirvana de los dharmas, las ciudades, la arquitectura, las organizaciones de varios campos, los diagramas, los cuerpos, etc. Y para responder a la pregunta de ¿qué es el nirvana?, podría sustituirse adecuadamente con una tesis diciendo ¿qué es la capacidad del cuerpo nirvánico? Eso es porque la respuesta sobre la capacidad virtuosa del cuerpo nirvánico está ubicada en la misma línea que este estudio tiene que seguir. Curiosamente, del estado del nirvana al que los buddhistas se refieren, se pueden encontrar conceptos semejantes en la historia de la filosofía occidental. Primero, se podría nombrar a Spinoza. En su célebre obra Ética, el concepto del cuerpo se describe por un estado que está lleno de la capacidad de afección. ${ }^{5}$ La segunda referencia es de Marx, en su famoso escrito Manuscritos Económico-Filosóficos de 1844, consideró las prácticas sociales y las acciones en las que los obreros transforman los objetos, lo que era una genuina labor de los proletarios. ${ }^{6,7}$ Por último, se puede ejemplificar el trabajo colectivo Mil Mesetas: Capitalismo y Esquizofrenia de Deleuze \& Guattari. El concepto denominado un cuerpo sin órganos, tiene un carácter muy parecido al cuerpo nirvánico. Un reto para hacer un cuerpo sin órganos se entiende gracias a establecer un nuevo marco de pensamiento apartándose de los significados absolutos y dejando los papeles permanentes de los sujetos sociales.

Para deducir el cuerpo nirvánico, sería estupendo si se pudiera recorrer brevemente los conceptos genealógicos siguiendo a Spinoza, Marx y Deleuze \& Guattari. ${ }^{8}$ Especialmente, el sentido del cuerpo

\footnotetext{
${ }^{5}$ Spinoza, B. v.o.1677. Ética (Ethicha: Ordine Geometrico Demonstrata). Madrid. Alianza Editorial, S.A. Versión español. Peña, V(tr.). 2007.

${ }^{6}$ Marx, K. Manuscritos Económicos y Filosóficos de 1844. Seoul. Theory and Practice. Versión coreana. Kang, Y.O.(tr.). 2007. p. 93,

${ }^{7}$ Shin, S.C. El Estudio sobre las Teorías del Deseo y del Cuerpo de Deleuze \& Guattari. Tesina master. Dongguk University. 2003. p. 32

${ }_{8}^{8}$ Originalmente, este tipo de estudio genealógico sobre el concepto del cuerpo, no es de este estudio. Para encontrar la versión
} 
sin órganos de Deleuze \& Guattari, podría ayudar a este estudio enriqueciendo su discurso y dando una solidez a la base de la lógica. Además, el léxico característico de Deleuze \& Guattrari es esencial para aplicar la ética nirvánica en el campo práctico.

\section{Baruch Spinoza}

La idea de una cosa singular existente en acto tiene como causa a Dios, no en cuanto es infinito, sino en cuanto se le considera afectado por la idea de otra cosa singular existente en acto, de la que Dios es también causa en cuanto afectando por una tercera, y así hasta el infinito. ${ }^{9}$

Spinoza. 1677. Ética.

Spinoza, en su célebre escrito Ética, insiste en deducir los principios éticos en un orden geométrico, basándose en las condiciones primitivas del cuerpo y la mente. Demostrando la esencia de Dios, Spinoza dilucida otra esencia de cuerpo. ${ }^{10}$ Para Spinoza, la más primordial y característica esencia del cuerpo es la afección, y con eso deduce que la afección fuera un esfuerzo de auto-causa igualmente a Dios. La capacidad de afección del cuerpo se puede cambiar depende de qué situación se disponga. Si se entiende con el estilo de Deleuze \& Guattari, se diría que un africano que cosecha el algodón en un campo, es un cosecha-dharma ${ }^{11}$, sin embargo en la Casa Blanca de Washington D.C. es el líderdharma. De igual manera, en una escala más pequeña, los dientes de los humanos cuando se come algo, se comprendería por un demolición-dharma de comida o digestión-dharma, pero en una pelea, es un ataque-dharma, obteniendo así un nuevo significado. De esta manera se entiende como si la afección del cuerpo al exterior fuese la virtud natal de los seres.

Cuando el cuerpo se encuentra con las situaciones y los objetos, desde éstos el cuerpo se afecta. Activamente su capacidad de afección modula su cuerpo y la situación, creativamente. Un africano se

original, se puede referenciar en el siguiente enlace: <Shin, S.C. El Estudio sobre las Teorías del Deseo y el Cuerpo de Deleuze \& Guattari. Tesina master. Dongguk University. 2003>>

${ }^{9}$ Spinoza, B. v.o. 1677. Ética (Ethicha: Ordine Geometrico Demonstrata). Madrid. Alianza Editorial, S.A. Versión español. Peña, V(tr.). 2007. p. 122

${ }^{10}$ Aquí el cuerpo se entiende como un bagaje de la mente y la carne humana.-(NdA)

${ }^{11}$ Originalmente, este tipo de denominación arbitraria uniéndose con una peculiar palabra, por ejemplo: war-machine, sexmachine, human-machine, dog-machine y etcétera, viene del estilo de Deleuze \& Guattari, incluso el estilo de la interpretación. $-(\mathrm{NdA})$ 
convierte en un esclavo porque un dueño lo castiga. Este tipo de afección pasiva no es la excelencia originaria de los seres y tampoco en el caso contrario del dueño. La afección tiene que surgir activamente en uno mismo para bien. La afección activa no se adhiere a los cuerpos en una mera parte de la sociedad distorsionada, sino, aunque sea en un ambiente difícil, el cuerpo debe tener autoestima para preservar su ser. Dicha afección en este contexto se entiende como conatus que es el esfuerzo para la auto-preservación, creando una nueva circunstancia. ${ }^{12}$ Para Spinoza este tipo de deseo de auto-preservación no es una reacción debida a alguna carencia, como Platón decía, sino que es un comportamiento inherente. Con dicho deseo, se podría mejorar la capacidad de la afección. Así que en este proceso, el cuerpo que está lleno de afección escapa desde la comprensión utilitarista y se conecta a las diversas líneas y dimensiones, donde al final se relaja en un gran flujo de creación decodificando y super-codificando el sentido del cuerpo.

El deseo es la decencia misma del hombre en cuanto es concebida como determinada a hacer algo en virtud de una afección cualquiera que se da en ella.

Aquí entiendo, pues, bajo la denominación de $<<d e s e o>>$ cualesquiera esfuerzos, impulsos, apetitos y voliciones del hombre, que varían según la variable constitución de él, y no es raro que se opongan entre sí de tal modo que el hombre sea arrastrado en distintas direcciones y no sepa hacia dónde orientarse. ${ }^{13}$

Spinoza. 1677. Ética.

\section{Karl Marx}

En este estudio, el concepto del proletario de Marx sería más comprensible si se leyera como un sinónimo del cuerpo de Spinoza. Y de igual manera, la afección sería correspondiente al concepto de

\footnotetext{
${ }^{12}$ Shin, S.C. El Estudio sobre las Teorías del Deseo y del Cuerpo de Deleuze \& Guattari. Tesina master. Dongguk University. 2003. pp. 11-12.

${ }^{13}$ Spinoza, B. v.o. 1677. Ética (Ethicha: Ordine Geometrico Demonstrata). Madrid. Alianza Editorial, S.A. versión española. Peña, V(tr.). 2007. pp. 262-263.
} 
trabajo de Marx. ${ }^{14}$

Marx prestó especial atención al fenómeno de captación del cuerpo de los proletarios, en el proceso de trabajo en el esquema de la economía política. Encontró el origen de la deformación del concepto de trabajo, cuyo otro nombre es el trabajo enajenado según su definición, ${ }^{15}$ y explica así los trabajadores enajenados, el trabajo enajenado y la objetivación del trabajo:

Este hecho, por lo demás, no expresa sino esto: el objeto que el trabajo produce, su producto, se enfrenta a él como un ser extraño, como un poder independiente del productor. El producto del trabajo es el trabajo que se ha fijado en un objeto, que se ha hecho cosa; el producto es la objetivación del trabajo. La realización del trabajo es su objetivación. Esta realización del trabajo aparece en el estadio de la Economía Política como des-realización del trabajador, la objetivación como pérdida del objeto y servidumbre a él, la apropiación como extrañamiento, como enajenación. ${ }^{16}$

De esta manera en la que los trabajadores se despojan de sus trabajos, al final se convierten en seres enajenados y cuerpos enajenados completamente en la economía política del Estado. Una visión ineficaz (desde los acaudalados) sobre la economía política $\left(\mathbf{C S D}^{17}\right)$, no condujo la humanidad al nirvana, sino que llevó a la destrucción de los cuerpos, trozo a trozo, literalmente. Los trabajadores empiezan a considerarse a sí mismos como animales porque tan sólo se concentran en las funciones básicas para sobrevivir: comer, beber, dormir y reproducirse. Marx dijo que si una vez se fijara esta manera de supervivencia en la sociedad, los trabajadores se reducirían a un producto miserable del capitalismo. ${ }^{18}$

En Tesis sobre Feuerbach, Marx argumenta sobre la actividad sensual. Entiende al humano como un ser corpóreo, viviente, real, sensual y objetivo que está lleno de vigor natural. Según la explicación de Marx, $<<$ el hombre tiene real sensualidad, objetos como el objeto de su ser o de su vida, o que él

\footnotetext{
${ }^{14}$ Shin, S.C. El Estudio sobre las Teorías del Deseo y del Cuerpo de Deleuze \& Guattari. Tesina master. Dongguk University. 2003. p. 32.

${ }^{15}$ Marx, K. Manuscritos Económicos y Filosóficos de 1844. Seoul. Theory and Practice. Versión coreana. Kang, Y.O.(tr.). 2007. p. 85.

${ }^{16}$ Marx, K. Manuscritos Económicos y Filosóficos de 1844. Versión Española. Fuente online desde Google books:

< https://books.google.es/books?id=0-KKBAAAQBAJ\&pg=PT1\&dq=Manuscritos+económicos+y+filosóficos>

${ }^{17}$ Co-surgimiento dependiente-(NdA)

${ }^{18}$ Marx, K. Manuscritos Económicos y Filosóficos de 1844. Versión española. Fuente online desde Google books:

< https://books.google.es/books?id=0-KKBAAAQBAJ\&pg=PT1\&dq=Manuscritos+económicos+y+filosóficos>. p.90.
} 
solamente puede expresar su vida de verdad, objeto sensual. >>19 El hombre trabaja constantemente en su natural y en su auto-creado medio ambiente. Ahora bien, esta actividad sería ontológicamente fundamental en el hombre. Es el concepto del hombre del siglo XIX de aquel tiempo, Feuerbach fue igual a muchos jóvenes hegelianos ${ }_{2}$ desde allí Marx encuentra un límite, que es que Feuerbach solamente concibió al hombre como un <<objeto de los sentidos>>, porque Feuerbach entiende el concepto de ser humano aparte de la realidad socio-política. Tal hombre se queda pasivo. ${ }^{20}$ Con esta premisa no se puede captar la actividad sensual, que es esencial para la vida del hombre, por lo que es necesaria la existencia de un placer en el trabajo, apartando así el trabajo enajenado. La actividad sensual se interpretaría como la afección de Spinoza en este contexto genealógico. ${ }^{21}$

El hombre se apropia su esencia universal de forma universal, es decir, como hombre total. Cada una de sus relaciones humanas con el mundo (ver, oír, oler, gustar, sentir, pensar, observar percibir, desear, actuar amar), en resumen, todos los órganos de su individualidad, como los órganos que son inmediatamente comunitarios en su forma (VII), son, en su comportamiento objetivo, en su comportamiento hacia el objeto, es la afirmación de la realidad humana; es, por esto, tan polifacética como múltiples son las determinaciones esenciales y las actividades del hombre; es la eficacia humana $y$ el sufrimiento del hombre, pues el sufrimiento, humanamente entendido, es un goce propio del hombre. 22

Karl Marx. 1844. Manuscritos Económicos y Filosóficos de 1844.

\section{Deleuze \& Guattari}

Los trabajos de Deleuze \& Guattari son bastante sugerentes en relación a los trabajos precursores de Spinoza y Marx. Especialmente una de sus obras <<Mil Mesetas: Capitalismo y Esquizofrenia>> de

\footnotetext{
${ }^{19}$ La frase original es: <...he has real sensuous objects as the object of his being or of his life, or that he can only express his life in real, sensuous objects. >. Oakley, A. (1984). Marx's Critique of Political Economy I. Oxon. Routledge. 2003. p. 85. ${ }^{20}$ Ibid. pp. 92-93.

${ }^{21}$ Shin, S.C. El Estudio sobre las Teorías del Deseo y del Cuerpo de Deleuze \& Guattari. Tesina master. Dongguk University. 2003. p. 32

${ }^{22}$ Marx, K. Manuscritos Económicos y Filosóficos de 1844. Versión española Fuente online desde Google books:

$<$ https://books.google.es/books?id=0-KKBAAAQBAJ\&pg=PT1\&dq=Manuscritos+económicos+y+filosóficos>
} 
alguna manera se podría considerar como un trabajo homenaje a los conceptos precursores que propusieron Spinoza y Marx, por ejemplo: la capacidad de afección del cuerpo y el concepto de labor sensual del hombre. Asombrosamente, el concepto denominado el Cuerpo sin Órganos tiene una inmensa similitud con el cuerpo nirvánico.

Deleuze fue un filósofo francés que se esforzó en aplicar las ideas de la escuela estoica en la época contemporánea, escapando de las perspectivas filosóficas mayoritarias basadas en Platón (427-347 a.C.) o Aristóteles (384-322 a.C.) cuyas posiciones siempre eran, indudablemente, predominantes en la historia de la filosofía occidental. ${ }^{23}$ Tal vez para ellos (Deleuze \& Guattari), el aparato analítico de los actuales filósofos occidentales no fue lo suficientemente adecuado para captar los nuevos fenómenos que surgieron en la época de ellos, es decir, no estaba capacitado para poder comprender las nuevas nociones y generar justamente los nuevos discursos fenomenológicos y éticos de los deseos y eventos peliagudamente enmarañados.

La escuela estoica fue fundada en Atenas en el año 300 a.C. por un filósofo chipriota llamado Zenón (336-264a.C.). Al inicio del periodo de dicha escuela estoica, Zenón y sus estudiantes consideraron que el alma del hombre era como un papiro en el cual se escriben las letras, y el exterior del sujeto se proyectaría en el alma y allí es donde se quedaría la imagen reflejada. Así que la pregunta sobre la verdad no presenta el mismo significado que en el platonismo. La escuela estoica entiende también el concepto de las imágenes proyectadas igual que los platónicos, pero no buscaban las ideas y las formas. Solamente, la escuela estoica definió el criterio de verdad como una imagen percibida. ${ }^{24} \mathrm{Al}$ contrario que los platónicos, los estoicos parecen que estaban intentando recuperar una dignidad pérdida desde el mundo telúrico y fenomenológico que había sido mutilado por la academia de Platón. Por eso, en la perspectiva estoica, la realidad es objeto, y es un fenómeno que ocurre desde su superficie. ${ }^{25}$ Cuando los objetos chocan entre sí, un efecto surge en la superficie; y cuando dicho efecto tiene algún sentido por alguna manera y contexto, se denomina evento ${ }^{26}$. Deleuze presta

\footnotetext{
${ }^{23}$ Lee, J.W. 사건의 철학(Filosofía de Evento). Seoul. 철학아카데미(Academia de Filosofía). 2003. p. 85.

${ }^{24}$ Historia de Filosofía Vol. I.: Academia de Ciencia de Rusia. Lee, E.H.(tr.) Seoul. Choong Won Moon Hwa Editorial.Versión Coreana. 1988. p.191

${ }^{25}$ Lee, J.W. 사건의 철학 (Filosofía de Evento). Seoul. 철학아카데미(Academia de Filosofía). 2003. p. 92.

${ }^{26}$ En un término filosófico, se podría traducir como un acontecimiento también, adecuadamente. -(NdA)
} 
atención a donde surge el evento. Aquí existe una brillante explicación metafórica de un filósofo coreano llamado Jung Woo Lee ${ }^{27}$, para hacer entender el concepto de evento. Según la palabra de Lee, los eventos manan desde la superficie de los objetos como en un juego de béisbol, cuando un bateador pega a la pelota y dicha pelota vuela y sale del campo, el evento denominado home run surge. Pero este evento tiene sentido ya que ha ocurrido en un juego de béisbol. ${ }^{28}$ Si hubiera un choque de un mero palo y una piedra en la luna, eso no tiene ninguna significación. Entonces aparece una pregunta ontológica crítica. Ya se entiende que los conceptos de los eventos surgen desde las superficies de los objetos. ¿pero, cuando no está ocurriendo nada, entonces los eventos dónde se encuentran? Este tipo de pregunta revela lo extraordinario de la contemplación ontológica de Deleuze. Lee entiende que los eventos son eventos implicados en los objetos.

Los objetos existen (existir); y los eventos subsisten (subsistir). Cuando los eventos no suceden, el concepto llamado home run no existe, sino que es inmanente de la superficie fenomenológica de los objetos, sujetos y materiales, por ejemplo: el bate, la pelota, los jugadores y sus condiciones físicas del día, el juez, el estadio, las reglas del béisbol, el clima, la situación económica de los espectadores etc. La agonía, el nirvana, $\mathbf{A D}^{29}, \mathbf{E D}^{30}, \mathbf{N Y}^{31}, \mathbf{4} \mathbf{N V}^{32}, \mathbf{C S D}^{33}$ y tales palabras, sí que son conceptos, o sea eventos. Además, son subsistentes. Si dichos conceptos encuentran una circunstancia adecuada, romperán la superficie sustancial y subirán los eventos a la superficie del mar llamado verdad según los estoicos, o simplemente fenomenología.

Otro ejemplo extraordinario de Deleuze \& Guattari se revela en una dimensión más enriquecida del concepto de evento cuya profundidad filosófica ya es insondable. Si existe una cárcel-máquina, ${ }^{34}$ se puede imaginar que aquí está penetrando en una línea y el concepto denominado cárcel es en sí mismo una línea. Dicha línea atraviesa varias dimensiones, por ejemplo: dimensiones de discursos judiciales y fisio-psicologías, cuerpos de guardias, horarios, prisioneros, estudios arquitectónicos, etc.

\footnotetext{
${ }^{27}$ Un filósofo coreano nació en 1959. Estudió en la facultad de ingeniería de La Universidad Nacional de Seoul. Y cambió su carrera por la filosofía. En el año 1985 ganó el grado de master con la tesina sobre Aristóteles y Galileo, en el año 1994 consiguió el doctorado con la tesis sobre Michel Foucault.-(NdA)

${ }^{28}$ Lee, J.W. 사건의 철학 (Filosofía de Evento). Seoul. 철학아카데미(Academia de Filosofía). 2003. p. 92

${ }^{29}$ Acumulación del Dolor-(NdA)

${ }^{30}$ Extinción del Dolor-(NdA)

${ }^{31}$ No-yo-(NdA)

${ }^{32}$ Las cuatro nobles verdades-( $\left.\mathrm{NdA}\right)$

${ }^{33}$ Co surgimiento dependiente-( $\left.\mathrm{NdA}\right)$

${ }^{34}$ Deleuze y Guattari suelen usar la expresión $<<$ la máquina $>>$ en el lugar de $<<$ la cosa $>>$. Si fuera el caso de Ando, él lo llamaría Shintai. En este estudio, esta palabra se entiende como un cuerpo o un dharma.-(NdA)
} 
Y dichas varias dimensiones de discursos consisten en sub-dimensiones igual que su dimensión superior. Así que para hacer una máquina se requieren varias dimensiones de discursos y sus subdimensiones las cuales son líneas, en otra palabra, diagrama. Deleuze \& Guattari lo llamaron en francés agencement, es decir disposición. La cárcel-máquina nace cuando dos dimensiones de discurso arquitectónico y jurisprudencial se relacionan sustancialmente. ${ }^{35}$ La línea no expresa sino esto: dharma, CSD, CsO, cuerpo, diagrama, agencement, a veces dimensión, shintai y máquina.

Si se expresara desde su perspectiva (Deleuze \& Guattari), cuando el proceso de $A D^{36}$ empieza a reproducir la agonía, el concepto de $\mathbf{A D}$ ganaría la contundencia fenomenológica. Entonces, dicho $\mathbf{A D}$ se podría captar como un concepto realizado, es decir, un evento, por ejemplo: una guerra, una hambruna, conflicto social y etcétera. ED $^{37}$ también se puede entender de igual modo. ED puede implicar el concepto denominado $\mathbf{N Y}^{38}$ que sea un producto deductivo de una dimensión superior que consiste en dos dimensiones virtuales de AD \& ED, y en otras dos más dimensiones sustanciales de AD \& ED. Así NY abre una nueva dimensión transcendental llamada nirvana, atravesando varias amalgamas de sub-dimensiones. En algún sentido NY y el nirvana son sinónimos.

El cuerpo es el cuerpo. Se mantiene por sí solo. No hay ninguna necesidad de órganos. El organismo nunca lo es. Los organismos son los enemigos del cuerpo. ${ }^{39}$

Antonin Artaud.

Deleuze y Guattari se refirieron a Artaud y al Cuerpo sin Órganos varias veces en sus trabajos previos, desde que Deleuze escribió Lógica del sentido en el año 1969. El Cuerpo sin Órganos, ya fue un vocabulario principal cuando Deleuze trabajó con Guattari. Lo interesante es que el concepto del Cuerpo sin Órganos (a partir de ahora se referirá como CsO), tiene una inmensa parte asemejada del

\footnotetext{
${ }^{35}$ Para más información, véase el capítulo llamado $<<L a$ Geología de Morales $>>$ del siguiente libro-(NdA):

$<$ Deleuze, G \& Guattari, F. v.o. 1980. Mil Mesetas : Capitalismo y Esquizofrenia 2. Massumi, B(tr.). Minneapolis. University of Minnesota Press. Versión inglesa. 1987. pp. 39-74.

${ }^{36}$ Acumulación del Dolor-(NdA)

37 Extinción del Dolor-(NdA)

38 No-yo-(NdA)

${ }^{39}$ Roger Dupouy, <<Du masochisme.>> Annales m'edico-psychologiques. Series 12. Vol. 2. 1929. p. 405.> Esta citación es de la fuente secundaria: <Deleuze, G \& Guattari, F. v.o. 1980. Mil Mesetas : Capitalismo y Esquizofrenia 2. Massumi, B(tr.). Minneapolis. University of Minnesota Press. Versión inglesa. 1987. p. 158>
} 
estado de NY. ¿Cómo el cuerpo nirvánico al que Deleuze \& Guattari se habrían referido? Para ellos el cuerpo nirvánico podría ser compatible con CsO. ${ }^{40}$ Como se expuso anteriormente, Deleuze utilizó el concepto de máquina como este estudio utiliza al dharma. Y aquí hay una razón de porqué Deleuze \& Guattari expresaron el cuerpo con el concepto de máquina. Intentaron quitar el carácter de relación orgánica del cuerpo humano re-denominándolo como la máquina. Cuando el cuerpo insiste en ser su atman (subjetividad), el mundo no es nada más que un infierno-máquina que reproduce el dolor eterno. Deleuze \& Guattari niegan el organismo, entendido como una relación permanente, porque si una máquina persiste en su subjetividad, dicha máquina pierde la capacidad de afección. Cuando a una persona discapacitada le faltan las manos, tendrá que utilizar su boca como sustituto, o a veces, esta persona va a dibujar algo con un pincel colocado en los dedos del pie. Los órganos no tienen que insistir en su subjetividad en el organismo (NY). Su boca es un beso-máquina cuando está con alguien que ama, pero también tiene que ser destrucción-máquina cuando introduce comida en su cavidad bucal para digerirlo bien. De igual manera, extendiendo la escala, cuando ha pasado un tsunami, el gimnasio municipal tiene que dejar su subjetividad para ser un refugio del pueblo; si no este gimnasio reproduce el dolor del pueblo. Se recuerda que este estudio trata de cómo funciona y se percibe el concepto de la línea para Deleuze \& Guattari visto anteriormente, diciendo que $<<$ La línea no expresa sino esto: dharma, CSD, cuerpo, diagrama, agencement, dimensión, shintai y máquina. >>. Aquí una línea llamada gimnasio-máquina se ha refugiado desde su subjetividad (organismo según Deleuze \& Guattari) conectándose con otras dimensiones de discursos (por ejemplo, el protocolo de calamidad, la compasión de los voluntarios, la intervención del ejército etc.), y al final ha sido un alojamientomáquina. Deleuze \& Guattari expresan esta línea en francés ligne de fuite, o sea línea de huida. ${ }^{41}$ Dejar su subjetividad de organismo refugiado para ser una línea de huida podría traducirse en el término buddhista adecuadamente así: dejar su atman para ser un estado de NY. Indudablemente, el NY per se es el nirvana. La metodología y la epistemología de Deleuze \& Guattari tiene una insondable importancia a la hora de aplicarlo en el buddhismo dialécticamente. Especialmente, al analizar las dimensiones en que los dharmas (o máquinas, según el término de los deleuzianos) se conectan y desconectan generando y deshaciendo muchas líneas de huidas.

\footnotetext{
40 Para más información, véase el capítulo llamado $<<$ ¿Cómo Hacerse un Cuerpo sin Órganos? >> del siguiente libro-(NdA): $<$ Deleuze, G \& Guattari, F. v.o. 1980. Mil Mesetas : Capitalismo y Esquizofrenia 2. Massumi, B(tr.). Minneapolis. University of Minnesota Press. Versión inglesa. 1987. pp. 149-166.

${ }^{41} \mathrm{En}$ inglés, se expresa por line of flight.-(NdA)
} 
Ahora, antes de proponer la conclusión de este capítulo, sería interesante terminar la parte de Deleuze \& Guattari citando la frase de Giorgio Agamben. Cuando estaba cerca del final de su vida, Louis Massignon (1883-1962), fundó una comunidad llamada Badaliya. Agamben interpreta la significación de Badaliya así:

Pero la badaliya admite otra interpretación. Según la intención de Massignon, de hecho, sustituir a alguno no significa compensar lo que le falta, ni corregir sus errores, sino expatriarse en él tal cual es, para ofrecer hospitalidad a Cristo en su misma alma, en su mismo tener-lugar. Esta sustitución no conoce ya un lugar propio, pero por ella en tener-lugar de todo ser singular es ya siempre común, espacio vacío ofrecido a la única, irrevocable hospitalidad. ${ }^{42}$

Giorgio Agamben. 1990. La Comunidad que Viene.

${ }^{42}$ Agamben, G. La Comunidad que viene. Valencia. Pre-Textos. José Luis Villancañas \& Claudio La Rocca (tr.) Versión española. 1996. pp. 20-21 


\section{Proposición sintética}

Finalmente, investigando los 6 estudios de casos y en este capítulo desarrollando dialécticamente las nociones cruciales de Spinoza, Marx y Deleuze \& Guattari, en la ética nirvánica se ha logrado un concepto más tangible si se equipara con el inicio de este estudio, pudiéndose aplicar en un nivel práctico. Aquí se encuentran los principios deducidos dialécticamente:

0. El carácter efímero del dharma hace entender la ética nirvánica.

1. La ética nirvánica no es un amor ágape incondicional. La ética nirvánica significa una iluminación que expresa que en este mundo no existe un dharma absoluto, así que los sujetos escapan desde la dimensión del ego, y pueden acceder a varias dimensiones de CSD $^{43}$-dharmas, donde al final se hacen reconocer como un cuerpo cósmico los dharmas ajenos y el mundo entero. Por lo cual, se completa una ecuación en la que amar a otro dharma es igual que amarse a sí mismo. La ética nirvánica no es una recomendación de un terapeuta sino es una manera de existir de los dharmas según la excelencia de sí en la perspectiva buddhista, o sea Conatus.

2. CSD que consiste en los dharmas, se entiende como máquina, diagrama, aparato, dispuesta tal y como es. ${ }^{44}$

3. La dimensión de diagrama no se delimita sólo a un campo físico, sino incluye hasta un campo metafísico, así que CSD puede ser cualquier tipo de constelación y producir varios deseos.

4. Así que un CSD producido, puede ser un resultado físico de los dharmas o un mero pensamiento.

5. Los dharmas pueden unirse o pueden conectarse a varios dharmas de varias dimensiones. Así que la apariencia de la forma de uniones es originariamente rizomática.

\footnotetext{
${ }^{43}$ Co-surgimiento dependiente-(NdA)

${ }^{44}$ La máquina es un concepto prestado desde el término de Deleuze \& Guattari.-(NdA)
} 
6. Debido a la forma del rizoma, se puede hablar de las dimensiones físicas y metafísicas a la vez. (se puede deducir desde los principios 3 y 4 )

7. La ética nirvánica es la pista para poder hablar de la estética nirvánica. 


\section{La Estética Nirvánica}

La arquitectura está ligada a la situación. A diferencia de la música, la pintura, la escultura, el cine y la literatura, una construcción (inmóvil) se entrelaza con la experiencia del lugar. El lugar de un edificio es más que un mero ingrediente en su concepción. Más bien, es su fundamento físico y metafísico.

La resolución de los aspectos funcionales del sitio y construcción, las vistas, ángulos del sol, la circulación y el acceso, son las cosas "físicas" que exigen las "metafísicas" de la arquitectura.

La arquitectura y el lugar deben tener una conexión experiencial, un vínculo metafísico, un vínculo poético.

Cuando una obra de arquitectura fusiona un edificio y una situación con éxito, surge una tercera condición. En esta tercera entidad, denotación y connotación se incorporan; la expresión está unida a la idea que se une al lugar. Lo sugerente y lo implícito son aspectos múltiples de una intención. ${ }^{1}$

Steven Holl. 1989. Anchoring.

\section{Resumen de las charlas estéticas hasta ahora}

Este estudio de casos de proyectos utopistas y zen-buddhistas ya ha revisado su peculiar estética y ha podido presenciar unas encarnaciones de los mantras del buddhismo.

En el caso de Howard, este estudio ha podido observar cómo realizó una cualidad medieval por medio de concentrar pequeños espacios en el centro y formando un precioso patio. En el caso de Wright y Le Corbusier, este estudio ha comprobado cómo el ser humano es absorbido brutalmente por el sistema y se le margina en su entorno de clase cuando el arquitecto malinterpreta la época motor y realiza la democracia de una manera distorsionada, o sea no democrática. Y en el caso de Constant,

\footnotetext{
${ }^{1}$ AAVV. Theory and Manifestoes of Contemporary Architecture. Jenks, C. \& Kropf, K. (ed.) Chichester. Wiley-Academy. 2006. p. 109.
} 
se ha podido comprobar que cuando alguna convicción política está contenida en las funciones urbanas y arquitectónicas, en sus diseños es posible captar visualmente dicha virtud.

En Katsura, la familia imperial de Hachijo ejercitando su cuerpo y consciencia en el jardín artificial, porque para ellos el nirvana no era un falso dualismo que desprecia el mundo telúrico y consagra el mundo ideal mitificando la utopía como si fuera algo intangible. Más bien, los Hachijos sabían que la salvación nirvánica tiene que ser una acción simultánea de los efectos entre la mente y el cuerpo, por lo que su jardín estaba meticulosamente compuesto para el ritual con el proceso de paseo, las casitas de té, Gepparo, el juego del barco y etcétera. Y en La Iglesia de la Luz, este estudio ha averiguado cómo los mantras del zen-buddhismo influencian la arquitectura contemporánea y la percepción espacial y mental.

Con los datos aportados, este estudio podría establecer unos principios estéticos, que se especifican a continuación: 


\section{Proposición sintética}

0. La estética nirvánica es un pensamiento y un esfuerzo positivo del diseño, para llegar al nirvana, y también es el resultado de los dharmas que ya habrían llegado al estado nirvánico.

1. Por la razón de que la estética nirvánica es un concepto que debe acompañar a la ética nirvánica, es imposible establecer un argumento estético puro. Sin embargo, gracias a la idiosincrasia de este concepto, no implica una desventaja de ambigüedad y límite del discurso, sino que es un enriquecimiento dialéctico sofisticado de las nociones multidisciplinares. (Este tipo de ejemplos ya se habían comprobado en los casos de Constant y Ando.)

2. La estética nirvánica es un ámbito que implica las diversas experiencias mentales y corporales.

3. Dicha experiencia diversa se refiere a una práctica del juego de percepción, a través de la experimentación del tiempo en un espacio con los elementos agradables de la naturaleza y la arquitectura.

4. Sin embargo, dicha experiencia ha de distinguirse de un obsoleto naturalismo o ecologismo trivial.

5. El flujo del espacio, su forma y su acceso, tiene que ser rizomático, para poder distribuir el flujo de energía incesantemente, generar y disfrutar más experiencias de lugares y asegurar la libertad de movimientos de los sujetos en un espacio agradable y abierto.

6. La forma del rizoma es la forma de red per se.

7. La transformación dinámica de las formas y el programa de la red rizomática según Deleuze, debido a los datos introducidos de los dharmas con el tiempo, es en sí mismo una virtud, como corresponde al principio de $\mathbf{N Y}^{2}$.

\footnotetext{
${ }^{2}$ No-yo-(NdA)
} 
8. La filosofía que disciplina los deseos del hombre y corta el espacio como si fuese un dharma inmutable, no es la virtud del nirvana, los diseños de este tipo de filosofía transforman la ciudad en una máquina enorme de $\mathbf{A D}^{3}$. Como NY es la virtud para todos los dharmas, los espacios que el hombre produce también toman el concepto de NY por su excelencia.

${ }^{3}$ Acumulación del Dolor-(NdA) 


\section{Apéndice}

La estructura conceptual de este estudio se basa en una simple frase: $<<$ Todos los dharmas son efímeros >>. Como la mayoría de las filosofías ortodoxas distinguen tres ramas, la epistemología, la ética y la estética, el discurso de este estudio también distingue dichas tres ramas. Sin embargo, este análisis es singular por dos razones cruciales.

La primera razón es que los discursos de las tres ramas se desarrollan dialécticamente, procesando los 6 casos de estudio, desde el nivel cero de la tesis que es lo efímero del dharma. Este estudio no pretende predicar ninguna verdad transcendental. Además, la conclusión de este estudio no estaba definida desde el principio, por lo que no progresa debido a una cierta dirección pre-decidida formando y escogiendo los argumentos para llegar a dicha cierta dirección, sino que se desarrolla y enriquece por sí mismo según su bondad, es decir, este estudio solamente intenta revelar como es lo efímero del dharma, cuando se contempla afrontando el nirvana y la utopía.

Y la segunda razón es que, los discursos como un análisis espectral, son difíciles de distinguir estrictamente por los tres territorios filosóficos. Eso es porque este estudio originalmente no ha desarrollado su argumento tectónicamente por la lógica de un ladrillo abajo y arriba otro. Sino que es como hacer rodar una bola de nieve desde la cúspide de la montaña, por lo que mientras va disminuyendo su altura, desde sus capas lógicamente formadas surgen otras y cada vez más fuertes, así que cuando haya llegado a la tierra, nadie podría imaginar cuánto habría aumentado la bola. Una pequeña frase (todos los dharmas son efímeros) ha sido una capa epistemológica, y posteriormente engrandeciéndose ha formado otras capas: ética y estética.

Por lo cual y como se ve, la huella de este estudio hasta ahora no presenta un límite de aplicación en ningún campo para esta perspectiva. Si se lleva a la calle, la escuela, el museo, el hospital o el parque, dicha perspectiva va a producir otros análisis. Como un navegador, naturalmente va a revelar los caminos. Si se expresa radicalmente, se diría que este estudio está efectuando este marco de pensamiento. 
El estudio ha hecho rodar esta pequeña bola de nieve desde un antiguo reino nepalí hasta el umbral de la ciudad contemporánea. Ya es el momento de poner este marco de pensamiento en el banco de pruebas para comprobar su valor. 


\section{CSD Mórbido}

\section{: Un ensayo sobre experimentar del cuerpo en la calle cotidiana}

La experiencia del cuerpo del hombre, se repite en la vida cotidiana y se acumula en una forma llamada memoria. Y dicha práctica se repite varias veces en un mismo patrón, se empiezan a generar pequeñas diferencias. Un día cualquiera que cayó la primera nieve del año, otro día que encontró a su amigo por casualidad y otro día en que se encontraba por primera vez después de independizarse de la casa de sus padres, cada día los recuerdos se acumulan en la calle, y eso hace que él o ella se apegue a la calle con cariño. Los patrones cambiantes de las sombras de temporada en la calle, el clima que se siente en la piel muy directamente, los ruidos insignificantes, el movimiento diario del sol, a veces una tormenta o un viento de primavera cuya sensación siempre es un encanto, enriquece la práctica de los días cotidianos. Así que la diferencia es un concepto inmanente al concepto de repetición. ${ }^{1}$ Al final, la calle produce un fuerte vínculo con el hombre. Las memorias preciosas hacen que la ciudad reconozca su bondad y su excelencia, restauran la vida cotidiana que fue mutilada y fragmentada hace mucho tiempo. Y sobre dicha memoria hay una cosa interesante que se ha de reconocer antes de empezar este capítulo. Aunque la memoria del hombre se considera que se guarda en el cerebro, sin embargo, cuando él o ella llega a un lugar peculiar, dicho lugar invoca las memorias personales en el hombre.

Así se encuentra una sensación, como si la memoria se hubiese guardado en un espacio físico, no en el cerebro humano. De esta manera las calles se convierten en una enorme biblioteca en la que se puede buscar referencias cerebrales para cada individuo, ya que en la memoria personal solamente él o ella pueden encontrarse.

\footnotetext{
${ }^{1}$ Lefebvre, H. v.o. 1992. Éléments de rythmanalyse: Introduction à la connaissance des rythmes. Seoul. Galmuri Publishing House. Versión Coreana. Ki Hun, J.(tr.) 2013. p.63.
} 
CSD $^{2}$ Mórbido se refiere a una constelación de los dharmas que se han unido de una manera no nirvánica; por lo que la constelación se queda como un mero aparato para reproducir el dolor y la agonía.

Este capítulo presenta los fenómenos urbanos que ocurren en la superficie de la ciudad de Valencia recorriendo estratégicamente las grandes calles, puntos de referencia, atractivos lugares naturales, monumentos y hasta calles pequeñas que funcionan como capilares sanguíneos del cuerpo en la ciudad.

Si se estudian muchas ciudades y en concreto Valencia se puede detectar y analizar una gran cantidad de CSD Mórbido. Se presenta a continuación un detenido estudio expresivo de la multitud de CSD Mórbido que aparece en la capital valenciana.

${ }^{2}$ Co-surgimiento dependiente-(NdA) 


\section{CSD Mórbido-01}

Ubicación: Gran Vía Marqués del Turia

Dharmas Fenomenológicos

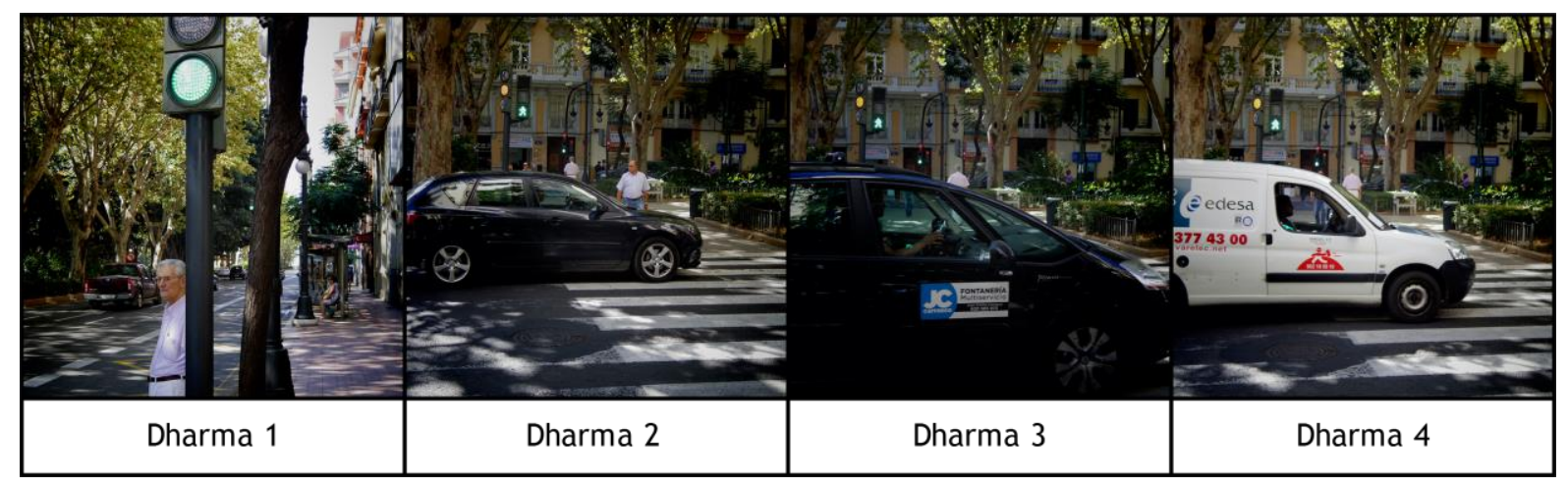

$A D^{3}$ Diagnosis

Los criadores (de caballos) son capaces de lograr la unidad mediante la combinación de lo lineal y lo cíclico. Mediante la alteración de las innovaciones y las repeticiones. Una serie lineal de los imperativos y los gestos se repite cíclicamente. ${ }^{4}$

Henri Lefebvre.1992. Éléments de Rythmanalyse.

AD1: La carencia de atenciones básicas para los peatones. Poca comprensión de la psicología behaviorista de los conductores y los viandantes en el plan de tráfico. Las señales anti-humanistas semafóricas no se adaptan al ritmo de los peatones. El plan de tráfico parece sólo para la fluctuación fluyente de los coches.

AD2: 34 segundos de señal verde para los peatones al cruzar, 3 segundos de señal verde que pestañea, 1 minuto y 23 segundos de señal rojo para los peatones; los coches pasan. Exactamente, un ciclo de dos minutos de las señales semafóricas. La obsesión de 2 minutos da presión a los

\footnotetext{
${ }^{3}$ Acumulación del Dolor-(NdA)

${ }^{4}$ Lefebvre, H. v.o.1992. Éléments de rythmanalyse. Londres-Nueva York. Continuum. Versión inglesa. Enden, S.\& Moore, G.(tr.) 2007. pp. 39-40.
} 
viandantes que cruzan urgentemente o pacíficamente gastando 3 minutos y 20 segundos para atravesar la calle.

AD3: En la carretera, el enfrentamiento del coche versus el hombre, es un juego con normas para los coches, pero es una ruleta rusa para el caminante. La intensidad de la obligación sobre el peatón de las normas de circulación es incomparable respecto a la obligación sobre los conductores. Esta pequeña verdad revela la cara espantosa de la calle. La palabra francesa dressage presenta la siguiente definición extraída del diccionario:

Dressage [dresa3] $m$

1. enderezamiento, levantamiento.

2. (de animal) doma, adiestramiento

3. Tecnol (de los metales) aplanamiento. ${ }^{5}$

AD4: La mayor parte de la frecuente violación del código de los peatones ocurre sin querer, ya que el ciclo del semáforo fue diseñado contra los humanos. Sin embargo, la mayor parte de la frecuente violación semafórica del coche ocurre cuando los semáforos parpadean. Los peatones se disciplinan por el ritmo antihumano debido al cumplimiento del código semafórico que implica no obstante un resultado letal para el peatón. ${ }^{6}$

\footnotetext{
${ }^{5}$ Diccionario Espasa Grande: español-francés français- espagnol (C) 2000 Espasa-Calpe. (C) WordReference.com LLC. Fuente online: $<$ http://www.wordreference.com/fres/dressage\#footer>

${ }^{6}$ El uso del término ritmo en este estudio, es según la influencia de Henri Lefebvre. Para más información, v.- <Lefebvre, H. Éléments de rythmanalyse. Londres·Nueva York. Continuum. Versión inglesa. Enden, S.\& Moore, G.(tr.) 2007.>
} 


\section{CSD Mórbido-02}

Ubicación: Calle Hernán Cortés

Dharmas Fenomenológicos

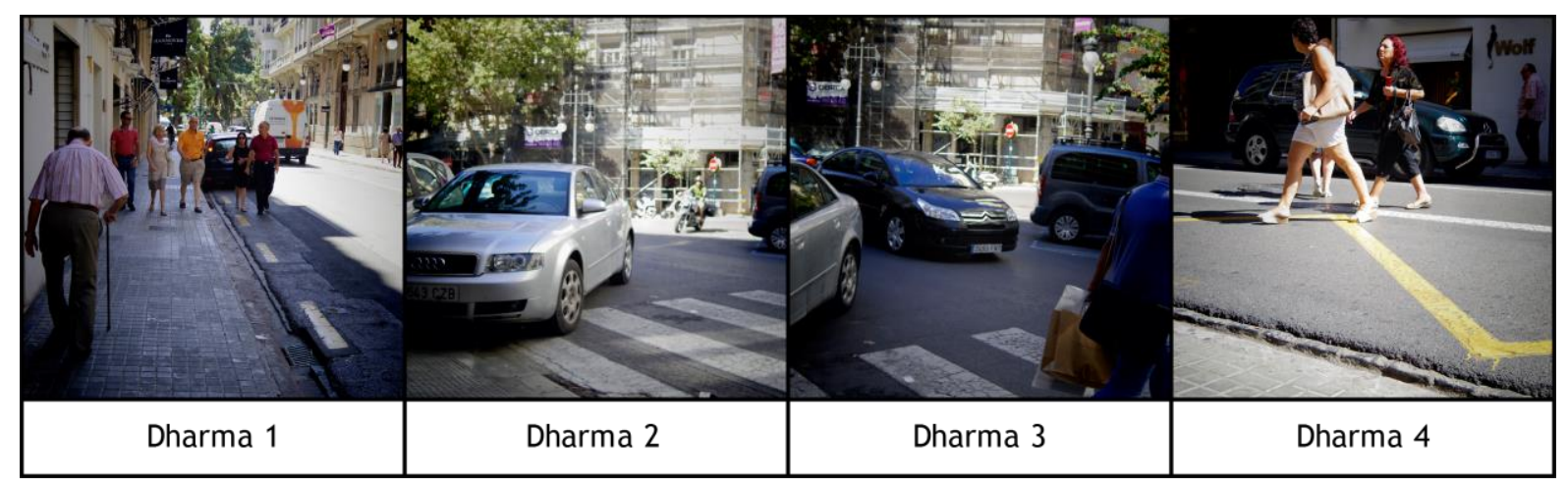

AD Diagnosis

AD1: Al igual que el caso de CSD Mórbido-01, se observa la ausencia de atención básica para los peatones en el plan de circulación.

AD2: El fracaso del plan de la acera.

AD3: La pobre condición del pavimento provee una gran incomodidad para los niños, adultos con niños, cochecitos, mujeres con tacones, gente mayor, discapacitados y discapacitados con silla de ruedas. El rango de anchura de la acera está sobre $182 \mathrm{~cm}-200 \mathrm{~cm}$. El margen de la acera y algunas superficies hundidas de la carretera por varias razones, crean una drástica irregularidad del pavimento. Indudablemente, estas cosas se relacionan directamente con la accesibilidad de la calle para los viandantes. Algunos coches se encuentran aparcados justo al lado del paso peatonal, bloqueando la vista de los peatones, por lo que éstos no saben si se acerca un coche o no hasta que cruzan $1 / 3$ del paso. Si la tasa de accidentes del coche contra el peatón no ha aumentado más, sería porque los peatones aguantan con uñas y dientes. Sería difícil considerar que es por la generosidad de los conductores ya que son los que normalmente están con prisa en la carretera.

AD4: disminuye el atractivo de la calle. Es una calle por la que la gente no quiere andar. 


\section{CSD Mórbido-03}

Ubicación: Calle Colón.

Dharmas Fenomenológicos

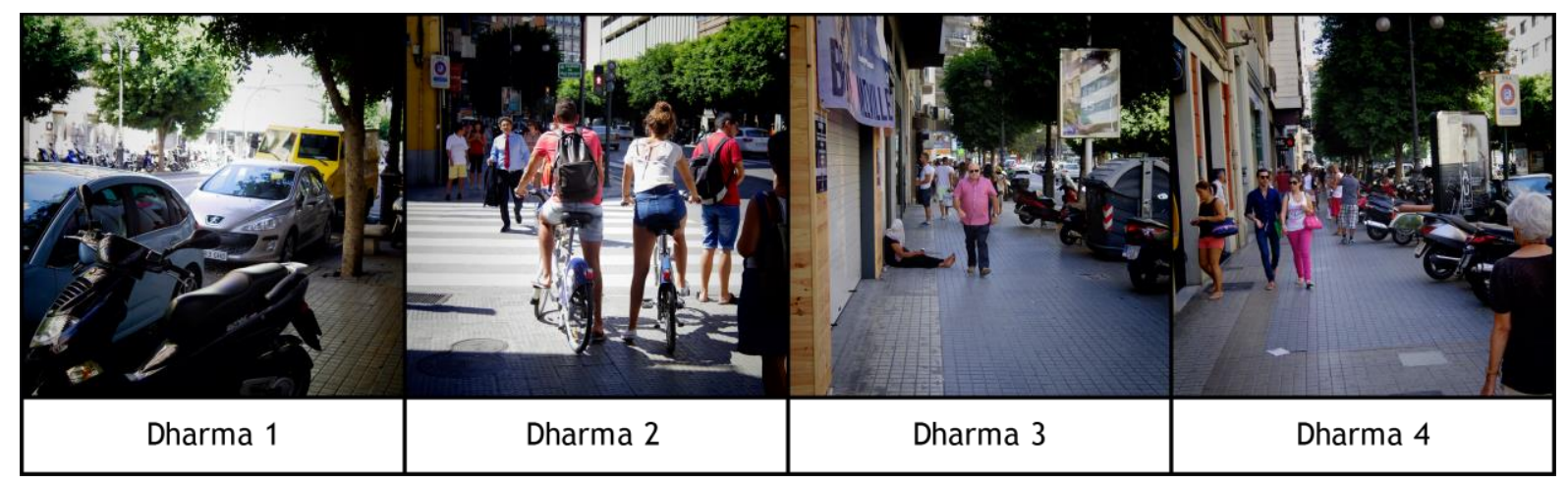

AD Diagnosis

AD1: Igualmente como el caso de CSD Mórbido-01, se visualiza la carencia de atenciones básicas para los peatones y poca comprensión de la psicología behaviorista de los conductores y los viandantes en el plan de tráfico.

AD2: El fracaso del plan de la acera.

AD3: la anchura de la acera es $517 \mathrm{~cm}$ de los cuales $270 \mathrm{~cm}$ están siendo utilizados para aparcar las motos o instalar carteles. La Calle Colón es un lugar utilizado como eje central de comunicación tanto que siempre está lleno de peatones. La gente pasa, no se queda porque no hay ninguna razón para que ocurra algún encuentro con deleite entre los ciudadanos. Este lugar carece de una estrategia espacial para abarcar la energía de la ciudad que proviene de los peatones. Los eventos inesperados y agradables pueden crear un vínculo entre los ciudadanos y hace que la ciudad se llene de vitalidad.

AD4: Al final la Calle Colón se queda como una mera vía de paso, no una calle dinámica que guarda una larga historia y renueva el casco urbano. La ciudad en la que ya no importa la memoria y la historia no puede ser sostenible. 
El Margen - donde la arquitectura y la ciudad encuentran las diversas actividades

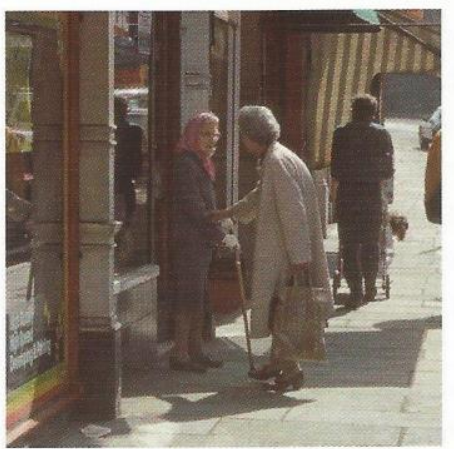

Charlar

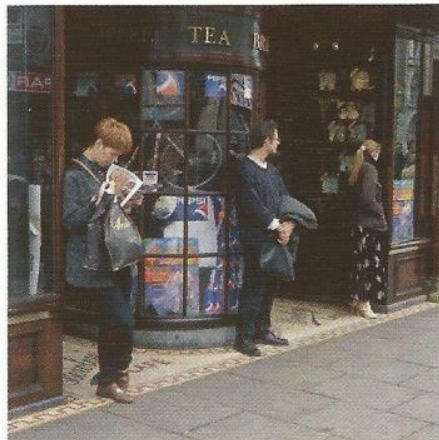

Estar en pie cercade la pared

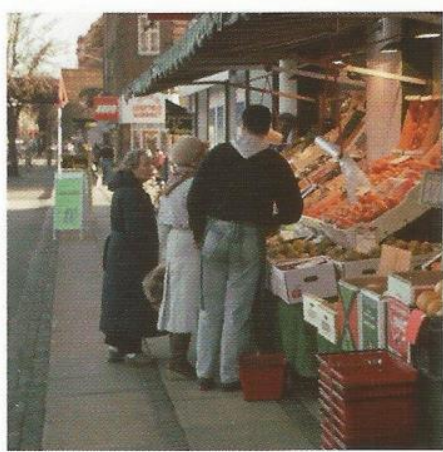

Comprar

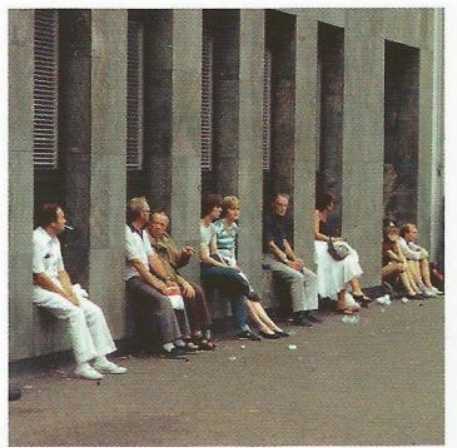

Sentarse en

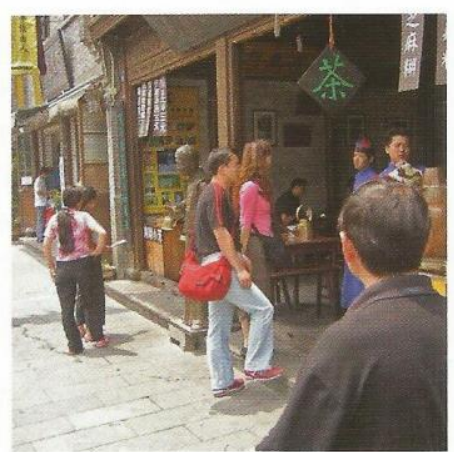

Entrando y Saliendo

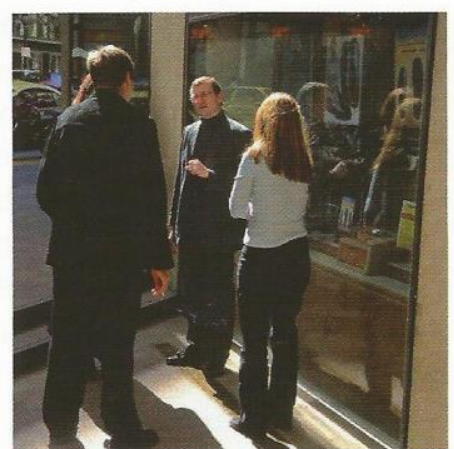

Tomando el descanso

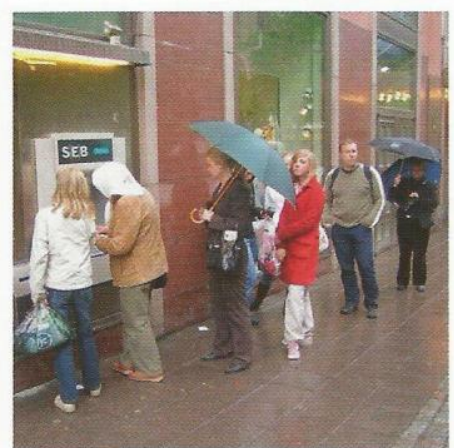

Interactuar con

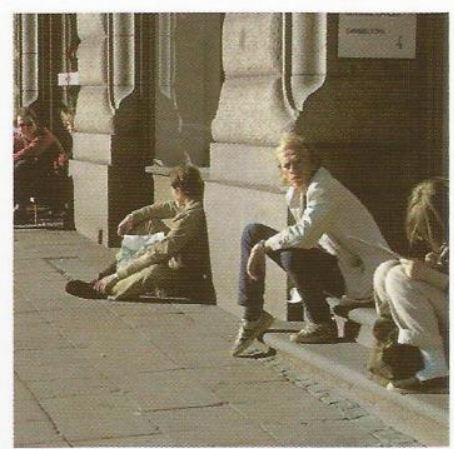

Sentarse cerca de

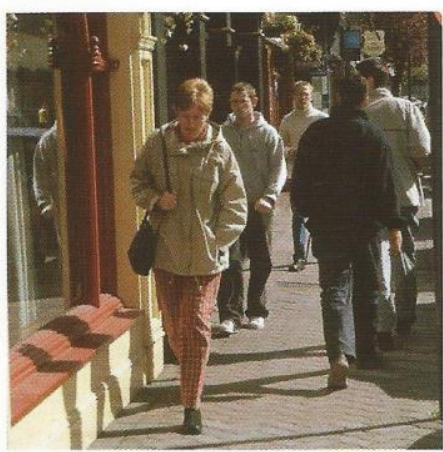

Caminando por a lado de la pared

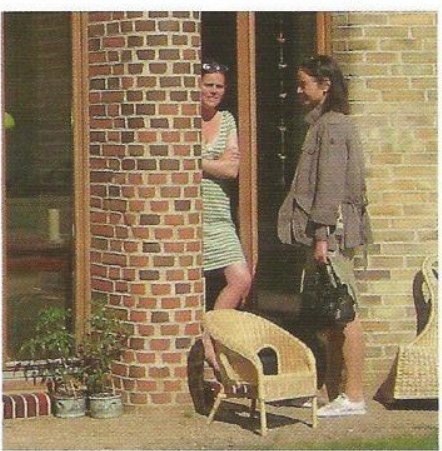

Estar a las puertas

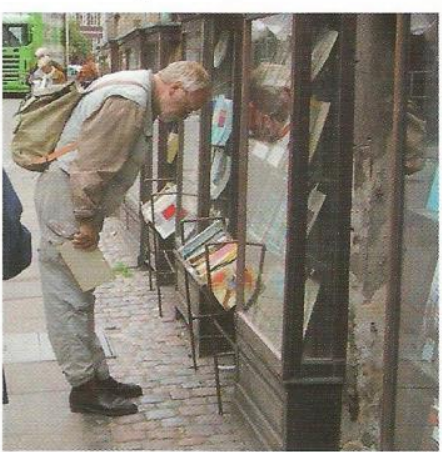

Mirar al escaparate

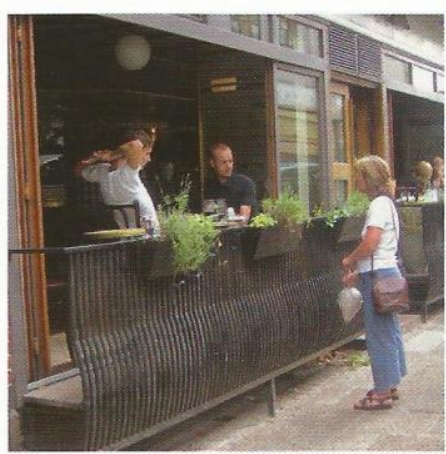

Mirar hacia dentro o hacia fuera

Figs. 11-1. El margen - donde la arquitectura y la ciudad encuentran diversas actividades. 


\section{CSD Mórbido-04}

Ubicación: Casco urbano y zona de comercios.

Dharmas Fenomenológicos

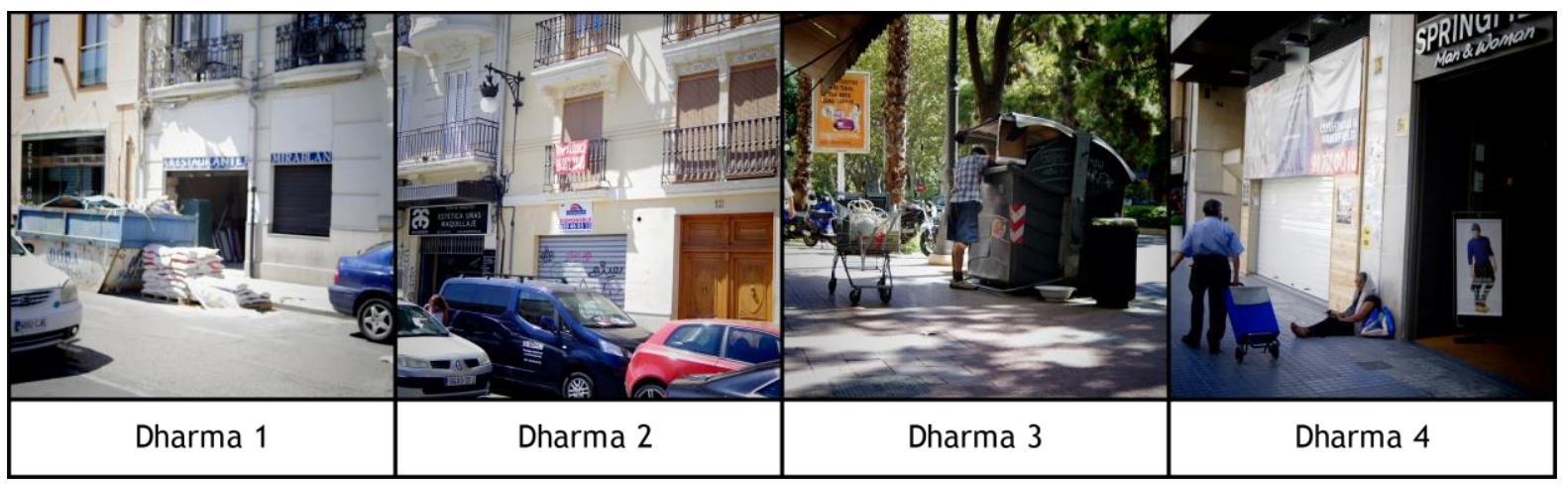

AD Diagnosis

AD1: Es un fenómeno mundial que el derecho y el salario real de los trabajadores disminuye cada día más constantemente, especialmente en los países que están dominados por la ideología del neoliberalismo. La inadecuación de la productividad laboral en economía con el crecimiento de los salarios reales de los trabajadores, citando los recientes 10 años de datos de la OCDE ${ }^{7}$ y la OIT ${ }^{8}$, es obvia como síntoma mundial de que algo está en mal funcionamiento. Y España también como otros países, no se aparta de esta gran tendencia. ${ }^{9}$

\footnotetext{
${ }^{7}$ Es la abreviatura de Organización para la Cooperación y el Desarrollo Económicos cuyo denominación original en inglés se conoce por OECD: Organisation for Economic Cooperation and Development.-(NdA.)

${ }^{8}$ Es la abreviatura de Organización Internacional del Trabajo cuyo denominación original en inglés se conoce por ILO: International Labour Organization.-(NdA.)

${ }^{9}$ ILO. Global Wage Report 2012/2013: Wages and equitable growth. International Labour Office - Geneva. Fuente online: <http://www.ilo.org/global/research/global-reports/global-wage-report/2012/WCMS_194844/lang--en/index.htm>
} 
Tendencias en el crecimiento de los salarios promedio y la productividad laboral en economías desarrolladas (índice: $1999=100$ )

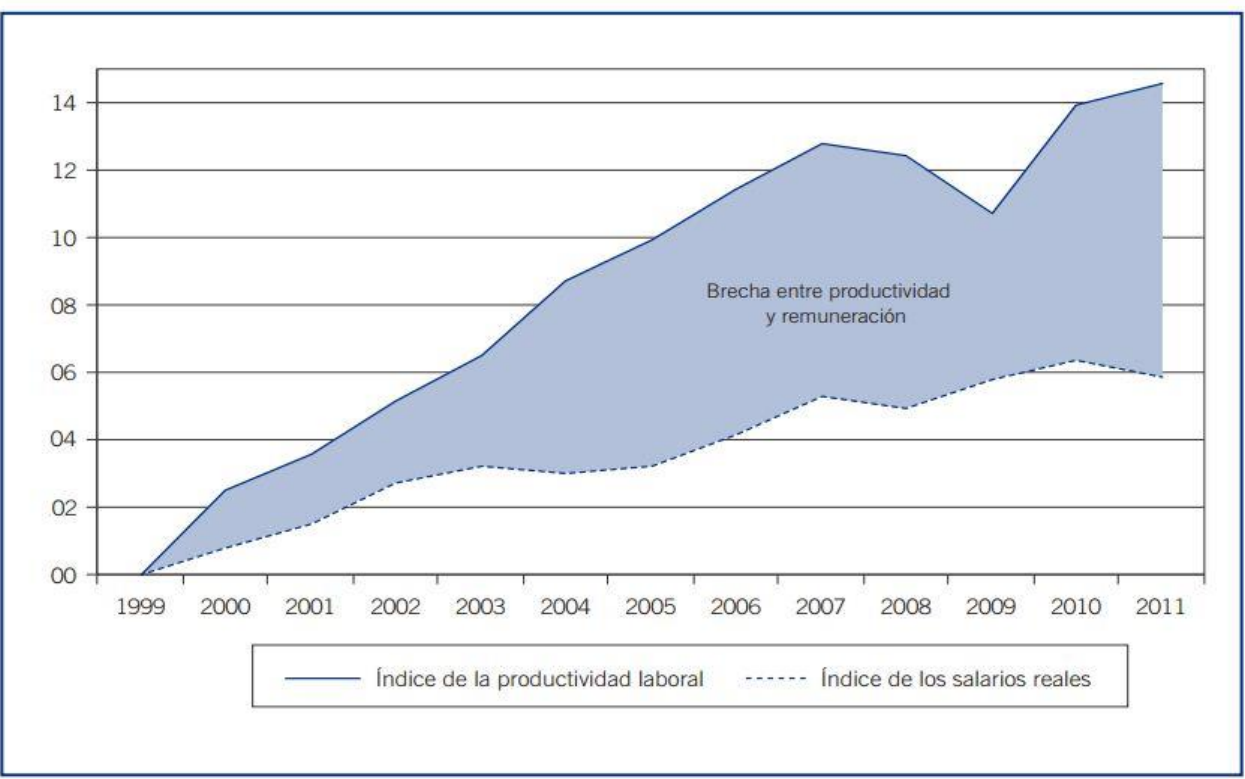

Nota: Debido a que los índices se refieren a promedios ponderados, los desarrollos en las tres economías desarrolladas más grandes (Estados Unidos, Japón y Alemania) tienen un impacto particular sobre este resultado. La productividad laboral se mide como producto por trabajador.

Fuentes: Global Wage Database de la OIT; Modelo Econométrico de Tendencias de la OIT, marzo 2012.

Tab. $11-1.10$

AD2: La deuda familiar de España, en el año 2000, fue de un $81,5 \%$ y este número aumentó hasta 136,3\% en el año $2010 .{ }^{11}$ Eso parece que tiene una profunda relación con los datos del gráfico del índice de pobreza humana y del índice de la brecha de pobreza. ${ }^{12}$ Especialmente, España enseña el número más alto en el gráfico del índice de brecha de pobreza entre los países registrados en la OCDE. Y estos números de tendencia que han seguido acelerando no parecen descender fácilmente.

\section{*Actualización de los datos estadísticos.}

Según el informe mundial sobre los salarios de este año (Global Wage Report 2016/2017), excluyendo a China, el crecimiento salarial fue $0,9 \%$ en 2015 , que es aún una gran caída comparando el 1,6 \% del 2012. Aunque había un periodo favorable tras el año 2010, sin embargo, considerando la crisis del 2008, eso aún no puede ser un buen resultado compensativo. Menor

\footnotetext{
${ }^{10}$ ILO. Global Wage Report 2012/2013: Wages and equitable growth. International Labour Office · Geneva. Fuente online: <http://www.ilo.org/wcmsp5/groups/public/---dgreports/---dcomm/documents/publication/wcms_194948.pdf>

${ }^{11}$ OECD. "Household Debt", in OECD Factbook 2013: Economic, Environmental and Social Statistics, OECD Publishing. Fuente Online: < http://dx.doi.org/10.1787/factbook-2013-28-en>

${ }^{12}$ OECD. "Poverty and gaps". OECD Factbook 2013: Economic, Environmental and Social Statistics. OECD Publishing. Fuente online: <http://dx.doi.org/10.1787/factbook-2013-26-en>
} 
crecimiento salarial respecto al aumento de productividad per capita es un fenómeno global. La disparidad salarial entre los trabajadores va empeorando cada día más. El salario medio ya no es una evidencia de que esta sociedad va bien o mejor, porque citando un caso real de Europa en 2010 , de las empresas que proveen un salario medio relativamente elevado, el $80 \%$ de sus trabajadores se quedaron por debajo de éste, mientras que el $20 \%$ de los que ocupan la cúspide de la pirámide reciben un salario excesivo.

05/01/2017.

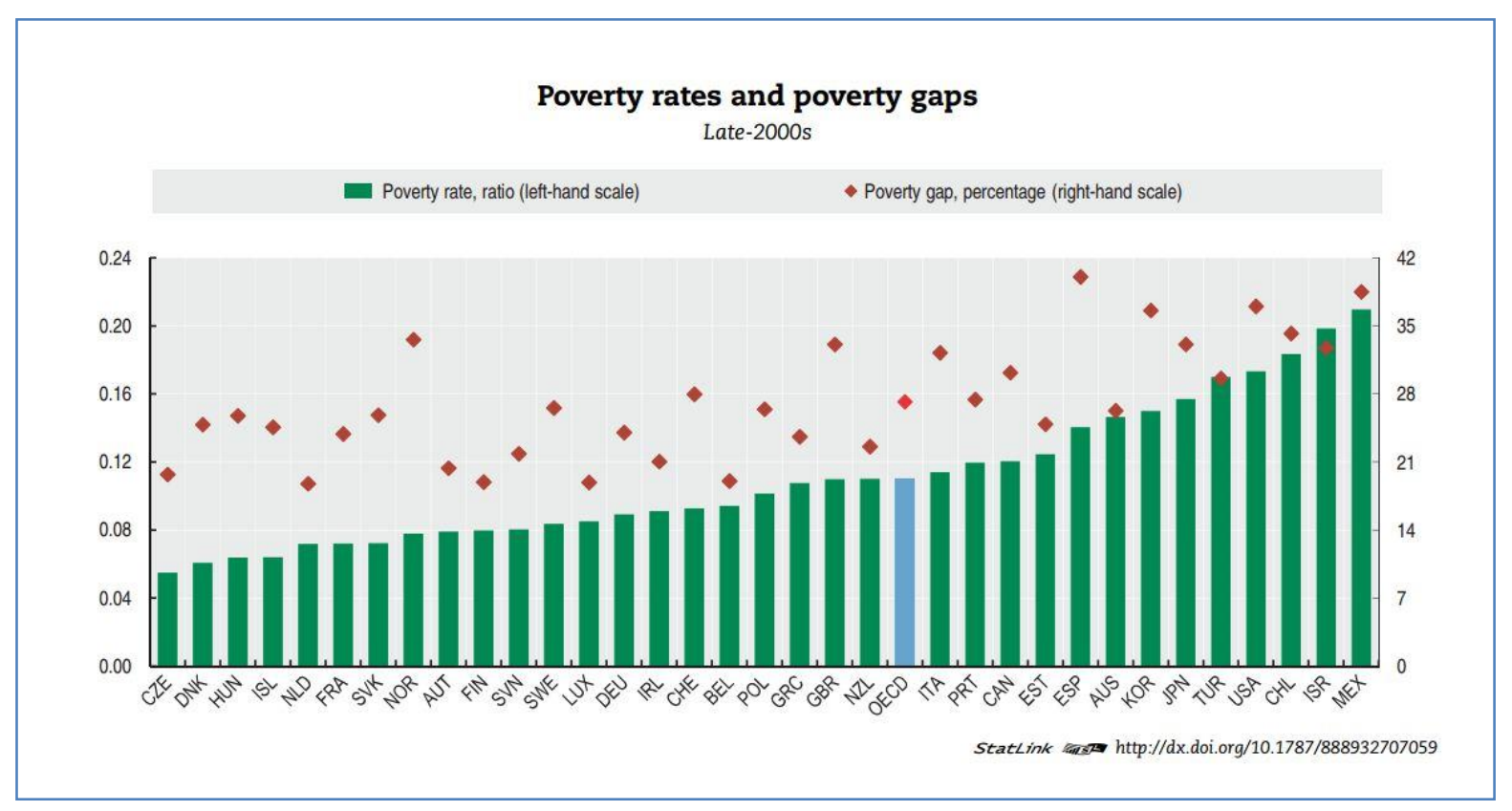

Tab. $11-2 .^{13}$

AD3: El aumento de la deuda familiar y el índice de pobreza de España expresan un síntoma del vacío en la clase media. Aparte del discurso de la re-distribución de la riqueza de la nación, el problema de dicho síntoma, la decadencia de la clase media, puede causar una crisis crucial del Estado. ${ }^{14}$ Como se observa en el gráfico de abajo, la tasa de desempleo de España está llegando a 26\%, y eso es casi 2,5 veces mayor que el de Francia. Comparando con el número del medio de los países registrados en la OCDE, es un número considerable.

\footnotetext{
${ }^{13}$ OECD. "Poverty and gaps". OECD Factbook 2013: Economic, Environmental and Social Statistics. OECD Publishing. Fuente online: <http://dx.doi.org/10.1787/factbook-2013-26-en>

${ }^{14}$ Para más información, v.- <OECD. 2011. Divided We Stand: Why Inequality Keeps Rising. OECD Publishing. Fuente online: <http://dx.doi.org/10.1787/9789264119536-en>
} 
*Actualización de los datos estadísticos.

Según el informe Ilamado World Employment Social Outlook 2016, la pobreza ha sido reducida en la mayor parte de los países durante las dos décadas anteriores. Sin embargo, irónicamente en la Europa del 2012, más de 300 millones de personas se quedaron en situación de pobreza. Además, en la zona de la EU, en el año 2014, la pobreza relativa fue 17.2 que es otro nuevo récord relevante comparado el 16.8 del año 2012.

05/01/2017.

(ILO. World Employment Social Outlook 2016: Transforming Jobs to end poverty. International Labour Office. Geneva: ILO. 2016.)

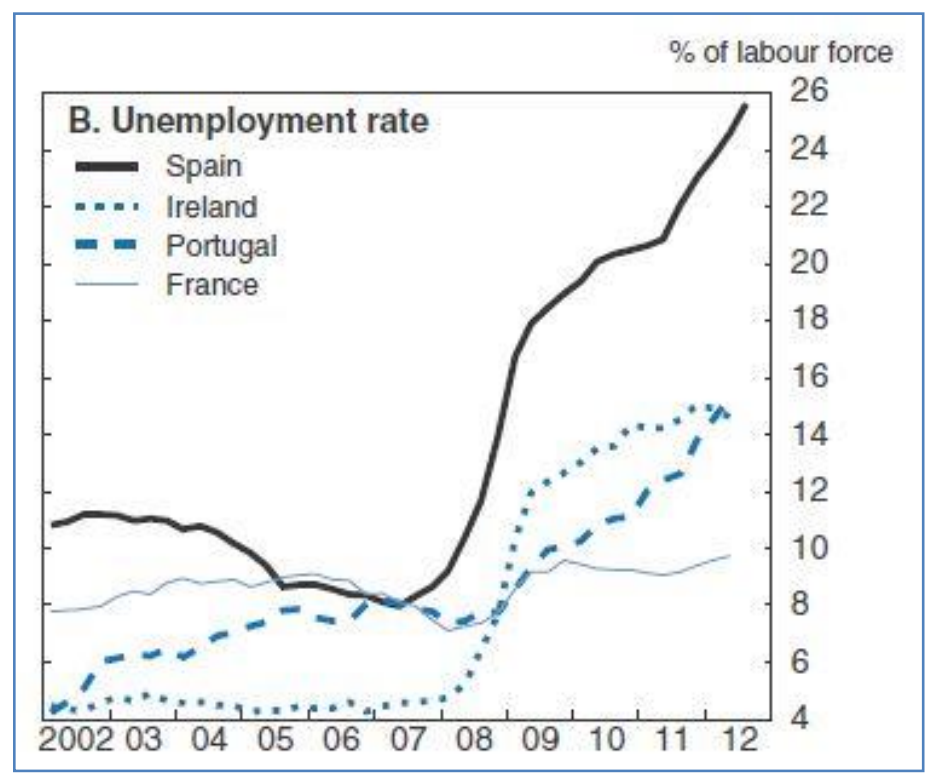

Tab. $11-3.15$

AD4: Un discurso sobre la solidaridad entre los ciudadanos implica temas de varios campos como está ejemplificado en AD1-3 de arriba. El hombre no puede sobrevivir sin manejar la vida social. La decadencia económica de los ciudadanos está relacionada profundamente con el hundimiento del alma humana. Nadie puede asegurar cual es el estado del alma de una persona, si él o ella está expulsado o expulsada a la calle después de perder todo. Este tipo de gente puede convertirse fácilmente en un

15 OECD. OECD Economic Surveys: Spain 2012. OECD Publishing. p.14. Fuente online: <http://dx.doi.org/10.1787/eco_surveys-esp-2012-en> 
espectador de la sociedad sin ningún interés. Y ese tipo de gente experimenta mucha dificultad en reconocer un sentimiento de pertenencia a cualquiera sociedad.

\section{*Actualización de los datos estadísticos.}

Según los datos del informe de OECD Employment Outlook 2016, definitivamente desde el año 2012 el problema de desempleo en España ha mejorado bajando paulatinamente la curva gráfica. Sin embargo, en 2015 la incidencia de empleo a tiempo parcial sigue aumentando drásticamente a un nivel muy elevado, junto con Irlanda, Italia y Letonia. España aún necesita mejorar la pésima calidad de muchos empleos y las oportunidades desiguales en el mercado de trabajo. Además, los jóvenes poco cualificados que están desconectados tanto del empleo como del aprendizaje se quedan abandonados permanentemente en el mercado laboral.

05/01/2017.

(OECD. OECD Employment Outlook 2016. OECD Publishing. Paris. 2016.) 


\section{CSD Mórbido-05}

Ubicación: Casco urbano y zona de comercios

\section{AD Diagnosis}

AD1: En el mismo contexto del caso de CSD Mórbido-04, existen muchos pequeños negocios en quiebra. Como es una tendencia mundial, actualmente, los países de la OCDE también se han encontrado en la misma situación que en España. Según el estudio de OCDE del año 2011, la tasa de supresión de los negocios grandes que tienen más de 10 empleados, muestran en el gráfico un número muy bajo y un estado muy estable. Sin embargo, en el caso de los negocios pequeños que tienen entre 1-4 de empleados, aparece una muy alta tasa de la desaparición del negocio. ${ }^{16}$ Las grandes inversiones de capitales como las tiendas de franquicia, pueden compensar las pérdidas en otras tiendas antes exitosas. Así pueden sobrevivir con más posibilidad y al final sobreviven solamente las tiendas de franquicia.

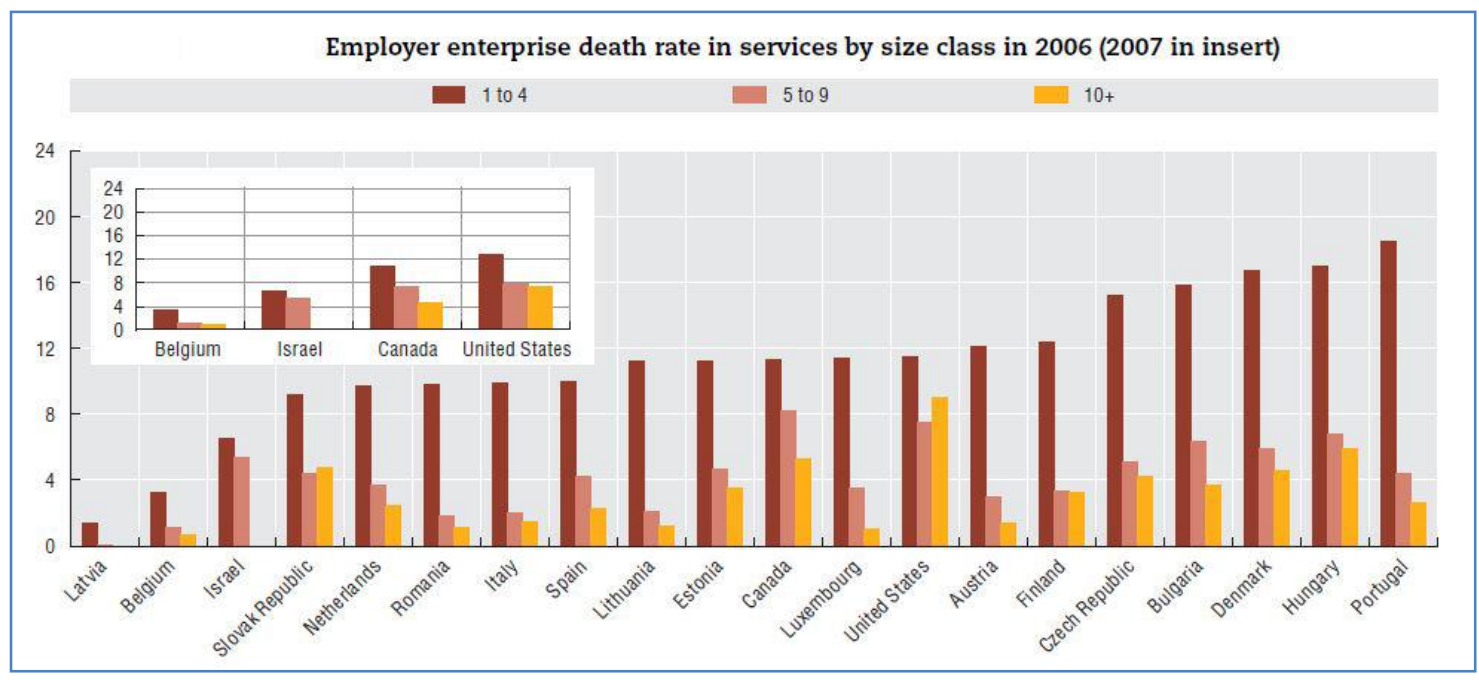

Tab. $11-4 .{ }^{17}$

${ }^{16}$ OECD. Entrepreneurship at a Glance 2011. OECD Publishing. p.58

${ }^{17}$ Ibid. p. 60. 
AD2: Los negocios pequeños (tamaño de 1-4 empleados) cuando van a la bancarrota en un barrio decadente, arruinan el paisaje urbano. Pero si fuera en un barrio atractivo donde los negocios pequeños van a la bancarrota, los negocios de grandes capitales (las tiendas de franquicia) sustituirían el lugar. La verdad es que las tiendas de franquicia tienen más posibilidades de salir con éxito. De todas formas, los negocios grandes sobreviven. En el caso uno, las tiendas de franquicia que se dirigen por la dirección de la marca pueden aguantar hasta que el barrio forma buen mercado para el negocio. En el caso dos, la tienda de franquicia está dirigida por un jefe particular y recibe instrucciones básicas y estrategias desde la sede para manejar la tienda, pagando una cierta cantidad de dinero mensualmente por derechos de marca. Si en este caso la tienda encuentra un fracaso, el jefe particular recibe todo el daño, pero, de todas formas, la pervivencia de la marca central de las tiendas de franquicia, está segura. Según el estudio de la OCDE, en España el número de negocios pequeños, es predominante, respecto a cualquier país registrado en la OCED. ${ }^{18}$ Por lo tanto la bancarrota de negocios pequeños en España, no tiene igual peso de significado que en los demás países.

AD3: las calles no atractivas destruyen las zonas periféricas lenta pero constantemente y mutilan las partes imprescindibles de la vida humana. Ya no se está feliz como antes cuando la gente pasa por estas calles.

AD4: Las partes enfermas de la ciudad se expanden, como tumores malignos.

\section{*Actualización de los datos estadísticos.}

Según el informe de OCED, Entrepreneurship at a Glance 2016, la estadística y el gráfico de la tasa de nacimiento y de mortalidad de las empresas y negocios demuestran números semejantes, sin embargo, estos días la tasa de mortalidad empresarial tiene tendencia a ser más fuerte que la del nacimiento. La tasa de mortalidad de las empresas que tienen más de 10 empleados, experimentan menos dificultades que los negocios pequeños. Es una fenomenología bastante predecible en el sistema del capitalismo. La tasa de supervivencia de las empresas también baja respecto a los años que tiene la empresa. Una empresa que lleva dos años tiene una mayor tasa de mortalidad que aquellas que llevan un año. Las empresas que llevan más de 5 años, estadística y necesariamente experimentan una gran desesperanza. Aunque todo es un fenómeno mundial, España lo experimenta más amargamente. No solo en los campos de la construcción, la industria o el sector servicios; sin ninguna

\footnotetext{
18 Ibid. p.44.
} 
excepción, el aumento de la tasa de mortalidad de las empresas españolas es un síndrome general de la economía del Estado. España aún no se ha librado de la post-crisis del 2008.

05/01/2017.

(OECD. OECD Entrepreneurship at a Glance 2016. OECD Publishing. Paris. 2016.) 


\section{CSD Mórbido-06}

Ubicación: Estación del Norte

Dharmas Fenomenológicos

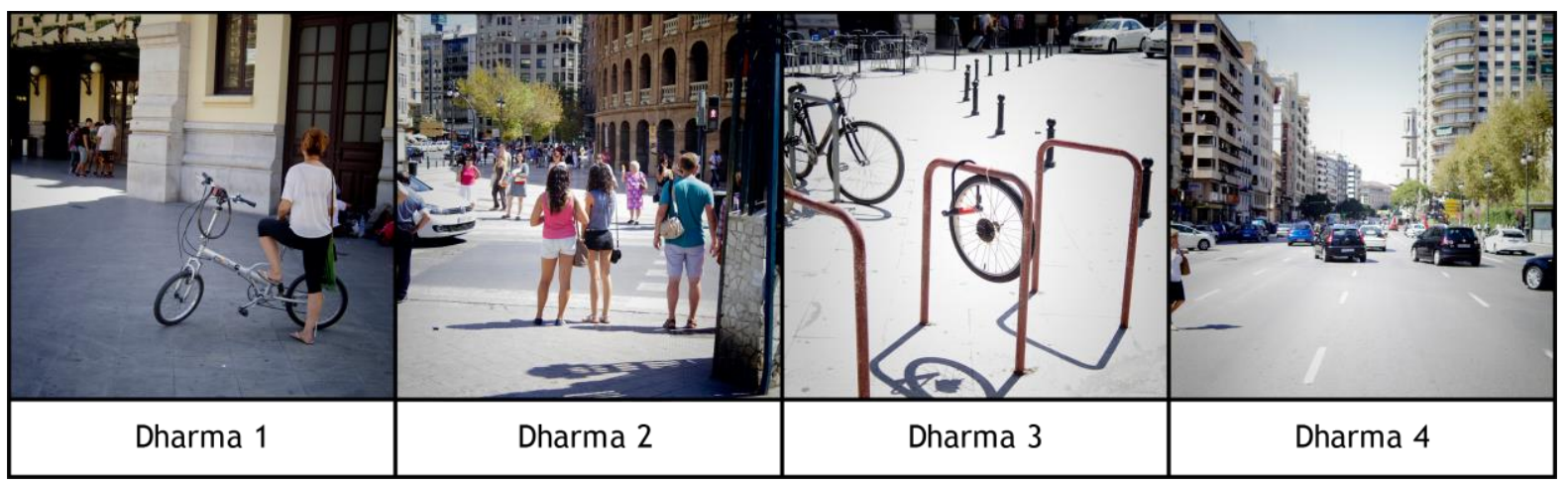

AD Diagnosis

AD1: Ahora, los robos de bicicletas son eventos cotidianos. Pobre condición del aparcamiento de bicicletas. Y pobre circulación en el carril bici.

AD2: Es una conclusión natural que la población que usa la bicicleta es baja. Y eso directamente está relacionado con el aumento de la población que usa coche propio.

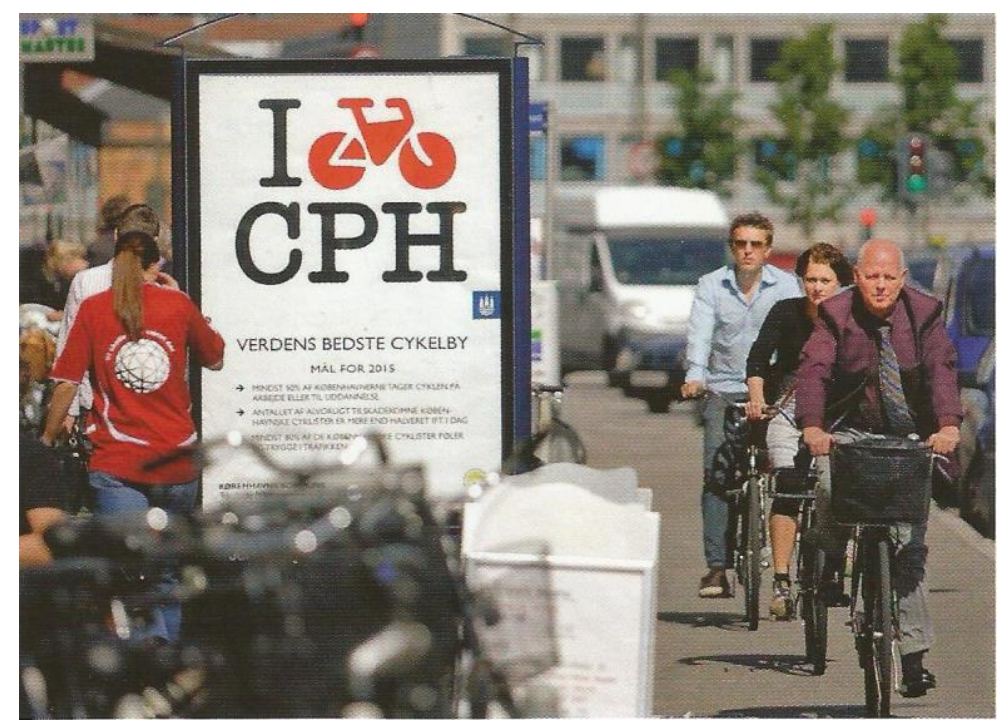

Fig. 11-2. Cartel diciendo I bike Copenhagen. 
AD3: El aumento del tráfico del coche puede influenciar de una manera perversa en el plan general de tráfico. Y esto va a arruinar la ciudad. Si se construyen más carreteras para solucionar el síntoma del embotellamiento se podría ganar un pequeño efecto provisional, sin embargo, definitivamente, la cantidad de coches urbanos aumenta igualmente. De este modo la ciudad se encuentra en una peor situación que antes siguiendo un círculo vicioso. La teoría falsa y no sostenible engañó a las ciudades mundiales durante $20-30$ años. ${ }^{19}$

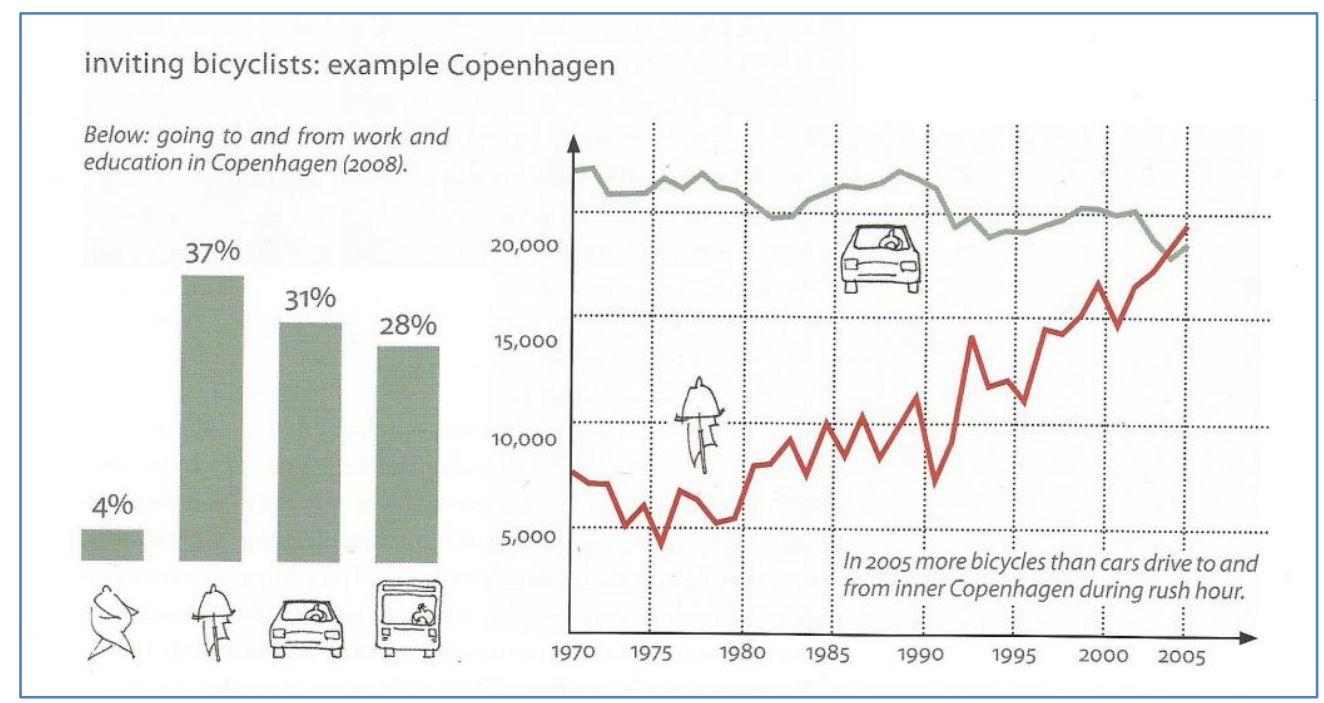

Tabs. 11-5. Los métodos para ir al trabajo y la escuela de Copenhagen en 2008

AD4: En Copenhague, la capital de Dinamarca, desde hace varios años se fomenta el tráfico de las bicicletas. La red que consta de unas buenas y consideradas rutas logra un efecto notable. En el año 2008, la población de desplazamiento que usa bicicleta fue un 37\%. Ahora el gol es de $50 \%{ }^{20}$

\footnotetext{
${ }^{19}$ Gehl, J. Cities for People. Washington DC. Island Press. 2010. p .93.
}

${ }^{20}$ Ibid. p.10. 


\section{CSD Mórbido-07}

Ubicación: Estación del Norte

Dharmas Fenomenológicos

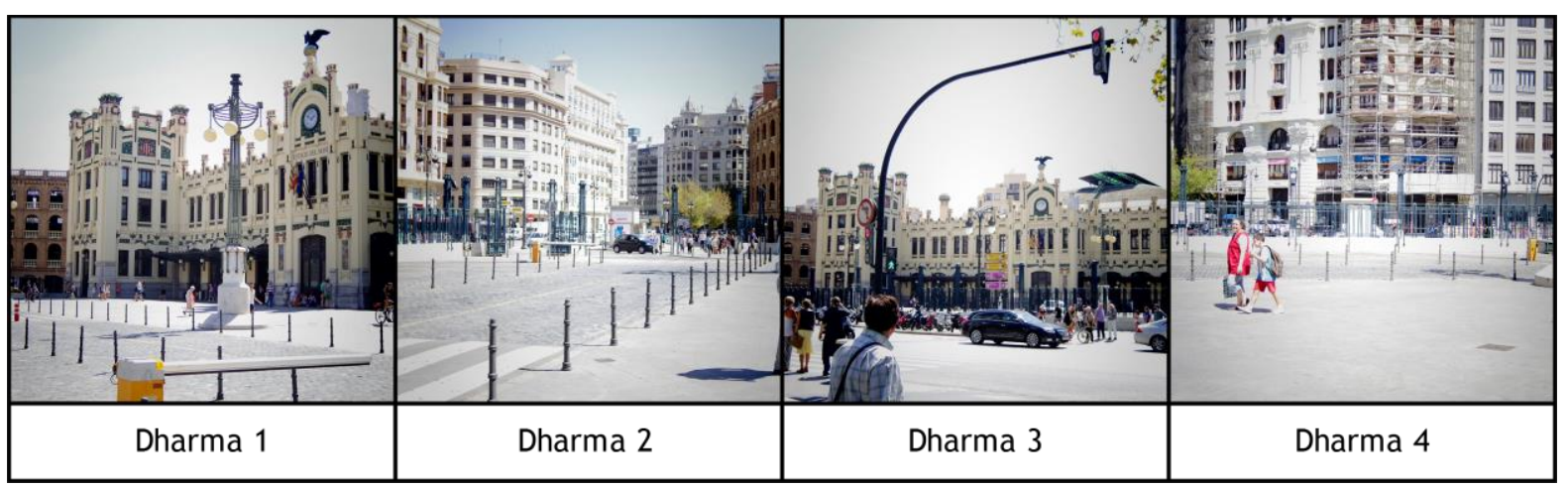

AD Diagnosis

AD1: Es un lugar extenso y precioso para ser un punto de referencia. La gente que vive en la ciudad de Valencia, queda con sus amigos de pie dando su espalda a la Estación. O la gente se sienta en el suelo de mármol a la entrada del metro. Porque no sienten la mayoría ninguna necesidad de esperar a su amigo, porque hay un muro mental entre la gente y la Estación del Norte. Sin embargo, la gente que viene desde la periferia de Valencia, los góticos, los roqueros de punk, los hippies y los fans de animación japonesa, quedan enfrente de la Estación del Norte. Ellos saben que es un espacio precioso y amigable. Debido a la cerca verde, se ve muy cerrado desde fuera. Por eso la gente necesita cargar mucha energía física y mental para entrar sin razón.

AD2: La función de circulación del coche y del aparcamiento se podría tratar fácilmente con los vigentes recursos espaciales que están al lado de la estación y el vasto aparcamiento del sur.

AD3: La imagen que se ve cerrada de la Estación del Norte es una imagen importante de Valencia para los viajeros y los ciudadanos. Este espacio puede convertirse en una preciosa plaza. Aun así, con una imagen cerrada, los coches pasando dentro de la plaza y sin ningún banco adecuado para sentarse, a mucha gente le gusta este lugar. Este espacio merece algo más. 
AD4: En la plaza, la gente se encuentra, se queda, se sienta en un banco o en el suelo, no le importa, y el espacio otra vez, distribuye la gente a las calles periféricas, así la ciudad se llena con vitalidad. Este lugar no es de este tipo. 


\section{CSD Mórbido-08}

Ubicación: Avenida del Marqués de Sotelo. (Estación del Norte - Ayuntamiento de Valencia)

Dharmas Fenomenológicos

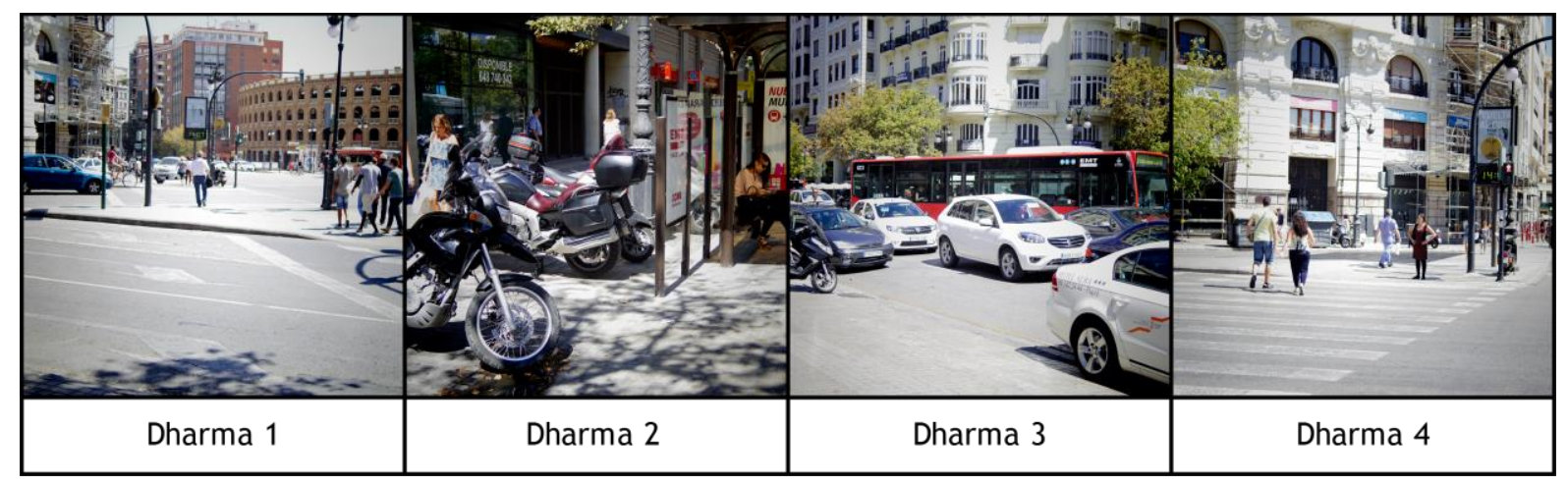

AD Diagnosis

AD1: En este lugar, no se puede pensar de dónde vienes y adónde vas. El viaje empieza solamente desde aquí. Este lugar no quiere saber qué quiere el caminante, casi parece marginarlo, y tiene una pobre relación con las calles de los alrededores. Primero desde la Estación del Norte, antes de salir del territorio de la estación, se tiene que cruzar un pequeño semáforo. Luego, hay que cruzar 6 carriles de carretera, y posteriormente se llega a una isla y allí se espera otra señal para cruzar otra carretera. No es imposible cruzar esta avenida, sin embargo, definitivamente está cortada visual y funcionalmente. Si el caminante ha cruzado la avenida, ya habrá andado más que 50 metros, y todo el pavimento es de asfalto. Si está cortada visualmente, la gente siente y piensa que está cortada mentalmente. El gesto de la avenida que da a los caminantes es: no se puede cruzar aquí.

AD2: Está igual que AD1 de CSD Mórbido-01.

AD3: La calle está fragmentada para los caminantes, la ciudad está fragmentada. Esta ciudad se llena de vitalidad y dinamismo cuando la gente camina con vitalidad y dinamismo. La avenida del Marqués de Sotelo es un espacio atractivo que posee numerosas arquitecturas históricas, un gesto de invitación tiene que expresarse visiblemente. 
AD4: Por ello el camino para ir a la Plaza del Ayuntamiento es muy duro. 


\section{CSD Mórbido-09}

Ubicación: Ayuntamiento de Valencia

Dharmas Fenomenológicos

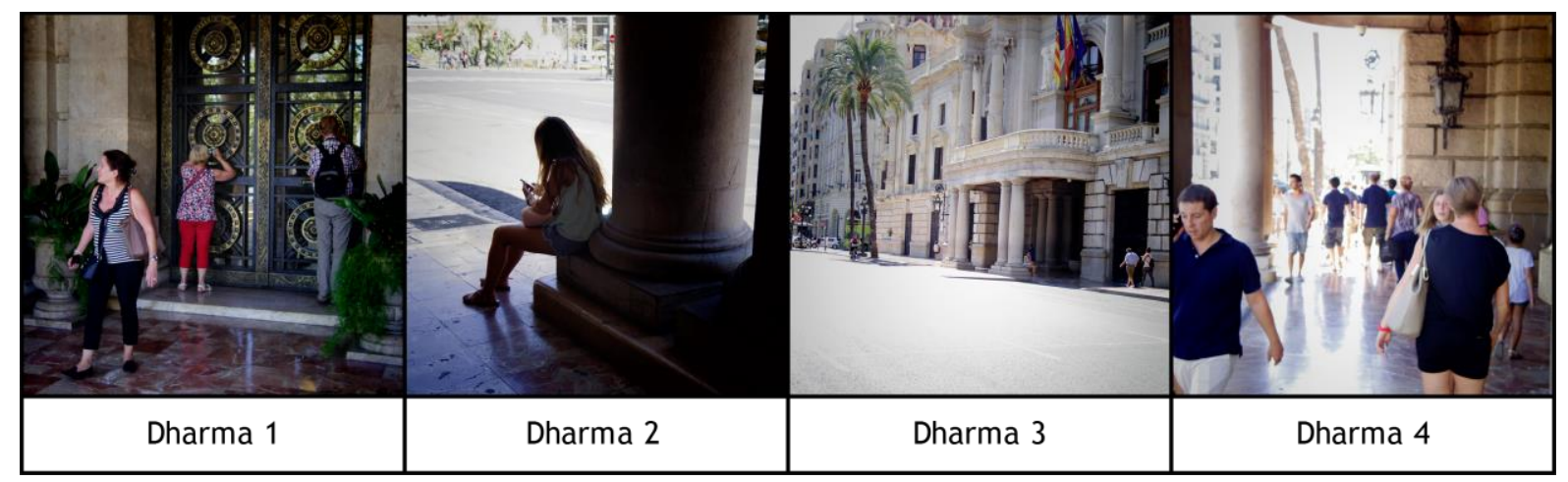

AD Diagnosis

AD1: Los caminantes pasan por la puerta del Ayuntamiento de Valencia cuya anchura es bastante estrecha si no es para el uso del ayuntamiento.

AD2: En la película llamada El Mago de Oz, que fue una versión adaptada de la novela llamada El Maravilloso Mago de Oz de Lyman Frank Baum, el mago de Oz tiene un carácter impersonal y transcendental para los ciudadanos de la Ciudad Esmeralda, porque él no ve a nadie y siempre esconde su pequeño cuerpo detrás de la cortina generando tan solo extravagantes efectos de sonido. Como un dios, pero él es un ser de carne. La puerta principal del Ayuntamiento de Valencia está cerrada siempre. Se ven los guardias y los policías. No es necesario que los funcionarios e incluso el alcalde expongan su presencia al público como si fueran los jefes de un bar de barrio, pero aún es verdad que sí que parece así. Eso puede interpretarse como una estrategia, los funcionarios y el alcalde de Valencia, se alejan de los públicos poco a poco. Qué pena que no se pueda ver el interior del ayuntamiento cuyo estilo sería espectacular como el estilo del exterior es espectacular neo-barroco. Es un alto contraste que en la Oficina de Correos se pueda pasar sin embargo al interior para cualquier asunto pequeño. Se puede entrar por la puerta principal para comprar un sello de 1euro. La antecámara del edificio tiene una cúpula maravillosa. Cuando cae la luz desde arriba, hay una sensación divina. 
${ }^{*}$ Actualización de los datos.

Actualmente el Ayuntamiento de Valencia permite visitar durante la mañana, tanto a turistas como a ciudadanos, la terraza o el museo histórico.

05/01/2017.

AD3: Principalmente, las puertas son para la comunicación; los muros son para bloquear. Si la puerta está siempre cerrada, eso no se llamaría puerta.

AD4: Los órdenes dóricos que están puestos enfrente de la puerta principal del ayuntamiento tienen la función de presentar una posición dominante frente a los visitantes. La democracia conscientemente y visualmente se aleja de los públicos; inconscientemente con la experiencia, en las vidas de los ciudadanos la imagen se fija.

El segundo y problema más general es el fracaso de la democracia local en muchas ciudades del mundo: sin embargo, eso se agrava por el hecho de que, en muchas ciudades, generalmente-incluso <<la corriente principal>>- la gente está cada vez menos interesada en el funcionamiento de su ciudad: la participación electoral cae a niveles muy bajos, y hay una sensación general de que las decisiones cruciales se hacen en otros niveles, por parte de otros organismos, a menudo fuera de su control (gran negocio internacional, burócratas de Bruselas)... Es como si el sentimiento de exclusión se extendiera a todos los niveles de la sociedad -potencialmente una amenaza ominosa para la cohesión social y política. ${ }^{21}$

\footnotetext{
${ }^{21}$ Hall, P., Pfeiffer, U. Urban futur 21: A Global Agenda for Twenty-first Century Cities. London, New York. E \& FN Spon. 2000. p.34
} 


\section{CSD Mórbido-10}

Ubicación: Plaza del Ayuntamiento

Dharmas Fenomenológicos

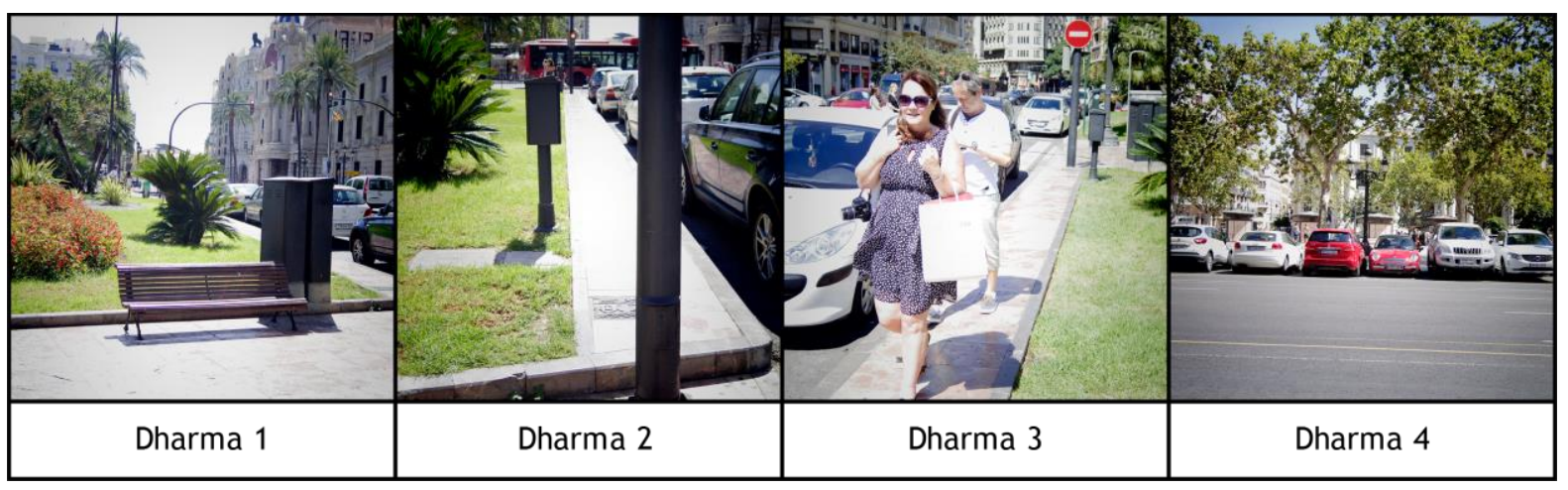

AD Diagnosis

AD1: La plaza está aislada. Considerando el carácter del espacio como una plaza, las velocidades de los coches son anormalmente rápidas.

AD2: La anchura de la calzada es bastante eficiente para digerir la abrumadora cantidad de coches. En Valencia, en general, cuando la señal del semáforo parpadea, los coches prefieren aumentar la velocidad del coche en lugar de pararse.

AD3: La verdad es que sólo los coches tienen garantizado su derecho de movimiento sin arriesgar la vida.

AD4: Una plaza aislada no es atractiva, porque su nombre es plaza. Los caminantes pasean. La acera no puede ser en general sostenible, porque los coches pasan también, pero esto tiene que planificarse de una manera inteligente y considerada. La vista desde el banco de la plaza hacia fuera, por ejemplo, el ayuntamiento, la oficina de correos o la fuente, es patética porque no se ve nada excepto los coches aparcados alrededor de la plaza. Es una plaza de aparcamiento. Es dudoso el por qué desde el principio se necesitaba una plaza. ¿Solamente fue para el aparcamiento? ¿O esto no era el plan original? 


\section{CSD Mórbido-11}

Ubicación: Calle de San Vicente Mártir (Plaza del Ayuntamiento - Plaza de la Reina)

Dharmas Fenomenológicos

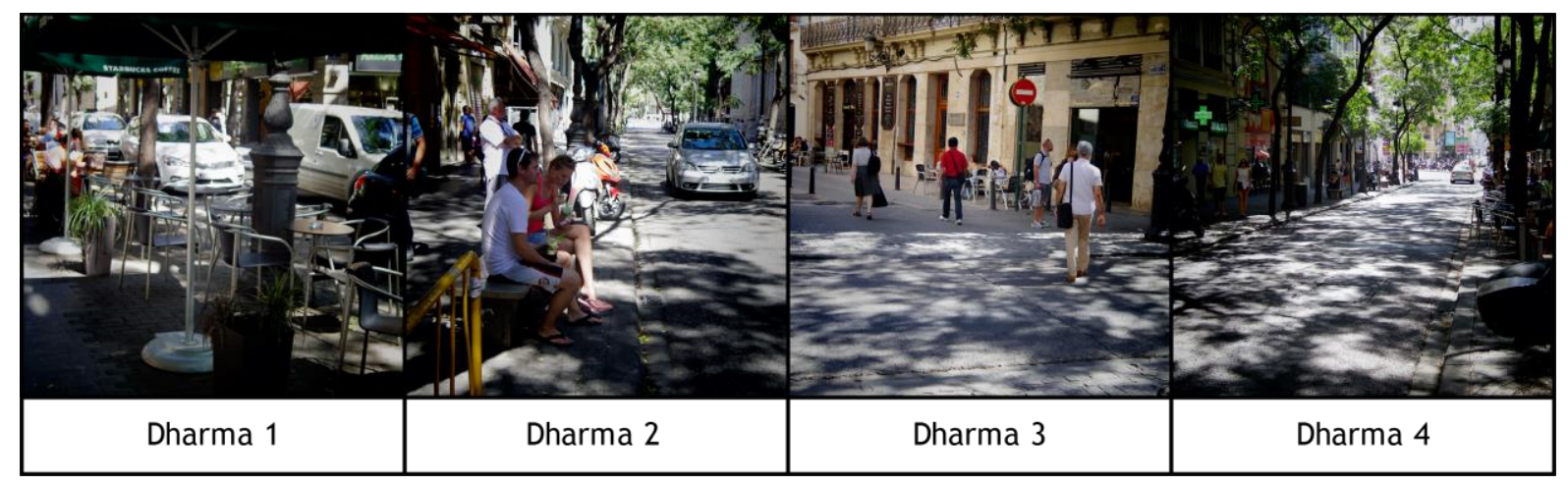

AD Diagnosis

AD1: En el primer tramo, entre la plaza de la Reina y la plaza del Ayuntamiento, a la gente le encanta tomar el café en la calle, al aire libre, tanto que incluso aguantan el hollín que los coches producen. Con las cafeterías, las viejas tiendas de ropa, los árboles grandes que bloquean amablemente el fuerte sol de Valencia en verano, la Iglesia de San Martín Obispo, etc., por los abundantes elementos históricos y naturales, esta calle puede ser muy atractiva.

AD2: $Y$ no hay suficiente paso de peatones.

AD3: La calle en su totalidad tiene una longitud impresionante de 2 kilómetros desde el sur la ciudad, con cercanía a la Estación del Norte y al Mercado Central, pasando por la Plaza del Ayuntamiento y llegando hasta la Plaza de la Reina. Y la Plaza de la Reina es importante porque está conectada con la Plaza de la Virgen, y la Plaza de la Virgen ésta conectada con la Puerta de Serranos la que da entrada al centro histórico de Valencia y conecta con el Jardín del Turia. Además, indudablemente, después Jardín del Turia se encuentra el Museo de Bellas Artes de Valencia y los Antiguos Jardines del Real Valencia. Lamentablemente ahora esta ruta solamente se expresa en un papel de turismo. No existe un vínculo decisivo para recordar estas rutas preciosas. No hay motivo para recordar la historia en la vida cotidiana valenciana. 
AD4: Es un camino de historia. La ciudad que olvida su historia y memoria, es fácil de atacar por las filosofías superficiales y las arquitecturas comerciales.

Una solución interesante extranjera de Brighton en Inglaterra es el uso compartido del espacio, tanto para peatones, como coches, etc., la calle ha recuperado el encanto de espacio.
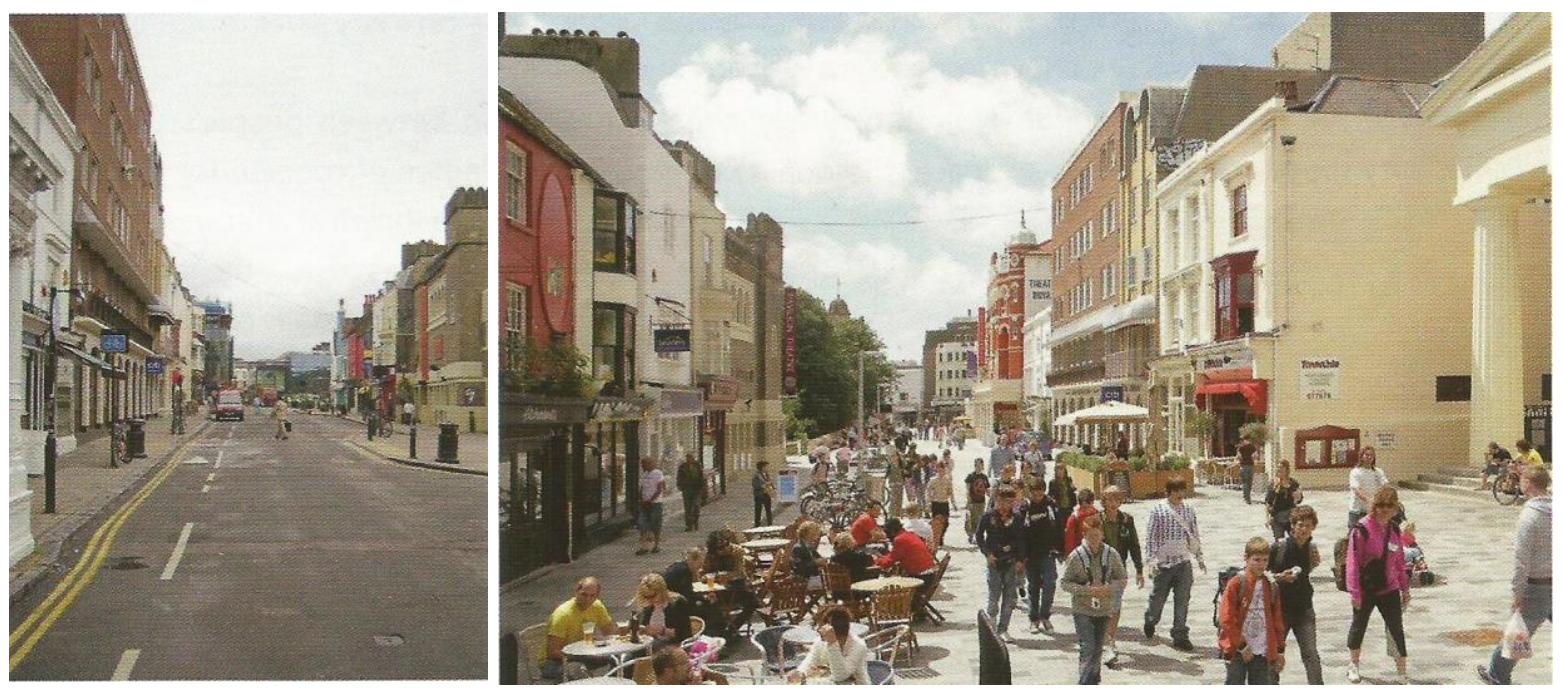

Fig. 11-3. Izquierda. Una calle de Brighton de Inglaterra, antes de 2006.

Fig. 11-4. Derecha. Una calle de Brighton de Inglaterra, después de la conversión, se transformó en una nueva calle con prioridad peatonal en Brighton de Inglaterra 


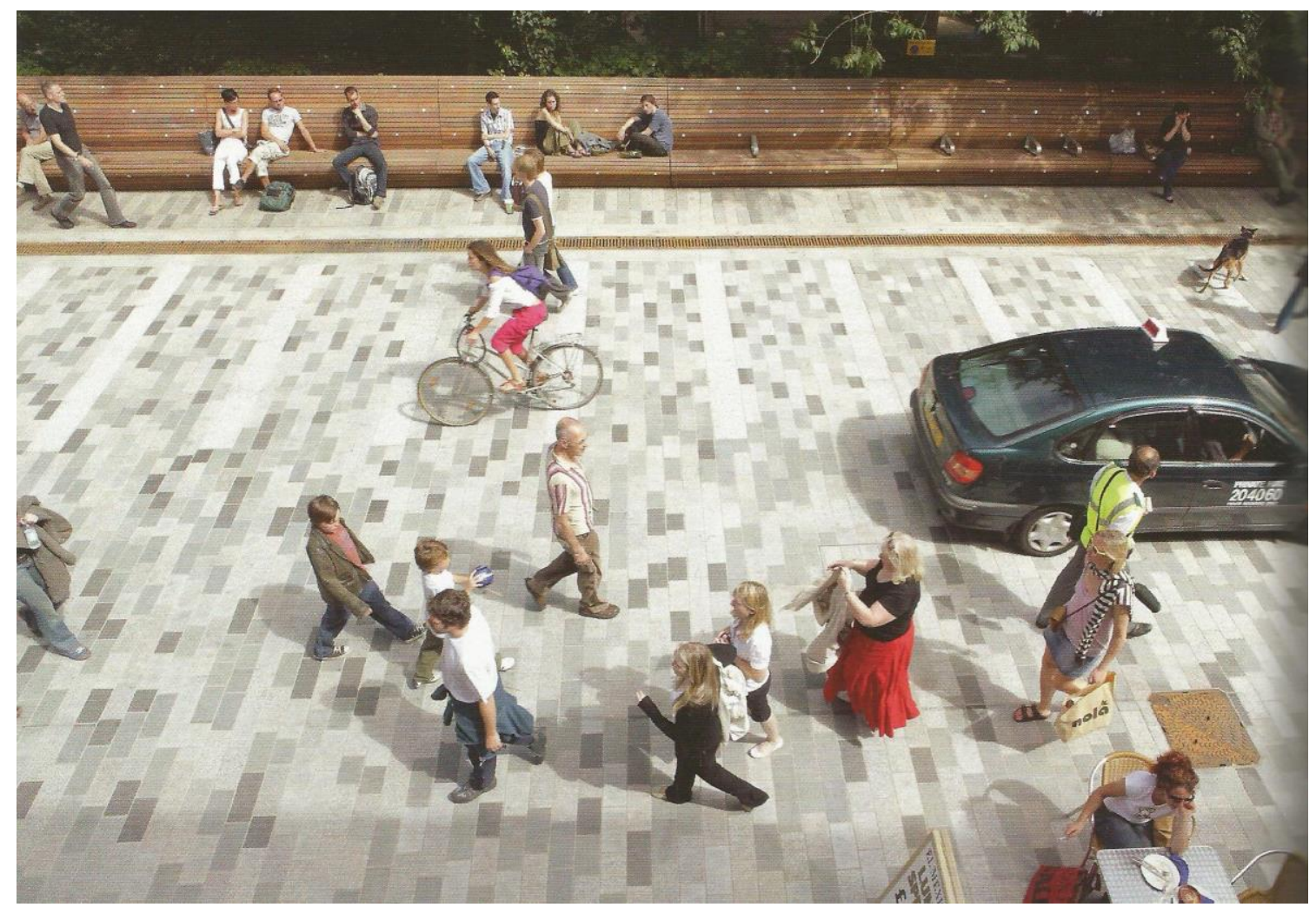

Fig. 11-5. Nueva Calle con prioridad del peatón en Brighton en Inglaterra. 


\section{CSD Mórbido-12}

Ubicación: Plaza de la Reina.

Dharmas Fenomenológicos

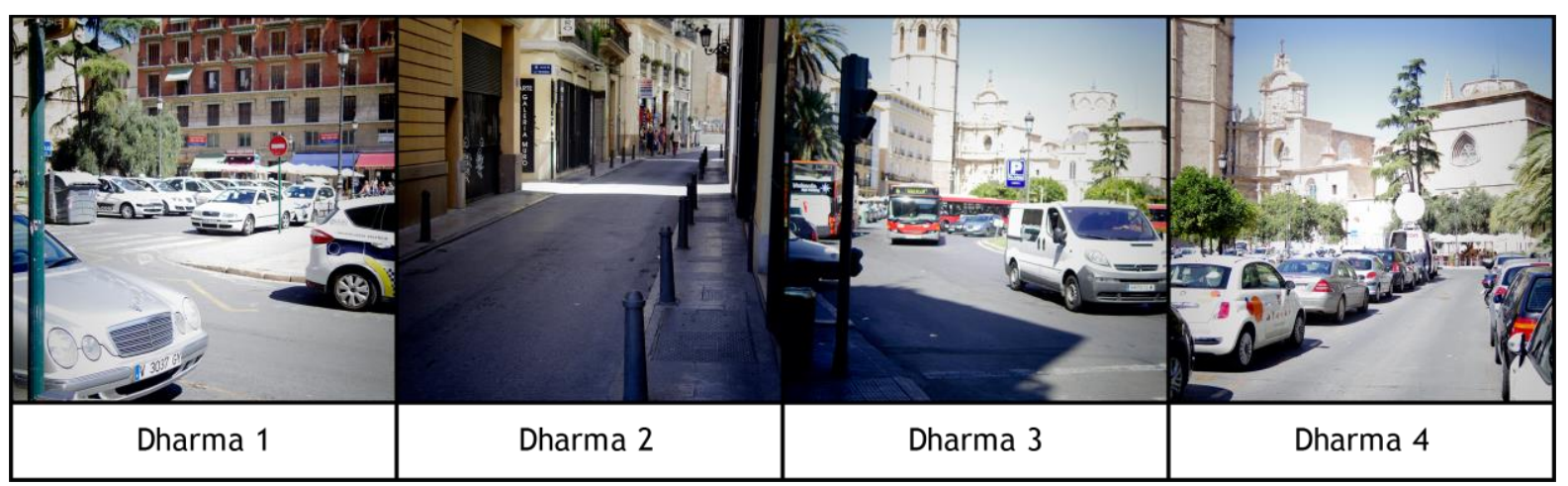

AD Diagnosis

AD1: Tráfico pesado en el centro histórico de la Ciudad de Valencia. La Plaza de la Reina no hace falta que se encargue de una gran cantidad de tráfico del centro histórico como si fuera un eje de tráfico que se encarga de la circulación y distribución del tráfico e incluso del aparcamiento. El desvío debería ser inminente.

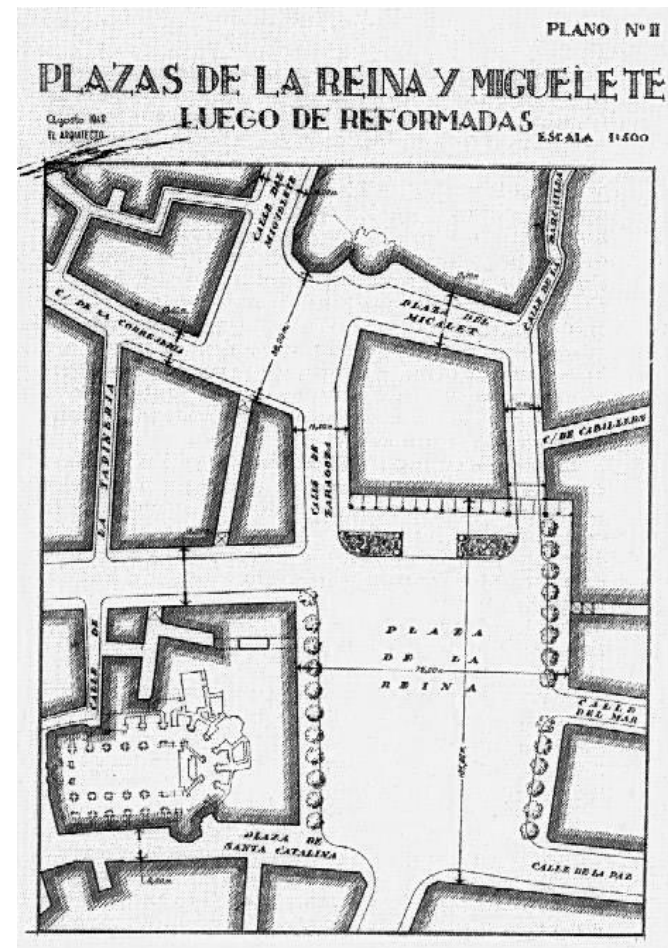

Fig. 11-6. Plaza de la Reina, después de la reforma por Javier Goerlich. 1949. 


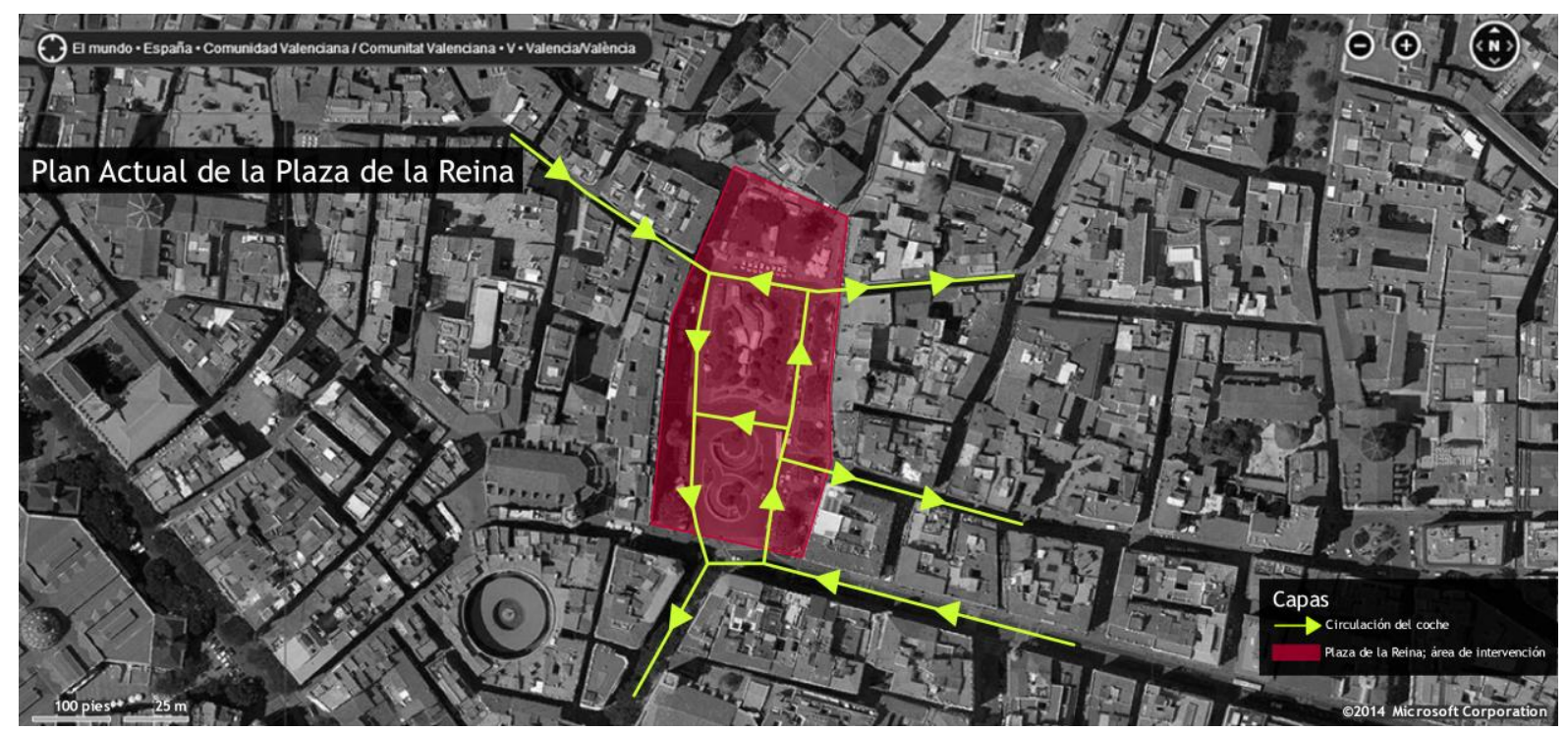

Fig. 11-7. Situación actual del tráfico de vehículos en la Plaza de la Reina.

AD2: Una buena plaza no se hace solamente poniendo flores, bancos y una fuente artificial en el césped. En este lugar falta la comprensión behaviorista de los eventos y programas que pueden ocurrir.

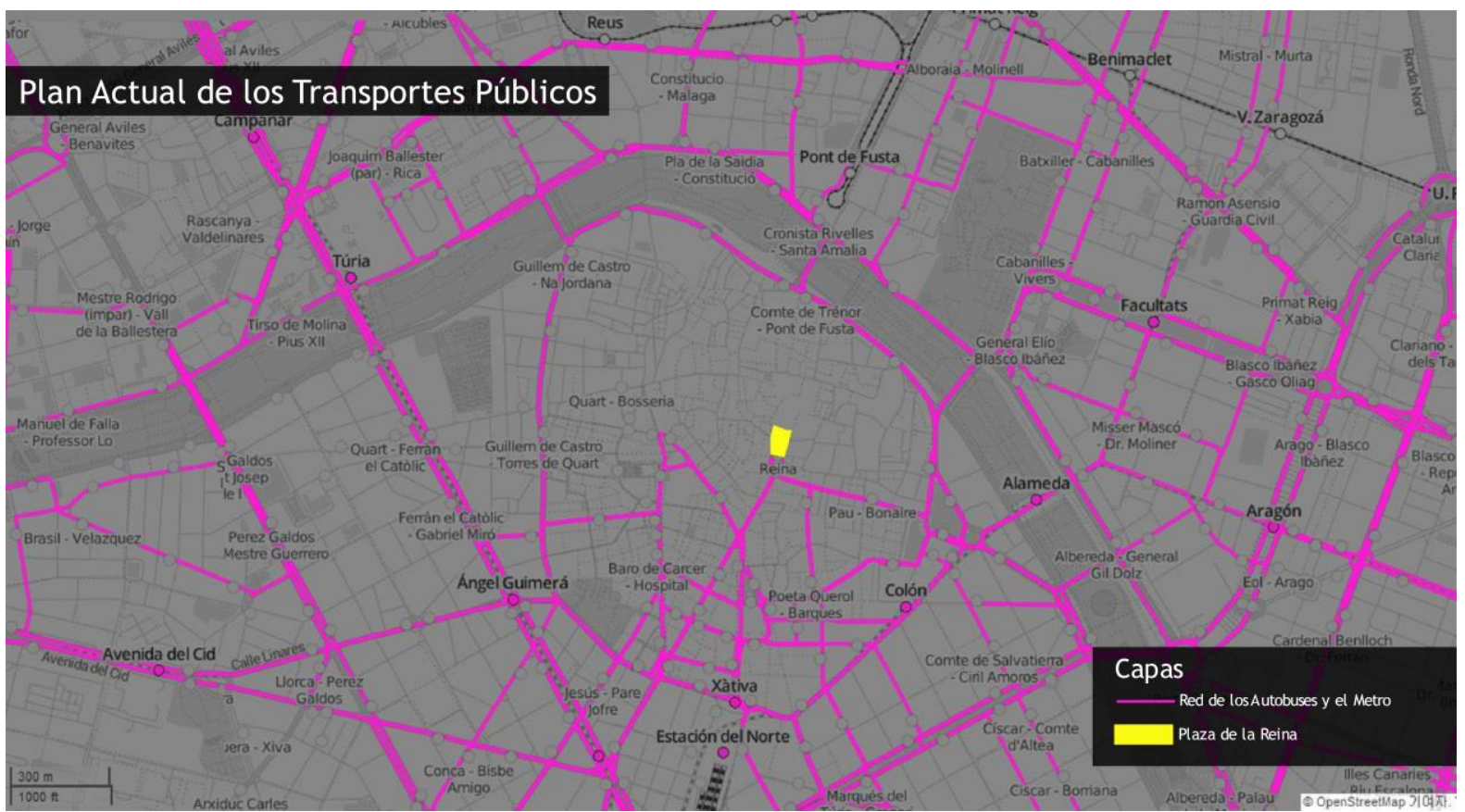

Fig. 11-8. Plan actual de los transportes públicos. 
AD3: La forma de la plaza se hizo por la forma de la circulación del coche, para la entrada y la salida de los coches del aparcamiento subterráneo. Es decir, primero el plan fue establecido para los coches, y luego los espacios sobrantes se habrían dispuesto para los espacios verdes.

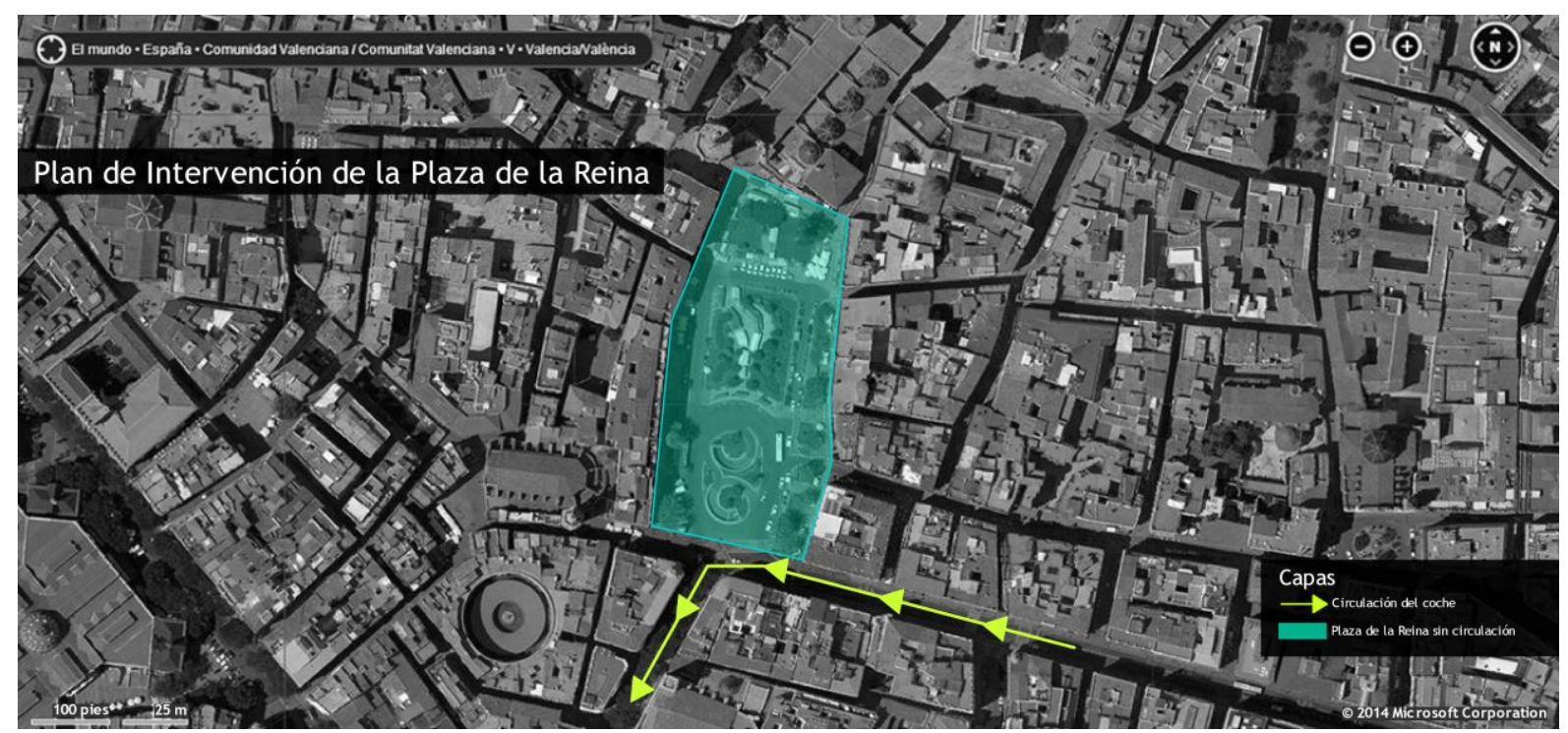

Fig. 11-9. PROPUESTA Plan de intervención de la Plaza de la Reina.

AD4: Desde lo alto de la Torre del Micalet, se puede entender todo lo que significa AD3. Es un diseño plano no tridimensional. La vida urbana se encaja en un diseño plano, o se mutila por el diseño. Es un bonito plano, pero si pasa alguien caminando por la plaza, dicha plaza se acerca como un gran dharma de dolor para el caminante. Las estrechas aceras y la presión de los coches en grandes cantidades no son agradables.

Presentamos el caso de la Piazza del Campo de Siena en Italia. En la plaza, no están incluidas muchas funciones, habrá muchas dificultades de aparcamiento y acceso para los coches. Sin embargo, la gente sigue queriendo volver a este espacio. 


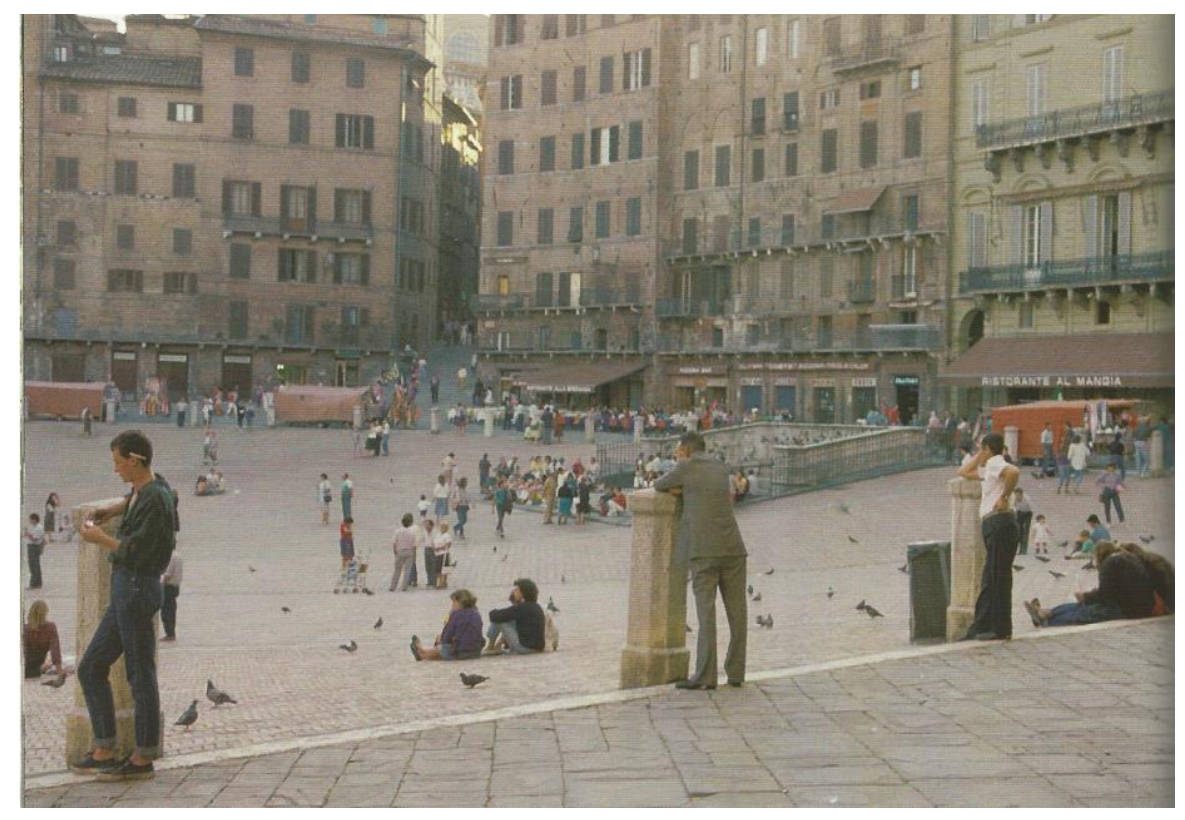

Fig. 11-10. Piazza del Campo, Siena, Italia.

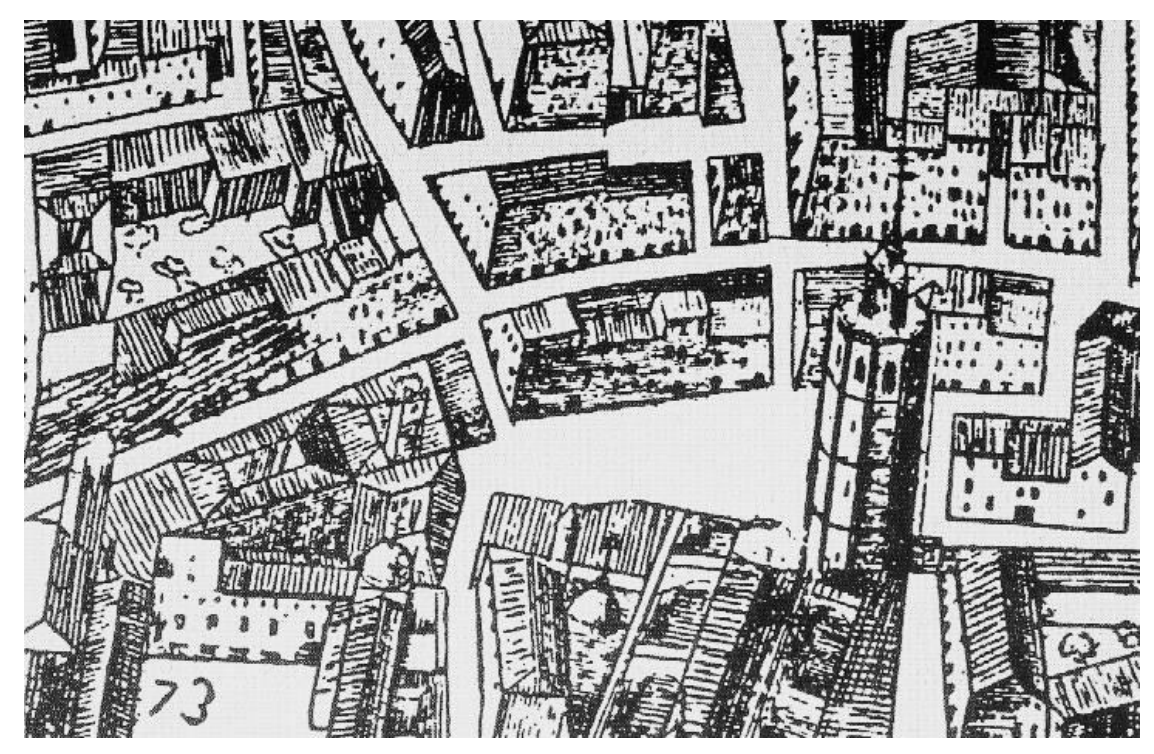

Fig. 11-11. Configuración inicial de la plaza del Miguelete en el plano Tosca. 1738. 


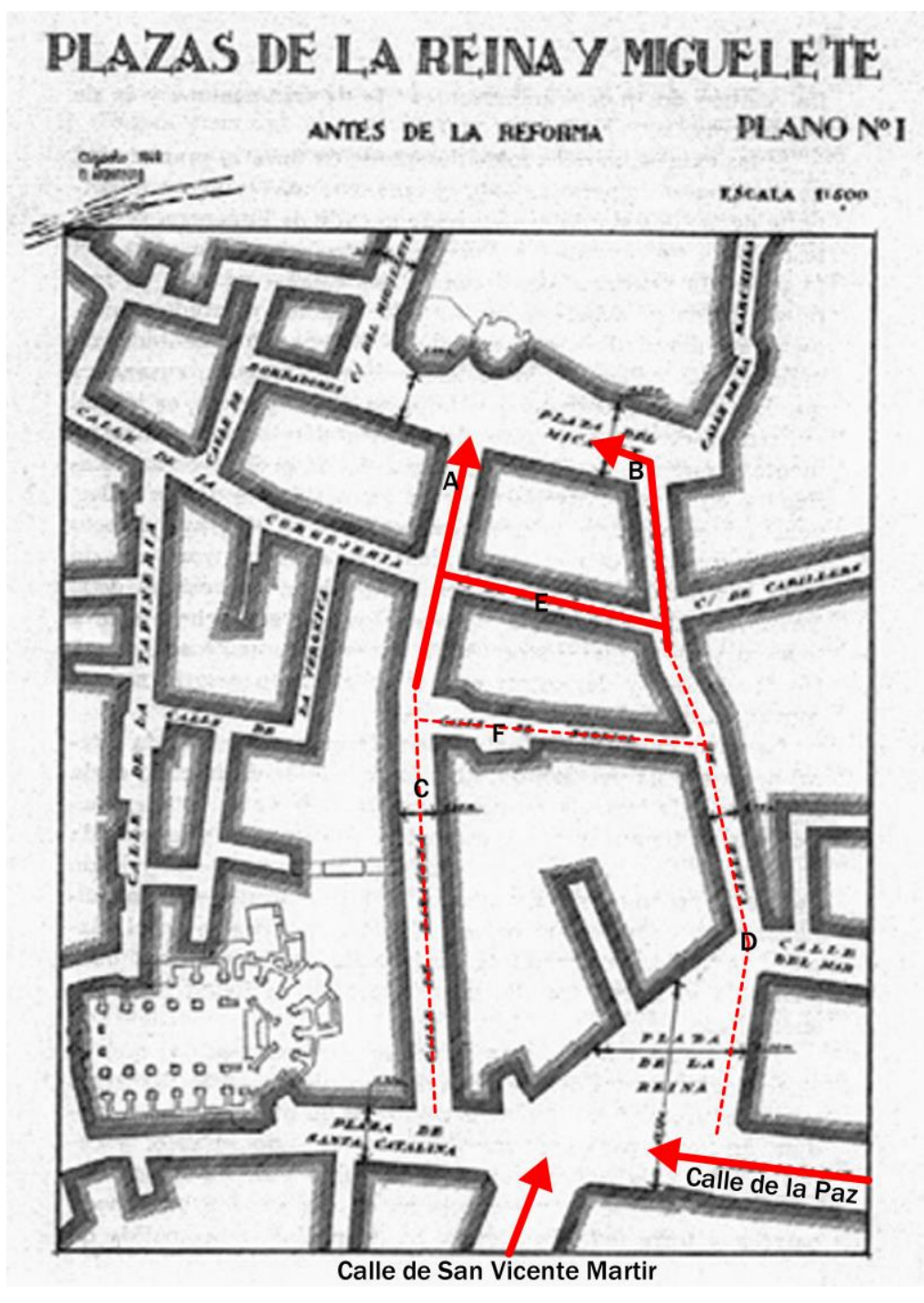

Fig. 11-12. El plan para la Plaza de la Reina de Luis Ferreres Soler. 1891.

La función actual de la Plaza de la Reina no es sino servir como aparato de circulación para los automóviles. Durante siglos, ¿qué pasó con los tramos del centro histórico junto a la catedral? Primero, el avance de la tecnología en varios campos. Y segundo, el cambio de la conciencia social de los ciudadanos.

Respecto al primer punto, el avance de la tecnología de automóviles, decir que la escala de percepción de la distancia de los humanos, cambió. En la ciudad medieval, la gente reconocía su entorno por los datos que podía adquirir al ritmo de sus pasos alegres, moderados y a veces con prisa. $Y$ en la ciudad actual, aunque sigue siendo así, existe otro factor llamado automóvil. La gente percibe la ciudad andando por la calle, y también conduciendo. Dos escalas distintas se han aplicado en esta plaza de forma no sofisticada, por lo que se generan choques entre ellas. 
Sobre el segundo punto, en aquella época la gente aún no sabía que significa el automóvil en la vida urbana, especialmente el hecho de que esta nueva tecnología podría amenazar los espacios públicos tan fácilmente como lo hace hoy en día.

Desde el sur hasta el norte, siguiendo la Calle San Vicente Mártir a partir del centro administrativo de Valencia, o desde el este al oeste, siguiendo la Calle de la Paz desde la Calle Colón que es el centro comercial de Valencia, cuando llegan a la Plaza de la Reina, a los peatones se les permite una pequeña relajación de la tensión del viaje, viviendo los ritmos del espacio. El centro histórico está adaptado a la escala de la vida medieval. Existen varios ritmos entre pilares y pilares, arquitecturas y arquitecturas, calles y calles; también entre calles y calles. Existen ritmos que pueden ser percibidos por los peatones. Ese ritmo fue la identidad del centro histórico de Valencia en su momento.

Además, esa pequeña relajación mencionada anteriormente no es el final de la ópera, sino que es una obertura para llegar al umbral de la plaza. Y desde este umbral, el proyecto del año 1891 de la Plaza de la Reina, en lugar de proveer un vasto espacio abierto, prefiere tocar más interludios a medida que los peatones atraviesan el espacio sintiendo los intervalos rítmicos de los pasos, las ventanas y puertas, los pilares, las arquitecturas y calles. Como una preparación para encontrar la catedral, que son A, B, C, D, E y F de la fig. 11-12, después de un pequeño descanso desde el umbral de la plaza, se va aumentando otra vez la tensión acercándose al lugar más profundo, y se experimentan dos perspectivas calculadas que proceden desde $A$ y $B$ donde al final se reconoce el por qué del ángulo de la fachada de la catedral está girado $18^{\circ}$ aprox. hacia el lado del norte de la plaza. Aquí se resuelve la tensión aumentada durante del viaje. En la época de Luis Ferreres Soler como se ve en su plan del año 1891, no existían las colisiones entre las escalas heterogéneas y trans-crónicas que son, una medieval y el otro moderna, como ocurre en la situación actual de Valencia. Sin embargo, se puede crear un espacio de transición manteniendo el tejido urbano medieval inmediato a la catedral, para recuperar el sentido urbano de la catedral misma. 


\section{CSD Mórbido-13}

Ubicación: Calle Navellos, Plaza de la Virgen, Calle Muro de Santa Anna.

Dharmas Fenomenológicos

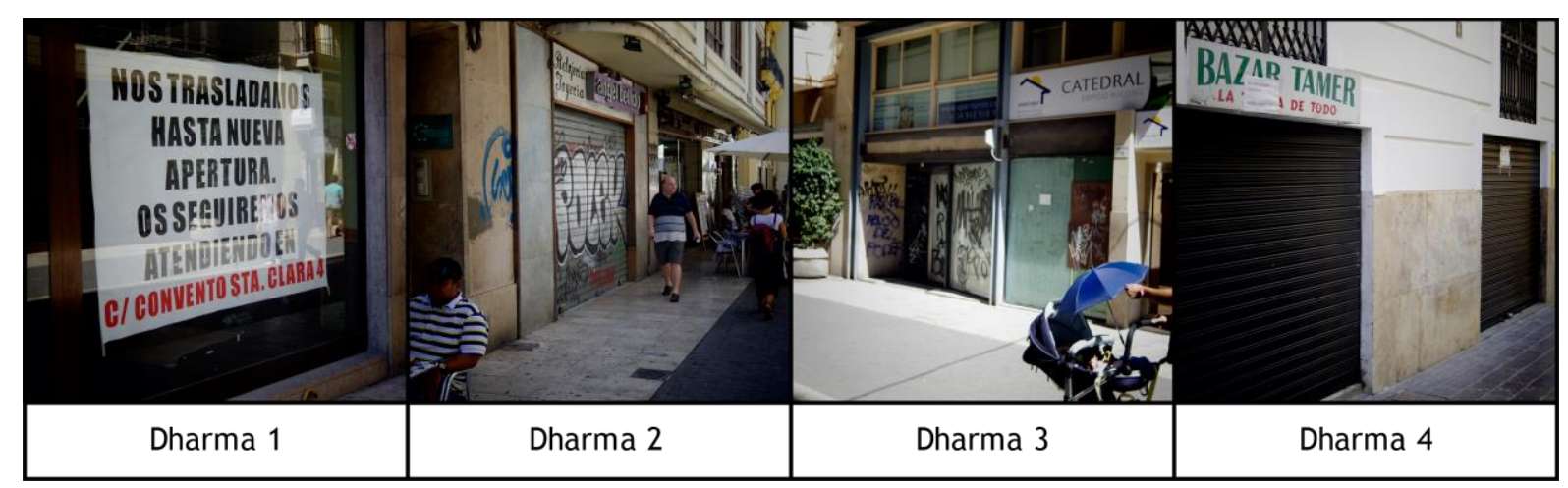

AD Diagnosis

AD1: Es la Misma situación que CSD Mórbido-05.

AD2: En esta calle, un mínimo de 6 locales están cerrados y esperan nuevos inquilinos con algún nuevo negocio.

AD3: Solamente las tiendas de franquicia están sobreviviendo aquí también. Cada día, las calles, poco a poco, aparecen distorsionadas en su identidad, demasiado globalizadas.

AD4: Pobre relación entre la Plaza de la Virgen y la Puerta de Serranos, no geográficamente sino psicológicamente, por el ambiente disuasorio de la calle. 


\section{CSD Mórbido-14}

Ubicación: Gran Vía Marqués del Turia cercano al Jardín del Turia.

Dharmas Fenomenológicos

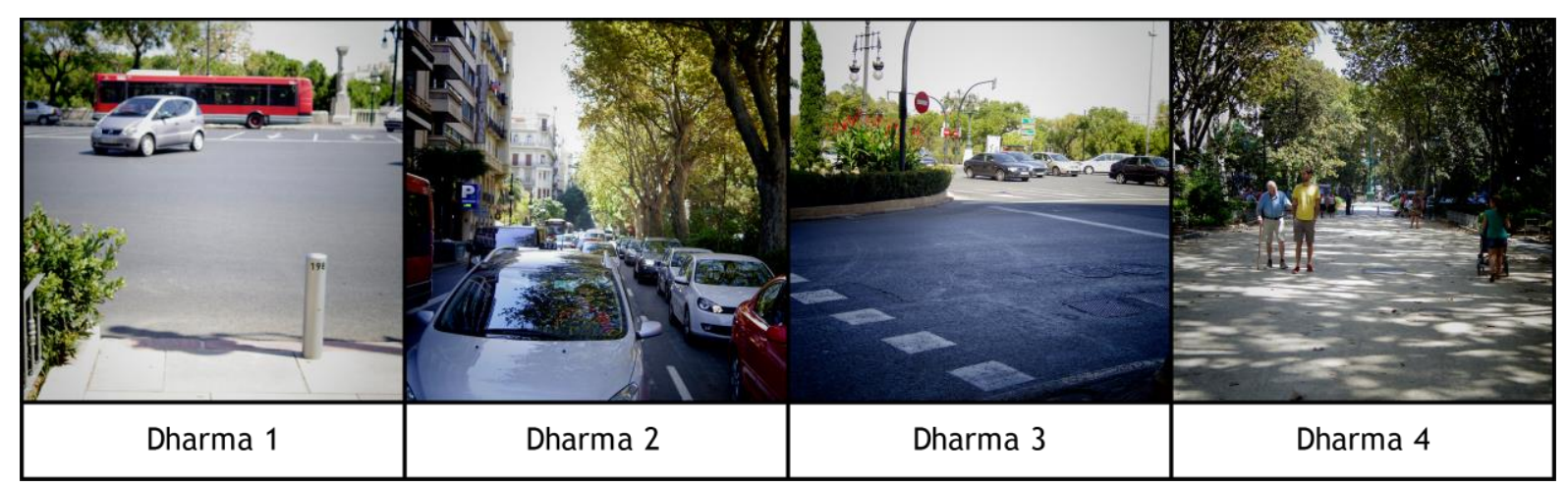

AD Diagnosis

AD1: El final de la gran vía está desconectado de una manera drástica.

AD2: El paseo pacifico se interrumpe incesantemente por los coches y las vastas calzadas.

AD3: La enorme cantidad del tráfico de la gran vía, la rotonda y la Avenida de Aragón inducen una velocidad abrumadora de los coches cuyos efectos amenazan a los caminantes. La velocidad física, la dureza metálica de los coches y el ruido de los tubos de escape, estas sensaciones de terror amenazan al peatón.

AD4: El espacio aislado y marginado por ausencia de la comprensión behaviorista humana apropiada, queda dominado ahora por situaciones pervertidas. La Gran Vía del Turia quiere conectarse al Jardín del Turia. 


\section{CSD Mórbido-15}

Ubicación: Avenida de Aragón.

Dharmas Fenomenológicos

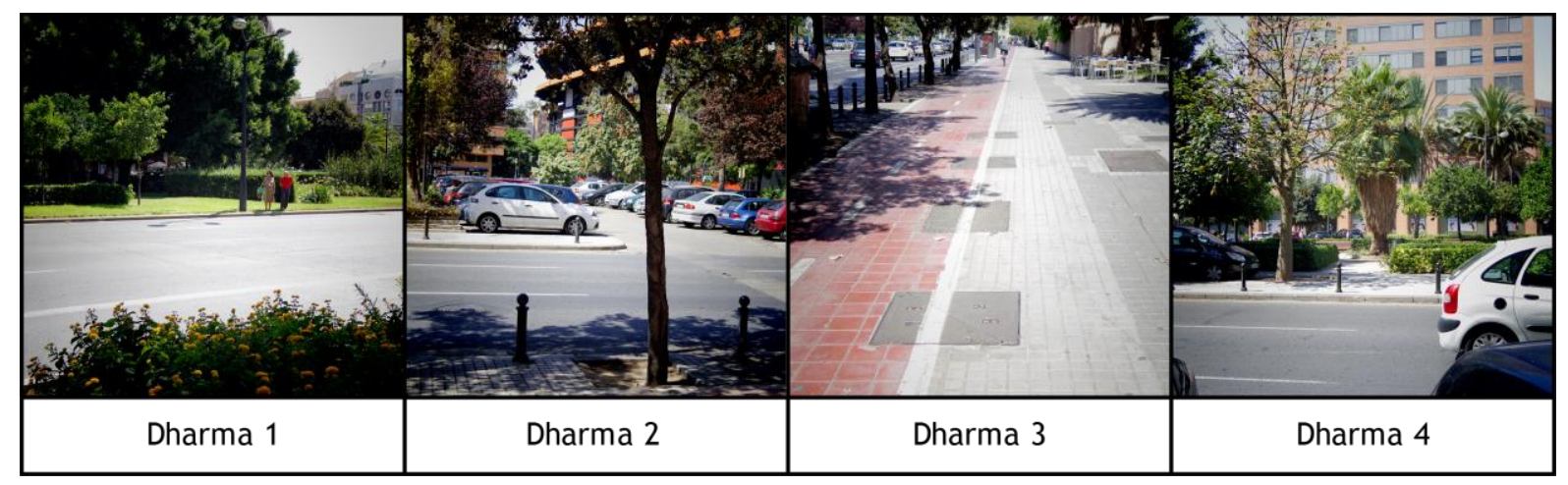

AD Diagnosis

AD1: Desde el principio la avenida es una ruta de aparcamiento. Es un camino aburrido. El peatón se siente como si estuviera caminando en una autopista. No es un deleite.

AD2: Cuando se entra a la Avenida de Aragón, el jardín que está entre las vías de calzada se ve como una isla. No es fácil saber dónde está la entrada.

AD3: Es un camino muy largo y aburrido. Primeramente, después de la creación de las calzadas para los coches, los peatones salen de la casa y se incorporan al sistema jerárquico de circulación. Así se descubre tristemente el significado de uno mismo en la ciudad. Las bicicletas, las paradas del metro y el autobús se sacrifican sin problema en favor de la circulación de los coches.

AD4: Cuando se cruza este tipo de semáforo, se requiere un valor considerable. No se siente misericordia desde las velocidades de los coches. Es una carretera-jardín de los coches.

En las siguientes imágenes de París o Brasilia se muestra el efecto que puede surgir en el espacio urbano cuando la arquitectura está en desacuerdo con la escala humana. 


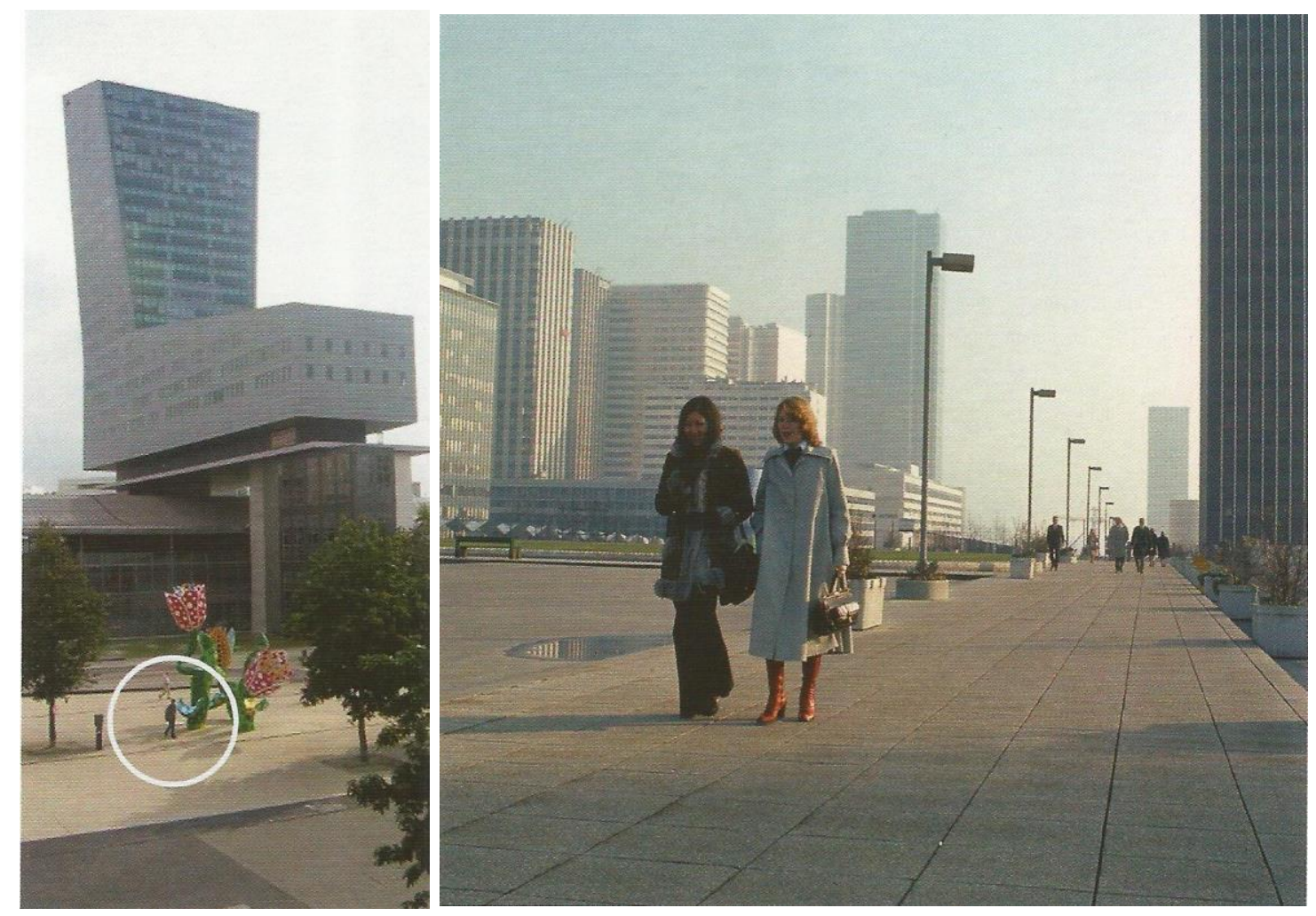

Figs. 11-13. Izquierda. Eurolille, Lille, Francia.

Figs. 11-14. Derecha. La Defence, Paris.

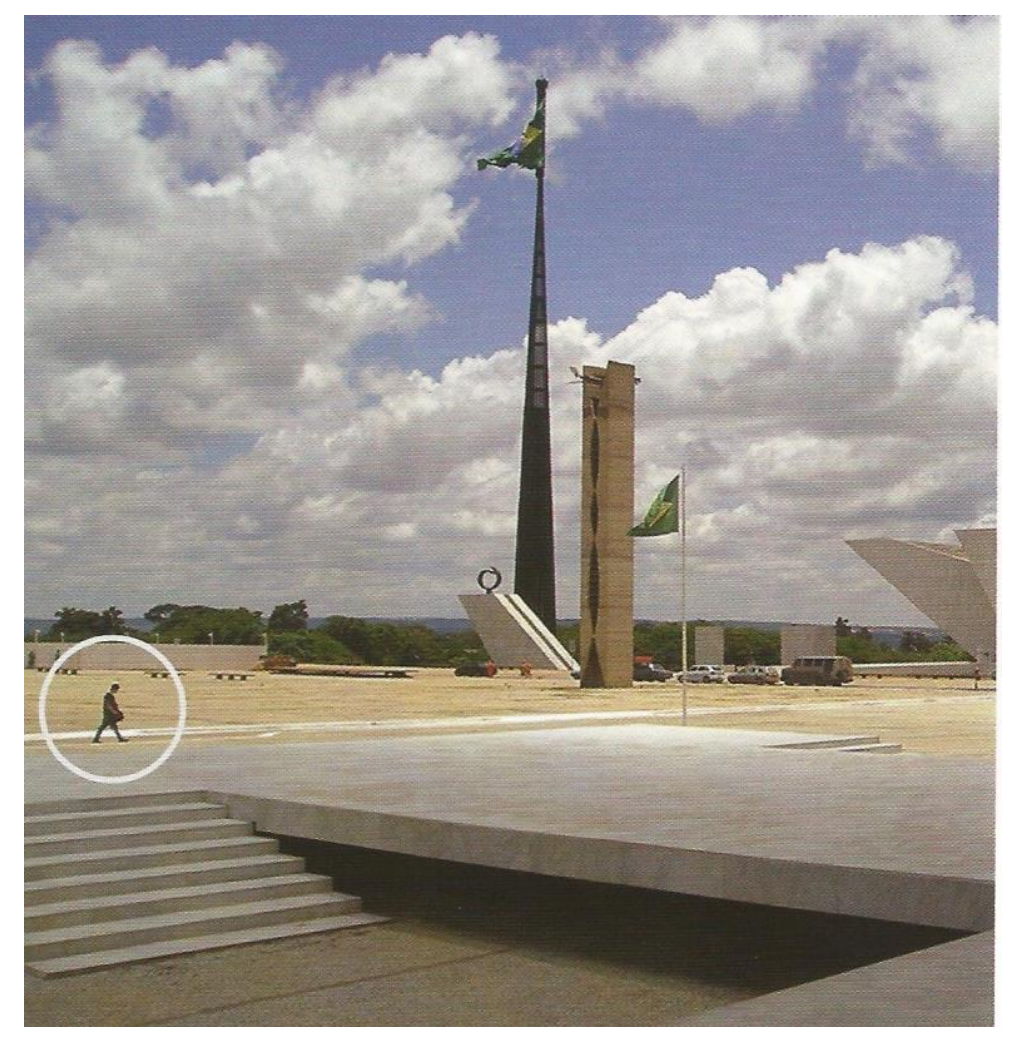

Fig. 11-15. Brasilia, Brasil. 


\section{CSD Mórbido-16}

Ubicación: Avenida Blasco lbáñez

Dharmas Fenomenológicos

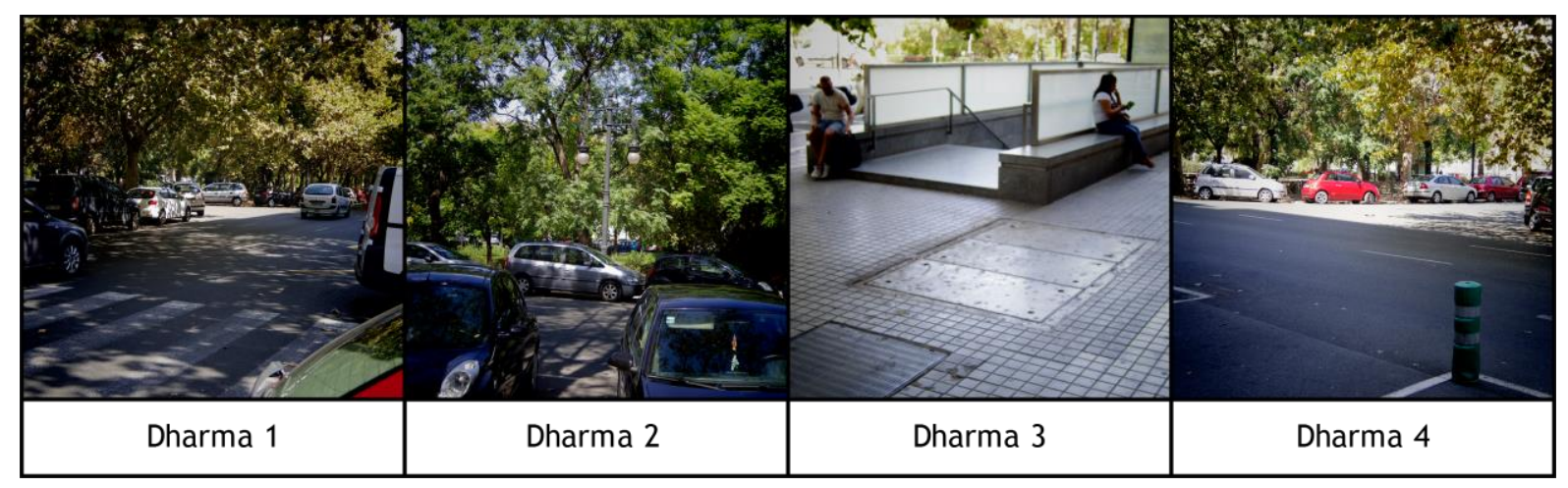

AD Diagnosis

AD1: Se observa frecuentemente unos puntos que parece que deberían tener un semáforo. Así ocurren los cruces peligrosos. Siempre hay un conflicto entre los coches y los peatones, incesantemente.

AD2: Cuando se pasa por la intersección de la Avenida Blasco lbáñez y la Avenida de Suecia, por la cantidad excesiva de los coches que hay aparcados en la avenida, la isla del camino-jardín se va aislando cada vez más, visualmente, físicamente y mentalmente.

AD3: Las islas de acera en el medio de la calzada surgen para no cortar el flujo de los coches. No parece un diseño sensible con el peatón.

AD4: Cuando se llega al final de la avenida, se experimenta un colapso mental. Al camino-jardín de la Avenida Blasco Ibáñez es difícil entrar. Se puede decidir andar por la acera de borde de los edificios. El camino para acceder a los Antiguos Jardines del Real de Valencia, desde la Avenida Blasco Ibáñez, también se interpreta de forma análoga. 


\section{CSD Mórbido-17}

Ubicación: Antiguos Jardines del Real Valencia - Calle General Elio - Plaza Llano del Real.

Dharmas Fenomenológicos

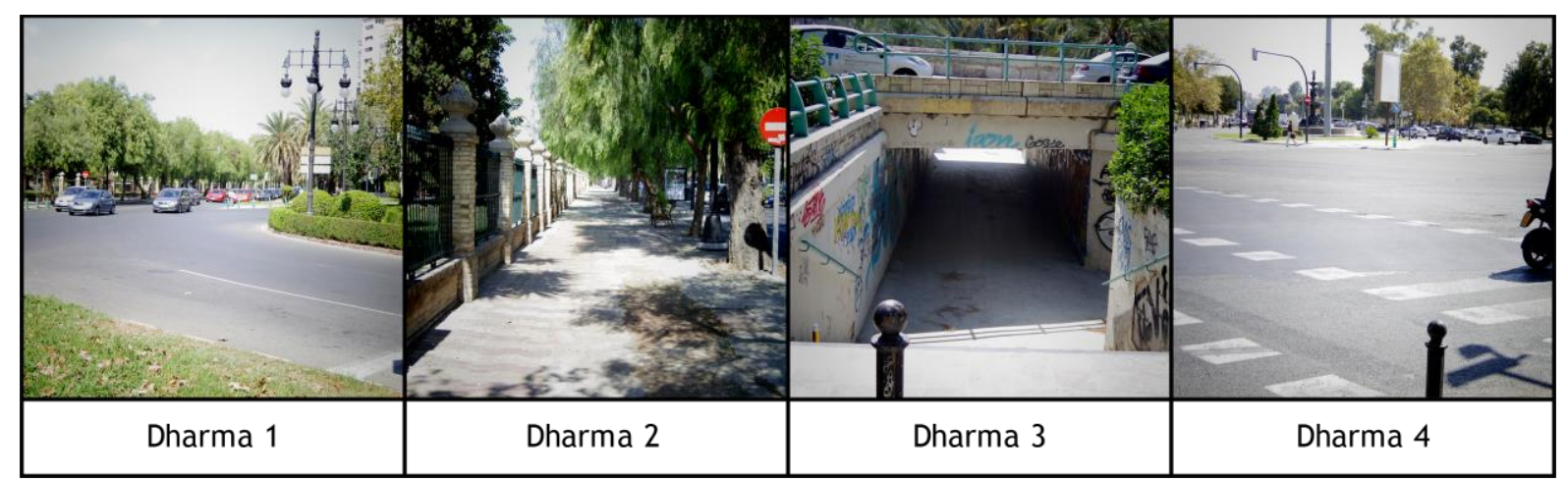

AD Diagnosis

AD1: Un camino fuera de escala. Sin consideración del ritmo y la dimensión humana.

AD2: Los peatones observan con inquietud los coches en la calzada cuya apariencia es la de una autopista, considerando las velocidades de los vehículos.

AD3: La imagen de esta calle se ha endurecido al máximo.

AD4: Las calles urbanas que tendrían que ayudar al hombre a sentir deseos sanos en el espacio según su excelencia, lo empobrecen en cambio. La ciudad es un AD-dharma enorme. 


\section{CSD Mórbido-18}

Ubicación: Calle San Pío V. (Museo de Bellas Artes San Pio V - Antiguo Jardín del Real de Valencia - Jardín del Turia) Dharmas Fenomenológicos

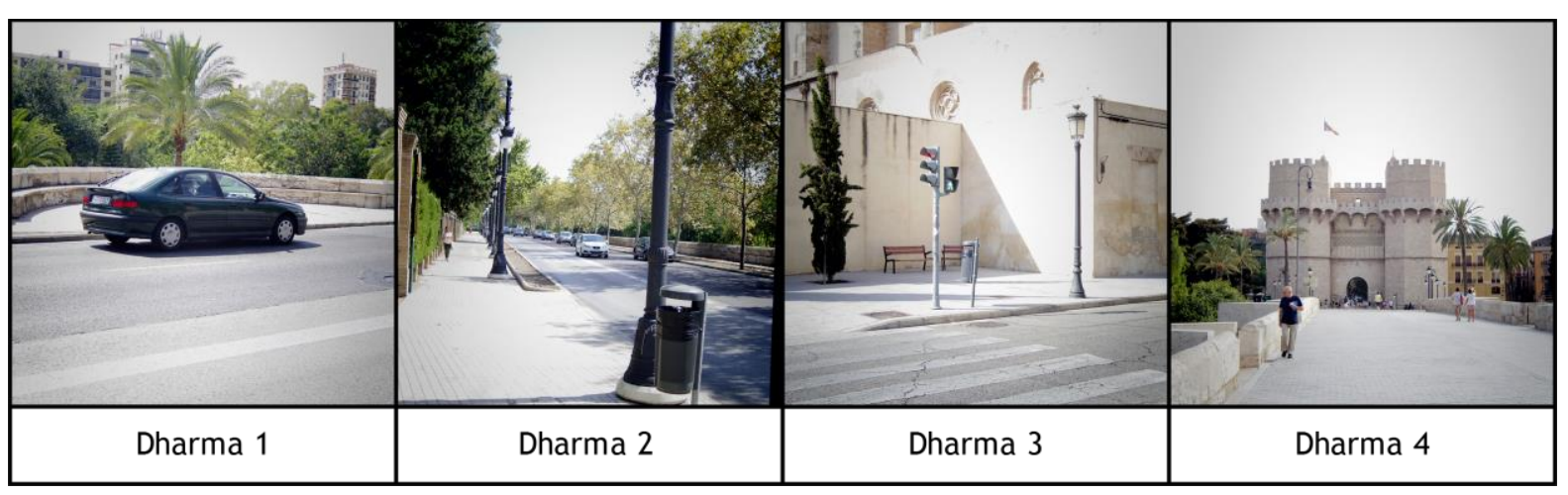

AD Diagnosis

AD1: Las aceras no son coherentes. Las falsas teorías nos engañaron hace décadas, y ahora especialmente a los países subdesarrollados.

AD2: Desmembración total, físicamente, visualmente, antropológicamente. No es rizomático, la red es la vida. Esta calle tiene una capacidad potencial de conexión con el Antiguo Jardín del Real de Valencia, el Museo de Bellas Artes San Pio V, el Jardín del Turia, las Torres de Serranos y hasta el centro histórico. Sin embargo, su potencial fue restringido por una nueva ideología en provecho del automóvil.

AD3: La gente transita, no se queda porque no quiere.

AD4: La vida cotidiana es un mundo que se experimenta pisando el suelo con el pie del hombre. Las calles tienen que conectar varios espacios. Si el barrio residencial tuviera únicamente la mera función de protección de la naturaleza salvaje, ¿para qué servirían los arquitectos? Los malos CSD $^{22}$ dharmas mutilan, aíslan, desconectan y matan la ciudad.

${ }^{22}$ Co-surgimiento dependiente-(NdA) 


\section{CSD Mórbido-19}

Ubicación: Avenida del Reino de Valencia

Dharmas Fenomenológicos

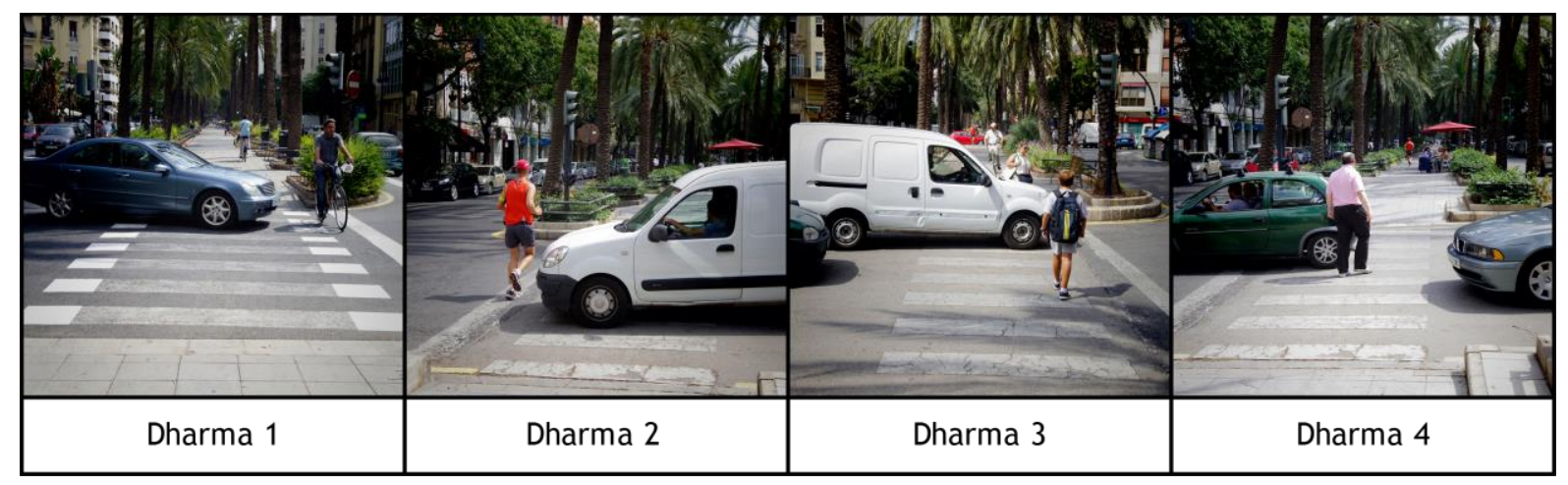

AD Diagnosis

AD1: Igual que la Gran Vía Marqués del Turia, la Avenida del Reino de Valencia tiene poca relación con el Jardín del Turia. No es rizomática.

AD2: Un sistema de circulación abusivo. La carencia de consideración sobre los peatones en el proceso de la planificación. Como hay varias escuelas (Centro Privado de Enseñanza Nuestra Señora de Loreto, Colegio inglés - Centro de Educación Infantil San Martin), la mayor parte de los transeúntes son niños y aun así ocurren numerosas violaciones semafóricas por parte de los coches. En una situación ambigua, algunos coches arriesgan las vidas ajenas en esta zona, cuando la velocidad del coche es más alta, esta tendencia es más fuerte.

AD3: La razón por la que los coches pueden tener alta velocidad en esta calle es porque responde al plan de tráfico. Cada vez cuando se pierde alguna fluencia, se fortalece el sistema expandiendo las vías y modificando el sistema semafórico, y así la cantidad de los coches aumenta sin problema incesantemente hasta hoy en día. Especialmente, en la Avenida Jacinto Benavente, Avenida Peris y Valero y el Puente del Ángel Custodio, las velocidades de los coches son impresionantes. 
AD4: El camino-jardín en medio de la avenida es muy agradable para los peatones. No se ven semáforos cuando se pasa desde un jardín al otro. Siempre los caminantes tienen mayor prioridad que los coches. Solamente, cuando se llega al final del camino, surgen las islas de acera en una forma triangular, debido a que se cruzan muchas calles en esta zona.

Durante el periodo de la investigación, se encontraron varios sucesos con accidentes automovilísticos en la calle, que incluso casi dañaron mi persona. Y todos han ocurrido en los semáforos. Este día representado en la fotografía, se muestra a una señora que no pudo esquivar un coche que venía sin comprobar el paso peatonal ni el semáforo. La fotografía fue tomada en el mismo momento del accidente (18/09/2015).

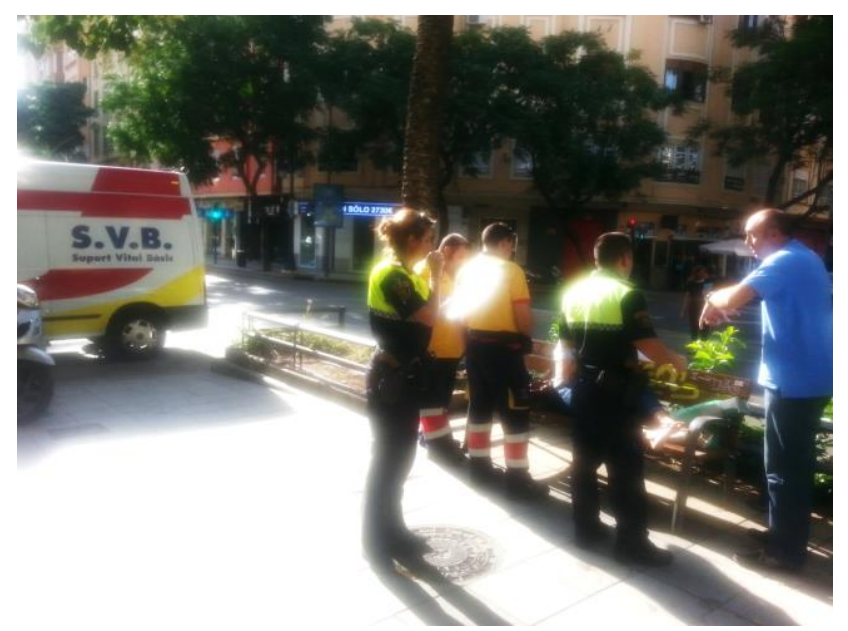

Fig. 11-16. Un día desafortunado para una señora en La Avenida de la Reina. El conflicto entre los coches y los seres humanos en los semáforos nunca termina. 


\section{CSD Mórbido-20}

Ubicación: Gran Vía de las Germanías

Dharmas Fenomenológicos

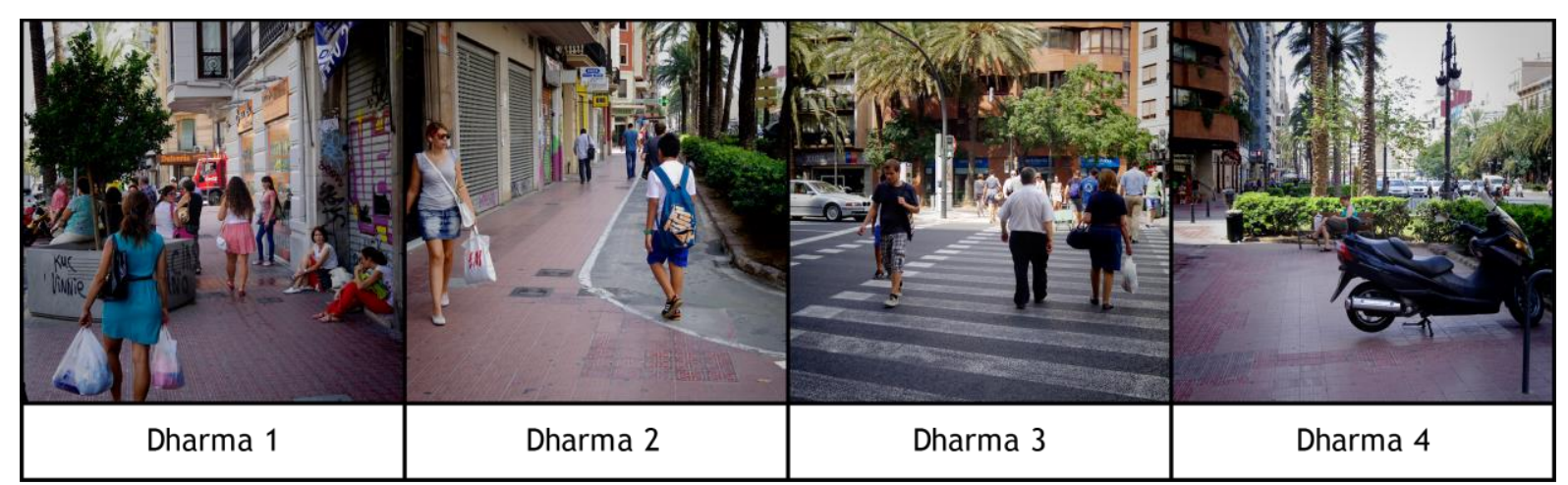

AD Diagnosis

AD1: Al considerar la cantidad de población en esta zona, no hay muchos elementos atractivos para que los peatones sientan deleite urbano.

AD3: El tránsito surge desde la zona de Xátiva y la zona de Ruzafa. La gente pasa y nada más.

AD2: Aún carece más de carriles de bici.

AD4: La gran vía es una arteria principal que provee la sangre a las pequeñas arterias periféricas. Y dicha función de la Gran Vía de Germanías es deficiente. Cuando llega al final, al túnel que pasa por un subterráneo del ferrocarril de la Estación del Norte, se siente como que está acabada de repente para siempre. 


\section{CSD Mórbido-21}

Ubicación: Gran Vía de Ramón y Cajal - Gran Vía de Germanías

Dharmas Fenomenológicos

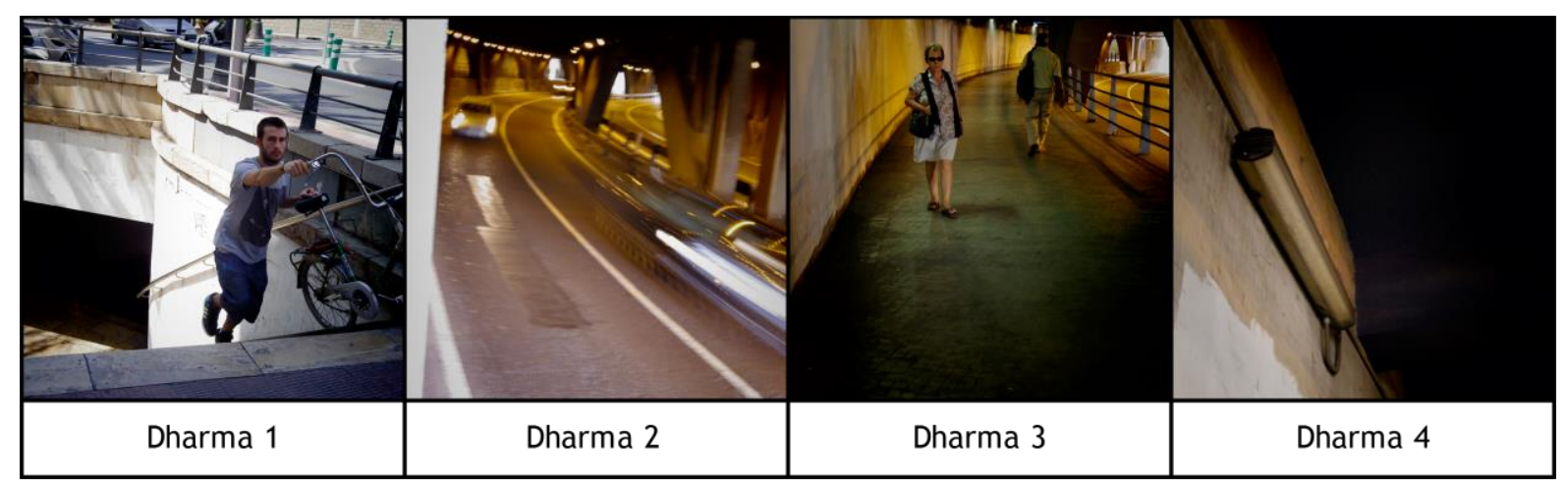

AD Diagnosis

AD1: Parece que las dos grandes vías están desconectadas, pero se conectan a través de un túnel subterráneo. Los peatones tienen que pasar por ese túnel oscuro y húmedo oliendo a orines. Y salen por unas escaleras escarpadas.

AD2: Los coches circulan a lado del pretil fluidamente, generando un ruido espantoso. Los peatones están protegidos físicamente, sin embargo, están atacados por el ruido y la oscuridad. El particular olor del túnel y el grafiti del muro sucio, avisan a los peatones que han entrado en una zona ajena.

AD3: Si no se está en el periodo de las Fallas, o en una situación extremadamente urgente, la gente suele vacilar antes de pasar este túnel por la noche.

AD4: Si se lleva una bicicleta, este camino no es recomendable debido a los obstáculos. 


\section{CSD Mórbido-22}

Ubicación: Gran Vía Ramón y Cajal

Dharmas Fenomenológicos

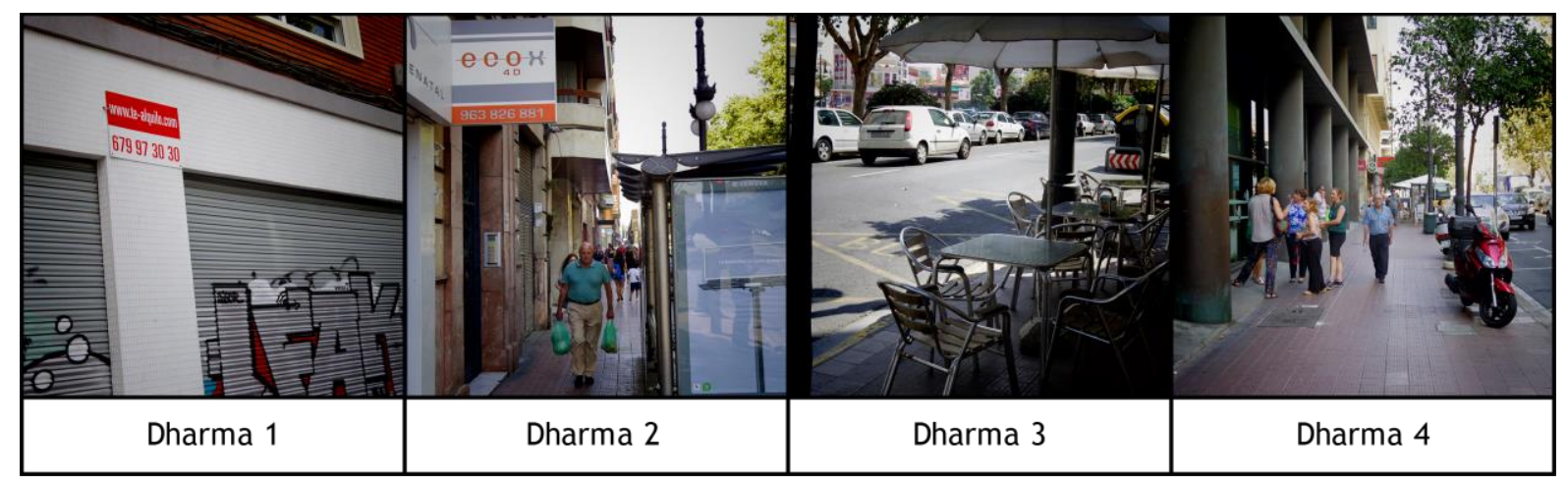

AD Diagnosis

AD1: Parece que es una zona aislada por varias razones, pero principalmente por el ferrocarril, y el túnel.

AD2: La zona se transforma en slum (barrio bajo). Es difícil de imaginar una cafetería que esté llena por la gente del barrio. A la gente le encanta tomar café en la terraza con el viento, tanto que aguantaría el hollín de los coches. Aquí se requiere un pequeño toque de caridad arquitectónica.

AD3: La gran vía se revivifica cuando llega a la Plaza de España. Se ve mucha gente. Sin embargo, la acera es extremadamente estrecha, tanto que no se puede creer que es una gran vía. La acera está invadida por los faroles, las papeleras y las cajas de electricidad. En esta circunstancia, no es fácil de imaginar un carril de bici.

AD4: Una calle no atractiva. 


\section{CSD Mórbido-23}

Ubicación: Gran Vía de Fernando el Católico.

Dharmas Fenomenológicos

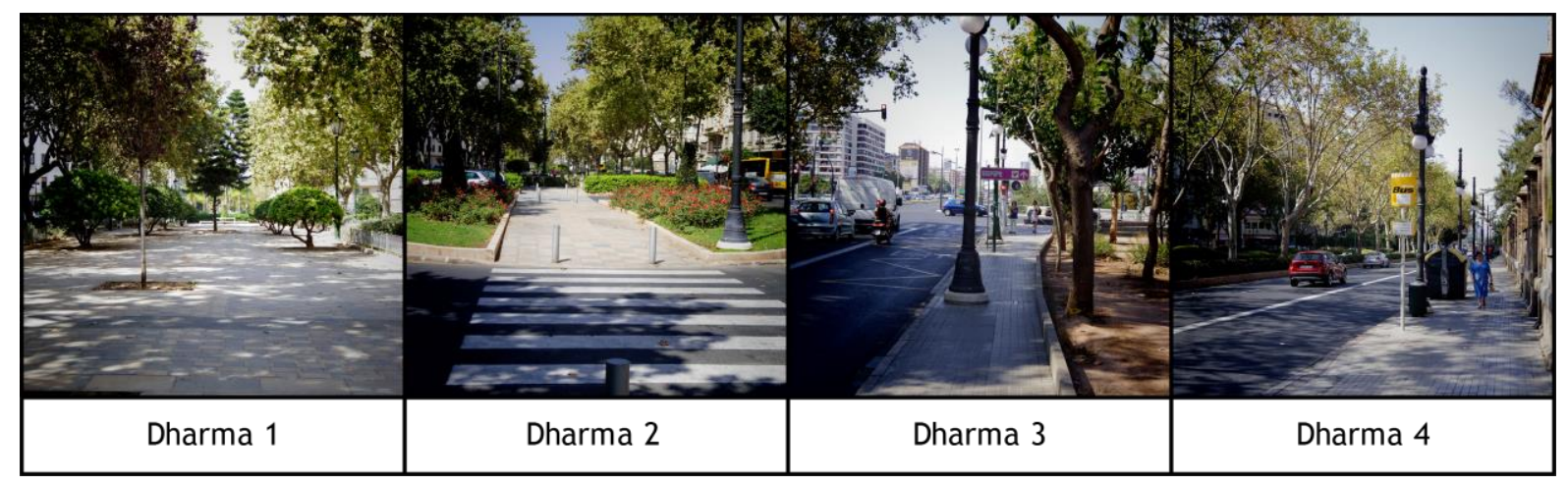

AD Diagnosis

AD1: De igual manera que la Gran Vía Marqués del Turia o de la Avenida Reino de Valencia, tiene una pobre relación. Físicamente está desconectada. En esta gran vía nada es rizomático.

AD2: La capacidad de incorporar deseos sanos en los ciudadanos cada día disminuye.

AD3: Esta calle en la que nada es rizomático influye en sus alrededores, en las calles periféricas, para que pierdan vitalidad. Se observan bastantes locales vacíos que esperan nuevos inquilinos. Es una zona totalmente devastada.

AD4: La Avenida del Cid tiene una importancia estratégica en la medida en que está relacionada por medio de la Calle Ángel Guimerá con la Calle de Guillem de Castro cuyo significado geográfico es primordial en el centro histórico, y también se relaciona con la Avenida de Pérez Galdós que está ubicada paralelamente a la Calle de Guillem de Castro y se cruza con la Calle Ángel Guimerá. De este modo la Avenida de Pérez Galdos puede incorporar las pequeñas calles periféricas en un proceso de regeneración urbana. De momento, es un mero dharma que produce un dolor. 


\section{CSD Mórbido-24}

Ubicación: Avenida del Cid

Dharmas Fenomenológicos

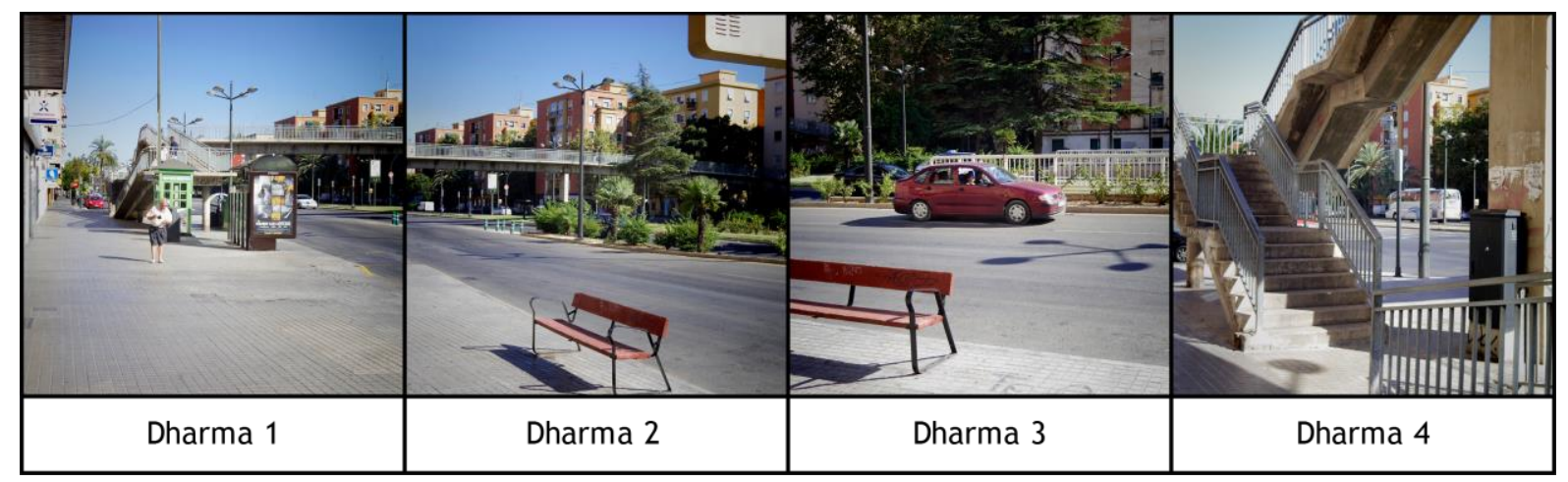

AD Diagnosis

AD1: Una avenida como una autopista.

AD2: La gente apenas sube y baja por el viaducto.

AD3: La ciudad está cortada. Un bosque de hormigón y asfalto, y una avenida no atractiva.

AD4: En este barrio, hay una cierta tendencia que es la afluencia de gente de una particular raza y clase de la sociedad. Los precios de las inmobiliarias también constituyen un motivo que no puede ser ignorado. La ciudad así, fragmenta la gente. 


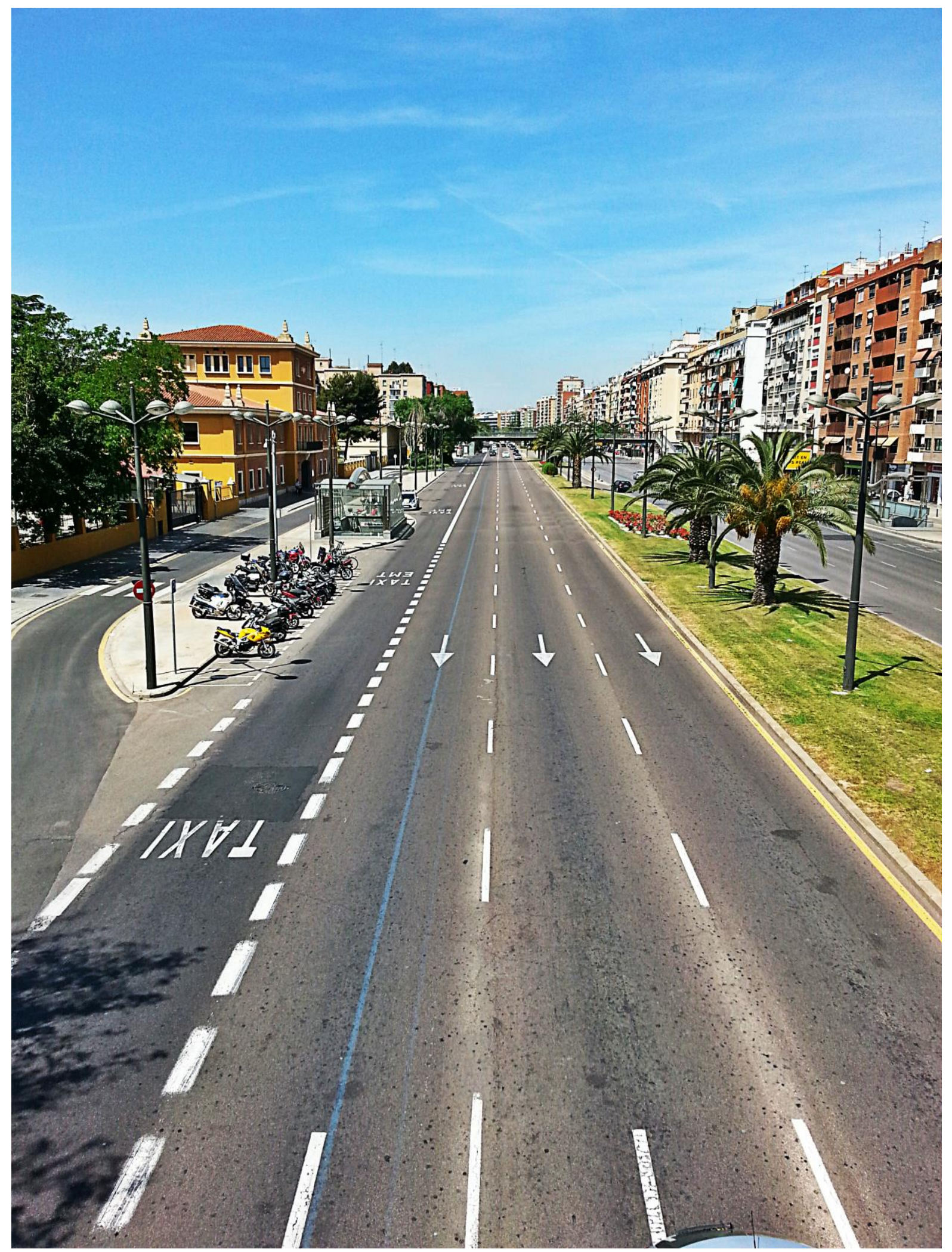

Fig. 11-17. Una imagen abrumadora de la Avenida del Cid que funciona como un AD dharma. 


\section{CSD Mórbido-25}

Ubicación: Jardín Botánico

Dharmas Fenomenológicos

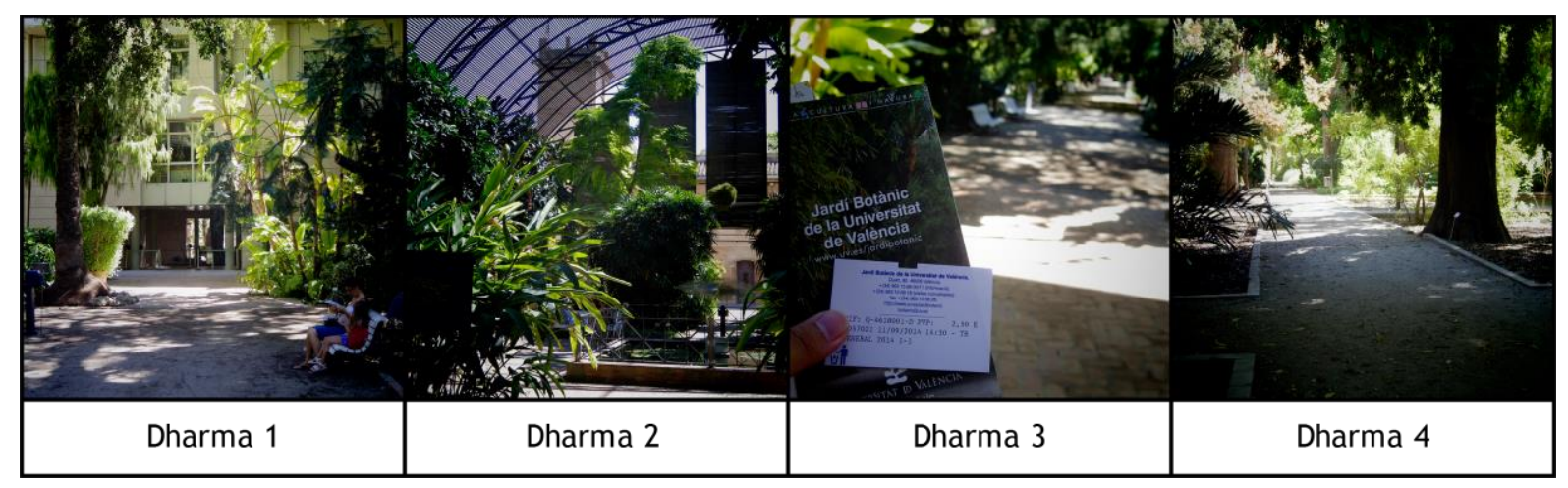

AD Diagnosis

AD1: La superficie del jardín es de casi $25.000 \mathrm{~m}^{2}$. Es un tamaño considerable. Pero posee una pobre accesibilidad ya que la parte que enfrenta al Paseo de la Pechina y el Jardín del Turia, está cerrada. Sería fantástico si tuviera un doble acceso, uno el vigente que está en la Calle Quart, y el otro, si es posible, en el Paseo de la Pechina para que se conecte con el Jardín del Turia y obtener así una fluencia amable.

AD2: El precio de la entrada es de 2,5 euros para un adulto. Es un jardín del barrio que tiene un tamaño colosal porque contiene numerosas especies de plantas. Claramente, vienen muchos más turistas que gente del barrio. El jardín ha de ser amado por los turistas, pero ha de ser más amado por la población valenciana. Algún método alternativo al plan de tarifa es necesario.

AD3: Como tiene poca accesibilidad al considerar su enorme superficie en el mapa, no se puede generar ningún efecto sinérgico con el Jardín del Turia. El interés inmanente de este jardín ha de mostrarse a los valencianos. Dos jardines están pegados en la imagen del satélite, pero son lejanos uno del otro y se tiene que dar una gran vuelta para desplazarse del uno al otro. 
AD4: Cada fin de mes, aquí se realizan conciertos de jazz. Este jardín está preparado para ser más amado por los ciudadanos al estar en proximidad también con el IVAM (Instituto Valenciano de Arte Moderno) y las Torres de Quart. 


\section{CSD Mórbido-26}

Ubicación: Parc de l'Antic Hospital - MuVIM (Museo Valenciano de la llustración y la Modernidad)

Dharmas Fenomenológicos

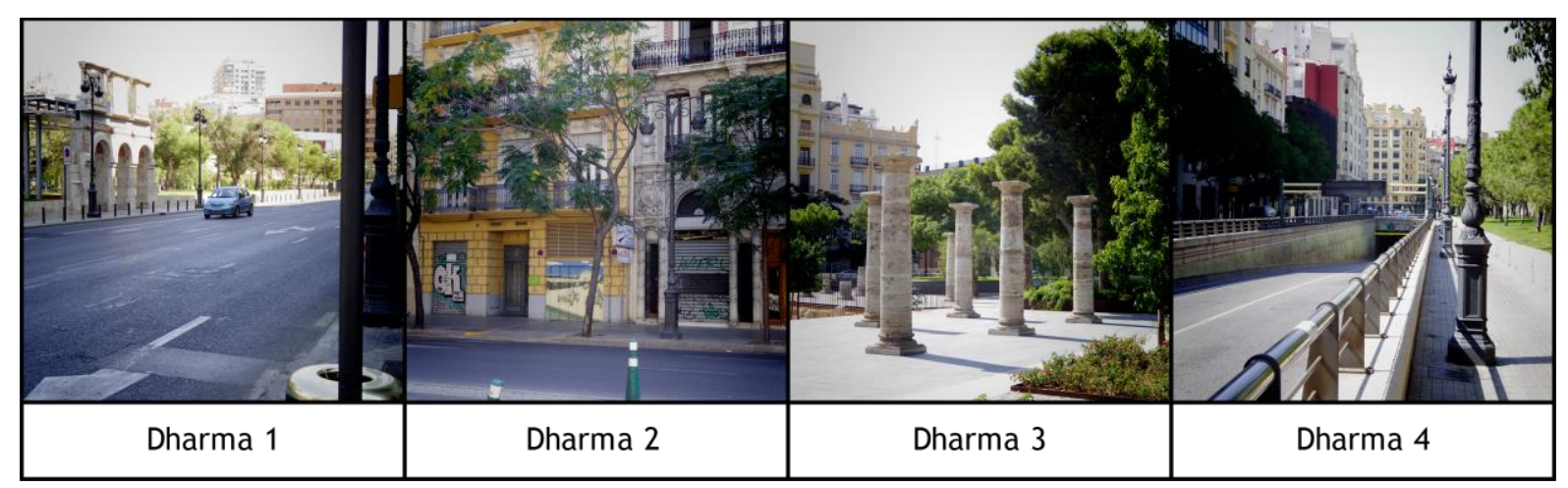

AD Diagnosis

AD1: Es un parque bonito con las ruinas arqueológicas. Aquí se reconoce nuevamente que la historia de Valencia no es corta. El túnel que pasa justo al lado del parque es un obstáculo para la gente que viene desde la calle de enfrente. Los coches suben la velocidad en este punto ya que el túnel es sólo para coches.

AD2: Al final, el parque funciona para la minoría de gente que viene desde el norte de éste. La Calle Hospital está llena de la vitalidad de los peatones y siempre ocupan las terrazas de las cafeterías. Desarrolla un efecto sinérgico con el parque. En esta calle los coches pasan selectivamente a una velocidad muy amable. El ámbito define la actitud de los coches. En esta calle, los coches desarrollan el mínimo nivel de velocidad de la ciudad en cualquier día y hora. ${ }^{23}$

AD3: Al considerar la velocidad de los coches que pasan por la Calle de Guillem de Castro, la estrecha acera para los peatones se destaca. La acera está protegida físicamente por un pobre método arquitectónico, sin embargo, no es fácil de borrar la sensación abrumadora de los coches con su velocidad y su ruido.

\footnotetext{
${ }^{23}$ Map data $@ 2015$ Google, basado en BCN IGN España. Fuente online: <maps.google.com>
} 
AD4: En esta calle la gente pasa, no se queda. La calle ya no es atractiva. Es difícil de imaginar la muralla medieval de la antigua Valencia. Eso es porque primero la memoria está olvidada en este espacio y segundo, porque no se intenta recordarla. 


\section{CSD Mórbido-27}

Ubicación: Calle de Guillem de Castro

Dharmas Fenomenológicos

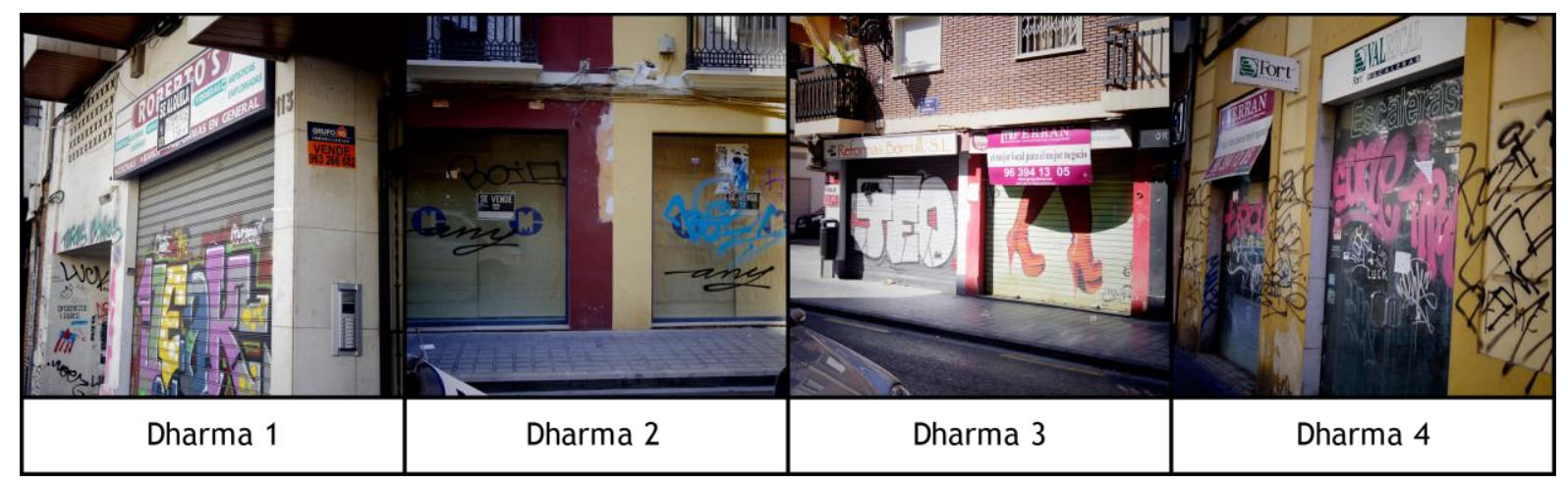

AD Diagnosis

AD1: Básicamente, los humanos son peatones; no hay que olvidarlo. El estado del pavimento de la calle es decepcionante, igual que la pobre condición del transporte público. Así la gente no quiere utilizar el transporte público sino tener un coche propio. Es un guion predecible.

AD2: El problema de CSD Mórbido-04,05, se revela aparentemente aquí también.

AD3: Si la calle pierde su vitalidad, su efecto posterior influencia en las pequeñas calles de los alrededores. Es necesario un método alternativo para resolver la presente situación hundida.

AD4: Las Torres de Quart están ubicadas en una posición crucial en la perspectiva geográfica. La Calle de Guillem de Castro, IVAM y el Jardín del Turia también tienen relación con Las Torres de Quart. Y la ruta por la Calle Quart llega hasta el barrio del Carmen cuya importancia es absoluta con la Plaza de la Virgen. Pero este barrio está estancado. Hay pocos caminantes; y hay numerosos locales vacíos. Las siguientes imágenes son de Melbourne donde se realizó un experimento interesante convirtiendo los callejones aislados en espacios más agradables. 

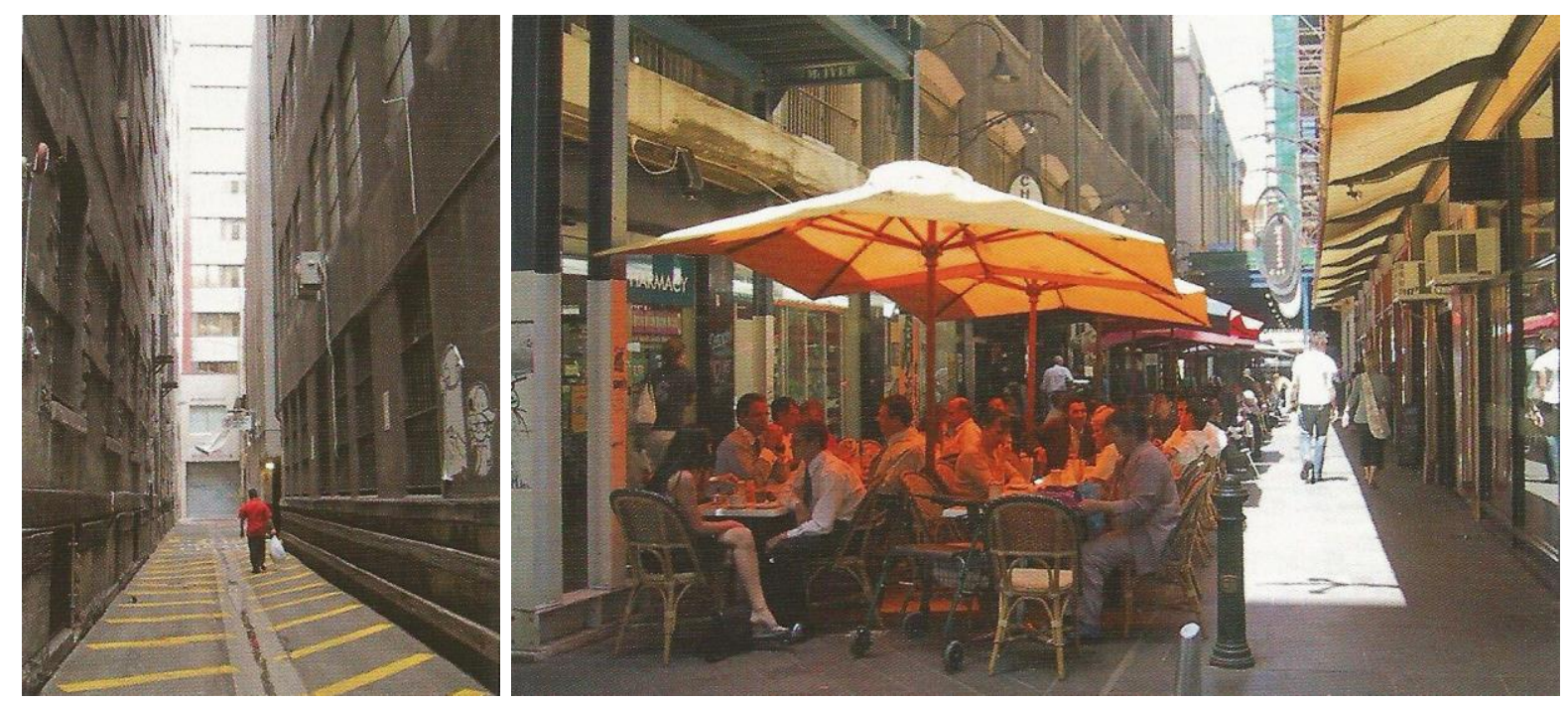

Fig. 11-18. Izquierda. Un callejón de Melbourne, antes de la conversión.

Fig. 11-19. Derecha. Un callejón oscuro de Melbourne donde solía ocurrirse crímenes ligeros.

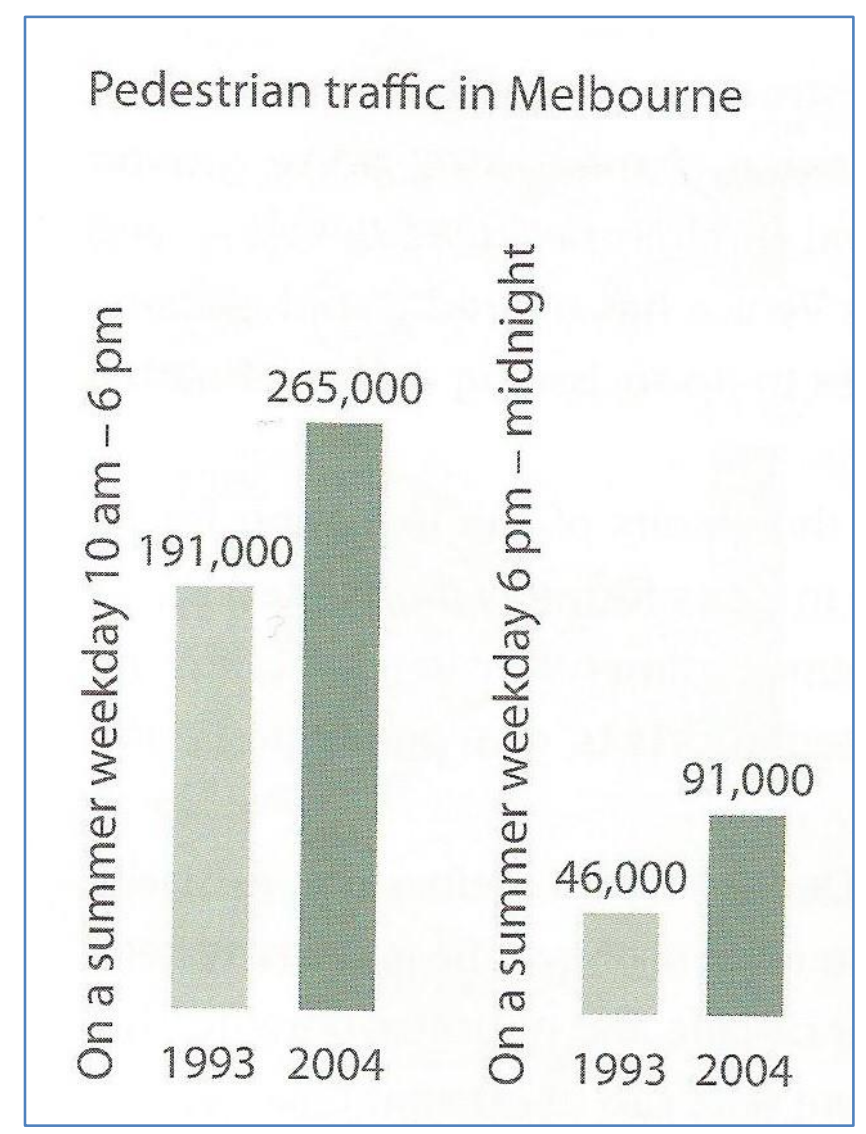

Tab. 11-6. Tráfico peatonal en Melbourne. 


\section{CSD Mórbido-28}

Ubicación: Paseo de la Pechina

Dharmas Fenomenológicos

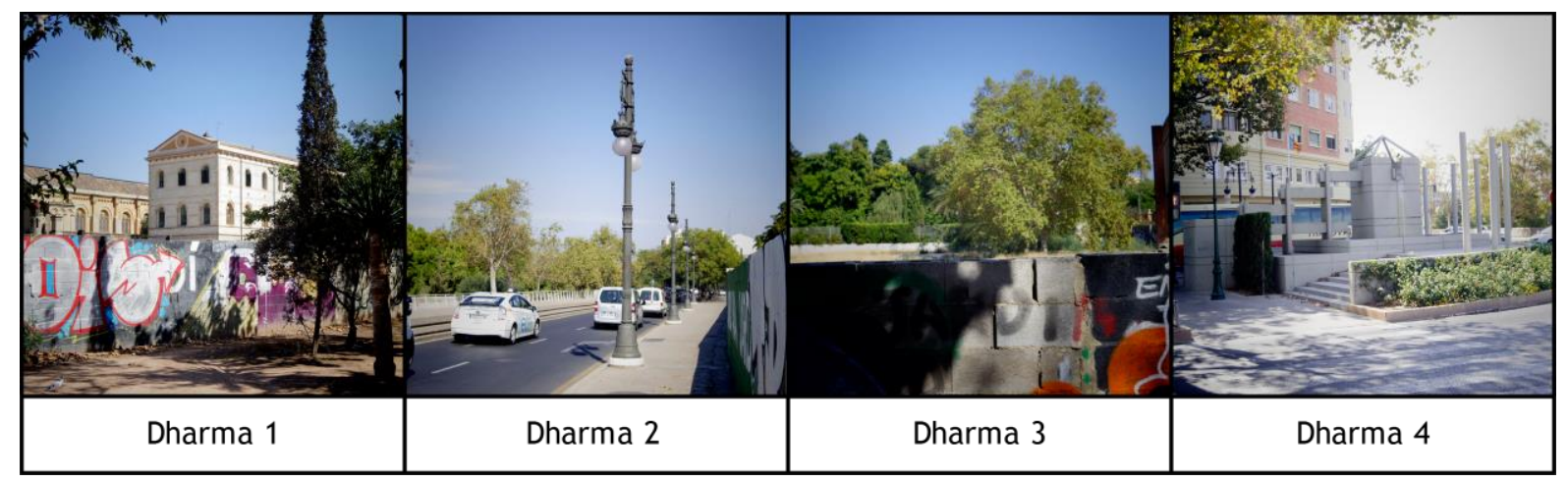

AD Diagnosis

AD1: La acera comienza con $265 \mathrm{~cm}$ de anchura. Considerando que los coches pasan a una gran velocidad y el alto muro, los peatones tienen una sensación horrible.

AD2: Si en la calle se siente ansiedad o alguna preocupación por la seguridad, la calle claramente no es atractiva.

AD3: Es una fragmentación. La vida peatonal está fragmentada y la ciudad está fragmentada. Igual que en la Gran Vía Marqués del Turia, existe una pobre vinculación entre La Gran Vía Fernando el Católico, el Paseo de la Pechina y el Jardín del Turia. El Paseo de la Pechina tiene un potencial para poder incorporar una ruta encantadora hacia el Nuevo Centro de Valencia, la Gran Vía de Fernando el Católico e incluso el centro histórico.

AD4: Actualmente, en general la ronda que bordea el Jardín del Turia está en la misma situación que el Paseo de la Pechina o peor. 


\section{CSD Mórbido-29}

Ubicación: Plaza Mercado (Mercado Central de Valencia - La Lonja de la Seda)

Dharmas Fenomenológicos

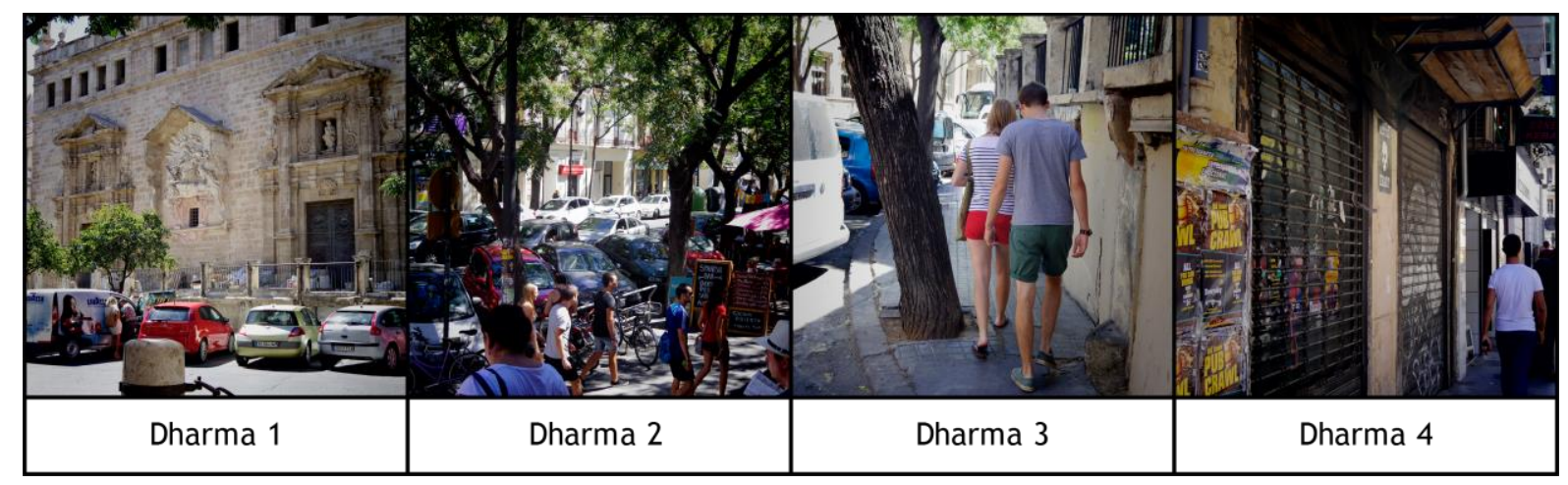

AD Diagnosis

AD1: Demasiados coches aparcados en la plaza, hace que el nombre de la plaza sea insignificante.

*Actualización de las situaciones.

Actualmente en la zona está restringido el acceso de los coches parcialmente, desde la zona del Mercado Central hasta la Lonja. Sin embargo, los coches aparcados, los autobuses turísticos y la pobre condición de las aceras aún resultan problemáticos.

05/01/2017.

AD2: Desde el principio es dudoso, por qué fue tan necesario este espacio enorme para el aparcamiento. La vista desde la terraza de la cafetería es horrible.

AD3: Es un barrio que se utiliza como un centro de distribución de las rutas turísticas por que se conecta directamente con el barrio del Carmen y la Plaza del Ayuntamiento. Sin embargo, el estado de la acera (el estado del pavimento, la anchura inadecuada, los obstáculos innecesarios y etcétera) es un nivel inaguantable. Desde aquí la gente se conecta con la Calle Quart, la Plaza del Tosal y en serie hasta la Plaza de la Virgen que es el corazón del centro histórico de Valencia. 
AD4: Si se aleja una calle hacia el noroeste desde la Plaza del Mercado, se ven los barrios bajos. La Plaza del Mercado está viva, porque tiene el Mercado Central de Valencia y La Lonja de la Seda. Estos elementos monumentales han de sacar sus máximos potenciales, para revivificar esta zona de nuevo. En los locales del barrio bajo, cada día surge un nuevo negocio y desaparece sin sonido. El flujo está cortado aquí. No es rizomático.
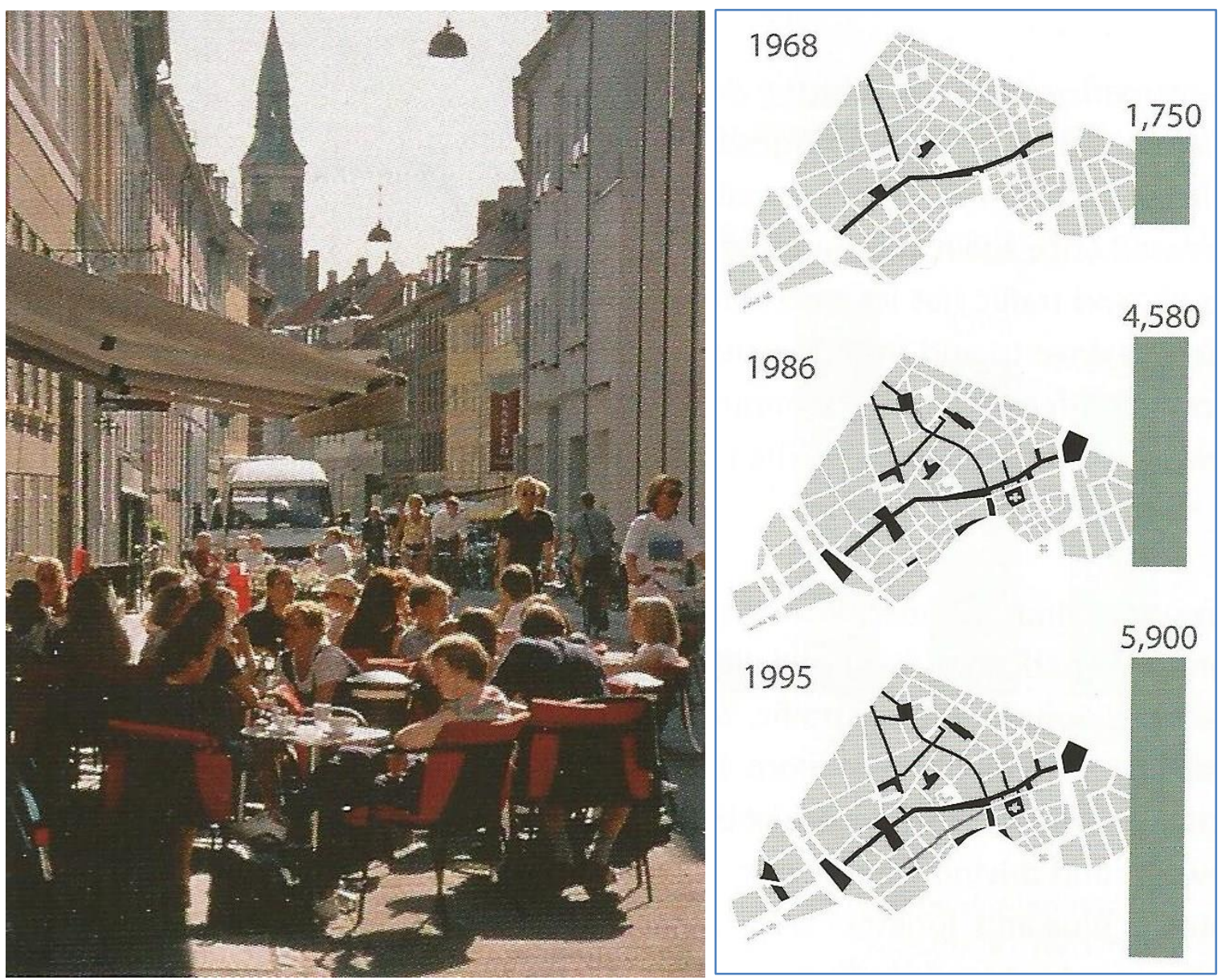

Fig. 11-20. Izquierda. Las actividades estacionarias y días de verano, desde el mediodía hasta las 4pm de Copenhagen

Tab. 11-7. Derecha. Aumento de la media de las actividades estacionarias y días de verano, desde el mediodía hasta las $4 \mathrm{pm}$ de Copenhagen 


\section{CSD Nirvánico}

: CSD¹ Nirvánico, se refiere a una conjugación de los dharmas que resuelven la agonía desarticulando la constelación de los $\mathbf{A D ^ { 2 }}$ dharmas. Así que naturalmente, CSD aquí tiene que tener la virtud del nirvana por medio de incorporar los dharmas de ED³-procesos. Son contrapuestas a CSD Mórbido del capítulo previo. El desarrollo de CSD Nirvánico en este estudio sigue los criterios de los capítulos 8, 9 y 10.

En este capítulo, los criterios de los capítulos 8, 9 y 10 se categorizan simplemente en 4 ramas según el carácter de los proyectos para facilitar la comprensión de las tendencias peculiares de cada CSD Nirvánico intuitivamente.

La primera cuestión que define el carácter del proyecto sería: ¿Este dharma o espacio hace posible experimentar la experiencia del nirvana en el sujeto, o sea Espacio Nirvánico? En segundo lugar: ¿Este dharma está enseñando la virtud de $\mathbf{N Y}^{4}$ como Espacio NY? La tercera cuestión se diría como: ¿Este dharma o CSD es del rizoma? Y finalmente, ¿El esquema de CSD tiene sostenibilidad? Así sencillamente podrían categorizarse.

Existe una sostenibilidad según se entiende normalmente que podíamos definir sostenibilidad biológica, es decir, sostenibilidad del medio ambiente. Pero también existe una sostenibilidad de tipo antropológico que implica el adecuado equilibrio y armonía del ser humano con su circunstancia.

Esta sostenibilidad antropológica implica los siguientes campos de argumento. El primer campo crucial de sostenibilidad sería <<la memoria $>>{ }^{5}$ La memoria se refiere a la identidad asumida en la comprensión y consideración del pasado. El segundo campo sería la <<la adecuación ambiental >>, que persigue una armonía con el entorno de tipo corpóreo-anímica. En la adecuación ambiental es muy importante la presencia de la naturaleza como elemento ancestral armonizador del ser humano. ${ }^{6}$

\footnotetext{
${ }^{1}$ Co-surgimiento dependiente-(NdA)

${ }^{2}$ Acumulación del Dolor-(NdA)

${ }^{3}$ Extinción del Dolor-(NdA)

${ }^{4}$ No-yo-(NdA)

${ }^{5}$ Javier Poyatos. Apuntes de clase. Master en Arquitectura Avanzada. Universidad Politécnica de Valencia.

${ }^{6}$ lbid.
} 
En algún sentido, el Espacio Nirvánico es un sinónimo de la adecuación ambiental. Pero, como el Espacio Nirvánico tiene un sentido más amplio que <<la adecuación ambiental >>, aquí surge una convergencia lógica entre <<la adecuación ambiental y el Espacio Nirvánico>>. Y el último campo crucial sobre la sostenibilidad antropológica es el $<<$ proyecto presente-futuro $>>$ que es el sentido vital que confiere al ser humano individual y colectivo la posesión de un proyecto abierto configurador del presente y del futuro. ${ }^{7}$ Este concepto se utiliza para poder percibir adecuadamente la sostenibilidad social, que es el equilibrio e incluso armonía entre los diversos grupos sociales, culturales, étnicos, etc. Este capítulo es para responder a las dudas surgidas de CSD Mórbido, según 4 categorías que son el Espacio Nirvánico, el Espacio NY, el Rizoma (o CSD) y la sostenibilidad antropológica. Además la sostenibilidad antropológica se refiere a: la memoria, la adecuación ambiental y el proyecto presentefuturo.

${ }^{7}$ Ibid. 


\section{CSD Nirvánico-01}

Tipo: Espacio Nirvánico (o la adecuación ambiental)

Referencia con CSD Mórbido: 01, 02, 03, 05, 09, 10, 12, 14, 15, 16, 19, 22, 27, 28.

\section{ED Propuesta}

Las referencias propuestas anteriormente presentan algo común entre ellas, y es que son lugares no atractivos. El significado de un lugar no atractivo podría interpretarse de varias maneras, pero, en esta situación se refiere a un lugar en el que la gente ya no quiere permanecer, la guerra de los coches versus los débiles cuerpos humanos, el sistema semafórico que soporta dicha guerra o cualquier lugar en el que no se produce la comprensión del comportamiento humano. Y para poder tratar todos los dolores que se producen debido a la enorme constelación de CSD Mórbido, han de proponerse los discursos directos que pueden tratar directamente los AD dharmas. La desarticulación de CSD Mórbido es el sinónimo de CSD Nirvánico.

ED1:

En las ciudades desarrolladas, los impuestos sobre la renta y las contribuciones a la seguridad social tienden a ser altos, mientras que, en el suelo o en el uso del espacio, energía y otros recursos, se ponen muy pocos impuestos. La gasolina es barata, y esto deja los costos económicos de la congestión del tráfico sin resolver. Tales estructuras fiscales son claramente perversas. No tienen sentido, tanto económica como socialmente, para incrementar los costos del trabajo a través de una carga adicional en un mundo desempleado. Ecológicamente, de igual manera tampoco tiene sentido para promover la ilusión de que la energía y otros recursos no-renovables son abundantes y pueden ser utilizado de forma barata. ${ }^{8}$

Desde la perspectiva del Espacio Nirvánico, la primera agonía que se puede pensar, entre los AD precursores, sería la confrontación de los coches versus los hombres. Las calles de una forma

\footnotetext{
${ }^{8}$ Hall, P., Pfeiffer, U. Urban future 21: A Global Agenda for Twenty-first Century Cities. London, New York. E \& FN Spon. 2000. p.67.
} 
inhumana hacen que el hombre experimente un contacto corporal y anímico con el ambiente de una manera violenta. La escasez de una comprensión adecuada sobre el behaviorismo del hombre implica errores en el proceso de regulación del tránsito vial. Parece que los intereses de la industria del automóvil tienen más proximidad con los responsables públicos que los intereses de los peatones.

ED2:

Sentirse protegido es crucial si esperamos que la gente acepte el espacio de la ciudad. En general, la vida y la gente misma hacen la ciudad más atractiva y segura en los términos de la seguridad experimentada y percibida.

Las condiciones para los peatones y los ciclistas se han deteriorado como resultado. Las aceras estrechas se han llenado poco a poco de señales de tráfico, parquímetros, bolardos, farolas y otros obstáculos colocados allí, así como "es el camino del tráfico motorizado más importante". Añadido a los obstáculos físicos, están las frecuentes interrupciones en el ritmo de caminar causados por las largas esperas en los semáforos, calles difíciles de cruzar, túneles subterráneos sombríos y puentes peatonales elevados. Todos estos ejemplos de organización de la ciudad tienen el propósito de proporcionar más espacio y mejores condiciones para los coches. Como consecuencia, caminar se ha vuelto más difícil y mucho menos atractivo. ${ }^{9}$

Jan Gehl. 2010. The Safe City.

La ciudad se invadió por los coches hace tiempo. Sin embargo, hay que fomentar la acera y el carril bici, vivificando así la ciudad mediante el hombre peatonal y los ciclistas, lo que no tiene nada que ver con inducir a los vehículos a que conduzcan más rápido o en mayor cantidad. A los peatones, también como a los coches, se les tienen que garantizar el derecho de movimiento sin arriesgar la vida. $Y$ esto es posible refrescando la consciencia pública, y replanteando el proceso de regulación del tráfico. Cuando el camino para los peatones se estrenó por primera vez en la Europa de los años 1960, la

\footnotetext{
${ }^{9}$ Gehl, J. Cities for People. Washington DC. Island Press. 2010. p.91.
} 
mayoría de la ciudad aún estaba acostumbrada a considerar y asegurar la movilidad de los peatones por medios coactivos, aunque fuera en un nivel mínimo. En aquel tiempo, sólo existían dos tipos de carriles: uno para el tráfico de vehículos y el otro para los caminantes. ${ }^{10}$

Si hubiera alguna situación insatisfactoria por alguna congestión de tráfico, directamente no se debe deducir que haya que poner más carriles para los automóviles. A causa de la complejidad del tema, a la hora de solucionarlo se tendría que abordar multilateralmente. Sin embargo, ahora, existen más opciones gracias al avance de la tecnología y una consciencia más abierta. Además, en la ciudad hay necesidades de circulación de los coches, e igualmente de los peatones. Ahora se pueden imaginar varios tipos de calles para la genuina democracia del tráfico. Actualmente cuando los urbanistas piensan en un plan de tráfico, pueden elegir las soluciones en un ancho rango de opciones, mayor que antes, por ejemplo: calle sólo para el tráfico de vehículos, bulevar, $30 \mathrm{~km} / \mathrm{h}$ de tráfico, prioridad peatonal, $15 \mathrm{~km} / \mathrm{h}$ de tráfico, peatones-coches calle, peatones y bicis calle, o una calle sólo para los peatones. ${ }^{11}$ Curiosamente, los recientes estudios e investigaciones urbanísticas, informan que cuando se mezclan los distintos tipos de tráfico físico en la misma calle, esta manera de compartir el espacio puede bajar el riesgo de accidente..$^{12,13}$

ED3: Cuando la calle es segura para los peatones, los ciudadanos pueden caminar por la ciudad. ¿Qué es caminar? Si el verbo caminar fuera un mero movimiento lineal desde un punto hasta otro punto en la coordenada cartesiana, aquí ya no hay nada que discutir. Pero, el acto de caminar tiene más significado que un movimiento. El humano cuando camina, anda, para, danza, se sienta, se tumba, con un ritmo de andante, moderado y fuerte. El hombre camina sintiendo el cambio del clima y de la temporada, los olores complejos, y los ruidos insignificantes del día. Mientras tanto, tal vez él o ella podrían reconocer el carácter efímero de los dharmas en los cambios de las cosas por el transcurso del tiempo, y otra vez, tal vez, podrían reconocer la providencia del cosmos. El hombre aprecia su experiencia con el cuerpo en la ciudad y crea un vínculo con ella; esta sensación se acumula en la memoria y en la calle. Un agradable encuentro con los elementos naturales y monumentales. $\mathrm{O}$ un

\footnotetext{
${ }^{10}$ lbid. p .93

11 lbid.

12 Ibid.

${ }^{13}$ Sin embargo, la disminución del riesgo de accidente en la calle es posible sólo cuando los peatones tienen la prioridad, por ejemplo, en una calle de uso mixto con peatones, coches, bicis o monopatín, donde naturalmente los peatones ganan la prioridad. Si no, otra vez, es una guerra aburrida entre los coches y los peatones. -(NdA)
} 
encuentro inesperado con los vecinos en el mercado o con un turista perdido en la plaza. Si hace buen sol, la gente simplemente se tumba en la plaza, y observa la ciudad. $Y$ hablan con otras personas con una mente más abierta en el espacio público, a pesar de ser ajenos o desconocidos. Improvisadamente, se pueden incorporar a una manifestación de la calle por su particular posición política. Ahora, caminar es una acción social y política.

La Calle Colón es una calle perdida para los peatones valencianos, porque a la ciudad le importa la eficiencia de los coches y sus velocidades adecuadas al aumento de la cantidad, pero comparando con eso, carecen de mucha información sobre los peatones. La Avenida Aragón es una autopista. Es una calle fuera de la escala humana. Las líneas bárbaras hacen la calle más aburrida y dolorosa. ${ }^{14} \mathrm{En}$ las referencias CSD Mórbido que se comentaron en el capítulo anterior ya no se podía encontrar ningún elemento divertido. Los espacios aburridos no son una virtud que la ciudad tenga que perseguir. Un pavimento amable invita a toda condición de gente: niños, tacones, silla de ruedas, gente mayor, mamá con un cochecito etc. Los bancos invitan a los peatones a que se sienten y aporten su historia personal a la calle. Un pequeño espacio para el agua es un recurso imprescindible para los niños. Porque no existen personas a las que no les encante el espacio acuático. Los varios, pero armónicos diseños de la fachada en los edificios, añaden hermosura al paseo diario. Estos elementos generan una sensación más intensa en el peatón, y la calidad de la experiencia espacial se enriquece.

ED4: En el año 2007, en Times Square de Nueva York, el 90\% de los usuarios eran peatones y sólo el $10 \%$ eran coches, sin embargo, la distribución del espacio estaba al revés. El $90 \%$ del espacio estaba destinado para tan sólo el 10\% de conductores, nada era democrático ni nirvánico. La ciudad de Nueva York necesitaba cambiar esta sencilla matemática más lógicamente. ${ }^{15}$ Los ciudadanos tenían vergüenza de que Broadway fuera dominado por los coches, no por el hombre. Ni siquiera hay espacio para sentarse en Broadway. ${ }^{16}$ Simplemente, la ciudad de Nueva York, redistribuyó el espacio para la

\footnotetext{
${ }^{14}$ Para saber más sobre este tipo de informaciones, v.-<Gehl, J. Cities for People. Washington DC. Island Press. 2010. pp. 129133.>

${ }^{15}$ Comentario de Janette Sadik-Khan. Commissioner, NYC Dept. of. Transportation (DOT) desde el siguiente reportaje de: <Dalsgaard, A. The Human Scale. The 10th EBS International Documentary Festival: Docs on City \& Architecture. Oct, 2013> ${ }^{16}$ Comentario de Jeff Risom de Gehl Architects desde el reportaje: <Dalsgaard, A. The Human Scale. The 10th EBS International Documentary Festival: Docs on City \& Architecture. Oct, 2013>
} 
gente, los coches y bicicletas. La acera fue reformada, se construyó una enorme red de carril bici. En pequeños espacios de las calles colocaron los bancos para los ciudadanos. Al final, las lesiones de los peatones por los accidentes de coche disminuyeron un $63 \%$. Al $74 \%$ de los ciudadanos les encantaba este tipo de renovación de la ciudad, incluso a los taxistas y los conductores. ${ }^{17}$ Disfrutar el tiempo en la calle es una bendición que se puede recibir sin pagar pero que necesita el espacio adecuado.

Una ciudad hermosa da una bella experiencia al hombre. La ciudad de Valencia está llena de patrimonios arquitectónicos en el casco urbano. Y en la zona de la Ciudad de las Artes y las Ciencias se muestra otro aspecto contemporáneo de Valencia. Como un collage armónico los elementos del Románico, Gótico, Renacimiento, Barroco y hasta de un estilo vanguardista están mezclados en una misma ciudad. Como es una obra amalgama del tiempo, se implica el Zeitgeist de cada época y eso insinúa naturalmente una temporalidad del espíritu del estilo, que fue el presente para la gente de aquel tiempo. La palabra inglesa $<<$ present $>>$ tiene dos significados principales. Uno es el presente y el otro es el regalo. Si se han cometido algunos errores, arreglar dichos errores es también el espíritu de la era. Los valencianos del presente tienen su regalo para vivir. Y eso se completa en otra nueva Valencia. Enfrente de La Catedral de Valencia, el Mercado Central, el Ayuntamiento etc., no están reservando suficientes espacios para los peatones. En la Plaza de la Reina, más de un $61 \%$ de la superficie de la plaza es para la circulación de los coches y los aparcamientos, y solo el 13\% es para el uso de la acera, pero la situación es que este $13 \%$ se ha de compartir con las terrazas de los bares. La vista en la terraza de algunos bares es bastante patética, porque no se ve la catedral sino sólo los coches aparcados y autobuses. Hay que recalcular el espacio público actual de una manera democrática para conseguir el genuino espacio público.

\footnotetext{
${ }^{17}$ Dalsgaard, A. The Human Scale. The 10th EBS International Documentary Festival: Docs on City \& Architecture. Oct, 2013.
} 


\section{CSD Nirvánico-02}

Tipo: Espacio NY

Referencia con CSD Mórbido: 07, 12, 15,21, 23, 24, 25, 29

\section{ED Propuesta}

Uno debe aplicarse a sí mismo diligentemente los entrenamientos adecuados para las diversas situaciones en las que uno mismo se encuentra. ${ }^{18}$

Sāntideva. The Guarding of Awareness.

ED1: El espacio NY se basa en esta sencilla verdad, y todas las doctrinas del buddhismo se refieren de manera idéntica, dicen todos los dharmas son efímeros o tendrían que serlo. Por eso, cuando algún dharma se fija en una particular posición y persiste en su ego dicho dharma empieza a formar un proceso de $\mathbf{A} \mathbf{D}^{19}$. Tal vez, si se describe a través de vocabularios contemporáneos, se diría que físicamente este argumento trata sobre el grado de libertad de los programas (eventos) en un espacio. En este sentido, la plaza es un lugar crucial. Este espacio se convierte en una parte de la vida urbana, un lugar de las reuniones cotidianas y lo más importante, en un lugar político, así que este lugar hace que los ciudadanos sean genuinos soberanos de la ciudad. Históricamente, cuando era necesario, el espacio de la plaza se convierte en otro lugar no de descanso, sino de lucha, para guerrear y resistir a una autoridad distorsionada. Así la plaza es un lugar atractivo debido a su alta libertad en la programación. La gente espera a su amigo en la plaza, toca un instrumento musical, se tumba en el suelo, se queda sin ninguna razón en particular y miran a los otros pacíficamente. Este lugar está invitando al hombre a que venga, participe y comparta el tiempo en el mismo espacio con los otros. ¿Entonces, el espacio NY, solamente se refiere a un espacio vacío, literalmente? La respuesta es que no puede ser sólo así. Construir un espacio NY, no significa solamente proveer un espacio literalmente vacío en el que se pueda hacer u ocurrir cualquier evento. Un espacio vacío no directamente corresponde a un espacio que tenga un alto nivel de libertad de programas. El espacio NY no es un simple nihilismo. Si el planeta explotara, o incluso el sistema solar entero, se exterminarían todos los

\footnotetext{
${ }^{18}$ Śāntideva. The Bodhisattvacaryāvatāra. Crosby, K. \& Skilton, A. (tr.). Oxford. Oxford University Press. 2008. p. 43.

${ }^{19}$ Acumulación del Dolor-(NdA)
} 
dolores AD- proceso. Este estudio no está buscando este tipo de libertad vacía, sino una libertad que esté llena de deleite como una celebración.

ED2: Como se ve en ED1, el espacio NY, básicamente, es un discurso ontológico. Su ontología es innegable, pero su existencia no se ve, sino que se revela por los eventos enriquecidos por medio de que el espacio no persiste en su ātman fijo. El espacio NY, o en otra palabra buddhista más ortodoxa, anātman abre un campo colosal de posibilidades de intervención y coexistencia los otros dharmas. Una perspectiva estratégica puede generar una situación humanista fácilmente. El espacio vacío no es un abandono sin plan, sino que es un vacío sofisticado que elimina los obstáculos innecesarios. A las personas les encanta las plazas de Italia, porque allí las plazas no están dominadas por los coches sino por la gente. Y allí no presentan ninguna construcción compleja para dar encanto a la gente; solo tienen buen sol, buen pavimento y el encanto del lugar. Aunque no hay nada allí, la gente encuentra razones para quedarse en una piedra de un tamaño adecuado para apoyar su espalda, un pequeño espacio para tumbarse, una buena sombra de árboles para el verano, un espacio de agua para los niños, los bancos siempre son populares. La gente quiere conversar con los demás. La plaza es un espacio de comunicación.

ED3: Aumentando los espacios para aparcamiento y circulación de coches, la plaza cada vez más se convierte en una isla rodeada no por mar, sino por los coches. Los ciudadanos perciben el concepto de la plaza como un mito. La Plaza del Ayuntamiento y La Plaza del Mercado de Valencia son ejemplos innegables. En estas plazas es necesario romper sus imágenes tan congeladas como un aparcamiento. Los obstáculos desordenados han de desaparecer. En un caso extremo, también existe un método llamado uso mixto. Cambiando el pavimento del espacio, los conductores ya no podrán proclamar su uso prioritario. Con el tiempo, la consciencia colectiva de los ciudadanos, ya sean peatones o conductores, reconocerán que el modo antiguo de usar la plaza era una barbaridad. Otras ciudades (por ejemplo: Nueva York, Melbourne, Paris, Oslo, Vancouver, Copenhagen, Strasbourg y etcétera) ya lo han experimentado y tienen brillantes ejemplos. Cuando se expande el espacio para un uso mixto de peatones, bicicletas y coches, la ciudad se transforma en más amable y cariñosa. 
ED4: El espacio no físico también tendría que considerarse como las plazas físicas. Las numerosas comunidades de Internet al final pueden producir encuentros físicos en un mundo real. Sin embargo, no hace mucho tiempo que los arquitectos y urbanistas descubrieron el buen uso de Internet o el smartphone, y de muchas aplicaciones que surgen cada día. 


\section{CSD Nirvánico-03}

Tipo: Rizoma (o CSD)

Referencia con CSD Mórbido: 06, 07, 08, 11, 13, 14, 18, 19, 20, 23, 25, 26, 27, 29

\section{ED Propuesta}

5. El flujo del espacio, su forma y su acceso, tienen que ser rizomático, para poder distribuir el flujo de energía incesantemente, generar y disfrutar más experiencias del entorno y asegurar la libertad de movimientos de los sujetos en un espacio agradable y abierto.

6. La forma del rizoma es la forma de red per se.

7. La transformación dinámica de las formas y el programa de la red rizomática, debido a los datos introducidos de los dharmas con el tiempo, es en sí mismo una virtud, coincidiendo con el principio de $\mathbf{N Y}$.

8. La filosofía que disciplina los deseos del hombre y limita el espacio como si fuese un dharma inmutable, no es la virtud del nirvana, los diseños con este tipo de filosofía transforman la ciudad en una máquina enorme de $\boldsymbol{A D}$. Como $\mathbf{N Y}$ es la virtud para todos los dharmas, los espacios que el hombre produce también toman el concepto de $\mathbf{N Y}$ por su excelencia. ${ }^{20}$

Proposiciones de La Estética Nirvánica de esta tesis

ED1: El rizoma tiene el carácter físico y no-físico al mismo tiempo, igual que el espacio NY. El rizoma ha de conectarse siempre a otro lugar para re-distribuir y re-conectar los flujos y energías. El rizoma es la red.

Una manera efectiva de fragmentar la ciudad es regular el tráfico vial y el sistema semafórico con la prioridad primera de mantener un flujo suave de tráfico y asegurar cierto espacio de aparcamiento. El plan de aceras, aparcamiento, muebles urbanos (caja de electricidad, papelera etc.) se establecerían

\footnotetext{
${ }^{20}$ v.-Capítulo 10 de este estudio.
} 
después de distribuir los espacios suficientes para los coches. Siempre el carril de bici es fácil de ignorar. Los peatones y ciclistas suelen sentir dificultad para recorrer la ciudad no como los coches. La ciudad así se fragmenta física y mentalmente. Si la mayoría de la gente prefiriera usar el coche propio en la ciudad -con la condición de que el dinero no fuese un problema-, dicha ciudad estaría mal diseñada. La red vigente de carril bici en Valencia no es capaz de conectar los ciclistas tranquilamente con los puntos importantes de ciudad. Si el problema fuese la carencia de espacio, entonces, hay que pensar en el espacio de uso mixto, para que las bicicletas puedan moverse en la calle sin escuchar el claxon agresivo a sus espaldas, en el caso en que no haya carril bici. De esta manera, la gente con el tiempo empieza a pensar que recorrer la ciudad no es nada agradable ni siquiera en bici. Utilizar los combustibles fósiles no es sostenible obviamente ya que tienen una cantidad finita. La consciencia colectiva de $<<$ yo compro el coche porque yo puedo $>>$ no es sostenible. De todas formas, el hombre es peatón. Aunque tuviese su coche propio tiene que llegar a la dirección andando, ya que el coche no puede llevar al conductor a su último lugar. El espacio de acera agradable y carril bici tendrían que asegurarse gradualmente en el sistema. La consciencia de unas minorías de conductores que piensan que en esta ciudad no es necesario carril de bici, sino que más bien aún falta espacio para los coches, tendría que reconducirse por la educación y la información pública.

ED2: No es humanista que después de establecer la red de carril de coches se distribuya el espacio sobrante al pueblo. Las calles son del pueblo. Como los conductores de coche, los peatones ta mbién pueden reclamar el derecho a la calle. Algunas plazas del centro histórico de Valencia por las entradas imprudentes de los coches están fragmentadas para los peatones y el paisaje urbano del casco urbano está alcanzando una densidad excesiva de coches. Primero, meticulosamente hay que formar la red de peatones, posteriormente las zonas no utilizadas próximas también irán revitalizándose paulatinamente. El problema presente es que la gente pasa pero no se queda. Y algunas zonas están olvidadas en la ciudad.

ED3: El Jardín del Turia es un espacio verde, allí la gente descansa y encuentra una pequeña paz que es difícil de encontrar cuando se está dentro del sistema urbano. Allí hay sol, agua, césped, árboles. Enfrente del Palau de la Música de Valencia se puede encontrar un enorme espacio con un pórtico 
polistilo y una fuente agradable. En el extremo este del jardín del Turia se encuentra el parque de las ciencias en el que existen las arquitecturas contemporáneas de Santiago Calatrava, y en el extremo oeste se halla el lago del Parque de cabecera sin duda querido por los valencianos y un bioparque educativo. El Jardín del Turia ha de conectarse con el casco urbano y las grandes vías. Debido a que las vías de circunvalación, situadas arriba en el casco urbano, generan una velocidad alta, la gente no pasa por la reducida acera de la vía de circunvalación. Hay que promocionar el Jardín del Turia e invitar a la gente a que acuda mediante una solución arquitectónica de accesibilidad para que se pueda neutralizar este fuerte bloqueo de los coches.

ED4: La red rizomática se refiere incluso a las redes no-físicas. De hecho, cuando Internet estaba tan activado en todo el mundo había gente que predijo que la gente ya no querría salir de casa y que el rango de la sociedad física disminuiría cada día más. Sin embargo, más bien la red de Internet puede provocar el encuentro físico incorporando la relación virtual, además incluso los servicios de alta calidad no se sirven de máquinas sino de seres humanos. Se dan reuniones del negocio o académicos también, en ellas se prefiere conversar y comunicarse en persona. Aunque la tecnología permite que se tengan reuniones virtuales por Internet sin embargo el contacto físico es empleado para conseguir la credibilidad de una manera más tradicional y humana. Así Internet y cualquier tipo de red virtual pueden tener la excelencia de facilitar y provocar el contacto físico de la ciudad. Los seres humanos son libres en la palma de su mano con el smartphone, conectándose a numerosos espacios virtuales a través de Internet y comunicándose con los otros. Existe un vocabulario en ingles llamado netizen que es una palabra compuesta de net + citizen, lógicamente significaría el ciudadano que vive en la ciudad llamada red. La gente se expresa, se reúne en la red, y ésta se expande no solo en el espacio virtual sino también en el mundo terrenal. El poder del smartphone es insondable. Ya es una época en la que se puede bajar cualquier tipo de información al teléfono sin cable. Actualmente, en algunas estaciones del metro de Valencia, se provee wifi gratis para los viajeros. Este tipo de consideración puede hacer que los turistas e incluso los ciudadanos sientan una hospitalidad muy amable de la ciudad. Los peatones acceden a otra capa virtual de la ciudad y así se sienten más vinculados con ella. El Internet es conveniente pero la aplicación del Smartphone es más conveniente fuera de casa. Aparte de la función de aportar diversas informaciones, en la red la gente expresa su opinión política. El 
hombre es un ser político. Internet y la infinidad de aplicaciones pueden generar las acciones políticas más que antes. Por Facebook o Twitter, la gente se informa y directamente reacciona en el espacio virtual. Los ciudadanos pueden ser más participantes con menor condición física que antes. Este tema indudablemente se relaciona con el tema de promocionar la democracia participativa directamente. Además esta tecnología puede ser una pista para resolver el problema de la solidaridad de los ciudadanos sin aislar ninguna persona. Como se ve en este argumento, está claro que la solidaridad de los ciudadanos naturalmente puede estimularse hasta la regeneración de la ciudad en un nivel social denominado 'sostenibilidad del presente-futuro'. No hace mucho tiempo que el mundo reconoce la potencialidad del buen uso del espacio virtual y su aplicación. Es necesario contemplar el futuro de esta tecnología con una cierta estrategia para utilizarla más activamente. 


\section{CSD Nirvánico-04}

Tipo: Sostenibilidad de la memoria

Referencia con CSD Mórbido: 03, 11, 26, 27, 28, 29

ED Propuesta

Los caminos están desolados, nadie transita por los senderos. El pacto se ha quebrantado, se desprecia a los testigos, ja nadie se le respeta! La tierra está de luto y languidece; el Líbano se avergüenza y se marchita; Sarón es como un desierto; Basán y el Carmelo pierden su follaje.

Isaías. 33:8-9. NVI.

ED1: Cuando se trata el tema de la regeneración urbana, hay que hablar sobre el aspecto físico e igualmente el aspecto no-físico. Y como se refirió anteriormente, el concepto de sostenibilidad de la memoria es indudablemente imprescindible cuando se habla sobre el aspecto no-físico de la regeneración urbana. La Calle Colón, Calle Xàtiva, Calle de Guillem de Castro, Paseo Pechina, Calle Conde de Trenor y Calle Pintor López forman la antigua silueta del casco urbano. La memoria de dichas calles existe solamente en el mito cartográfico de la antigua Valencia, no pudiendo conectarse con el presente. Cada día más por la intervención de los grandes capitales, la ciudad pierde su identidad. Sólo, las torres de Serranos y las torres de Quart apenas están trasmitiendo la última nostalgia de Valencia. Cuando los descendientes venideros perciban que estas calles ya no son atractivas y son obsoletas, sin recordar la historia, la identidad de la ciudad se queda solamente en unas simples letras, sin espíritu. Ya se sabe que sin la base histórica y la identidad el estado no puede ser sostenible, como se aprende de la historia humana. Básicamente, los conceptos de Espacio Nirvánico y Espacio NY, son filosofías y argumentos que derivan del atractivo y el encanto del espacio. Y estos conceptos pueden amplificar sus poderes más estratégicamente en los espacios donde se guarda la memoria de los lugares. No es creíble que el actual casco urbano de Valencia vaya a curarse a sí mismo naturalmente. Los barrios de las referencias $(03,11,26,27,28$ y 29) están enfermos. Además estos barrios no están comunicados bien con el transporte público. Las aceras para los peatones y el carril bici tampoco se encuentran en buena situación. Las fachadas de las arquitecturas 
insinúan que aquí existe un barrio degradado. Cuando el peatón pisa el camino de la historia, la historia se transforma en una experiencia personal del hombre carnal. La tierra aprieta al hombre para que no se separe de la historia.

ED2: Las rutas que han de recuperarse más prioritariamente serían las combinaciones de las zonas verdes y los monumentos arquitectónicos.

1. Ruta 1. Tipo lineal: Estación del Norte \& Plaza de Toros - Plaza del Ayuntamiento - Plaza de la Reina - Catedral de Valencia - Plaza de la Virgen - Torres de Serranos - Jardín del Turia Museo de Bellas Artes de Valencia - Jardines del Real - Avenida Blasco Ibáñez - Playa La Malvarrosa - Puerto de Valencia.

2. Ruta 2. Tipo lineal: Estación del Norte \& Plaza de Toros - Plaza del Ayuntamiento -Mercado Central de Valencia \& La Lonja de la Seda - Plaza del Tossal - Calle Quart - Torres de Quart - Jardín Botánico - IVAM (Institut Valencià d'Art Modern) - Jardín del Turia - Parque de Cabecera - BioParc.

3. Ruta 3. Tipo circular: Calle Xàtiva - Calle de Guillem de Castro \& Paseo Pechina - Calle Blanquería - Calle Conde de Trenor - Calle Pintor López - Plaza Temple - Plaza Tetuán Plaza Alfonso El Magnánimo - Calle Colón - Calle Xàtiva

4. Ruta 4. Tipo circular: Jardín del Turia - Gran Vía Marqués del Turia - Gran Via de las Germanías - Gran Vía de Ramón y Cajal - Gran Vía de Fernando el Católico - Jardín del Turia

ED3: En los alrededores de los monumentos hay que proveer pavimentos dignos y algunas marcas visibles de una manera sofisticada que indique las rutas para que los peatones y los turistas puedan reconocer los monumentos y perciban la identidad de la ciudad en su interior. 
ED4: Después de formar estas rutas, también hay que tratar los barrios degradados. En algunas zonas y debido a que no hay posibilidad de salir con éxito, incluso los negocios del gran capital tampoco quieren invertir. A los negocios pequeños no vale la pena referirse, ya que la situación es así. Las fachadas pierden sus colores originales, y las piedras se rompen con el tiempo. La intervención tiene que surgir por un motivo no lucrativo, por lo menos en una corta perspectiva. Entonces, la intervención tiene que surgir de algunos cuerpos gubernamentales o de algunas ONG con los fondos nacionales y si es necesario con los fondos internacionales. Instantáneamente se puede imaginar una intervención a un nivel de la Comunidad Valenciana. Se pueden expropiar los locales que no son activos, y alquilarlos a un precio económico o gratuitamente a los artistas de la ciudad. Y dichos artistas pueden dedicarse a sus actividades exclusivas generando precisamente sus obras. Así que se pueden generar otras nuevas rutas, por medio de este programa, y la gente puede hacer peregrinación a los estudios de los artistas. Como los artistas reciben un cierto interés desde la comunidad, los artistas pueden exponer dichosamente sus estudios en algunos periodos o en algunos eventos especiales. Por ejemplo, una clase de bellas artes hacia el público, o una exposición de cada estudio particular en cada período, por lo que pueden provocar más visitas de las personas incluidos los turistas. Como se mueve mucha gente en el barrio, poco a poco la zona se vivifica y se puede crear hasta oportunidades de empleo. Finalmente puede ser la creación de una nueva cultura en la época actual. Rehabilitar los locales pertenecientes a los barrios degradados, la creación de oportunidades de empleo y el cuidado de los artistas que no son capaces de crear riqueza tan sólo por las actividades de su carrera, directamente se conecta a un concepto de inclusión social. ${ }^{21}$

En Japón, hay una ciudad llamada Kanazawa que podría ser un ejemplo muy deseado para las ciudades que están en diversas circunstancias de decadencia. Kanazawa fue una ciudad histórica en la que estaban conservadas muy bien las artes, las artesanías y el paisaje urbano tradicionales. En los años 1980, todas las ciudades de Japón experimentaron altas tasas de crecimiento de la economía y la ciudad de Kanazawa también confluyó en la tendencia de globalización, intensificando la industria textil. Sin embargo, después de las buenas épocas de gloria, vino el colapso de la burbuja económica.

\footnotetext{
${ }^{21}$ Para más informaciones, v- <Sasaki, M. Urban regeneration through cultural creativity and social inclusion: Rethinking creative city theory through a Japanese case study. Elsevier Ltd. 4 de Mayo. 2010>
} 
Hasta aquí la historia de esta ciudad es igual a la de otras ciudades en general. Sin embargo, en el año 1996, un evento relevante surgió destacando y haciendo especial a Kanazawa sobre muchas otras ciudades. La ciudad abrió El Pueblo de Arte de los Ciudadanos de Kanazawa en una fábrica de hilado desocupada y en los almacenes abandonados adyacentes. Este lugar abría las 24 horas en respuesta a las peticiones de los ciudadanos. Tal modo de utilización flexible fue decisión del alcalde, para que los trabajadores pudieran usar la instalación de varios tipos de estudios después de cumplir las responsabilidades laborales. Los ciudadanos tuvieron mucho cariño patriótico sobre esta instalación, porque la instalación funcionaba con toda la participación voluntaria de los ciudadanos. Los ciudadanos eligieron dos directores entre ellos para la gestión de la instalación. En octubre de 2008, la ciudad solicitó unirse a la UNESCO como ciudad creativa y cultural, y fue registrada sin problemas en junio de 2009. Esto es un notable ejemplo de cómo una ciudad en decadencia se puede salvar a sí misma transformándose en una ciudad creativa y cultural por medio de la creación de una infraestructura cultural de un modo democrático. La Ciudad Kanazawa demostró cómo la colaboración ciudadana, el cuerpo gubernamental y los diversos campos de expertos, podían deliberar como buenos políticos y tomar decisiones en un proceso transparente comunicándose entre sí. ${ }^{22}$

La gestión activa e independiente de la instalación es un notable ejemplo de participación, institución cultural de los ciudadanos en el Japón contemporáneo. En suma, a través de la participación activa de la ciudadanía, las instalaciones industriales abandonadas se utilizaron para construir las nuevas infraestructuras culturales, un nuevo lugar para la creatividad cultural. ${ }^{23}$

Sasaki, M. 2010. Urban regeneration through cultural creativity and social inclusion.

\footnotetext{
${ }^{22}$ Sasaki, M. Urban regeneration through cultural creativity and social inclusión: Rethinking creative city theory throuth a Japanese case study. Elsevier Ltd. 4 de Mayo. 2010. El artículo de la citación fue traducido desde el inglés al español por Pilje Lee quien es el autor de esta tesis doctoral. Además, la aplicación del formato de negrita al texto en algunas frases fue realizado por el autor Lee también. En la versión original las frases negritas no son destacadas. -(NdA) ${ }^{23} \mathrm{lbid}$.
} 


\section{CSD Nirvánico-05}

Tipo: Sostenibilidad del proyecto presente-futuro

Referencia con CSD Mórbido: 04, 05, 06, 09, 13, 24, 27

\section{ED Propuesta}

ED1: Una vez al año, hay un período en Valencia en el que la ciudad se convierte en una utopía para los peatones, todas las rutas peatonales son más prioritarias que los coches, el período de las Fallas. Las Fallas son un legado cultural de los antiguos valencianos que fortalece el sentimiento de vínculo entre los vecinos y a veces también con la gente desconocida de la ciudad en todos los callejones y puntos de referencia. Aparte de la bondad de la inclusión social, esta fiesta de Valencia tiene un potencial muy grande en la economía turística. El sector turístico es efectivo para crear oportunidades de empleo. Básicamente, la mayor parte del sector servicios e incluso del turismo, requieren la labor del hombre cuidando a los clientes con cariño y detalles. También la calidad del servicio sube y baja dramáticamente dependiendo del cuidado personal. En el sector de servicios no se requiere tan alto nivel técnico en general, por eso este campo puede tener un papel primordial en la regeneración de la ciudad, especialmente en el ámbito de la inclusión social, generando numerosos trabajos especialmente para las mujeres y la gente que no tiene un fondo de alta educación. Si bien la ciudad tuviese abundantes recursos patrimoniales o extraordinaria gastronomía, si no se puede encontrar la hospitalidad en el servicio, la decadencia del sector del turismo de la ciudad no puede ser sostenible considerando la tasa de la re-visita de los turistas. ${ }^{24}$ Cuando la ciudad está en período de decadencia económica, está claro que el turismo sería el sector más susceptible de activación económica. Como la mayor parte de las ciudades de España son así, la influencia del turismo en Valencia es crucial. Afortunadamente, Valencia es una ciudad conocida tradicionalmente en el campo turístico internacional gracias a los rebosantes patrimonios, gastronomías y al clima fantástico mediterráneo. Hay que pensar que el turismo es sostenible.

\footnotetext{
${ }^{24}$ Para saber más sobre este tipo de informaciones, v- $<$ Antonio $\mathrm{P}$. Russo ${ }^{\mathrm{a}}$, Jan van der Borg ${ }^{\mathrm{b}}$. Planning considerations for cultural tourism: a case study of four European cities. Elsevier Ltd. 2002.>
} 
ED2: Tanto la accesibilidad física como la virtual tienen una importancia primordial en la ciudad: líneas de aviones, relación entre el aeropuerto y la ciudad, estaciones de trenes, autobuses nacionales, barcos y posicionamientos online de una manera amable, gratuita en la web del ayuntamiento, oficina de turismo y aplicaciones turísticas desde el smartphone.

ED3: Cuando se trata la sostenibilidad del proyecto presente-futuro, la inclusión social es un factor imprescindible para que el discurso entre en el núcleo del problema directamente. Por eso, como la teoría de $\mathbf{4} \mathbf{N V}^{25}$ (AD ${ }^{26} \& \mathbf{E D}^{27}$ ), aquí no cabe duda que hay que tratar los vagabundos de la calle. Hay que hablar de dónde surgen los vagabundos. Sin embargo, también hay que pensar, al contrario en este caso, considerando la mortalidad del hombre. El método fundamental sería la teoría de ED; pero tendría que existir un método secundario para cuidar las situaciones urgentes. Cuando una persona racional encuentra una comida contaminada por radioactividad en la calle, primeramente, esta persona tendría que tirar el plato a la basura; participar en el movimiento de energía anti-nuclear y pensar en aplicarse para la próxima elección del gobierno, estas opciones son métodos fundamentales, pero siempre, tirar el plato es lo primero. Además, normalmente se tarda más tiempo en el proceso administrativo del gobierno comparado con el de las ONG o con cualquier tipo de cuerpo no burocrático. Por eso, el acercamiento burocrático para poder tratar el factor fundamental y el acercamiento rizomático para poder atender los problemas urgentes, son necesarios igualmente. ${ }^{28} \mathrm{La}$ ineficiencia del sistema burocrático se puede complementar cooperando con los cuerpos no gubernamentales. El partnership es inevitable.

<<Olvídalo. Son una de las razas más desagradables de la Galaxia -en realidad no malvada, sino de mal carácter, burocrático, rígido e insensible. Que ni siquiera mueve un dedo para salvar a sus propias abuelas del Ravenous Bugblatter Beast de Traal sin órdenes firmadas por triplicado, enviadas, devueltas, preguntadas, perdidas, encontradas, sometidas a consulta pública, perdidas otra vez, y finalmente enterradas en una tierra suave durante tres meses y recicladas como encendedores.>>

\footnotetext{
${ }^{25}$ Las cuatro nobles verdades.-(NdA)

${ }^{26}$ Acumulación del Dolor.-(NdA)

${ }^{27}$ Extinción del Dolor.-(NdA)

${ }^{28}$ El acercamiento rizomático también puede tratar el factor fundamental. Aquí no cabe duda. Solamente, aquí se expresa así porque la mayoría de los países son de sistema burocrático.-(NdA)
} 
ED4: Los motivos para mover las fuerzas pueden surgir conectando los dharmas. Improvisadamente, se puede pensar en un pequeño escenario. Hay vagabundos. Simplemente, se empieza con una idea de que hay que proveer los alimentos a los mendigos que no pueden solucionar su comida. En Valencia hay numerosos restaurantes y bares diseminados por la población, comparándolo con otras ciudades españolas. Entonces, aquí hay dos dharmas: uno los vagabundos y el otro los numerosos restaurantes. Claro que los restaurantes son dharmas lucrativos, de momento no son voluntarios. Aquí se requiere una intervención de otro dharma que pueda conectar dichos dos dharmas. El nuevo dharma puede ser un cuerpo gubernamental o un tipo de ONG. ¿Pero cómo? Como todo el mundo sabe, el gobierno tiene una cierta cantidad de presupuesto para la salud y bienestar de las clases necesitadas. Y las ONGs tienen voluntad de proveer la labor y patrocinar los proyectos de ayuda. Los dharmas necesarios se conectan así. Los restaurantes proveen las comidas sobrantes a los vagabundos. Entonces, el gobierno provee una ventaja de impuesto a los restaurantes participantes en el proyecto. Para poder planear y ejercitar el proyecto, los expertos de la ONG pueden cooperar con el gobierno. Así la ineficiencia del sistema burocrática se soluciona y se puede ahorrar el tiempo, dinero y labor al mismo tiempo. De todas formas, como existe una cierta cantidad de presupuesto asignado a este tipo de proyecto, los gobiernos de las comunidades no tienen una particular razón para disgustarse. Los restaurantes reciben una ventaja de impuesto (motivo directo), participan en el movimiento de inclusión social por medio de dedicar su propio recurso y se cultiva el patriotismo y civismo (motivo secundario). Además, cuando la economía de la ciudad está en decadencia, como la actual Valencia, es un proyecto bienvenido por todos. En el siguiente capítulo se proporcionarán más detalles prácticos sobre dicho proyecto.

\footnotetext{
${ }^{29}$ Adams, D. v.0.1979. The Hitch Hiker's Guide to the Galaxy. New York. Pan Books, Ltd. Del Rey Trade Paperback Edition.
} 2009. p.48. 


\section{Anexo}

La sociedad contemporánea es una sociedad múltiple como las estrellas múltiples del universo. La metodología para captar los

CSDs que penetran en las capas sociales, sistémicas, institucionales, económicas, físicas, culturales etc., ha sido influencia de

Raoul Bunschoten que es el líder de CHORA. Su manera de trabajo es bastante similar al de Deleuze y Guattari. Bunschoten delimitó los 4 géneros ${ }^{30}$ para definir y captar las energías urbanas, sin embargo, en esta tesis se ha utilizado la idea originaria de Deleuze y Guattari para poder diseñar los CSD con más potencialidad y para poder percibir mayor variabilidad de dimensiones de interpretación. De esta forma no debería existir malinterpretación de plagio.

${ }^{30}$ Los 4 géneros son: Branding, Earth, Flow y Incorporation. Branding se refiere a: historia, ropa, memoria colectiva, creación de valor, etc., Earth se refiere a: ecología, cielo, biodiversidad, recurso del agua, tierra, administración del agua, propiedad, territorio, organización espacial, etc., Flow se refiere a: tráfico, transporte, barcos, fabricación, industria, información, economía, productos etc., Incorporation se refiere a: acciones políticas y constelaciones políticas, grupos, organizaciones gubernamentales etc.-(NdA) Para más informaciones véase: Bunschoten, R. Urban Flotsam. Eindhoven. 010 Publishers. 2001. pp. 422, 432 . 


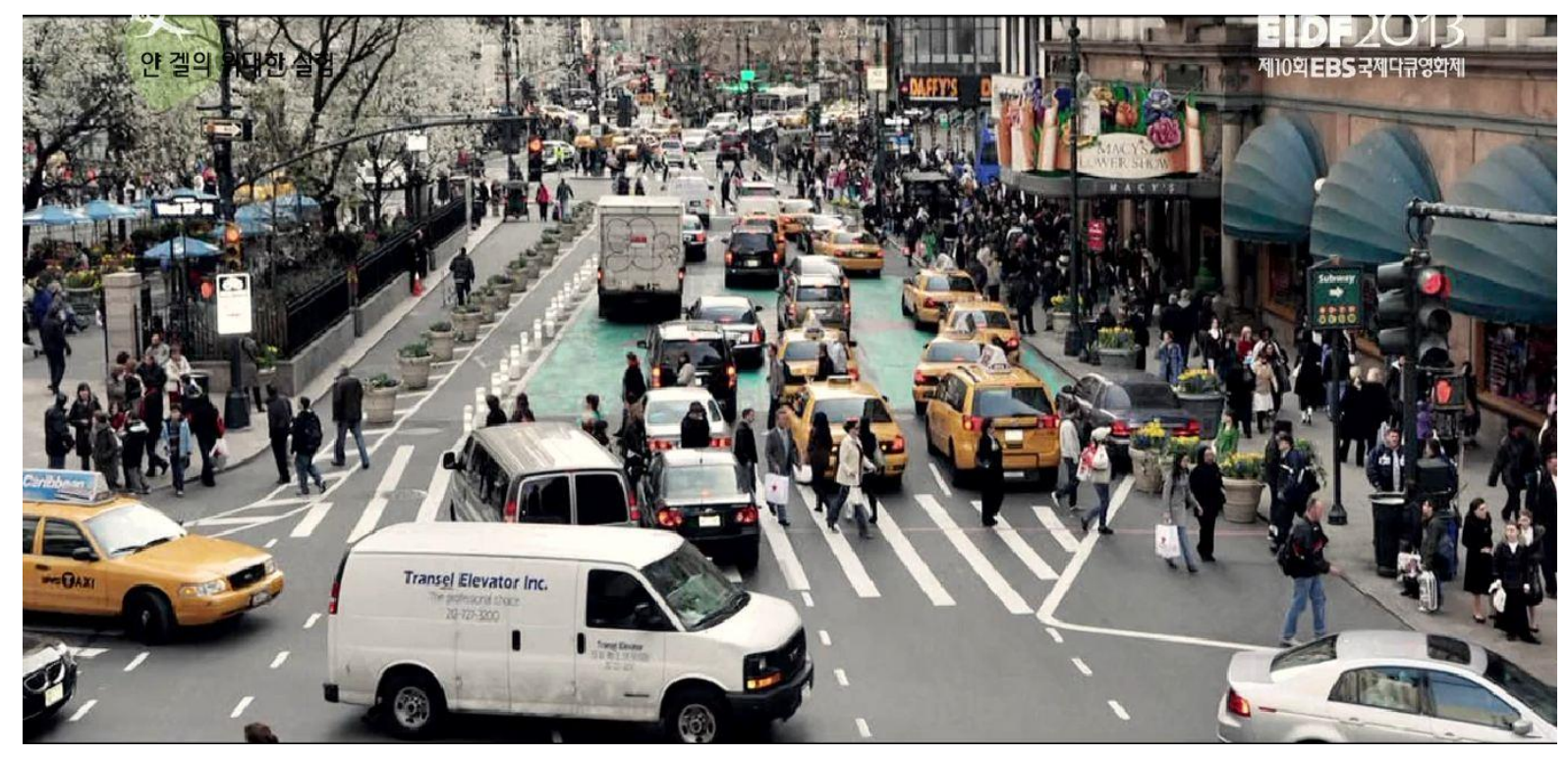

Fig. 12-1. Una calle antes de la conversión en Nueva York.

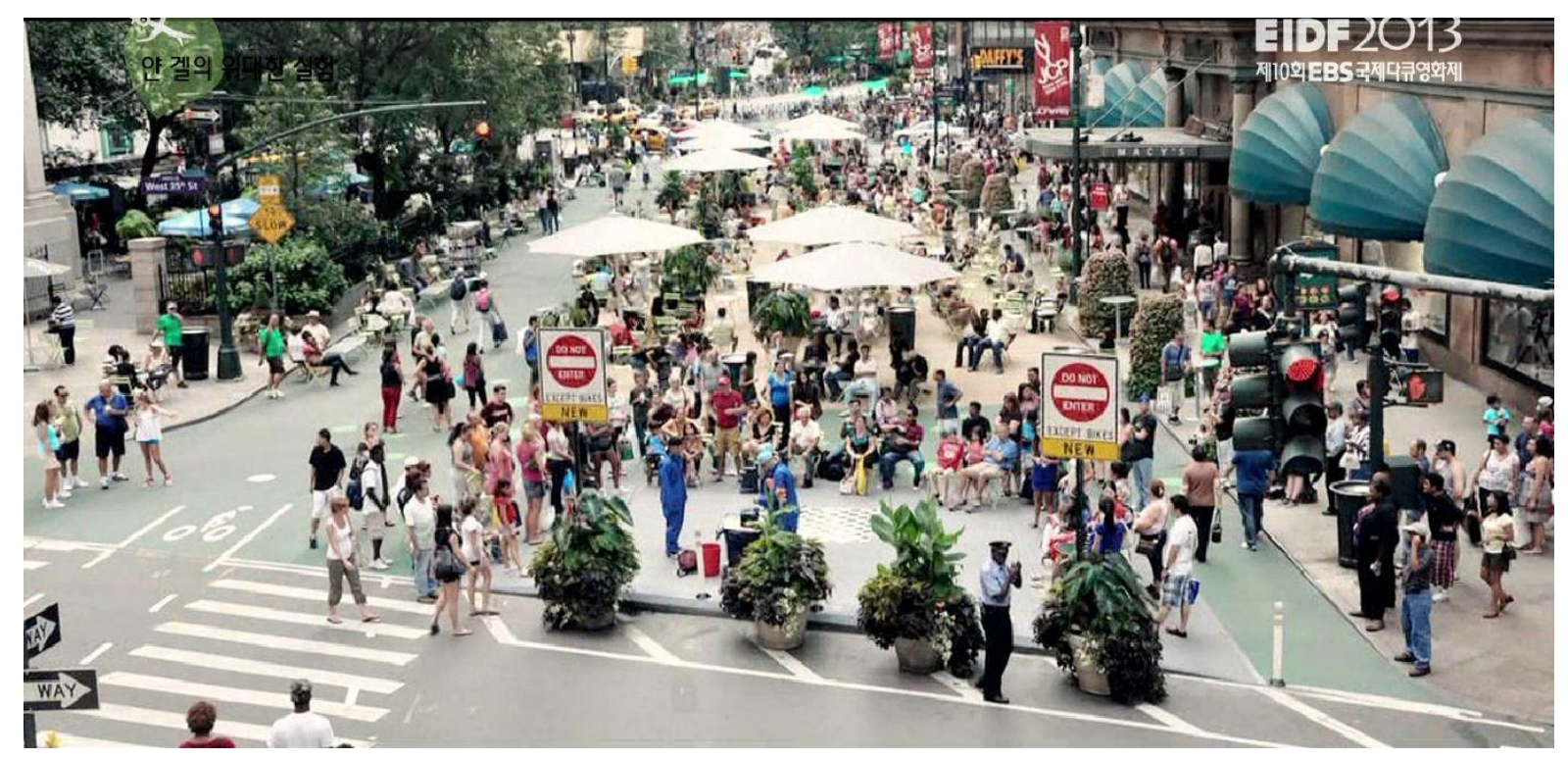

Fig. 12-2. La calle después de la conversión en Nueva York. 


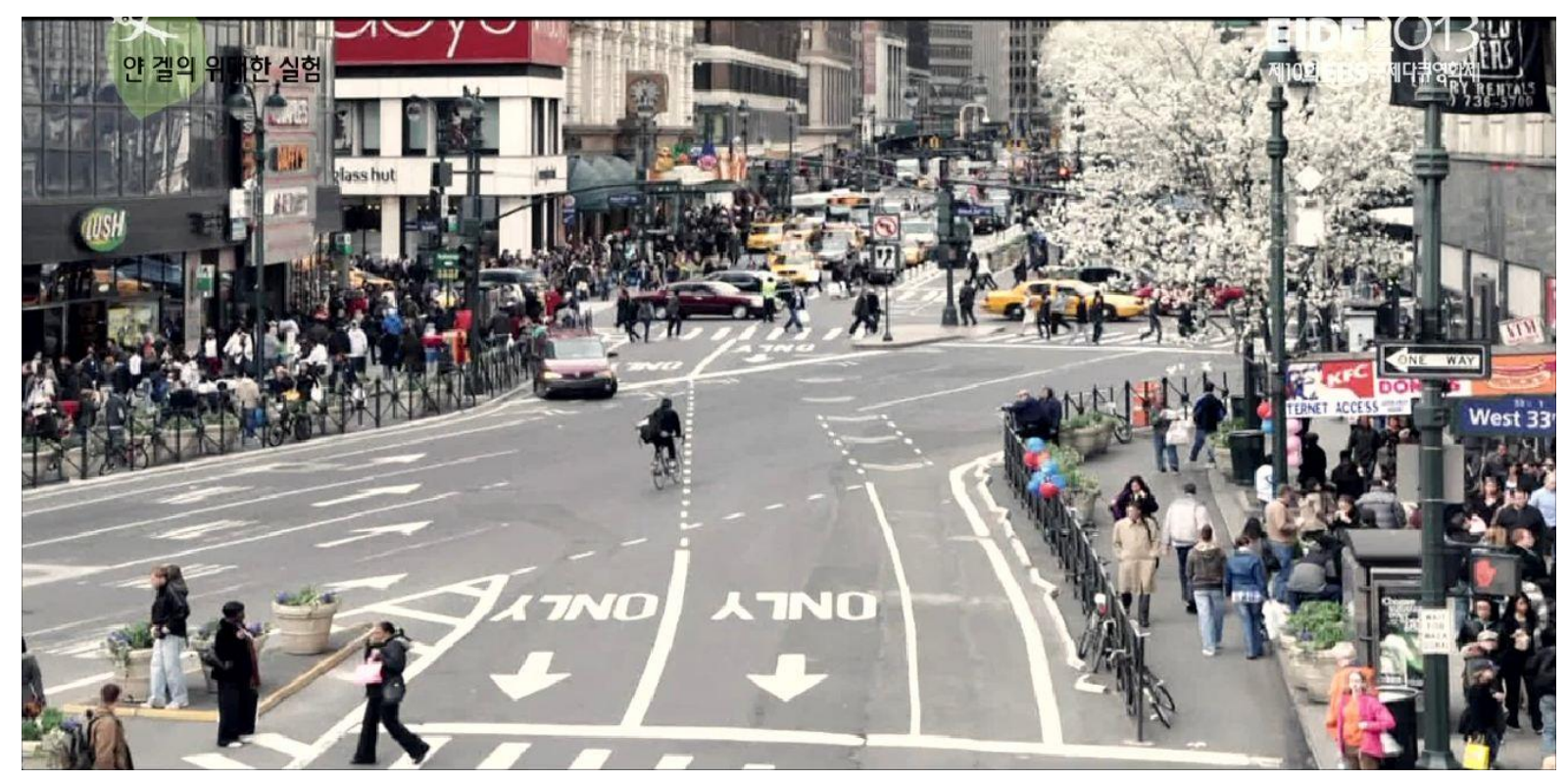

Fig. 12-3. Los carriles de coches antes de la conversión en Nueva York.

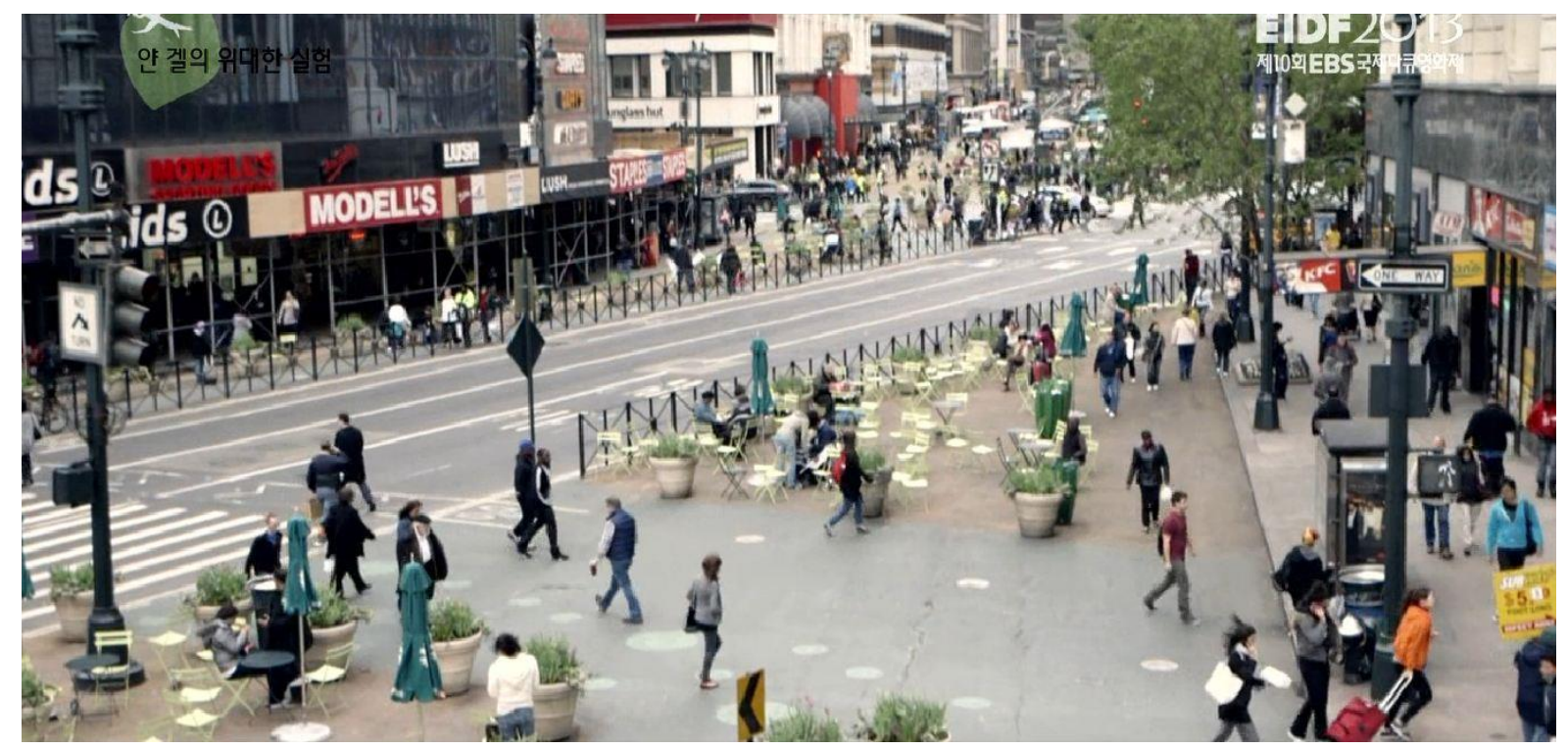

Fig. 12-4. Los carriles de coches se convirtieron en una pequeña plaza en Nueva York. 


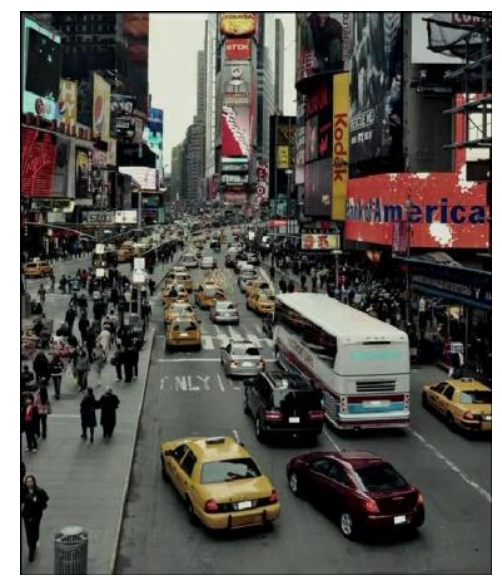

Fig.12-5. Antes de la conversión de Broadway en la ciudad de Nueva York.

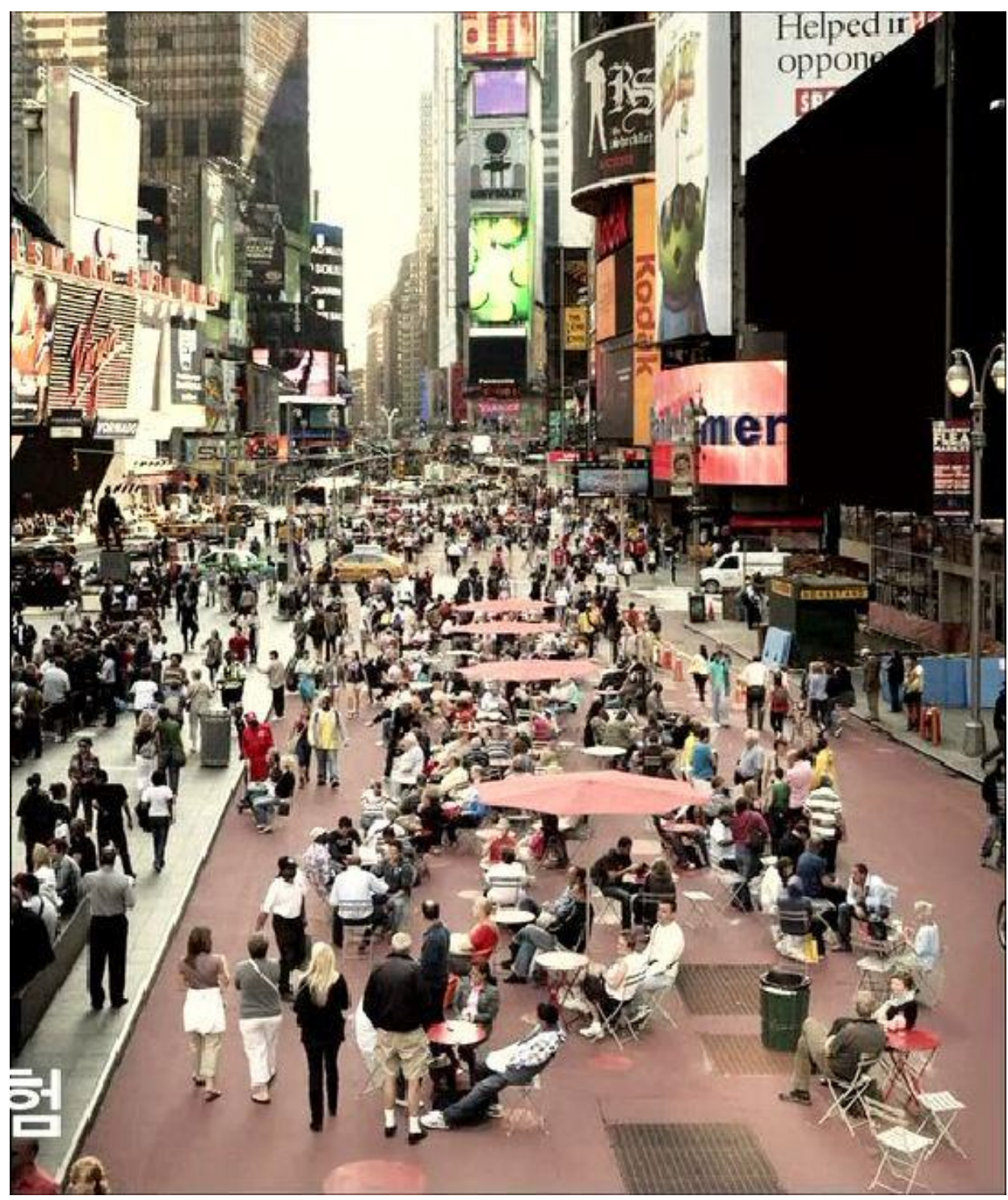

Fig. 12-6. Después de la conversión de Broadway en la ciudad de Nueva York. 


\section{NY-Intervención}

: NY1-Intervención es un capítulo que expone algunos de los CSD² Nirvánicos del capítulo 12, captando las ideas desde un nivel práctico para que sean asequibles. Es decir, una secularización de los mantras buddhistas e implantación de los CSD-dharmas nirvánicos en una ciudad real. Y los juegos de NY Intervenciones se analizarán según los criterios pertenecientes a los capítulos 8, 9 y 10. De esta manera este capítulo prueba la contundencia y factibilidad para la intervención en el área urbana.

\section{NY Intervención 1}

\section{: Mi Casa Tu Casa}

Tipo de NY-Intervención: Espacio NY, Sostenibilidad del presente-futuro

Referencia con CSD Mórbido: 04, 05, 09, 13, 24, 27

Ciudadanos, por medio de la aplicación del móvil, pueden participar o solicitar el programa que se llama <<Mi Casa Tu Casa >>. Este programa se utiliza para proveer más alojamientos, que faltan en algunos períodos festivos. Además, permite atraer a los turistas potenciales que aún no se han decidido debido a los hoteles demasiado costosos, especialmente en algún período festivo o dependiendo de la economía de la ciudad. Aparte de los alojamientos, los participantes ciudadanos pueden registrar su coche, bicicleta o monopatín en el ayuntamiento por las mismas razones ya nombradas. Según las circunstancias de los solicitantes, se puede participar individualmente, o en conjunto con un guía para los turistas que se alojan en su piso, para que su producto turístico sea más exhaustivo.

\section{Las ventajas fácilmente deseables:}

\footnotetext{
${ }^{1}$ No-yo.-(NdA)

${ }^{2}$ Co-surgimiento dependiente.-(NdA)
} 
1. Crear numerosos itinerarios que no existían anteriormente. Depende de los caracteres de los participantes, el color del itinerario puede generarse de numerosas maneras. Arquitectónicos, gastronómicos, shopping, discotequeros, pinacotecas. Se puede generar un itinerario original (no institucionalizado por las agencias lucrativas cuyo primer objetivo es más prioritario que otros de la lista). Un viaje único y original.

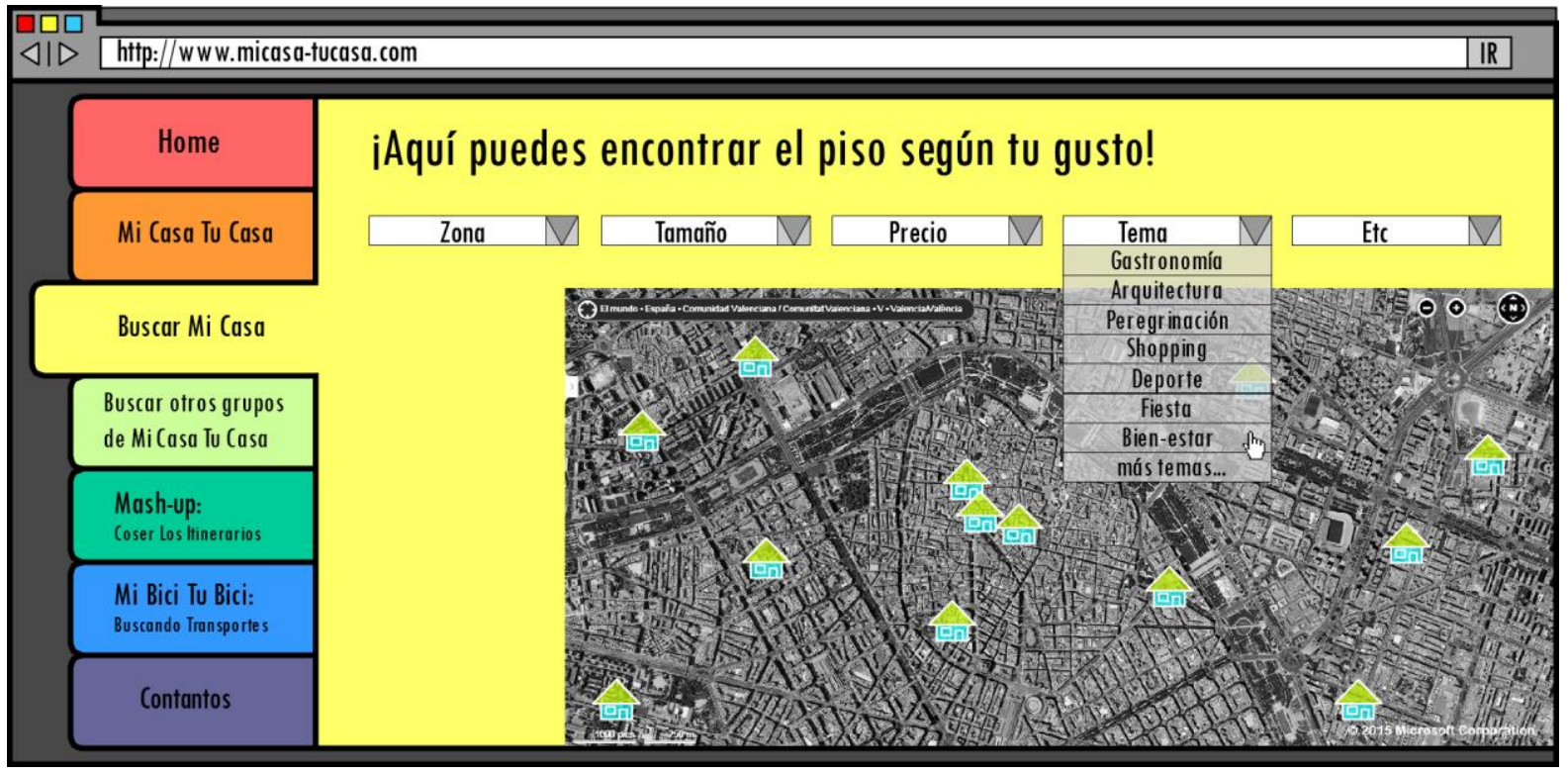

Fig. 13-1. Diseño 1 de la página web para Mi Casa Tu Casa.

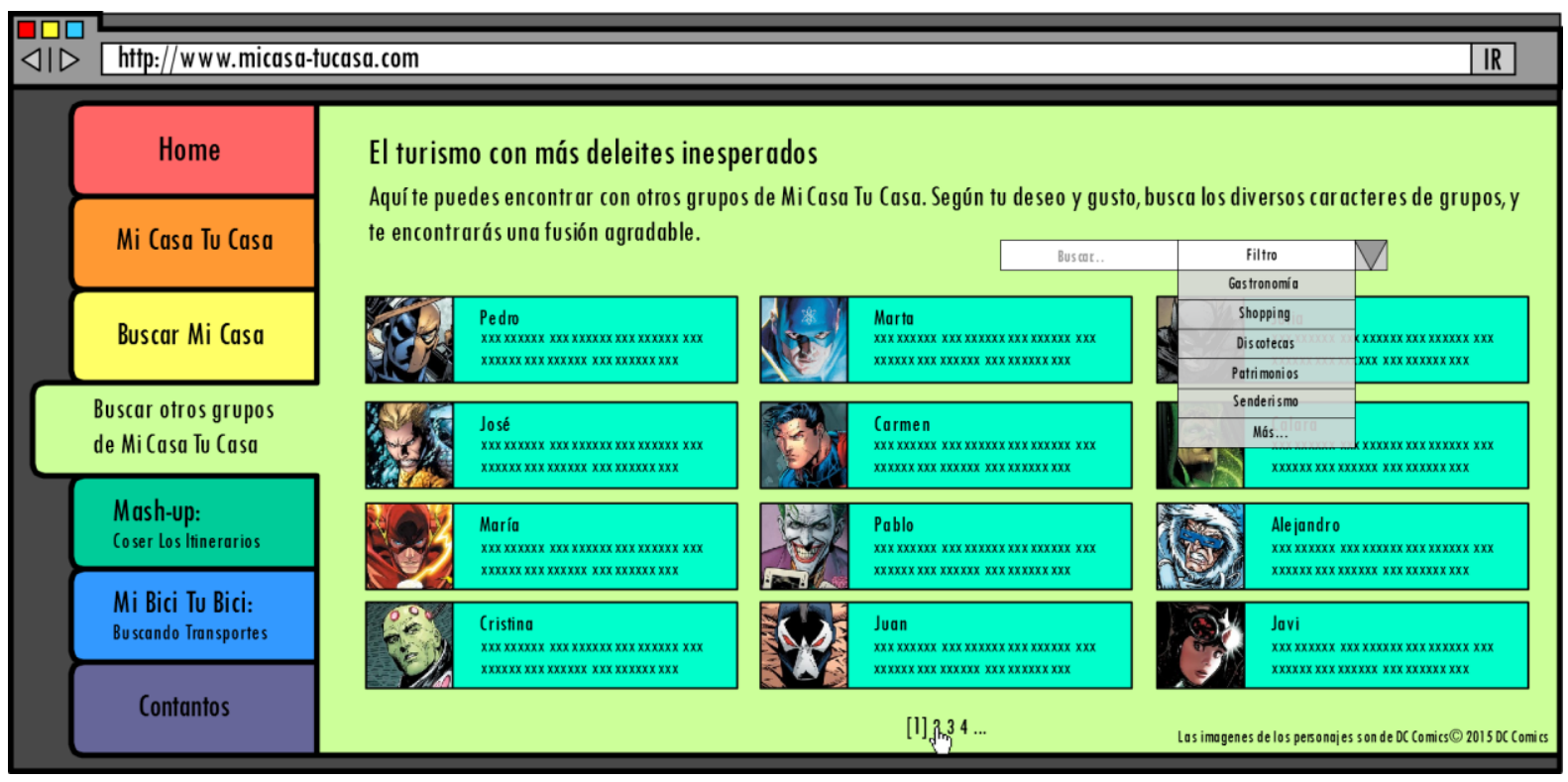

Fig. 13-2. Diseño 2 de la página web para Mi Casa Tu Casa. 
2. La solidaridad de la sociedad. Los turistas pueden comunicarse con otros turistas con esta aplicación, pueden hacer la toma de decisiones rápidamente para unir sus itinerarios unos con otros. Por ejemplo, un turista que se aloja junto un solicitante cocinero (el que le va a proporcionar un itinerario gastronómico), y otro turista, que se aloja con otro solicitante de turismo arquitectónico, estos dos turistas se van a reunir en esta aplicación superponiendo sus distintos itinerarios, generando así un compuesto híbrido, en el cual van a realizarse parte de ambos recorridos. Es decir, por causa de la petición de más de un grupo (mínimo serían dos grupos), los participantes ciudadanos (solicitantes) tienen que mezclar sus particulares itinerarios, así crean más itinerarios exóticos hibridados. Eso significa que depende de los caracteres de los turistas y de los ciudadanos participantes. El carácter de turismo que se define es cada vez diferente.

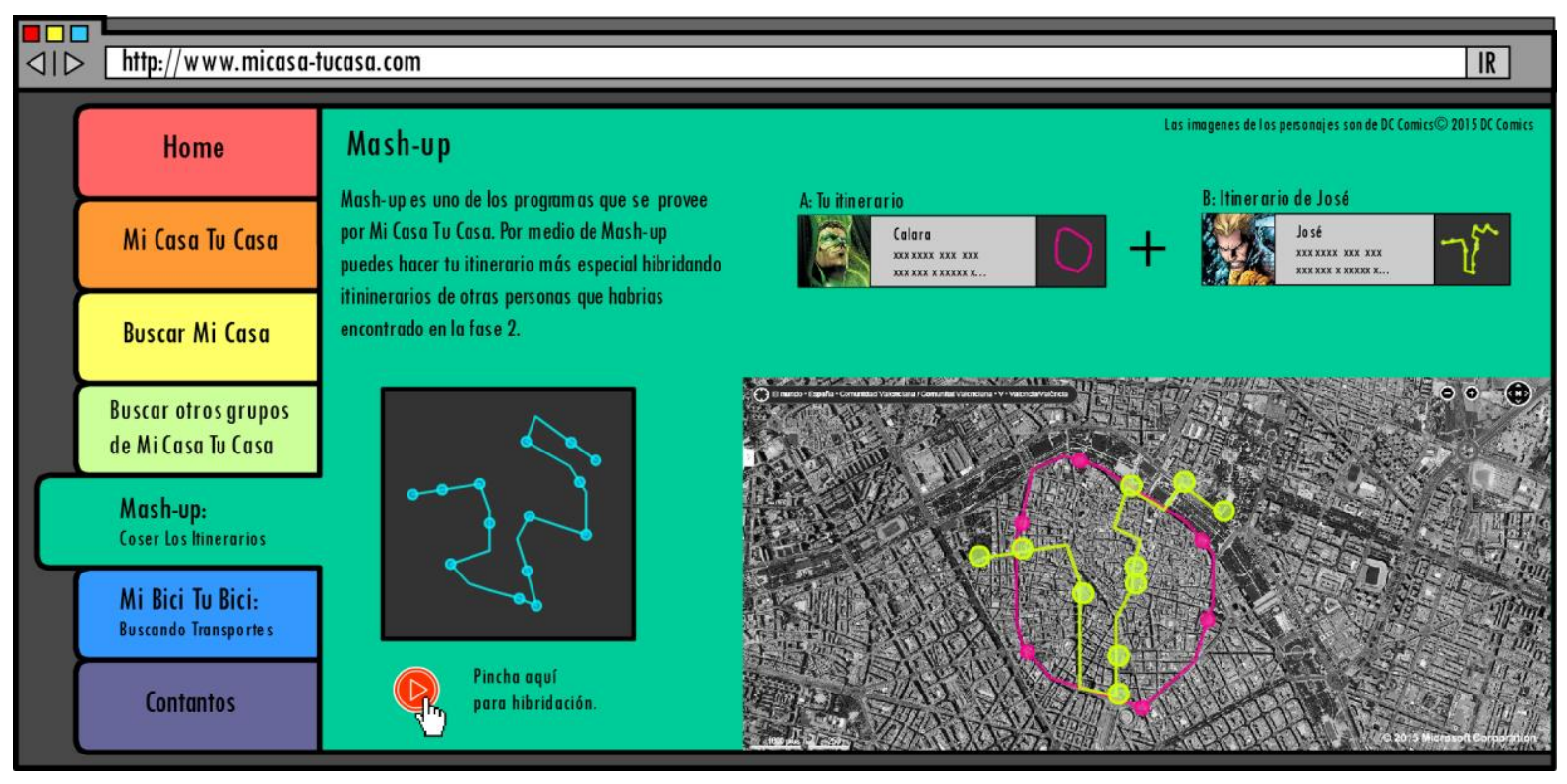

Fig. 13-3. Diseño 3 de la página web para Mi Casa Tu Casa.

Reflexión total: Incesantemente, en ese tipo de reunión de los ciudadanos es donde se encuentran numerosos encuentros de alegría. La relación con los ciudadanos se fortalecerá en dicha dinámica situación, y se potenciará debido a la creación de numerosos mapas virtuales.

Los mapas se pueden doblar, rasgar, cortar, pegar, superponer y coser como se quiera. ${ }^{3}$

\footnotetext{
${ }^{3}$ Esta manera de expresión sobre el mapa o la cartografía, es de Gilles Deleuze en su célebre obra <Mil mesetas: Capitalismo y Esquizofrenia 2>--(NdA)
} 
3. Los participantes pueden generar riqueza por haber ofrecido sus alojamientos, en algunos casos, pueden generar un beneficio adicional por ser un guía. También con su bicicleta, coche o monopatín. Todos los intereses que surgen en el período, vuelven a los participantes, en forma de pago que se habría realizado por la aplicación o gracias a la web. El precio de mantenimiento de la aplicación y atención técnica se quedan en el gobierno local con un mínimo de comisión. O si es necesario, sin comisión. Porque hay bastante aumento de los ingresos tributarios del gobierno local. Eso permite asegurar la claridad en el mercado negro. Se aplica la teoría de juegos. El gobierno conduce a los ciudadanos en una situación estratégica de decisión e incluso el nivel de su participación. Posiblemente, el gobierno local ofrece los programas normativos, compensaciones o penalidades. ${ }^{4}$ Así proporciona un ambiente en el que les dejan tomar la decisión estratégicamente a los ciudadanos.

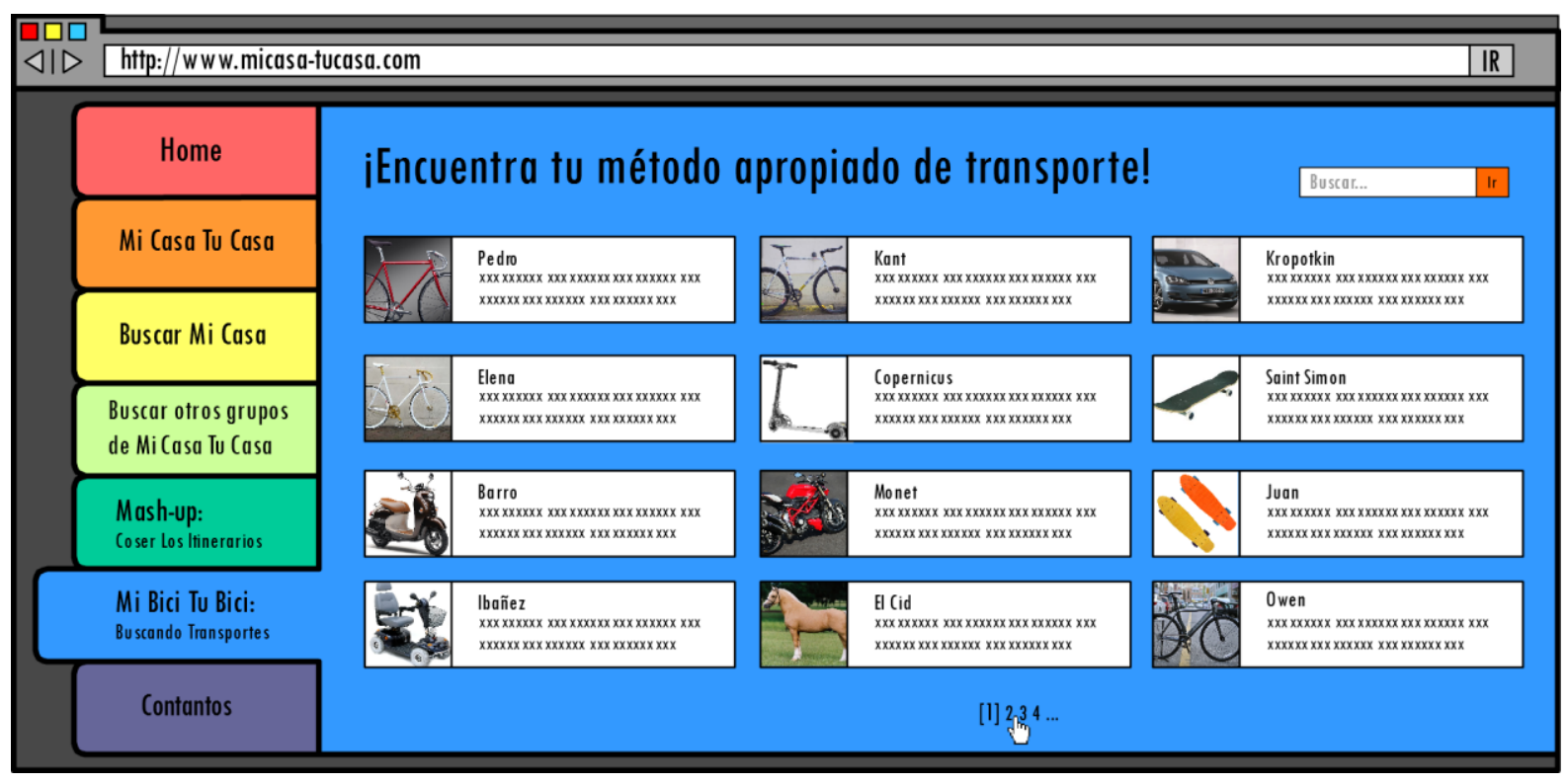

Fig. 13-4. Diseño 4 de la página web para Mi Casa Tu Casa.

4. Interactividad. La aplicación reflejará directamente su opinión, seguidamente se puede transformar en un espacio político. La aplicación puede evolucionar, o tendría que hacerlo.

${ }^{4}$ v.- ED03 de Nirvánico-05. 
5. Consolidar la interactividad y mutua-dependencia entre los ciudadanos y el gobierno local. Asegura la democracia participativa genuina de los ciudadanos.

6. Se forma una imagen idiosincrásica de la ciudad para el turismo.

7. Sería una relación con menos negocio respecto los cuerpos del capitalismo. El turismo es recibido con un ambiente más amigable y a menor escala. El alojamiento y el guía están combinados por medio de un participante ciudadano y el turista. Esta intensidad de su intimidad supera al de los turismos vigentes de otra ciudad. Finalmente, se considerará al turista más a largo plazo, para su vuelta en un futuro.

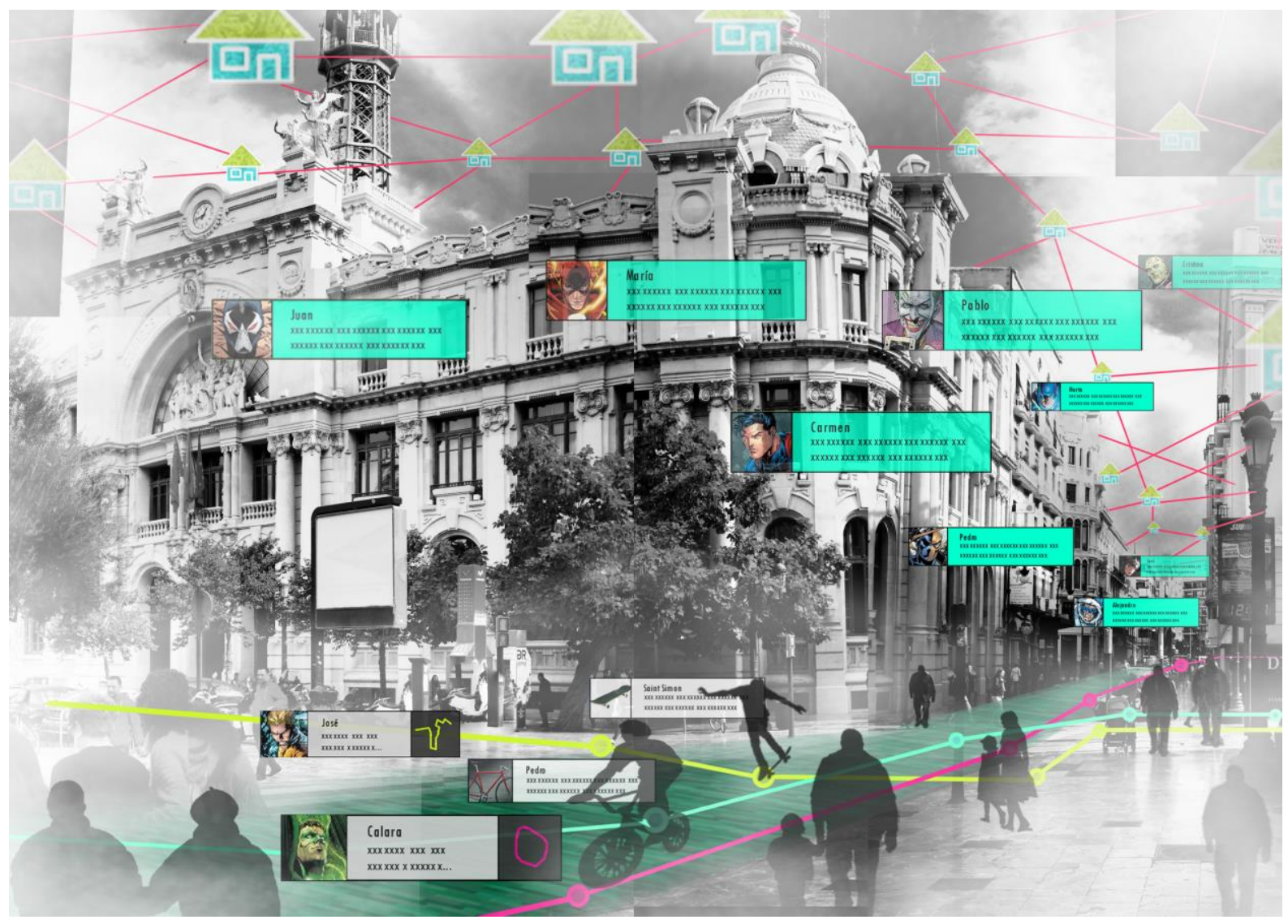

Fig. 13-5. Fotomontaje de Mi Casa Tu Casa.

Valoración por el criterio epistemológico con arreglo a la proposición nirvánica del capítulo 8 
En primer lugar, no cabe duda sobre la factibilidad del proyecto. Como está explicado en el anterior capítulo, los actores de este proyecto son: ciudadanos, turistas, cuerpos gubernamentales, negociadores de la comunidad, ONG, etc. La relación de intereses entre los actores y la credibilidad del proyecto, ya están explicadas en ED03 de CSD Nirvánico-05. En $<<$ Mi casa tu casa >, no existe las organizaciones absolutas. (Proposición sintética nº 0, Epistemología Nirvánica). Los ciudadanos participantes deciden el nivel de participación y expresan sus diversos deseos en las incesantes situaciones estratégicas. Los grupos turísticos surgen improvisadamente en el proceso de la producción de los itinerarios, y desaparecen en un instante después de satisfacer cada uno de los arbitrarios deseos. La aparición de los dharmas y su desaparición ocurren drásticamente en cada momento, esta dinámica hace que el proyecto sea sostenible. (Proposición sintética $n^{\circ} 4$, Epistemología Nirvánica). El canon de que ningún dharma tiene que ser absoluto, se aplica igualmente a los cuerpos gubernamentales y ONG. Ellos solamente están conectados para otros dharmas como asistentes, ya que la constelación puede descomponerse y sustituirse por otra forma y carácter de constelación. Es decir, los turismos obsoletos que no pueden percibir y captar los deseos de los actores dharmas turísticos, se descomponen. (Proposición sintética no 2, Epistemología Nirvánica). Y el proyecto está tratando los dharmas de CSD Mórbido-04, 05, 09, 13, 24 directamente. (Proposición sintética $n^{\circ}$ 3, Epistemología Nirvánica). Por medio de crear la página web y su aplicación para el Smartphone llamada <<Mi Casa Tu Casa >>, a los ciudadanos participantes les surgen ciertos intereses por su labor honesta y con las reglas del juego, el movimiento claro de los capitales ayuda al gobierno de la comunidad en el término de los impuestos. En el foro de la aplicación, instantáneamente e improvisadamente surgen los grupos de turistas y ciudadanos nativos según los gustos particulares, así surgen los incontables itinerarios para incorporar todos los barrios degradados y callejones de la ciudad. Cada día más la aplicación va a producir una actividad social dinámica.

\section{Valoración por el criterio ético con arreglo a la proposición nirvánica del capítulo 9}

Este proyecto está enseñando cómo el concepto de que los dharmas son efímeros puede provocar una acción ética visiblemente. Cada uno de los sujetos de las acciones, está conectado a la aplicacióndharma primeramente para el propio interés, sin embargo, el diagrama de flujo de la riqueza reproduce 
las riquezas y fluye a todos los dharmas conectados. Ayudarse a sí mismo y ayudar a los ajenos, esta distinción pierde el sentido ya que todos son beneficiarios. También es la ortodoxia en el término del adoctrinamiento del buddhismo $\left(\mathbf{N Y}^{5}\right)$. (Proposición sintética $n^{\circ}$ 0,1. Ética Nirvánica). El diagrama del proyecto produce los variados deseos de los sujetos. Desde la perspectiva gubernamental, el proyecto asegura la claridad de la microeconomía y puede proveer la protección apropiada a los consumidores y negociadores de escala pequeña desde el mercado negro por la ley. Los dharmas de los ciudadanos y los turistas incesantemente producen nuevos mapas para expresar sus propios deseos mezclándose con los de los ajenos, ahora el mapa se convierte en un producto turístico. Dentro del diagrama, los sujetos son consumidores y al mismo tiempo son productores, por eso esta estructura de la dualidad hace que el proyecto sea más sostenible. (Proposición sintética nํㅜ 3. Ética Nirvánica). Además, la forma en que los actores dharmas y las organizaciones acceden al proyecto de Mi Casa Tu Casa, tiene la peculiar apariencia del rizoma. Ellos en cualquier momento pueden cortar su conexión y pueden conectarse a otro dharma para formar otro CSD. (Proposición sintética nº 5. Ética Nirvánica).

\section{Valoración por el criterio estético con arreglo a la proposición nirvánica del capítulo 10}

El proyecto comienza desde un espacio virtual de Internet, y éste se completa cuando los actores dharmas recorren toda la ciudad pisando los pavimentos. Los turistas participantes, para completar cada uno su peculiar itinerario, se convierten en cartógrafos. Ellos deambulan por la calle desconocida. Y se adhieren a la ciudad con el cuerpo, ya no solamente en lo físico sino también con una intimidad y vinculación personal. Porque un cartógrafo para dibujar su cartografía en el proceso naturalmente necesita utilizar su propia energía y labor, pero en este caso se mezclan con materiales personales adicionales, por ejemplo, la memoria personal, tendencia de actividad, gusto gastronómico, el arte, la situación en la que el sujeto se encuentra, con quién va a realizar el viaje, el objetivo del viaje, etcétera. Todas las cartografías se completan con cariño mezclándose con dichos materiales personales. Lo que pisa el sujeto es ya un Espacio Nirvánico. El Espacio Nirvánico es un lugar que provee la experiencia corporal y anímica sana. (Proposición sintética no 3, 4. Estética Nirvánica). Y la apariencia de las cartografías que los participantes producen en el diagrama llamado Mi Casa Tu Casa es

\footnotetext{
${ }^{5}$ No-yo.-(NdA)
} 
totalmente rizomática. Porque se mezclan libremente accediendo a los ajenos participantes-dharmas en la web y ejemplificando otros datos de la web. La cartografía se completa atravesando las dimensiones físicas y no físicas. (Proposición sintética no 6. Estética Nirvánica) 


\section{NY Intervención 2}

\section{: La Cabaña de Cartón del Tío Tom}

Tipo de NY-Intervención: Espacio NY, Sostenibilidad del presente-futuro

Referencia con CSD Mórbido: 04, 05, 09, 13, 27

Hay un hombre que se puede encontrar en la calle Colón, allí él está sentado siempre mendigando. El nombre de ese señor es Tom y tiene una discapacidad en la pierna. El verano de Valencia es más caliente que en cualquier otra ciudad europea, pero también esta ciudad tiene un invierno bastante frío debido a la humedad del mar Mediterráneo. Sin embargo, el tío Tom, este año no tiene tanta preocupación comparable con sus anteriores inviernos. El mes pasado, el tío Tom pudo conectarse a un restaurante local por medio del programa de la inclusión social encargado por el ayuntamiento de Valencia como proyecto de regeneración urbana. El tío Tom va cada dos días a una taberna que está ubicada en la Calle Ciscar. Tom dijo que le parecía que ese restaurante se estaba encargando de las alimentaciones de los que están en alguna situación problemática como él. Según el comentario del jefe de dicha taberna, como es característico del restaurante es inevitable que ellos preparen los ingredientes frescos cada día, sin importar que pudiesen o no venderlo todo. Considerando la complejidad de la sociedad, la crisis también es fatídicamente multidisciplinaria. Generalmente a las personas si no les conviene la situación del bolsillo, de todas formas, pueden comer en casa en un precio humilde y económico, sin gastar el pago extravagante del restaurante. Por eso, la industria de la alimentación y hostelería son sensibles a las circunstancias económicas. Pero, gracias al programa de la inclusión social del ayuntamiento, aunque no tuviesen una colosal convicción moral, los negociadores de los restaurantes, han podido llegar a una conclusión de que es un beneficio mutuo. Proveyendo las comidas a los mendigos, ellos reciben una ventaja con la reducción de impuestos y un subsidio económico desde el gobierno. Eso sería posible, porque el gobierno tiene una cierta proporción del presupuesto para asignar a este tipo de proyecto como el bienestar e higiene pública, pero para eso el gobierno necesita un colaborador para administrar los proyectos y labores. En este caso, cooperando con un grupo de ONG se ha podido solucionar este tipo de problema fácilmente sin crear un nuevo departamento para este proyecto. Para poder realizar el proyecto, el gobierno 
necesitaba numerosos expertos de los campos de la sociología, economía, TIC (tecnología de la información y la comunicación) y etcétera. Eso significa un gasto enorme del prepuesto que se relaciona con la factibilidad del proyecto directamente. Pero, la ONG, con sus varios años de experiencia en este campo, ha planeado toda la agrupación de los mendigos y los restaurantes con detalle en los cálculos económicos de cada barrio. Sin un proceso burocrático en el cual la toma de decisión suele ser paulatina, el proyecto se desarrolló rápidamente. Como los actores-dharmas se conectan unos a otros en un mismo nivel democrático, el feedback también fue rápido. Es decir, para el gobierno, los negociadores, ONG y otros varios actores, el plan fue una delicia. Desde la perspectiva económica, el gobierno ha podido ahorrar un presupuesto de cantidad considerable, los negociadores han podido recibir un subsidio y ventaja del impuesto, los mendigos no mueren en el invierno por hambruna. Y en la perspectiva social, los actores experimentan físicamente, participan y se dedican al proyecto con sus energías y tiempo, así se visualiza en el plan claramente el vínculo con la comunidad y el patriotismo. En algún momento en la ciudad ha surgido un fenómeno en el que los restaurantes locales quieren colaborar en este proyecto del Tío Tom, ya que algunos ciudadanos prefieren comer en estos restaurantes para que alguna proporción de su gasto sea destinado al donativo. Así se ha creado una nueva cultura de donación. ${ }^{6}$

Es beneficioso considerando el gasto secundario que surge de la necesidad social, por ejemplo, ante los pequeños delitos de los mendigos y la seguridad de la calle. Según el comentario del director del proyecto del ayuntamiento, desde este año, después de iniciar el plan de la inclusión social, la tasa de los delitos de los mendigos ha disminuido notablemente. Así que el gasto en la acción de patrulla, ambulancia y camión de bomberos disminuye, por lo que también baja el gasto para administrar el centro de detención y prisión. De manera multilateral, este proyecto estaba sacando un efecto sinérgico.

Y ahora, el ayuntamiento, como un proyecto adicional, anunció un plan llamado <<La cabaña del tío Tom >> para proteger a los ciudadanos que no tienen hogar en el invierno, porque el tío Tom ahora puede solucionar su problema de alimentación, pero sigue estando sin hogar. El equipo del proyecto

\footnotetext{
${ }^{6}$ Sí que existía esta forma de donación, sin embargo, este proyecto tiene más intimidad entre los donantes y los intermediarios en la medida en que los donantes pueden sentir el proyecto dentro de los procesos y la sensación de participación en la piel, creciendo juntos en la misma sociedad. Además, el primer motivo de la donación es que no es necesario que sea filantrópica. Lo esencial de este proyecto es demostrar las relaciones de los dharmas individuales funcionando respectivamente, pero con mayor perspectiva, están viviendo y creciendo juntos. Es decir, la virtud de No-yo.
} 
del ayuntamiento ha decidido distribuir las casas de cartón a los sin-hogares. El requisito para recibir el beneficio del proyecto es fácil. Primero, el solicitante tiene que registrarse en el ayuntamiento con sus datos personal como: nombre, sexo, edad, y presentar la condición de que asiste a una escuela de capacitación profesional. Después de afirmar dicha condición, los registrados sin-hogar reciben los beneficios del proyecto que son: en primer lugar, la casa de cartón debe tener una función de termoaislamiento, en segundo lugar, se asigna a un restaurante del barrio como el tío Tom, con el mismo programa de la inclusión social del equipo y en tercer lugar asistir al taller de capacitación profesional. Constantemente los agentes de la ONG y el ayuntamiento proveen las oportunidades de encontrar trabajos relacionados con las técnicas que habrían adquirido en el taller. La casa de cartón fue diseñada gracias a la asociación con un equipo de investigación de la Universidad. La casa, como es de cartón, era posible de plegar y desplegar. Además, por su ligereza de material, tenía libertad de su movilidad. La casa fue diseñada sólo para sentarse y tumbarse dentro. A cada casa de cartón se le asigna un número registrado por el equipo de ONG, también se le asigna una particular dirección con el código postal del barrio. De esta manera el gobierno ha sido más capaz de reconocer la cantidad de los sin-hogares y facilita que los políticos tomen las decisiones acordes a esto. El primer objetivo de este proyecto fue proteger los sin-hogares y capacitarles para que puedan encontrar un empleo digno y no aislarlos de la sociedad.

Los lugares para las instalaciones han sido realizados por medio de las participaciones de los ciudadanos. El ayuntamiento recibió las solicitaciones de las comunidades de las fincas. Y después de unos procesos de reflexión con los criterios de los expertos de ONG, las fincas seleccionadas reciben un curso de educación según las normas especiales elaboradas por los psicólogos, sociólogos, pedagogos de la educación especial y diversos consejeros para que los residentes eviten racismo o cualquier tipo de maltrato y discriminación que ocurre a veces sin querer por ignorancia. Las casas de cartón entran en las fincas. Es necesario porque los cartones especiales tienen resistencia contra la lluvia y nieve, pero no fueron diseñados para que aguanten todo el invierno por razones económicas. Además, los sin-hogares, de esta manera pueden experimentar una vida colectiva con la comunidad. También es un proceso imprescindible en el término de la inclusión social. Así que, en un futuro, los sin-hogares pueden pertenecer a alguna sociedad sin una resistencia mental y los originales residentes 
de las fincas pueden cultivar la mentalidad más abierta en la que los sin-hogares son iguales como ellos. Después de pasar las reflexiones del equipo del proyecto, las fincas de los barrios reciben nuevos residentes, personas sin-hogar. En los casales de las fallas de las fincas, no ocupando mucho volumen, las cajas de cartón han sido instaladas recibiendo muchas bienvenidas de los falleros. Y el gobierno de la comunidad ha pensado un sistema de compensación de este programa. Los detalles de dicho sistema se han diseñado por los expertos del grupo de la ONG basándose en las teorías de los juegos donde se colocan los actores en las situaciones estratégicas según las tomas de decisiones de los actores, constantemente.

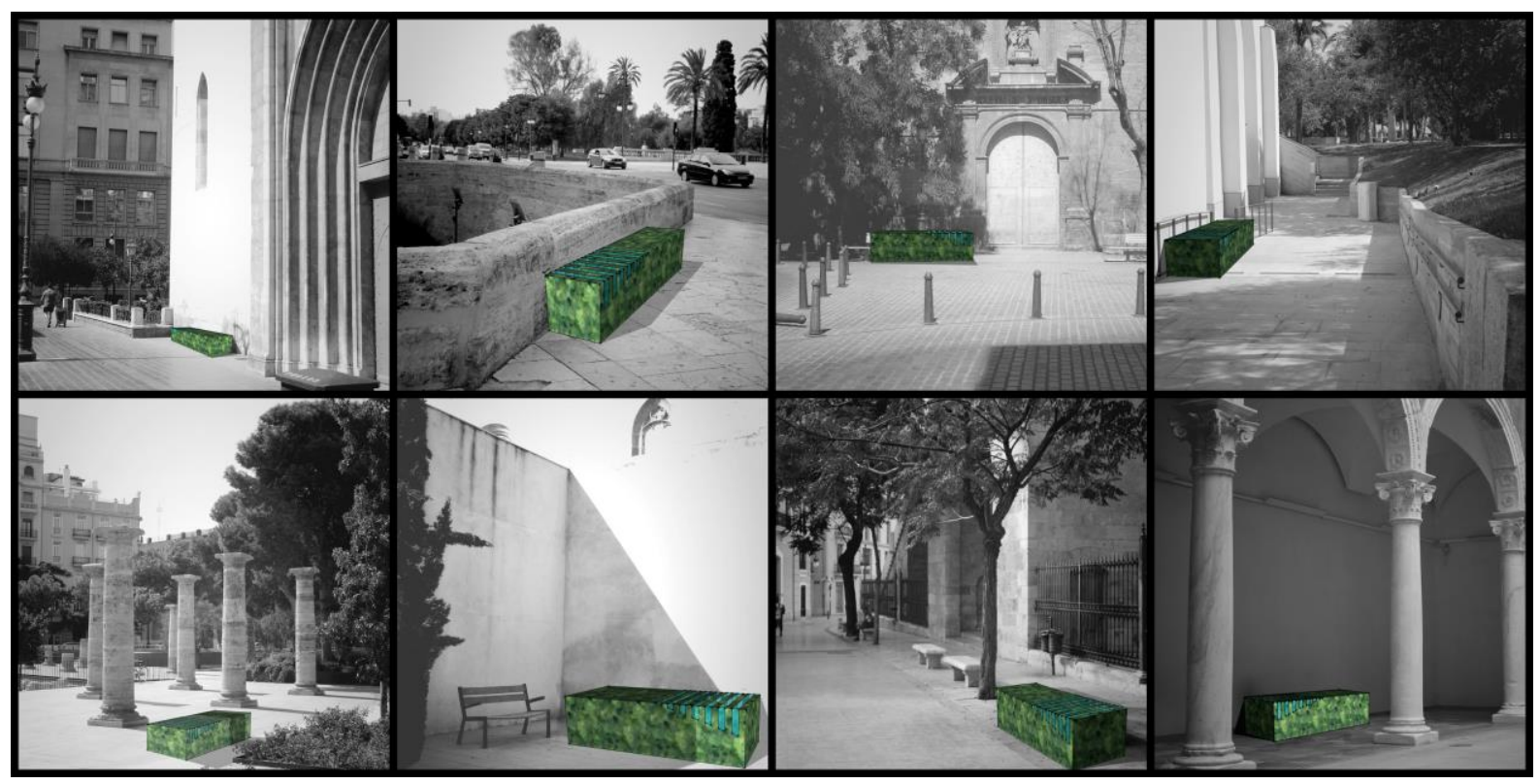

Figs. 13-6. Refugio de la calle.

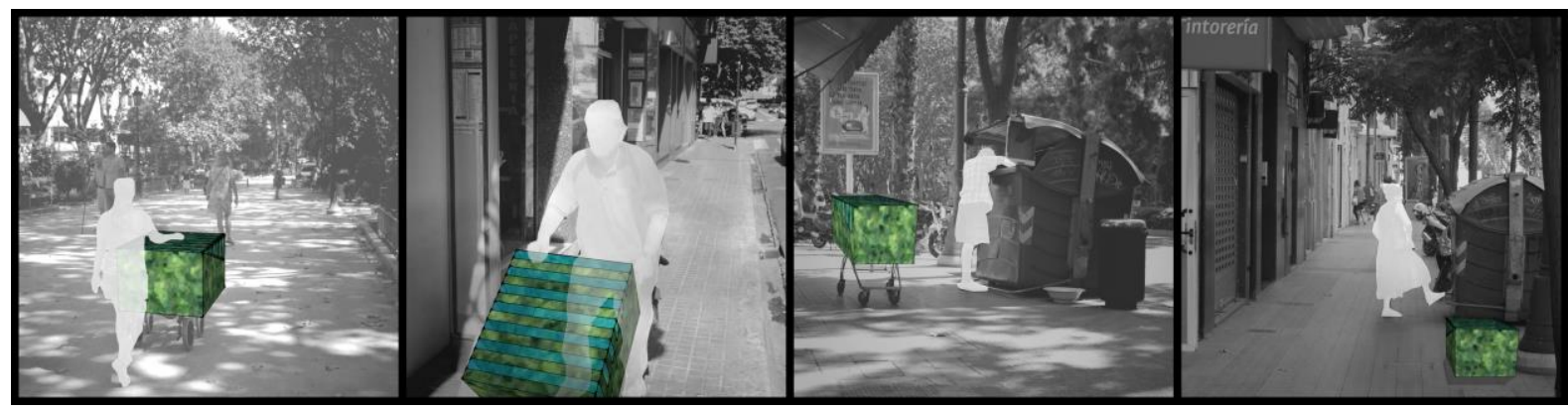

Figs. 13-7. Movilidad del refugio. 


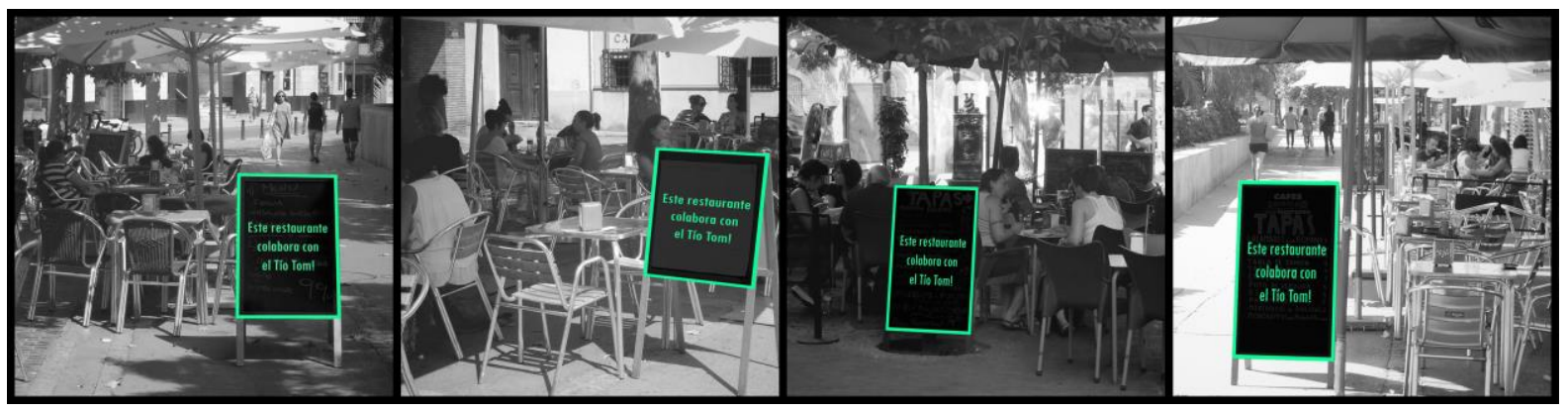

Figs. 13-8. Colaboración de los restaurantes.

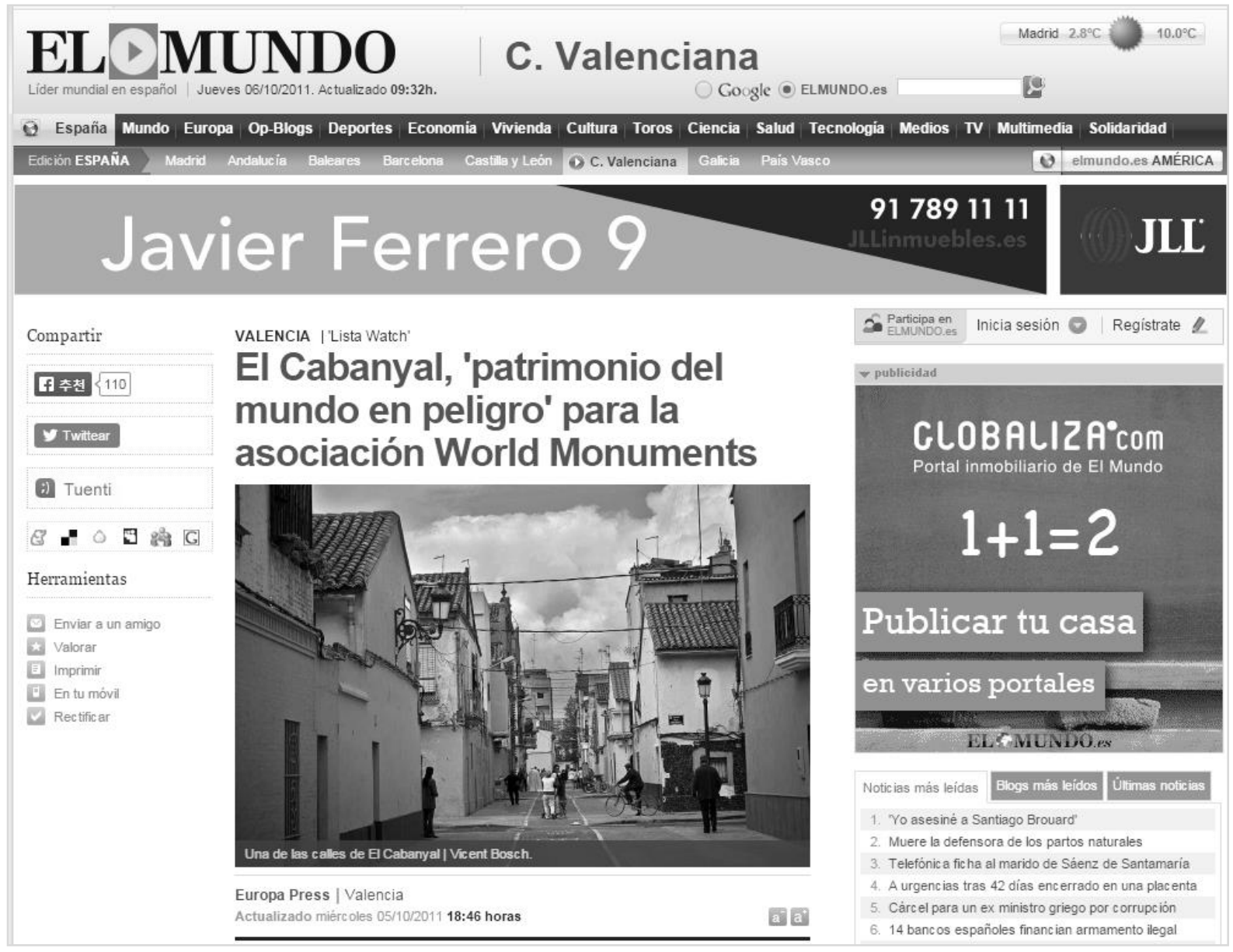

Fig. 13-9. Artículo de El Mundo. 


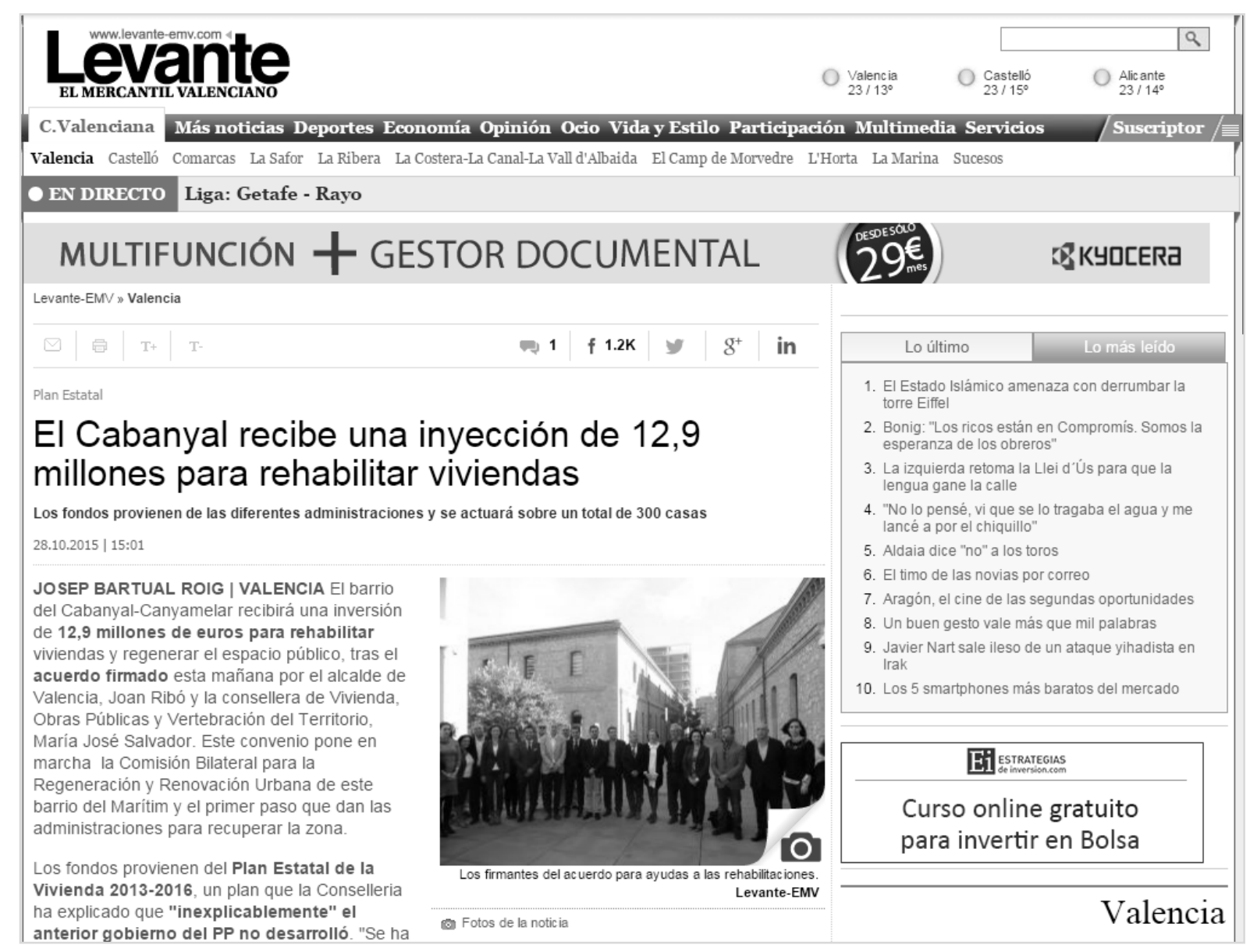

Fig. 13-10. Artículo de Levante.

El equipo que había desarrollado el proyecto llamado $<<$ Mi Casa Tu Casa $>>$, que es una rama del departamento de la regeneración urbana del ayuntamiento, ha decidido lanzar un nuevo proyecto mediante la cooperación con la UNESCO. ${ }^{7}$ El equipo ha cooperado con numerosos expertos nacionales e internacionales para estudiar sobre el casco urbano de Valencia y otros edificios históricos que son de uso residencial. Recogiendo y acumulando los datos, el equipo ha empezado a reconocer los asuntos relativos al patrimonio histórico en profundidad. Además, los menesteres y problemas de los barrios, la rehabilitación social, la conservación de lo histórico y los valores culturales estaban incluidos en el área de la intervención. ${ }^{8}$ Pronto, haciendo incesantes actividades de lobby en la UE por

\footnotetext{
${ }^{7}$ La historia del programa MEDA II, fue un caso real en Estambul. La manera del procedimiento y el desarrollo es una mera nueva versión revestida de dicho caso. En este estudio, ha prestado su historia para demostrar cómo el proyecto puede realizarse. Solamente, algunas denominaciones se han sustituido adaptándose a Valencia. -(NdA) Para más informaciones véase: Müge Akkar Ercan. "Challenges and conflicts in achieving sustainable communities in historic neighbourhoods of Istanbul". Habitat International. № 35. 2011. pp. 295-306.

${ }^{8}$ Müge Akkar Ercan. "Challenges and conflicts in achieving sustainable communities in historic neighbourhoods of Istanbul". Habitat International. № 35. 2011. p. 301.
} 
los miembros del proyecto del departamento y de los especialistas de las ONGs, el proyecto ha podido entrar en la lista de los proyectos de la UE, para que sea financiado dentro del programa MEDA II. ${ }^{9} \mathrm{La}$ financiación inicial ha sido medida en 14 millones de euros por el programa cubriendo 5 años del periodo, y 9,3 millones de euros de la contribución municipal han sido reservados para el proyecto. ${ }^{10}$ Diversos tipos de expertos han participado para perfeccionar el proyecto sin distinguir los caracteres de los cuerpos ya sean gubernamentales, especulativos, filantrópicos u ONGs. AUMSA Actuaciones Urbanas Municipales SA es una empresa de desarrollo en la cual el $50 \%$ de la propiedad es de la Ciudad de Valencia, IMC Consulting que es una empresa consultora de Reino Unido, GRET que es un grupo de intercambio tecnológico y de investigación con sede en Francia, Fondo para el Apoyo de los Trabajos de Mujeres que es una organización española no-gubernamental, numerosos cuerpos y organizaciones internacionales han participado para ayudar a que el proyecto salga con éxito. ${ }^{11} \mathrm{El}$ equipo del proyecto trabaja de una manera democrática y rizomática comunicando en el tiempo real con feedback, sin tener ningún cuerpo centralizado. Por eso en el proceso de la toma de decisión se ha podido procesar con velocidad. El equipo del proyecto basándose en los datos analizados por los consultores del programa MEDA II, ha decidido intervenir en la situación donde la vida urbana cada día se destruye por el pobre paisaje urbano, pobreza social y la transformación gradual del casco urbano en un barrio degradado. Primero, el equipo ha intervenido a nivel de las calles revistiendo los pavimentos viejos y rotos, re-diseñando las rampas y escaleras, poniendo nuevos muebles urbanos de diseño cuidado. ${ }^{12}$ Y luego, ha empezado categorizando los datos dados del programa MEDA II. Según la gravedad de las condiciones de los edificios, se han detectado 3 niveles de urgencias como: una reparación extensiva, media y básica. En el rango de intervención de los edificios antiguos del casco urbano, se incluye más o menos los siguientes trabajos: crear habitaciones más grandes, baños separados del inodoro, crear una cocina independiente, reparar las escaleras, reparar las paredes

\footnotetext{
9 ...El programa MEDA puede financiar asistencia técnica, formación, desarrollo institucional, información, seminarios, estudios, proyectos de inversión e iniciativas que pongan de manifiesto el carácter comunitario de la ayuda...Fuente online: $<$ http://europa.eu/legislation_summaries/external_relations/relations_with_third_countries/mediterranean_partner_countries/r15 006_es.htm>

${ }^{10}$ Müge Akkar Ercan. "Challenges and conflicts in achieving sustainable communities in historic neighbourhoods of Istanbul". Habitat International. № 35. 2011. p. 301.

11 Ibid.

12 lbid.
} 
interiores, techos y suelos, asegurar la estructura, conectarse a la red de gas natural, reparar las fachadas y cubiertas, renovar el sistema eléctrico, etc. ${ }^{13}$

Sin embargo, no todos los edificios solicitados se han aceptado en este programa. De todas formas, los beneficios del proyecto podían ser efectivos con la condición de que los residentes de las fincas y otros interesados demostrarán las actitudes activas al participar en el juego. Como se refirió anteriormente, este proyecto tiene un sistema de compensación. Las fincas que han participado en el proyecto de <<La Cabaña de Cartón del Tío Tom>>, y los ciudadanos que han participado en el proyecto de Mi Casa Tú Casa, han sido prioritarios para esta oferta. Restaurando las arquitecturas en el centro histórico, aparte de los hoteles, los alojamientos de los particulares han sido más atractivos y se ha vivificado más el proyecto de $<<$ Mi Casa Tu Casa $>$. Pero, los verdaderos beneficiarios, los dueños de los locales y los edificios, tenían que firmar la condición antes de ejecutar las renovaciones de sus propiedades, afirmando que no van a subir el precio del alquiler ni de venta durante los próximos 5 años para evitar los movimientos especulativos. El equipo ha llegado a la conclusión de que son necesarios más equipos para poder ejecutar el proyecto. Por eso, al iniciar las renovaciones en los barrios degradados y edificios antiguos, de una vez se ha creado 400 trabajos fijos que anteriormente eran renovables. Además, el equipo ha contratado 20 trabajadores entre los jóvenes profesionales de la localidad a fin de que pudiesen ganar experiencias en las restauraciones arquitectónicas y que enseñen y entrenen a los que atienden en el taller de capacitación profesional como el tío Tom. El tío Tom también ha podido encontrar un sitio para la práctica con una condición permanente. En el primer curso, aproximadamente 50 personas se han entrenado y capacitado para trabajar. Era una intervención holística en el aspecto de la regeneración urbana.

\section{Valoración por el criterio epistemológico con arreglo a la proposición nirvánica del capítulo 8}

El proyecto llamado <<La Cabaña de Cartón del Tío Tom >> ha sido un juego de escenario que ha demostrado exitosamente cómo un $\mathbf{C S D}^{14}$ dharma de una forma de red rizomática funciona en los

\footnotetext{
13 Ibid. p. 302.

${ }^{14}$ Co-surgimiento dependiente.-(NdA)
} 
campos multidisciplinares con sinergia. Los elementos que se percibieron como CSD Mórbidos, se han categorizado apropiadamente, y las relaciones entre los dharmas también se han podido observar. Los actores-dharmas a veces abandonando su antiguo propio papel, tomaban otros papeles para que encajaran en un gran ED ${ }^{15}$ proceso. Los cuerpos conectados a CSD llamado $<<$ La Cabaña de Cartón del Tío Tom>> cada uno perseguía su propio propósito libremente transformándose en otra forma de dharma en el esquema de CSD. Aquí un capitalismo-dharma a veces se transforma en una filantropíadharma. (Proposición sintética no 0. Epistemología Nirvánica). El partnership (asociación) ha hecho posible las participaciones de los expertos multidisciplinares y la garantía del presupuesto para la realización del proyecto que es siempre lo más difícil. La factibilidad y la sostenibilidad del proyecto se han demostrado por el diagrama claramente. De hecho, la parte de la rehabilitación de los edificios del centro histórico, se ha basado en un caso real de Estambul cuyo resultado fue también exitoso. (Proposición sintética no 1, 4. Epistemología Nirvánica). Indudablemente, el proyecto es sostenible porque el ED proceso se ha tratado como $\mathbf{A D}^{16}$ proceso directamente, así que la constelación de los pervertidos dharmas que solamente producían las agonías y dolores, se ha descompuesto. (Proposición sintética no 3, 4. Epistemología Nirvánica).

\section{Valoración por el criterio ético con arreglo a la proposición nirvánica del capítulo 9}

En el proceso y desarrollo del proyecto, aunque al principio los actores-dharmas tenían cada uno diferentes motivos, los caracteres de los dharmas empiezan tener distintos colores porque el diagrama de CSD fue diseñado para que reprodujese la bondad colectiva desde el principio. Los dharmas se incorporan deseando cada uno sus particulares intereses, pero en una gran perspectiva, CSD ha sido un enorme ED. (Proposición sintética nº 0, 1, 3. Ética Nirvánica). Cuando el equipo del proyecto diseñó el diagrama de una forma rizomática, ya era posible de predecir lo que CSD va a producir según su virtud excelente. (Proposición sintética no 2, 4, 5. Ética Nirvánica). Además, el equipo ha demostrado que el diagrama fue efectivo en el aspecto social, no sólo en el aspecto de la regeneración urbana física. Y la ciudad iba a experimentar un cambio drástico de una manera rizomática. Esto actúa como

\footnotetext{
${ }^{15}$ Extinción del Dolor.-(NdA)

${ }^{16}$ Acumulación del Dolor.-(NdA)
} 
una guerrilla, sin ningún centro específico de la expansión, al final cubre toda la ciudad poco a poco. (Proposición sintética no 7. Ética Nirvánica).

Valoración por el criterio estético con arreglo a la proposición nirvánica del capítulo 10

Obviamente, la forma nirvánica implica una práctica corporal y anímica. En este NY Intervención, se observa en un proyecto cómo los individuales actores-dharmas se incorporan generando diversos CSDs, en los campos multidisciplinares de la sociología, la economía, la política, el urbanismo, etc. Una asociación rizomática ha facilitado la generación de los cuerpos de dharmas que tienen nuevos objetivos sociales y políticos. Como son rizomas, los complejos caracteres de dharmas se han reunido y mezclado. El espacio en el que el escenario se desarrolla, es totalmente de $\mathbf{N Y}^{17}$. Además, este proyecto se expande desde una casa a otra, así provoca el nirvana de esta ciudad, que fue una gran máquina de $\mathbf{A D}^{18}$. (Proposición sintética $n^{\circ}$ 3, 4, 6, 7, 8, 9. Estética Nirvánica)

\footnotetext{
${ }^{17}$ No-yo.-(NdA)

${ }^{18}$ Acumulación del Dolor.-(NdA)
} 


\section{NY Intervención 3}

\section{: Camino de Todos Santos}

Tipo de NY-Intervención: Espacio NY, Sostenibilidad de la memoria.

Referencia con CSD Mórbido: 03, 07, 11, 12, 17, 21, 26, 27, 28, 29.

La acción de andar es una actividad física que se comprende desde un punto geográfico hasta otro punto, pero también es una actividad social en la medida en que el hombre se encuentra con el entorno durante el viaje diario y eso puede involucrar numerosas intervenciones de otros seres aun cuando el hombre no tuviese un cierto objetivo de acción. En el periodo de Las Fallas, que es el más grande festival de Valencia, los valencianos andan las calles y dominan la ciudad. En este período la mayoría de las grandes avenidas y calles del centro se adaptan para los peatones. Y los ciudadanos se reúnen en La Plaza del Ayuntamiento para escuchar los petardos del pirotécnico y ver la cremà. Superficialmente, la mayoría de las acciones son así, sin embargo, en el proceso de éstas, la gente se mezcla con los ajenos en un espacio público, y experimenta sensorialmente con ojos, piel y oídos las emociones que los otros ciudadanos producen en el mismo espacio. En todo el período de Las Fallas, la gente camina por la calle. En el proceso de esta acción repetitiva, el sujeto produce la experiencia mezclando una práctica corporal y los datos sensoriales que se habrían generado en el entorno durante su viaje. Al fin, como un complejo bagaje las memorias del hombre se impregnan en el cuerpo. Cuando el sujeto camina por el espacio histórico de la ciudad, la historia se impregna en el cuerpo del peatón. Esta recién hecha experiencia personal, es una nueva capa de la historia que se acumula como un nuevo estrato. Dicha experiencia personal aún no es la historia de la calle, sino que se queda como una imagen, originalmente igual que todas las capas de la historia. De este modo, la ciudad puede ser cada vez más sostenible en la memoria. Eso provoca que el hombre se acerque más a la ciudad. La inclusión social puede ser un regalo de la sostenibilidad de la memoria.

1. Ruta 1. Una ruta, tipo lineal que conecta las plazas y las zonas verdes, desde la Estación del Norte hacia los Jardines del Turia. 
Estación del Norte \& Plaza de Toros - Plaza del Ayuntamiento - Plaza de la Reina - Catedral de València - Plaza de la Virgen - Torres de Serranos - Jardín del Turia - Museo de Bellas Artes de Valencia - Jardines del Real - Avenida Blasco lbáñez - Playa La Malvarrosa - Puerto de Valencia.

2. Ruta 2. Una ruta, tipo lineal que empieza desde la Estación del Norte e intenta conectar el centro histórico con las partes oeste de Valencia

Estación del Norte \& Plaza de Toros - Plaza del Ayuntamiento -Mercado Central de Valencia \& La Lonja de la Seda - Plaza del Tossal - Calle Quart - Torres de Quart - Jardín Botánico IVAM (Institut Valencià d’Art Modern) - Jardín del Turia - Parque de Cabecera - BioParc.

3. Ruta 3. Una ruta, tipo circulatorio que dibuja la silueta del centro histórico de Valencia.

Calle Xàtiva - Calle de Guillem de Castro \& Paseo Pechina - Calle Blanquería - Calle Conde de Trenor - Calle Pintor López - Plaza Temple - Plaza Tetuán - Plaza Alfonso El Magnánimo - Calle Colòn - Calle Xàtiva.

4. Ruta 4. Una ruta, tipo circulatorio para estimular las zonas degeneradas y abandonadas conectando con los Jardines del Turia y las grandes vías con mejor accesibilidad. (CSD Mórbido-04, 05, 13, 14, 17, 19, 20, 21, 22, 27, 28)

Jardín del Turia - Gran Vía Marqués del Turia - Gran Vía de las Germanías - Gran Vía de Ramón y Cajal - Gran Vía de Fernando el Católico - Jardín del Turia. 


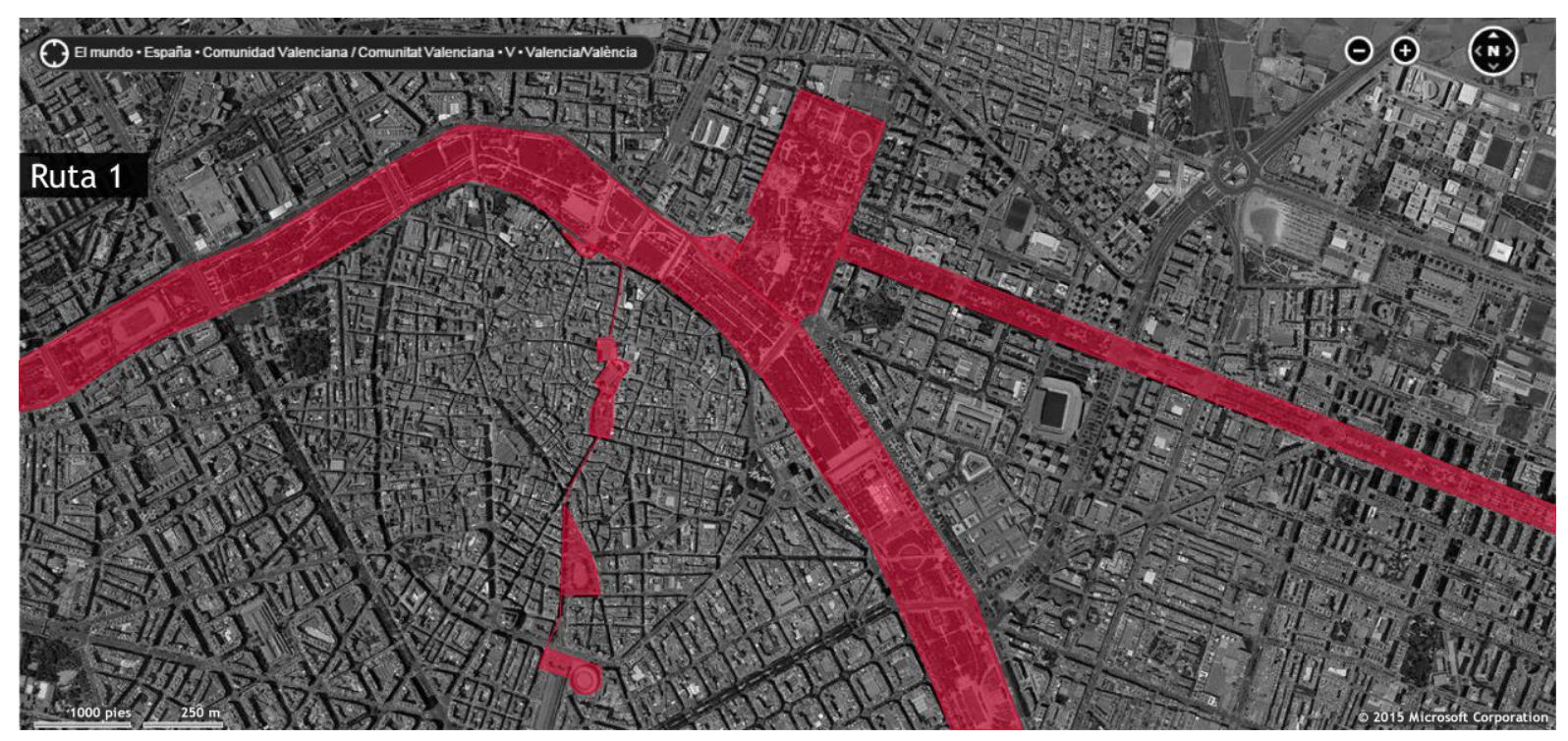

Fig. 13-11. Ruta 1.

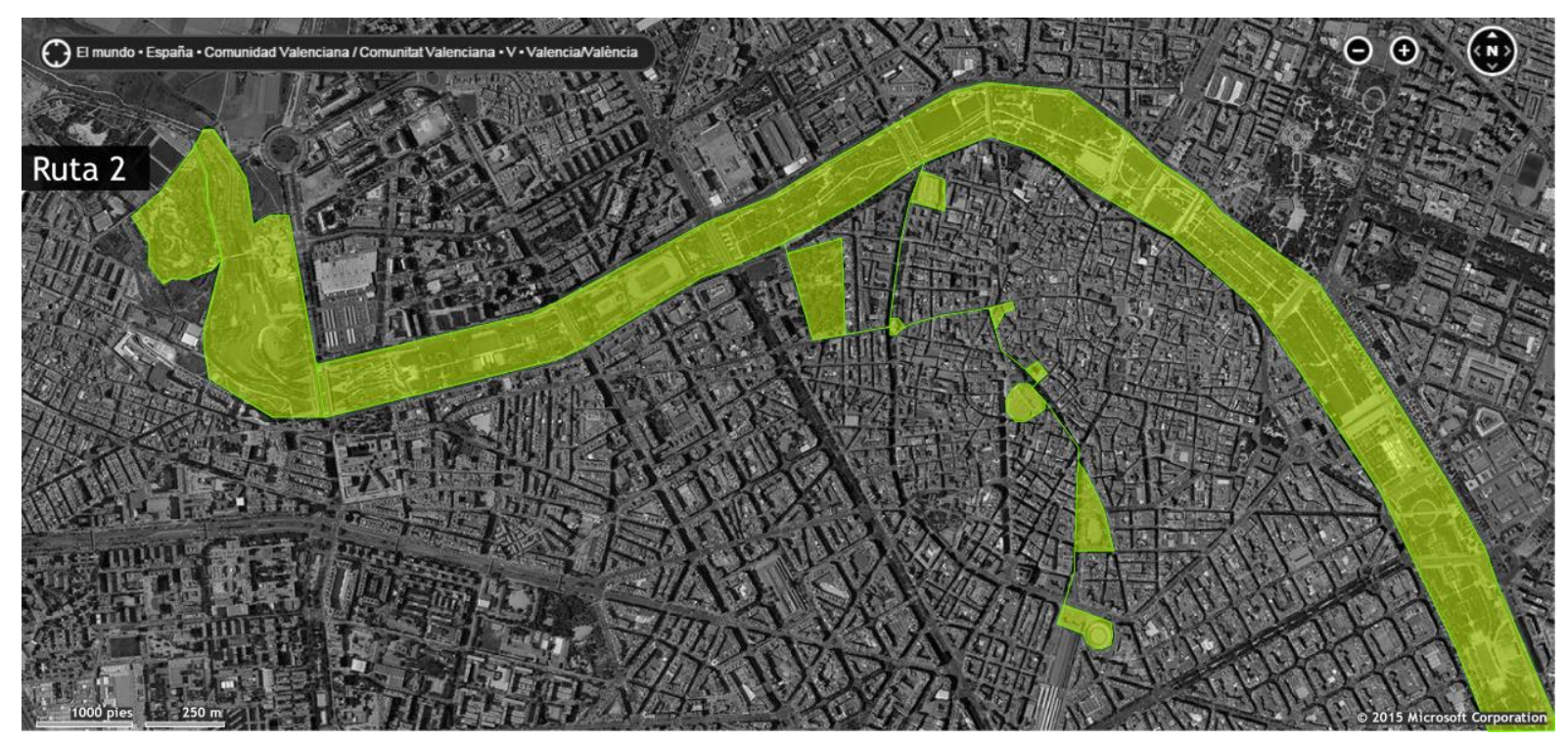

Fig. 13-12. Ruta 2. 


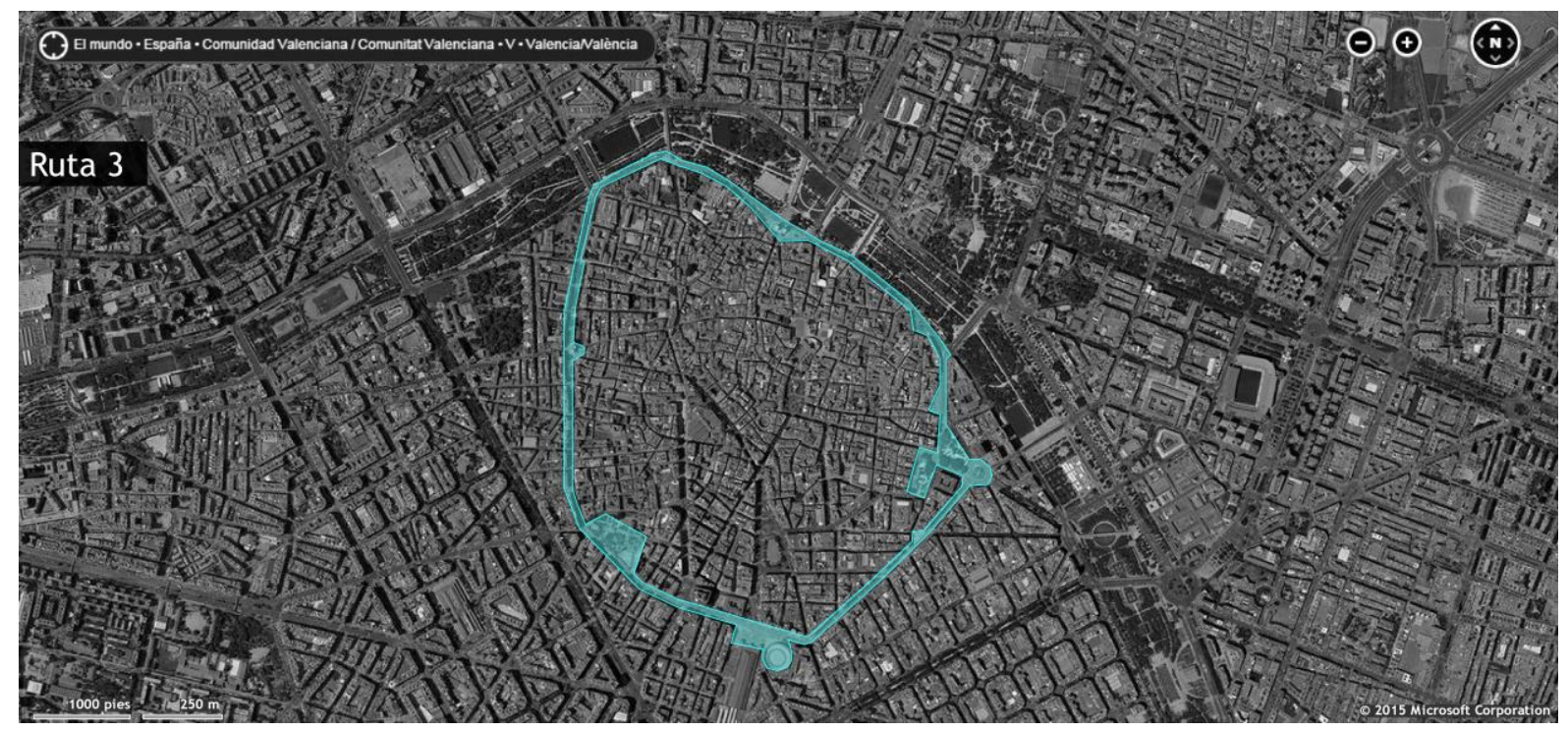

Fig. 13-13. Ruta 3.

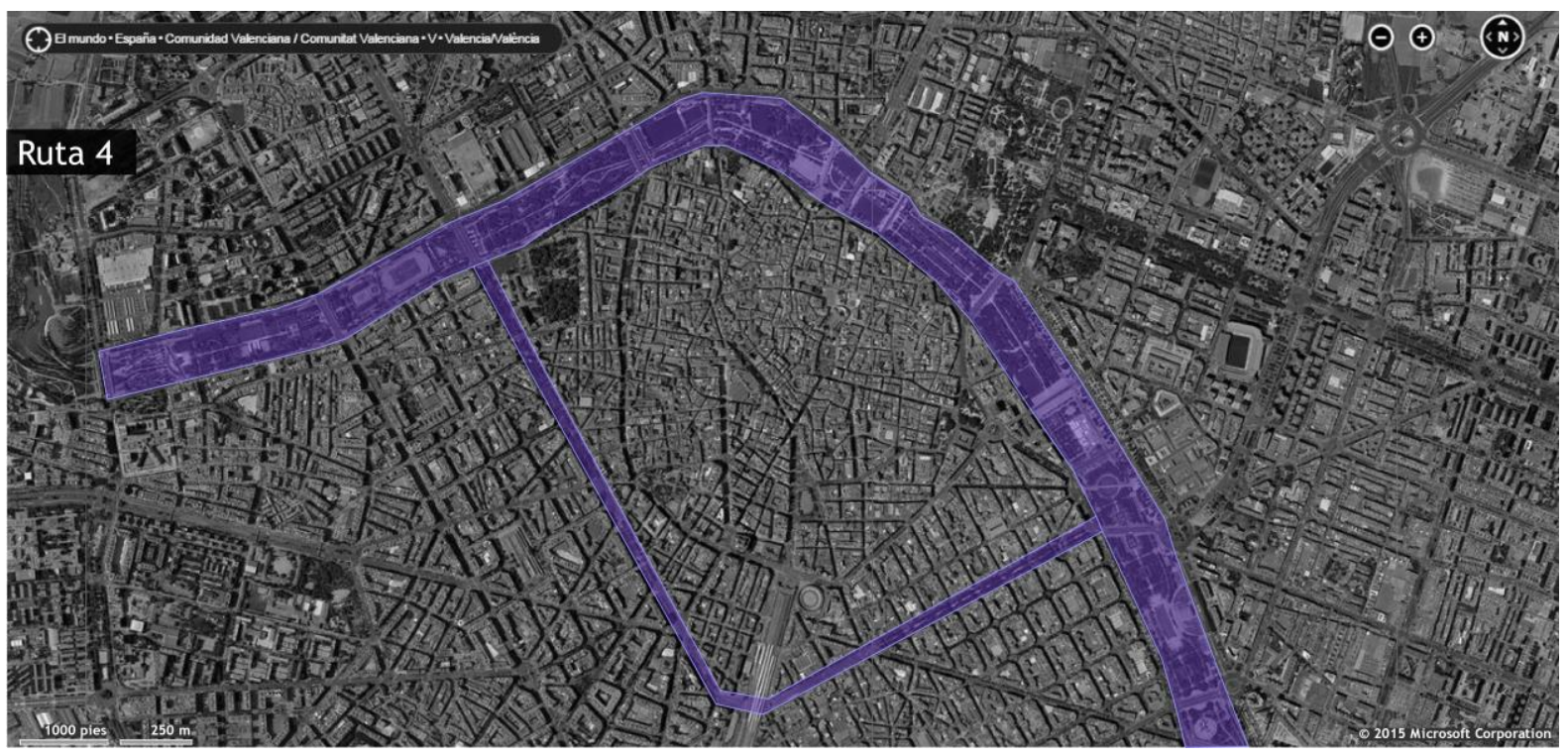

Fig. 13-14. Ruta 4.

Valoración por el criterio epistemológico con arreglo a la proposición nirvánica del capítulo 8

Las 4 rutas sugeridas como un prototipo del proyecto invitan a los hombres a los paseos cotidianos. Un camino puede ser solo un espacio transitorio para llegar a algún lugar específico, pero por lo menos en este proyecto, un camino puede tener su propio sentido por todas las actividades que surgen en dicho espacio transitorio. Este proyecto llamado "Camino de Todos los Santos" es la voz de los espacios cotidianos de las calles de Valencia, que hace a la gente reconocer que había otro estilo en 
el uso de las calles sin seguir el ritmo de las máquinas. El proyecto no pretende deshacer todo el sistema preexistente, sino que tan solo quiere asegurar un mínimo de espacio en el que se pueda sembrar este tipo de conciencia social. (Proposición sintética no 0, 1. Epistemología Nirvánica). Los sistemas actuales de tráfico y del peatón resultan una constelación sólida realizada por los diversos dharmas que siguen la ideología utilitarista, y por otra parte el Camino de Todos los Santos analiza los vínculos entre los dharmas mal hechos e intenta reorganizarlos o crear un dharma totalmente nuevo para insertarlo en la combinación de los dharmas actuales. (Proposición sintética nํ2, 3. Epistemología Nirvánica). Todas las prácticas que se ejercitan en las calles se acumulan en la memoria de los sujetos y gracias a sus características las rutas pueden deformarse e incesantemente producir nuevas cartografías. (Proposición sintética nº 4. Epistemología Nirvánica).

\section{Valoración por el criterio ético con arreglo a la proposición nirvánica del capítulo 9}

La barbaridad del vigente sistema de tráfico y la pobre condición de los peatones son dharmas de AD. Y las cuatro rutas pueden tratar directamente esos vínculos, que son dharmas de AD. Todos los dharmas son efímeros, así que se deshacen en el proceso de ED. (Proposición sintética no 0 . Ética Nirvánica). Por la razón de que las cuatro rutas son CSD, ellas se pueden descomponer, conectar, modificar libremente por los sujetos que las utilizarán en un futuro. (Proposición sintética no 2. Ética Nirvánica). Como se ve en los caracteres de los dharmas los cuales consisten en la generalidad del proyecto, el Camino de Todos Santos no trata sólo de un aspecto físico sino de una vida saludable en aspecto físico y anímico. (Proposición sintética no 3, 4. Ética Nirvánica). Repitiendo lo dicho, el proyecto también es un dharma. Los dharmas de varias dimensiones forman un CSD de manera rizomática. Debido a que el método de hacer un CSD es rizomático, también lo es el proceso de su muerte. (Proposición sintética no 5 . Ética Nirvánica).

\section{Valoración por el criterio estético con arreglo a la proposición nirvánica del capítulo 10}

Todas las creaciones y destrucciones de los dharmas son experimentadas por los sujetos que caminan las rutas. Los sujetos, dentro del proyecto, conocen la angustia y la paz. Es decir, el proyecto en sí 
mismo es una herramienta para llegar al nirvana. (Proposición sintética $n^{\circ} 0$. Estética Nirvánica). El diseño del proyecto se enfoca en los cambios que los sujetos perciben según el transcurso del tiempo en sus vidas cotidianas. (CSD Nirvánico-04). La sostenibilidad del proyecto depende de la repetición de las prácticas. Una experiencia cotidiana personal no se hace saber como la historia o la memoria de la ciudad, sino que posiblemente la mayor parte de ella se quede insignificante al final. Pero si se repite con el tiempo, en la calle, una memoria o algún particular recuerdo surgirá y formará una capa, y si se repite de este modo todo se irá acumulando. El proyecto intenta también tratar el tema de la inclusión social. Las acciones que surgen de las cuatro rutas no son imágenes estáticas, sino que siempre están en un proceso de gran acumulación en las memorias mediante la apropiada consideración del pasado y del presente. (Proposición sintética nº 5. Estética Nirvánica). Además, los caminantes poseen el poder de modificar libremente las cartografías, es decir, de realizar la virtud de NY. (Proposición sintética nº 7. Estética Nirvánica). 


\section{NY Intervención 4}

\section{: Galería-Túnel del tiempo}

Tipo de NY-Intervención: Espacio NY, Espacio Nirvánico.

Referencia con CSD Mórbido: 01, 02, 05, 08, 10, 13, 14, 15, 16, 19, 20, 22, 23, 25, 26, 27, 29

Ubicación: Gran Vía Marqués del Turia - Río Turia

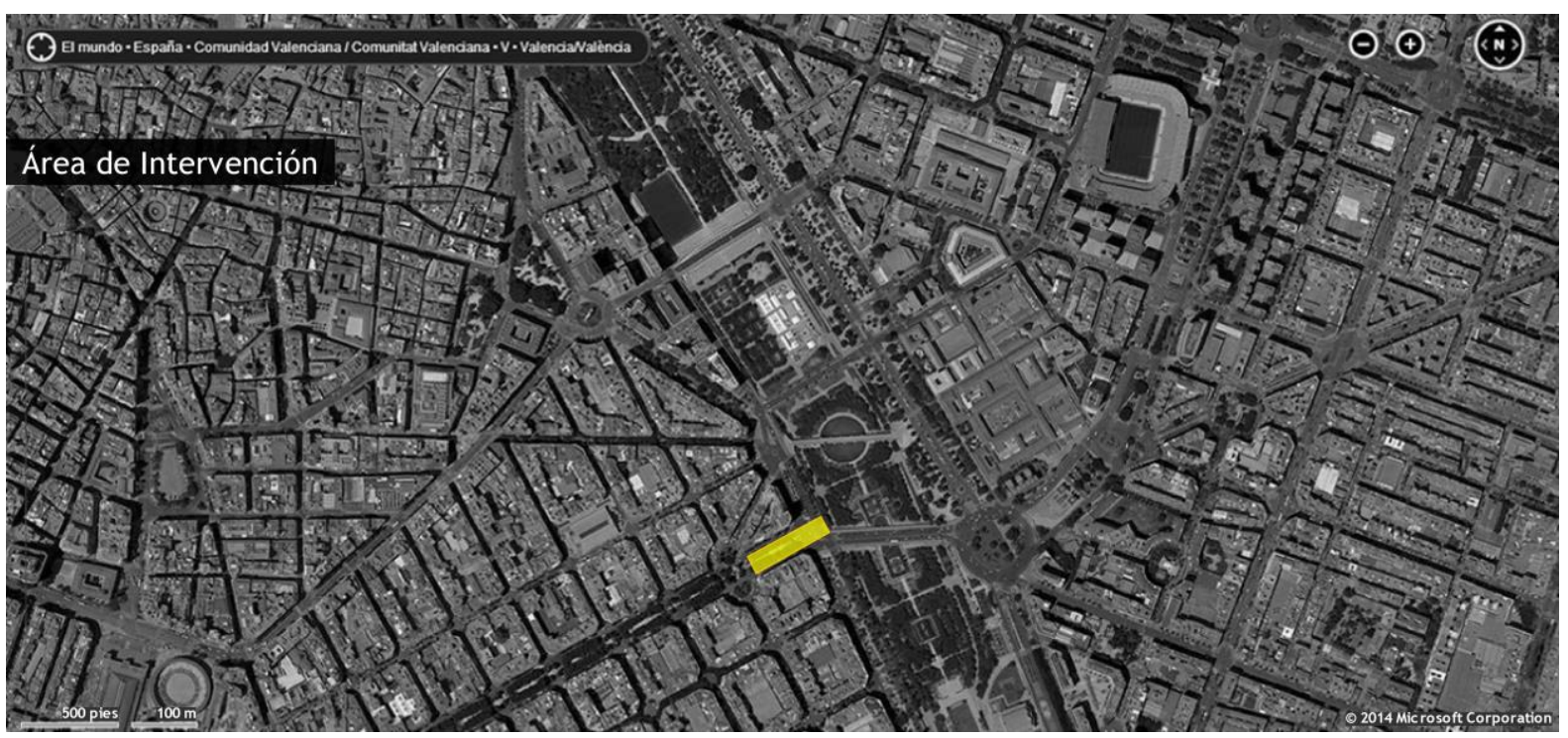

Fig. 13-15. Área de intervención.

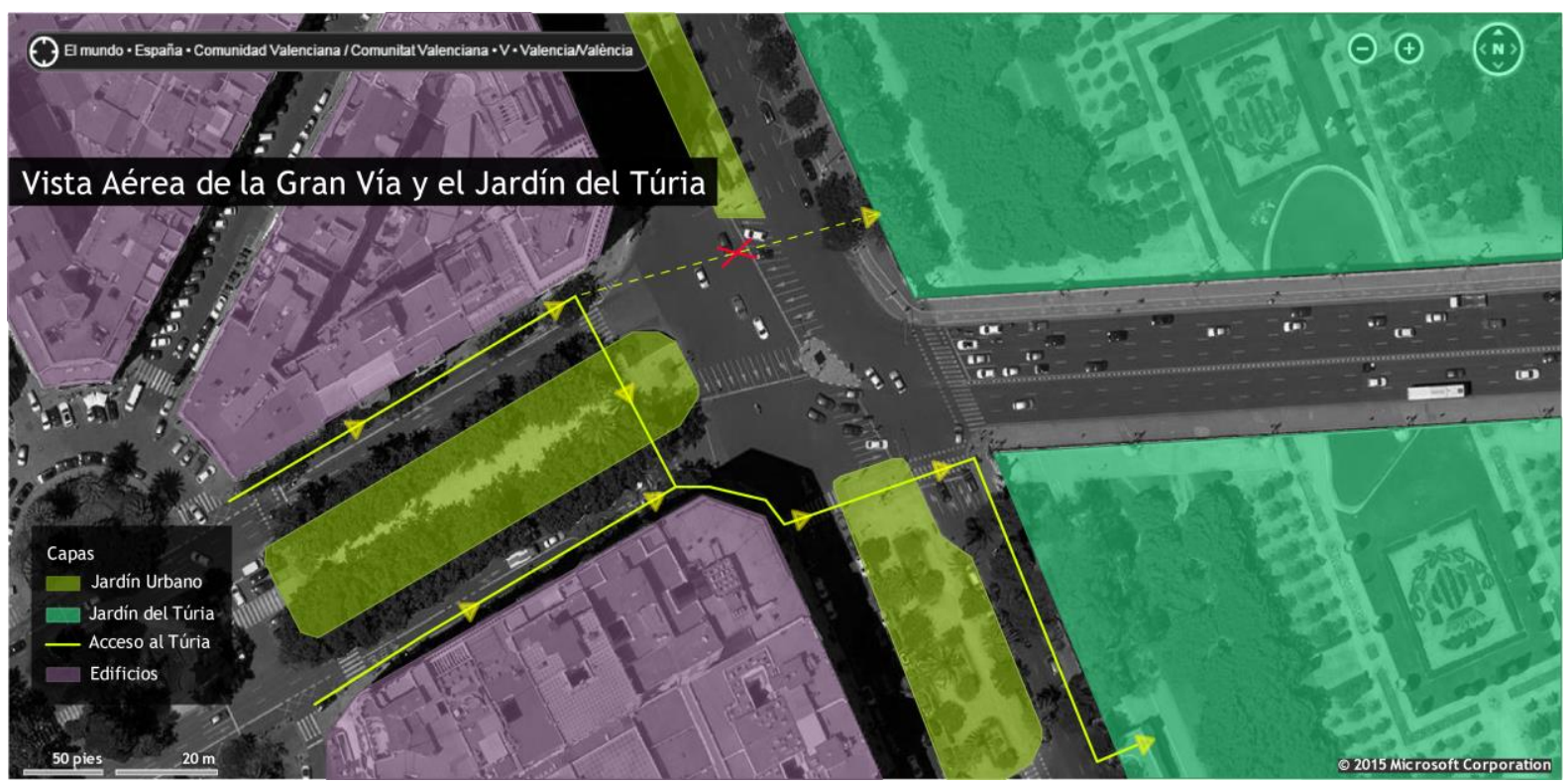

Fig. 13-16. Vista Aérea de la Gran Vía Marqués del Turia y el Jardín del Turia. 
Es muy evidente que está hacia aquí y allá á la vez, y que lo que yo llamo $<<m i$ presente»> participe á la vez de mi pasado y de mi provenir. De mi pasado desde luego, pues, <<el momento en que hablo está ya lejos de mí>>, de mi porvenir después, pues es sobre el porvenir hacia donde tiendo, y si pudiese fijar este presente indivisible, este elemento infinitesimal de la curva del tiempo, es la dirección del porvenir la que mostraría. Es menester, pues, que el estado psicológico que llamo $<<m i$ presente»> sea á la vez una percepción del pasado inmediato y una determinación del porvenir inmediato. Ahora bien, el pasado inmediato, en tanto que percibido, es, como veremos, sensación, puesto que toda sensación traduce una sucesión muy larga de sacudimientos elementales; y el porvenir inmediato, en tanto que se determina, es acción o movimiento. Mi presente es á la vez, pues, sensación y movimiento; y puesto que mi presente forma un todo indiviso, este movimiento debe atenderse á esta sensación, y prolongarla en acción. ${ }^{19}$ De donde afirmo que mi presente consiste en un sistema combinado de sensaciones y de movimientos. Mi presente es, por esencia, sensoriomotor. ${ }^{20}$

Henri Bergson. 1896. Materia y Memoria.

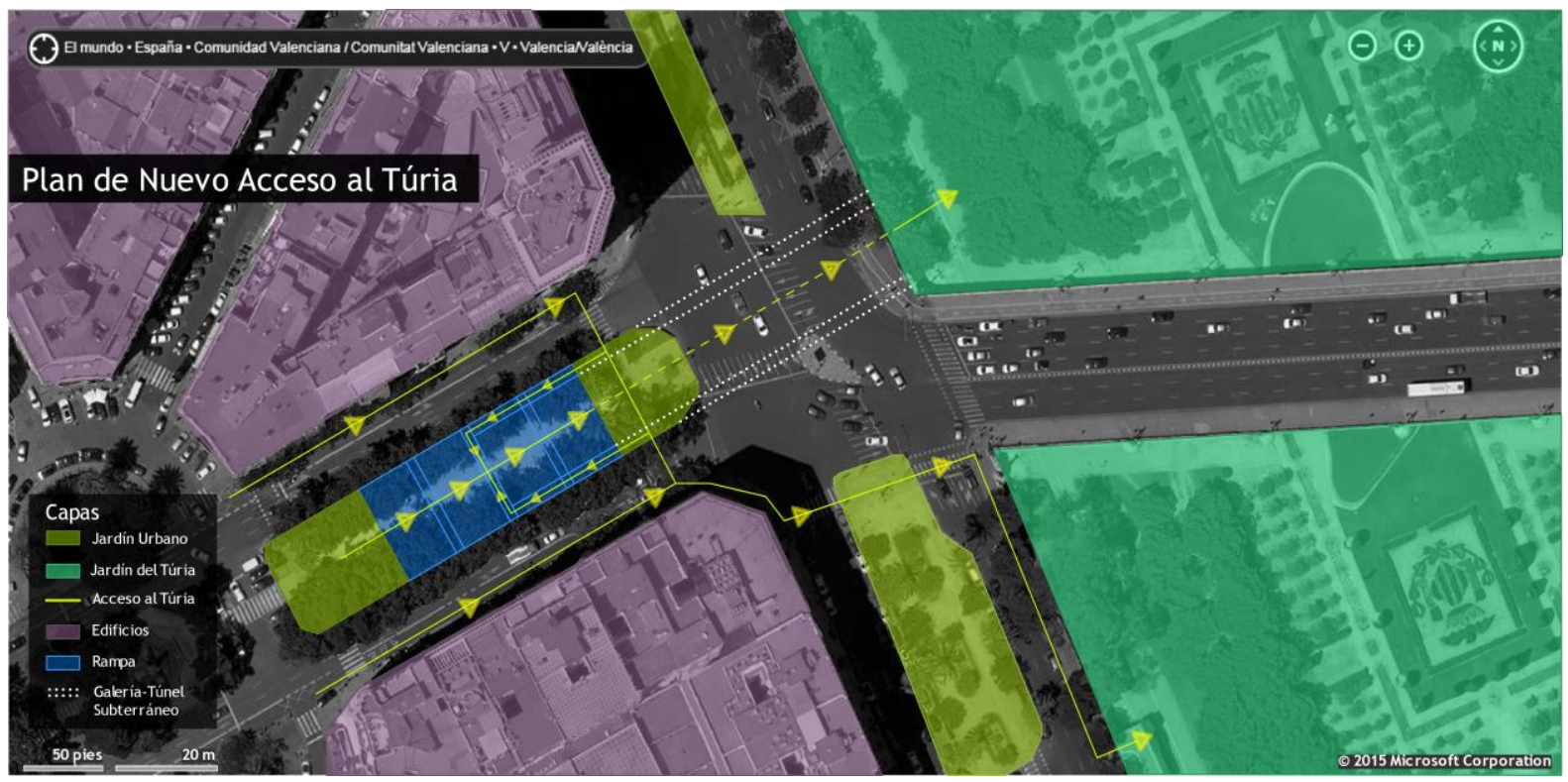

Fig. 13-17. Plan de Nuevo Acceso al Turia.

\footnotetext{
${ }^{19}$ En la versión original, el libro de Bergson, no está marcado en negrito. La expresión del negrito es la intención del autor de este estudio.-( $\mathrm{NdA})$

${ }^{20}$ Bergson, H. Materia y Memoria. Madrid. Libreía de Victorianos Suarez \& Librería de Fernando Fé, Navarro, M. (tr.) Versión espñola. 1900. p 179.
} 


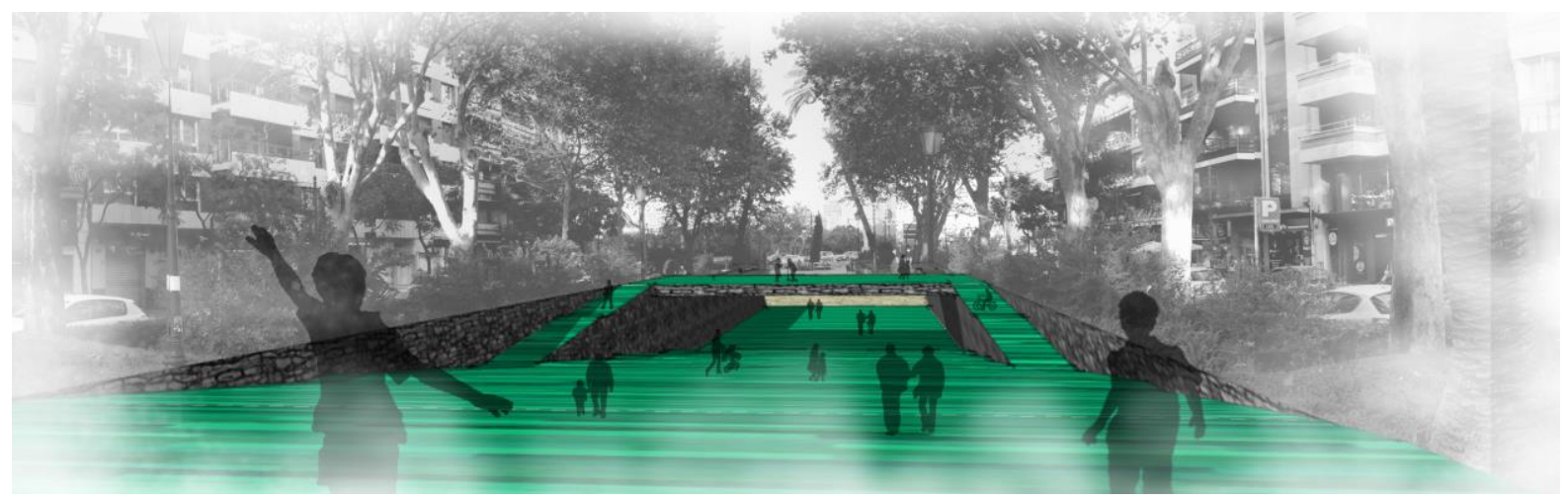

Fig. 13-18. Un fotomontaje del túnel.

Cortando la superficie de la ciudad, se revela la tierra cruda. Desde la gran vía Marqués del Turia hasta el nivel del Jardín del Turia, se construye un túnel. Como hay diferencias entre los niveles de la superficie de la gran vía cuyo nivel se considera $0 \mathrm{~m}$, y el otro del Jardín del Turia (antiguo Río Turia) cuyo nivel se considera $-5 \mathrm{~m}$, este túnel tiene una forma de rampa. La vista que se observa desde la gran vía hacia abajo del Jardín del Turia, es un paisaje familiar, sin embargo, la otra imagen del Jardín que se encuentra cortando la superficie de la ciudad, es la tierra primitiva que se había sepultado hace 5 décadas por la trágica riada.

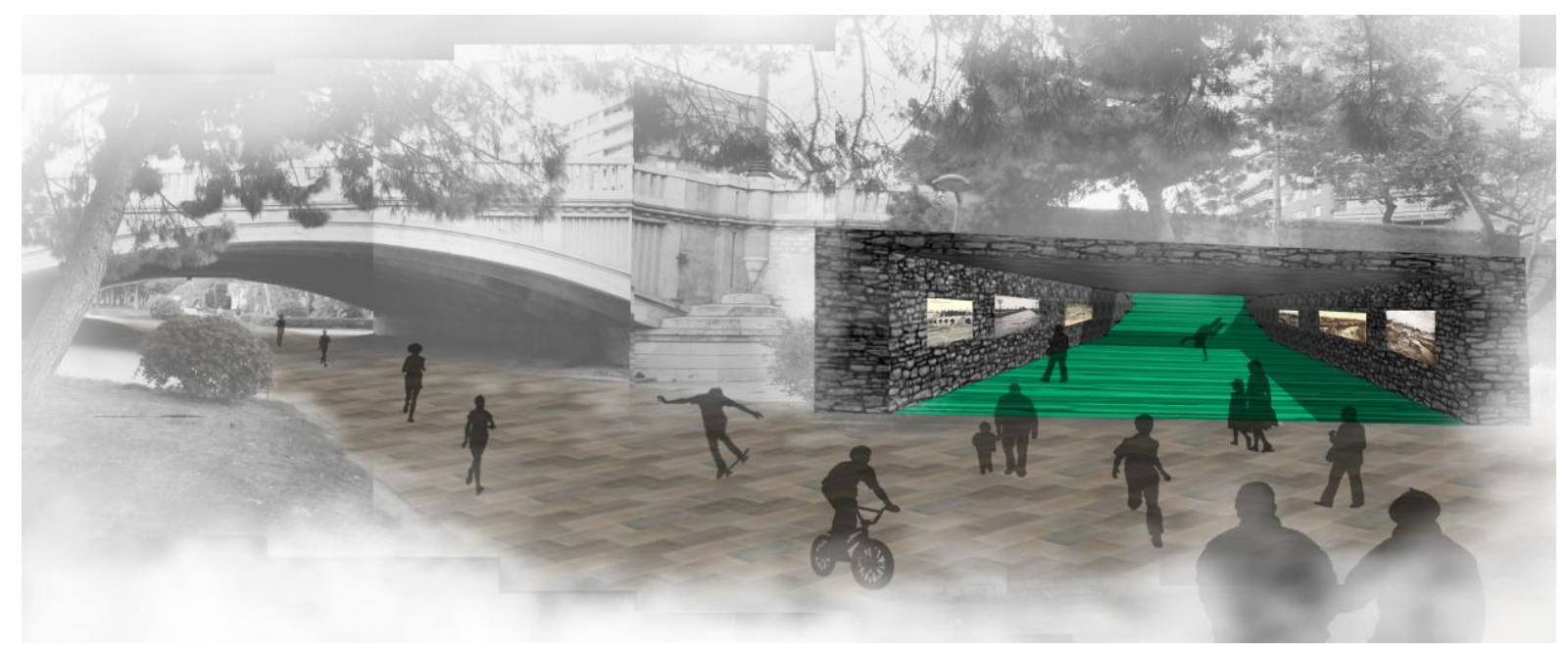

Fig. 13-19. Un fotomontaje del túnel.

Cuando se destapa la apertura de la tierra que había sido enterrada, literalmente y físicamente, se habla sobre la presencia de medio siglo antes del Río Turia. Siguiendo la rampa, en el túnel, se establece una galería fotográfica del Turia que expone las antiguas imágenes del Río y el proyecto 
después del evento trágico del año 1957. Las imágenes que han perdido su color de la galería-túnel, ahora se agitan y golpean la percepción de la imagen, la memoria, y el tiempo presente de los humanos. Por eso este túnel es un espacio ambiguo como un aparato interesante para experimentar este cambio de espacio y tiempo. Aquí sobreviene una invitación del paseo desde un día cotidiano y mágico, y repitiendo la práctica corporal y anímica, la memoria del cuerpo se queda en la tierra y apenas se distingue desde el puro pasado. Este tipo de repetición va a invocar un cambio fundamental de la vida urbana. Hay que recordar la famosa tesis de Hume que se refirió también por Deleuze, diciendo que: $<<$ La repetición no modifica nada en el objeto que se repite, pero cambia algo en el espíritu que la contempla.>> ${ }^{21}$ Por eso, este proyecto es sobre un túnel para conectar los espacios rizomáticamente, pero también es sobre el Espacio Nirvánico y anímico.

Si el mundo va a contener un espacio público, no se puede organizar para una generación y tampoco planearse sólo para vivir. Se debe transcender la duración de la vida del hombre mortal. Sin la transcendencia en un potencial de inmortalidad terrena, no política, estrictamente hablando, no es posible ni un mundo común ni un dominio público. ${ }^{22}$

Hannah Arendt. 1958. La Condición Humana.

Valoración por el criterio epistemológico con arreglo a la proposición nirvánica del capítulo 8

La Utopía no viene desde el reino de los cielos, sino que, si se invocara, tendría que construirse desde la tierra. El túnel es un aparato para conciliar los vigentes sistemas de tráfico y semafóricos, pero también es el tema de los derechos mutilados de los caminantes. El túnel crea un nuevo dharma combinando los dharmas preexistentes, y en una macro-perspectiva, el proyecto es un CSD. (Proposición sintética no 1. Epistemología Nirvánica). Crear una nueva combinación de los dharmas, significaría literalmente una creación de un nuevo CSD, pero por otro lado es una descomposición de los dharmas patológicos. (Proposición sintética no 0, 2. Epistemología Nirvánica). La incisión revela la tierra de los años 1950s de Valencia y en el medio de este evento, el sujeto del presente naturalmente

\footnotetext{
${ }^{21}$ Deleuze, G. Diferencia y Repetición. Buenos Aires. Presses Universitaires de France. Versión española. María Silvia Delpy y Hugo Beccacese (tr.). 2002. p. 119

${ }^{22}$ Arendt, H. v.o. 1958. The Human Conditon. Chicago. Universtiy of Chicago Press. 1998. p.55.
} 
se involucra. La memoria acumulada y sepultada hace más clara la sensación del sujeto involucrado durante el paseo. La tierra olvidada se restaura junto a su época también perdida, y de esta manera el túnel existirá en el futuro en el mismo contexto ontológico. El túnel es para este tipo de experimento, corporal y anímico. (Proposición sintética no 4. Epistemología Nirvánica).

\section{Valoración por el criterio ético con arreglo a la proposición nirvánica del capítulo 9}

El proyecto no trata de las ideas pervertidamente desarrolladas del utilitarismo y del neoliberalismo, sin embargo, sí que trata de un ambiente en el que se pueda fomentar la conciencia social haciendo a los sujetos reconocer los valores olvidados, que deben recuperarse. Los creadores de las leyes como los hombres del congreso, la industria del automóvil y petróleo, las actividades del Lobby, etcétera eran los mayores elementos que decidían la calidad del paseo en el área urbana. Es irónico ya que se diseña el plan de la acera después de asegurar el flujo y la comodidad del tráfico. Las aceras fragmentadas sin razón son la evidencia que demuestra cuál es la prioridad al legislar y hacer los planos urbanísticos. Las víctimas son los caminantes. Para conciliar estos dharmas -que parecen incompatibles- el túnel crea una nueva forma de vinculación entre ellos. Los dharmas se levantan (Pratittyasamutpāda). Un dharma no deshace a otro dharma para existir, más bien, un dharma existe gracias al levantamiento de otro. El proyecto no quiere predicar sobre un amor incondicional, sino sobre un respeto básico a todos los dharmas que tienen cada uno su teleología para cada situación efímera, sabiendo que al final todos los dharmas forman un CSD. Una vez si se ha reconocido dicha manera de cosmovisión, la distinción entre el yo-dharma y ajenos-dharmas pierde su sentido. (Proposición sintética $n^{\circ}$ 1. Ética Nirvánica). Como se describe arriba, el túnel es un CSD. (Proposición sintética no 2. Ética Nirvánica). La experiencia sensorial empieza desde la estimulación de las memorias del sujeto. Descubrir las memorias de 1950s es revelar el deseo de la tierra que una vez fue sepultada por las aguas. El área de intervención no está limitada solamente en la dimensión física. (Proposición sintética no 2, 3. Ética Nirvánica).

Valoración por el criterio estético con arreglo a la proposición nirvánica del capítulo 10 
La estética del túnel es visualizar las interacciones entre los dharmas. El diseño del proyecto, en otras palabras, disponer y componer los dharmas en los lugares apropiados, se manifiesta en una forma arquitectónica. (Proposición sintética $n^{\circ} 0$. Estética Nirvánica). Debido a que el proceso del argumento del proyecto procedió basándose en la base sólida de la epistemología y la ética nirvánica, la distinción estricta entre los discursos de estas tres dimensiones es imposible.

En el proyecto aparecen los materiales con los que se ha de contemplar, con las diversas experiencias corporales y anímicas. (Proposición sintética no 1, 2. Estética Nirvánica). La experiencia agradable del tiempo y espacio con los elementos de la naturaleza y la arquitectura, forman un diseño estético y hace un espacio ético. El espacio provee deleite y gracia. El flujo de la conciencia del sujeto que pasea por el túnel es difícil de captar ya que fluye. El movimiento es libre en la medida en que la transformación de la cartografía siempre está en el proceso. La apariencia del proyecto tiene semejanza a una red que se conecta y desconecta entre los dharmas de diversas dimensiones de una manera no burocrática y sin tener ninguna fuerza central. (Proposición sintética nº 6. Estética Nirvánica). 


\section{Secularización}

Desde el capítulo 11 hasta el 13, este estudio ha pretendido dilucidar los conceptos nirvánicos que se han adquirido en los capítulos 8,9 y 10, para que sean más cualificados y que sus discursos no sólo traten los campos filosóficos y teóricos. Ahora que dichos conceptos están justificados al poseer contundencias en el nivel arquitectónico y urbanístico, y además están acreditados en la perspectiva hermenéutica del buddhismo, es un momento magnífico para compendiar la huella de esta tesis en un diagrama de sencillos rasgos algorítmicos.

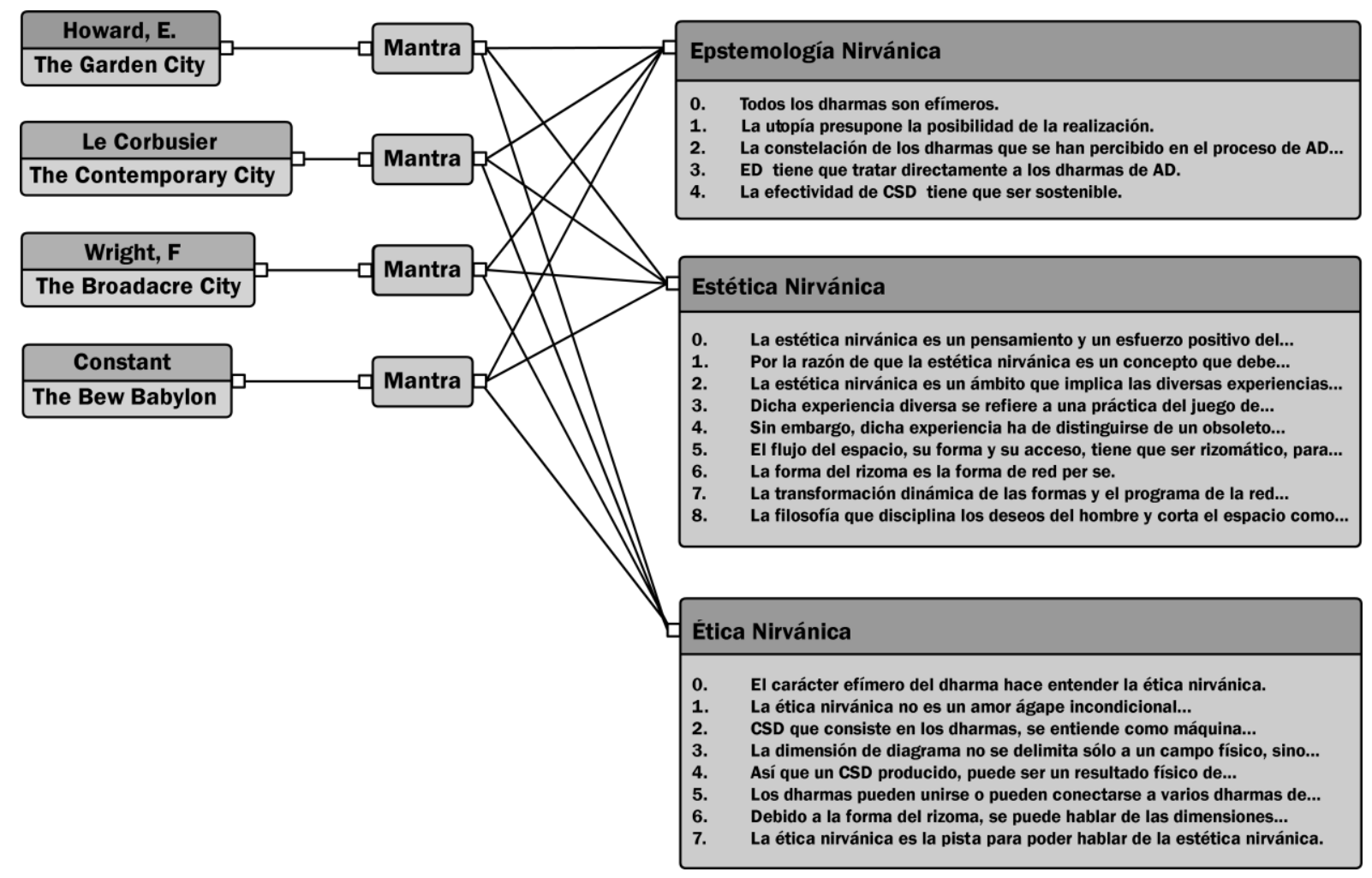

Fig. 14-1. Cuadro de desarrollo 1.

En primer lugar, existe la esencia del buddhismo que funciona como la piedra clave del arco, ejercitando su influencia a lo largo de toda la estructura de la tesis. Los cuatro proyectos utopistas de occidente no solamente son materias para discriminar o exaltar ideas regionales particulares, sino que 
toman el papel de dovelas que generan tensión con la dovela central respectivamente. En el mismo contexto, no cabe duda de que los otros dos proyectos zen-buddhistas de oriente no han hecho más que enriquecer el prisma de los discursos y establecer razonamientos sólidos situándose en la base, actuando como dovelas basales.

Segundo, las esencias dialécticamente extraídas se han canonizado y estandarizado, distinguiendo los tres ensayos filosóficos cuyos campos consisten en la epistemología, la ética y la estética. De nuevo, el proyecto se ha podido considerar mediante los filtros de los capítulos CSD Mórbido y CSD Nirvánico, que consisten en tres estilos de proyectos nirvánicos. Dichos tres tipos de Espacion Nirvánico, Espacio NY y CSD son realizados en NY Intervención, virtualmente en Valencia según sus ciertas delimitaciones de campo. Básicamente, este estudio trata de las teorías del urbanismo y la arquitectura, necesariamente dentro de su rama, incluyendo el campo de la antropología filosófica y social.

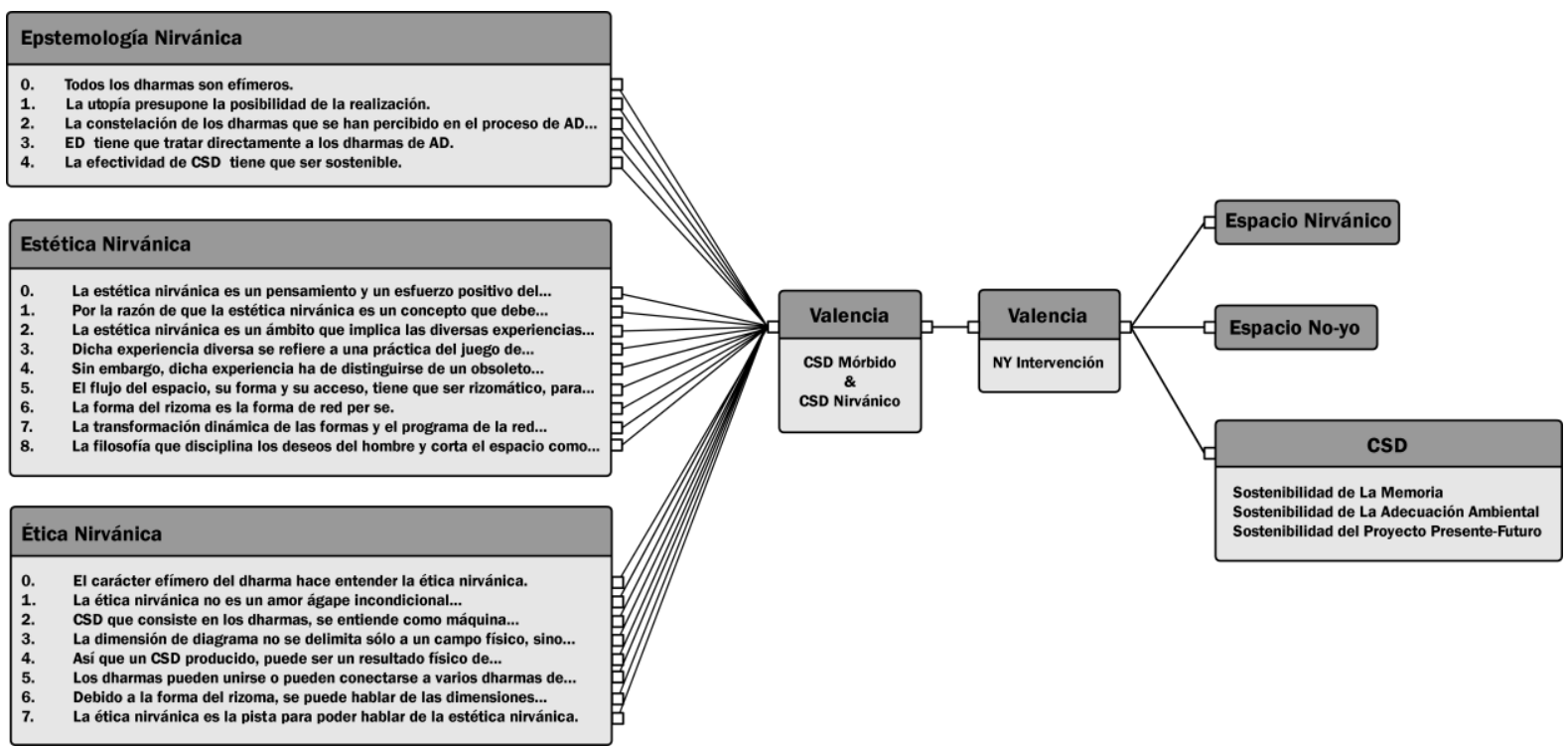

Fig. 14-2. Cuadro de desarrollo 2.

Entonces, surge un empeño olvidado debido a los mantras buddhistas que se han estandarizado a fin de que sea una herramienta de diagnóstico en los espacios patológicos, y que funcionen como criterios al ejercitar los proyectos en el nivel práctico. Por lo cual, en este sentido se observa una cierta carencia en la que todavía no parece adecuado considerarlo como una herramienta práctica a causa 
de su descomunal aspecto argumental (aprox. 30 páginas de los ensayos: la epistemología, la ética y la estética) para poder utilizarse y adaptarse rápidamente en el campo profesional cuyas condiciones circunstanciales del trabajo siempre están en un proceso variante.

Para poder utilizar esta máquina pesada, es necesario reducir el volumen de los fatigosos discursos filosóficos en una forma más sencilla y refinar los conceptos para que sean vocabularios más universales. Sin embargo y a pesar de que los conceptos habrían estado universalizados, no podrán corresponder exactamente sus términos a las definiciones de la Real Academia Española, porque no deben de decolorar toda la idiosincrasia de este estudio, pero aun siendo así, la gran operación es ineludible. De nuevo, la herramienta tiene que poder utilizarse y adaptarse rápidamente en el campo real, objetivos imprescindibles de este capítulo. Después de todo, lo que se ha de revelar próximamente es una sutil versión del original y es un prototipo estratégico para incorporar al campo académico y profesional al mismo tiempo.

Al principio de esta tesis, por razón de que el argumento de este estudio empezó desde un espacio sencillo, algunos conceptos buddhistas no estaban definidos todavía arquitectónicamente. Sin embargo, gracias a este peculiar carácter, como está adecuadamente apelado, la necesidad ontológica de este estudio ha hecho posible enriquecer los discursos, considerándose la clave para superar el límite fatídico del urbanismo moderno.

Desde los tres conceptos espaciales (Espacio Nirvánico, Espacio NY, CSD), se extraen unos elementos cruciales -que son necesarios para su definición y que se reagrupan según su universalidad entre los elementos semejantes, a fin de que los elementos trascendentales tengan un sentido más familiar en el término secular. Asimismo, a causa de la generalización, las simplificaciones conceptuales son inevitables, sin embargo, este tipo de razonamiento es factible con la condición de que si esta presuposición es justa, que es la lógica de que si fuese posible extraer las virtudes esenciales desde los proyectos nirvánicos, una obra hecha con las dichas extraídas virtudes nirvánicas, habría de ser nirvánica sin controversia, aunque sea en un lugar totalmente diferente. ${ }^{1}$

\footnotetext{
1 Es una lógica deductiva tan sencilla como buscar las diferentes respuestas desde una función matemática viable introduciendo los valores y encontrar las soluciones justas que están consideradas en la misma.-( $\mathrm{NdA})$
} 
Los espacios temáticos desde los capítulos 11, 12 y 13, pueden re-categorizarse por los siguientes vocabularios enriquecidos en la dimensión nirvánica.

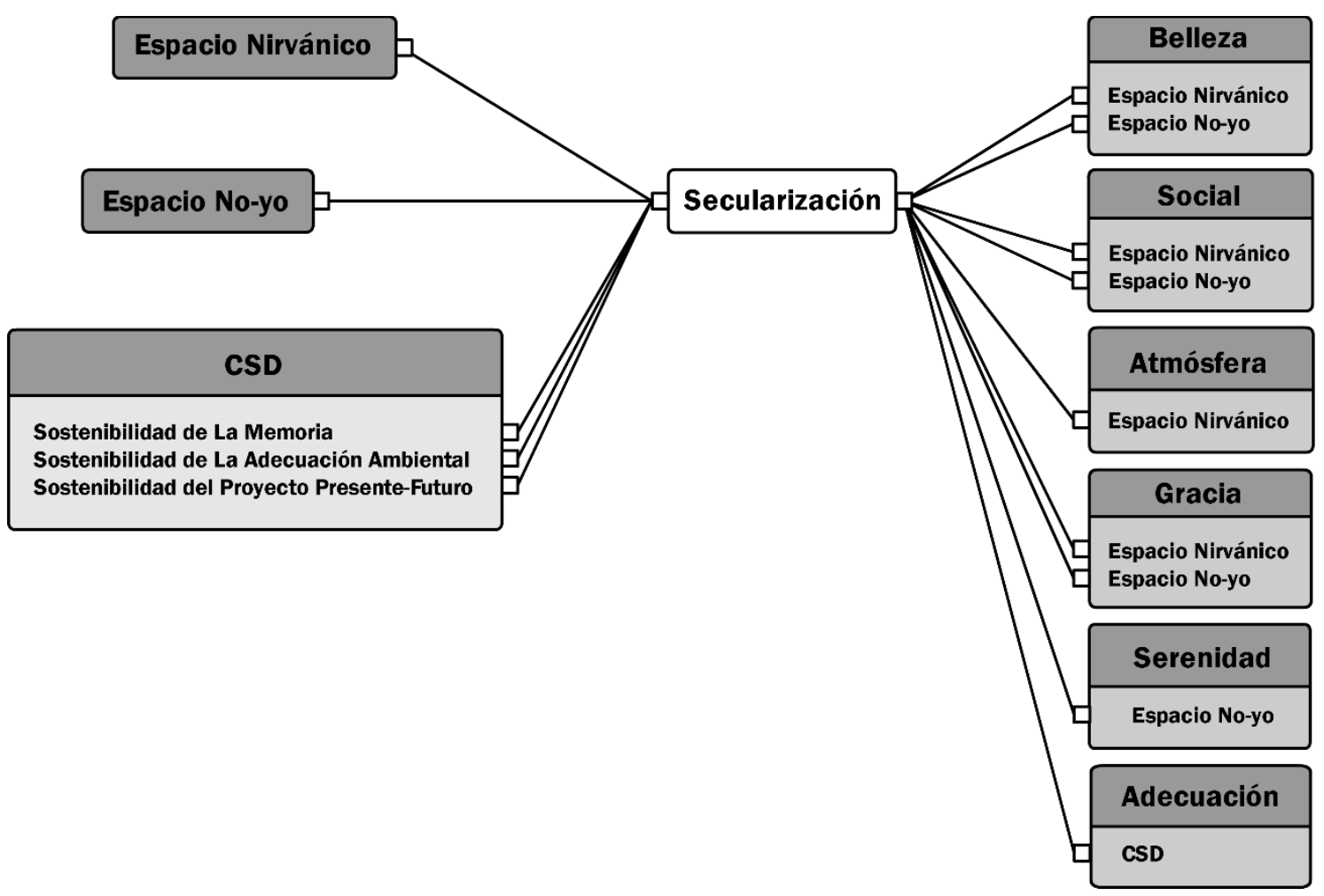

Fig. 14-3. Cuadro de desarrollo3. 


\section{Belleza}

\section{:Definición de RAE ${ }^{2}$ \\ 1. f. Cualidad de bello. \\ 2. f. Persona o cosa notable por su hermosura.}

El primer concepto es Belleza. Este concepto, por su definición tan vago y ambiguo, se suele utilizar con amplio sentido sin un peculiar foco, sin embargo, debido a este carácter general, permite la posibilidad de que se pueda involucrar incluso en los conceptos trascendentales. En el discurso buddhista, el término denominado belleza tampoco es tan distinto respecto a la definición del diccionario de la RAE. Tan sólo en este caso se refiere: una actitud de armonización en la perspectiva estética. Este tipo de virtud se encontraba comúnmente en Espacio Nirvánico y Espacio NY. ${ }^{3} \mathrm{Si}$ alguien se cuestiona qué es la belleza, es decir la belleza nirvánica, suele imaginarse las siguientes imágenes zen: las líneas austeras, la habitación estática con el suelo de tatami, el espacio minimalista, el jardín-miniatura que recuerda alguna típica escena de la naturaleza, los materiales rústicos, la postura de loto, la sonrisa pacífica del monje etc. Sin embargo, estas dichas imágenes son producciones superficiales, no son esencias de la belleza nirvánica, son desafortunadamente deficientes interpretaciones que desmiembran y degeneran el concepto. Sí que existía una época en que dichas imágenes eran los elementos imprescindibles, pero esa tradición es una tergiversación de la enseñanza de Dogen (1200-1253) que es el célebre maestro zen de Japón. Cuando Dogen predicaba de la importancia de Za-zen cuyo significado literal es meditar(禪：zen) sentado(坐：za), había unos detalles, directrices que él destacaba para poder entrar al nivel más profundo de meditación. Los materiales pueden utilizarse según las circunstancias arquitectónicas y culturales de cada época. Si ocurre algún fetichismo en la enseñanza del Dogen, sería como ver un árbol sin ver el bosque. Los contenidos de la metáfora, pueden ser variantes con estilos. Los elementos que pueden ser fácilmente malentendidos provienen de la próxima citación. Algunas palabras se destacan mediante el subrayado e indudablemente, no lo están en la versión original.

\footnotetext{
${ }^{2}$ Diccionario de la lengua española. Real Academia Española. Madrid. la $23^{a}$ edición. 2016.

${ }^{3}$ Para más informaciones, véase el capítulo 12 de este libro-(NdA)
} 
Ahora, al hacer zazen es deseable tener una habitación tranquila. Deberías ser moderado comiendo y bebiendo, abandonando todas las engañosas relaciones. Siéntate dejando todo de lado, sin pensar en la bondad ni en la maldad, en lo correcto ni en lo incorrecto. Así, habiendo parado las diversas funciones de tu mente, abandona la idea de convertirte en Buddha. Esta verdad contenida no es sólo para el zazen sino para todas tus acciones diarias.

Normalmente un tatami cuadrado y grueso se pone en el suelo cuando estás sentado encima de un cojín. Podrías sentarte también en la completa o media posición de loto. Antiguamente, primero colocabas tu pie derecho en tu muslo izquierdo y luego tu pie izquierdo en tu muslo derecho. Hoy en día, sólo puedes poner tu pie izquierdo en tu muslo derecho. Tu vestimenta debería ser raída y holgada, pero con esmero. Lo siguiente, pon tu mano derecha en tu pie izquierdo y tu palma izquierda en tu palma derecha, con los pulgares apenas tocándose. Siéntate derecho, sin inclinarse a la izquierda o a la derecha, ni hacia delante ni atrás. Tus oídos deberían estar en el mismo plano que tus hombros y tu nariz en línea con tu ombligo. Tu lengua debería estar situada contra el paladar y tus labios y dientes firmemente cerrados. Respecto a tus ojos mantenlos cuidadosamente abiertos, respira tranquilamente a través de tus orificios nasales. Finalmente, habrás regulado tu cuerpo y mente de esta manera. Respira profundamente, balancea tu cuerpo de izquierda a derecha, entonces siéntate firme como una roca. No pienses en nada. ¿Cómo se ha hecho esto? Mediante pensar en el más allá del pensamiento y la nada. Estos son los fundamentos del zazen. ${ }^{4,5}$

Dogen.

Por tanto, este estudio ha de responder a la pregunta: ¿Se puede encontrar algún ejemplo de la belleza nirvánica en las arquitecturas contemporáneas, cumpliendo el sentido de la belleza nirvánica superado las escenas superficiales y las formas tradicionales destacadas por Dogen? En este sentido se encuentra por ejemplo el Museo Mímesis de Alvaro Siza. El estilo de Siza en ese proyecto se emplea mediante el rigor de las líneas decisivas y los volúmenes aplomados como una roca, tal vez se puede legitimar una imagen firme de la arquitectura. Sin embargo, en el Museo Mímesis, dichas líneas y volúmenes representan totalmente la virtud de $\mathbf{N} \mathbf{Y}^{6}$. Para quedarse armonizado en aquel lugar el museo, su arquitectura habría requerido un volumen enorme para cumplir sus programas satisfactoriamente. En este caso, el estilo de Siza gana el juicio de ser excelente bajo los pálidos cielos y la tierra desabrida de la ciudad de Paju, que se está desarrollando recientemente como la ciudad satélite de Seoul, de forma drástica a partir de un pueblo agricultor. La primera imagen del museo

\footnotetext{
${ }^{4}$ Hoover, T. The Zen Experience. New York. PLUME. 1980.

${ }^{5}$ Los subrayados en palabras no existen originalmente. En esta citación se habían puesto para destacar la intención del autor. $-(\mathrm{NdA})$

6 No-yo-(NdA)
} 
recuerda a unas rocas artificiales gigantescas o a unos cachalotes cuyas cabezas siempre dan la impresión colosal de la naturaleza. Como una pintura rústica en el lienzo, con la modestia -sin ninguna proclamación de Ego (NY), el edificio discreto se queda entre el dicho cielo y la dicha tierra del horizonte de Paju, pero su presencia es elegante sin veleidad cumpliendo su papel como un museo no trivial. El edificio parece que pretende eludir el uso de los ángulos agudos que suelen ser muy llamativos, no como los arquitectos del desconstructivismo (v.-figs. 14-4, 5, 6, 7). Gracias a eso, los ángulos de $90^{\circ}$ llaman la atención con las grandes curvas del edificio. Las ventanas y las puertas intentan quedarse lo más cerca del nivel cero de la tierra, así se crea un efecto en el que se preserva la parte plana de la superficie de la fachada al máximo nivel. También, la pulcritud de la fachada, no eventualmente, como si fuera una pantalla de un cielo mimético, incorpora el mundo y la arquitectura. Al final, la arquitectura no queda arrogante gracias a un volumen tan rico y siendo las líneas curvas monumentales, componiendo de esta forma una relación no unilateral entre la arquitectura y el mundo. Así como el agua permite la vida a los peces, y el cielo proporciona la vida a los pájaros, el cielo también hace la vida al museo y la arquitectura hace lo mismo al cielo. ${ }^{7}$ El mundo presta el espacio al museo, al mismo tiempo, el museo recrea el mundo en la misma escena. El agua no se esfuerza para reflejar la luna; el agua no tiene mente. ${ }^{8}$ La arquitectura nirvánica o la ciudad nirvánica también han de abrazar esta virtud natural. Cuando se muestra este tipo de relación de CSD $^{9}$, la arquitectura automáticamente es juzgada para que sea bella nirvánicamente. La virtud llamada Belleza, principalmente en este estudio, se refiere a una actitud arquitectónica y estética que se puede juzgar visualmente para que sea nirvánico. Tal vez, eso se parece a CSD. Los peces no pueden vivir fuera del agua, e igualmente los pájaros sin el aire. Porque se impulsan juntos dependiendo mutuamente(CSD).

\footnotetext{
7 v.-Watts, A. The Way of Zen. New York. Vintage Books. 1985. Fue referido en Shobogenzo de Dogen. Obviamente, Dogen no habría imaginado la posibilidad de malinterpretación de su metodología doctrinaria en el futuro. -(NdA)

${ }^{8}$ Zenrin dijo en su poesía que <<el agua no posee la mente para recibir su imagen>>. Si el agua practica la virtud de No-yo, entonces, ya eso tiene que considerarse como que el agua ha llegado al nirvana. Para más informaciones, vease: Watts, A. The Way of Zen. New York. Vintage Books. 1985. -(NdA)

${ }^{9}$ Co-surgimiento dependiente-(NdA)
} 

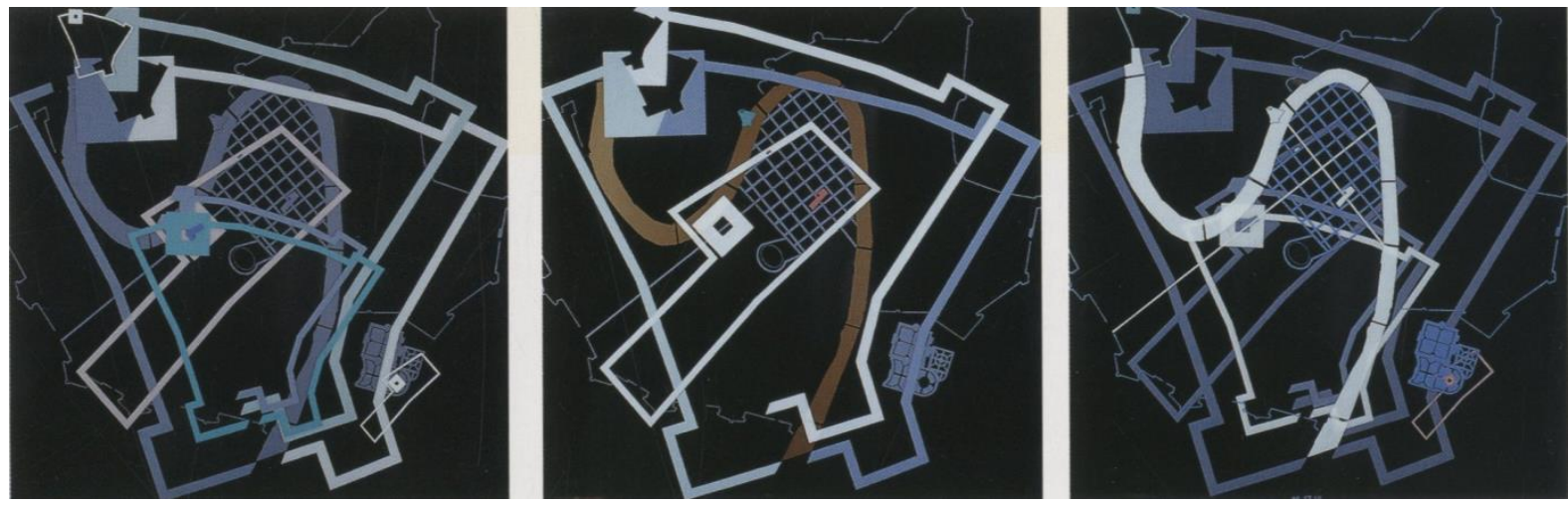

Fig. 14-4. Diagramas serigrafiados de Flechas en movimiento, Eros y otros errores.

Peter Eisenman.1985. Verona, Italia.

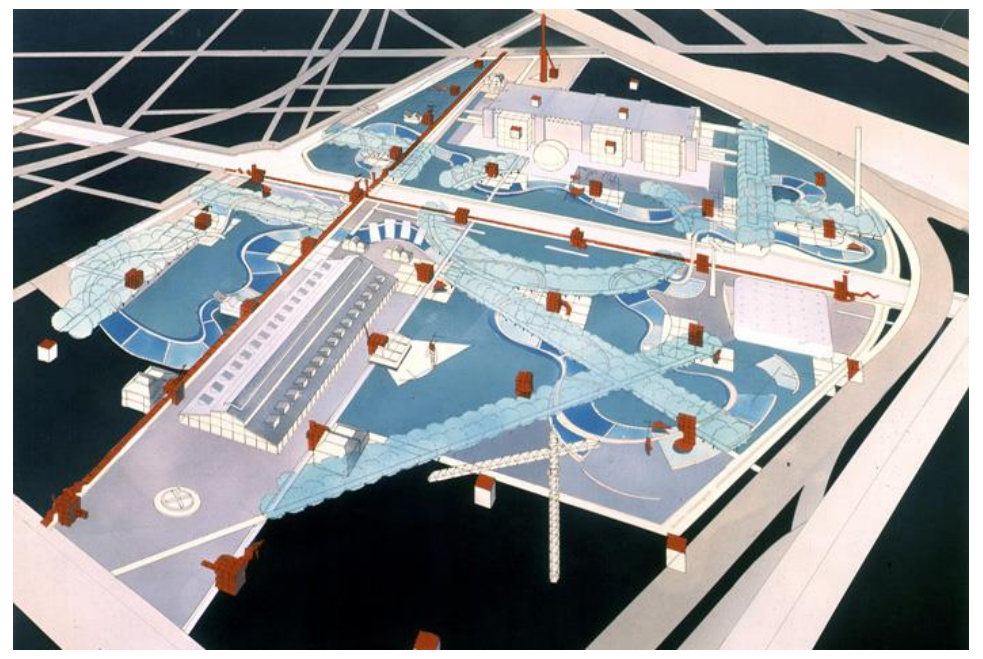

Fig. 14-5. Parc de la Villette de Bernard Tschumi. 1982-1998. Paris, Francia.

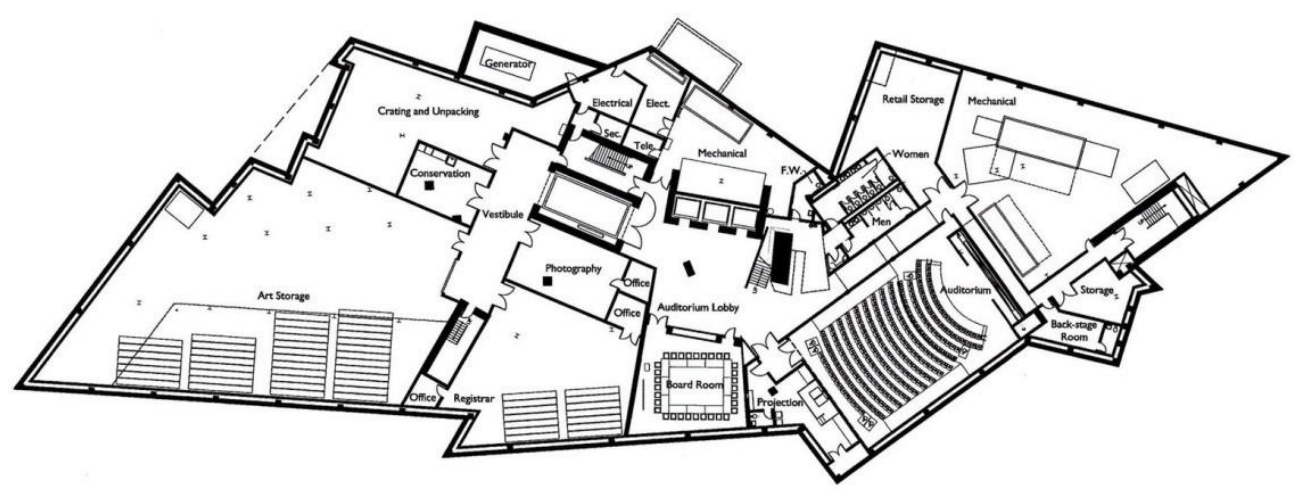

Fig. 14-6. El plano de Denver Art Museum deDaniel Libeskind. 2006. Denver, Estados Unidos 


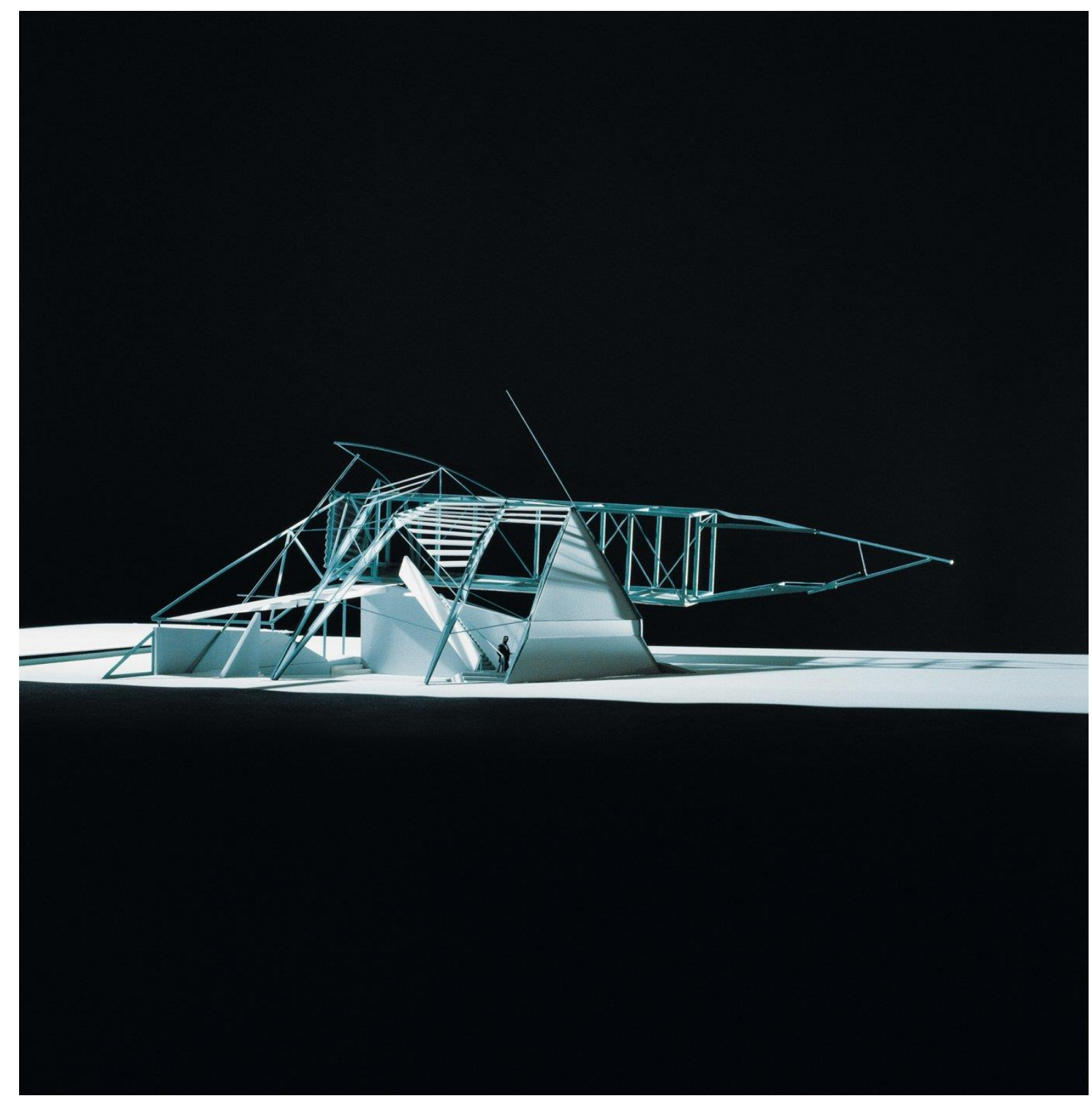

Fig. 14-7. La maqueta de Open House de Coop Himmelblau. 1983. California, Estados Unidos. 


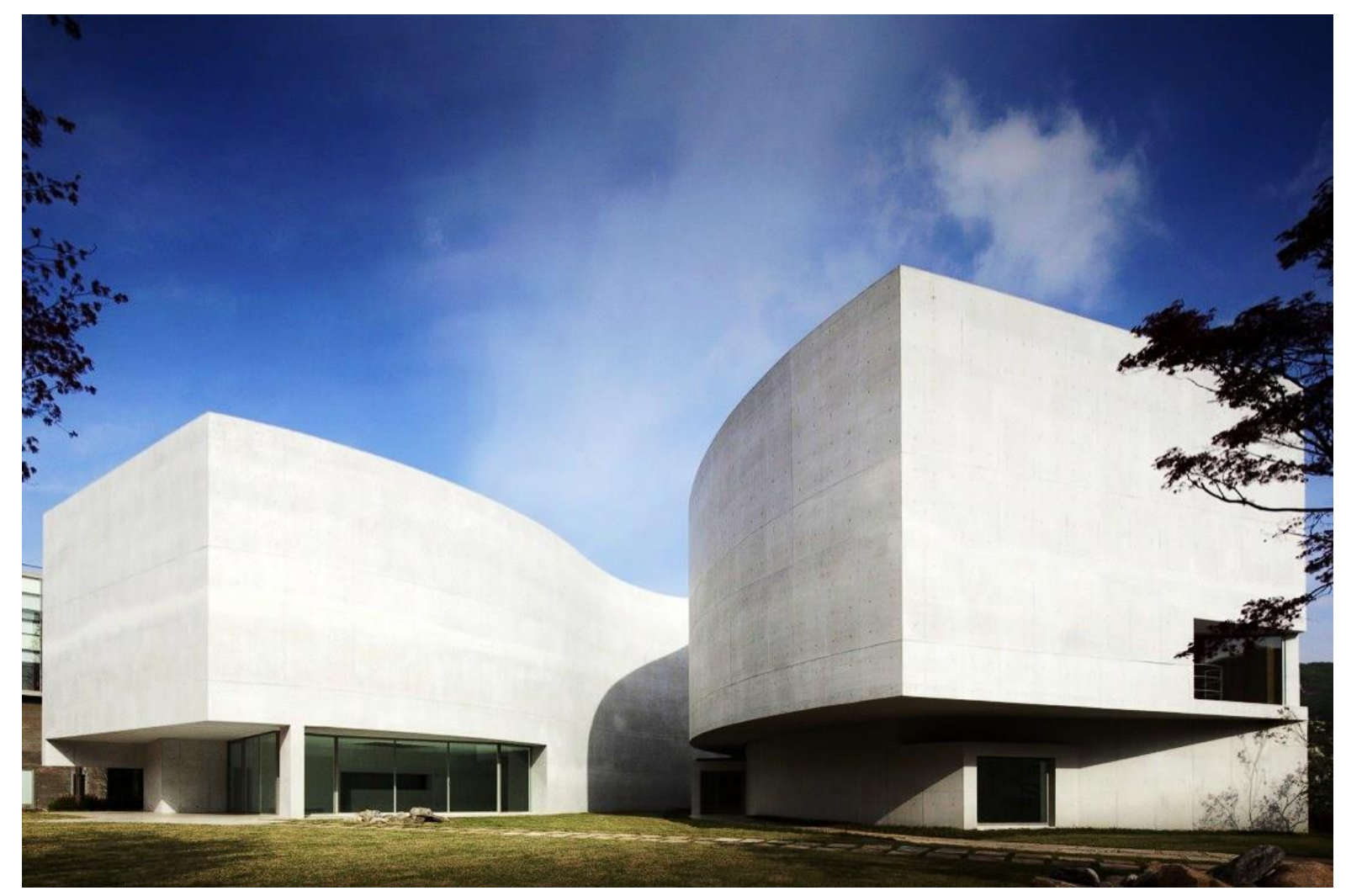

Fig. 14-8. El exterior de Museo de Mimesis. Alvaro Siza. 2009. Paju, Corea del Sur.

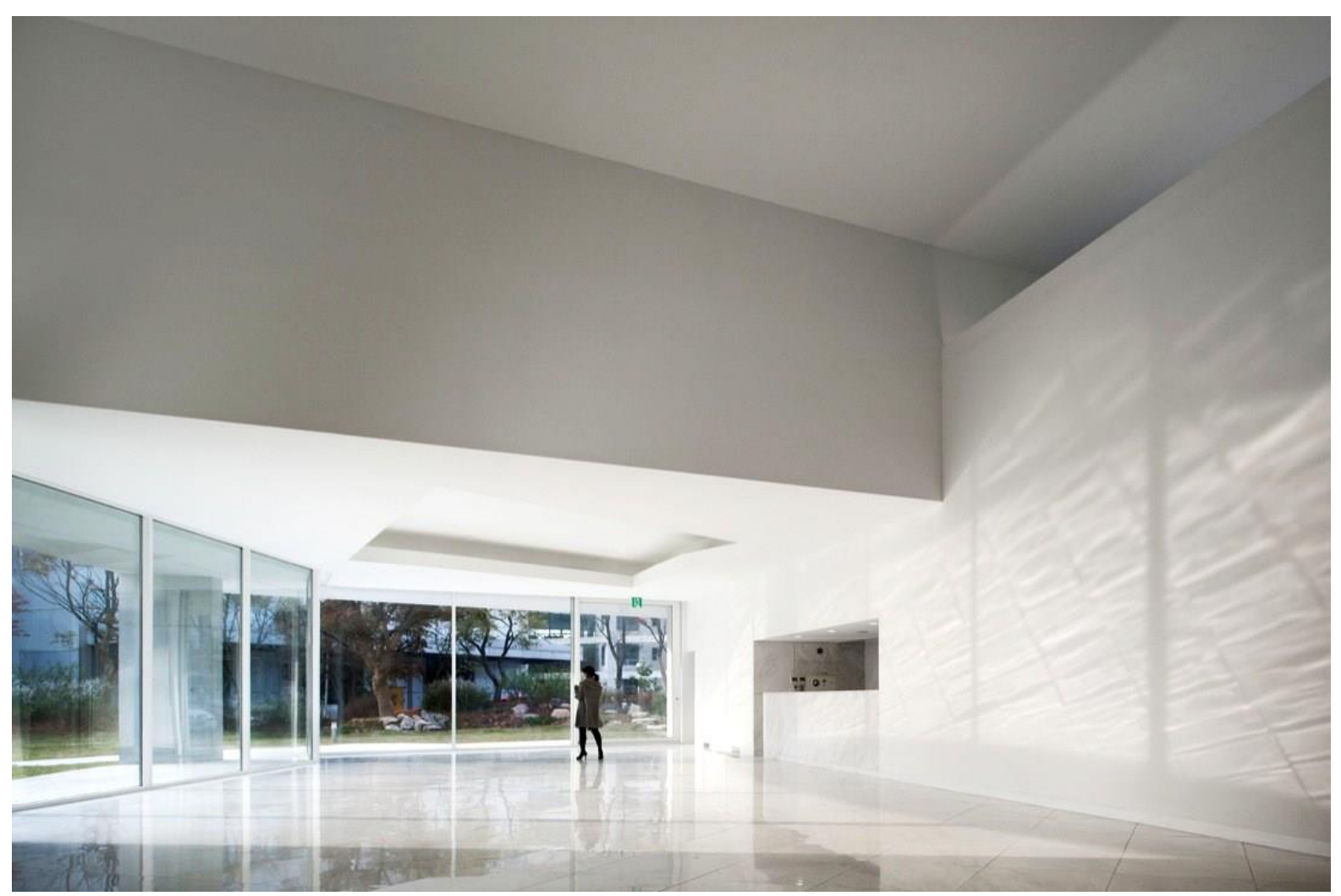

Fig. 14-9. El panorama desde el interior hacia el exterior del Museo de Mimesis. 


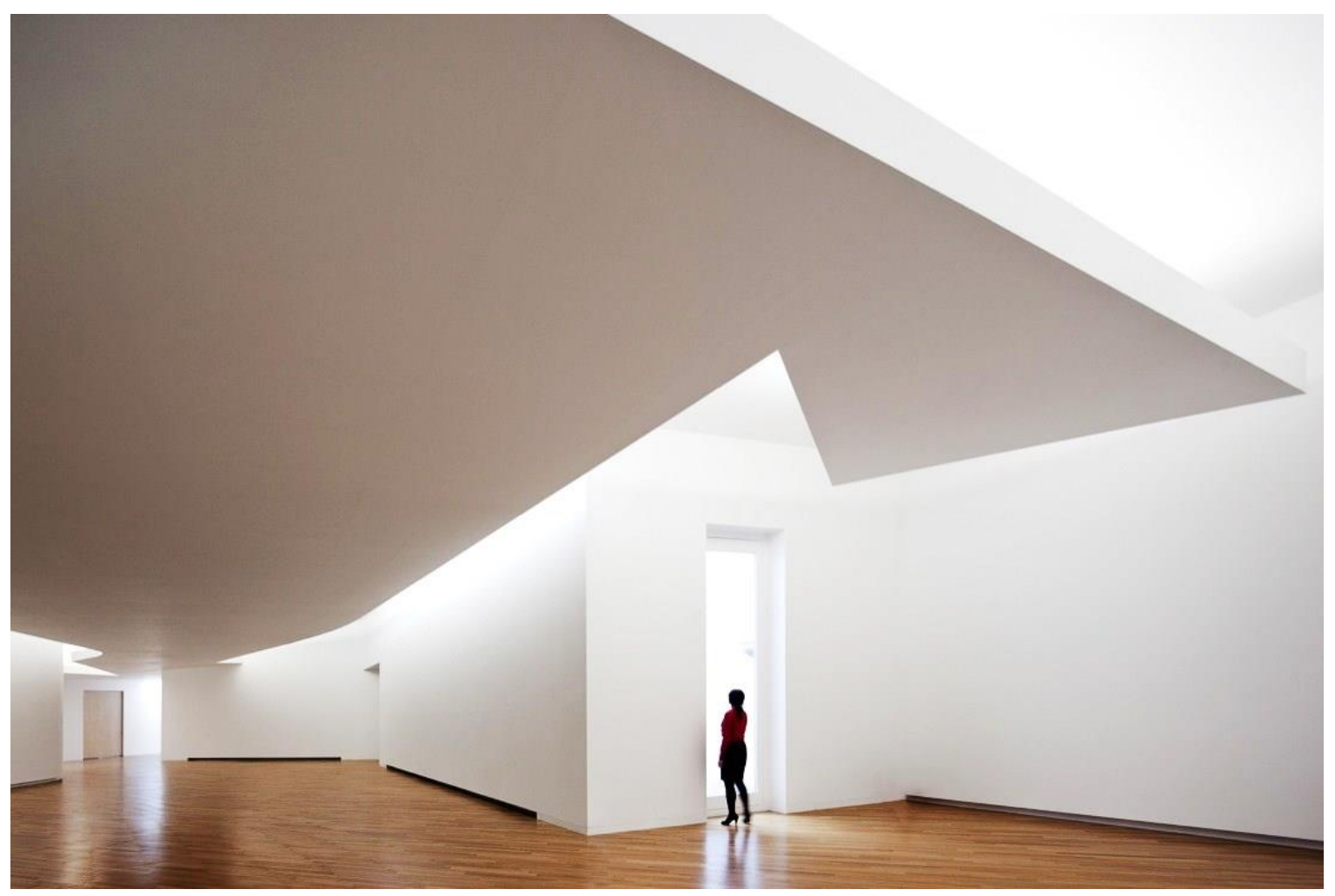

Fig. 14-10. El panorama desde el interior del Museo de Mimesis.

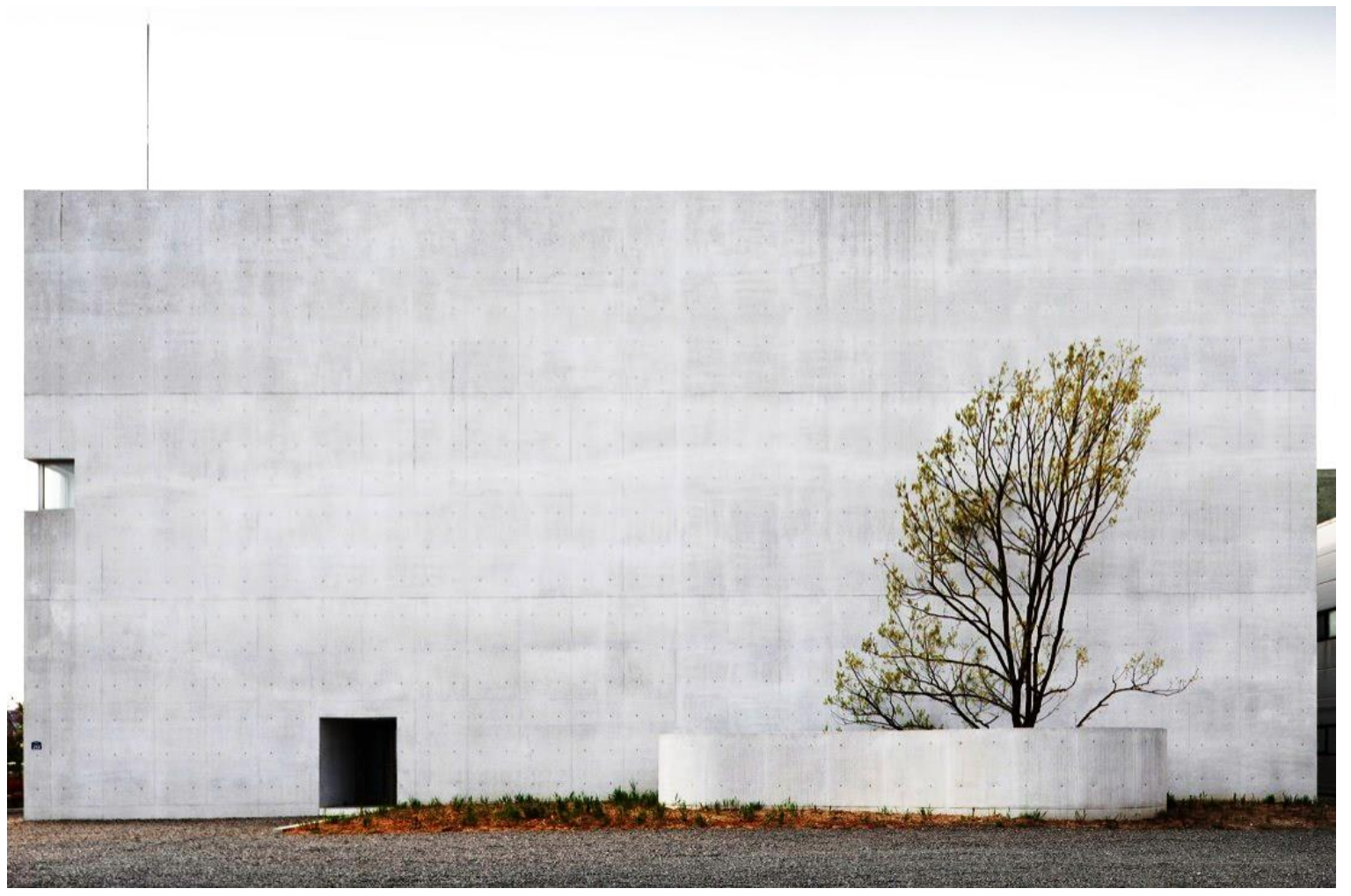

Fig. 14-11. La elevación plana del Museo de Mimesis. 


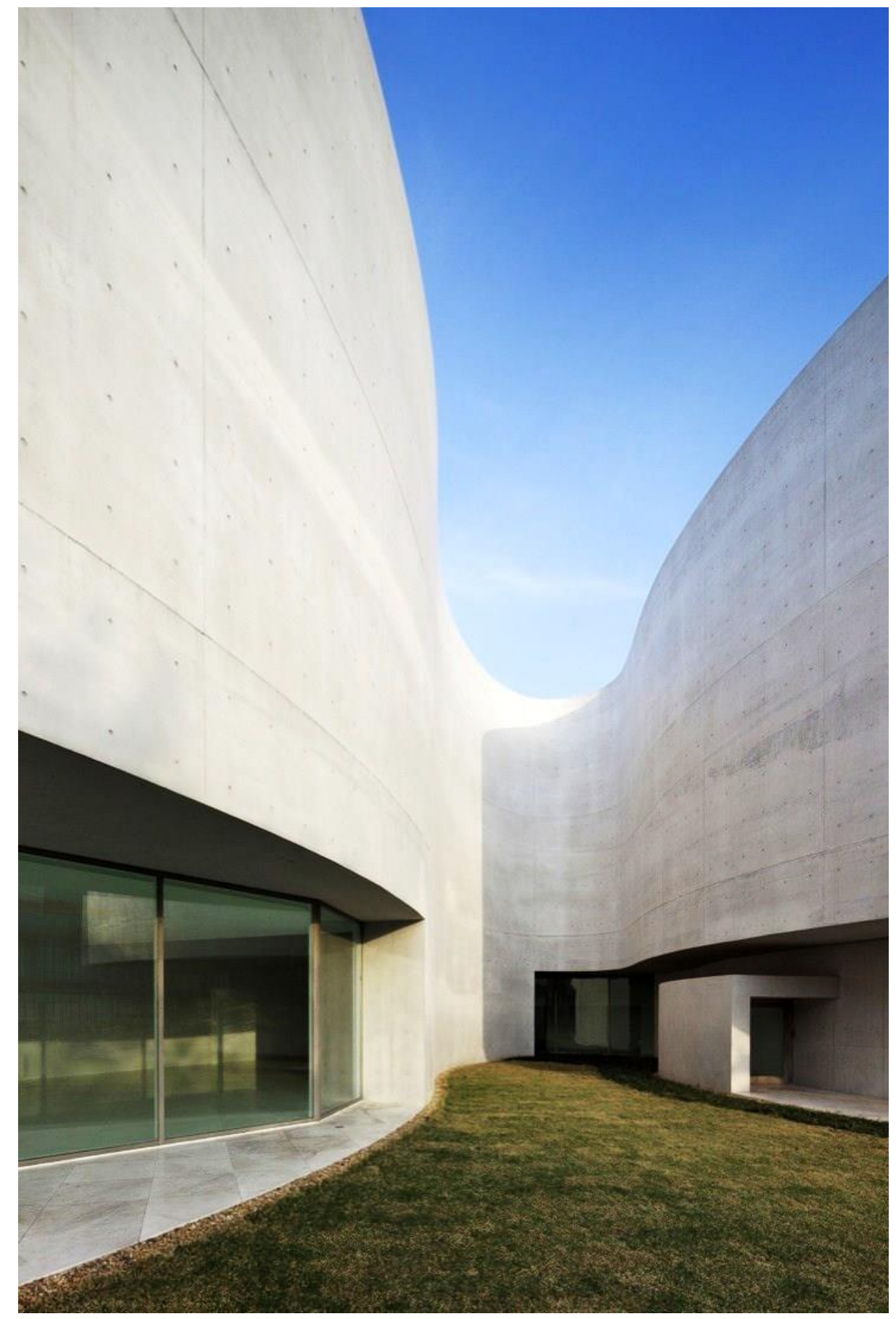

Fig. 14-12. La elevación plana del Museo de Mimesis. 


\section{Social}

Perdí el límite de mi cuerpo físico. Tenía mi piel, por supuesto, pero sentí que estaba de pie en el centro del cosmos. Hablé, pero mis palabras habían perdido su significado. Vi a la gente que viene hacia mí, pero todos eran el mismo hombre. Todos eran yo. ${ }^{10}$

Sokei-an Sasaki.

Este ensayo sorprendente de Sokeian Sasaki, es una obra maestra que describe el último grado de la facultad del conocimiento, al cual se podría llegar por medio del za-zen. La última etapa de la epistemología, en este momento, parece que tiene algunas partes consonantes con el concepto de Anātman(NY: No-yo), especialmente la parte en que pierde todo el sentido la distinción entre yo y los ajenos. El lazo fatídico entre el humano y dharma es un yugo con el que se tiene que cargar hasta terminar la vida mortal, sin embargo, solamente Sasaki en su experimento de ideas, está percibiendo el origen del universo y su destrucción final mediante una forma cabalística de zazen que fue totalmente transcendental en este caso. Todos los dharmas se someten al principio de Pratītyasamutpāda(CSD: Co-surgimiento dependiente). Pero si una vez la persona ha reconocido el genuino sentido de CSD, él o ella, podrán romper la cadena del yugo. Deshacer la cadena de CSD, no significa una aislación de sí mismo, ni destruir todos los dharmas físicamente, más bien, es la apertura de otra dimensión transcendental donde se pierde el sentido de las preguntas sobre la distinción entre los dharmas y hasta el sentido de las preguntas de percepción y no-percepción. Al final, la acción de perseguir el Tao(道: camino en chino), o sea buscar la verdad del universo, ha de acabar influyendo en la sociedad humana, considerando las responsabilidades éticas y sociales. Un distinguido maestro zen, fue preguntado por una persona que decía: ¿Por qué vosotros los seguidores del Tao, siempre hacéis el zazen en el monasterio de la montaña, sin prestar ninguna atención (o interés) en el mundo secular y a los vecinos? El maestro zen, poniendo énfasis en la insignificancia de las acciones de distinción entre sí y los ajenos, apeló desde el principio la imposibilidad de establecer el concepto de narcisismo. Por eso el zen no es una mera meditación para el propósito constructivo de alguien en su vida, sino que se ubica más allá, ya que es una acción moral que hace más confusa la línea de distinción entre los

\footnotetext{
10 Watts, A. The Way of Zen. New York. Vintage Books. 1985.
} 
dharmas. El maestro también responde que el zen no es una obsesión de sí, sino que más bien es una obsesión sobre el universo. Y obviamente dicha obsesión del universo ha de conllevar una mejora social.

... En consecuencia, el mero auto-amor es imposible; se resuelve naturalmente en un amor de todas las cosas. Expresado de esta manera, la enseñanza Zen se convierte, al instante, en una profunda filosofía moral. Donde no hay distinción entre el universo y nosotros mismos, el concepto mismo del ego es inadecuado. No podemos pensar en nosotros mismos sin pensar al mismo tiempo en los demás. Zen no es, pues, una obsesión con el yo, sino más bien una obsesión con el universo, con todas las cosas de la naturaleza hacia el mejoramiento social de todos. ${ }^{11}$

El concepto llamado social, al que este estudio pretende revestir de nuevo, se refiere a una cualidad espacial que suele mostrarse en el campo arquitectónico y urbanístico. Dicha virtud, en este estudio solía encontrarse en los proyectos de Espacio Nirvánico y Espacio NY. ¿Entonces, la ya nombrada actitud espacial que persigue el mejoramiento social, en qué tipo de espacio podría expresarse? Las arquitecturas y ciudades no son esculturas en las que nosotros vivimos y pervivimos de generación en generación. La arquitectura y la ciudad tienen que provocar la mejora de la sociedad a la que pertenecen los dharmas físicos y no-físicos, en el proceso de la formación de los espacios. Por eso no son solamente esculturas. En este sentido, gracias a esta sociabilidad del espacio, todas las arquitecturas y las ciudades, tienen una dimensión pública, ya que de todas formas las arquitecturas y sus conjuntos tienen un poder de influencia social. Y no cabe duda de que dicha influencia social surge desde el espacio físico. Entonces, ¿Cuál es la manera plausible para hacer de nuestros vecinos, no unos insignificantes ajenos sino mediante los encuentros agradables con ellos, realizar la verdadera integración social? Esta tesis no trata de las metodologías no democráticas ni de la expropiación injustificada de las arquitecturas. Simplemente, el concepto llamado social se trata con esta pregunta: ¿cómo los arquitectos y urbanistas pueden ayudar al espacio en el que la bondad humana pueda revelarse? Como el agua no se esfuerza para reflejar la imagen de la luna, el espacio arquitectónico también tiene que ser así. Y eso es la fuerza para provocar la participación de los ciudadanos hasta en

\footnotetext{
11 Hoover, T. The Zen Experience. New York. The New American Library, Inc. 1980. pps. 220-221.
} 
el espacio no-físico. Así el espacio social fortalece y apoya la base física de la democracia. Por ejemplo, en un espacio público, en la calle, la gente charla, entra a las tiendas, camina junto a la pared y en la pared se inclina con el cuerpo, lee un periódico, espera a alguien, toma el sol y descansa saliendo desde la oficina, en la calle se alarga una despedida sin ningún propósito especial, compra verduras, mira los productos del escaparate con ligero interés, se tumba en la plaza y holgazaneando haciendo cosas no productivas capitalistas y piensa en algo de su vida, mira los pasajeros de la calle, se moja por la lluvia, y vive años y décadas. La ciudad tiene que poder invitar a la gente al exterior para que camine con los ajenos. No sería tarde para hablar sobre el papel social de los espacios y consolidar la solidaridad social, después de que en las calles se consigan dichos cariños narrativos primero. Además, no sería posible sin cursar estos procesos.

Nosotros construiremos para la gente. Nosotros desarrollaremos las ciudades y lugares donde es agradable estar, donde podemos conocernos (entre sí) en un entorno inspirador. ${ }^{12}$

Minister of Culture of Denmark, Marianne Jelved

Hay un ejemplo admirable de Jan Gehl. El proyecto fue realizado en el año 2013 en Largo do San Francisco de Brasil por el equipo de Gehl Architects. El cliente era Sao Paulo Urbanismo. El lugar original estaba envuelto por las baratas cercas azules y producían las angustias urbanas. El equipo de intervención decidió quitar las maliciosas cercas primero, y se cambió el sistema de semáforos para dar una accesibilidad más segura. También se pusieron aceras refinadas y la colocación del carril bici no fue olvidado. El resultado de la intervención fue maravilloso. El tiempo medio de permanecer en el espacio de la gente se aumentó al $237 \%$. Antes de la intervención, la población máxima era de 43 personas en el espacio, pero ahora en la hora óptima del día y durante el fin de semana, este pequeño espacio carga 150 personas, transformándose en una plaza atractiva. ${ }^{13}$ La gente trae la comida y comen y cenan, y mientras no sea ilegal, realizan cualquier tipo de actividad. El espacio ahora sujeta

\footnotetext{
12 “A people focused national architecture policy". Gehl Architects. 2014.

Fuente online: <<http://gehlarchitects.com/story-article/a-people-focused-national-architecture-policy/>>

13 "More people-friendly megacity". Gehl Architects. 2013.

Fuente online: <http://gehlarchitects.com/cases/a-more-people-friendly-megacity/>
} 
a la gente para que no se pierda sola en el universo social. La gente estaba anhelando este tipo de espacio público. No hay duda de que el espacio nirvánico ha de ser también social.
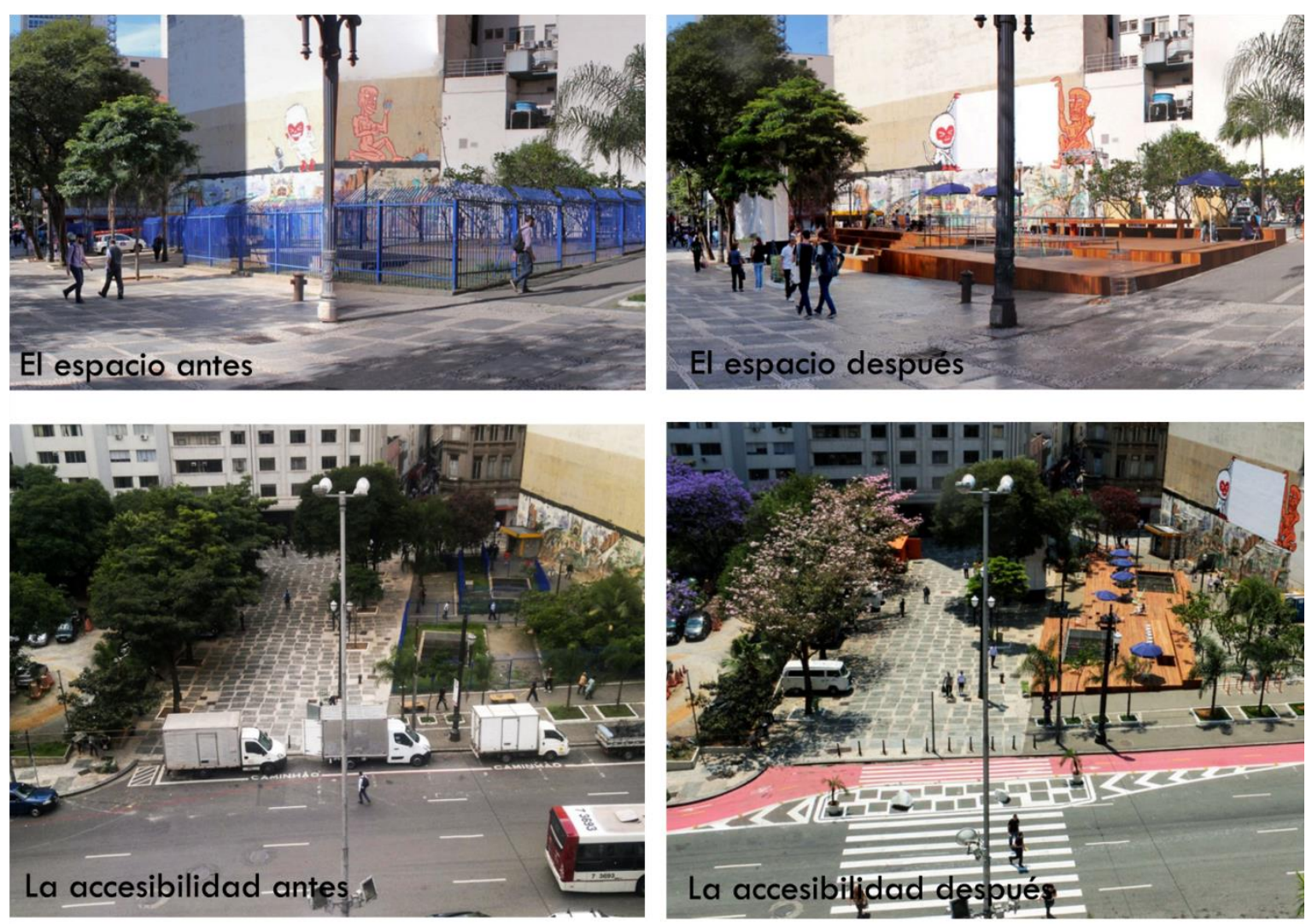

Figs. 14-13. Antes y después de Largo de San Francisco. 


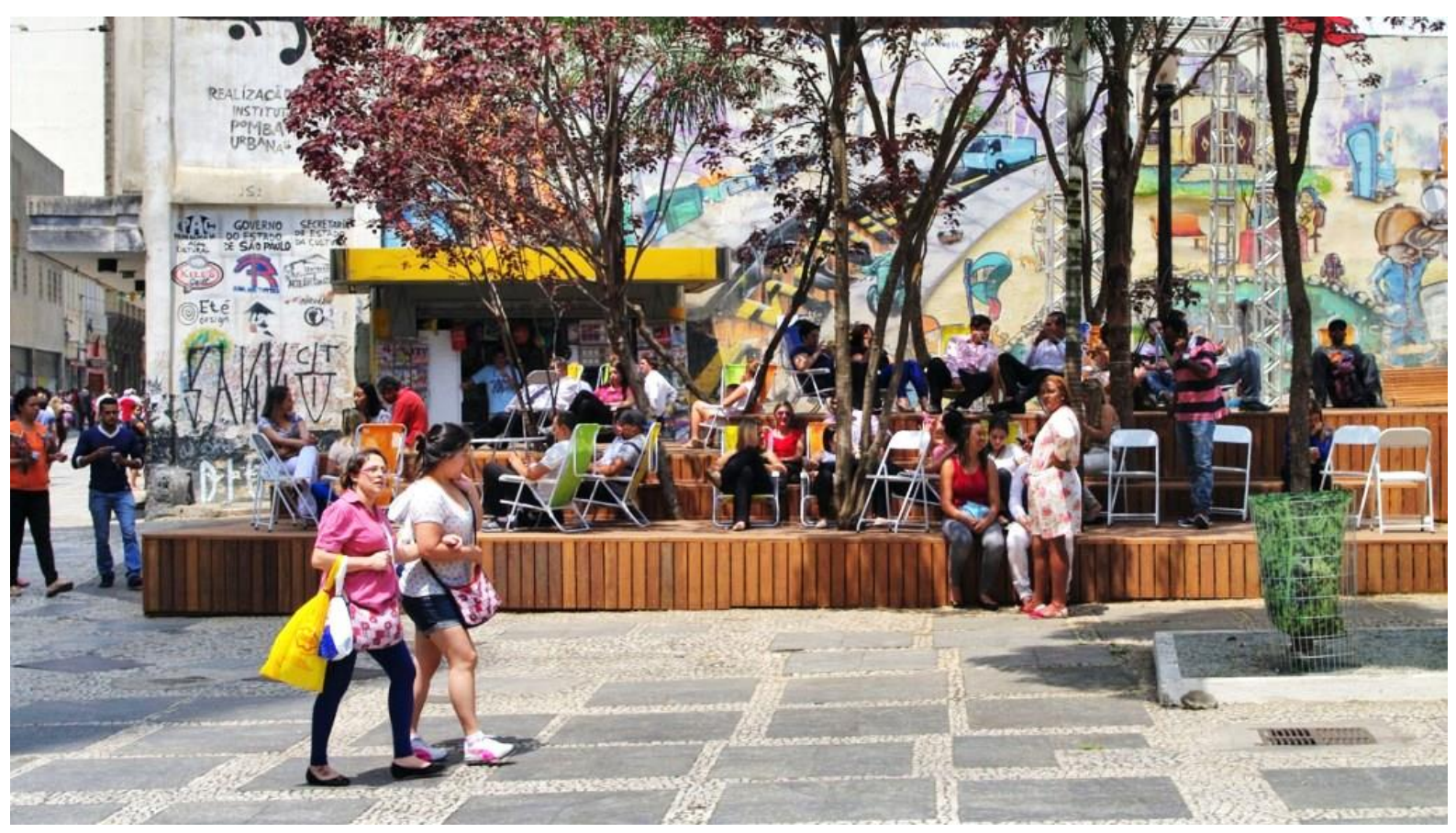

Fig. 14-14. Nueva terraza de madera.

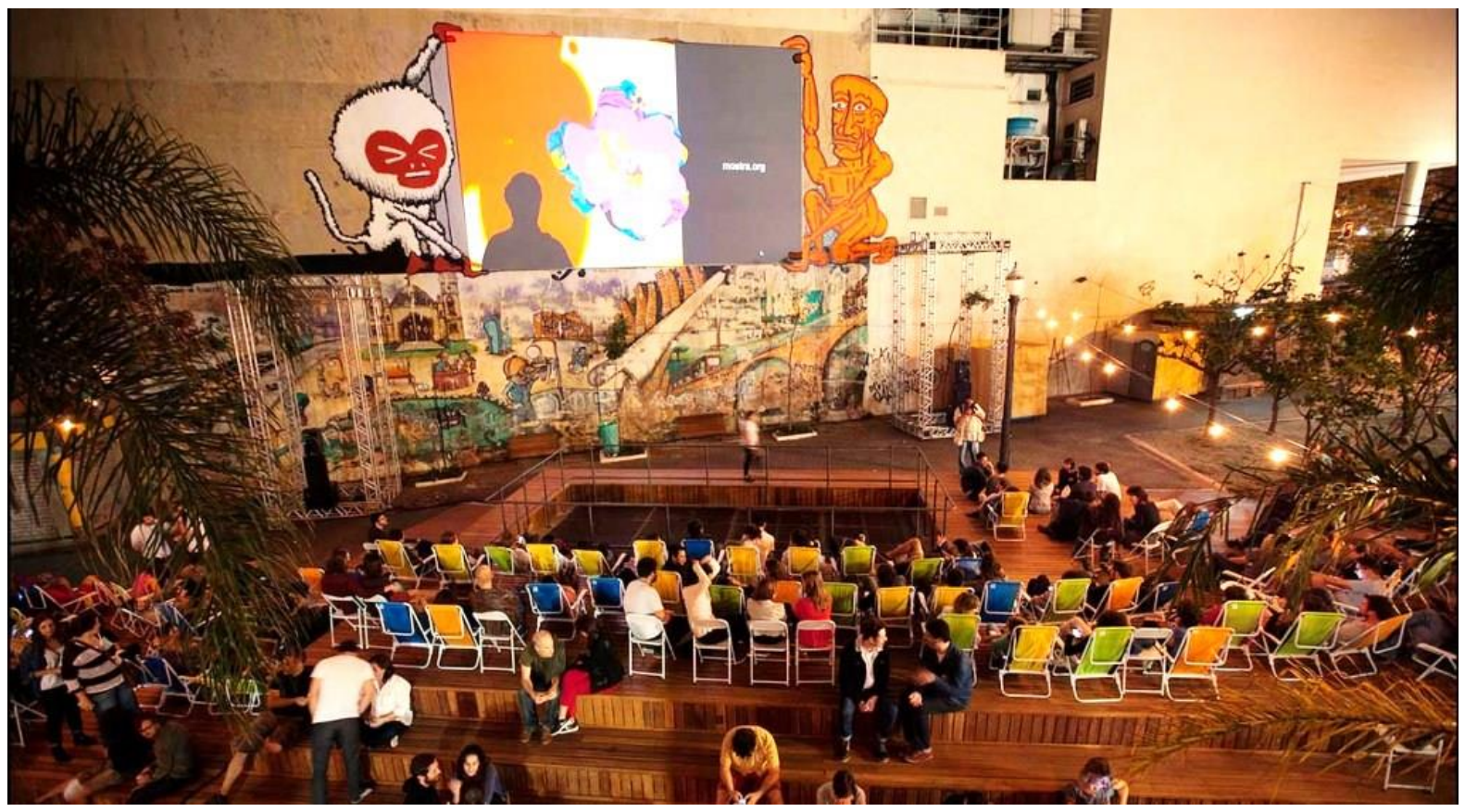

Fig. 14-15. Concierto nocturno al aire. 


\section{More people passing \& staying at peak hours}

\section{Before}

In 2013 before the pilot project began, $\mathbf{4 3}$ people were

spending time in the square at peak hours.

Impact after implementation The number of people passing or staying at the square at peak hours has gone up by $\mathbf{2 3 7} \%$.

\section{$237 \%$}

more people

spend time

at the square

(Average of

peak hour counts)
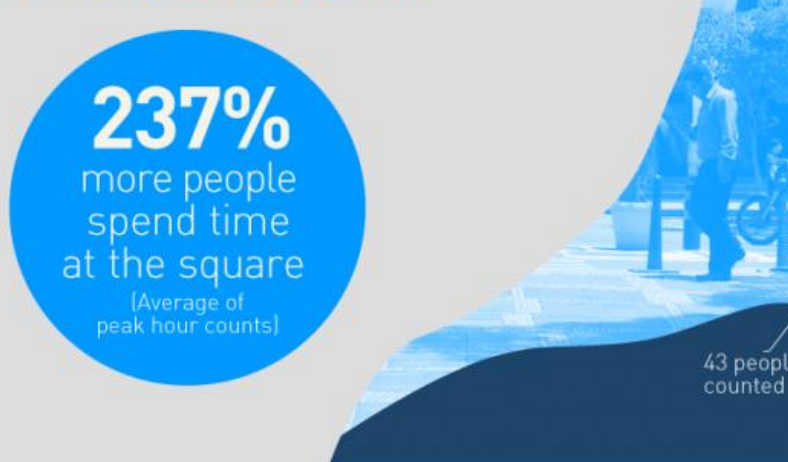

150 people

counted

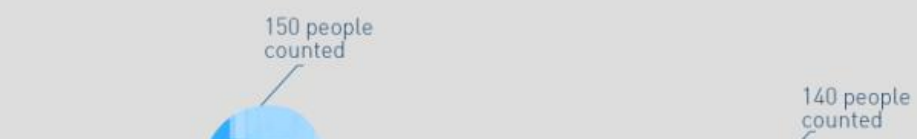

$8 \mathrm{~h}$

9h $10 \mathrm{~h}$

$|11 \mathrm{~h}| 12 \mathrm{~h}$

$13 \mathrm{~h}$

Tab. 14-1. Trayectoria antes y después de la población usuaria por hora. 


\begin{abstract}
Atmósfera
Un objeto largo es el largo cuerpo de Buddha;

Un objeto corto es el corto cuerpo de Buddha. ${ }^{14}$
\end{abstract}

Zenrin.

La Amósfera en este estudio significaría indagar la excelencia de la influencia anímica entre los sujetos y los espacios naturales e incluso artificiales. Por eso, el discurso de dicha influencia anímica, naturalmente, se ubica en los campos arquitectónicos y urbanísticos. La consciencia de la influencia anímica podría inyectar al sujeto por algún método artificial o percibirla por sí mismo. ¿Qué es la verdad? Es una pregunta vaga y al mismo tiempo imponderable. En 1984 de George Orwell, la obra maestra más famosa entre las novelas distópicas, O'Brien reprende a Winston en el proceso de adoctrinamiento diciendo: $<<j E s o$ fue estúpido, Winston, estúpido!>>. Mediante la fuerza se puede modificar el cuerpo humano y extraer la iluminación distorsionada. El cuerpo retorcido, deshaciendo las relaciones de CSD $^{15}$ entre el mundo-dharma y el ego-dharma, renace o vegeta como un tronco de carpintería sin nervio simpático. El espacio nos da el mensaje con su peculiar gramática. Opresivo, brillante, depresivo, benigno, modesto, fastuoso, pacifico, dinámico, con diversos caracteres emotivos, el espacio nos invita o sitúa en su presencia. En este sentido, la interpretación de Foucault pellizca la parte oscura humana del deseo enfermo sobre el poder, resultando especialmente interesante cuando trata los planes arquitectónicos de la prisión y del hospital en los que se encuentran los cuerpos sojuzgados(v.-fig. 1416). ${ }^{16}$ 獨起 (Dokuokoshi en pronunciación japonesa: levantarse independientemente solo per se) fija los dharmas en su mundo solitario; 緣起 (Euwokoshi: Co-surgimiento dependientemente) libera los dharmas desde las angustias ontológicas. En La Iglesia de la Luz, Ando sustituyó la existencia de la cruz en una ausencia humilde, en lugar de enfatizar la existencia física de la cruz de madera o de hormigón cuya presencia nunca puede ser celestial, sino artificial antes que sagrado. La forma de interpretación teológica de Ando hace contraste con las tradiciones occidentales. En la teología occidental también existen varias interpretaciones hermosas y apropiadas que responden a cada

\footnotetext{
14 Watts, A. The Way of Zen. New York. Vintage Books. 1985. p. 144.

15 Co-surgimiento dependiente-(NdA)

${ }^{16}$ Para más información; v. Vigiliar y Castigar de Michel Foucault y Panóptico de Jeremy Bentham.
} 
época. En el caso de Ando, también es una de las numerosas interpretaciones de la vigente época, con la que intentan redefinir la relación entre Dios y los humanos. En esta iglesia no se apela que la enorme cruz sea la verdad. La verdad, a veces, es mejor no expresarla con la palabra humana; porque siempre existen riesgos de mala interpretación debido a los límites del lenguaje humano. El Dios de Ando en la iglesia se desprende de sus pesados ropajes ( $y$ ahora estamos más que nunca cerca del cielo). La Atmósfera, en el término de este estudio, se refiere entonces a una sensación del ambiente en el proceso de percibir $\mathbf{N} \mathbf{Y}^{17}$. Es decir, la sensación es la ilustración de que todos los dharmas son efímeros, aquí permanece una forma sencilla de existir de los dharmas. Los dharmas son transitorios; por eso todos son especiales. Y ahora la cosmovisión supera la pregunta de cuál es especial y cuál no lo es. Repitiendo lo dicho, sólo queda una forma de existir de los dharmas; esta sensación se refiere la Atmósfera.

Taoísmo, el confucianismo y Zen son expresiones de una mentalidad que se siente completamente como en casa en este universo, y que ve al hombre como una parte integral de su entorno. La inteligencia humana no es un espíritu encarcelado en secreto y en silencio sino un aspecto de todo el organismo intrincadamente equilibrado del mundo natural.... ${ }^{18}$

La Atmósfera, que es una influencia anímica, requiere una premisa un experimento espacial y corporal. Y dicho experimento, sin controversia, ha de practicarse por medio de las relaciones entre los humanos-dharmas. El proyecto llamado La Cabaña de Cartón del Tío Tom en el capítulo 13, provee las prácticas con la que los ciudadanos experimentan sus capacidades influenciables formando una parte o un vínculo del proyecto. Las prácticas de las influencias son espirituales y anímicas, y, al final cambia la sociedad total. El reino de los cielos empieza desde mi corazón mismo; no desde ningún otro lugar, ciudad, país ni en otro planeta. En este punto, la ortodoxia cristiana también es consonante con el buddhismo. Al acercase el periodo de las Fallas de Valencia, este tipo de espíritu puede encontrarse en todas las calles en la ciudad. Las Fallas, antigua fiesta pagana en la que los ciudadanos

\footnotetext{
17 No-yo-(NdA)

18 Watts, A. The Way of Zen. New York. Vintage Books. 1985. p. 192.
} 
exorcizaban o invocaban buena suerte quemando los viejos y rotos muebles, se ha revestido ahora en un espíritu de nueva era. El papel de la influencia de una plaza no se puede ni comparar con la de las Fallas. Es algo más allá que concepto social de Jan Gehl. Para formar el dharma llamado las Fallas cuyo tamaño es colosalmente abrumador, requieren todas las participaciones de los barrios(CSD). Los eventos de los barrios y sus vínculos aparecen y desaparecen frecuentando libremente las dimensiones físicas y sociales, y se reafirma su totalidad. El territorio, la política, la cultura, la familia, los turistas y el turismo, las empresas y sus comercialismos, la seguridad de la calle, el sistema de semáforos, el sistema de metro y el autobús y etcétera, los dharmas de diversas dimensiones, sus bordes se transforman en una forma más velada(NY). Los ciudadanos pisan el pavimento de asfalto el cual era un objeto exclusivo de los coches. Las calles son enormes con su nueva medida de anchura. Los ciudadanos enseñan sus cuerpos dominando la ciudad con sus propios pies, y se iluminan. La plaza que siempre estaba llena de los arrogantes coches brutales, los expulsa en este periodo de las Fallas. En la calle, se queda una sencilla verdad que es, la ciudad es algo que puede derrocarse por los ciudadanos, y también algo que se les puede arrebatar en cualquier momento de ceguera. Cuando termina el período de las Fallas, al día siguiente, como todos los dharmas son efímeros, empieza un día de horario coloquial. Los dharmas vuelven al estado de NY desvinculándose desde las fallasdharma. La Atmósfera es un espacio físico y no-físico que permite el establecimiento de este tipo de cosmovisión. En este sentido, la Atmósfera es un concepto expandido del concepto social. 


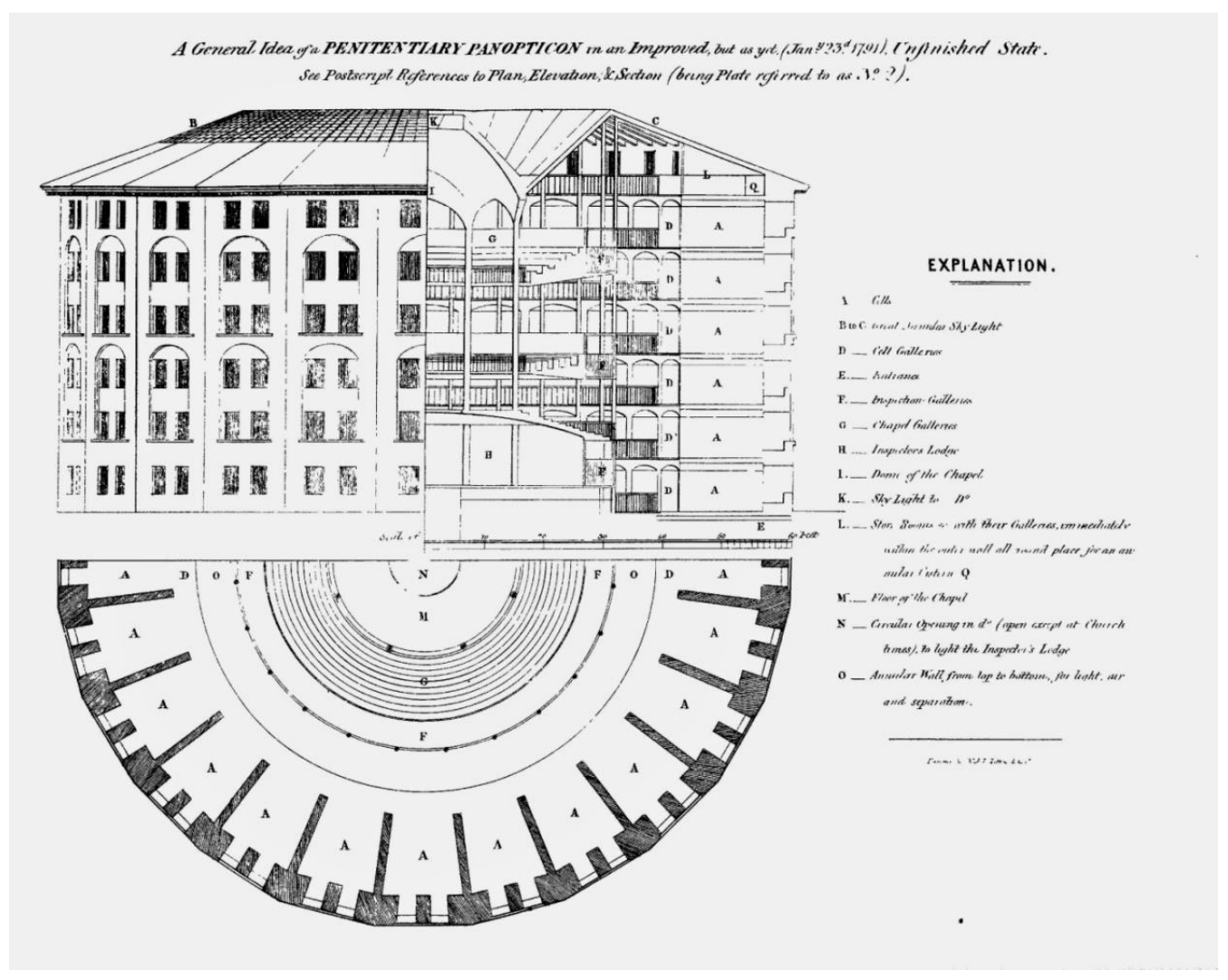

Fig. 14-16. Panóptico de Jeremy Bentham. 1791. 


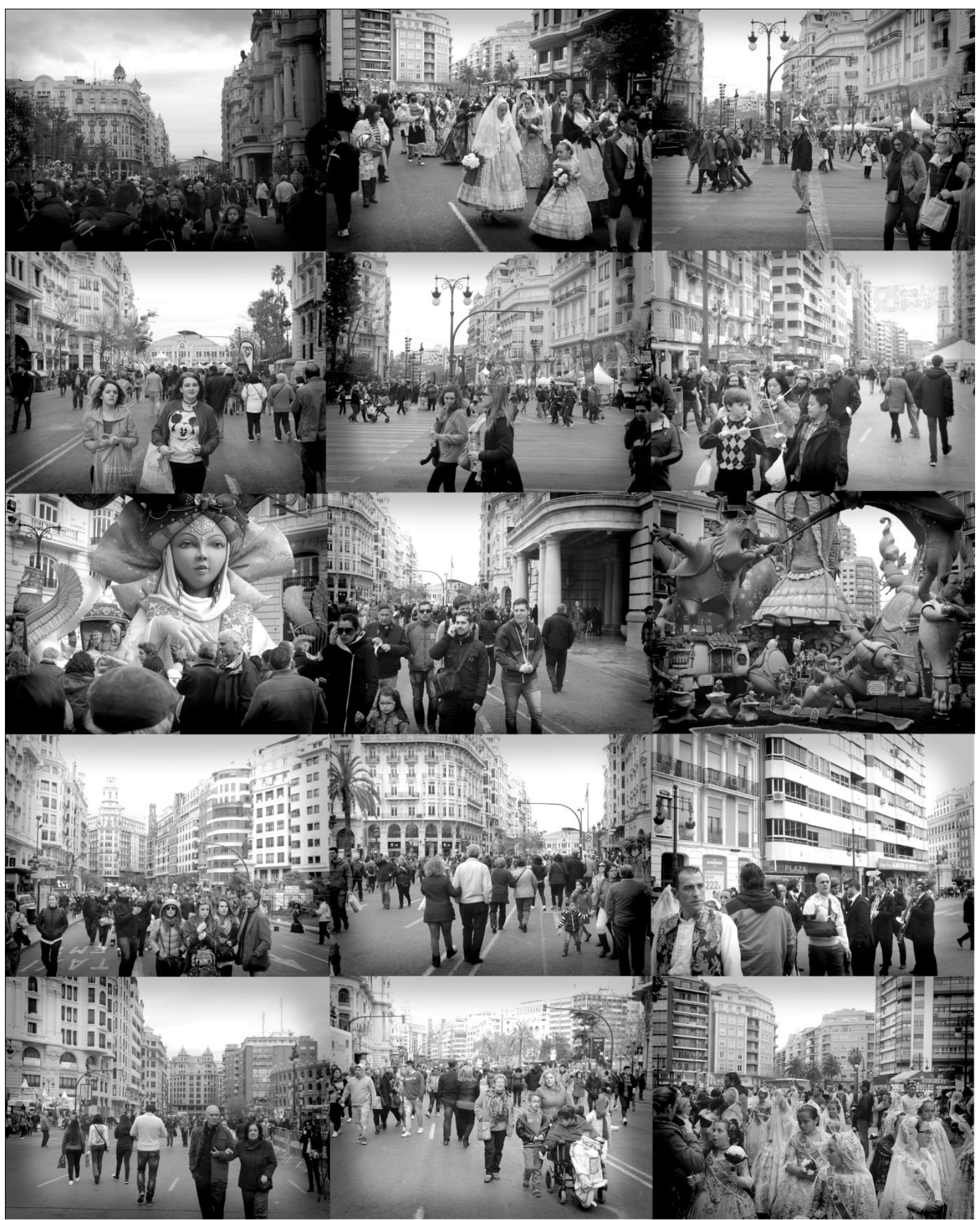

Figs. 14-17. Los peatones libres en el periodo de Las Fallas de Valencia. 


\section{Gracia}

En la zona cultural de Asia, el término de Tao, representado por la letra china 道, literalmente significa el camino y una definición más ampliada sería un camino para llegar a la verdad. Por eso, El Sendero Medio, denominado también Noble camino óctuple, y reproducido por la letra china 八正道 significaría 8 caminos correctos, pueden significar: Ocho caminos justos para llegar a la verdad. El taoísmo es una palabra compuesta de sendero e-ismo. Entre los buddhistas es el mantra más básico y principal en las prácticas para perseguir la verdad, que es la enseñanza de Siddhartha, ahora mitificada y consagrada por sus seguidores posteriores. Sin embargo, ya se sabe que en el buddhismo existe un principio en el que no hay dharma permanente. Los mantras son dharmas. Por eso, siempre el buddhismo advertía que una vez un mantra se ha consagrado desde aquel momento puede producir una agonía. Es irónico porque el mantra para llegar al nirvana puede traer la agonía también. En la famosa biblia llamada Tao Te Ching(chino:道德經), Lao-Tse(chino: 老子, a. C. Siglo 6 5 - a.C. 531) empieza su primera frase así: <<Tao ya no es Tao desde el momento que lo nombre Tao >>. Indudablemente, dicha tesis habla sobre lo inexpresable de la verdad última, y a la vez, posiblemente está apelando a tener precaución para no perder la verdad estando demasiado cegado por la divinidad. A pesar de que el habla es el método para pensar, para interpretar y averiguar la verdad no hay que percibirla quedándose en el límite del lenguaje.

Si te encuentras el Buddha, mata el Buddha.

Si te encuentras los patriarcas, mata los patriarcas.

Rinzai, El Registro de Rinzai(㯺濟錄).

La enseñanza tan radical y polémica de Rinzai(臨濟, ¿? - 867) en su Registro del Ringai, es una expresión radical que destaca la importancia del reconocimiento de que cualquier enseñanza de Siddhartha también es un dharma que no es eterno, sino efímero. 公案, en japonés Kōan, es una rama de buddhismo que sigue a este tipo de enseñanza más apasionadamente. Por eso, los seguidores de 
Kōan, prefieren los métodos más primitivos -que se pueden adquirir en las vidas cotidianas- que el mantra del Noble Camino Óctuple. Se muestra posteriormente una célebre frase que describe el carácter crucial de Kōan. Este tipo de tradición viene, desde luego, desde China. Antiguamente los chinos no ponían mucha importancia en la lógica del sistema axiomático que no tiene las contradicciones internas, más bien preferían pensar de manera intuitiva. De esta forma se consideraba como la manera para ver la verdadera cara del mundo. ${ }^{19}$

\section{不立文字}

Como la verdad no se puede establecer su significado mediante las palabras,

\section{呚外別傳}

Se imparte, aparte de los libros sagrados

以心傳心

Eso se introduce desde la mente a la mente,

直指人心

Así se reconoce el caracter del buddha,

\section{見性成佛}

Y que cumplan el buddha. ${ }^{20}$

Cuando T'ung-shan fue preguntado, <<¿Qué es el Buddha?>> Él respondió, $<<i$ Tres libras de linol>>21

Como se observa en las frases anteriores, en las tradiciones orales hay muchos relatos divertidos. Eso no es una desmesura prosaica que produce sentimientos jocosos, haciendo bricolajes con las materias divinas y blasfemas de igual manera. Tampoco produce ningún divertimiento pervertido que critica a la debilidad ajena. La gracia de Kōan es más pura e inocente, como Harpo de los Hermanos Marx. En la película llamada Pistoleros de Agua Dulce (1931), su título original Monkey Buiness, resulta cómico cuando el personaje choca el mundo contra su cuerpo, pero allí no hay maldad alguna, aunque no parece ni siquiera que sepa qué es la bondad.

Un monje preguntó a Ts'ui-wei, <<¿Por qué razón vino el Primer Patriaca desde Occidente?>> Ts'ui-

\footnotetext{
19 <<간화선 [看話禪]〉> Encyclopedia of Korean Culture. 한국민족문화대백과사전.

Fuente online: <<http://encykorea.aks.ac.kr/Contents/Index>>

${ }^{20}$ Llegar al nivana y ser el buddha son sinónimos, y se expresa tradicionalemente: cumplir el buddha.-(NdA.)

21 Hoover, T. The Zen Experience. New York. The New American Library, Inc. 1980. p. 145.
} 
wei respondió, <<Pásame aquella madera. >> Tan pronto como se lo pasó, Ts'ui-wei le pegó con ella. ${ }^{22}$

Existe un esfuerzo de los seguidores de Kōan para llegar al nirvana y para no atraparse por el límite de lenguaje y las perspectivas doctrinales. Exactamente a causa de dicho esfuerzo, en las prácticas de ellos a veces surge una conversación chistosa y acción paradójica, lo que no era fácil de comprender o ser aceptado por la sociedad. Evitaron las perspectivas dogmáticas, experimentaron las conversaciones improvisadas y arbitrarias, creyendo en la posibilidad de que así tal vez podrían correr la cortina en la que tenía que estar escondido el nirvana. ¡Y qué extático e intensivo es el deleite de reconocer la verdad! Las conversaciones de los Kōans de aquella época aún tienen poder para romper el marco de pensamiento de esta era. En el ámbito nirvánico, si se pudiese reconocer la providencia del universo, el proceso habría de conllevar una energía alegre a los humanos. La emoción humana que enfrenta la gran providencia de Dios, sería lo colosal o la sublimidad -que también es una impresión que la Atmosfera puede dar al entorno- pero, también, no hay que olvidar de que allí existe otra emoción que es la gracia. No es necesario enfatizar la alegría que se puede obtener leyendo la biblia, sin embargo, la gracia de probar el trozo de la verdad escuchando a los Kōans (las conversaciones de los maestros) es aún más emocionante. Así, se entiende Kōan como un tipo de esfuerzo para llegar al nirvana, como muchos otros practicantes buddhistas.

En una ocasión, Ma-tsu and Po-chang fueron a dar un paseo, cuando vieron algunos gansos salvajes que pasaban volando. <<¿Qué son?>> preguntó Ma-tsu. <<Son gansos salvajes,>> dijo Po-chang. <<¿Dónde van?>> Ma-tsu exigió la respuesta. Po-chang respondió, $<<Y a$ se han ido volando.>> De repente Ma-tsu agarró a Po-chang por la nariz y se lo retorció por lo que él gritó de dolor. <<¿Cómo,>> gritó Ma-tsu, <<podrían alguna vez haber volado?>>23

Cuando los seguidores de Kōan intentan ver el mundo por medio de una nueva perspectiva surgen unas emociones deleitantes descomponiendo el sentido común. Por eso, Kōan es la gracia. Una vez, el célebre artista francés Duchamp puso un váter en la galería de arte, no en el baño. El objet de los

\footnotetext{
22 Ídem.

${ }^{23}$ Ibid. p. 140.
} 
dadaístas revela el mismo tipo de lógica del pensamiento que los seguidores de Kōan. Este tipo de retos y pruebas tentativas no son siempre exitosas, pero proveen sensaciones frescas y agradables. El imaginarse el mundo de los cómics como una realidad era la nutrición espiritual para los activistas de Archigram. Las ciudades de Plug-in City, Walking City, Instant City y otros numerosos proyectos de Archigram, ofrecían el gusto al espectador como si estuviera leyendo un cómic. Las actividades de Archigram que rompieron el sentido común fueron bastante sensacionales para aquel campo de arquitectura aburrida. Los seguidores de Kōan que practicaban las actividades imprevistas, también se sitúan en la misma coherencia. Enfrente de la iglesia, y dentro de la pinacoteca, en la plaza, en los espacios santos y divinos, estaba puesta La Cabaña del Cartón del Tio Tom quien era un vagabundo. También, se habían quitado los coches de la plaza para restituir el espacio a los ciudadanos, rompiendo la lógica del capitalismo en el proyecto de Nothingness. Cuando se aparta la obsesión dogmática, surge un espacio heterogéneo y extraño, que es la gracia para ver la verdadera cara de nuestra sociedad estropeada y enferma, y es el humor con la actitud más agresiva. La gracia inesperada de esto tipo de proyectos es un elemento imprescindible para describir el espacio nirvánico.

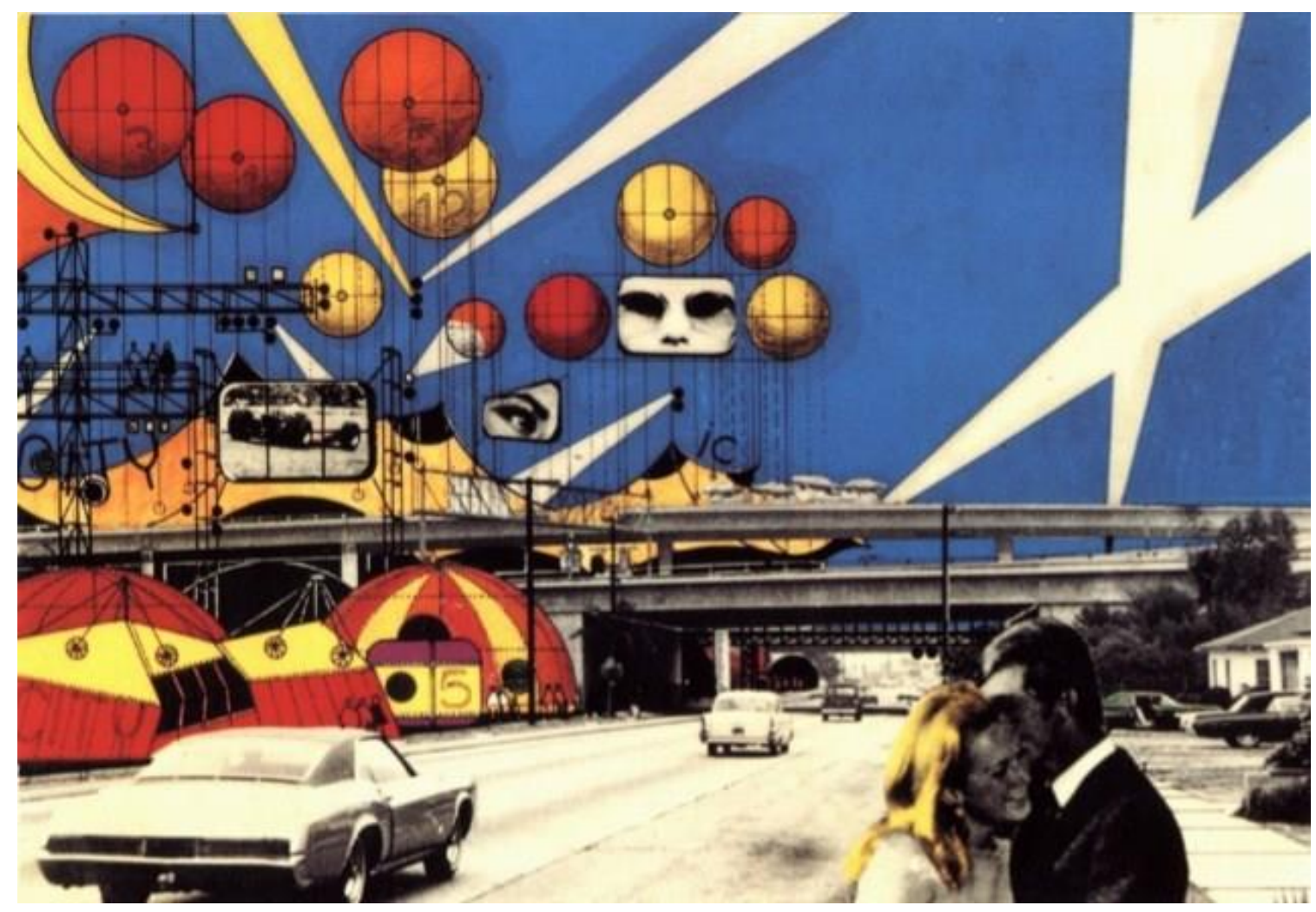

Fig. 14-18. Instant City. Archigram. 1951. 


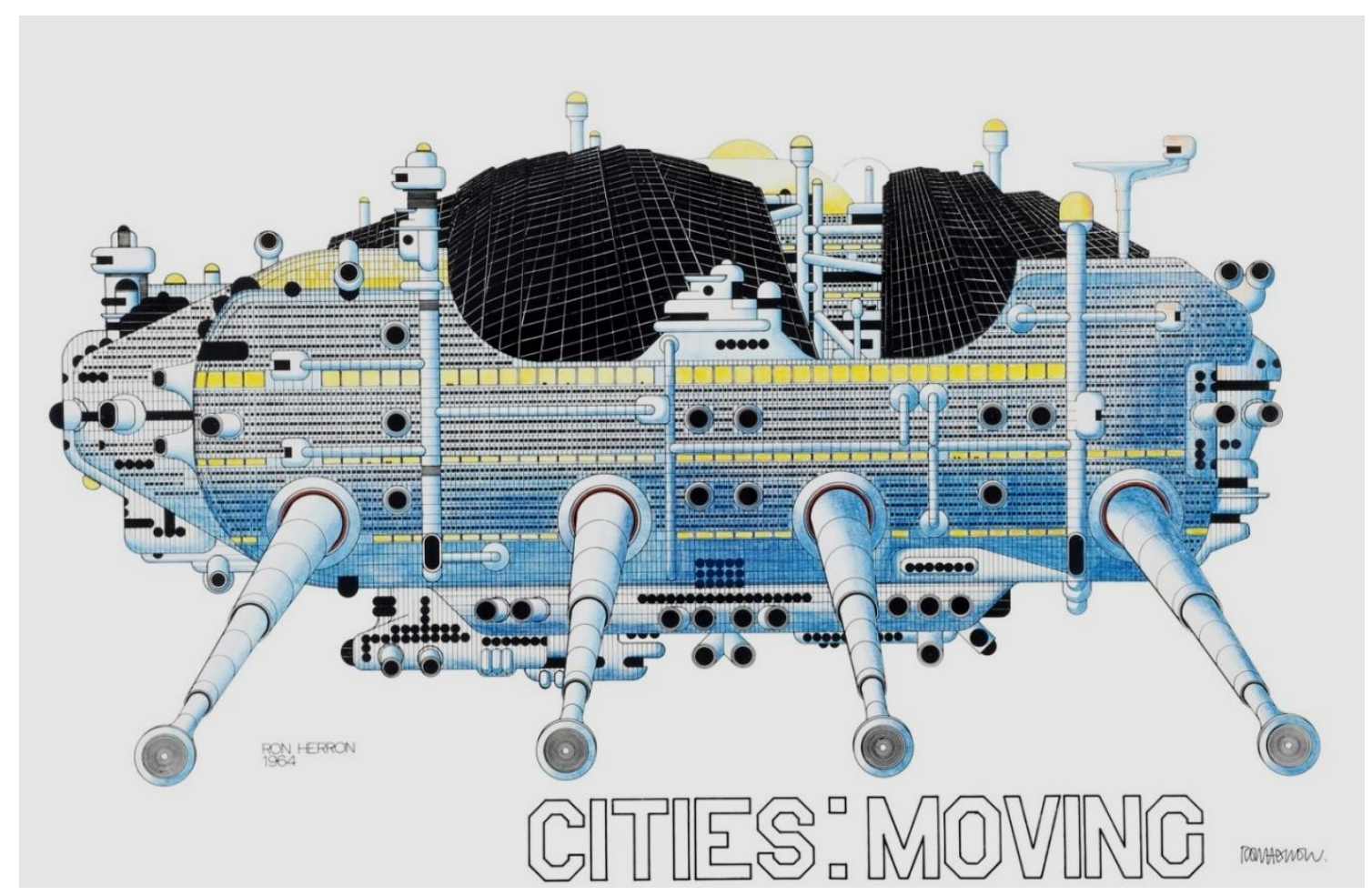

Fig. 14-29. Walking City. Archigram. 1964.

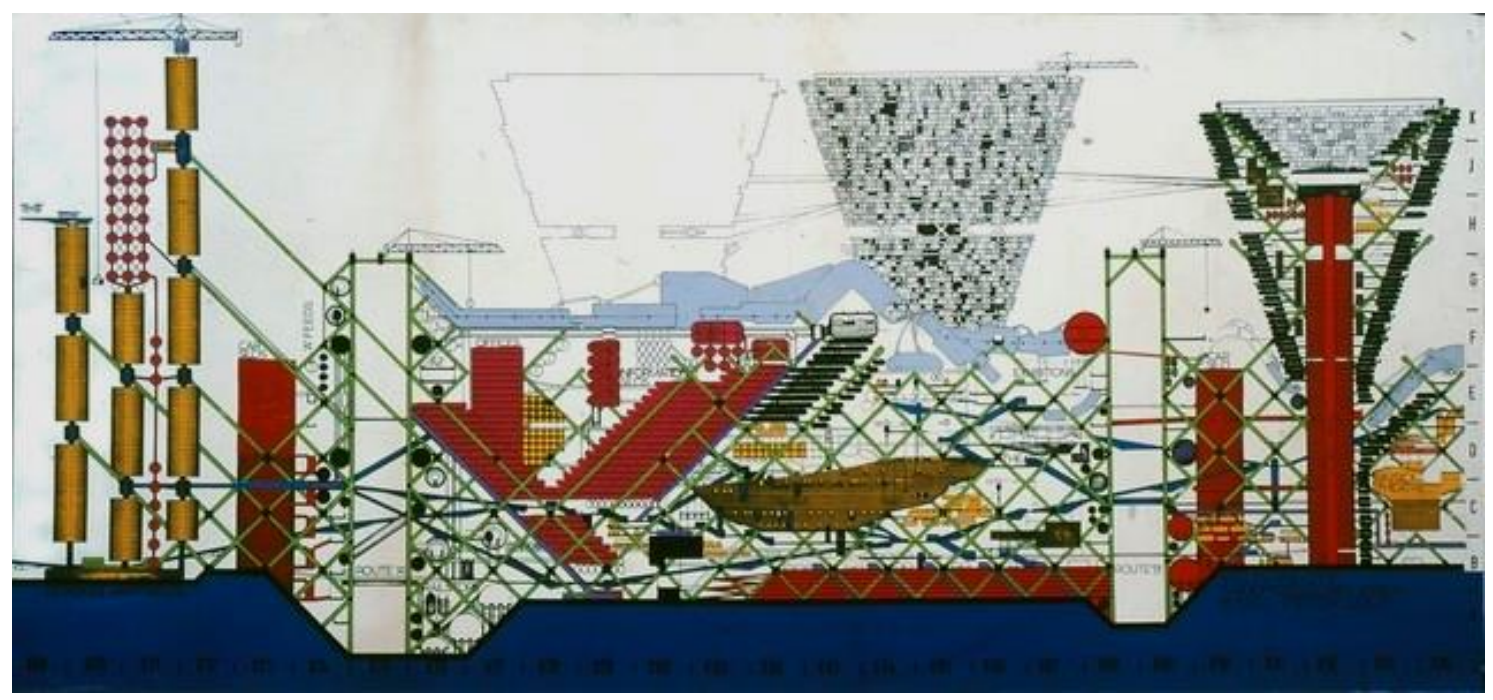

Fig. 14-20. Plug-In City. Archigram. 1964. 


\section{Serenidad}

Los anteriores conceptos de Belleza, Social, Atmósfera y Gracia, sin controversia, se aplican a los campos social, filosófico, estético, arquitectónico, etc. Pero este concepto se establece especialmente en el campo de la arquitectura ética para abarcar la paz paisajística y la armonía medioambiental. E igualmente con la actitud espacial de $\mathbf{N Y}^{24}$, también es un término parecido con el concepto eco-friendly que es el término más conocido cuando se trata el tema los impactos ambientales, pero dicho concepto no cubre todo el rango de definición de la Serenidad, la cual lleva la base del argumento buddhista. La idea se basa sobre una ética medioambiental más avanzada, implicando las acciones de causa sui (NY) que es superior que las éticas basadas en premios y castigos o éticas basadas en el resultado, las cuales tienen sus ciertos límites fatídicos como está demostrado repetitivamente en esta tesis. El ensayo de Zenrin es un ejemplo brillante que explica qué es la ética medioambiental buddhista.

\section{Entrando al bosque no toca la hierba.}

Entrando al agua no produce onda. ${ }^{25}$

\section{Zenrin}

La Serenidad no es un simple credo naturalista, sino más bien una comprensión de las relaciones entre el humano, la arquitectura y el medioambiente, las cuales no son unidades independientes o dominantes entre ellos, actúan como partes integrales del universo. Con dicha comprensión la Serenidad se expresa por acciones. Si Zenrin fuera un arquitecto, no describiría el concepto de la Serenidad tan solo como un diseño menos molesto al paisaje o con menos impactos ambientales. Estas cosas sustanciales son importantes por supuesto como el tema de la sostenibilidad. Sin embargo, la cuestión principal trata sobre la filosofía que puede sostener las acciones.

El campo de la influencia de la arquitectura, las ciudades o cualquier tipo de estructura espacial, no se delimita sólo a las dimensiones físicas y ecológicas, porque los espacios proveen especialmente

\footnotetext{
${ }^{24}$ No-yo-(NdA)

${ }^{25}$ Cit. en Watts, A. The Way of Zen. New York. Vintage Books. 1985. p. 169.
} 
una influencia anímica a los humanos. Para investigar los campos ecológicos y físicos, existen varios programas, por ejemplo, Ecotec Analysis de Autodesk, que sería una de las herramientas más queridas en el campo de la arquitectura sostenible. Entonces, si es tan importante analizar los efectos ambientales de los diseños, también el análisis sobre el proceso de fertilización y destrucción de las almas en los espacios igualmente tendría su importancia. Por eso, aquí se requiere una visión más amplia que eco-friendly. Divulgar fervientemente las arquitecturas monásticas de Japón no puede invocar el nirvana ni el sistema ecológico sostenible. Desde hace tiempo el mundo presta una fuerte atención al concepto llamado la sostenibilidad. Agenda 21 y Carta de Leipzig apelan la importancia de estos temas, que otra vez el mundo contemple el concepto de sostenibilidad en la perspectiva más exhaustiva. Esta era contemporánea incuba un nuevo espíritu y la arquitectura ha de corresponderlo. Plantar los árboles, mantener el césped, cavar la tierra y regar con el agua y poner arbustos y flores, estas cosas son detalles circunstanciales, no son esenciales de la escena de zen.

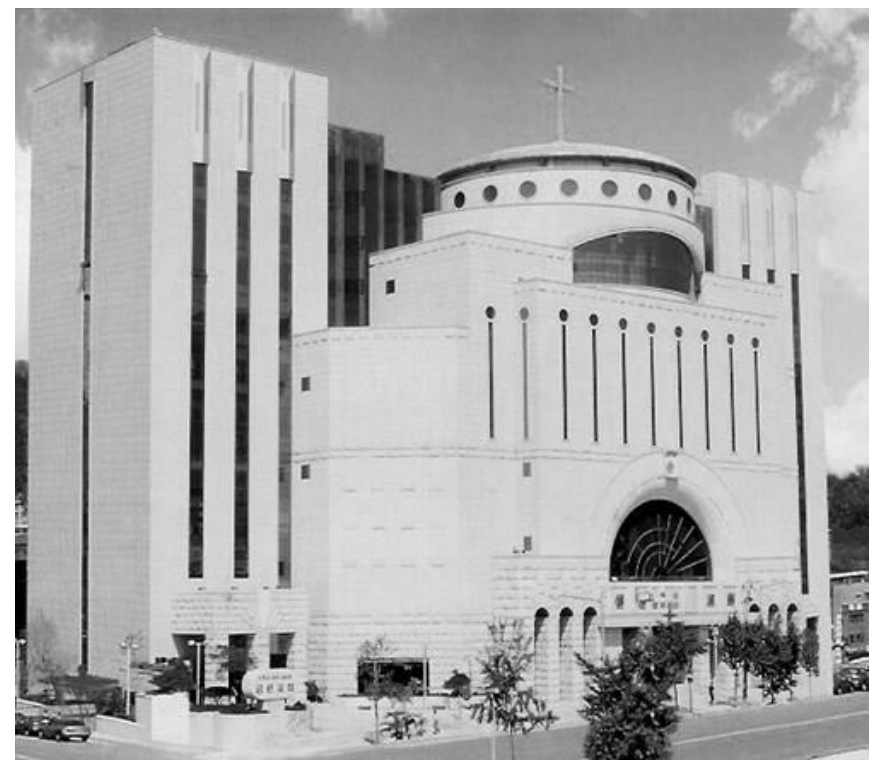

Fig. 14-21. Una iglesia contemporánea pero equivocada en Seoul de Corea.

La iglesia de la imagen se encuentra con una fachada horriblemente grande y cerrada notificando la nueva epifanía de la edad oscura. Malinterpretando la retórica de la arquitectura clásica, la iglesia incuba en vano el deseo de poder heredar el espíritu antiguo. La iglesia no se categoriza en ningún movimiento de la historia de la arquitectura, ni renacimiento, ni barroco, ni neoclásico etc. Al Dios 
hebreo no parece gustarle su vestido de barato capitalismo asiático. Imaginando la intención del fotógrafo, también, se puede saber que la relación entre la iglesia y las arquitecturas circundantes está siendo ignorada totalmente, incluso la escala. El volumen tan pesado de la iglesia desea francamente la oración de la bendición pervertida para más prosperidad económica, en una manera obviamente equivocada como en la mayoría de las iglesias contemporáneas de Corea. El Dios extranjero está mal interpretado en Corea, como lo fue Buddha príncipe tibetano, en Europa y Norte América.

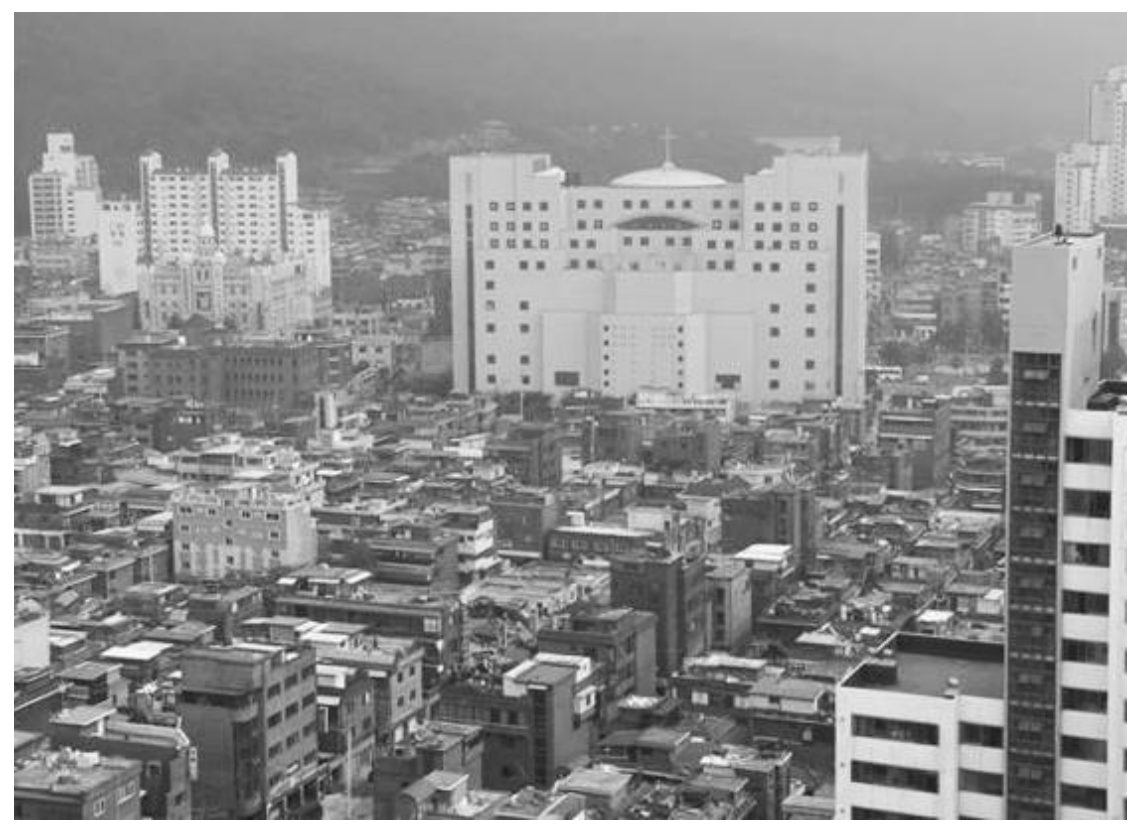

Fig. 14-22. Relación con los edificios adyacentes.

Y a unos que hablaban de que el templo estaba adornado de hermosas piedras y ofrendas votivas, dijo: <<En cuantos a estas cosas que veis, días vendrán en que no quedará piedra sobre piedra, que no sea destruida.>>

El diseño de la iglesia, refleja una interpretación de los humanos quienes son débiles y mortales y que desean que la iglesia perdure durante siglos y siglos. La cruz en la cima de la iglesia, provee una escena patética a causa de un contraste exorbitante. El amor y la obediencia que Jesucristo enseñó 
cuando murió en la cruz, para esta iglesia no son virtudes deseables. La iglesia implica las agonías sostenibles. Además, ni siquiera es bonito, en el término estético general.

Dios es como 不立文字 (no se puede establecer su significado mediante las palabras), cualquier templo extravagante o lujoso no podría expresar la grandeza de Dios. El significado de Dios cristiano no podría introducirse por la fuerza en estas piedras de mármol. ¿Si Dios es omnipresente, por qué la gente busca a Dios en una iglesia tan lujosa?

Hay un templo buddhista llamado Seonamsa en un pueblo pequeño ubicado en el margen de la Península Coreana. El significado de su nombre en chino 仙簏寺 es las piedras celestiales, porque antiguamente según la leyenda allí un ser celestial jugaba al Go -que es un juego de mesa el cual se juega con las pequeñas piedras blancas y negras en una tabla cuadrada de madera. ¿En este templo buddhista, morará Dios? Las arquitecturas allí no proclaman nada, sino que están intentando, calladamente y humildemente, vivir allí pidiendo a la naturaleza que permitiera la convivencia con los monjes buddhistas.

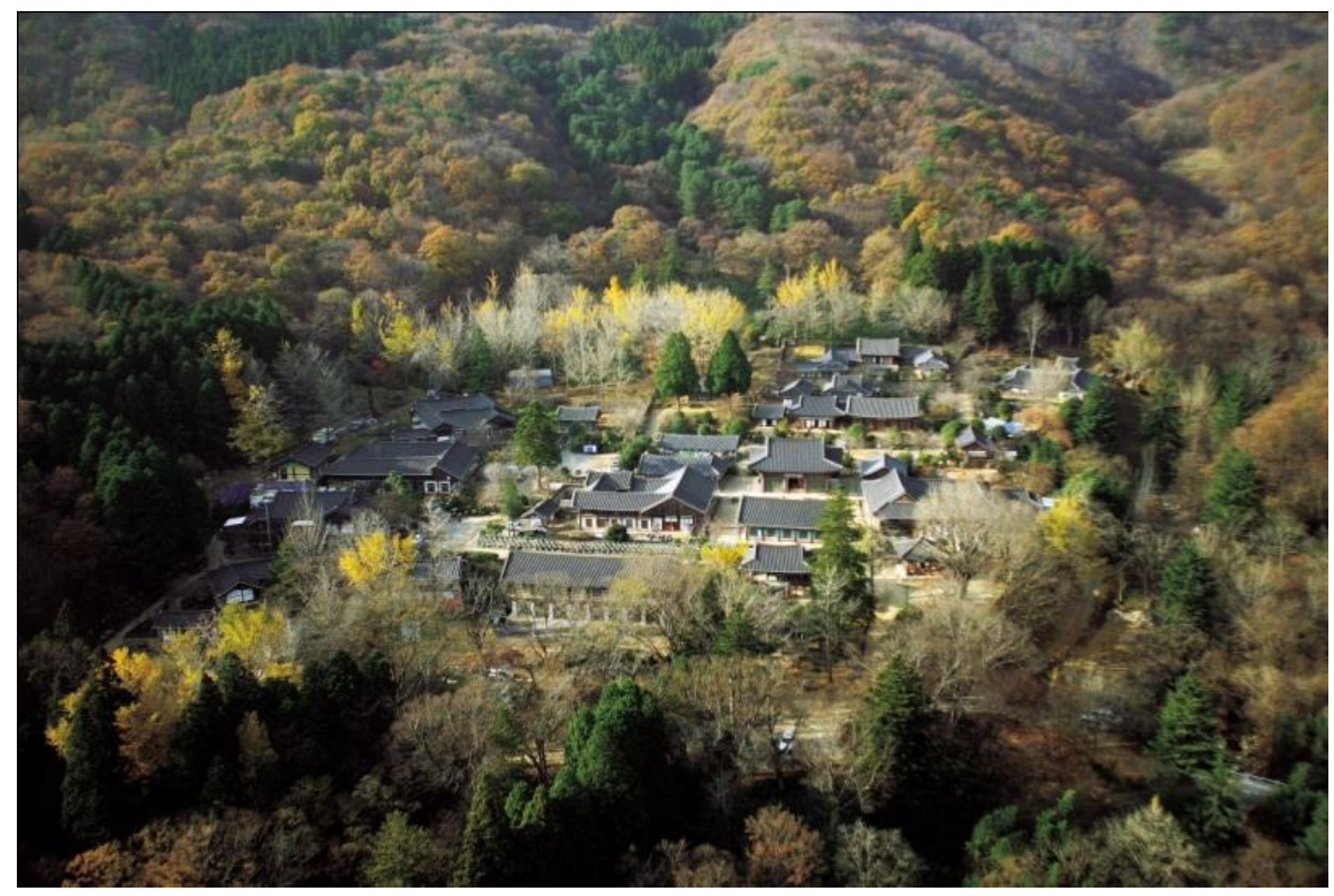

Fig. 14-23. Vista completa de Seonamsa. Suncheon, Corea del Sur. 


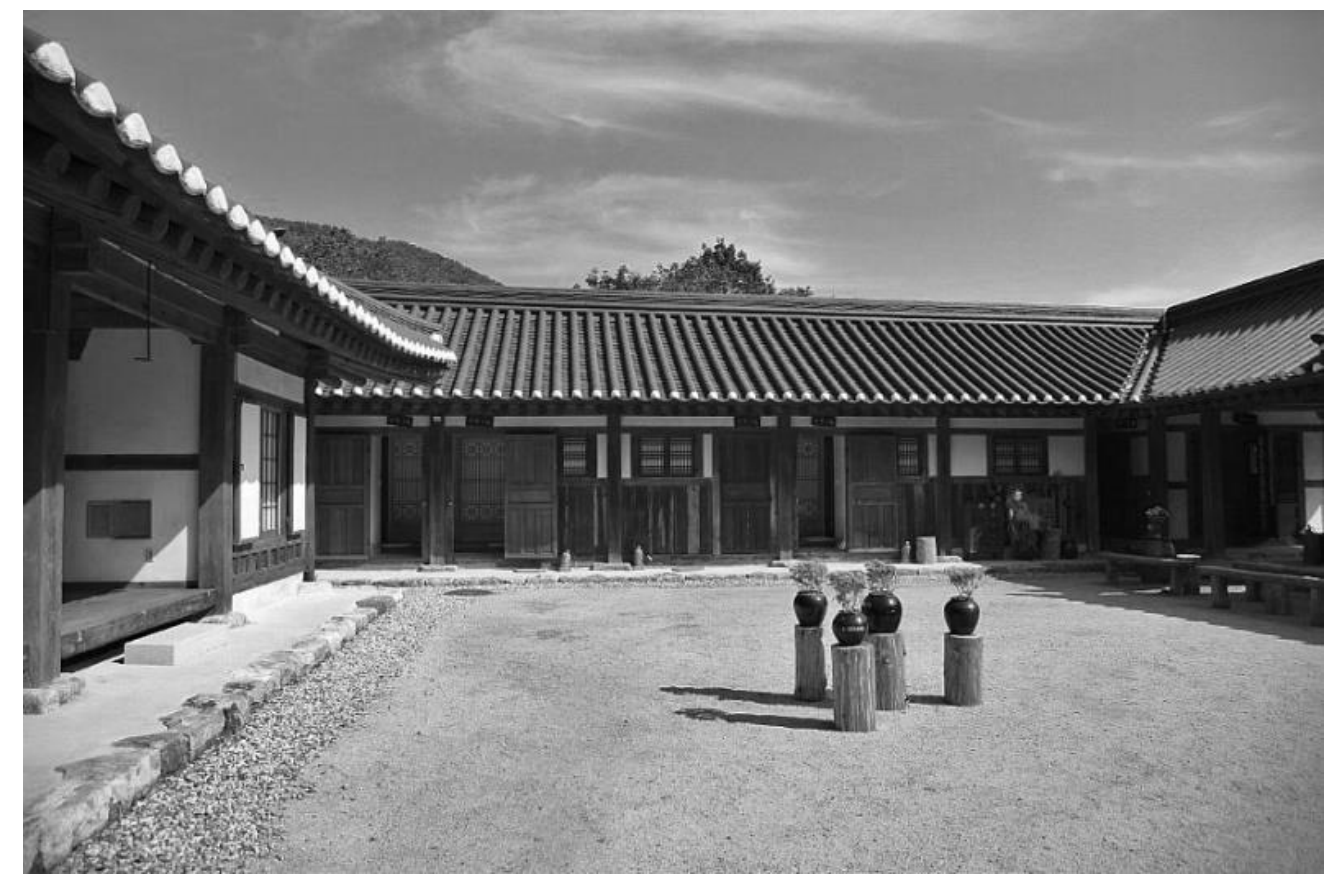

Fig. 14-24. Patio de Seonamsa.

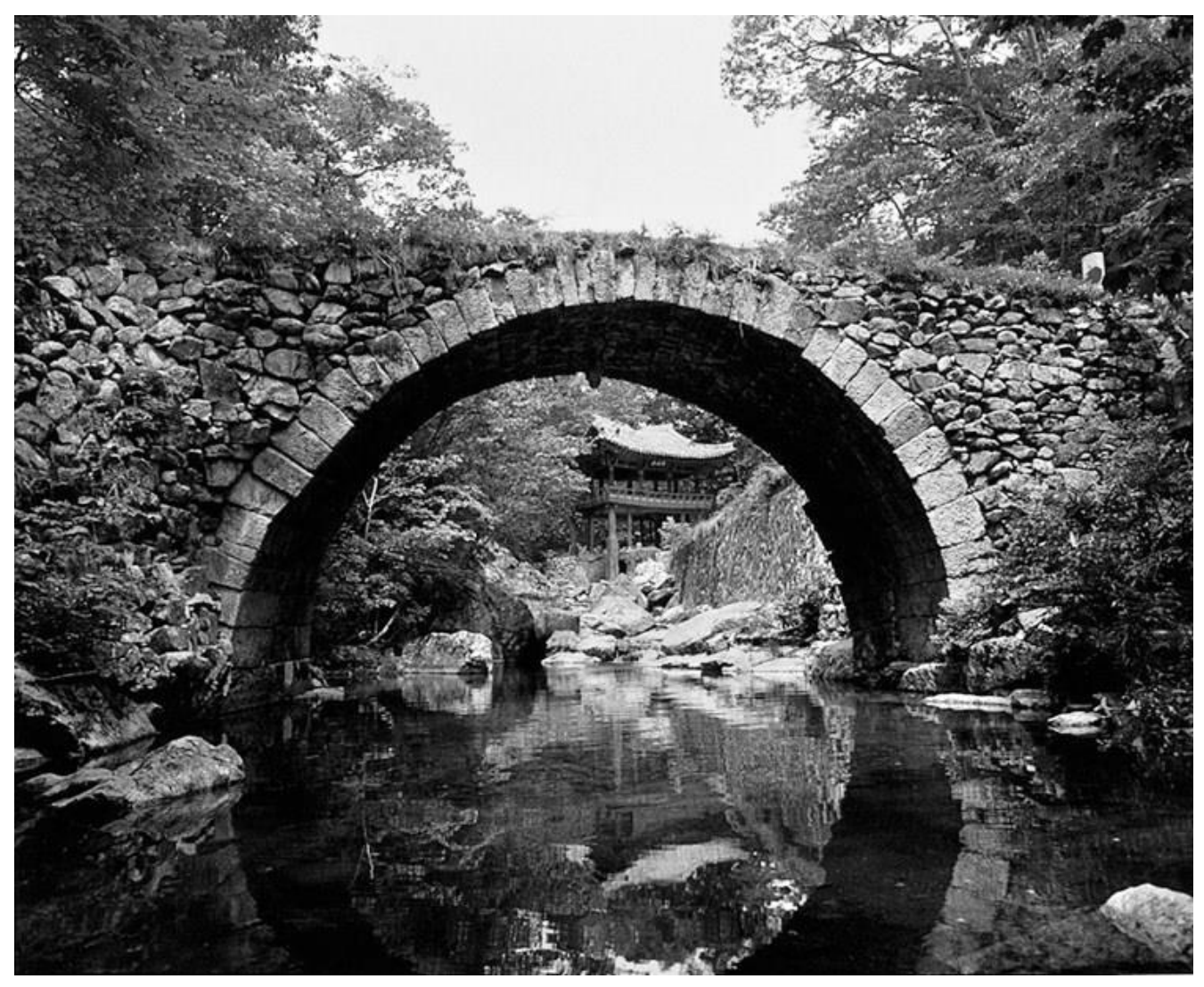

Fig. 14-25. Puente llamado Seungsun-Kyo para ir a Seonamsa. 
La arquitectura ciertamente propugna el concepto llamado sostenibilidad, porque los edificios no son de prefabricación, y todos son materiales naturales, pero eso se considera por la circunstancia histórica. Considerando el paisaje montañoso, los edificios no quieren romper la serenidad de la escena. Pero cuando es necesario, utilizan las líneas rectas en las elevaciones y en los planos también, sin duda con dignidad. Porque el hombre-dharma también aquí tiene que poder vivir, como un monte-dharma, son igualmente importantes, e indudablemente con delicada precaución. Observando el plano del lugar, se ve que los pequeños edificios están todos dispuestos en diferentes niveles según la curva del nivel de la montaña. Los materiales naturales de los edificios hacen armonía con la naturaleza. Los techos de piedra, las paredes y suelos de barro, las ventanas de papel, las columnas de madera, y el jardín de tierra, estas cosas requieren, constantemente, un inmenso nivel de manejo manual, ya que son efímeros como los seres humanos. Los papeles de las ventanas no duran un año, así que cada año necesitan de un revestimiento. El jardín de tierra, antes de la madrugada, se deja sin huella de pasos humanos, organizando la superficie utilizando la escoba de bambú que dibuja un patrón plano y virtuoso en el suelo. Las hojas caídas son la huella de la naturaleza, y limpiarlas es la fuerza del hombre. Estas fuerzas cotidianas, provocan un cambio en las mentes de los practicantes.

La repetición no cambia nada en el objeto que se repite, sin embargo, cambia algo en el espíritu que la contempla.

David Hume. 1739. Tratado de la Naturaleza Humana.

Se ve en las imágenes que casi el $50 \%$ de las elevaciones de la arquitectura son techos (v.-figs. 1422, 23). Los techos con el color muy oscuro, suavizan la presencia de las arquitecturas sin romper visualmente lo estacionario del paisaje. No es una coincidencia eventual el realizar una inmensa dedicación a las partes secundarias -en el término de la eficiencia, en las que la gente ni siquiera va a utilizarlas directamente. Para no dañar a la tierra, no estacan las columnas en ella, sino que solamente las establecen con ayuda de algunas piedras. Al no perforar dichas piedras, ni excavar la tierra, para poder ganar la seguridad estructural, es necesario un peso monstruoso arriba de las columnas. Los techos no son de paja, sino que son ladrillos pesados. Los ladrillos del techo, en los tejados, con el tiempo y a causa de la masa gravitatoria de la naturaleza, se deslizan entre ellos, a fin de que se 
conviertan en curvas naturales (v.-figs. 14-26,28) La actitud humilde para la naturaleza se expresa con los elementos del diseño. Desde el principio, la cuestión de $<<$ ¿quién es el dominante de este territorio?>>, no existía. La cerca de la imagen nos da confusión de si ella existe para el árbol o el humano (v.-fig. 14-27). Y al final, considerando estos detalles, surge una interpretación comprensible de la Serenidad que es: la paz paisajística y la armonía ambiental. La Serenidad surge naturalmente en el estado en que se percibe el hombre, la arquitectura, el ambiente, artificial o natural, y todo como una parte integral del cosmos.

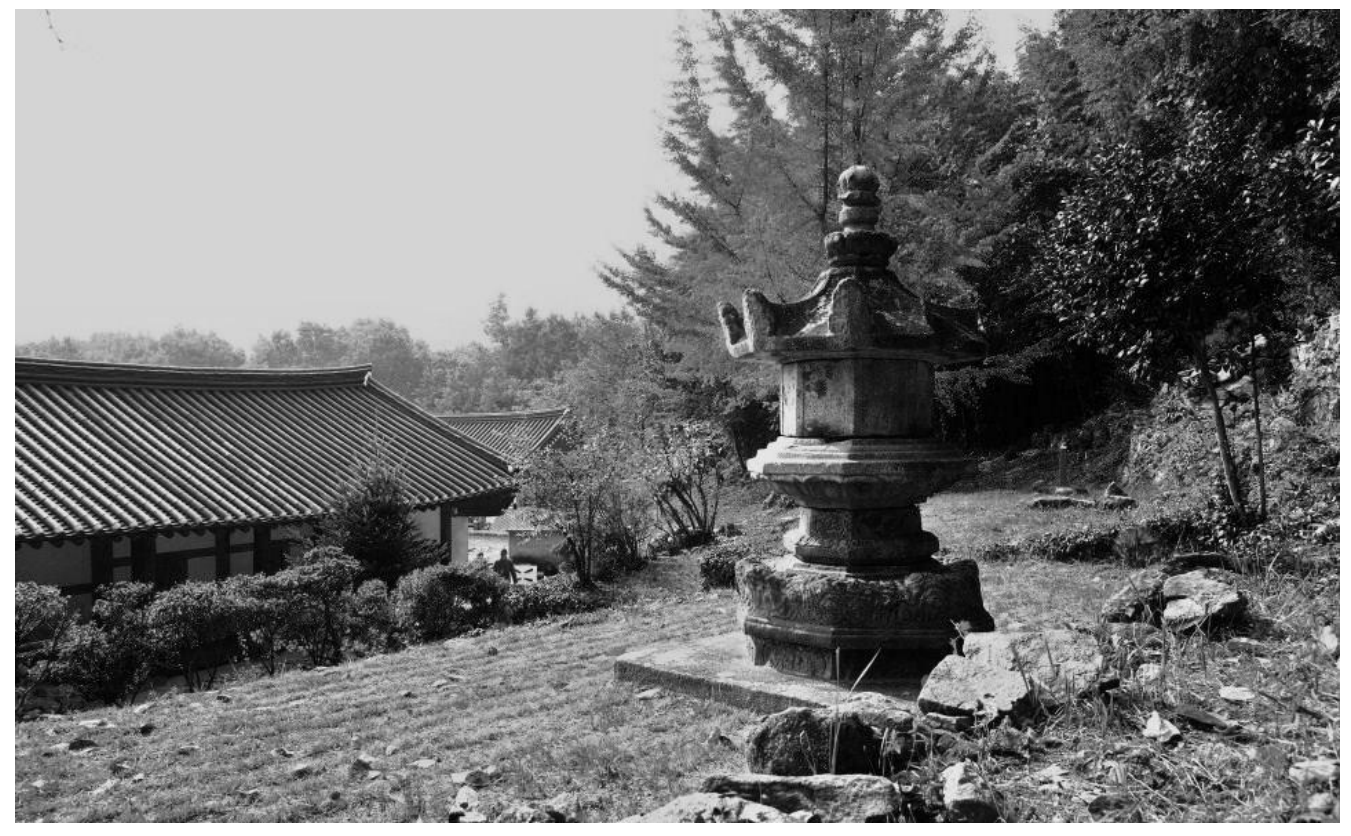

Fig. 14-26. Patio trasero de Seonamsa. 


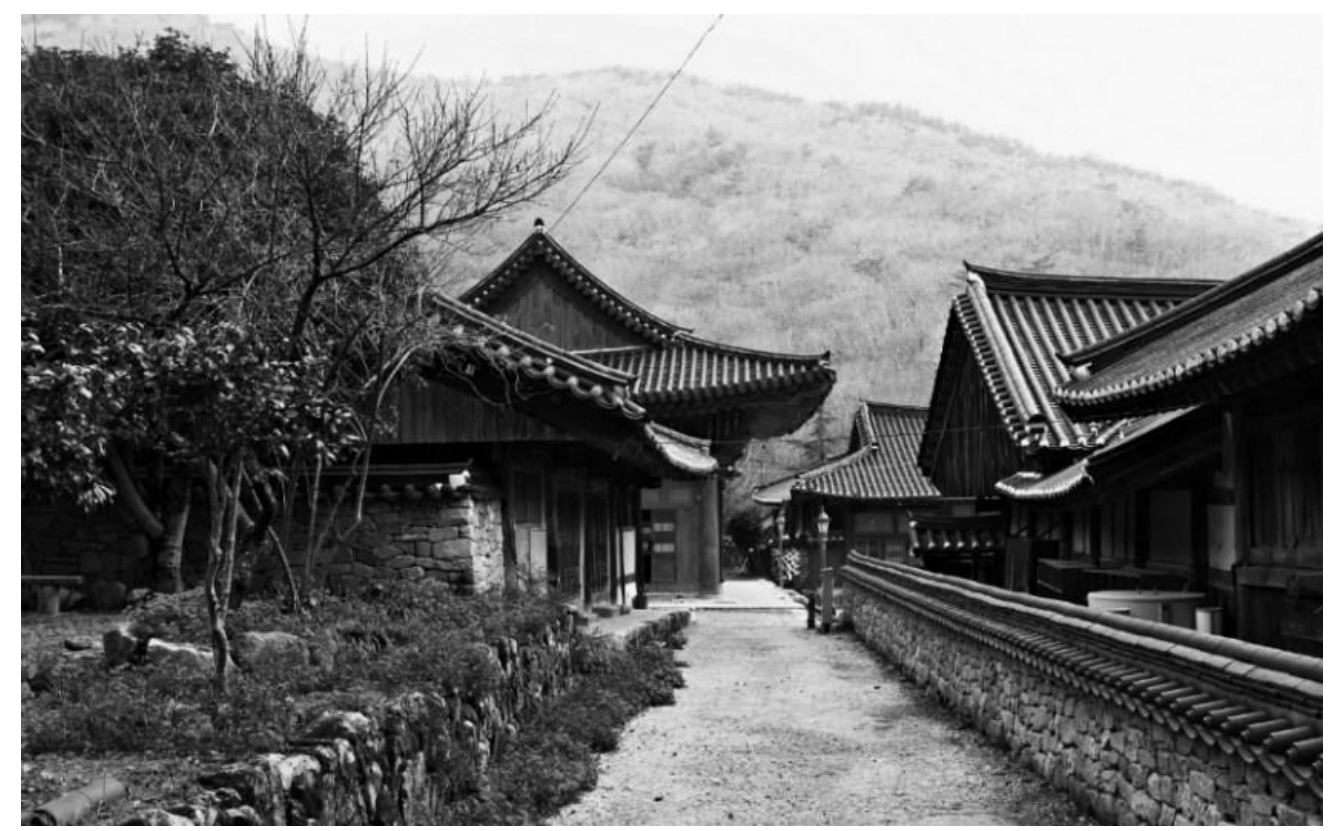

Fig. 14-27. Los edificios en distintos niveles.

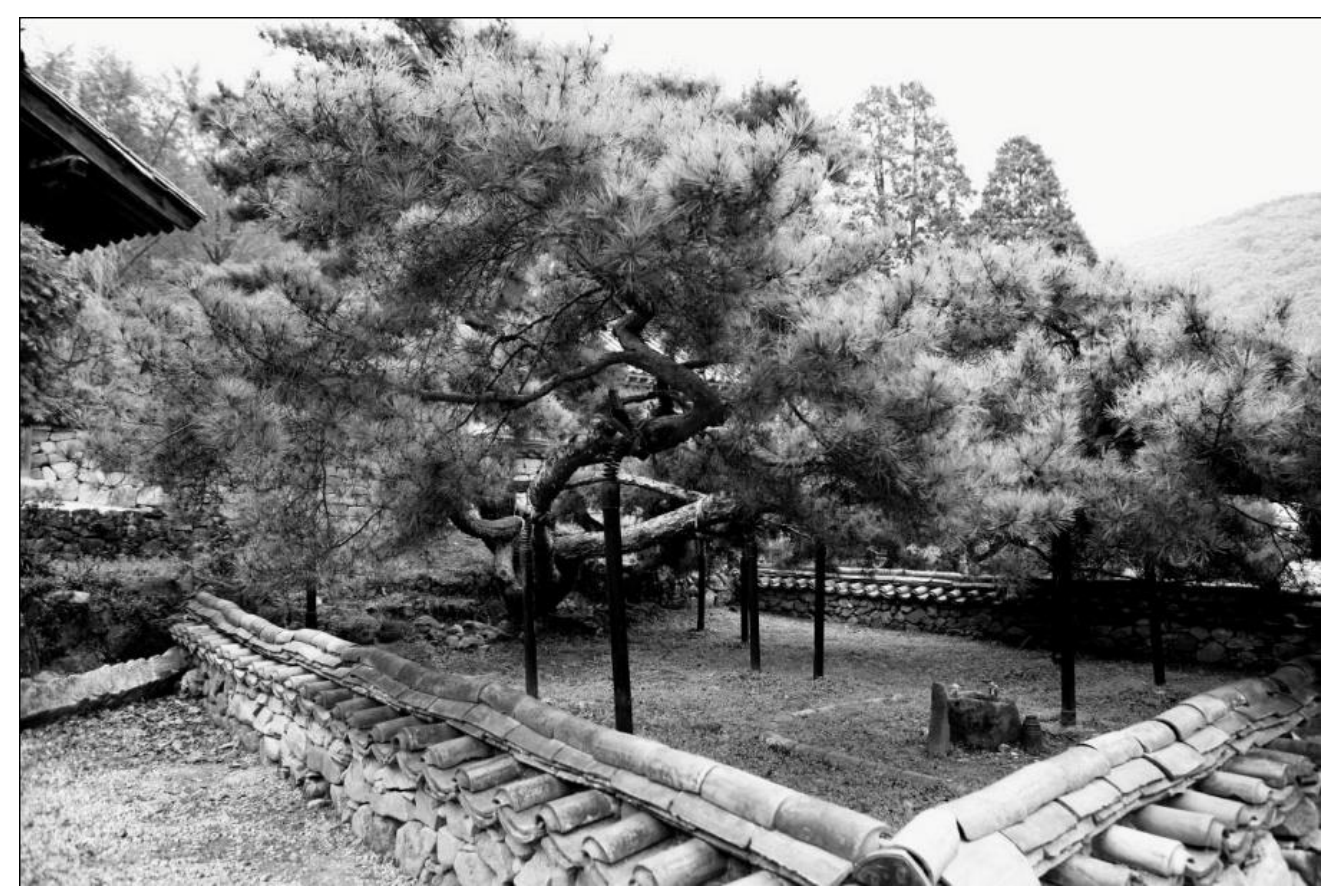

Fig. 14-28. Wasong el pino tumbado. 


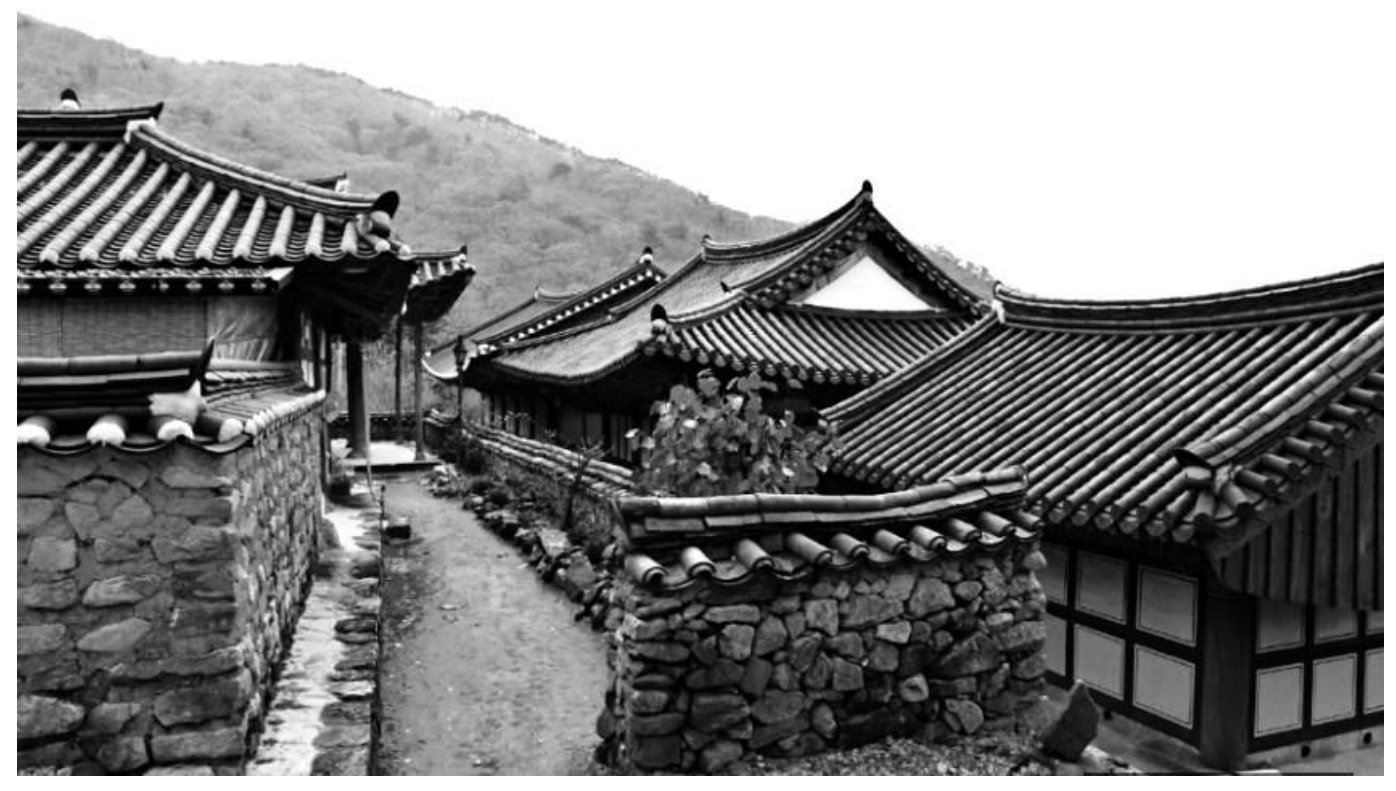

Fig. 14-29. Los techos recortados de edificios de Seonamsa contra el horizonte. 


\section{Adecuación}

El último criterio de este estudio es la Adecuación. También como otros términos precursores de este capítulo, tiene su significado amplio y general y, por eso, todos han sido necesarios en el proceso de la secularización de esta tesis. La Adecuación, particularmente, en este estudio se capta como la sostenibilidad en sentido amplio. Para ser una buena adecuación, es necesario que su forma de existir y uso sean sostenibles. La sostenibilidad en sentido amplio, como se refirió en capítulo 12 llamado CSD Nirvánico, implica tres campos juiciosos cuales son: <<la memoria $>$ que se refiere a la identidad asumida en la comprensión y consideración del pasado, <<la adecuación ambiental $>>$ que se refiere a la armonía antropológica y la experiencia anímica y corporal del ser humano con la naturaleza y por último <<el proyecto presente-futuro » que hace referencia a la posesión de un proyecto abierto que configura el presente y el futuro al ser humano individual y colectivo. Por eso, la adecuación aquí significa: la forma de existir de un ser, arquitectura, sociedad, idea, máquina y etcétera que es sostenible per se y exhaustivo en la memoria, la naturaleza y el proyecto presente-futuro. En algún sentido, la Adecuación es sinónimo de CSD ${ }^{26}$.

Para entender el concepto de la adecuación, sería extraordinario recordar el proyecto llamado Galería-Túnel del tiempo del capítulo 13. Entendiéndose el sistema del tráfico como la circulación sanguínea, y los coches como células. En este marco de pensamiento se suele cometer el error de que se capten los elementos que interfieren la circulación de los coches como el colesterol. Por eso, la circulación rápida pero junto con los pobres peatones no puede satisfacer el criterio de la adecuación. El espacio ha de distribuirse democráticamente. La adecuación, por eso, requiere la virtud de $\mathbf{N Y}^{27}$ para los dharmas que consisten la cadena de CSD, o sea, otra perspectiva más amplia. Los caminantes en el principio del proyecto no ejercitaban la virtud de NY, más bien se les mutilaron sus derechos de espacio mientras los coches disfrutaban sus privilegios degenerados. En el espacio de NY, para que los dharmas sean sostenibles, hay que presuponer NY de los dharmas de CSD. Y el túnel provee el acceso directo a la naturaleza para los ciudadanos, protegiéndolos de la violencia de los coches (la naturaleza). El túnel recuerda la relación de la particular identidad del espacio revelando la relación

\footnotetext{
26 Co-surgimiento dependiente-( $\mathrm{NdA})$

27 No-yo-(NdA)
} 
entre el hombre y la naturaleza, que es la sección de la tierra con la galería fotográfica de los años de 1950(la memoria y la adecuación ambiental). Estas prácticas cotidianas hacen posible a los sujetos que experimenten el espacio democrático entre los coches y los caminantes, conciliando entre los diversos dharmas de diferentes intereses. Cuidar de nuestro vecino que se encuentra en problemas, participar en la votación, discutir para la bondad común, preservar la naturaleza, comer sano, y saber proteger los valores humanistas son para la adecuación de la virtud NY (el proyecto presente-futuro). Por eso, el concepto llamado CSD, el cual incorporaba los tres cruciales campos de la sostenibilidad en sentido amplio, se ha secularizado por un nuevo concepto llamado la adecuación cuya significación no delimita sólo <<ser una buena adecuación mecánica>>, sino que incluye la perspectiva antropológica social y filosofía. 


\section{Sobre algunos puntos difíciles}

$<<$ Todos los dharmas son efimeros >>, diciendo esta frase el presente estudio comenzó a plantear el discurso, en orden, incorporando la epistemología, la ética y la estética en la perspectiva arquitectónica y urbanística. Gracias a esta forma de progreso, ha sido posible captar los campos de la antropología social y filosófica, los cuales son hoy en día los temas más destacados en los discursos del urbanismo, sin controversia. Pero también, gracias a esta forma de argumentación, los campos de los discursos no podían trazar las líneas divisorias exactamente de sus territorios argumentales, lo cual ha sido referido varias veces en el transcurso del vigente estudio. Por lo tanto, los seis criterios virtuosos proclaman sus peculiares colores y además contienen algunas virtudes adicionales. Solamente, la virtud principal fue nombrada para captar los sentidos principales. Según algunos casos, existen los espacios compuestos que no se pueden capturar sólo por un criterio. Por ejemplo, en la Casa Azuma (construida en el año 1976) de Tadao Ando, se pueden encontrar dichos espacios compuestos. Cuando llueve, el morador tiene que ir al baño mojándose porque la mitad del techo está abierto al cielo (v.-fig. 14-32). Este extraño techo obliga a realizar dicha labor al morador de la casa. Es una gracia. También es una experiencia corporal con la naturaleza del hombre. Cuando el sol cae en el patio, y el suave soplido del viento, la luz que fluye por las paredes del hormigón armado expuesto generando los matices; estas cosas son aparatos para generar una interacción entre el morador y el medioambiente (v.-figs. 14-31, 33). A veces, cosas bellas hablan sobre la adecuación, y al mismo tiempo sacan el tema de la gracia. De nuevo, los seis criterios secularizados de este capítulo se entienden como una constelación de los puntos estratégicos de los mantras buddhistas, con el propósito de entenderlos más fácilmente y poder adaptarse con rapidez en el campo real omitiendo los pesados argumentos. 


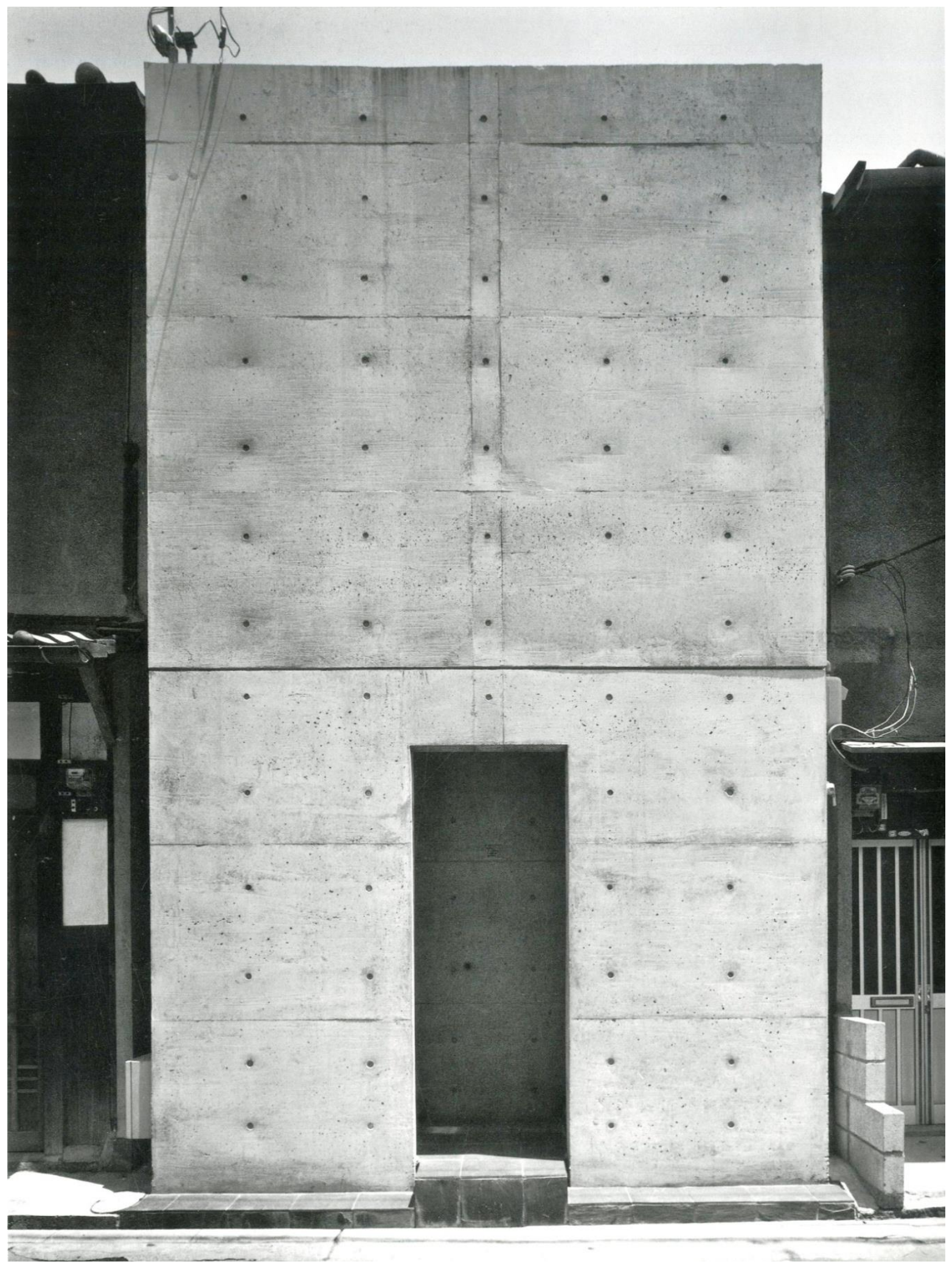

Fig. 14-30. La fachada de la Casa Azuma 


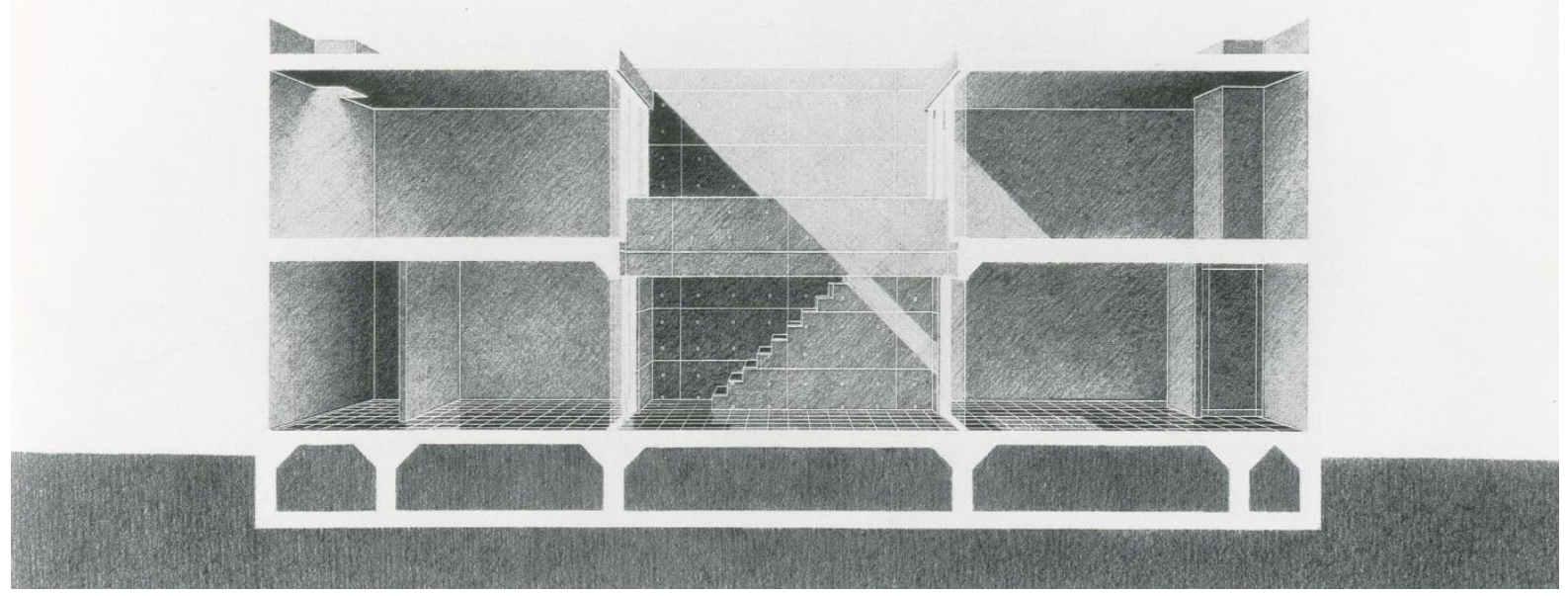

Fig. 14-31. La perspectiva seccionada de la Casa Azuma.

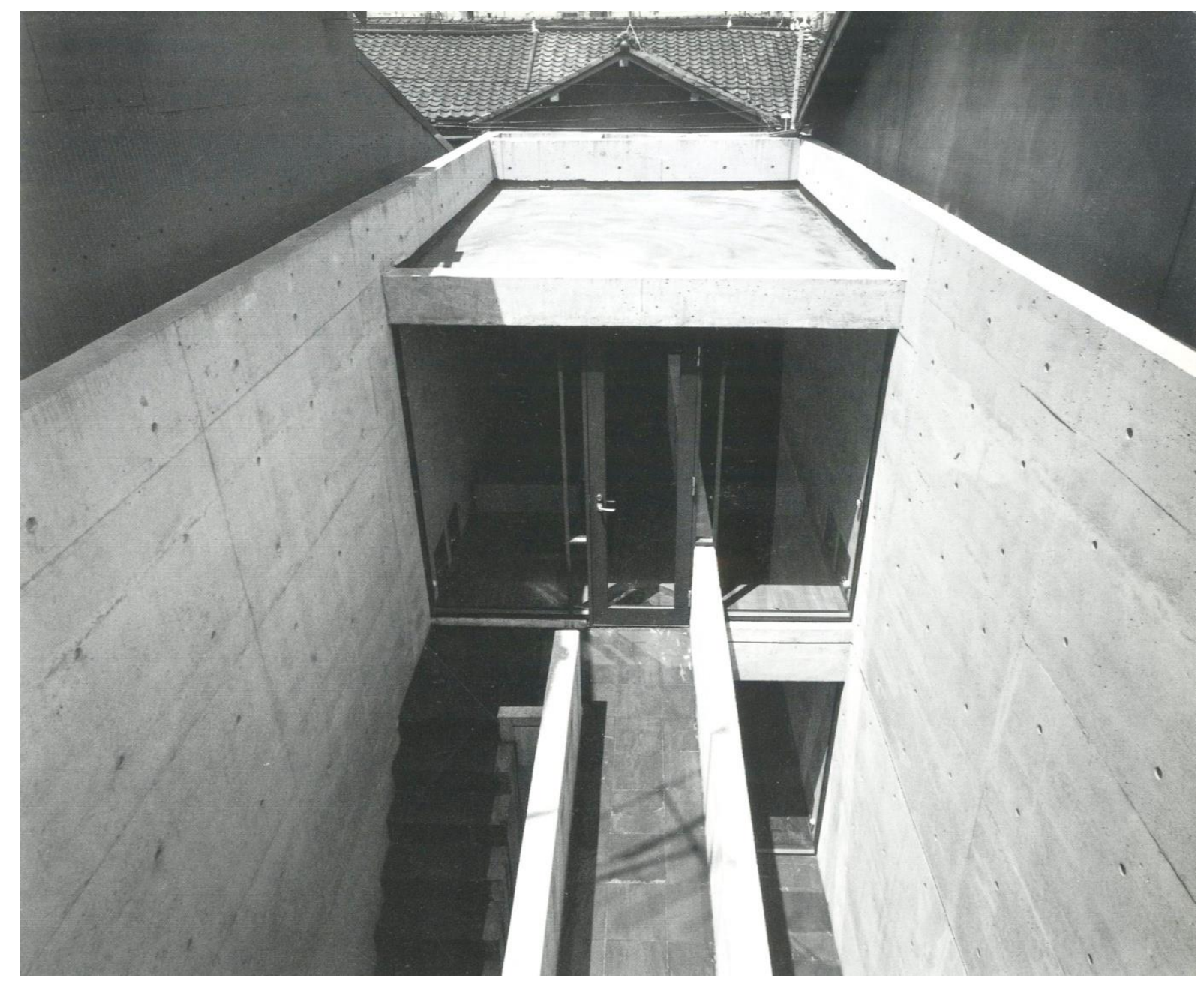

Fig. 14-32. El puente. Planta 1. 


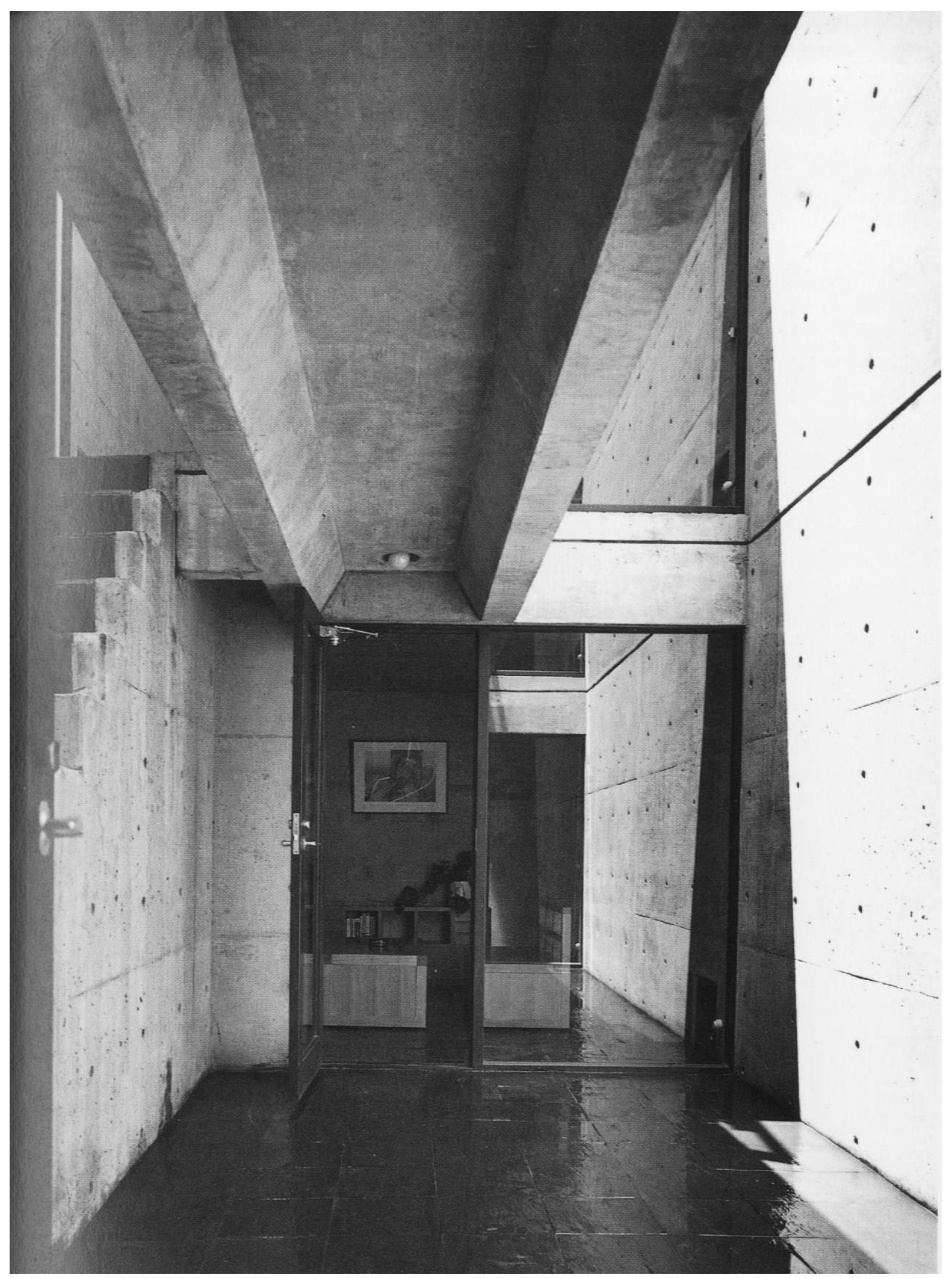

Fig. 14-33. Sala de estar. Planta 0. 


\section{Los seis conceptos secularizados en los casos anteriores}

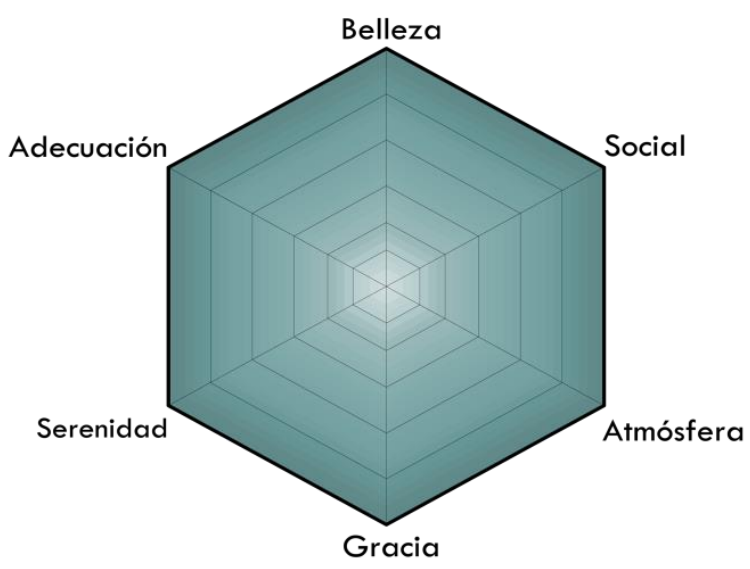

Fig. 14-34. Los seis conceptos en una forma hexagonal.

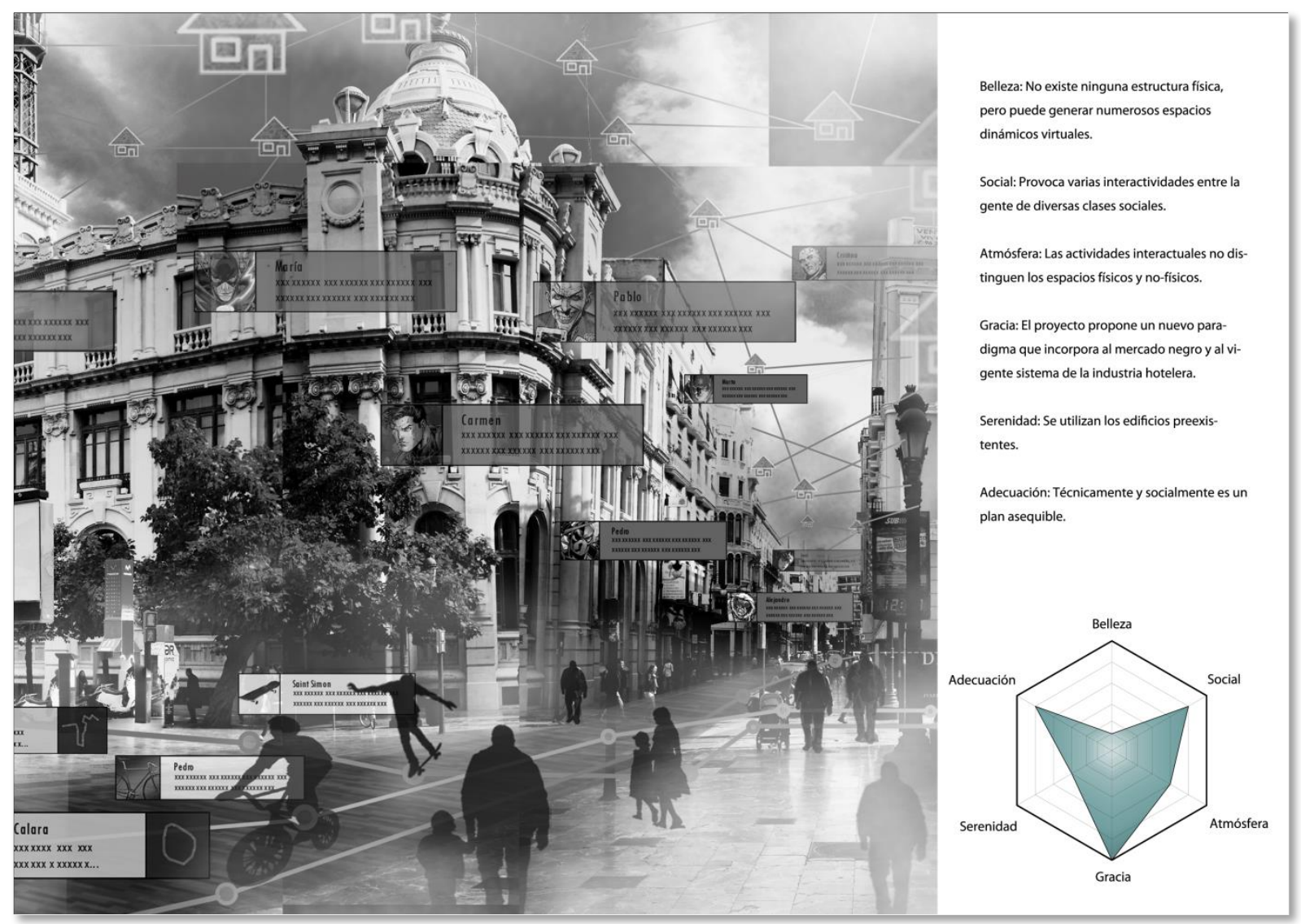

Fig. 14-35. Las especificaciones del proyecto Mi Casa Tu Casa. 


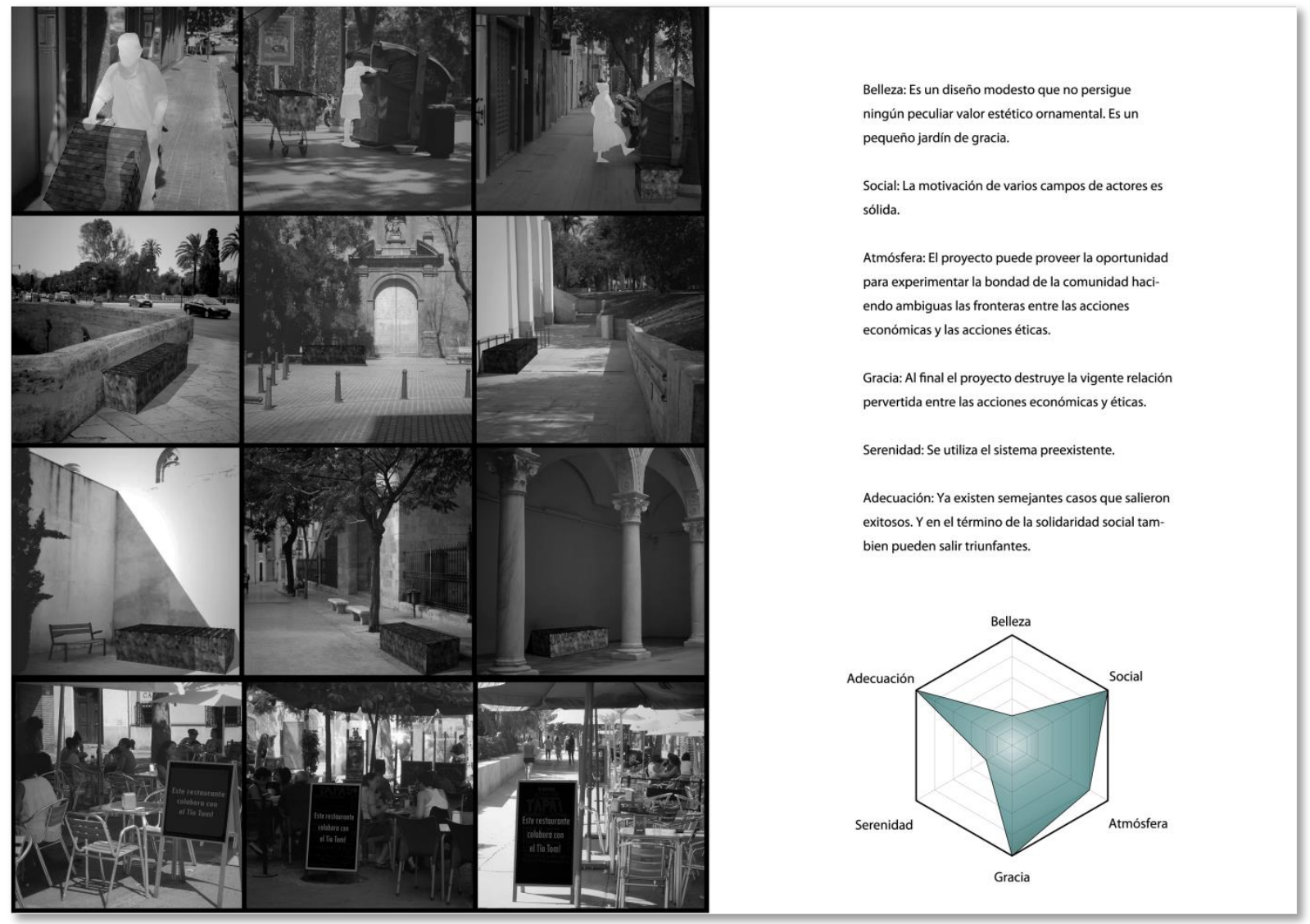

Fig. 14-36. Las especificaciones del proyecto de La Cabaña de Cartón del Tío Tom. 


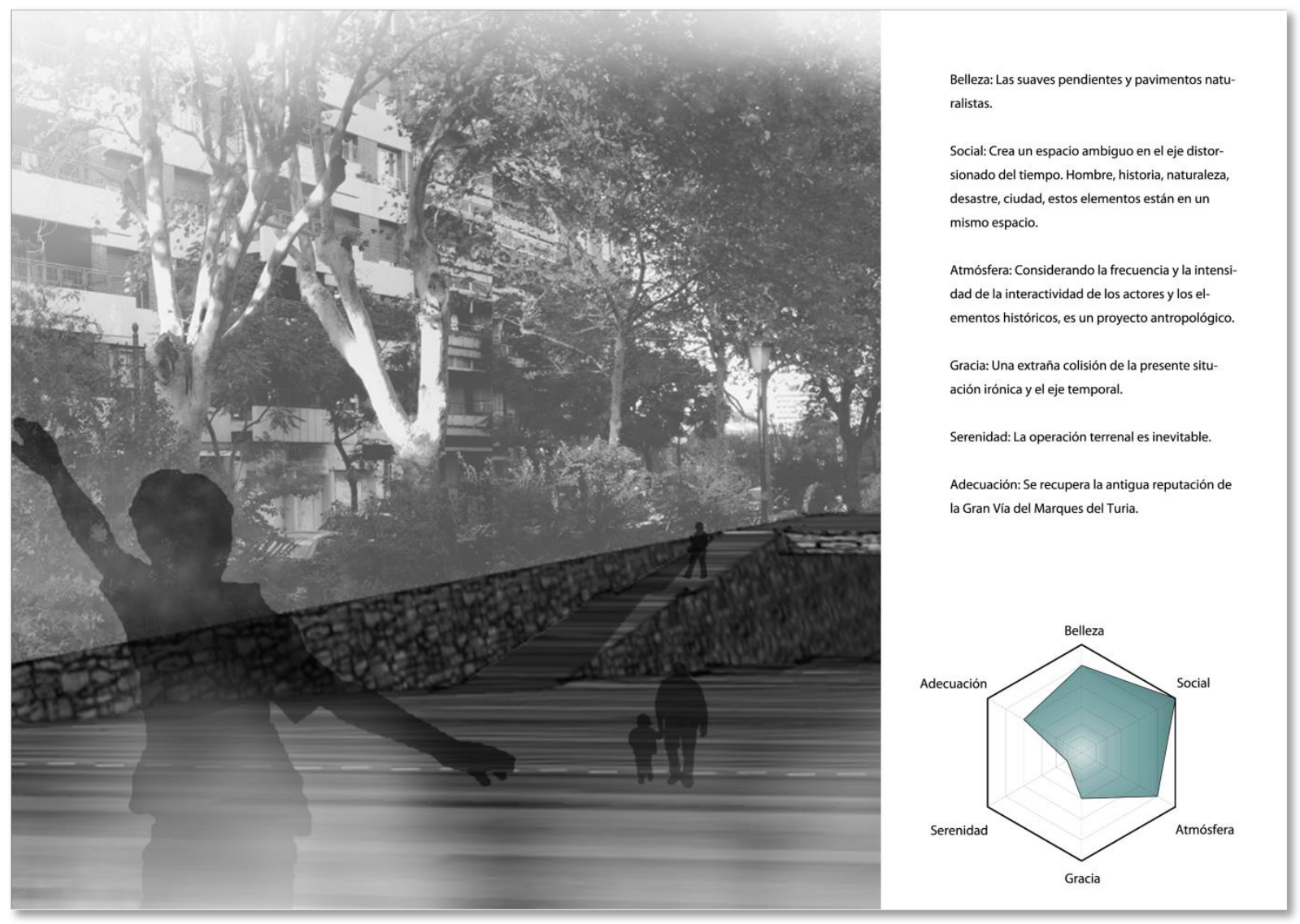

Fig. 14-37. Las especificaciones del proyecto Galería-Túnel del Tiempo. 


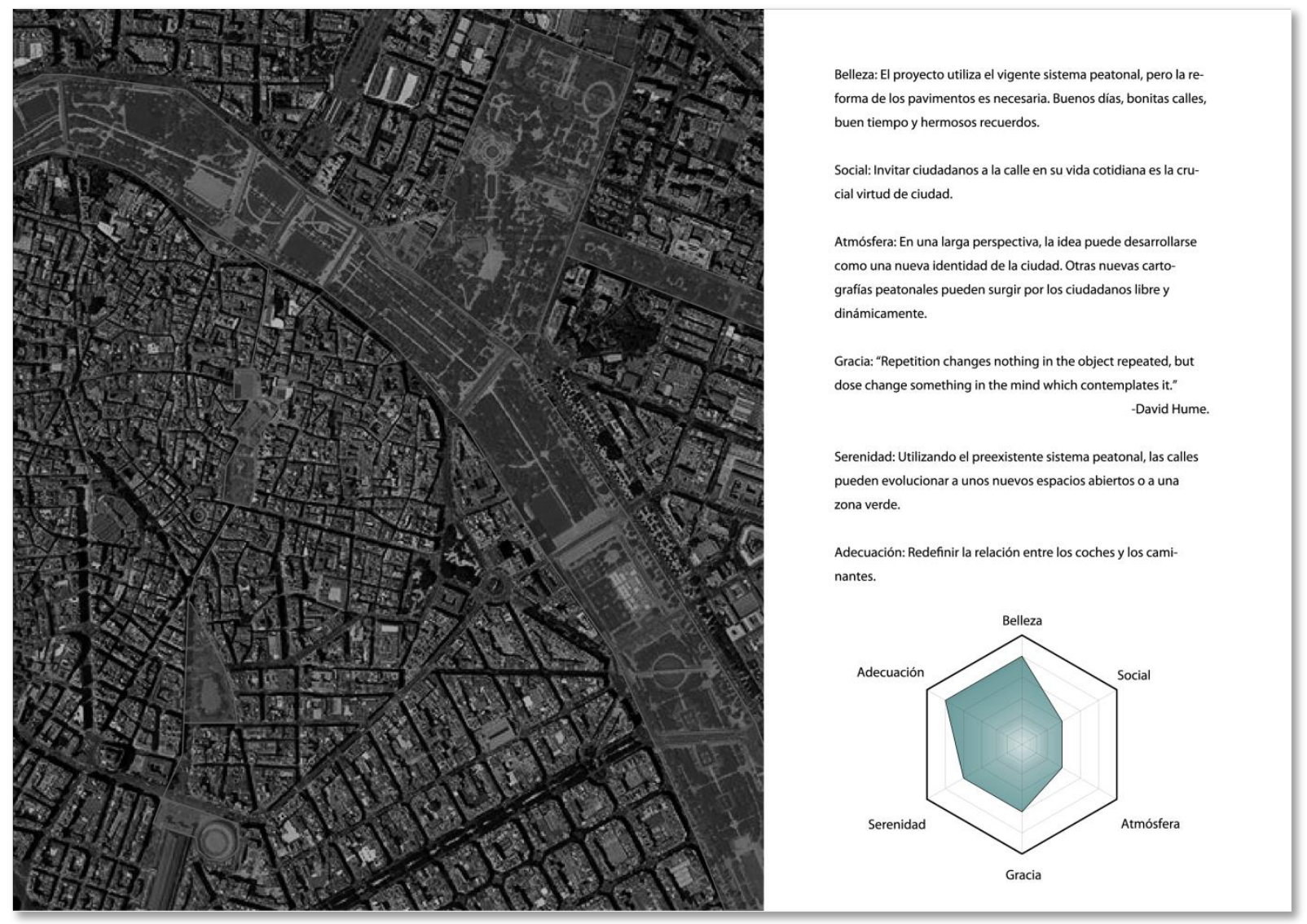

Fig. 14-38. Las especificaciones del proyecto Camino de Todos Santos. 


\section{Discusión General de los Resultados}

\section{逢佛殺佛,}

Si encuentras el buddha, mata al buddha.

\section{逢祖殺祖}

Si encuentras el antepasado, mata al antepasado. ${ }^{1}$

\section{臨滦義玄 (Linji Yixuan:?-866). 臨濟錄 (Apuntación de Linji).}

En una obra clásica del buddhismo llamada Apuntación de Linji, hay una frase que dice: $<<S i$ encuentras el buddha, mata al buddha, si encuentras el antepasado, mata al antepasado.>> Cuando viene otra época con una distinta situación, tal vez, puede ser que sea necesario arreglar y reexaminar la contundencia de esta investigación. Eso es porque es importante no quedarse atrapado en los rígidos cánones y las perspectivas dogmáticas, si no el buddhismo se transformaría en una religión monstruosa junto con esta tesis. La enseñanza de Siddhartha no es algo que se pueda captar de una forma absoluta y dogmática. Hay que encontrar lo esencial en el adoctrinamiento rompiendo la superficie de los cánones contemplándolos y diciendo <<Ningún dharma puede ser permanente, sino efímero.>> La relación ambigua entre el nirvana y el dolor, es comparable al haz y el envés de una hoja que son al mismo tiempo lejanos y cercanos. Únicamente, este estudio ha demostrado el proceso de la materialización de dicha relación ambigua por medio de las relaciones de los dharmas que ejercitan sus poderes en diversas dimensiones.

Debido a la complejidad urbana, existe cada vez mayor dificultad en predecir cuánto más serán complejas las teorías fragmentarias del urbanismo. Pero el pensamiento sobre dichas cuestiones, en

\footnotetext{
${ }^{1}$ Se ha traducido por el autor de esta tesis. Lee, Pilje(tr.)-(NdA)
} 
las que las teorías del urbanismo estarían cada día o cada año más enmarañadas que el anterior, posee un carácter escéptico porque su finalidad está predestinada obviamente.

La ciudad es una complejidad, el discurso sobre los materiales en que consiste la ciudad resulta un bagaje de complejos elementos. Esto implica la formación de los discursos de varios géneros que definen los contenidos. Sin embargo, no es cierto que esta peculiar situación haga imposible la formación del discurso. No es fácil de definir los movimientos de las fragmentarias teorías del urbanismo contemporáneo en una frase (por ejemplo, los de las Escuelas y los despachos de arquitectos estrellas: AA School, Harverd GSD, ETH Zurich, TU Delft, OMA, FOA, BIG, MVRDV, Unstudio, CHORA y etcétera) en una frase. Sin embargo esto no es nada más que: un collage de los pensamientos dilucidados y recopilados con un cierto menester tendencial según cada periodo del tiempo. Aunque sea una teoría nueva no nace sin precedente, por lo menos no sin una cierta necesidad pedida por la circunstancia urbana que se habría formado con el contexto de la historia humana. Así que ninguna teoría es huérfana sino que tiene un padre llamado la era. Al fin esas fragmentarias son intentos para poder captarse por la generalidad de la teoría del urbanismo.

Esta tesis no intenta crear un urbanismo perfecto o una filosofía absoluta como una panacea para cualquier tipo de paciente. Solamente, este estudio obtiene su significado de existencia como si fuera el fruto de esta era y ha podido demostrar sinceramente su efectividad y contundencia en el campo real, que se consideraría solamente tal y como el espíritu humilde del tiempo. Repetitivamente, durante el transcurso del estudio, se ha apelado que éste es un desafío o una búsqueda para hallar una idea alternativa confrontando la doctrina buddhista sobre el Nirvana y las teorías de la utopía, porque las teorías del urbanismo moderno tenían una cierto límite para ser utilizadas como una herramienta capaz de captar los dharmas que ejercitan sus poderes en varias dimensiones físicas y no físicas en esta época.

El principio de la idea de esta tesis fue básico -más allá de la bondad, maldad, justicia, injusticia, excelencia, virtud, etc. La expansión de la idea tenía que recorrer necesariamente dichos conceptos metafísicos. Para poder ser un discurso que no se quedara en el aire, a veces era necesario las 
indagaciones filosóficas y esto tenía que ser estructurado. Y finalmente, se ha podido hablar sobre el nirvana en una ciudad mediterránea existente que es Valencia. Pero en el capítulo 14, surgió una necesidad de crear otra herramienta de diagnóstico que sea una forma más sencilla para evitar largos argumentos que podrían ser inefectivos en el campo profesional y que pueda aplicarse y adaptarse rápidamente. Así que una sutil versión del original también fue creada por un propósito estratégico.

La razón de que el adoctrinamiento del buddhismo se sienta familiar y cercano -para los sujetos- más que otras mayores religiones, sería porque el buddhismo no se basa en cánones proféticos con una autoridad sublime, sino en una iluminación humilde y personal de un hombre nepalí llamado Siddhartha. Indudablemente, el Espíritu Santo que se refiere en el cristianismo, mora en todos los cristianos, así que podrían existir algunos puntos compatibles en esta parte..$^{2}$

Tal vez, la tesis del buddhismo a la que apelan los dharmas efímeros puede reconocerse tal y como un mero nihilismo o pesimismo. La perspectiva buddhista que niega la ética categórica, parece que se apoya en las posiciones de los utilitaristas, sin embargo por la razón de que el buddhismo afirma una obvia virtud de la naturaleza, se podría confundir con Aristóteles, entonces si se admite dicha posición, habría que aceptar el destino final de cada dharma definitivo que no es compatible con el mantra de $\mathbf{N Y}^{3}$. Así la ética de Aristóteles no puede explicar cómo es posible la ética incondicional. La epistemología de Deleuze y Guattari tiene su particular especialidad en crear un argumento sobre las máquinas y diagramas con una retórica sofisticada, pero a veces todavía tiene su límite en los términos que ellos utilizan porque aún parece que necesitan afinarlo para poder quitar el tono abstracto excesivo, si es para aplicarse en el urbanismo y la arquitectura. Como todo es la máquina, la reducción del mundo a una liviana máquina es una conclusión lógica. El mundo en el que ellos (Deleuze y Guattari) quieren vivir, existe la palabra $<<y, y, y, y \ldots>>$. Por eso, ellos buscan el sentido del universo sólo hasta aquí.

\footnotetext{
${ }^{2}$ Claro que aquí pueden existir algunos puntos polémicos; si se entiende el nirvana como un dualismo entre el estado del nirvana y el estado de dolor, en este caso el estado del nirvana sería correspondiente al concepto de la idea que perseguía Platón. Sin embargo, una cosa clara es que, el mundo de las ideas de Platón es un mundo abstracto al que no se puede llegar por lo que no es físico. Al contrario de la cosmovisión de Platón, en la perspectiva buddhista, el estado del nirvana y el dolor tienen una relación telúrica. No se puede llegar al nirvana sin el mundo terrenal. Además la importancia de llegar al nirvana depende de la iluminación personal, no celestial. Eso es porque el buddhismo es difícil de captarse desde el dualismo y el monismo.-(NdA.)

${ }^{3}$ No-yo.(NdA)
} 
Para ellos la última fórmula para captar el universo sería la conjunción llamada $<<y>>.{ }^{4}$ Ahora bien, surge la siguiente pregunta: ¿y qué? Si esta tesis de $<<y>>$ en sí misma tiene sentido y se considera a sí mismo tal y como una virtud, el argumento se acaba y no se puede proceder más. ¿Entonces, la perspectiva nirvánica puede responder a esta pregunta, más allá de la conjunción de y? Sí que puede. La respuesta de dicha pregunta fue el Nirvana.

La teoría del Nirvana no solo explica los sentidos epistemológicos, sino también puede explicar los conceptos éticos en una deducción espontánea, porque dentro de la manera de existir de los sujetos, se revela lo que es hacer el bien o el mal. Cuando un dharma se alaba a sí mismo insistiendo en su ser (es contrario al NY), fatídicamente dicho dharma $\left(\mathbf{A D} \mathbf{D}^{5}\right)$ tiene que deshacer a otros dharmas y al final las cadenas de los dharmas $\left(\mathbf{4} \mathbf{N V}^{6}\right)$ se convierten en unas máquinas viciadas que solamente producirían las agonías del infierno. Todos los dharmas son efímeros y se captan por las cadenas de AD o ED7 . Todos los dharmas, básicamente, son neutrales: aún no se pueden categorizar; sino que todos se quedan en un campo indefinido de purgatorio. Sin embargo, una vez que hayan incorporado en una cadena de los dharmas, se reconoce su virtud que son dharmas santos o impíos. Cuando los dharmas se visten de una forma física en la tierra, de dicha manera explicada, el hombre entiende que el adoctrinamiento del nirvana ya no es intangible sin más, y al final reconoce el genuino espíritu bello el cual ya es un concepto empírico y tangible que se ha incrustado en el entorno. La armonía de los dharmas se percibe empíricamente en el entorno. En esta fase, los sujetos ya son independientes de los sistemas compulsivos y anacrónicos (patriarcado, despotismo, totalitarismo y etc.).

Como está demostrado anteriormente en los capítulos 8,9 y 10, mediante un análisis taxonómico normal no se puede percibir el Nirvana adecuadamente. Las numerosas teorías filosóficas y cuyos hijos son las teorías del urbanismo, están predestinadas desde el principio a dónde se quiere llegar con sus argumentos. Por lo cual, para este estudio existía la obligación de seguir las raíces de las filosofías y al mismo tiempo escapar del marco de sus funciones. Dicha obligación o necesidad

\footnotetext{
${ }^{4}$ Deleuze, G \& Guattari, F. v.o. 1880. Mil Mesetas: Capitalismo y Esquizofrenia 2. Seoul. Saemulgyul Publishing House. Edición coreana. Kim,Jl(tr.) 2001. pp. 54-55.

${ }^{5}$ Acumulación del Dolor.-(NdA)

${ }^{6}$ Las cuatro nobles verdades.-(NdA)

${ }^{7}$ Extinción del Dolor.-(NdA)
} 
naturalmente ha guiado este estudio y en cómo tiene que proceder. Es decir, había que presuponer la existencia de una dimensión transcendental. El argumento sobre la estética nirvánica también está ubicado en el mismo contexto previo.

Hacer bien el cálculo y hacer bien la matemática es diferente; el calculador no puede responder al matemático qué significa el número calculado. Indagar en los vastos datos y en las diversas teorías no ha sido una ardua tarea, sin embargo cuando dichos datos encontrados empezaban a tener una fórmula dialécticamente, ha sido muy laborioso buscar el significado de dicha fórmula en el mundo físico. Los datos obtenidos en un proceso dialéctico entre el Nirvana y la Utopía, al final han sido dispuestos en las proposiciones sintéticas cuya factibilidad y efectividad ha sido probada en el nivel práctico aplicándolo en la ciudad de Valencia. La estética nirvánica juzga el valor estético en un criterio en el que el diseño debe mostrarse cómo y cuánto se represente la virtud de NY. La estética nirvánica es un concepto componente que se desarrolló en el buddhismo desde la ética nirvánica, así que naturalmente dentro de su concepto ya está incrustado el propósito del diseño, es decir si algún diseño gana una buena sentencia en el sentido ético, eso significa que dicho diseño es estético también. En otra perspectiva, por ejemplo, la ética kantiana, eso es la respuesta para la cuestión sobre el enfrentamiento de la naturaleza humana y la libertad por medio de la razón. La manera de conciliación de las dos dimensiones de los kantianos parece moderno y la de esta tesis parece un estilo anticuado como la filosofía clásica griega, cuyo proceso de argumento también procede como "la idea $\rightarrow$ Bondad (o el bien) $\rightarrow$ Belleza" en esta manera. Sin embargo, cuando los kantianos se obsesionan en los propósitos de existencia, al instante pierden la virtud de NY, así que las diferencias entre las dos perspectivas son obvias. 


\section{Conclusión}

El comienzo de la tesis establece alguna herramienta analítica mediante una confrontación estratégica de dos conceptos heterogéneos, como son la Utopía y el Nirvana. Dichos dos conceptos tenían varios aspectos consonantes entre sí filosóficamente. Posteriormente, gracias a una serie de investigaciones de cuatro proyectos utopistas y dos proyectos zen-buddhistas, esta tesis ha podido establecer una perspectiva dialéctica. La herramienta tenía que ser capaz de percibir los incontables fenómenos que surgen cruzando las multidisciplinares dimensiones físicas y no-físicas en la ciudad contemporánea, cuya apariencia es como una red compleja. La herramienta tenía que poder analizar los síntomas urbanos y tratar los cuerpos subyugados de los síntomas adecuadamente. La premisa de esta tesis ha sido la posibilidad de una hibridación de los conceptos de Utopía en Occidente y de Nirvana en Oriente. Teóricamente se considera que se puede proponer una contrapartida para los fragmentos de las teorías contemporáneas en este campo. Así naturalmente, el estudio procedió comprobando la premisa de si esta teoría podía invocar el estado nirvánico de una ciudad, sostenible o no.

La complejidad de las ciudades de hoy en día, impone un empeño a los urbanistas para que sean cualificados en responder conjuntamente a la presente situación tan dinámica. Diversas dimensiones de la física, la cartografía, la economía, la cultura, la raza, la política, la educación, los recursos naturales, el terrorismo, el totalitarismo, el anarquismo, la democracia, el arte, internet, etcétera, producen los discursos multidimensionales combinándose de las maneras cada vez más complejas, siendo las ciudades cada día más grandes y diferentes.

La búsqueda de la ciudad nirvánica, básicamente empieza estableciendo su discurso desde una proclamación epistemológica buddhista que es: <<Ningún dharma es permanente, sino efímero〉>. Aquí el discurso sobre la posibilidad de percibir la Idea (o la Verdad) que existiría más allá de la fenomenología, no fue necesario. Aunque no pudiese reconocer la verdad de las cosas, la realidad es que por lo menos la cognición de la fenomenología de los asuntos aún es posible. Presumir alguna idea transcendental no sería tarde después de contemplar la realidad que ya está en la mano. La 
epistemología nirvánica entiende el mundo así. Si el universo se hubiera creado de forma que su manera de existir fuera sostenible, los dharmas que constituyen este universo también tendrían cada uno su manera sostenible de ser. Siddhartha creía en eso como una virtud. Él creyó que la virtud de todos los dharmas era Pratītyasamutpāda en sánscrito, su significado literal en español fue traducido en esta tesis como CsD (Co-surgimiento Dependiente). Este príncipe tibetano entendió el universo como un bagaje de numerosos dharmas que se levantan (reúnen) y desaparecen (se desvinculan) por las condiciones circunstanciales. Por lo cual, un dharma sólo puede existir en la vinculación de sus sub-dharmas elementales, asimismo, se puede decir que desde el principio ningún dharma puede existir sólo por sí mismo, llegando por lo cual a la conclusión de que ningún dharma es permanente por su forma de ser, sino que es efímero. No-yo no significa una negación de la ontología ni nihilismo. Más bien, es un reconocimiento del genuino ser cuya forma de existir está condicionado por las circunstancias no inmortales. Al negar esta forma de existir de los dharmas, surge una obsesión y el universo empieza producir las angustias y el mundo se queda no sostenible o sostenible de forma pervertida.

La investigación está enfocada en comprobar la contundencia del resultado de este estudio en la perspectiva urbanística y arquitectónica. La herramienta forjada en las tres ramas filosóficas, epistemología, ética y estética, ha sido aplicada en la ciudad mediterránea de Valencia. La herramienta, simplemente, no sólo enfocaba superficialmente las fenomenologías oscuras en el área urbana. En realidad, en el capítulo llamado CSD Mórbido, la herramienta funcionaba como un contrabandista pasando los límites argumentales de varios campos, excavando la superficie y, al final comprobó su aprovechamiento que es la posibilidad de generar más discursos para poder tratar los deseos pervertidos de las fuerzas en varias dimensiones (por ejemplo, ética colectiva, psicología, política, sistema de transporte, economía, cultura, solidaridad ciudadana, educación, etc.). En CSD Nirvánico, la tesis modificó o desmontó las conexiones de los dharmas patológicos que producían sólamente las agonías urbanas según el principio 4NV. Si en algún espacio se requiere una intervención urbanística, no se ejercitaría el plan sólo porque es bueno en general, sino porque tiene que tener su filosofía. Este tipo de intervenciones no funciona con una vaga directriz ambigua sin criterio. El fruto del capítulo fue proponer un evidente ejemplo para el trabajo cuando se aplica la herramienta en el proyecto con una 
mayor fuerza teleológica de la intervención, al entrar en otra dimensión del discurso desde el campo urbanístico y arquitectónico.

Indudablemente, el fruto de la cosecha era una máquina pesada y pesada significa 29 hojas de argumento. Y eso podía ser un obstáculo en algunas situaciones urgentes o en las circunstancias que están en un cambio drástico y dinámico como las ciudades de hoy en día. Una simplificación, o sea la secularización era otro resultado para dar rapidez a la herramienta reduciendo su colosal volumen argumental, y los términos buddhistas de difícil comprensión fueron re-categorizados según sus caracteres de virtudes buddhistas. El hexágono de las 6 virtudes era una versión estratégica para poder incorporarse al campo profesional y académico. Este estudio hizo la reconsideración de los principios que fueron establecidos en los capítulos 8,9 y 10, y que al final demostró una práctica de la genuina virtud de Siddhartha reconsiderando la excelencia de los adoctrinamientos.

Como ningún dharma puede ser perpetuo, la contundencia de la tesis tampoco podría ser eterna. Solamente, sería suficiente si esta tesis gana su razón de existir comprobando su utilidad y su espíritu en esta era. Desde el principio, fue un gran experimento aplicar la idea del nirvana al espacio urbanístico y arquitectónico, debido a que la noción del nirvana podía quedarse en el campo mítico para siempre, creyendo que una persona va al infierno o que llega al nirvana vivo o tal vez póstumamente. La ciudad es un lugar y se otorga su significado, por eso para una ciudad es imposible ser juzgada por un médico respecto la vida o la muerte, sólo existe con el tiempo. La ciudad puede ser sostenible en una forma virtuosa o también ser una mera máquina que produce monstruosas agonías. La contundencia y la factibilidad de la tesis ya está demostrada. Esta tesis también puede ser fosilizada o mitificada sin virtud del No-yo, y si ocurre este tipo de obsesión y se queda como una pervertida perspectiva dogmática sería un discurso de otro tiempo. 
La ciudad del nirvana sería una ciudad-dharma, lógicamente. Esta tesis no es nada más que un dharma. Por eso dicho dharma es un $C S D^{1}$ que consiste en varios dharmas. Depende de la situación, este estudio reproduce la extinción del dolor (ED) como se ha podido observar en los anteriores proyectos, y también, al contrario, puede reproducir la acumulación del dolor (AD) cuando la circunstancia cambiase en el tiempo venidero.

${ }^{1}$ Co-surgimiento dependiente. -(NdA) 


\section{Bibliografía}

\section{Libros}

AAVV. Diccionario de la Lengua Española. Real Academia Española. 22. a edición. 2001.

AAVV. The City Reader. Oxon. Routledge. LeGates. R. T. \& Stout, F. (eds). 2011.

AAVV. Urban Planning in a Changing World: The Twentieth Century Experience. London. E \& FN Spon. 2000.

AAVV. The Activist Drawing: Retracing Situationist Architectures from Constant's New Babylon to Beyond. Zegher, C \& Wigley, M. (ed.) New York, Cambridge, Massachusetts. The Drawing Center \&The MIT Press. 2001.

AAVV. Katsura: Imperial Villa. New York. Phaidon Press Ltd. 2011.

AAVV. Situationist International Anthology. Knabb, Ken(ed. \& tr.) Berkeley. Bureau of Public Secrets. 2006.

AAVV. Historia de Filosofía Vol. I.: Academia de Ciencia de Rusia. Lee, E.H.(tr.) Seoul. Choong Won Moon Hwa Editorial.Versión Coreana. 1988.

AAVV. Theory and Manifestoes of Contemporary Architecture. Jenks, C. \& Kropf, K. (ed.)

Chichester. Wiley-Academy. 2006.

AAVV: Funciones y Derarrollo Urbano de Valencia. Valencia. FERMAR. 1976.

AAVV. Carne de Zen, Huesos de Zen: Antología de Historias Antiguas del Budismo Zen. (Zen Bones. Zen Flesh). Madrid. Editorial EDAF, S. A. Versión española. López-Mingo, R. (tr.) 2000.

AAVV. 101 Cuentos Zen. (101 Zen Stories.) Barcelona. Galaxia Gutenberg, S. L. version española. Fibla, J. (tr.) 2012.

AAVV. Temporary Urban Spaces: Concepts for the Use of City Spaces. Basel-Boston-Berlín. BirkhäuserPublisher for Architecture. Haydn, F., Temel, R. (ed.) 2006.

AAVV. Future City. Abingdon, Nueva York. Spon Presss. Read, S., Rosemann, J. Eldkijk, J.(ed.) 2005.

AAVV. Arquitectura y Turismo: Perepción, representación y lugar. Barcelona, Naucalpan, Amadora. Editorial Gustavo Gili, SL. Lasansky, M. Mclaren, B. (ed.) 2006.

Ando, T.(1991) Tadao Ando: Details 1. Tokyo. A.D.A. EDITA Tokyo. Futagawa, Y.(ed.), Eisenman, P.(criticismo). 1999.

Ando, T. Tadao Ando: Complete Works. Francesco Dal Co(ed.). London. Phaidon Press Limited. 1995.

Ando, T. Tadao Ando: Light and Water. New York. The Monacelli Press, Inc. 2003.

Adams, D. v.o.1979. The Hitch Hiker's Guide to the Galaxy. New York. Pan Books, Ltd. Del Rey Trade Paperback Edition. 2009. 
Agamben, G. La Comunità che Viene. Valencia. Pre-Texto. José Luis Villancañas \& Claudio La Rocca (tr.) Versión española. 1996.

Arendt, H. v.o.1958. The Human Condition. London. The University of Chicago Press, Ltd. 1998.

Alfaguara, S. A. TAURUS. Version española. Herrero, R. F. (tr.) 1988.

Batchelor, S. v.o.1997. Buddhism without Beliefs. Moraza, Ignacio José (tr.). Madrid. Gaia ediciones. 2008.

Baek, J. Nothingness: Tadao Ando's Christian Sacred Space. Oxon. Routledge. 2009.

Bunschoten, R. Urban Flotsam. Eindhoven. 010 Publishers. 2001.

Berthier, F. v.0.1989. Le jardín du Ryoanji. (El jardín zen). Barcelona. Editorial Gustavo Gili, SL. Versión española. Carmen Artal(tr.) 2007.

Blau, E., Rupnik, I. Project Zagreb: Transition as Condition, Strategy, Practice. Barcelona. Actar. 2007.

Bergson, H. v.o.1968. Duration and Simultaneity. (Dureé et Simultanéité). Manchester. Clinamen Press Limited. Versión Inglésa. Jacobson, L., Lewis, M. (tr.) 1999.

Bergson, H. Matter and Memory. New York. Cosimo, Inc. Versión inglesa. 2007.

Bergson, H. Time and Free Will: An Essay on the Immediate Data of Consciousness. (Essai sur les donnees immediate de la conscience.) Nueva York. Dover Publications, Inc. versión inglesa. Pogson, F. L. (tr.) 2001.

Bergson, H. Henri Bergson: Memoria y Vida. (Bergson: Méoire et vie) Madrid. Alianza Editorial, S. A. Versión española. Armiño, M. (tr.) Deleuze, G. (ed.) 1977.

Chomsky, N. Profit Over People: Neolberalism and Global Order. New York. Seven Stories Press. 1999.

Chomsky, N. Hegemony or Survival: America`s Quest For Global Dominance. London. Penguin Books. 2004.

Claeys, G. Searching for Utopia: The history of an idea. Condor, M(tr). Madrid. Ediciones Siruela. Versión española:2011.

Constant. La Nueva Babilonia. Lambert, J.C.(ed.) Barcelona. Editorial Gustavo Gili. Versión española. 2009.

Debord, G. v.o. 1967. La Société du Spectacle. Smith, D.N.(tr) New York. Zone Books. Versión inglesa: The Society of the Spectacle. 1994.

Deleuze, G., Guattari, F. v.o. 1980. Mil Mesetas: Capitalismo y Esquizofrenia. (Mil Plateaux:capitalisme et schizophizophrénie) Valencia. Pre-textos. Versión española. Pérez, J. (tr.) 2000.

Deleuze, G., Félix, G. v.o. 1980. Mil Mesetas: Capitalismo y Esquizofrenia. Kim, J.I.(tr) Seoul. Saemulgyul Publishing House. versión coreana. 2003.

Deleuze, G \& Guattari, F. v.o. 1980. A Thousand Plateaus : Capitalism and Schizophrenia. Massumi, B(tr.). Minneapolis. University of Minnesota Press. Versión inglesa. 1987. 
Deleuze, G. Diferencia y Repetición. Buenos Aires. Presses Universitaires de France. Versión española. María Silvia Delpy y Hugo Beccacese (tr.). 2002.

Deleuze, G., Guattari, F. v.o.1972. El Anti Edipo: Capitalismo y Esquizofrenia. (L'Anti-Oedipe: Capitalisme et schizophrénie) Barcelona, Buenos Aires, México. Paidós. Versión española. Monge, F. (tr.) 1998.

Deshimaru, T. La Práctica del Zen: y cuatro textos canónicos Zen. (La Pratique du Zen) Barcelona. Editorial Kairós. Versión española. Rovira, P., Samblancat, N. (tr.) 2000.

Foucault, M. v.o. 1975. Discipline \& Punish: The Birth of the Prision. (Surveiller et punir: Naissance de la Prison). Nueva York. A Division of Random House, Inc. version inglesa. Sheridan, A. (tr.) 1995.

Furier, C. v.o. 1808. Théorie des quatre movements et des destinées generals. Byun, G.C.(tr.,ed.) Seoul. Book World. Versión coreana. 2007.

Fishman, R. Urban Utopias in the Twentieth Century. Cambridge, Massachusetts. The MIT Press. 1982.

Gans, D. The Le Corbusier Guide. New York. Princeton Architectural Press. 2000.

Gehl, J. Cities for People. Washington DC. Island Press. 2010.

Harvey, D. A Brief History of Neoliberalism. Oxford. Oxford University Press. 2007.

Harvey, D. Spaces of Global Capitalism: Towards a Theory of Uneven Geographical Development. London-New York. Verso. 2006.

Hall, P. v.o. 1988, Cities of Tomorrow: An Intellectual History of Urban Planning and Design in the Twentieth Century. Freixa, Consol(tr). Barcelona. Ediciones Serbal. Versión española 1996.

Howard, E. Garden Cities of To-Morrow. London. S. Sonnenschein \& Co., Ltd. segunda edición. 1902.

Hall, P. v.o. 1988, Cities of Tomorrow: An Intellectual History of Urban Planning and Design in the Twentieth Century. Im, C.H \& Ahn, G.H(tr). Seoul. Hanul books. Versión coreana: 2009.

Huizinga, J. v.o. 1938. Homo ludens. Imaz, E.(tr) Madrid. Alianza Editorial, S. A. Versión española. 2012.

Holl, S. v.o. 1992-1994. Questions of Perception: Phenomenology of Architecture. Puente, M.(tr.,ed.) Barcelona. Editorial Gustavo Gili, S. L. Versión española: Cuestiones de Percepción: Fenomenología de la Arquitectura. 2011.

Harvey, P. An Introduction to Buddhist Ethics: Foundations, Values and Issues. Cambridge. Cambridge University Press. 2000.

Hall, P., Pfeiffer, U. Urban Future 21: A Global Agenda for Twenty-first Century Cities. London, New York. E \& FN Spon. 2000.

Hegel, G. Lecciones sobre la Filosofía de la Historia Universal: Introducción General. Valencia. Universitat de Valencia. Gaos, J. (tr.) versión española. 1992.

Hoover, T. The Zen Experience. New York. PLUME. 1980.

Ikeda, D. Budismo, Primer Milenio. (Buddhism, the First Millennium.) Madrid. Altea, Tarus, 
Kropotkin, P. v.o. 1902. Mutual Aid: A Factor of Evolution. Seoul. Greenbee. Ha, S. W. (tr.,ed.) version coreana. 2012.

Kant, I. Observaciones acerca del sentimiento de lo bello y de lo sublime. Madrid. Alianza Editorial, S. A. versión española. Moreno, L.(tr.) 1990.

Le Corbusier. v.o. 1929. Urbanisme. Etchells, F.(tr.) New York. Dover Publications, Inc. Versión inglesa. 1987.

Lee, J.W. 사건의 철학(Filosofía de Evento). Seoul. 철학아카데미(Academia de Filosofía). 2003.

Lefebvre, H. Éléments de rythmanalyse. Londdon-New York. Continuum. Versión inglesa. Enden, S. \& Moore, G. (tr.) 2007.

Marx, K. Manuscritos Económicos y filosóficos de 1844. (Ökonomisch-philosophische Manuskripte aus dem Jahre 1844.) Seoul. Theory and Practice. Versión coreana. Kang, Y.O.(tr.). 2007.

Mumford, L. v.o. 1922. The Story of Utopias. Boni and Liveright, Inc.. $4^{\text {a }}$ edición. 1928.

Negri, A. \& Hardt, M. v.o. 2009. Commonwealth. Goyang. April Books. Jung, N.Y \& Yoon, Y.G.(tr.) Versión Coreana. 2014.

Nietzche, F. v.o. 1872. The Birth of Tragedy (Die Geburt der Tragödie aus dem Geiste der Musik). Nueva York. Dover Publications, Inc. version inglésa. Fadiman, C. (tr.) version inglesa.1995.

Oakley, A. v.o. 1984. Marx's Critique of Political Economy I. Oxon. Routledge. 2003.

Ortega y Gasset, J. Meditación de la técnica y otros ensayos sobre ciencia y filosofía. Madrid. Alianza Editorial. 2004.

Platón. Politeia (República). Lee, H(tr). Seoul. Doduls. 2006.

Proudhon, P. J. 1840. ¿Qué es la Propiedad? Lee, Y. J(tr.). Seoul. Acanet. Versión coreana. 2013

Paans, O., Pasel, R. Situantional Urbanism: Directing postwar urbanity. Berlín. jovis Verlag GmbH. 2014.

Platón. La República. Madrid. Aguilar, S. A. Versión española. Míguez, J.(tr.) 1988.

Rowe, C. \& Koetter, F. Collage City. Cambridge, Massachusetts. The MIT Press. 1983.

Rodowick, D. N. v.o. 1998. Gilles Deleuze's Time Machine. Seoul. Greenbee Publishing Company. Kim, J.H.(tr.) Versión Coreana. 2007.

Riechmann, J. Un Mundo Vulnerable: Ensayos sobre Ecología, Ética y Tecnociendia. Madrid.Los Libros de la Catarata. 2000.

Suzuki, D. Budismo Zen. (The Awakening of Zen.) Barcelona. Editorial Kairós. Versión española. Tobajas, A. (tr.) 1998.

Spinoza, B. v.o. 1677. Ética demostrada según el orden geométrico. Peña, Vidal(tr). Madrid. Alianza Editorial. 9ed. Version española. 2007. 
Sadler, S. The Situationist City. Massachusetts. The MIT Press. 1999.

Sāntideva. The Bodhisattvacaryāvatāra. Crosby, K. \& Skilton, A. (tr.). Oxford. Oxford University Press. Versión inglesa. 2008.

Sandel, M. Justice: What's the Right Thing to Do? Nueva York. Farrar, Straus and Giroux. 2009.

Tafuri, M. v.o. 1973. Architecture and Utopia: Design and Capitalist Development. (Progetto e utopia: Architettura e sviluppo capitalistico.) Massachusetts. The MIT Press. Penta, B. L. (tr). Versión inglesa 1976.

Vidal, C. Buda El Príncipe. Madrid. Rotapapel, S.L.. 2011.

Villalba, D. Zen en la plaza del Mercado. Madrid. Santillana Ediciones Generales, S. L. 2008.

Wigley, M. Constant's New Babylon: The Hyper-Architecture of Desire. Rotterdam. 010 Publisher. 1998.

Watts, A. The Way of Zen. New York. Vintage Books. 1985. 


\section{Revistas}

Antonio P. Russoa, Jan van der Borg ${ }^{\mathrm{b}}$. Planning considerations for cultural tourism: a case study of four European cities. Elsevier. Elsevier Ltd. 2002.

El Croquis: Tadao Ando 1989/1992. Madrid. El Croquis Editorial. 1993. nº 58.

ILO. Global Wage Report 2012/2013: Wages and equitable growth. International Labour Office · Geneva. Fuente online:

$<<$ http://www.ilo.org/wcmsp5/groups/public/---dgreports/---

dcomm/documents/publication/wcms_194948.pdf>>

ILO. Global Wage Report 2016/2017: Wage inequality in the workplace. International Labour Office. Geneva: ILO. 2016.

ILO. World Employment Social Outlook 2016: Transforming Jobs to end poverty. International Labour Office. Geneva: ILO. 2016.

Müge Akkar Ercan. Challenges and conflicts in achieving sustainable communities in historic neighbourhoods of Istanbul. Habitat International. № 35. 2011.

Naja \& de Ostos. Pamphlet Architecture: 29. Ambiguous Space. Nueva York Princeton Architectural Press. 2008.

OECD. Growing unequal?: Income Distribution and Poverty in OECD Countries. OECD Publishing. 2008.

OECD. "Household Debt". OECD Factbook 2013: Economic, Environmental and Social Statistics, OECD Publishing. Fuente Online: <<http://dx.doi.org/10.1787/factbook-2013-28-en>>

OECD. "Poverty and gaps". OECD Factbook 2013: Economic, Environmental and Social Statistics. OECD Publishing. Fuente online: <<http://dx.doi.org/10.1787/factbook-2013-26-en>>

OECD. Divided We Stand: Why Inequality Keeps Rising, OECD Publishing. 2011. Fuente online: <<http://dx.doi.org/10.1787/9789264119536-en>>

OECD. OECD Economic Surveys: Spain 2012. OECD Publishing. Fuente online: <<http://dx.doi.org/10.1787/eco_surveys-esp-2012-en>>

OECD. Entrepreneurship at a Glance 2011. OECD Publishing.

OECD. Crisis Squeezes Income and Puts Pressure on Inequality and Poverty. OECD Publishing. 15. Mayo. 2013.

Fuente online:< < http://www.oecd.org/social/inequality.htm>>

OECD. "Household Income and Wealth". OECD Factbook 2013. OECD Publishing. 2013. Fuente online:

<<http://www.oecd.org/std/03_Household_income_and_wealth.pdf $>>$

OECD. OECD Employment Outlook 2016. OECD Publishing. Paris. 2016.

OECD. OECD Entrepreneurship at a Glance 2016. OECD Publishing. Paris. 2016.

Sasaki, M. Urban regeneration through cultural creativity and social inclusión: Rethinking creative 
city theory throuth a Japanese case study. Elsevier. Elsevier Ltd. 4 de Mayo. 2010.

\section{Tesis}

Shin, S.C. El Estudio sobre las Teorías del Deseo y el Cuerpo de Deleuze \& Guattari. Tesina master. Dongguk University. 2003.

\section{Lecturas}

Javier Poyatos. Apuntes de clase. Master en Arquitectura Avanzada. Universidad Politécnica de Valencia. 2012.

Kim, Yong-Ok. Do-ol encuentra la India. Lectura de serie en el aire en EBS (Educational Broadcasting System), Corea. El programa fue emisionado Desde el 29 de gosto y hasta el 29 de noviembre del año 2002 durante 3 meses contando veintiocho lecturas.

Sandel, M. Justice. Lectura de Harvard University.Fuente online:<< http://www.justiceharvard.org>>

\section{Películas}

Dalsgaard, A. <The Human Scale>. The 10th EBS International Documentary Festival: Docs on City \& Architecture. Oct, 2013.

Frick, M. <Tadao Ando: From Emptiness To Infinity>. The 10th EBS International Documentary Festival: Docs on City \& Architecture. Oct, 2013 


\section{Otras fuentes}

AAVV. Buddha. Encyclopædia Britannica Editorial. 2014. Fuente online:

<<http://global.britannica.com/EBchecked/topic/83105/Buddha>>

A people focused national architecture policy. Gehl Architects. 2014. Fuente online:

<<http://gehlarchitects.com/story-article/a-people-focused-national-architecture-policy/>>

Bowker, J. The Concise Oxford Dictionary of World Religions. Oxford University Press. 1977.

Fuente online:<<http://www.encyclopedia.com/topic/dharma.aspx\#1>>

Constant, New Babylon. The Hague. The Haags Gemeetenmuseum. 1974. p. 3. Fuente online:

<http://isites.harvard.edu/fs/docs/icb.topic709752.files/WEEK\%207/CNieuwenhuis_New\%20Babylon.

pdf $>$

Constant. Autodialogue on New Babylon. Opus International \#27. 1971. Anon.(tr.) Fuente online:

$<$ http://www.notbored.org/autodialogue.html>

Diccionario Espasa Grande: español-francés français- espagnol (c) 2000 Espasa-Calpe.

(C) WordReference.com LLC. Fuente online: <http://www.wordreference.com>

Encyclopedia of Korean Culture. 한국 민족문화대백과사전.

Fuente online: <<http://encykorea.aks.ac.kr/Contents/Index>>

Kropotkin, P. 1902. Mutual Aid: A Factor of Evolution. Fuente de online:

< http://www.marxists.org/reference/archive/kropotkin-peter/1902/mutual-aid/index.htm>

More people-friendly megacity. Gehl Architects. 2013. Fuente online:

<<http://gehlarchitects.com/cases/a-more-people-friendly-megacity/>>

Map data C2015 Google, basado en BCN IGN España. Fuente online: <maps.google.com>

Marx, K. Manuscritos Económico y Filosíficos de 1844. Versión español. Fuente online desde Google books:

<<https://books.google.es/books?id=0KKBAAAQBAJ\&pg=PT1\&dq=Manuscritos+económicos+y+filos óficos >>

Situationist International Online: <http://www.cddc.vt.edu/sionline/presitu/manifesto.html> 


\section{Créditos Fotográficos}

\section{Capítulo 0}

Fig. 0-1. La primera página del hebreo Sefer Yetzirah, o Libro de la Creación, siglo XV. Derechos de Autor. Claeys, G. Utopía Historia de una idea. Hong Kong. Ediciones Siruelas, S.A., Edición española. Condor, M. (ed.) 2011.

Fig. 0-2. El amor en la Edad de Oro (c.1585-1589), Pauwels Franck. Derechos de Autor. Claeys, G. Utopía - Historia de una idea. Hong Kong. Ediciones Siruelas, S.A., Edición española. Condor, M. (ed.) 2011.

Fig. 0-3La Torre de Babel, por Lucas van Valckenborgh (1594). Derechos de Autor. Claeys, G. Utopía - Historia de una idea. Hong Kong. Ediciones Siruelas, S.A., Edición española. Condor, M. (ed.) 2011.

Fig. 0-4. La llegada de los ingleses a Virginia por Thodor de Bry. Public. Derechos de Autor. Claeys, G. Utopía - Historia de una idea. Hong Kong. Ediciones Siruelas, S.A., Edición española. Condor, M. (ed.) 2011.

Figs. 0-5. Utopía de Tomás Moro, 1516. Derechos de Autor. Claeys, G. Utopía - Historia de una idea. Hong Kong. Ediciones Siruelas, S.A., Edición española. Condor, M. (ed.) 2011.

Fig. 0-6. El Paraíso de Mahoma, c. 1030. Derechos de Autor. Claeys, G. Utopía - Historia de una idea. Hong Kong. Ediciones Siruelas, S.A., Edición española. Condor, M. (ed.) 2011.

Fig. 0-7. Dibujo de E. C. Broch, de la edición de 1894 de Los viajes de Gulliver. Derechos de Autor. Claeys, G. Utopía Historia de una idea. Hong Kong. Ediciones Siruelas, S.A., Edición española. Condor, M. (ed.) 2011.

Fig. 0-8. Litografía coloreada c. 1874 de Robinsón Crusoe y su criado Vie. por Daniel Defoe. Derechos de Autor. Claeys, G. Utopía - Historia de una idea. Hong Kong. Ediciones Siruelas, S.A., Edición española. Condor, M. (ed.) 2011.

Fig. 0-9. Portada de Un mundo feliz, 1932 de Aldous Huxley. Derechos de Autor. Claeys, G. Utopía - Historia de una idea. Hong Kong. Ediciones Siruelas, S.A., Edición española. Condor, M. (ed.) 2011.

Fig. 0-10. Vista en perspectiva del Falansterio de Charles Fourier. Derechos de Autor. Claeys, G. Utopía - Historia de una idea. Hong Kong. Ediciones Siruelas, S.A., Edición española. Condor, M. (ed.) 2011.

Fig. 0-11. Paul Gauguin, Tierra deliciosa (Te nave nave fenua), 1892. Derechos de Autor. Claeys, G. Utopía - Historia de una idea. Hong Kong. Ediciones Siruelas, S.A., Edición española. Condor, M. (ed.) 2011.

Fig. 0-12. Buddha en el nirvana, Tiet, siglo XVIII. Derechos de Autor. Claeys, G. Utopía - Historia de una idea. Hong Kong. Ediciones Siruelas, S.A., Edición española. Condor, M. (ed.) 2011.

\section{Capítulo 2}

Fig. 2-1. Diagrama №1 para Ciudad Jardín de Ebenezer Howard. Derechos de Autor. Hall, P. Urban and Regional Planning. Oxon. Routledge. 2011.

Fig. 2-2. Diagrama №2 para Ciudad Jardín de Ebenezer Howard. Derechos de Autor. AAVV. The Ciity Reader. Oxon. Routledge. 2011.

Fig. 2-3. Diagrama №3 para Ciudad Jardín de Ebenezer Howard. Derechos de Autor. AAVV. The Ciity Reader. Oxon. Routledge. 2011

Fig. 2-4. Diagrama №5 para Ciudad Jardín de Ebenezer Howard. Derechos de Autor. Fishman, R. Urban Utopias in the Twentieth Century. Cambridge, Massachusetts, London, England. The MIT Press. 1982

Fig. 2-5. La Ciudad Social de Ebenezer Howard. Derechos de Autor. Hall, P. Urban and Regional Planning. Oxon. Routledge. 2011.

Fig. 2-6. Comida del Domingo de la Clase obrera en la Ciudad-Jardín de Unwin. Derechos de Autor. Hall, P. Cities of Tomorrow. Paju. Hanul Academy 792. 2009.

Fig. 2-7. Jardín interno de la residencia de Unwin-Parker. Derechos de Autor. Hall, P. Cities of Tomorrow. Paju. Hanul Academy 792. 2009.

Fig. 2-8. Plan de Letchworth Ciudad-Jardín. Derechos de Autor. Hall, P. Urban and Regional Planning. Oxon. Routledge. 2011.

Fig. 2-9. Letchworth la primera ciudad-jardín. Derechos de Autor. Hall, P. Cities of Tomorrow. Paju. Hanul Academy 792. 2009. 
Fig. 2-10. Letchworth desde el aire. Derechos de Autor. Hall, P. Urban and Regional Planning. Oxon. Routledge. 2011.

\section{Capítulo 3}

Fig. 3-1. Autopista de intercambio de Broadacre City. Derechos de Autor. Fishman, R. Urban Utopias in the Twentieth Century. Cambridge, Massachusetts, London, England. The MIT Press. 1982.

Fig. 3-2. Casa de Berma para trabajadores cooperativos. Derechos de Autor. Fishman, R. Urban Utopias in the Twentieth Century. Cambridge, Massachusetts, London, England. The MIT Press. 1982.

Fig. 3-3. Casa de Berma. Derechos de Autor. Fishman, R. Urban Utopias in the Twentieth Century. Cambridge, Massachusetts, London, England. The MIT Press. 1982.

Fig. 3-4. Dibujo de pincel de Frank Lloyd Wright. Derechos de Autor. Fishman, R. Urban Utopias in the Twentieth Century. Cambridge, Massachusetts, London, England. The MIT Press. 1982.

Fig. 3-5. La maqueta del apartamento para Broadacre City de Frank Lloyd Wright. Derechos de Autor. Fishman, R. Urban Utopias in the Twentieth Century. Cambridge, Massachusetts, London, England. The MIT Press. 1982.

Fig. 3-6. La maqueta del circo de Broadacre City de Frank Lloyd Wright. Derechos de Autor. Fishman, R. Urban Utopias in the Twentieth Century. Cambridge, Massachusetts, London, England. The MIT Press. 1982.

Fig. 3-7. Plano del centro de Broadacre City. Derechos de Autor. AAVV. The Ciity Reader. Oxon. Routledge. 2011.

Fig. 3-8. The Broadacre City de Frank Lloyd Wright. Derechos de Autor. Fishman, R. Urban Utopias in the Twentieth Century. Cambridge, Massachusetts, London, England. The MIT Press. 1982.

Fig. 3-9. Típica casa en la tierra en pendiente de Broadacre City. Derechos de Autor. Fishman, R. Urban Utopias in the Twentieth Century. Cambridge, Massachusetts, London, England. The MIT Press. 1982

\section{Capítulo 4}

Fig. 4-1. La básica estructura de la Casa Dom-Ino. Derechos de Autor. Fishman, R. Urban Utopias in the Twentieth Century. Massachusetts. The MIT Press. 1982.

Fig. 4-2. Un grupo de casas Dom-Ino de Le Corbusier. Derechos de Autor. Fishman, R. Urban Utopias in the Twentieth Century. Cambridge, Massachusetts, London, England. The MIT Press. 1982.

Fig. 4-3. El Plan Voisin de Le Corbusier para Paris. Derechos de Autor. Fishman, R. Urban Utopias in the Twentieth Century. Cambridge, Massachusetts, London, England. The MIT Press. 1982

Fig. 4-4. La maqueta del Plan Voisin de Le Corbusier. Derechos de Autor. Fishman, R. Urban Utopias in the Twentieth Century. Cambridge, Massachusetts, London, England. The MIT Press. 1982.

Fig. 4-5. Apartamentos para las elites de la Ciudad Contemporánea de Le Corbusier. Derechos de Autor. Fishman, R. Urban Utopias in the Twentieth Century. Cambridge, Massachusetts, London, England. The MIT Press. 1982.

Fig. 4-6. Distrito del negocio de la Ciudad Contemporánea. Derechos de Autor. Fishman, R. Urban Utopias in the Twentieth Century. Massachusetts. The MIT Press. 1982.

Fig. 4-7. El centro de la Ciudad Contemporánea de Le Corbusier. Derechos de Autor. Fishman, R. Urban Utopias in the Twentieth Century. Cambridge, Massachusetts, London, England. The MIT Press. 1982.

Fig. 4-8. Una super-autopista de la Ciudad Contemporánea de Le Corbusier. Derechos de Autor. Fishman, R. Urban Utopias in the Twentieth Century. Cambridge, Massachusetts, London, England. The MIT Press. 1982.

Fig. 4-9. El plan de la Ciudad Contemporánea de Le Corbusier. Derechos de Autor. Fishman, R. Urban Utopias in the Twentieth Century. Cambridge, Massachusetts, London, England. The MIT Press. 1982.

Fig. 4-10. Jardín colgado del apartamento de Le Corbusier. Derechos de Autor. Fishman, R. Urban Utopias in the Twentieth Century. Cambridge, Massachusetts, London, England. The MIT Press. 1982.

Fig. 4-11. Villa-Apartamento para la élite de Le Corbusier. Derechos de Autor. Fishman, R. Urban Utopias in the Twentieth Century. Cambridge, Massachusetts, London, England. The MIT Press. 1982. 


\section{Capítulo 5}

Fig. 5-1. Oppera Collecttiva, Pinot Gallizio, Asger Jorn, Constant. Derechos de Autor. Situacionistas. Barcelona. Museu d'Art Contemporani de Barcelona(ed.) ACTAR. 1996.

Fig. 5-2. Pas de puissance - Imagination, Asger Jorn. Derechos de Autor. Situacionistas. Barcelona. Museu d'Art Contemporani de Barcelona(ed.) ACTAR. 1996.

Fig. 5-3. Poussin, Asger Jorn. Grand baiser au Cardinal d'Amérique, Asger Jorn. Derechos de Autor. Situacionistas. Barcelona. Museu d'Art Contemporani de Barcelona(ed.) ACTAR. 1996.

Fig. 5-4. Life continues to be free and easy, Guy Debord. Derechos de Aurtor. Sadler, S. The situationist city. Massachusetts. The MIT Press. 1999.

Fig. 5-5. La Ciudad Desnuda, Guy Debord. Derechos de Autor. Situacionistas. Barcelona. Museu d'Art Contemporani de Barcelona(ed.) ACTAR. 1996.

Fig. 5-6. Dibujo de la Nueva Babilonia en el viaje de Constant. Derechos de Autor. Wigley, M. The Hyper-Architecture of Desire. Roterdam. 010 Publishers. 1998.

Fig. 5-7. Figuras del espacio en Nueva Babilonia de Constant. Derechos de Autor. Wigley, M. The Hyper-Architecture of Desire. Roterdam. 010 Publishers. 1998.

Fig. 5-8. Dibujo para un laberinto movible de Constant. Derechos de Autor. AAVV. The Activist Drawing. Cambridge, Massachusetts, London, England. The MIT Press. 2001.

Fig. 5- 9. Grupo de Sectores de Constant. Derechos de Autor. AAVV. The Activist Drawing. Cambridge, Massachusetts, London, England. The MIT Press. 2001.

Fig. 5-10. Imagen de sectores de Nueva Babilonia de Constant. Derechos de Autor. Wigley, M. The Hyper-Architecture of Desire. Roterdam. 010 Publishers. 1998.

Fig. 5-11. La maqueta del sector de la Nueva Babilonia de Constant. Derechos de Autor. Wigley, M. The Hyper-Architecture of Desire. Roterdam. 010 Publishers. 1998.

Fig. 5-12. Laberintorium de Constant. Derechos de Autor. Wigley, M. The Hyper-Architecture of Desire. Roterdam. 010 Publishers. 1998.

Fig. 5-13. Mapa del sector amarrillo de Constant. Derechos de Autor. Wigley, M. The Hyper-Architecture of Desire. Roterdam. 010 Publishers. 1998.

Fig. 5-14. Plan y sección de sectores agrupados de Constant. Derechos de Autor. AAVV. The Activist Drawing. Cambridge, Massachusetts, London, England. The MIT Press. 2001.

Fig. 5-15. Nueva Babilonia Amsterdam de Constant. Derechos de Autor. AAVV. The Activist Drawing. Cambridge, Massachusetts, London, England. The MIT Press. 2001.

Fig. 5-16. Nueva Babilonia Holanda, Antwerpen, Roterdam, Paris, de Constant. Derechos de Autor. AAVV. The Activist Drawing. Cambridge, Massachusetts, London, England. The MIT Press. 2001.

Fig. 5-17. Nueva Babilonia Ruhrgebiet de Constant. Derechos de Autor. AAVV. The Activist Drawing. Cambridge, Massachusetts, London, England. The MIT Press. 2001.

Fig. 5-18. Sector Oriental de Constant. Derechos de Autor. Situacionistas. Barcelona. Museu d'Art Contemporani de Barcelona(ed.) ACTAR. 1996.

Fig. 5-19. Cluster City de Peter Smithson, 1952. Derechos de Autor. Massachusetts Institute of Technology. 1998.

\section{Capítulo 6}

Fig. 6-1. Plano general de Katsura. Derechos de Autor. Katsura-Imperial Villa. Milano. Phaidon Press Ltd. Ponciroli, V (ed.) 2011.

Fig. 6-2. El complejo de Shoin. Derechos de Autor. Katsura-Imperial Villa. Milano. Phaidon Press Ltd. Ponciroli, V (ed.) 2011. 
Fig. 6-3. La puerta imperial desde la puerta principal. Derechos de Autor. Katsura-Imperial Villa. Milano. Phaidon Press Ltd. Ponciroli, V (ed.) 2011.

Fig. 6-4. El pino Sumiyoshi. Derechos de Autor. Katsura-Imperial Villa. Milano. Phaidon Press Ltd. Ponciroli, V (ed.) 2011.

Fig. 6-5. Embarcadero en el río Katsura. Derechos de Autor. Katsura-Imperial Villa. Milano. Phaidon Press Ltd. Ponciroli, V (ed.) 2011.

Fig. 6-6. La puerta del jardín. Derechos de Autor. Katsura-Imperial Villa. Milano. Phaidon Press Ltd. Ponciroli, V (ed.) 2011.

Fig. 6-7. La parte trasera de la valla de bambú. Derechos de Autor. Katsura-Imperial Villa. Milano. Phaidon Press Ltd. Ponciroli, $\mathrm{V}$ (ed.) 2011.

Fig. 6-8. La valla del spicebush cerca de la puerta central. Derechos de Autor. Katsura-Imperial Villa. Milano. Phaidon Press Ltd. Ponciroli, V (ed.) 2011.

Fig. 6-9. La puerta del jardín y la entradad a la Koshoin. Derechos de Autor. Katsura-Imperial Villa. Milano. Phaidon Press Ltd. Ponciroli, V (ed.) 2011.

Figs. 6-10. El complejo de los Shoines desde el estanque. Derechos de Autor. Katsura-Imperial Villa. Milano. Phaidon Press Ltd. Ponciroli, V (ed.) 2011.

Fig. 6-11. El Koshoin desde el este. Derechos de Autor. Katsura-Imperial Villa. Milano. Phaidon Press Ltd. Ponciroli, V (ed.) 2011.

Fig. 6-12. El camino de piedras a Koshoin. Derechos de Autor. Katsura-Imperial Villa. Milano. Phaidon Press Ltd. Ponciroli, V (ed.) 2011.

Fig. 6-13. La gran terraza y Tsukimidai. Derechos de Autor. Katsura-Imperial Villa. Milano. Phaidon Press Ltd. Ponciroli, V (ed.) 2011.

Fig. 6-14. Tsukimidai de Koshoin. Derechos de Autor. Katsura-Imperial Villa. Milano. Phaidon Press Ltd. Ponciroli, V (ed.) 2011.

Figs. 6-15. La primera habitación desde la segunda habitación de Koshoin. Derechos de Autor. Katsura-Imperial Villa. Milano. Phaidon Press Ltd. Ponciroli, V (ed.) 2011.

Fig. 6-16. La segunda habitación y la sala de la terraza desde la primera habitación de Koshoin. Derechos de Autor. KatsuraImperial Villa. Milano. Phaidon Press Ltd. Ponciroli, V (ed.) 2011.

Fig. 6-17. Sala de la terraza de Koshoin. Derechos de Autor. Katsura-Imperial Villa. Milano. Phaidon Press Ltd. Ponciroli, V (ed.) 2011.

Fig. 6-18. Los techos de Koshoin y Chushoin desde Shingoten. Derechos de Autor. Katsura-Imperial Villa. Milano. Phaidon Press Ltd. Ponciroli, V (ed.) 2011.

Fig. 6-19. El frente sur de Chushoin. Derechos de Autor. Katsura-Imperial Villa. Milano. Phaidon Press Ltd. Ponciroli, V (ed.) 2011.

Fig. 6-20. El complejo de Shoin. desde el lateral izquierdo, Shingote, Gakkinoma y Chushoin. Derechos de Autor. KatsuraImperial Villa. Milano. Phaidon Press Ltd. Ponciroli, V (ed.) 2011.

Fig. 6-21. La segunda y tercera habitación de Chushoin. Derechos de Autor. Katsura-Imperial Villa. Milano. Phaidon Press Ltd. Ponciroli, V (ed.) 2011.

Fig. 6-22. La tercera habitación desde la segunda habitación de Chushoin. Derechos de Autor. Katsura-Imperial Villa. Milano. Phaidon Press Ltd. Ponciroli, V (ed.) 2011.

Fig. 6-23. Sala de la terraza cerrada desde el frente al sur de Chushoin. Derechos de Autor. Katsura-Imperial Villa. Milano. Phaidon Press Ltd. Ponciroli, V (ed.) 2011.

Fig. 6-24. Gakkinoma desde el este. Derechos de Autor. Katsura-Imperial Villa. Milano. Phaidon Press Ltd. Ponciroli, V (ed.) 2011.

Fig. 6-25. Gakkinoma desde el sur. Derechos de Autor. Katsura-Imperial Villa. Milano. Phaidon Press Ltd. Ponciroli, V (ed.) 2011.

Fig. 6-26. La gran terraza de Gakkinoma. Derechos de Autor. Katsura-Imperial Villa. Milano. Phaidon Press Ltd. Ponciroli, V (ed.) 2011. 
Fig. 6-27. La gran terraza y a la derecha Chushoin. Derechos de Autor. Katsura-Imperial Villa. Milano. Phaidon Press Ltd. Ponciroli, V (ed.) 2011.

Fig. 6-28. Sala de la terraza de Gakkinoma. Derechos de Autor. Katsura-Imperial Villa. Milano. Phaidon Press Ltd. Ponciroli, V (ed.) 2011.

Fig. 6-29. El frente sur de Shingoten. Derechos de Autor. Katsura-Imperial Villa. Milano. Phaidon Press Ltd. Ponciroli, V (ed.) 2011.

Fig. 6-30. Gakkinoma y Chushoin desde la terraza de Shigoten. Derechos de Autor. Katsura-Imperial Villa. Milano. Phaidon Press Ltd. Ponciroli, V (ed.) 2011.

Fig. 6-31. Detrás de Shingoten. Derechos de Autor. Katsura-Imperial Villa. Milano. Phaidon Press Ltd. Ponciroli, V (ed.) 2011.

Fig. 6-32. El patio oeste de Shingoten. Derechos de Autor. Katsura-Imperial Villa. Milano. Phaidon Press Ltd. Ponciroli, V (ed.) 2011.

Fig. 6-33. El techo de Shingoten. Derechos de Autor. Katsura-Imperial Villa. Milano. Phaidon Press Ltd. Ponciroli, V (ed.) 2011.

Fig. 6-34. La esquina sureste de la terraza cerrada de Shingote. Derechos de Autor. Katsura-Imperial Villa. Milano. Phaidon Press Ltd. Ponciroli, V (ed.) 2011.

Fig. 6-35. La terraza cerrada desde la primera y segunda habitación de Shingoten. Derechos de Autor. Katsura-Imperial Villa. Milano. Phaidon Press Ltd. Ponciroli, V (ed.) 2011.

Fig. 6-36. La primera y segunda habitación de Shingoten desde la terraza cerrada. Derechos de Autor. Katsura-Imperial Villa. Milano. Phaidon Press Ltd. Ponciroli, V (ed.) 2011.

Fig. 6-37. Camino del río y camino a Shokintei que es la casa de té. Derechos de Autor. Katsura-Imperial Villa. Milano. Phaidon Press Ltd. Ponciroli, V (ed.) 2011.

Fig. 6-38. El área de la ceremonia del té de Gepparo. Derechos de Autor. Katsura-Imperial Villa. Milano. Phaidon Press Ltd. Ponciroli, V (ed.) 2011.

Fig. 6-39. Gepparo desde el norte. Derechos de Autor. Katsura-Imperial Villa. Milano. Phaidon Press Ltd. Ponciroli, V (ed.) 2011.

Fig. 6-40. Koshoin desde Gepparo. Derechos de Autor. Katsura-Imperial Villa. Milano. Phaidon Press Ltd. Ponciroli, V (ed.) 2011.

Fig. 6-41. La habitaicón de Shoiken la casa de té. Derechos de Autor. Katsura-Imperial Villa. Milano. Phaidon Press Ltd. Ponciroli, V (ed.) 2011.

Fig. 6-42. La terraza de Shokintei la casa de té. Derechos de Autor. Katsura-Imperial Villa. Milano. Phaidon Press Ltd. Ponciroli, V (ed.) 2011.

Fig. 6-43. Shokintei, casa de té desde el este. Derechos de Autor. Katsura-Imperial Villa. Milano. Phaidon Press Ltd. Ponciroli, V (ed.) 2011.

Fig. 6-44. El Puente Shirakawa. Derechos de Autor. Katsura-Imperial Villa. Milano. Phaidon Press Ltd. Ponciroli, V (ed.) 2011.

Fig. 6-45. El camino de piedra a Shokatei la casa de té. Derechos de Autor. Katsura-Imperial Villa. Milano. Phaidon Press Ltd. Ponciroli, V (ed.) 2011.

Fig. 6-46. El final del paseo. Se ven los Shoines desde el sur. Derechos de Autor. Katsura-Imperial Villa. Milano. Phaidon Press Ltd. Ponciroli, V (ed.) 2011.

\section{Capítulo 7}

Fig. 7-1. Dibujo del concepto. Derechos de Autor. Tadao Ando. Italia. TASCHEN GmbH. Philip Joidio (ed.) 2001.

Fig. 7-2. Dibujo del plano. Derechos de Autor. Tadao Ando. Italia. TASCHEN GmbH. Philip Joidio (ed.) 2001.

Fig. 7-3. Perspectiva hacia al altar. Derechos de Autor. Tadao Ando. Italia. TASCHEN GmbH. Philip Joidio (ed.) 2001.

Fig. 7-4. Altar. Derechos de Autor. Tadao Ando. Italia. TASCHEN GmbH. Philip Joidio (ed.) 2001. 
Fig. 7-5. Altar de la escuela del domingo. Derechos de Autor. Tadao Ando-Light and Water. Italia. The Monacelli Press, Inc. 2003.

Fig. 7-6. Interior de la escuela del domingo. Derechos de Autor. Tadao Ando-Light and Water. Italia. The Monacelli Press, Inc. 2003.

Fig. 7-7. Altar y apertura. Derechos de Autor. Tadao Ando-Light and Water. Italia. The Monacelli Press, Inc. 2003.

Fig. 7-8. Apertura lateral. Derechos de Autor. Tadao Ando-Light and Water. Italia. The Monacelli Press, Inc. 2003.

Fig. 7-9. Exterior desde la calle. Derechos de Autor. Tadao Ando-Light and Water. Italia. The Monacelli Press, Inc. 2003.

Fig. 7-10. Luz que entra por la pared de hormigón armado. Derechos de Autor. Tadao Ando-Light and Water. Italia. The Monacelli Press, Inc. 2003.

Fig. 7-11. Suelo con la luz de la apertua del crucifijo. Derechos de Autor. Tadao Ando-Light and Water. Italia. The Monacelli Press, Inc. 2003.

Fig. 7-12. Axonometrico, elevación sur y detalles del crucifijo exterior. Derechos de Autor. Tadao Ando Details 1. Tokyo. A.D.A. Edita Tokyo Co., Ltd. Yukio Futagawa(ed.) 1991.

Fig. 7-13. Plano del lugar. Derechos de Autor. Tadao Ando Details 1. Tokyo. A.D.A. Edita Tokyo Co., Ltd. Yukio Futagawa(ed.) 1991.

Fig. 7-14. Plano y Sección A-A. Derechos de Autor. Tadao Ando Details 1. Tokyo. A.D.A. Edita Tokyo Co., Ltd. Yukio Futagawa(ed.) 1991.

\section{Capítulo 11}

Fig. 11-1. El margen - donde la arquitectura y la ciudad encuentran las diversas actividades. Derechos de Autor. Jan Gehl Cities for People. Washington, DC. ISLAND PRESS. 2010.

Fig. 11-2. Cartel diciendo I bike Copenhagen. Derechos de Autor. Jan Gehl Cities for People. Washington, DC. ISLAND PRESS. 2010.

Fig. 11-3. Una calle de Brighton de Inglaterra, antes de 2006. Derechos de Autor. Jan Gehl Cities for People. Washington, DC. ISLAND PRESS. 2010.

Fig. 11-4. Una calle de Brighton de Inglaterra, después de la conversión, se transformó en una nueva calle con prioridad peatonal en Brighton de Inglaterra. Derechos de Autor. Jan Gehl Cities for People. Washington, DC. ISLAND PRESS. 2010.

Fig. 11-5. Nueva Calle con prioridad del peatón en Brighton en Inglaterra. Derechos de Autor. Jan Gehl Cities for People. Washington, DC. ISLAND PRESS. 2010.

Fig. 11-6. Plaza de la Reina, después de la reforma por Javier Goerlich. 1949.

Fig. 11-7. Plan actual de la Plaza de la Reina. Un plan personal del autor. La imágen de satélite: @ 2015 Microsoft Corporation.

Fig. 11-8. Plan actual de los transportes públicos. Un plan personal del autor. La imagén de satélite: @ OpenStreetMap.

Fig. 11-9. Plan de intervención de la Plaza de la Reina. Un plan personal del autor. La imágen de satélite: @ 2015 Microsoft Corporation.

Fig. 11-10. Piazza del Campo, Siena, Itaia. Derechos de Autor. Jan Gehl Cities for People. Washington, DC. ISLAND PRESS. 2010.

Fig. 11-11. Configuración inicial de la plaza del Miguelete en el plano Tosca. 1738.

Fig. 11-12. El plan para la Plaza de la Reina de Luis Ferreres Soler. 1891.

Fig. 11-13.Eurolille, Lille, France. Derechos de Autor. Jan Gehl Cities for People. Washington, DC. ISLAND PRESS. 2010.

Fig. 11-14. La Defence, Paris. Derechos de Autor. Jan Gehl Cities for People. Washington, DC. ISLAND PRESS. 2010.

Fig. 11-15. Brasilia, Brazil. Derechos de Autor. Jan Gehl Cities for People. Washington, DC. ISLAND PRESS. 2010. 
Fig. 11-16. Avenidad de la Reina, Valencia. Una foto personal del autor.

Fig. 11-17. Avenida del Cid, Valencia. Una foto personal del autor.

Fig. 11-18. Una callejón de Melbourne, antes de la conversión. Derechos de Autor. Jan Gehl Cities for People. Washington, DC. ISLAND PRESS. 2010.

Fig. 11-19. Un callejón oscuro de Melbourne donde solía ocurrirse crímenes ligeros. Derechos de Autor. Jan Gehl Cities for People. Washington, DC. ISLAND PRESS. 2010.

Fig. 11-20. Las actividades estacionarias y días de verano, desde el mediodía hasta las $4 \mathrm{pm}$ de Copenhagen. Derechos de Autor. Jan Gehl Cities for People. Washington, DC. ISLAND PRESS. 2010.

\section{Capítulo 12}

Fig. 12-1. Una calle antes de la conversión de Nueva York. Ghel Architects. Derechos de Autor. Dalsgaard, A. The Human Scale. The 10th EBS International Documentary Festival Docs on City \& Architecture. Oct, 2013

Fig. 12-2. Una calle después de la conversión de Nueva York. Derechos de Autor. Dalsgaard, A. The Human Scale. The 10th EBS International Documentary Festival Docs on City \& Architecture. Oct, 2013

Fig. 12-3. Los carriles de coches antes de la conversión de Nueva York. Derechos de Autor. Dalsgaard, A. The Human Scale. The 10th EBS International Documentary Festival Docs on City \& Architecture. Oct, 2013

Fig. 12-4. Los carriles de coches se convirtieron en una pequeña plaza de Nueva York. Derechos de Autor. Dalsgaard, A. The Human Scale. The 10th EBS International Documentary Festival Docs on City \& Architecture. Oct, 2013

Fig.12-5. Antes de la conversión de Broadway en la Ciudad de Nueva York. Derechos de Autor. Dalsgaard, A. The Human Scale. The 10th EBS International Documentary Festival Docs on City \& Architecture. Oct, 2013

Fig. 12-6. Después de la conversión de Broadway en la Ciudad de Nueva York. Derechos de Autor. Dalsgaard, A. The Human Scale. The 10th EBS International Documentary Festival Docs on City \& Architecture. Oct, 2013

\section{Capítulo 13}

Fig. 13-1. Diseño 1 de la página web para Mi Casa Tu Casa. Un fotomontaje personal del autor.

Fig. 13-2. Diseño 2 de la página web para Mi Casa Tu Casa. Un fotomontaje personal del autor.

Fig. 13-3. Diseño 3 de la página web para Mi Casa Tu Casa. Un fotomontaje personal del autor.

Fig 13-4. Diseño 4 de la página web para Mi Casa Tu Casa. Un fotomontaje personal del autor.

Fig. 13-5. Fotomontaje de Mi Casa Tu Casa. Un fotomontaje personal del autor.

Fig. 13-6. Refugio de la calle. Un fotomontaje personal del autor.

Fig. 13-7. Movilidad del refugio. Un fotomontaje personal del autor.

Fig. 13-8. Colaboración de los restaurantes. Un fotomontaje personal del autor.

Fig. 13-9. Articulo de El Mundo. EL MUNDO @ 2015 Unidad Editorial Información General S.L.U

Fig. 13-10. Articulo de Levante. Levante @ 2015 Levante. EL MERCANTIL VALENCIANO.

Fig. 13-11. Ruta 1. Un plan personal del autor.

La imágen de satélite: @ 2015 Microsoft Corporation.

Fig. 13-12. Ruta 2. Un plan personal del autor.

La imágen de satélite: ( 2015 Microsoft Corporation.

Fig. 13-13. Ruta 3. Un plan personal del autor.

La imágen de satélite: @ 2015 Microsoft Corporation.

Fig. 13-14. Ruta 4. Un plan personal del autor. 
La imágen de satélite: ( 2015 Microsoft Corporation.

Fig. 13-15. Área de intervención. Un plan personal del autor.

La imágen de satélite: (c) 2015 Microsoft Corporation.

Fig. 13-16. Vista Aérea de la Gran Vía y el Jardín del Túria. Un plan personal del autor. La imágen de satélite: @ 2015 Microsoft Corporation.

Fig. 13-17. Plan de Nuevo Acceso al Túria. Un plan personal del autor. La imágen de satélite: (c) 2015 Microsoft Corporation.

Fig. 13-18. Un fotomontaje del túnel. Un fotomontaje personal del autor.

Fig. 13-19. Un fotomontaje del túnel. Un fotomontaje personal del autor.

\section{Capítulo 14}

Fig. 14-1. Una imagen personal del autor.

Fig. 14-2. Una imagen personal del autor.

Fig. 14-3. Una imagen personal del autor.

Fig. 14-4. Flechas en Movimiento, Eros y otros erroresTracing Eisenman: Peter Eisenman Complete Works. . Derechos de Autor. Thames \& Hudson, 2006. Eisenman Architects, 2006.

Fig. 14-5. Parc de la Villette. Derechos de Autor. Bernard Tschumi Architects.

Fig. 14-6. Denver Art museum. Derechos de Autor. Daniel Libeskind. Studio Libeskind. 2006

Fig. 14-7. Open House. Coop Himmelblau. Derechos de Autor. Gerald Zugmann.

Fig. 14-8. Mimesis Museum. Alvaro Siza. Derechos de Autor. Fernando Guerra FG+SG

Fig. 14-9. Mimesis Museum. Alvaro Siza. Derechos de Autor. Fernando Guerra FG+SG

Fig. 14-10. Mimesis Museum. Alvaro Siza. Derechos de Autor. Fernando Guerra FG+SG

Fig. 14-11. Mimesis Museum. Alvaro Siza. Derechos de Autor. Fernando Guerra FG+SG

Fig. 14-12. Mimesis Museum. Alvaro Siza. Derechos de Autor. Fernando Guerra FG+SG

Fig. 14-13. Derechos de Autor. GEHL ARCHITECTS.

Fig. 14-14. Derechos de Autor. GEHL ARCHITECTS.

Fig. 14-15. Derechos de Autor. GEHL ARCHITECTS.

Fig. 14-16. Derecos de Autor. Jeremy Bentham.

Fig. 14-17. Una imagen personal del autro.

Fig. 14-18. Instant City. 1951. Derechos de Autor. Peter Cook, Archigram.

Fig. 14-19. Archigram, Walking City (Project 064), 1964 . Derechos de Autro. Deutsches Architekturmuseum

Fig. 14-20. The Plug-In City. 1964. Derechos de Autor. Peter Cook, Archigram.

Fig. 14-21. 금란교회. Derechos de Autor. 하나플러스건축사 사무소. Hanaplus Architects.

Fig. 14-22. 금란교회. Derechos de Autor. () 배불뚝이<<http://blog.joins.com/sdragon52>>

Fig. 14-23. 순천 선암사 전경 順天 仙岩寺 Derechos de Autor. Cultural Heritage Administration of Korea

Fig. 14-24. Derechos de Autor. 2012 꿈지킴이 
<<http://hwajun89.blog.me/>>

Fig. 14-25. 순천 선암사 승선교. Derechos de Autor. Cultural Heritage Administration of Korea

Fig. 14-26. 순천 선암사 대각암 부도. Derechos de Autor. Cultural Heritage Administration of Korea

Fig. 14-27. Derechos de Autor. 2012 마음 청소

<<http://blog.daum.net/jaihack/7779874>>

Fig. 14-28. 와송 누은 소나무. Derechos de Autor. Cultural Heritage Administration of Korea

Fig. 14-29. Derechos de Autor. 2012 마음 청소

<<http://blog.daum.net/jaihack/7779874>>

Fig. 14-30. Row House de Tadao Ando. Derechos de Autor. A.D.A. EDITA Tokyo Co., Ltd.

Fig. 14-31. Row House de Tadao Ando. Derechos de Autor. A.D.A. EDITA Tokyo Co., Ltd.

Fig. 14-32. Row House de Tadao Ando. Derechos de Autor. A.D.A. EDITA Tokyo Co., Ltd.

Fig. 14-33. Row House de Tadao Ando. Derechos de Autor. A.D.A. EDITA Tokyo Co., Ltd.

Fig. 14-34. Una imagen personal del autro.

Fig. 14-35. Una imagen personal del autro.

Fig. 14-36. Una imagen personal del autro.

Fig. 14-37. Una imagen personal del autro.

Fig. 14-38. Una imagen personal del autro.

Fig. 14-39. Una imagen personal del autro. 


\section{Tablas}

\section{Capítulo 11}

Tab. 11-1. Derechos de Autor. AAVV. "Global Wage Report 2012/2013: Wages and equitable growth." International Labour Office · Geneva.

Tab. 11-2. Derechos de Autor. "Poverty and gaps". OECD Factbook 2013: Economic, Environmental and Social Statistics. OECD Publishing.

Tab. 11-3. Derechos de Autor. OECD (2012). OECD Economic Surveys: Spain 2012. OECD

Publishing. Fuente online: <<http://dx.doi.org/10.1787/eco_surveys-esp-2012-en>>

Tab. 11-4. Derechos de Autor. OECD (2011). Entrepreneurship at a Glance 2011. OECD Publishing.

Tab. 11-5. Derechos de Autor. Jan Gehl Cities for People. Washington, DC. ISLAND PRESS. 2010.

Tab. 11-6. Derechos de Autor. Jan Gehl Cities for People. Washington, DC. ISLAND PRESS. 2010.

Tab. 11-7. Derechos de Autor. Jan Gehl Cities for People. Washington, DC. ISLAND PRESS. 2010.

\section{Capítulo 14}

Tab. 14-1. Derechos de Autor. Gehl Architects. GEHLARCHITECTS.COM 
